\title{
Mapping and modeling soil organic carbon in the Eastern Allegheny Plateau and Mountains using legacy data
}

\author{
Katey M. Yoast
}

Follow this and additional works at: https://researchrepository.wvu.edu/etd

\section{Recommended Citation}

Yoast, Katey M., "Mapping and modeling soil organic carbon in the Eastern Allegheny Plateau and Mountains using legacy data" (2015). Graduate Theses, Dissertations, and Problem Reports. 7010. https://researchrepository.wvu.edu/etd/7010

This Thesis is protected by copyright and/or related rights. It has been brought to you by the The Research Repository @ WVU with permission from the rights-holder(s). You are free to use this Thesis in any way that is permitted by the copyright and related rights legislation that applies to your use. For other uses you must obtain permission from the rights-holder(s) directly, unless additional rights are indicated by a Creative Commons license in the record and/ or on the work itself. This Thesis has been accepted for inclusion in WVU Graduate Theses, Dissertations, and Problem Reports collection by an authorized administrator of The Research Repository @ WVU. For more information, please contact researchrepository@mail.wvu.edu. 


\title{
MAPPING AND MODELING SOIL ORGANIC CARBON IN THE EASTERN ALLEGHENY PLATEAU AND MOUNTAINS USING LEGACY DATA
}

\author{
Katey M. Yoast
}

Thesis submitted to the College of Agriculture, Natural Resources, and Design at West Virginia University in partial fulfillment for the requirements for the degree of Masters of Science in Soil Science

\section{Committee:}

James A. Thompson, Ph.D., Chair

Louis M. McDonald, Ph.D.

Brenden E. McNeil, Ph.D.

Michael P. Strager, Ph.D.

Division of Plant and Soil Sciences

Morgantown, West Virginia

2015

Keywords: soil organic carbon, geographically weighted regression kriging, NRCS, Kellogg Soil Survey Laboratory, SSURGO, random forest, uncertainty, MLRA 127 


\begin{abstract}
Mapping and Modeling Soil Organic Carbon in the Eastern Allegheny Plateau and Mountains Using Legacy Data
\end{abstract}

Katey M. Yoast

The deeply dissected topography and diverse climate of the Eastern Allegheny Plateau and Mountains (Major Land Resource Area (MLRA) 127) create challenges for dynamicpedoecological modeling needed for ecosystem management adaptation to a changing climate. The spatial distribution of soil organic carbon (SOC), one of the most dynamic soil properties, has been previously estimated and mapped using the State Soil Geographical Database (STATSGO2) and the more detailed Soil Survey Geographic Database (SSURGO) for MLRA 127, estimating mean SOC to a depth of $1 \mathrm{~m}$ to be 2.60 and $4.40 \mathrm{~kg} \mathrm{~m}^{-2}$, respectively. Previous studies have shown that these approximations underestimate true carbon stock due to unpopulated organic horizons and inconsistencies within the databases. Between 1960 and 2009, the USDA-NRCS Kellogg Soil Survey Lab (KSSL) sampled and characterized 254 pedons within MLRA 127 based on soil survey needs. Each pedon had a site description and associated chemical and physical lab analyses to support its taxonomic classification. Data mining revealed that $13 \%$ of these 254 pedons lacked soil organic carbon data for one or more horizons and $50 \%$ lack bulk density (BD) values. Random forest (RF) and median and mean techniques were assessed, validated, and then used to populate missing BD and SOC data. Geographically weighted regression (GWR) and GWR kriging (GWRK) techniques were then used to model SOC stock in MLRA 127 using prepared and fully populated KSSL pedons and environmental covariates. The resulting SOC predictions were independentaly validated with measured Rapid Carbon Assessment ( $\mathrm{RaCA}$ ) samples and uncertainty was assessed using the fuzzy k-means with extragrades algorithm. Comparisons between GWR and GWRK models created in this study to the RaCA prediction model developed by NRCS showed that nonparametric spatial modeling techniques such as GWRK and RF are able to effectively predict SOC stock within a MLRA. The error rates calculated from the GWR, GWRK, and RaCA models were much lower than previous studies, indicating that SOC prediction by MLRA might be the most suitable way for 
NRCS to predict SOC stock and that GWRK should be the recommended approach for DSM of SOC. Total biosphere carbon calculated using the Forest Inventory Analysis (FIA) model and substituting GWRK soil for soil carbon and forest litter revealed that soils contain $79 \%$ of the total carbon in the terrestrial biosphere of MLRA 127. The methodology presented in this thesis, beginning with preparing KSSL data and ending with an interpolated GWRK model with 95\% prediction intervals depicting the SOC stock of the upper $1 \mathrm{~m}$ of soil in MLRA 127, is recommended to the NRCS as a guideline for future DSM approaches. Creating, validating, and assessing uncertainty of a SOC model created from measured data and environmental covariates will enhance the understanding of terrestrial biosphere carbon and support national climate change initiatives such as the U.S. Carbon Cycle Science Program. 


\section{Table of Contents}

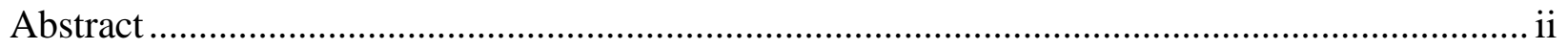

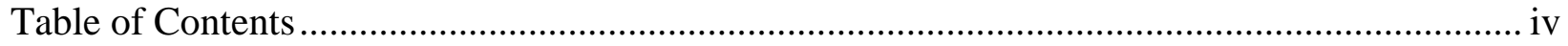

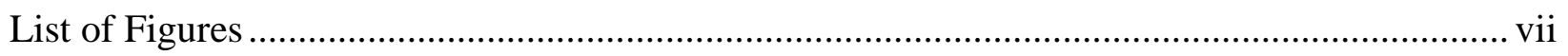

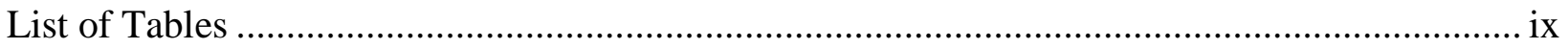

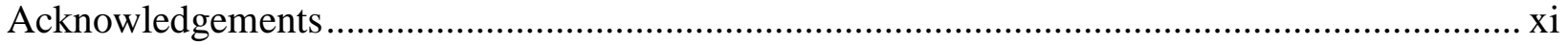

Chapter 1: Modeling Soil Organic Carbon Stock from Legacy Data and Environmental

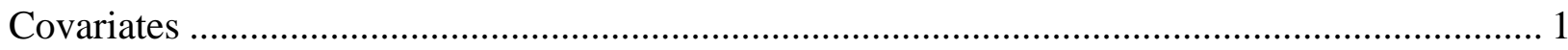

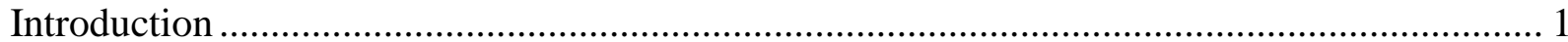

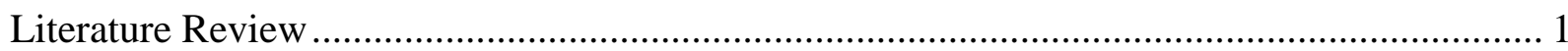

Properties of Soil Organic Carbon........................................................................... 1

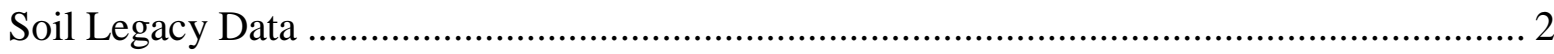

Digital Soil Mapping of Soil Organic Carbon.............................................................. 7

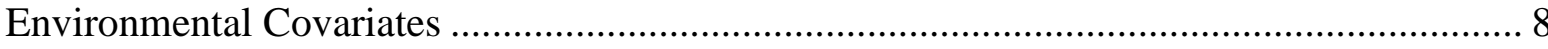

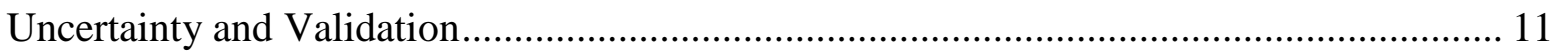

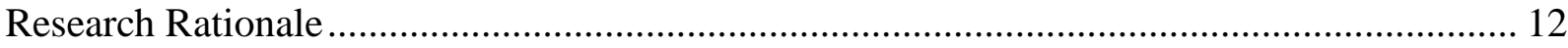

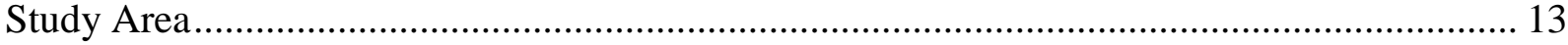

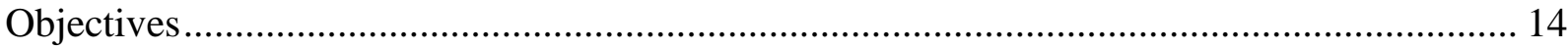

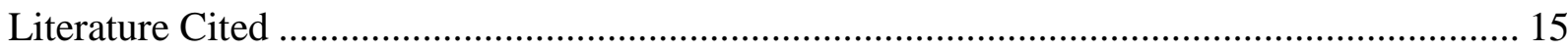

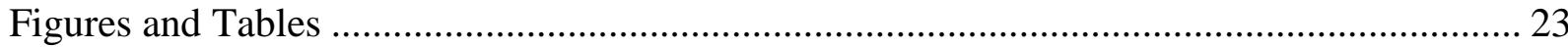

Chapter 2: Populating Missing Soil Organic Carbon Legacy Data ......................................... 29

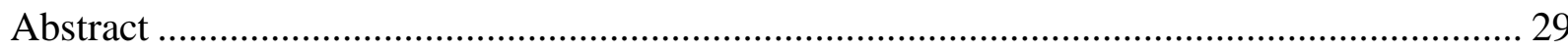

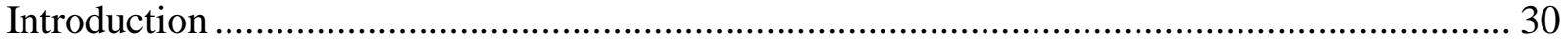

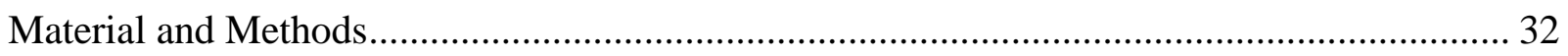

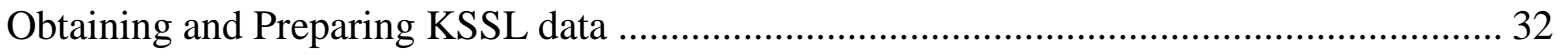

Carbon-equivalent Correction Factor ......................................................................... 33

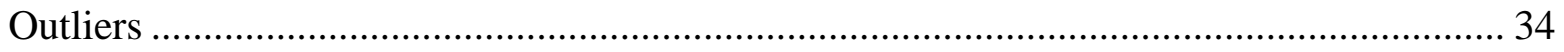

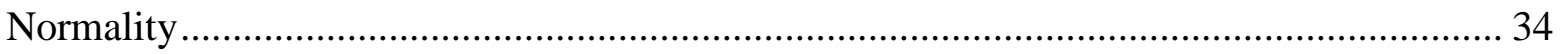

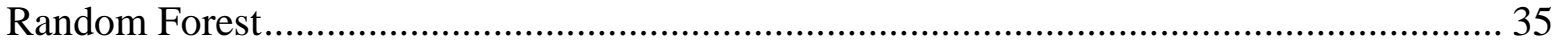

Mean and Median by Horizon Designation and Texture Class ....................................... 36

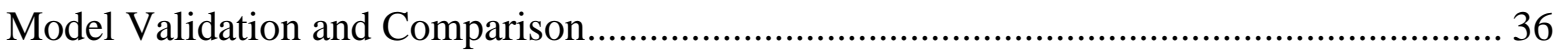




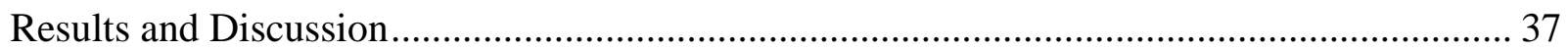

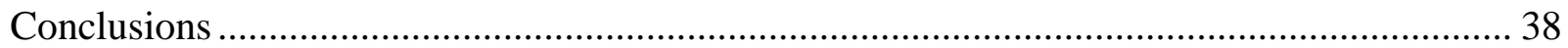

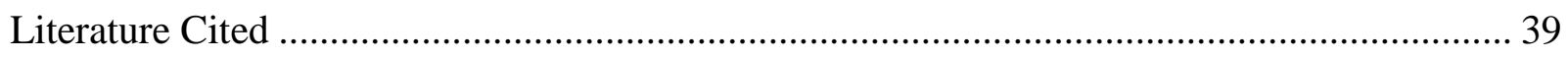

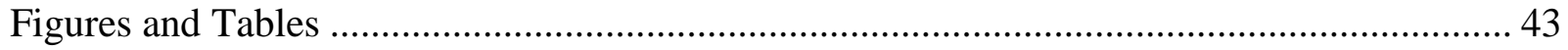

Chapter 3: Modeling Soil Organic Carbon through Geographically Weighted Regression Kriging $\ldots$

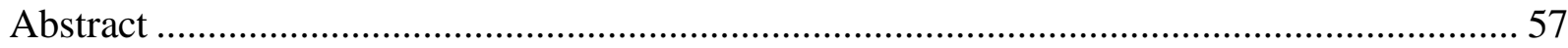

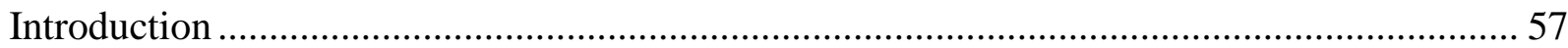

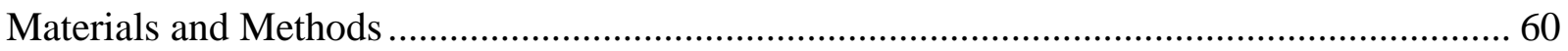

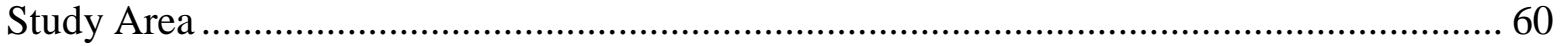

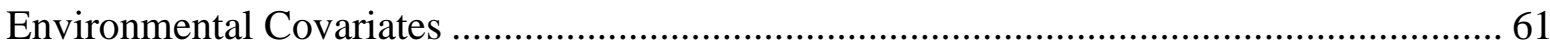

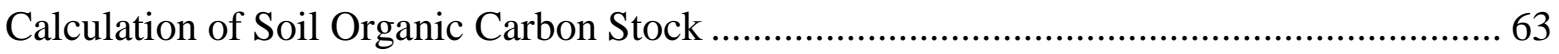

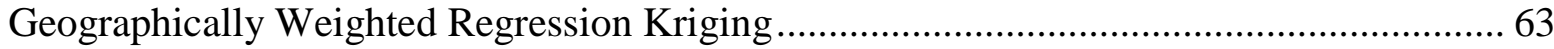

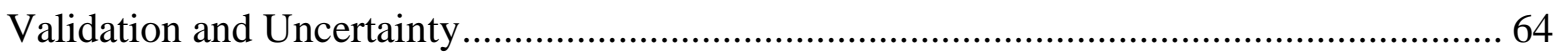

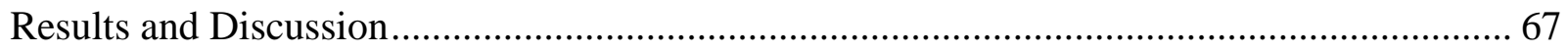

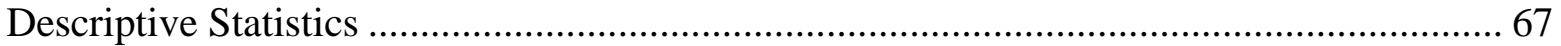

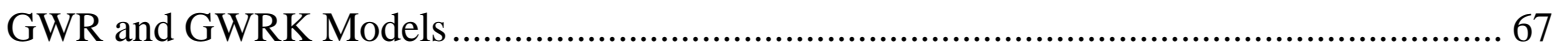

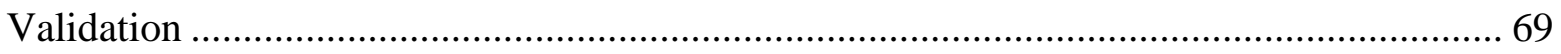

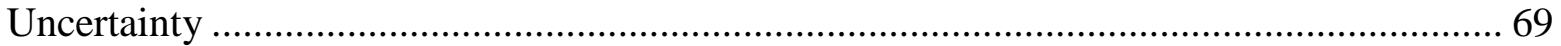

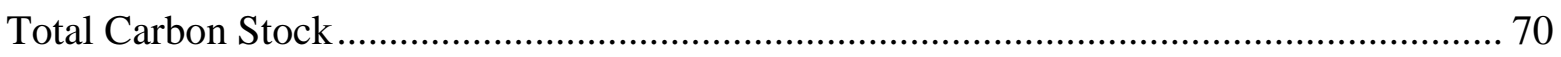

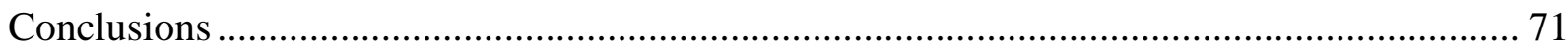

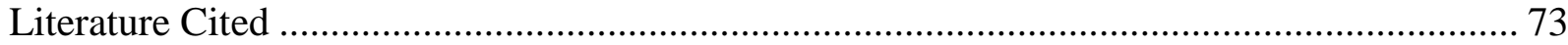

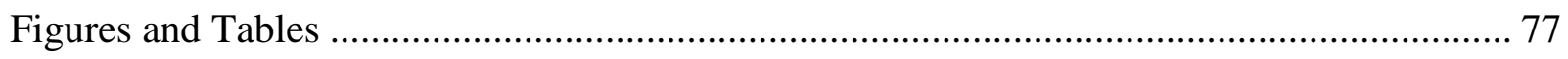

Chapter 4: Conclusions and Recommendations for the Natural Resources Conservation Service

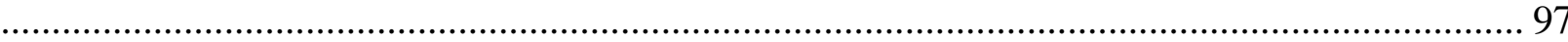

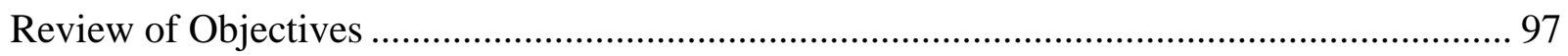

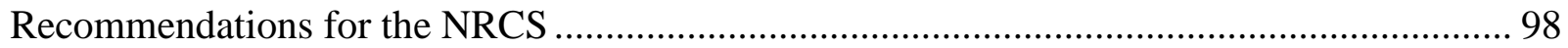

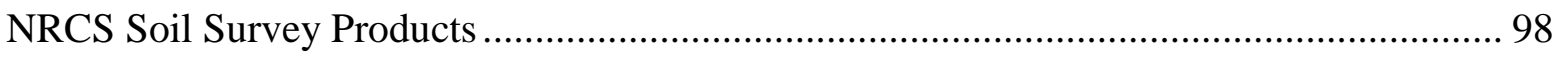

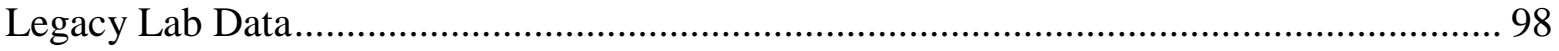

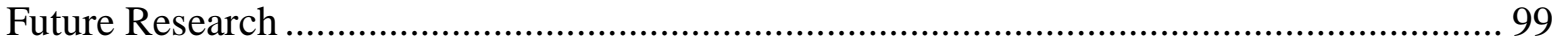

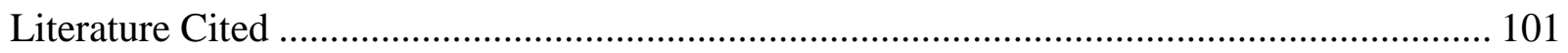


Appendix A: Kellogg Soil Survey Laboratory Site Data for Pedons in MLRA 127................ 103

Appendix B: Kellogg Soil Survey Laboratory Pedon Data for Sites in MLRA 127 ................ 138

Appendix C: R Code Used for Outlier Detection and Normality Testing .............................. 227

Appendix D: R Code Used for Random Forest Models ................................................... 228

Appendix E: Microsoft Excel Code for Calculating Mean and Median by Horizon and Texture

Appendix F: Soil Organic Carbon Stock of Rapid Carbon Assessment Sites in MLRA 127 .... 231

Appendix G: Soil Organic Carbon Stock of Pedons Described and Sampled by Sponaugle (2005) 


\section{List of Figures}

Figure 1.1 Structure and hierarchy of USDA-NRCS Major Land Resource Area Offices (MOs) and soil survey products from most general and smallest scale MOs to most specific $\mathrm{x}, \mathrm{y}$ sites and pedons, edited from

(http://www.nrcs.usda.gov/wps/portal/nrcs/detail/soils/survey/geo/?cid=nrcs142p2_053637)... 23

Figure 1.2 The Eastern Allegheny Plateau and Mountains (MLRA 127) encompassing ............. 24

parts of Maryland, New York, Pennsylvania, Virginia, and West Virginia................................. 24

Figure 2.1 The relationship between model complexity and error adapted from Fortmann-Roe (2012)

Figure 2.2 Two examples of the box and whisker plots used to determine outliers in horizon designation and texture class combinations.

Figure 2.3 Scatter plot of predicted and observed SOC percentages using the mean by horizon and texture method with outliers included. 45

Figure 2.4 Scatter plot of predicted and observed SOC percentages using the RF method. ....... 45 Figure 2.5 Scatter plot of predicted and observed organic horizon SOC percentages using the RF method. 46

Figure 2.6 Scatter plot of predicted and observed mineral horizon SOC percentages using the RF method 46

Figure 2.7 Scatter plot of predicted and observed BD values using the median by horizon and texture method with outliers included

Figure 2.8 Scatter plot of predicted and observed BD values using the RF method.

Figure 2.9 Scatter plot of predicted and observed organic horizon BD values using the RF method

Figure 2.10 Scatter plot of predicted and observed mineral horizon BD values using the RF method. 48

Figure 3.1 The Eastern Allegheny Plateau and Mountains (MLRA 127) encompassing ............. 77

parts of Maryland, New York, Pennsylvania, Virginia, and West Virginia.

Figure 3.2 Cluster performance graph as a function of number of classes, fuzzy performance index (FPI), and the modified partition entropy (MPE) calculated using FUZME software. ...... 78 Figure 3.3 Residuals from the GWR model interpolated using OK. 79 
Figure 3.4 SOC stock in the upper meter of soil in MLRA 127 predicted by GWRK with the following resolution sizes: (a) $250 \mathrm{~m}$, (b) $800 \mathrm{~m}$, and (c) 2,000 m. 80

Figure 3.5 SOC stock in the upper meter of soil in MLRA 127 predicted through GWR. ........ 81

Figure 3.6 SOC stock in the upper meter of soil in MLRA 127 predicted through GWRK with 2,000 m spatial resolution. 82

Figure 3.7 SOC stock in the upper meter of soil in MLRA 127 predicted by RaCA (Soil ........ 83

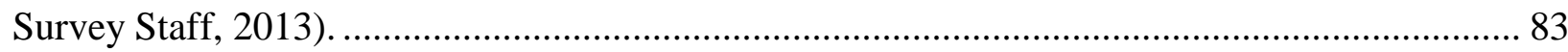

Figure 3.8 SOC stock in the upper meter of soil in MLRA 127 currently in STATSGO2. ....... 84 Figure 3.9 SOC stock in the upper meter of soil in MLRA 127 currently in SSURGO............ 85

Figure 3.10 Confusion index of SOC stock in the upper meter of soil in MLRA 127 .............. 86 calculated using fuzzy $k$-means with extragrade analysis. As the confusion index increases, the difference between the dominant and subdominant classes become negligible and there is confusion with the classification of the observation.

Figure 3.11 Lower 95\% prediction limit for the upper meter of SOC stock across MLRA 127 calculated using fuzzy k-means with extragrade analysis.

Figure 3.12 Upper 95\% prediction limit for the upper meter of SOC stock across MLRA 127 calculated using fuzzy k-means with extragrade analysis. 88

Figure 3.13 Total carbon stock, including above and below ground sources, in MLRA ........... 89 127 as reported by the Forest Inventory and Analysis tool with $250 \mathrm{~m}$ resolution. .................. 89

Figure 3.14 Total carbon stock, including above and below ground sources, in MLRA ............ 90 127 as reported by the Forest Inventory and Analysis tool, substituting the geographically weighted regression kriging representative values for soil organic carbon with 2,000 m.......... 90

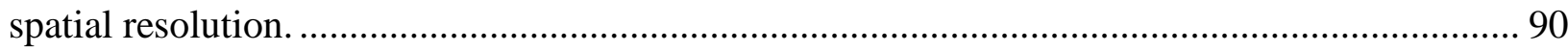

Figure 3.15 Total carbon stock, including above and below ground sources, in MLRA 127 as reported by the Forest Inventory and Analysis tool, substituting the lower 95\% prediction limit geographically weighted regression kriging for soil organic carbon with 2,000 m spatial resolution.

Figure 3.16 Total carbon stock, including above and below ground sources, in MLRA 127 as reported by the Forest Inventory and Analysis tool, substituting the upper 95\% prediction limit geographically weighted regression kriging for soil organic carbon with 2,000 m spatial resolution 


\section{List of Tables}

Table 1.1 The four soil SOC fractions and their size, stability, turnover time, and key functions adapted from PIRSA (2010). 25

Table 2.1 A comparison of machine learning techniques adapted from Montillo (2009). 52

Table 2.2 The D'Agostino chi-square, skewness, and kurtosis statistics for both SOC and BD with and without outliers by horizon and texture.

Table 2.3 Observation and outlier sample sizes by final horizon designation as suggested by Sequeira et al. (2014).

Table 2.4 Random Forest parameters and their resulting mean square errors and variances explained for SOC and BD.

Table 2.5 Coefficient of determination values for SOC predictions of mineral (min), organic (org), and both mineral and organic (min+org) horizons using RF, mean, and median methods. 54 Table 2.6 Root mean square errors for SOC predictions of mineral (min), organic (org), and both mineral and organic (min+org) horizons using RF, mean, and median methods. 55

Table 2.7 Coefficient of determination values for BD predictions of mineral (min), organic (org), and both mineral and organic (min+org) horizons using RF, mean, and median methods. 55 Table 2.8 Root mean square errors for BD predictions of mineral (min), organic (org), and both mineral and organic (min+org) horizons using RF, mean, and median methods. 56

Table 3.1. Normality and spatial autocorrelation analysis of the covariates used to predict SOC.

Table 3.2 Average SOC Estimates for the upper $1 \mathrm{~m}$ of soil in the Eastern Allegheny Plateau and Mountains adapted from Jenkins (2001)

Table 3.3 Statistical summary of the GWRK model with the following resolution sizes: $250 \mathrm{~m}$, $800 \mathrm{~m}$, and $2,000 \mathrm{~m}$.

Table 3.4 Statistical summary of the GWR, GWRK, and RaCA SOC stock models in MLRA 127.

Table 3.5 Estimations of the total SOC stock in the upper $1 \mathrm{~m}$ of soil in MLRA 127. LowGWRK represents the lower 95\% prediction interval and highGWRK represents the higher 95\% prediction interval. 
Table 3.6 Estimations of the sources of above and below ground carbon stock in MLRA 127 from the Forest Inventory and Analysis tool.

Table 3.7 Estimations of the total carbon stock in MLRA 127 from the Forest Inventory and Analysis tool and the the Forestry Inventory and Analysis tool with SOC and Forest Litter Carbon replaced with GWRK SOC stock. LowGWRK represents the lower 95\% prediction interval of the GWRK SOC, rvGWRK represents the modeled SOC, and highGWRK represents

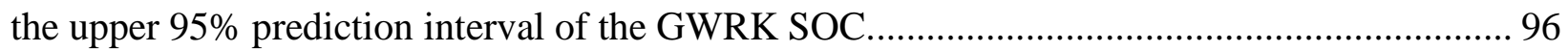




\section{Acknowledgements}

This thesis was created out of the partnership between the Natural Resources Conservation Service (NRCS) and West Virginia University. I would like to first thank my advisor, Dr. James Thompson, for presenting me with the opportunity to return to West Virginia University as a Master's student. His support and guidance gave me the confidence to pursue my dream of earning a Master's Degree in Soil Science. I'm very grateful for his patience and those long talks about statistics, pedogenesis, and digital soil mapping. Thanks, Dr. Thompson!

I would like to thank my previous NRCS coworkers Jason Martin of Rock Springs, WY, Rob Tunstead of Hammonton, NJ, and Susan Demas of Hammonton, NJ, for their encouragement to further my education. Thank you to Dave Kingsbury, NRCS Soil Survey Region 6 Leader, for welcoming me on board with his staff in Morgantown. It has been and will be such a great joy to work with Dave, Skip Bell, Wendy Noll, Mike Jones, Rob Pate, Jared Beard, Tim Dilliplane, Jason Teets, Debby Cunningham, Alan Moore, and Jeff Thomas. NRCS soil scientists work together as a family and I'm incredibly blessed to work with such an amazing group of people in West Virginia!

I want to thank the folks at the Geospatial Research Unit, including Bill and Sharon Waltman, Tom D'Avello, Travis Nauman, Aaron Burkholder, and Jordan Helmick, for their assistance and support throughout the development of my thesis. I would also like to thank Stephanie Connolly (USFS) for pedon data and guidance throughout this project. Thanks to Joan Wright (WVU) for lab instruction and troubleshooting the LECO with me!

I would like to sincerely thank Dr. Louis McDonald, Dr. Brenden McNeil, and Dr. Michael Strager for their time and suggestions as committee members for this thesis. Their commitment and dedication throughout this project has been astounding!

I would like to thank my husband, John Yoast, for all of his love and support throughout the past three years. It is not always easy to love and support a graduate student (long nights, frozen dinners, and constant successes and failures), but he has never left my side. Whether it was encouraging words, listening to my seminars, making late night coffee runs, or offering a shoulder to lean on, I wouldn't have made it through graduate school without him!

I would like to thank my parents for all of the love and support they have shown me throughout my life. I wouldn't be where I'm at today without their advice, discipline, and love. I would also like to sincerely thank Nana Mathis for always telling me to smile and think of clams whenever I gave a talk. Nana helped me conquer my fear of public speaking and inspired me to always press on with a smile! Thanks, Nana!

Finally I would like to thank God for His grace, guidance, love, and strength throughout my life and my time at WVU. My success is solely due to His grace and the aforementioned people $\mathrm{He}$ used to guide me. "For lack of guidance a nation falls, but victory is won through many advisers."-Proverbs 11:14 NIV 


\section{Chapter 1: Modeling Soil Organic Carbon Stock from Legacy Data and Environmental Covariates}

\section{Introduction}

Soil organic carbon (SOC), a dynamic soil property and the largest pool of terrestrial organic carbon in the biosphere (Jobbágy and Jackson, 2000; Minasny et al., 2013; Stockmann et al., 2013), plays a critical role in supplying nutrients to plants, improving soil structure and aggregate stability, contributing to cation exchange capacity, and developing sustainable land management practices (Schulte, 1988; Droogers and Bouma, 1997; Jobbágy and Jackson, 2000; Stolt et al., 2010; Batlle-Auguilar et al., 2011). Numerous studies have attempted to understand the importance of SOC, estimate carbon stock, and model SOC stock and change on regional, national, and global scales (Jobbágy and Jackson, 2000; Guo and Gifford, 2002; Batlle-Auguilar et al., 2011; Grunwald, 2011; Minasny et al., 2013). Although global estimates of SOC stocks have been made, the dynamic nature and vertical distribution of SOC remains poorly understood (Jobbágy and Jackson, 2000; Heimann and Reichstein, 2008). Given this time of changing climate and increased demand for soil productivity, it is imperative that SOC models are used to help manage soil carbon sequestration and carbon greenhouse gas fluxes in and out of ecosystems. In order to understand the dynamic nature of SOC and its relation togreenhouse gas fluxes, it is important to first recognize what SOC is and its role in pedogenesis, identify the interrelated variables that influence SOC, and then examine previous studies that will aid in the development of quantifying SOC for a desired geographical area.

\section{Literature Review}

\section{Properties of Soil Organic Carbon}

In the terrestrial food web, organic matter is deposited by plants and animals and is then utilized by primary consumers such as algae, bacteria, or fungi to produce humus. Soil organic matter (SOM), containing approximately $58 \%$ SOC, is defined as all materials of biological origin found in soils regardless of state of decomposition, including plant and animal residues on the surface or in soils, living roots, biological organisms, decomposing or decomposed litter, and burnt material of varying sizes (PIRSA, 2010). According to Stolt et al. (2010), SOM is a major fuel source for microbial activity, provides macro- and micronutrients, serves as a sink for heavy metals, is a major contributor to soil exchange capacity, is the storehouse of all SOC, and is a 
crucial component of soil aggregation, infiltration, and structure. SOC is comprised of four separate carbon fractions (Table 1) that vary in size, decomposition rate, and function: plant residues, particulate organic matter (POM), humus, and recalcitrant organic matter (PIRSA, 2010). Organisms (including microorganisms and vegetation) are one of the five soil forming factors of soil formation (Jenny, 1941). Organisms break down litter to produce nutrients that support plant growth. Over time the non-labile carbon that is produced through SOM decomposition accumulates and binds to soil particles, producing a carbon sink and contributing to soil structure. The rate of decomposition and extent of the carbon sink depends on the other soil forming factors: climate, parent material, relief, and time (Jenny, 1941).

Stockmann et al. (2013) published a summary of all of the knowns and unknowns regarding SOC and outlined the following knowns at a global scale: (i) soil contains about 2,344 Gt of SOC in upper three meters with 1,500 Gt occurring in the first meter and $615 \mathrm{Gt}$ in the upper twenty centimeters of the soil profile, (ii) approximately $8.7 \mathrm{Gt}$ of carbon are emitted to the atmosphere globally each year by anthropogenic sources, (iii) humus has a turnover rate of approximately 27 years, and (iv) decomposition of organic matter returns most of the carbon in litter to the atmosphere. Although the carbon cycle is well known, the processes that enable the carbon cycle remain poorly understood. According to Stockmann et al. (2013), the following interactions need further research: (i) the interaction between temperature and the labile and recalcitrant form of SOC; (ii) the long-term effects of priming soils with organic matter; (iii) the interactions of microbial communities during organic matter decomposition and stabilization; (iv) the long-term effect of land management and environmental factors on SOM; (v) the distribution of SOM in the soil matrix and the effects of biological, chemical, and physical processes overtime; (vi) the amount of respired versus transferred $\mathrm{C}$ during decomposition; and (vii) the overall composition of SOM. Given all of the unknown interactions and complexities of SOC, field and lab observations, legacy data, and digital soil mapping (DSM) should be utilized when available to better quantify the dynamic spatiotemporal nature of SOC (Droogers and Bouma, 1997; Stolt et al., 2010; Batlle-Aguilar et al., 2011; Minasny et al., 2013; Sulaeman et al., 2013).

\section{$\underline{\text { Soil Legacy Data }}$}

The United States Department of Agriculture-Natural Resources Conservation Service (USDA-NRCS) maintains soil surveys encompassing 9.7 million $\mathrm{km}^{2}$ in the United States (U.S.) 
and its territories as two vector and raster map products: the soil survey geographic (SSURGO) database and U.S. General Soil Map (STATSGO2), formerly the State Soil Geographic (STATSGO) database. SSURGO is made up of approximately 3,000 independent soil surveys (Thompson et al., 2012) that have different vintages and scales ranging from 1:12,000 to 1:125,000. STATSGO2 was created through the generalization of legacy independent soil surveys where available; spatial covariates such as geology, topography, vegetation, climate, and Land Remote Sensing Satellite (LANDSAT) images were used in combination with tacit knowledge to map areas that didn't have legacy soil surveys. STATSGO2 is mapped at 1:250,000 for all of the U.S. and its territories except for Alaska which is mapped at 1:1,000,000 (Grunwald et al., 2011). Soil Surevy Offices are responsible for maintaining and updating STATSGO2 and SSURGO for their respective Major Land Resource Areas (MLRA) (Fig. 1.1). MLRA are geographically associated land resource units that are important delineations for interstate, regional and national planning (United States Department of Agriculture, 2006). Both SSURGO and STATSGO2 display soils as discrete map units that contain one or more soil components. STATSGO2 is made up of soil association units that contain up to 21 named components (soil series or higher taxa) while SSURGO map units only contain one to three named components (Causarano et al., 2008). Although a STATSGO2 or SSURGO map unit may contain more than one soil component in its tabular data stored in the National Soil Information System (NASIS) database, soil components and their associated soil properties are not depicted spatially. Instead, map unit properties are spatially represented by the dominant soil component, area weighted average, or the most limiting soil component (Soil Survey Division Staff, 1993; Tesfa et al., 2009). This representative component falls within the range in characteristics (RIC) listed in the Official Soil Series Descriptions (OSD) and is supported by tacit knowledge of soil scientists and Kellogg Soil Survey Laboratory (KSSL) data from the National Cooperative Soil Survey (NCSS) soil characterization database.

Legacy data in the United States, consisting of STATSGO2, SSURGO, KSSL pedons, historic soil surveys, and field observations, are currently being used for land use and management planning (regional and field-scale) and as covariates for DSM. These legacy products, suitable for regional land use planning and management, are generalized and static, are not designed for field-scale interpretation or DSM, often contain discontinuities at survey area boundaries and methodological discrepancies, and lack uncertainty or error assessments (Moore 
et al., 1993; Hartemink et al., 2008; Grunwald et al., 2011). Problems associated with legacy soil data are a result of the origin of soil surveys and sampled pedons, ranging from the lack of a statistical sampling design to age of completion to the decisions made by soil survey project leaders. To combat the simplest problem with legacy data-discontinuities and discrepancies at political boundaries - the NRCS is currently harmonizing existing soils data stored in the NASIS database through the Soil Data Join Recorrelation (SDJR) project. SDJR is designed to consolidate similar map units in soil survey areas across an MLRA, evaluate and document each map unit, eliminate as many tabular join issues as possible, and populate NASIS with future field and spatial editing projects (Anderson, 2012). Through SDJR, the KSSL pedons will be updated to current Soil Taxonomy (Soil Survey Staff, 2014) and correlated to the appropriate soil series. SDJR is the first step in creating a seamless soils dataset for the U.S. that will allow future disaggregation and rasterization of soil survey data (Golden, 2012). In order to utilize legacy soil data as an input for DSM, the data must first be prepared (Sulaeman et al., 2013). Preparing legacy soil data consists of addressing inconsistencies in the database and differences in methodologies, tabular harmonization such as SDJR, and removing erroneous data. Once prepared, legacy soil data can be used to train geospatial models in order to explore spatial and temporal soil pattens and properties (Grunwald et al., 2011; Sulaeman et al., 2013).

Lab characterization pedon data and site descriptions for soils sampled by NRCS are available to the public through the NCSS soil characterization database. Approximately 20,000 pedons were sampled by soil scientists in the United States over the last 40 years for university or federal research, establishment of a soil series, soil survey updates, or population of RIC in OSD (NCSS National Cooperative Soil Characterization Database, 2013). When considering SOC modeling, some KSSL pedons are missing bulk density (BD) and SOC data (especially for organic horizons), rock fragment content, land use information, sampling protocol information, and proper georeferencing (Jenkins, 2001; West et al., 2010; Minasny et al., 2013; Wills et al., 2013). Wills et al. (2013) examined the KSSL database and found that of the 176,000 horizons with C measurements, only $40 \%$ had BD values populated. Furthermore, all the BD values were determined using the saran coated clod method (3B1c) (Burt, 2004). Using the clod method on soil horizons with high root, organic matter, or rock fragment contents may result in an inaccurate BD determination (Jenkins, 2001). Of the 176,000 carbon measurements, $28 \%$ were analyzed by dry combustion (4H2a1-3) (Burt, 2004), 65\% by wet combustion (6A1c) (Burt, 
2004), and 7\% with both. In dry combustion, all forms of soil $\mathrm{C}$ are converted into carbon dioxide $\left(\mathrm{CO}_{2}\right)$ and the evolved $\mathrm{CO}_{2}$ is measured. SOC is then calculated by subtracting inorganic C (carbonates) from total C. Wet combustion, also known as the Walkley-Black modified aciddichromate digestion, involves chemically oxidizing the most active forms of $\mathrm{SOC}$ to $\mathrm{CO}_{2}$ with ferrous sulfate $\left(\mathrm{FeSO}_{4}\right)$ and then quantifying the $\mathrm{FeSO}_{4}$ used in the chemical reaction (Soil Survey Staff, 2011). Due to its higher precision, accuracy, and lower chemical production, dry combustion has become the standard SOC method for the KSSL and most of the world (Tivet et al., 2012). SOC estimates by wet combustion, used by the KSSL prior to the 1990s, have been shown to underestimate true SOC content due to incomplete oxidation (Tivet et al., 2012; Michaelson et al., 2013), overestimate SOC in deeper horizons (Grossman et al., 2001), and be invalid if SOC is greater than $8 \%$ (Soil Survey Staff, 2011). In order to avoid methodological biases in datasets with both wet and dry combustion measurements, a C-equivalent correction regression factor must be applied to horizons analyzed by wet combustion (Tivet et al., 2012; Wills et al., 2013).

\section{Estimating Missing Legacy Data}

Because missing data is a common problem with soil legacy pedons, techniques such as parametric multiple linear regression (MLR), pedotransfer functions (PTF), and look-up tables are often used to infer missing data (Sequeira et al., 2014). According to Batjes (2003), the most desirable method for filling data gaps is collecting additional measured soil data, followed by using national expert estimates and common sense, and lastly using taxotransfer rules to derive soil property estimates. Missing BD values are predominately calculated from PTF that incorporate other soil properties within the same horizon, such as SOC or clay content, and/or site properties such as land cover (Brejda et al., 2001; Calhoun et al., 2001; Nave and Johnson, 2011; Michaelson et al., 2013). Calhoun et al. (2001) compared PTF developed from field, lab, and field + lab data and found that field + lab PTF predicted BD with the highest accuracy. Although PTF have been shown to be useful for populating missing legacy data, Tomasella et al. (2000) warn against applying regionally developed PTF to other regions and against using correlated variables in order to avoid multicolinearity. Wills et al. (2013) and West et al. (2010) used a nationally derived mean BD of $1.45 \mathrm{~g} \mathrm{~cm}^{-3}$ for mineral soils and $0.25 \mathrm{~g} \mathrm{~cm}^{-3}$ for organic horizons to replace missing BD in KSSL pedons. Similarly, Buell and Markewich (2004) calculated missing BD from median BD of soil texture class. Batjes et al. (2003) suggest using 
the median instead of the mean to better estimate the center of the data.Parametric techniques, such as MLR, yield a continuous equation that is often a result of implausible normality assumptions (Minasny et al., 2008). Thus, non-parametric techniques such as random forests (RF), artificial neural networks (ANN), k-nearest neighbor (k-NN), and boosted regression trees (BRT) are best suited for estimating missing soil legacy data. These four techniques have been shown to perform similarly, although researchers have preferred one method over another in several studies (Nemes et al., 2006; Hudak et al., 2008; Myers et al., 2009; Strobl et al., 2009; Ghehi et al., 2011). Myers et al. (2009) compared the following modeling techniques to predict BD: RF, BRT, regression tree, general additive models (GAM), multivariate adaptive regression splines (MARS), and generalized linear models (GLM). They found all techniques to perform similarly, with MARS performing the best by only a slight margin. Sequeira et al. (2014) created PTF using the RF algorithm to predict BD from horizon designation, median depth of the horizon, thickness, and texture class. When BD values were available from horizons above or below the horizon with a missing $\mathrm{BD}$ value, $\mathrm{BD}$ of the available horizon was incorporated into the RF algorithm. The RF algorithm is unique in that it is recursive, allows continuous and categorical variables with up to 32 categories each, incorporates interactions among predictor variables, can handle unbalanced classes, produces variable importance, and requires little data manipulation. Montillo (2009) summarized the advantages and limitations of ANN, k-NN, BRT, support vector machines (SVM), and MARS (Table 2). He concluded that RF has about the same accuracy as SVM and ANN, but is conceptually more interpretable, faster to train, has fewer parameters, can handle missing data, readily handles larger numbers of predictors, and doesn't require cross-validation. BRT are often more accurate at predicting a continuous response, but perform about the same as RF for classification. Spatial autocorrelation is not directly accounted for in any of the aforementioned models unless position information was incorporated as covariates in the models. Mascaro et al. (2014) found that incorporating position information in their RF model enhanced the predictive ability of the model by accounting for spatial autocorrelation. According to Montillo (2009), RF is advantageous over BRT in that it grows trees independently of one another, is quicker, requires fewer parameters, and does not over-fit the data. Contradictorily, some studies have shown that RF can over-fit data, especially in small datasets. The ntree and mtry parameters should be tuned for every RF model to reduce the chance of over-fitting (Segal, 2004; Statnikov et al., 2008). 
In order to utilize KSSL data, Sulaeman et al. (2013) suggest the following preparation steps: (i) identification, selection, database development and population; (ii) tabular and spatial harmonization; and (iii) dataset integration. Missing data are best predicted using a nonparametric statistical model like RF with uncorrelated field and lab data as input variables. Preparing legacy data for the DSM framework provides a benchmark for future DSM studies and additional data collections. Although DSM modeling is the future of soil survey, it can never be a complete substitute for detailed ongoing collection of field and lab data (Elith et al., 2006; Tsai et al., 2010; Sulaeman et al., 2013).

\section{Digital Soil Mapping of Soil Organic Carbon}

DSM is a quantitative spatial modeling technique established in the 1990s that combines environmental covariates, such as the soil forming factors established by Jenny (1941), with legacy data or current field and lab observations to infer pedogenic properties or patterns across various temporal and/or spatial scales (Brungard, 2009; Grunwald, 2010; Minasny et al., 2013). By expanding the work of Jenny (1941), McBratney et al. (2003) developed the scorpan spatial prediction function:

$$
\mathrm{S}=f(\mathrm{~s}, \mathrm{c}, \mathrm{o}, \mathrm{r}, \mathrm{p}, \mathrm{a}, \mathrm{n})+\varepsilon
$$

where a soil property or class (S) is a function of soil observations (s), climate (c), organisms (o), relief (r), parent materials (p), age (a), and spatial position (n), and $\varepsilon$ are the spatially correlated errors (residuals). The empirical quantitative function $(f)$ can represent complex non-linear data-

mining techniques such as regression trees and RF, simple linear models, or geostatistical models such as kriging (McBratney et al., 2003; Minasny et al., 2013).

The scorpan function assumes that soil observations used to calibrate the model represent the entire range of variation of the c, o, r, p, a, and n covariates and that the scorpan covariates correlate with soil properties (Minasny et al., 2008). Areas with limited or traditional legacy data do not represent the entire range of variation of the covariates, but are often the only source of SOC data due to budget and time constraints (Minasny et al., 2008, 2013). Bui et al. (2009) developed a linear decision tree model from sparse, non-statistical legacy point data and scorpan covariates to estimate SOC stock in Australia. They concluded that estimating SOC with subkilometer resolution is possible with limited and biased legacy point data if soil forming factors 
are incorporated into the DSM model. Soil properties or classes have been predicted at unsampled locations using geospatial methodologies since the late 1960s. Geospatial techniques have greatly expanded since then due to the establishment of geographic information systems (GIS), remote sensing, and the availability of high resolution digital datasets (Kumar et al., 2012). Today soil properties can be predicted continuously across a geographical area using scorpan covariates and an empirical quantitative function $(f)$. MLR, ordinary kriging (OK), regression trees, and regression kriging $(\mathrm{RK})$ are the most common quantitative functions used for DSM of SOC (Kumar et al., 2012). RK is different from MLR, OK, and regression trees in that it incorporates kriged residuals with global regression to account for spatial autocorrelation and trend, capturing more of the variability in the dataset. Kumar et al. (2012) refers to MLR, OK, regression trees, and RK models as stationary because they do not vary with absolute location across space. Geographically weighted regression (GWR) is a simple regression function that allows varying coefficient weights for the environmental covariates across space. Although GWR uses spatially varying covariate coefficients, it does not directly consider spatial autocorrelation in model development (Kumar et al., 2012). Geographically weighted regression kriging (GWRK) combines the frameworks of GWR and RK models to account for spatial nonstationarity and spatial autocorrelation of the residuals. Kumar et al. (2012) compared RK and GWRK and found that GWRK more precisely estimated SOC stock in Pennsylvania.

Minasny et al. (2013) reviewed previous studies of DSM of SOC and composed an outline of future considerations. The considerations of Minasny et al. (2013) for advancing the art and science of mapping SOC include: (i) obtaining representative and statistically-based soil samples, (ii) obtaining the best possible covariate data with the least amount of artifacts and error, (iii) further investigating the spatial decomposition of covariate datasets, (iv) estimating change in SOC through change in covariate data, (v) incorporating mechanistic simulation models for spatial prediction, (vi) developing a global soil map of SOC at a fine resolution, and (vii) developing new techniques to better predict SOC change. As finer resolution covariate data and statistically-designed soil samples become more available, it is expected that uncertainty in SOC models will be reduced and more variance will be explained by the model.

\section{Environmental Covariates}

Environmental covariates used in DSM differ depending on the study area, available data, and the correlation between the desired soil property or class and its environmental influences. 
Soil observations, consisting of soil legacy data or recent field or lab measurements, are either fully incorporated into the model or are split into model training and validation sets (Kumar et al., 2012). The other scorpan covariates are used to train the model and create a continuous predictive surface.

Climate data exist in the form of measurements at meteorological stations and can be combined with a digital elevation model (DEM) data and derivatives to produce a continuous climate raster (Brungard, 2009). In the U.S., the Parameter-elevation Regressions on Independent Slopes Model (PRISM) provides gridded 30-year normals at a resolution of $800 \mathrm{~m}$ for the following climatic properties: precipitation, average maximum temperature, average temperature, and average minimum temperature. Meteorological station data in the U.S. are available through the National Oceanic and Atmospheric Administration (NOAA) and through NRCS in the form of Soil Climate Analysis Network (SCAN) and SNOTEL data.

Vegetation is often chosen to represent organisms given the impracticality of quantifying fauna (Brungard, 2009). Normalized Difference Vegetation Index (NDVI) is commonly used in DSM to capture vegetative cover from red and near infrared (NIR) reflectance. The red band captures the absorption of chlorophyll while the NIR band captures leaf cellular structure and plant health. The Global Land Cover Facility (GLCF) created a national NDVI data set for the U.S. from 16- day snapshots collected onboard the Moderate-resolution Imaging Spectroradiometer (MODIS) satellite from 2001 to 2006 (Carroll et al., 2004). Previous studies have either chosen one representative 16-day coverage for NDVI or used weighted regression techniques to compile multiple 16-day snap shots. Mishra et al. (2010) used the MODIS NDVI values of June 26 to July 112001 to estimate SOC stock in several Midwestern states while Gray and Song (2012) used a composite MODIS NDVI created from weighted nonlinear least squares regression to produce a temporal model of leaf area index. Landsat 7 Enhanced Thematic Mapper (ETM+) bands 2 (green visible), 4 (NIR), and 7 (mid-infrared (MIR)) along with NDVI have been used to represent the vegetation scorpan component (Boettinger et al., 2008). Landsat Geocover, designed by the Global Landcover Facility (GLCF), simplified Landsat 7 ETM+ downloads for DSM by allowing users to download 2-4-7 and 2-3-4 band combinations without having to download all Landsat bands and scenes (GLCF, 2005). Remotely sensed Landsat multi-spectral data should be considered to help represent vegetation, parent material, and soil scorpan covariates in DSM (Boettinger et al., 2008). 
Relief is the most widely used scorpan covariate in DSM (Minasny et al., 2013). Terrain attributes of relief exist as primary or secondary DEM derivatives. Primary derivatives, such as slope gradient, slope aspect, slope curvatures, and flow direction are calculated directly from elevation. Secondary derivatives such as the compound topographic index (CTI) are combinations of primary derivatives that describe spatially dependent processes (Brungard, 2009). Brungard (2009) found that 52-88\% of the variation in SOC, depth of the A horizon, and soil depth was explained by slope gradient and CTI at a spatial resolution of $30 \mathrm{~m}$ in a $275 \mathrm{~km}^{2}$ study area in southwest Utah. Minasny et al. (2013) suggest that terrain attributes should be used in DSM at resolutions less than $100 \mathrm{~m}$ while landscape position should be used with resolutions greater than $100 \mathrm{~m}$. Jasiewicz and Stepinski (2012) developed a pattern recognition landform classifier technique that identifies geormorphological phonotypes (geomorphons) from a DEM. Every cell in a DEM is assigned an appropriate geomorphon and a pattern recognition algorithm determines the appropriate spatial scale at each location. The ten most common landform elements derived from geomorphons are: flat, peak, ridge, shoulder, spur, slope, pit, valley, footslope, and hollow (Jasiewicz and Stepinski, 2012). These elements help differentiate soils based on landscape position, similar to traditional soil survey, but in a raster format. Other landform delineation techniques (Schmidt and Hewitt, 2004; Iwahashi and Pike, 2007) have also been used to represent relief. Schmidt and Hewitt (2004) developed a fuzzy land element classification algorithm that assigns fuzzy membership in 15 land elements to each raster cell. Iwahashi and Pike (2007) used an automated nested-means classification algorithm to assign landform classes based on the mean of slope gradient, local convexity, and surface texture in nested two-fold partitions.

Parent material, often represented by lithology, determines the chemical composition and grain size of minerals that are exposed to chemical weathering at the beginning of pedogenesis (Brungard, 2009). Bedrock geology is mapped in the U.S. by the United States Geological Survey (USGS) at a scale of 1:250,000. Gamma radiometrics have been shown to correlate with soil moisture, clay content, and SOC and have been used in DSM models to help represent parent material (Minasny et al., 2013). A gamma radiometric survey measures the spatial distribution of potassium (K), thorium (Th), and uranium (U) within the upper 30-45 cm of the soil profile. The resulting RBG image shows $\mathrm{K}$ as a percentage and $\mathrm{Th}$ and $\mathrm{U}$ as parts per million (ppm) (DEPI, 
2013). Gamma radiometrics, along with other remotely sensed imagery such as Landsat, give continuity to USGS lithology polygons to better represent parent materials.

The age of soil is an important covariate to consider when using DSM due to its influence on chemical, biological, and physical soil reactions. Since age determination techniques such as optical luminescence are labor and cost intensive, soil age has not previously been characterized in DSM models (Brungard, 2009). The spatial position of soil is inherently built into DSM. Minasny et al. (2013) composed a summary table of covariates used in previous SOC studies (Table 3). Environmental covariates provide the geospatial link that enables soil scientists to model aspects of pedogenesis.

Uncertainty and Validation

Minasny et al. (2013) reviewed previous DSM of SOC studies and found that most studies involved compiling a soils database and covariate datasets for an area of interest, training a prediction function with soil observations, interpolating or extrapolating a prediction function over the area of interest, and validating the prediction function with existing or independent datasets. Out of the 40 studies they reviewed, half were not validated and the other half were validated using cross-validation or internal validation. Uncertainty was not addressed in most of the studies. Both validation and uncertainty estimations are needed to assess the overall accuracy of a model and for interpretation and risk assessment management (Nemes et al., 2009).

Uncertainty is a measure of confidence for a prediction from model structure, inputs, and parameters (Malone et al., 2011; Minasny et al., 2013). In their review of DSM of SOC, Minasny et al. (2013) found that SOC content and rock fragment content were the main sources of uncertainty when modeling SOC stock. Most data mining studies of SOC did not address uncertainty, while most geostatistical studies did. Previous geostatistical studies have quantified uncertainty through Monte Carlo simulation, Taylor analysis, bootstrapping, Bayesian approaches, or an empirical fuzzy k-means with extragrades algorithm (Minasny et al., 2013). Minasny et al. (2013) suggest using the fuzzy k-means with extragrades algorithm to quantify uncertainty for large geographical areas or when combing data mining tools with RK due to its high computational power and ability to quantify model parameter uncertainty. The fuzzy kmeans with extragrades algorithm partitions covariates into several classes, where each class is represented by a prediction interval derived from the empirical distribution as a weighted average of membership values. This approach identifies and penalizes observations outside of 
the domain of the calibration data and allows a new observation to be assigned to an established class based on class centroids (Minasny et al., 2013). Malone et al. (2011) developed the fuzzy kmeans with extragrades approach and found that it performed well with SOC and available water holding capacity (AWC). Malone et al. (2011) suggest that future work be done to further test the approach with different calibration sample sized and soil attributes. Methods for improving uncertainty estimations are continually being tested and updated in order to better capture the extent to which errors are propagated through a model.

Validation of modeled SOC is performed through cross-validation, internal validation, or independent sampling. Cross-validation techniques, such as leave-one-out and n-fold, recursively split observations within a database by leaving one out or splitting into $n$-folds to assess the accuracy of the calibrated model. Internal validation is performed by splitting or randomly holding back observations using a pre-determined percentage of the database to train a model and is then tested with the observations that were held back. Ancillary data are used to validate a model using the independent sampling technique (Minasny et al., 2013). Of the 40 studies that Minasny et al. (2013) reviewed, only half were validated. The random holdback internal validation method was used for all of the validated SOC studies. Both the cross-validation and internal validation techniques may produce biased estimates due to biased data inputs or spatially correlated prediction errors. Although unbiased independent sampling is the recommended validation approach, time and affordability often limit the applicability of independent validation. When uncertainty and validation assessments are both included in a study, the end user is able to better understand the nature and distribution of the input data, model error, and the overall accuracy and applicability of the model. Uncertainty and validation allow for a better understanding of the dynamic nature of SOC in relation to its correlated covariates across space and are thus needed for all SOC prediction studies (Minasny et al., 2013).

\section{Research Rationale}

Because soil contains three to four times more carbon than the atmosphere (BatlleAguilar et al., 2011), small changes in SOC content can have great impacts on the global carbon budget (Bui et al., 2009). In order to understand, predict, and manage these impacts, an initial assessment of SOC stock and its dynamic nature is needed within the realm of soil survey (Stolt et al., 2010). Due to its unique and diverse vegetative, climatic, geologic, and pedogenic properties, MLRA 127 (Eastern Alleghany Plateau and Mountains) was chosen as the study area 
for this research. SOC estimates for MLRA 127 have historically incorporated soil databases or soil characterization data gathered for soil survey purposes, not on actual SOC studies designed for MLRA 127 (Jenkins, 2001). SSURGO and STATSGO2 databases have often underestimated true SOC stock due to lack of organic horizon population and conservative representative values (Zhong and Xu, 2011; Nauman et al., 2012). SOC estimates for MLRA 127 range from $2.2 \mathrm{~kg} \mathrm{~m}^{-}$

2 (Bliss et al., 1995) to $32.0 \mathrm{~kg} \mathrm{~m}^{-2}$ (Kern, 1994) (Table 4). This wide range of SOC stock estimates coupled with lack of uncertainty assessments and validation indicates a need to better understand and capture SOC variability across MLRA 127.

\section{Study Area}

MLRA 127 includes parts of five states (Maryland, New York, Pennsylvania, Virginia, and West Virginia) and encompasses $50,370 \mathrm{~km}^{2}\left(19,440 \mathrm{mi}^{2}\right)$ (Fig. 1.2). The physiography of this area consists of the Kanawha and Allegheny Mountain Sections of the Appalachian Plateaus Province of the Appalachian Highlands, and is located just west of the Allegheny Front (United States Department of Agriculture, 2006). The high escarpment of the Allegheny Front separates the deeply dissected Appalachian Plateaus Province (MLRA 127) to the west from the folded and faulted Valley and Ridge Province (MLRA 147) to the east (United States Department of Agriculture, 2006). Elevation ranges from 300 to $800 \mathrm{~m}$ (980 to 2,625 ft) in the plateau portion of MLRA 127 to 1,100 to $1,400 \mathrm{~m}(3,600$ to 4,600 ft) in the mountainous portion located in southeastern West Virginia. The geology of MLRA 127 consists of alternating beds of sandstone, limestone, coal, and shale of the Permian, Mississipian, Pennsylvanian, and Cambrian ages. River valleys in this region are composed of stratified, unconsolidated alluvial deposits of sand, silt, clay, and gravel, with some outwash and glaciofluvial deposits in the northwest corner of Pennsylvania (United States Department of Agriculture, 2006). The footslopes and mid to lower backslopes of hills consists of colluvium from residual bedrock. MLRA 127 has all four climatic seasons, with an average annual temperature of 6 to $12^{\circ} \mathrm{C}$ (43 to $54^{\circ} \mathrm{F}$ ). Most of the precipitation occurs as intense, convective thunderstorms occurring in the spring and summer. Average annual precipitation ranges from 840 to $1,725 \mathrm{~mm}$ (33 to $68 \mathrm{in}$ ), increasing in a southern direction and with elevation. Average annual snowfall ranges from $890 \mathrm{~mm}$ (35 in) in southern MLRA 127 to 2,285 mm (90 in) in the northern part (United States Department of Agriculture, 2006). The frost-free period ranges from 115 days in high elevations or in the north to 205 days in the lower elevations of southern MLRA 127. Ultisols and Inceptisols are the dominant soil 
orders of MLRA 127, with Entisols, Alfisols, and Spodosols occurring to a lesser extent. The soils in this area are dominantly in the udic or aquic moisture regimes and mesic temperature regime, with the high-elevation and northern soils occurring in the perudic moisture regime and frigid temperature regime (United States Department of Agriculture, 2006). These soils have mixed or siliceous mineralogy and are generally moderately deep to very deep with excessively well to somewhat poor drainage classes. MLRA 127 supports high-quality hardwoods, such as oak, black cherry, yellow-poplar, and maple, at the lower elevations and intermixed deciduous and coniferous species at higher elevation, including red spruce, hemlock, birch, maple, black cherry, and beech (United States Department of Agriculture, 2006). Due to the geographical makeup of MLRA 127, most of the area is forested (76\%). The remaining areas have been cleared to support crops (7\%), pasture (7\%), urban development $(6 \%)$, other land uses $(3 \%)$, and water (1\%) (United States Department of Agriculture, 2006).

\section{Objectives}

This research was aimed at developing a framework for the NRCS to model SOC as a continuous function using legacy KSSL data and environmental covariates. The objectives of this research were to:

a) Populate missing KSSL data using RF, median by horizonation and texture class, and mean by horizonation and texture class to provide a better input for the DSM of SOC.

b) Model SOC through GWRK as a function of harmonized legacy KSSL data and environmental covariates and assess the validity and uncertainty of the GWRK model.

c) Assess ecosystem carbon using the Forest Inventory Analysis model and GWRK SOC model to determine the role that SOC has in relation to terrestrial biosphere carbon. 


\section{Literature Cited}

Anderson, S. USDA-NRCS. 2012. The Coastal Plainer: Spring 2012. MLRA connection: soil data join recorrelation (SDJR) soil survey projects.

<http://www.mo15.nrcs.usda.gov/news/newsletter/v16n1/sdjr.html>.

Batjes, N.H. 2003. A taxotransfer rule-based approach for filling gaps in measured soil data in primary SOTER databases. (ver. 1.1; GEFSOC Project). Technical Report 2003/03, ISRIC World Soil Information, Wageningen.

Batlle-Aguilar, J., A. Brovelli, A. Porporato, and D.A. Barry. 2011. Modeling soil carbon and nitrogen cycles during land use change. A review. Agronomy for Sustainable Development. 31: 251-274.

Bliss, N.B., S.W. Waltman, and G.W. Peterson. 1995. Preparing a soil carbon inventory for the United States using geographic information systems. In: Lal, R, J. Kimble, E. Levine, and B.A. Stewart (eds). Soils and Global Change. CRC Press Inc, Boca Raton, FL. 275-295.

Boettinger, J.L., R.D. Ramsey, J.M. Bodily, N.J. Cole, S. Kienast-Brown, S.J. Nield, A.M. Saunders, and A.K. Stum. 2008. "Landsat spectral data for digital soil mapping”. Digital Soil Mapping with Limited Data, ED: Hartemink, A.E., McBratney, A.B., Mendonça Santos, M.L. Springer, Dordrecht. 15-30. Print.

Brejda, J.J., M.J. Mausbach, J.J. Goebel, D.L. Allan, T.H. Dao, D.L. Karlen, T.B. Moorman, and J.L. Smith. 2001. Estimating surface soil organic carbon content at a regional scale using the National Resource Inventory. Soil Science Society of America Journal. 65:842-849.

Brungard, Colby W. 2009. “Alternative sampling and analysis methods for digital soil mapping in southwestern Utah.” All Graduate Theses and Dissertations. Paper 472. $<$ http://digitalcommons.usu.edu/etd/472>.

Buell, G.R. and H.W. Markewich. 2004. Data compilation, synthesis, and calculations used for organic-carbon storage and inventory estimates for mineral soils of the Mississippi River Basin. U.S. Geological Survey Professional Paper 1686-A. $<$ http://pubs.er.usgs.gov/publication/pp1686A>.

Bui, E., B. Henderson, and K. Viergever. 2009. Using knowledge discovery with data mining from the Australian Soil Resource Information System database to inform soil carbon mapping in Australia. Global Biogeochemical Cycles. 23:GB4033, 1-15. 
Burt, R., Ed. 2004. Soil Survey Laboratory Methods Manual, Soil Survey Investigations Report No. 42 Version 4.0. Lincoln, NE: Natural Resources Conservation Service, U.S. Department of Agriculture.

Calhoun, F.G., N.E. Smeck, B.L. Slater, J.M. Bigham, and G.F. Hall. 2001. Predicting bulk density of Ohio soils from morphology, genetic principles, and laboratory characterization data. Soil Science Society of America Journal. 65: 811-819.

Carroll, M.L., C.M. DiMiceli, R.A. Sohlberg, and J.R.G. Townshend. 2004. 250m MODIS Normalized Difference Vegetation Index, Collection 4, University of Maryland, College Park, Maryland.

Causarano, H.J., P.C. Doralswamy, G.W. McCarty, J.L. Hatfield, S. Milak, and A.J. Stern. USDA-ARS. 2008. EPIC modeling of soil organic carbon sequestration in croplands of Iowa. Journal of Environmental Quality. 37:1345-1353.

Department of Environment and Primary Industries (DEPI). 2013. Radiometrics. Victorian Resources Online. 〈http://vro.dpi.vic.gov.au/dpi/vro/vrosite.nsf/pages/landform_glossary_radio>.

Droogers, P. and J. Bouma. 1997. Soil survey input in exploratory modeling of sustainable soil management practices. Soil Science Society of America Journal. 61: 1704-1710.

Elith, J., C.H. Graham, R.P. Anderson, M. Dudik, S. Ferrier, A. Guisan, R.J. Hijmans, F. Huettmann, J.R. Leathwick, A. Lehmann, J. Li, L.G. Lohmann, B.A. Loiselle, G. Manion, C. Moritz, M. Nakamura, Y. Nakazawa, J.M. Overton, A.T. Peterson, S.J. Phillips, K.S. Richardson, R. Scachetti-Pereira, R.E. Schapire, J. Soberón, S. Williams, M.S. Wisz, and N.E. Zimmermann. 2006. Novel methods improve prediction of species' distributions from occurrence data. Ecography. 29:2, 129-151.

Ghehi, N.G., A. Nemes, A. Verdoodt, E. Van Ranst, W.M. Cornelis, and P. Boeckx. 2011. Nonparametric techniques for predicting soil bulk density of tropical rainforest topsoils in Rwanda. Soil Science Society of America Journal. 76 (4): 1172-1183.

The Global Landcover Facility (GLCF). 2005. Landsat GeoCover Degree Subset. University of Maryland Institute for Advanced Computer Studies, College Park, MD. < http://glcf.umd.edu/data/degree/>.

Golden, M. 2012. NB 430-13-01 SOI - Implementation of soil data join recorrelation initiative. $<$ http://directives.sc.egov.usda.gov/viewerFS.aspx?hid=32528>. 
Gray, J. and C. Song. 2012. Mapping leaf area index using spatial, spectral, and temporal information from multiple sensors. Remote Sensing of Environment. 119: 173-183.

Grossman, R.B., D.S. Harms, D.F. Kingsbury, R.K. Shaw, and A.B. Jenkins. 2001. Assessment of soil organic carbon using the U.S. soil survey, in Assessment methods for soil carbon, edited by R. Lal, J.M. Kimble, R.F. Follett, and B.A. Stewart. 87-104.

Grunwald, S. 2010. Current State of Digital Soil Mapping and What is Next? In: J.L. Boettinger et al. (eds.), Digital Soil Mapping, Progress in Soil Science 2, Springer. 3-12.

Grunwald, S., J.A. Thompson, and J.L. Boettinger. 2011. Digital soil mapping and modeling at continental scales: finding solutions for global issues. Soil Science Society of America Journal. 75:4, 1201-1213.

Guo, L. B. and R.M. Gifford. 2002. Soil carbon stocks and land use change: a meta-analysis. Global Change Biology. 8: 345-360.

Hartemink, A.E., A.B. McBratney, and M.L. Mendonça-Santos (ed.). 2008. Digital soil mapping with limited data. Springer-Verlag, Dordrecht, the Netherlands.

Heimann, M. and M. Reichstein. 2008. Terrestrial ecosystem carbon dynamics and climate feedbacks. Nature. 45:289-292. <http://ic.ucsc.edu/ acr/eart254/Heimann\%26Reichstein2008.pdf>.

Hudak, A.T., N.L. Crookston, J.S. Evans, D.E. Hall, and M.J. Falkowski. 2008. Nearest neighbor imputation of species-level, plot scale forest structure attributes from LiDAR data. USDA Forest

Iwahashi, J and R.J. Pike. 2007. Automated classifications of topography from DEMs by an unsupervised nested-means algorithm and a three-part geometric signature. Geomorphology86, 409-440.

Jasiewicz, J. and T. F. Stepinski. 2012. Geomorphons - a pattern recognition approach to classification and mapping of landforms. Geomorphology. 182: 147-156.

Jenkins, A. 2001. Organic Carbon and Fertility of Forest Soils on the Allegheny Plateau of West Virginia. M.S. thesis, West Virginia University, Morgantown, WV. <http://etd.wvu.edu/templates/showETD.cfm?recnum=2486>.

Jenny, H. 1941. Factors of soil formation. McGraw-Hill, New York, New York, USA.

Jobbágy, E. G. and R.B. Jackson. 2000. The vertical distribution of soil organic carbon and its relation to climate and vegetation. Ecological Applications. 10:423-436. 
Kern, J.S. 1994. Spatial patterns of soil organic carbon distribution in the contiguous United States. Soil Science Society of America Journal. 58: 439-455.

Kumar, S., R. Lal, and D. Liu. 2012. A geographically weighted regression kriging approach for mapping soil organic carbon stock. Geoderma. 189-190: 627-634.

Malone, B.P., A.B. McBratney, and B. Minasny. 2011. Empirical estimates of uncertainty for mapping continuous depth functions of soil attributes. Geoderma. 160: 614-626.

Mascaro, J., G.P. Asner, D.E. Knapp, T. Kennedy-Bowdoin, R. E. Martin, C. Anderson, M. Higgins, K. Dana Chadwick. 2014. A tale of two "forests:" random forest machine learning aids tropical forest carbon mapping. PLoS ONE 9(1): e85993. <http://journals.plos.org/plosone/article?id=10.1371/journal.pone.0085993>

McBratney, A.B., M.L. Mendonca Santos, and B. Minasny. 2003. On digital soil mapping. Geoderma. 117: 3-52.

Michaelson, G.J., C.L. Ping, M. Clark. 2013. Soil pedon carbon and nitrogen data for Alaska: an analysis and update. Open Journal of Soil Science. 3: 132-142.

Minasny, B., McBratney, A.B., 2002. FuzME version 3.0, Australian Centre for Precision Agriculture, The University of Sydney, Australia.

Minasny, B., A.B. McBratney, N.J. McKenzie, and M.J. Grundy. 2008. Predicting soil properties using pedotransfer functions and environmental correlation. N.J. McKenzie, M.J. Grundy, R. Webster, A.J. Ringrose-Voase (Eds.). Guidelines for Surveying Soil and Land Resources, Australian Soil and Land Survey Handbook Series, CSIRO Publishing, Melbourne (2008). 349-367.

Minasny, B., A.B. McBratney, and R.M. Lark. 2008. "Digital soil mapping technologies for countries with sparse data infrastructures". Digital Soil Mapping with Limited Data, ED: Hartemink, A.E., McBratney, A.B., Mendonça Santos, M.L. Springer, Dordrecht. 15-30. Print.

Minasny, B., A.B. McBratney, B.P. Malone, and I. Wheeler. 2013. Digital mapping of soil carbon. Advances in Agronomy. 118: 1-47.

Mishra, U., R. Lal, D. Liu, and M. Van Meirvenne. 2010. Predicting the spatial variation of the soil organic carbon pool at a regional scale. Soil \& Water Management \& Conservation. Soil Science Society of American Journal. 74 (3): 906-914. 
Moore, I.D., P.E. Gessler, G.A. Nielsen, and G.A. Peterson. 1993. Soil attribute prediction using terrain analysis. Soil Science Society of America Journal. 57: 443-452.

Myers D.B., S. Grunwald, G.M. Vasques and W.G. Harris. 2009. Pedotransfer functions for carbon methods and bulk density estimation in Florida soils. ASA-CSSA-SSSA Meeting, Pittsburgh, PA, Nov. 1-4, 2009.

Nakaya, T. 2014. GWR 4.0 Software. Centre for GeoInformatics. University of St. Andrews. < http://geoinformatics.wp.st-andrews.ac.uk/gwr/gwr-downloads>.

National Cooperative Soil Survey (NCSS) National Cooperative Soil Characterization Database. 2013. <http://ncsslabdatamart.sc.egov.usda.gov>.

Nauman, T.W., J.A. Thompson, N.P. Odgers, and Z. Libohova. 2012. Fuzzy disaggregation of conventional soil maps using database knowledge extraction to produce soil property maps.B. Minasny, B. Malone, A. McBratney (Eds.), Digital Soil Assessments and Beyond: 5th Global Workshop on Digital Soil Mapping, Sydney, Australia (2012).Nave, L. and K. Johnson. 2012. National soil carbon network: database calculations and quality assessment. International soil carbon network. 1-8.

Nemes, A. W.J. Rawls, and Y.A. Pachepsky. 2006. Use of the nonparametric nearest neighbor approach to estimate soil hydraulic properties. Soil Science Society of America Journal. 70 (2): 327-336.

Nemes, A., B. Quebedeaux, and D.J. Timlin. 2009. Ensemble approach to provide uncertainty estimates of soil bulk density. Soil Science Society of America Jouranl. 74: 1938-1945.

Primary Industries and Resources South Australia (PIRSA) (Rural Solutions SA Group). June 2010. PIRSA discussion paper - Soil carbon and climate change. 1-76. <http://www.pir.sa.gov.au/_data/assets/pdf_file/0006/137904/PIRSA_soil_carbon_and_cli mate_change.pdf>.

Schmidt, J., A. Hewitt. 2004. Fuzzy land element classification from DTMs based on geometry and terrain position. Geoderma 121, 243-256.

Schulte, E.E. 1988. Recommended soil organic matter tests. In: Recommended Chemical Soil Test Procedures for the North Central Region. North Central Reg. Publ. 221 (Revised). North Dakota Agric. Exp. Stn. Bull. 499. Fargo, ND. 29-32. 
Segal, M.R. 2004. Machine Learning Benchmarks and Random Forest Regression. Technical Report, Center for Bioinformatics \& Molecular Biostatistics. University of California, San Francisco.

Sequeira, C.H., S.A. Wills, C.A. Seybold, and L.T. West. 2014. Predicting soil bulk density from incomplete datasets. Geoderma. 213: 64-73.

Soil Survey Division Staff. 1993. Soil survey manual. Soil Conservation Service. U.S.

Department of Agriculture Handbook 18.

Soil Survey Staff. 2011. Soil Survey Laboratory Information Manual. Soil Survey Investigations

Report No. 45, Version 2.0. R. Burt (ed.). U.S. Department of Agriculture, Natural Resources Conservation Service.

Soil Survey Staff. 2014. Keys to Soil Taxonomy, 12th ed. USDA-Natural Resources

Conservation Service, Washington, DC.

Sponaugle, C.L. 2005. Properties and acid risk assessment of soils in two parts of the Cherry

River watershed, West Virginia. M.S. thesis, West Virginia University, Morgantown, WV. <http://hdl.handle.net/10450/4425>.

Statnikov A., L. Wang, and C. Aliferis. 2008. A comprehensive comparison of random forests and support vector machines for microarray-based cancer classification. BMC Bioinformatics. 9:139.

Stockmann, U., M.A. Adams, J.W. Crawford, D.J. Field, N. Henakaarchchi, M. Jenkins, B. Minasny, A.B. McBratney, V. de R. de Courcelles, K. Singh, I. Wheeler, L. Abbott, D.A. Angers, J. Baldock, M. Bird, P.C. Brookes, C. Chenu, J.D. Jastrow, R. Lal, J. Lehmann, A.G. O’Donnell, W.J. Parton, D. Whitehead, and M. Zimmermann. 2013. The knowns, known unknowns, and unknowns of sequestration of soil SOC. Agriculture, Ecosystems, and Environment, 164: 80-99.

Stolt, M.H., P.J. Drohan, and M.J. Richardson. 2010. Insights and Approaches for Mapping Soil SOC as a Dynamic Soil Property. Soil Science Society of America Journal. 74:5, 1685-1689.

Strobl, C., J. Malley, and G. Tutz. 2009. An introduction to recursive partitioning: Rationale, application, and characteristics of classification and regression trees, bagging, and random forests. Psychological Methods. 14, 323-48

Sulaeman, Y., B. Minasny, A.B. McBratney, M. Sarwani, and A. Sutandi. 2013. Harmonizing legacy soil data for digital soil mapping in Indonesia. Geoderma, 192: 77-85. 
Tesfa, T.K., D.G. Tarboton, D.G. Chandler, and J.P. McNamara. 2009. Modeling soil depth from topographic and land cover attributes. Water Resources Research. 45, W10438: 1:16.

Thompson, J A., T.W. Nauman, N.P. Odgers, Z. Libohova, and J.W. Hempel. 2012.

Harmonization of legacy soil maps in North America: Status, trends, and implications for digital soil mapping efforts. In B. Minasny, B.P. Malone, and A.B. McBratney (Eds.), Digital Soil Assessments and Beyond: Proceedings of the 5th Global Workshop on Digital Soil Mapping 2012, Sydney, Australia. CRC Press, New York. p. 97-102.

Tivet, F., J. Carlos de Morases Sá. P. R. Borszowskei. P. Letourmy, C. Briedis, A. Oliveira Ferreira, J. Burkner dos Santos, and T. Massao Inagaki. 2012. Soil carbon inventory by wet oxidation and dry combustion methods: effects of land use, soil texture gradients, and sampling depth on the linear model of c-equivalent correction factor. Soil Science Society of America Journal. 76:1048-1059.

Tomasella, J., M.G. Hodnett, and L. Rossato. 2000. Pedotransfer function for the estimation of soil water retention in Brazilian soils. Soil Science Society of America Journal. 64: 327-338. Tsai, C-C, Z-S Chen, Z-Y Hseu, C-T Duh, and H-Y Guo. 2010. SOC storage and management strategies of the forest soils based on the forest soil survey database in Taiwan. Proc.of Int. Workshop on Evaluation and Sustainable Management of Soil Carbon Sequestration in Asian Countries. Bogor, Indonesia Sept. 28-29, 2010.

United States Department of Agriculture, Natural Resources Conservation Service. 2006. Land Resource Regions and Major Land Resource Areas of the United States, the Caribbean, and the Pacific Basin. U.S. Department of Agriculture Handbook 296.

United States Department of Agriculture, Natural Resources Conservation Service. LRR-MLRALRU Land Resource Hierarchy.

< http://www.nrcs.usda.gov/wps/portal/nrcs/detail/soils/survey/geo/?cid=nrcs142p2_053638>.

United States Department of Agriculture - United States Forest Service. Forest Inventory and Analysis DataMart. FIADB version $5.1<$ http://apps.fs.fed.us/fiadbdownloads/datamart.html>. Accessed: 10/11/2014.

West, L.T., S.W. Waltman, S. Wills, T.G. Reinsch, E.C. Benham, C.S. Smith, and R. Ferguson. 2010. Soil carbon stocks in the US: current data and future inventories. USDA-NRCS. Proc. of Int. Workshop on Evaluation and Sustainable Management of Soil Carbon Sequestration in Asian Countries. Bogor, Indonesia. Sept. 28-29, 2010. 
Wills, S., C. Seybold, J. Chiaretti, C. Sequeira, and L. West. 2013. Quantifying tacit knowledge about soil SOC stocks using soil taxa and official soil series descriptions. Soil Science Society of America Journal.

Zhou, X., H.S. Lin, and E.A. White. 2008. Surface soil hydraulic properties in four soil series under different land uses and their temporal changes. Catena. 73:180-188.

Zhong, B., and Y.J. Xu. 2011. Scale effects of geographical soil datasets on soil carbon estimation in Louisiana, USA: A comparison of STATSGO and SSURGO. Pedosphere. 21(4): 491-501. 
Figures and Tables

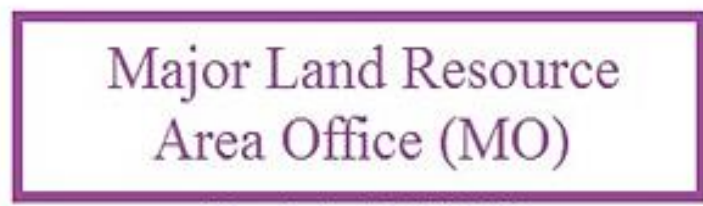

Map Scale: $1: 7,500,000$

Land Resource Region (LRR)

Map Scale: $1: 3,500,000$

Major Land Resource
Area (MLRA)

Map Scale: $1: 250,000$

STATSGO2

General Soil Map

Map Scale: $1: 24,000$

SSURGO

Detailed Soil Map

Map Scale: $<1: 12,000$

Components

Soil Series

Map Scale: 1:1

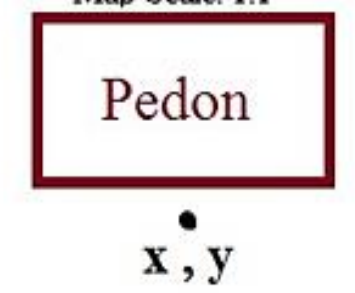

Figure 1.1 Structure and hierarchy of USDA-NRCS Major Land Resource Area Offices (MOs) and soil survey products from most general and smallest scale MOs to most specific x,y sites and pedons, edited from

(http://www.nrcs.usda.gov/wps/portal/nrcs/detail/soils/survey/geo/?cid=nrcs142p2_053637). 


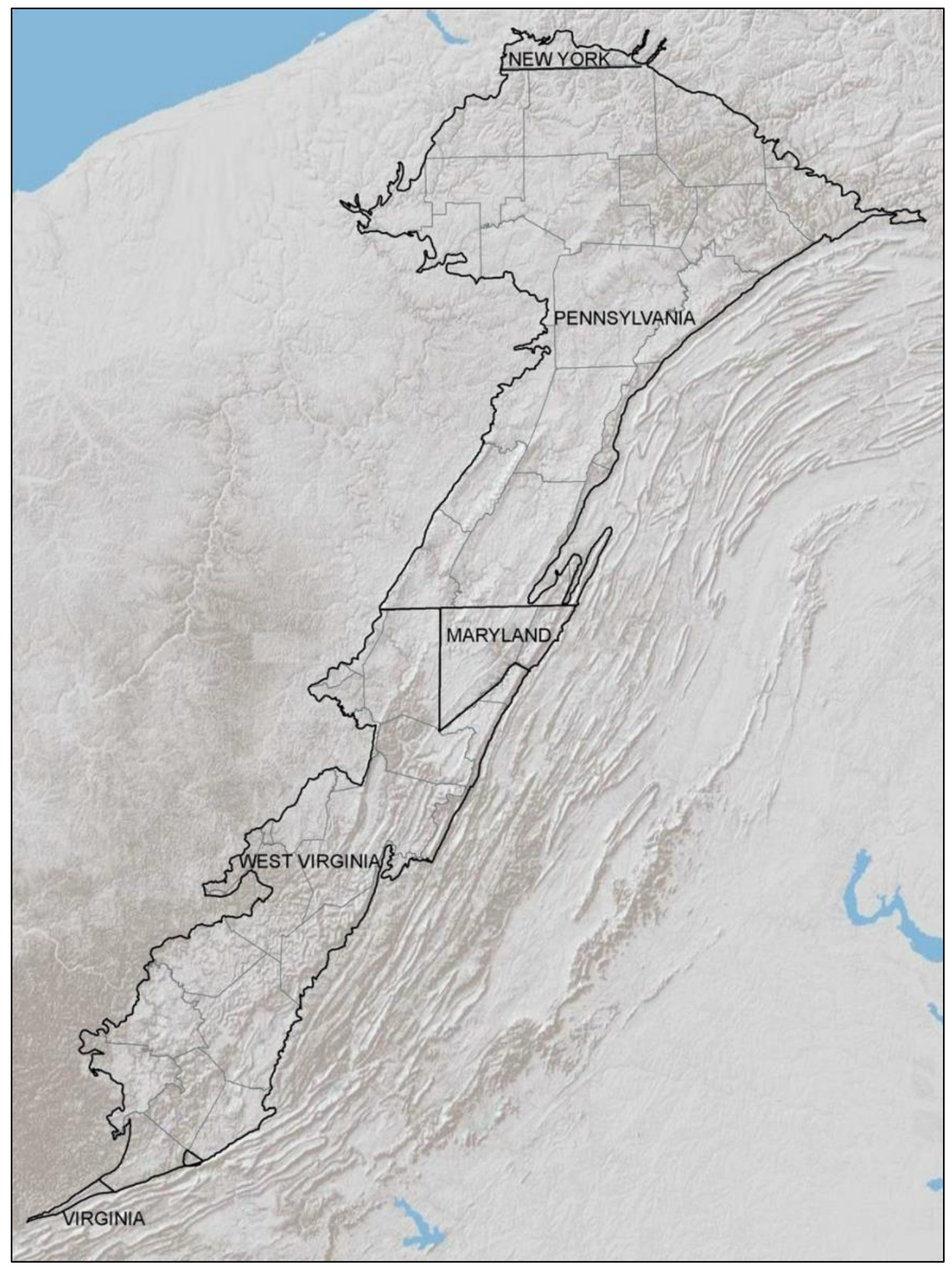

Figure 1.2 The Eastern Allegheny Plateau and Mountains (MLRA 127) encompassing parts of Maryland, New York, Pennsylvania, Virginia, and West Virginia. 
Table 1.1 The four soil SOC fractions and their size, stability, turnover time, and key functions adapted from PIRSA (2010).

\begin{tabular}{|c|c|c|c|c|}
\hline $\begin{array}{l}\text { Organic Carbon } \\
\text { Pool }\end{array}$ & Size & Stability & $\begin{array}{l}\text { Turnover } \\
\text { Time }\end{array}$ & Key Functions \\
\hline $\begin{array}{l}\text { Crop Residues (shoot } \\
\text { and root residues on and } \\
\text { in the soil) }\end{array}$ & $>2 \mathrm{~mm}$ & Labile & Days & $\begin{array}{l}\text { Crop residues are readily broken down by } \\
\text { microorganisms to provide energy and } \\
\text { nutrients to the biological community in the } \\
\text { soil. }\end{array}$ \\
\hline $\begin{array}{l}\text { Particulate Organic } \\
\text { Matter (smaller plant } \\
\text { debris) }\end{array}$ & $0.05-2 \mathrm{~mm}$ & & & $\begin{array}{l}\text { Particulate organic matter (POM) is } \\
\text { broken down relatively quickly in suitable } \\
\text { conditions, but more slowly than crop } \\
\text { residues. POM is important for soil } \\
\text { structure and provision of energy for } \\
\text { biological processes and nutrients. }\end{array}$ \\
\hline $\begin{array}{l}\text { Humus (decomposed } \\
\text { material dominated by } \\
\text { molecules stuck to soil } \\
\text { minerals) }\end{array}$ & $<0.05 \mathrm{~mm}$ & & & $\begin{array}{c}\text { Humus plays a role in all key soil functions, } \\
\text { but is particularly important in the retention } \\
\text { and provision of nutrients. }\end{array}$ \\
\hline $\begin{array}{l}\text { Recalcitrant Organic } \\
\text { Matter (biologically } \\
\text { stable, dominated by } \\
\text { pieces of charcoal) }\end{array}$ & Variable & $\begin{array}{l}\text { Very } \\
\text { stable/relatively } \\
\text { inert }\end{array}$ & $\begin{array}{l}\text { Hundreds of } \\
\text { years }\end{array}$ & $\begin{array}{l}\text { Recalcitrant organic matter decomposes } \\
\text { very slowly and if present in large enough } \\
\text { quantities, can contribute to cation } \\
\text { exchange capacity as well as mediating soil } \\
\text { temperature. }\end{array}$ \\
\hline
\end{tabular}


Table 1.2. A comparison of machine learning techniques adapted from Montillo (2009).

\begin{tabular}{|c|c|c|c|c|c|}
\hline Characteristic & Neural Networks & SVM & Trees & MARS & k-NN, Kernals \\
\hline Natural handling of "mixed" data & 0 & 0 & O & O & 0 \\
\hline Handling of missing data & O & O & O & O & O \\
\hline $\begin{array}{l}\text { Robustness to outliers in input } \\
\text { space }\end{array}$ & 0 & ○ & 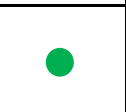 & 0 & 0 \\
\hline $\begin{array}{l}\text { Insensitive to monotone } \\
\text { transformations of inputs }\end{array}$ & O & 0 & ○ & 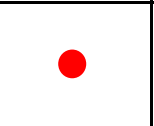 & ○ \\
\hline Computational scalability (large N) & O & O & O & O & O \\
\hline Ability to deal with irrelevent inputs & O & 0 & O & O & O \\
\hline $\begin{array}{l}\text { Ability to extract linear } \\
\text { combinations of features }\end{array}$ & 0 & O & 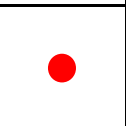 & 0 & O \\
\hline Interpretability & O & 0 & $\theta$ & 0 & 0 \\
\hline Predictive power & 0 & 0 & 0 & 0 & 0 \\
\hline
\end{tabular}

Key: $=$ good, $=$ fair, and $\bigcirc=$ poor. 
Table 1.3. A review of environmental covariates used in digital soil mapping of carbon. Adapted from Minasny et al. (2013).

\begin{tabular}{|c|c|}
\hline Covariates & References \\
\hline Aerial Image & Chen et al., 2000; Muńoz and Kravchenko, 2011 \\
\hline Apparent Electrical Conductivity & Simbahan et al., 2006; Miklos et al., 2010 \\
\hline (Lea) ra & $\begin{array}{l}\text { McKenzie and Ryan, 1999; Henderson et al., 2005; Bui et al., 2009; Mishra et al., } \\
\text { 2009; Stroorvogel et al., 2009; Mishra et al., 2010; Phachomphon et al., 2010; Martin } \\
\text { et al., 2011; Zhang et al., 2011; Wheeler et al., in press }\end{array}$ \\
\hline Compound Topographic Index & Moore et al., 1993; Gessler et al., 2000; Rawlins et al., 2009 \\
\hline Depth to Groundwater & Meersmans et al., 2008; Kempen et al., 2011 \\
\hline Elevation/Relief/Slope & $\begin{array}{l}\text { McKenzie and Ryan, 1999; Henderson et al., 2005; Simbahan et al., 2006; Bui et al., } \\
\text { 2009; Mishra et al., 2009; Rawlins et al., 2009; Phachomphon et al., 2010; Vasques et } \\
\text { al., 2010; Razakamanarivo et al., } 2011\end{array}$ \\
\hline Gamma Radiometrics & Malone et al., 2009; Rawlins et al., 2009; Miklos et al., 2010; Wheeler et al., in press \\
\hline Hyperion Hyperspectral Data & Gomez et al., 2008 \\
\hline Hyperspectral image & $\begin{array}{l}\text { Selige et al., 2006; Stevens et al., } 2010 \text { Grimm et al., 2008; Meersmans et al., 2008; } \\
\text { Mora-Vallejo et al., 2008; Bui et al., 2009; Stroorvogel et al., 2009; }\end{array}$ \\
\hline Land Cover/Use & $\begin{array}{l}\text { Mendonca Santos et al., 2010; Mishra et al., 2010; Kempen et al., 2011; Martin et al., } \\
\text { 2011; Wiesmeier et al., 2011; Zhang et al., } 2011\end{array}$ \\
\hline Landsat & $\begin{array}{l}\text { Henderson et al., 2005; Minasny et al., 2006; Huang et al., 2007; Bui et al., 2009; } \\
\text { Malone et al., 2009; Marchetti et al., 2010; Mendonca Santos et al., 2010; Vasques et } \\
\text { al., } 2010\end{array}$ \\
\hline Legacy Lab Data & Henderson et al., 2005; Bui et al., 2009; Mishra et al., 2009; Mishra et al., 2010; \\
\hline Lithology & $\begin{array}{l}\text { McKenzie and Ryan, 1999; Henderson et al., 2005; Bui et al., 2009; Mendonca Santos } \\
\text { et al., 2010; Mishra et al., 2010; Wiesmeier et al., 2011; Wheeler et al., in press }\end{array}$ \\
\hline NDVI & $\begin{array}{l}\text { Bou Kheir et al., 2010; Burnham and Sletten, 2010; Mishra et al., 2010; Zhao and Shi, } \\
\text { 2010; Kunkel et al., } 2011\end{array}$ \\
\hline Paleogeography & Kempen et al., 2011 \\
\hline Parent Material & Grimm et al., 2008; Bou Kheir et al., 2010 \\
\hline Potential Insolation & Kunkel et al., 2011 \\
\hline Remotely Sensed VIS-NIR-SWIR & Bartholomeus et al., 2011 \\
\hline Soil Classification & $\begin{array}{l}\text { Henderson et al., 2005; Simbahan et al., 2006; Grimm et al., 2008; Meersmans et al., } \\
\text { 2008; Bui et al., 2009; Rawlins et al., 2009; Bou Kheir et al., 2010; Phachomphon et } \\
\text { al., 2010; Ungaro et al., 2010; Kempen et al., 2011; Martin et al., 2011; Wiesmeier et } \\
\text { al., 2011; Zhang et al., 2011 }\end{array}$ \\
\hline Surface Reflectance from IKONOS & Simbahan et al., 2006 \\
\hline $\begin{array}{l}\text { Terrain Attributes/Topography/ } \\
\text { Geomorphology }\end{array}$ & $\begin{array}{l}\text { Mueller and Pierce et al., 2001; Henderson et al., 2005; Thompson and Kolka, 2005; } \\
\text { Minasny et al., 2006; Grimm et al., 2008; Mora-Vallejo et al., 2008; Malone et al., } \\
\text { 2009; Stroorvogel et al., 2009; Bou Kheir et al., 2010; Marchetti et al., 2010; } \\
\text { Mendonca Santos et al., 2010; Miklos et al., 2010; Mishra et al., 2010; Muńoz and } \\
\text { Kravchenko, 2011; Zhao and Shi, 2010; Kempen et al., 2011; Wiesmeier et al., 2011; } \\
\text { Wheeler et al., in press }\end{array}$ \\
\hline Vis-NIR Portable Spectrometer & Huang et al., 2007; Gomez et al., 2008; Muńoz and Kravchenko, 2011 \\
\hline
\end{tabular}


Table 1.4. Average SOC Estimates for the upper $1 \mathrm{~m}$ of soil in the Eastern Allegheny Plateau and Mountains adapted from Jenkins (2001).

\begin{tabular}{|l|c|}
\hline Source & SOC $\mathbf{( k g ~ ~ ^ { - 2 }}$ ) \\
\hline Kern (1994) & \\
$\quad$ Ecosystem Approach & $28.1-32.0$ \\
$\quad$ Soil Taxonomy & $13.6-15.0$ \\
Eswaran et al. (1993) & \\
$\quad$ World Soils Map & $10.6-12.1$ \\
Bliss et al. (1995) & \\
$\quad$ Soil Interpretation Database & 2.2 \\
Jenkins (2001) & \\
$\quad$ Mesic Series & $8.9-11.7$ \\
$\quad$ Frigid Hardwood Sites & $12.9-18.8$ \\
$\quad$ Frigid Spruce Sites & $11.3-13$ \\
Mishra et al. (2010) & 2.6 \\
STATSGO2 MLRA 127 & 4.4 \\
gSSURGO MLRA 127 & 9.0 \\
Rapid Carbon Assessment & \\
\hline
\end{tabular}




\title{
Chapter 2: Populating Missing Soil Organic Carbon Legacy Data
}

\author{
Abstract \\ Soil organic carbon (SOC), a dynamic soil property and the largest pool of terrestrial \\ organic carbon in the biosphere, plays a critical role in supplying nutrients to plants, improving \\ soil structure and aggregate stability, contributing to cation exchange capacity, and developing \\ sustainable land management practices. Due to cost of sampling and laboratory analyses, legacy \\ soil data are often used to train and validate SOC models. Missing data and methodological \\ inconsistencies are common limitations to legacy soil databases such as the Kellogg Soil Survey \\ Laboratory (KSSL) database. Data preparation, including data assemblage, updating series \\ correlation, methodological correction factors, normality testing, outlier assessment, and \\ estimation and validation of missing data, is essential for the extrapolation of soil properties \\ across space. MLRA 127 (Eastern Alleghany Plateau and Mountains) was chosen as the study \\ area for this research due to its complex, high dissected topography and diverse climatic, \\ vegetative, and pedogenic properties that present challenges to pedoecological mapping. KSSL \\ pedons sampled by the Natural Resources Conservation Service (NRCS) within MLRA 127 were \\ downloaded from the National Cooperative Soil Survey (NCSS) soil characterization database \\ and classified using the most current version of U.S. Soil Taxonomy. Because SOC stock is \\ calculated from rock fragments (volume \%), SOC (\%), soil thickness, and $33 \mathrm{kPa}$ bulk density (g \\ $\mathrm{cm}^{-3}$ ), these specific data were prepared. SOC data that were determined by wet combustion were \\ converted to dry combustion total carbon percentages using a nationally developed pedotransfer \\ function (PTF) to avoid methodological biases. Missing SOC and bulk density (BD) data were \\ predicted using random forest (RF) and mean and median values by horizon designation and \\ texture class. Outliers were identified using box and whisker plots and were both incorporated \\ and removed from analysis to determine their role in prediction. RF performed best at predicting \\ $\mathrm{BD}\left(\mathrm{R}^{2}=0.69, \mathrm{RMSE}=0.16\right)$. Mean by horizon designation and texture class with outliers \\ included performed slightly better than $\mathrm{RF}$ for $\mathrm{SOC}\left(\mathrm{R}^{2}=0.93, \mathrm{RMSE}=3.96\right.$ and $\mathrm{R}^{2}=0.9$, \\ RMSE $=4.7$, respectively). RF is a better predictor model for mineral horizons while mean by \\ horizon and texture class is better for predicting organic horizons. Given the stability of \\ prediction and simplicity of training and validation, $\mathrm{RF}$ is the recommended method for \\ populating missing soil legacy data.
}




\section{Introduction}

Lab characterization pedon data and site descriptions for soils sampled by the NRCS are available to the public through the NCSS soil characterization database. Approximately 20,000 pedons were sampled by soil scientists in the United States over the last 40 years for university or federal research, establishment of a soil series, soil survey updates, or population of the range in characteristics for a soil series (NCSS National Cooperative Soil Characterization Database, 2013). Some of these KSSL pedons are missing BD and SOC data (especially for organic horizons), rock fragment content, land use history, sampling protocols, and are not always georeferenced (Jenkins, 2001; West et al., 2010; Minasny et al., 2013; Wills et al., 2013). Wills et al. (2013) examined the KSSL national database and found that of the 176,000 horizons with SOC measurements, only $40 \%$ had BD values populated. All of the BD were measured using saran coated clods (3B1c) (Burt, 2004). Using the clod method on soil horizons with high root content, organic matter, or rock fragment content may result in inaccurate BD (Jenkins, 2001). Of the 176,000 carbon measurements, $28 \%$ were characterized by dry combustion (4H2a1-3) (Burt, 2004), 65\% by wet combustion (6A1c) (Burt, 2004), and 7\% with both. In dry combustion, all forms of soil carbon are converted into carbon dioxide $\left(\mathrm{CO}_{2}\right)$ and the evolved $\mathrm{CO}_{2}$ is measured. SOC is then calculated by subtracting inorganic carbon (carbonates) from total carbon. Wet combustion, performed as the Walkley-Black modified acid-dichromate digestion, involves chemically oxidizing the most active forms of SOC to $\mathrm{CO}_{2}$ with ferrous sulfate $\left(\mathrm{FeSO}_{4}\right)$ and then quantifying the $\mathrm{FeSO}_{4}$ used in the chemical reaction (Soil Survey Staff, 2011). Due to its high precision, accuracy, and low chemical wastes, dry combustion has become the standard SOC method for the NRCS and most of the world (Tivet et al., 2012). SOC estimates by wet combustion, used by the KSSL prior to the 1990s, have been shown to underestimate total SOC due to incomplete oxidation (Tivet et al., 2012; Michaelson et al., 2013), overestimate SOC in deeper horizons (Grossman et al., 2001), and be invalid if SOC is greater than $8 \%$ (Soil Survey Staff, 2011). In order to avoid methodological biases in datasets with both wet and dry combustion measurements, a carbon-equivalent correction regression factor must be applied to horizons analyzed by wet combustion (Tivet et al., 2012 and Wills et al., 2013).

Populating missing soil legacy data has been historically achieved through pedotransfer functions (PTF). For calculating SOC, these functions are usually only applicable to the study area for which they were developed, often contain correlated variables that lead to 
multicolinearity, and make implausible normality assumptions (Tomasella et al., 2000; Minasny et al., 2008). Because most soil data are not normally distributed even with common transformations, nonparametric techniques such as boosted regression tree (BRT), random forest (RF), k-nearest neighbor (k-NN), and neural networks are recommended (Jobbágy and Jackson, 2000; Minasny et al., 2008; Keller et al., 2012; Pan et al., 2013; Razafimbelo et al., 2013). These four techniques have been shown to perform similarly, although researchers have preferred one method over another among different studies (Nemes et al., 2006; Hudak et al., 2008; Myers et al., 2009; Strobl et al., 2009; Ghehi et al., 2011). Myers et al. (2009) compared RF, BRT, regression tree, general additive models (GAM), multivariate adaptive regression splines (MARS), and generalized linear models (GLM) techniques to predict BD. They found all techniques to perform similarly, with MARS performing the best by only a slight margin. Montillo (2009) summarized the advantages and limitations of artificial neural networks (ANN), k-NN, BRT, SVM, and MARS (Table 2.1). He concluded that RF has about the same accuracy as SVM and ANN, but is more interpretable, faster to train, has fewer parameters, can handle missing data, readily handles larger numbers of predictors, and doesn't require cross-validation. BRT are often more accurate at predicting a continuous response, but perform about the same as RF for classification. According to Montillo (2009), RF is advantageous over BRT because RF grows trees independently of one another, is quicker to run, requires less parameters, and does not over-fit the data.

There are two main sources of model prediction error that lead to over- or under-fitting a dataset: bias and variance (Fig. 2.1). Error due to bias is the difference between the average modeled predictions and the actual values. Error due to variance is a measure of the variability within the modeled predictions for a given point over several model iterations. Through RF, many decision trees are generated based on a random sampling of covariates and points within the training dataset. These decision trees are then averaged together to yield a "full" RF model. The bias error of a full RF model is equal to the bias error of a single decision tree, but variance error in the full model will be lower than that of a single decision tree (Breiman, 2001;

Fortmann-Roe, 2012). Given the complexity of RF models, variance error is the most common cause of over-fitting.

According to Batjes (2003), the most desirable method for filling data gaps is collecting additional measured soil data, followed by using national expert estimates and tacit knowledge, 
and lastly using taxotransfer rules to derive soil property estimates. Wills et al. (2013) and West et al. (2010) used a nationally derived mean BD of $1.45 \mathrm{~g} \mathrm{~cm}^{-3}$ for mineral soils and $0.25 \mathrm{~g} \mathrm{~cm}^{-3}$ for organic horizons to replace missing BD in KSSL pedons. Similarly, Buell and Markewich (2004) calculated missing BD from median BD of soil texture class. Sequeira et al. (2014) used RF to predict missing KSSL BD from the following soil properties: horizon designation, textural class, median soil horizon depth, and horizon thickness. The measured BD of horizons above, below, adjacent, or not adjacent to horizons missing BD measurements were also incorporated in the RF model when applicable. The objective of this study was to incorporate the methodology used by Sequira et al. (2014) and develop a standard methodology for populating missing KSSL data for use in digital soil mapping and modeling. Missing SOC and BD were predicted and cross-validated from prepared KSSL data using RF and mean and median values by horizon designation and texture.

\section{Material and Methods}

\section{Obtaining and Preparing KSSL data}

KSSL site and pedon data within MLRA 127 were downloaded from the NCSS soil characterization database and were then prepared for missing KSSL data population. Preparation included evaluating site and pedon data, updating the pedon taxonomic classification to current U.S. Soil Taxonomy (Soil Survey Staff, 2014), and assembling site and pedon data into one database (Sulaeman et al., 2013). Only sites that were georeferenced or contained detailed site location descriptions were used in this study. Mine soils and pedons that could not be fully classified in U.S. Soil Taxonomy were also excluded from this study. As a result, 254 pedons within MLRA 127 were evaluated, updated to current U.S. Soil Taxonomy (Soil Survey Staff, 2014), and correlated to an established soil series (Appendices A and B). During the evaluation, it was found that 135 of the 254 sites were not correlated to any soil series and two of the 254 sites were not sampled or correlated as any soil series. When updated to current Soil Taxonomy, 169 of the 254 pedons had properties outside of the Range in Characteristics (RIC) of the correlated series and were therefore identified as series taxadjuncts. The most common properties outside of the RIC were horizon color or texture and depth to fragipan, argillic horizon, or bedrock. Forty of the 128 pedons in the KSSL database were correlated to the incorrect soil series based on the current version of Soil Taxonomy. 
KSSL data can be queried from the NCSS characterization database and downloaded by layer data tiers that contain pedon ID, soil horizons and depths, soil property analyses, and corresponding KSSL methods (Burt, 2004). Site data containing geographic location and pedon data containing taxonomic classifications can also be downloaded. For this study, the following horizon data were downloaded from the NCSS soil characterization database: field and lab texture class, sand, silt, clay, total nitrogen, $\mathrm{C}: \mathrm{N}$, $\mathrm{pH}$ in water, SOC, total carbon, carbonates, 33 $\mathrm{kPa} \mathrm{BD}$, oven-dried BD, sodium, base saturation, extractable acidity, aluminum, aluminum plus half iron oxalate, cation exchange capacity (CEC), optical density, and rock fragments $>2 \mathrm{~mm}$. Horizon Munsell value, Munsell chroma, estimated rock fragment volume, geographic coordinates, series sampled as, series correlated as, taxonomy, new series correlated as, depth class, epipedon, and land cover were manually recorded for each site or horizon from site and pedon descriptions. Sites were then projected in ArcGIS and intersected with geology (Dicken et al., 2005; Nicholson et al., 2005), temperature regime (Waltman et al., 2006), and moisture regime (Winzeler et al., 2013). These three properties were added to the MLRA 127 KSSL database due to their importance in soil series and taxonomic classification. For the KSSL horizons in MLRA 127, it was found that 50\% were missing BD and $13 \%$ were missing SOC.

\section{Carbon-equivalent Correction Factor}

Total carbon by dry combustion was first used in 1993 for the KSSL pedons in MLRA 127. All pedons sampled before 1993 quantified SOC by wet combustion. Only the eighteen pedons sampled in 1995 measured carbon by both wet and dry combustion. In order to avoid methodological biases in this study, a carbon-equivalent correction regression factor was used to adjust SOC in pedons sampled prior to 1993 (Tivet et al., 2012; Wills et al., 2013). Tivet et al. (2012) recommend using carbon-equivalent correction factors derived from data within the area of interest instead of using regionally or nationally derived correction factors. Since the eighteen pedons that contained both wet and dry combustion measurements only represented three counties in MLRA 127, a nationally developed carbon-equivalent correction regression factor developed by Wills et al. (2013) was used to transform SOC values sampled before 1993:

$$
(\mathrm{OC}(\text { dry combustion })=0.25+0.86(\text { wet combustion }))
$$


Since zero or trace amounts of carbonates were reported for all pedons in MLRA 127, total carbon from dry combustion was assumed to be SOC.

$\underline{\text { Outliers }}$

KSSL pedon data, like most environmental data, contain outliers due to errors associated with sampling, field description, lab analyses, data entry, or uncharacteristic environmental variability. In this study, methods for populating missing lab data were compared with and without outliers. Outliers were detected visually and quantitatively for horizon and texture class combinations of SOC content and BD using box-and-whisker plots. Outliers were identified as samples that extended above or below the whiskers. The whiskers represented 1.5 times the interquartile range (IQR) for the given horizon designation and corresponding texture classes (Sequeira et al., 2014) (Fig. 2.2).

Normality

Normality was assessed visually by histograms and statistically by the D'Agostino's test in R with and without outliers (Appendix C). The D'Agostino's test was chosen to assess normality because sample sizes of SOC and BD were greater than 50 (U.S. EPA, 2002). The D'Agostino skewness, kurtosis, and chi-squared statistics for both SOC and BD with and without outliers by horizon and texture were calculated in R. Skewness is a measure of asymmetry and is calculated in Appendix $\mathrm{C}$ as:

$$
\sqrt{b_{1}}=m_{3} / m_{2}^{3 / 2}
$$

where

$$
m_{k}=\sum\left(x_{i}-\bar{x}\right)^{k} / n
$$

and $\bar{x}$ is the sample mean.

$$
\bar{x}=\sum x_{i} / n
$$

Kurtosis is a measure of curvature and is calculated as: 


$$
b_{2}=m_{4} / m_{2}^{2}
$$

[Eq. 2-5]

The D'Agostino chi-squared statistic is an omnibus test in that it can detect deveations from normality caused by skewness or kurtosis (D'Agostino et al., 1990). It is calculated as:

$$
K^{2}=Z^{2}\left(\sqrt{b_{1}}\right)+Z^{2}\left(b_{2}\right)
$$

where $Z^{2}\left(\sqrt{b_{1}}\right)$ and $Z^{2}\left(b_{2}\right)$ are normal approximations of skewness and kurtosis and $K^{2}$ has approximately a chi-squared distribution with two degrees of freedom when normally distributed. The skewness, kurtosis, and D'Agostino statistics revealed that the data were not normally distributed (Table 2.2). Logarithmic and square root transformations were also explored, but failed to exhibit normality. Because the data were not normally distributed, nonparametric techniques such as RF, median, and mean were used in this study on the untransformed dataset.

$\underline{\text { Random Forest }}$

$\mathrm{RF}$ is a nonparametric, recursive partitioning machine learning technique that trains regression trees with a random subset of covariates and a random sample from the training set. In standard classification and regression trees (CART), each node is determined based on the best split among all variables. In RF, each node is split using the best among a subset of predictors (mtry) randomly sampled at each node (Liaw and Wiener, 2002). Samples that were not randomly selected for the contruction of a given decision tree are used for out-of-bag error (ERR ${ }_{\text {Oов }}$ ) calculations. ERR ${ }_{\text {Oов }}$ is an internal cross-validation technique built into RF models that can be used to prevent over-fitting and determine the optimal number of trees (ntree) and mtry values to minimize model error (Vincenzi et al., 2011). According to Breiman (2001), RF is robust against over-fitting. Contradictorily, some studies have shown that RF can over-fit data, especially in small datasets. The ntree and mtry parameters should be tuned for every RF model to reduce the chance of over-fitting (Segal, 2004; Statnikov et al., 2008).

Prepared KSSL SOC and BD data were randomly split into $70 \%$ training and 30\% testing datasets (Appendix D). Because the randomForest package in $\mathrm{R}$ can only handle 32 categories within a given variable, horizon designations were grouped into 13 final horizon designations (Table 2.3) (Sequeira et al., 2014). The following variables were included in the RF model: median horizon depth, horizon designation, texture class, sand, silt, clay, Munsell value, Munsell 
chroma, epipedon, pedon depth, land cover, soil order, geologic age, dominant geologic rock type, second dominant geologic rock type, geologic group, temperature regime, $\mathrm{pH}$, moisture regime, soil climate zone derived from the tactic knowledge of MLRA 127 soil scientists, soil taxonomic mineralogy class, clay activity class, subgroup, great group, and particle-size class. The ntree and mtry parameters in the RF model were determined by the lowest ERRoOB in each model (Table 2.4) (Vincenzi et al., 2011). Once the model was created from the training set, it was applied to the test set. Because outliers did not affect the performance of RF, only RF with outliers is reported in this study.

Mean and Median by Horizon Designation and Texture Class

The same training and test sets used in the RF model were used to calculate the mean and median of each horizon designation and texture class combination in the training set (Appendix E). These means and medians were then applied to the test set. If a horizon designation texture class combination (e.g., A/silty clay) had only one observation or was not in the training or test set, it was assigned the mean or median value of the closest texture class (e.g., A/silty clay loam). The texture class nearest on the texture triangle was determined to be the closest texture class.

\section{Model Validation and Comparison}

Linear regression was used to determine the relationship between observed and predicted values for the RF model and mean and median techniques:

$$
y_{i}=\beta_{0}+\beta_{1} x_{i}+u_{i}
$$

where $y_{i}$ is the predicted value for sample $i, x_{i}$ is the observed value for sample $i, \beta_{1}$ is the slope of the best fit line, $\beta_{0}$ is the intercept, and $u_{i}$ is the error term for observation $i$. The coefficient of determination $\left(\mathrm{R}^{2}\right)$ (Eq. 8) and root mean square error (RMSE) (Eq. 9) statistical tests were used for model validation and comparison:

$$
\begin{array}{r}
R^{2}=1-\frac{\sum_{i=1}^{n}\left(y_{i}-\hat{y}_{i}\right)^{2}}{\sum_{i=1}^{n}\left(y_{i}-\bar{y}_{i}\right)^{2}} \\
\mathrm{RMSE}=\sqrt{\frac{\sum_{i=1}^{n}\left(y_{i}-\hat{y}_{i}\right)^{2}}{n}}
\end{array}
$$


where $\mathrm{n}$ is the number of observations, $\mathrm{i}$ is the sample, $y_{i}$ is the dependent variable, $\hat{y}_{i}$ is the predicted value, and $\bar{y}_{i}$ is the mean of the $y_{i}$ values (UCLA Statistical Consulting Group, 2011).

Variable importance quantified by the RF model was used to assess the dataset and compare the different RF models. The variable importance measurement in a RF model estimates the relative importance of a variable by quantifying prediction error when OOB data for a given variable are permuted while all others are left unchanged. Prediction error is first calculated on the OOB portion of the data and then for each variable using a random permutation of the values for a given variable. Lastly, the differences in prediction errors for each variable are averaged over all trees. In RF regression trees, variable importance is quantified using the following parameters: percentage increase in mean squared errors (\% IncMSE) and increase in node purity (IncNodePurity). The \%IncMSE is the difference between the prediction errors averaged over all trees, normalized by the standard deviation of the differences. The IncNodePurity is measured by residual sum of squares as the total decrease in node impurities as a result of splitting on a given variable, averaged over all trees. Higher values in both of the \%IncMSE and IncNodePurity parameters indicate more important variables in the RF model (Liaw and Wiener, 2002).

\section{Results and Discussion}

Outliers did not limit the predictability of the models (Tables 2.5 through 2.8). Mean by horizon designation and texture with outliers performed slightly better than RF for predicting $\operatorname{SOC}\left(\mathrm{R}^{2}=0.93, \mathrm{RMSE}=3.96\right.$ and $\mathrm{R}^{2}=0.9, \mathrm{RMSE}=4.7$, respectively) (Figs. 2.3 through 2.6; Tables 2.5 and 2.6), while RF performed best for predicting $B D\left(\mathrm{R}^{2}=0.69\right.$, $\left.\mathrm{RMSE}=0.16\right)$ (Figs. 2.7 through 2.10; Tables 2.7 and 2.8). The RF model performed best for mineral horizons while mean by horizon and texture performed best for predicting organic horizons. The small sample size and high variability in the organic horizons limited the predictability of the RF model, making the mean and median techniques more desireable for predicting organic horizons. When all horizons were being modeled, however, the RF model outperformed the mean and median models in stability of prediction for both BD and SOC.

Horizon designation and soil taxonomic great group were found to be important variables for predicting BD and SOC (Figs. 2.11 and 2.14). For SOC, horizon designation, color (Munsell chroma and value), and depth were more important for predicting organic horizon while horizon texture and soil taxonomic great group were more important for predicting mineral horizons (Figs. 2.12 and 2.13). For BD, horizon designation, depth, and soil taxonomic great group were 
more important for predicting organic horizons while Munsell chroma, soil taxonomic group, and dominant geologic rock type were more important for predicting mineral horizons (Figs. 2.15 and 2.16). Epipedon and land cover were the least important variables for predicting BD and SOC.

The BD RF models of Sequeira et al. (2014) had similar $\mathrm{R}^{2}$ and RMSE values as those in this study. The $\mathrm{R}^{2}$ and RMSE statistics for the SOC models were higher than BD, indicating that the covariates were explaining more of the variance in the model, but the standard deviation of the unexplained variance was higher. SOC values in the full model ranged from 0.01 to $73.7 \%$ while BD values ranged from 0.04 to $2.01 \mathrm{~g} \mathrm{~cm}^{-3}$. Given the high variability in SOC, it is logical that SOC has a higher standard deviation of unexplained variance than BD. The high variance in the SOC data coupled with the complexity of the RF model might have led to over-fitting (Fortmann-Roe, 2012). Future research is needed to detect and account for over-fitting in RF models (Segal, 2004; Statnikov et al., 2008; Fortmann-Roe, 2012).

\section{Conclusions}

Data preparation, updating soil series correlation, methodological correction factors, normality testing, outlier assessment, and estimation and validation of missing data is essential for data extrapolation (Sulaeman et al., 2013). In this study, KSSL data were downloaded and assembled for MLRA 127, taxonomic classification and series correlation were updated to current Soil Taxonomy, wet combustion SOC values were converted to dry combustion through a PTF, normality was tested by D'Agostino's statistic, outliers were identified through box and whisker plots, and known BD and SOC data were split into training and testing sets for analysis. Given the stability of prediction and simplicity of training and validation, RF is the recommended method for populating missing soil legacy data (Sequeira et al., 2014). RF, having similar predictive power as all other nonparametric machine learning techniques, provides a quick, interpretable estimation of any soil property that can be improved with more data and variables (Nemes et al., 2006; Hudak et al., 2008; Myers et al., 2009; Strobl et al., 2009; Ghehi et al., 2011). Although RF is the recommended method for populating missing soil legacy data, research is still needed to detect and account for over-fitting in RF models (Segal, 2004; Statnikov et al., 2008; Fortmann-Roe, 2012). Tuning of the ntree and mtry have been shown to

reduce over-fitting in RF models, but techniques have not been developed to measure the amount of over-fitting that occurs in RF models (Segal, 2004; Statnikov et al., 2008). 


\section{Literature Cited}

Breiman, L. 2001. Random Forests. Machine Learning. 45 (1): 5-32.

Buell, G.R. and H.W. Markewich. 2004. Data compilation, synthesis, and calculations used for organic-carbon storage and inventory estimates for mineral soils of the Mississippi River Basin. U.S. Geological Survey Professional Paper 1686-A. $<$ http://pubs.er.usgs.gov/publication/pp1686A>.

Burt, R., Ed. 2004. Soil Survey Laboratory Methods Manual, Soil Survey Investigations Report No. 42 Version 4.0. Lincoln, NE: Natural Resources Conservation Service, U.S. Department of Agriculture.

D’Agostino, R.B., A. Belanger, and R.B. D’Agostino Jr. 1990. A suggestion for using a powerful and informative test for normality. The American Statistician. 44: 316-321.

Dicken, C.L., S.W. Nicholson, J.D. Horton, S.A. Kinney, G. Gunther, M.P. Foose, and J.A.L. Mueller. 2005. Integrated Geologic Map Databases for the United States: Delaware, Maryland, New York, Pennsylvania, and Virginia: U.S. Geological Survey Open-File Report 2005-1325, U.S. Geological Survey, Reston, VA.

Fortmann-Roe, S. 2012. Understanding the bias-variance tradeoff. < http://scott.fortmannroe.com/docs/BiasVariance.html>.

Ghehi, N.G., A. Nemes, A. Verdoodt, E. Van Ranst, W.M. Cornelis, and P. Boeckx. 2011. Nonparametric techniques for predicting soil bulk density of tropical rainforest topsoils in Rwanda. Soil Science Society of America Journal. 76 (4): 1172-1183.

Grossman, R.B., D.S. Harms, D.F. Kingsbury, R.K. Shaw, and A.B. Jenkins. 2001. Assessment of soil SOC using the U.S. soil survey, in Assessment methods for soil carbon, edited by R. Lal, J.M. Kimble, R.F. Follett, and B.A. Stewart. 87-104.

Hudak, A.T., N.L. Crookston, J.S. Evans, D.E. Hall, and M.J. Falkowski. 2008. Nearest neighbor imputation of species-level, plot scale forest structure attributes from LiDAR data. USDA Forest Service/University of Nebraska-Lincoln Faculty Publications. Paper 211. <http://digitalcommons.unl.edu/usdafsfacpub/211>.

Jenkins, A. 2001. SOC and Fertility of Forest Soils on the Allegheny Plateau of West Virginia. M.S. thesis, West Virginia University, Morgantown, WV. <http://etd.wvu.edu/templates/showETD.cfm?recnum=2486>. 
Jobbágy, E. G. and R.B. Jackson. 2000. The vertical distribution of soil SOC and its relation to climate and vegetation. Ecological Applications. 10:423-436.

Keller, J.K., K.K. Takagi, M.E. Brown, K.N. Stump, C.G. Takahashi. 2012. Soil SOC storage in restored salt marshes in Huntington Beach, California. Bulletin of Southern California Academy of Sciences. 111 (2). <http://scholar.oxy.edu/scas/vol111/iss2/5>.

Liaw, A. and M. Wiener. 2002. Classification and regression by randomForest. R News. 2/3: 1822.

Michaelson, G.J., C.L. Ping, M. Clark. 2013. Soil pedon carbon and nitrogen data for Alaska: an analysis and update. Open Journal of Soil Science. 3: 132-142.

Minasny, B., A.B. McBratney, N.J. McKenzie, and M.J. Grundy. 2008. Predicting soil properties using pedotransfer functions and environmental correlation. N.J. McKenzie, M.J. Grundy, R. Webster, A.J. Ringrose-Voase (Eds.). Guidelines for Surveying Soil and Land Resources, Australian Soil and Land Survey Handbook Series, CSIRO Publishing, Melbourne (2008). 349-367.

Minasny, B., A.B. McBratney, B.P. Malone, and I. Wheeler. 2013. Digital mapping of soil carbon. Advances in Agronomy. 118: 1-47.

Montillo, A.A. "Random Forests," Lecture in Statistical Foundations of Data Analysis. April 2009. <http://www.dabi.temple.edu/ hbling/8590.002/Montillo_RandomForests_4-22009.pdf>.

Myers D.B., S. Grunwald, G.M. Vasques and W.G. Harris. 2009. Pedotransfer functions for carbon methods and bulk density estimation in Florida soils. ASA-CSSA-SSSA Meeting, Pittsburgh, PA, Nov. 1-4, 2009.

National Cooperative Soil Survey (NCSS). 2013. National Cooperative Soil Characterization Database. <http://ncsslabdatamart.sc.egov.usda.gov>.

Nemes, A. W.J. Rawls, and Y.A. Pachepsky. 2006. Use of the nonparametric nearest neighbor approach to estimate soil hydraulic properties. Soil Science Society of America Journal. 70 (2): 327-336.

Nicholson, Suzanne W., Dicken, Connie L., Horton, John D., Labay, Keith A., Foose, Michael P., and Mueller, Julia A. L., 2005, Preliminary integrated Geologic Map Databases for the United States: Kentucky, Ohio, Tennessee, and West Virginia: U.S. Geological Survey Open-File Report 2005-1324, U.S. Geological Survey, Reston, VA. 
Pan, C., H. Zhao, X. Zhao, H. Han, Y. Wang., and J. Li. 2013. Biophysical properties as determinants for soil SOC and total nitrogen in grassland salinization. PLoS ONE. 8(1): e54827.doi:10.1371/journal.pone.0054827.

Razafimbelo, T., T. Chevallier, A. Albrecht, L. Chapuis-Lardy, F. Nirina Rakotondrasolo, R. Michellon, L. Rabeharisoa, and M. Bernoux. 2013. Texture and SOC contents do not impact amount of carbon protected in Malagasy soils. Science Agriculture. 70 (3): 204-208.

Segal, M.R. 2004. Machine Learning Benchmarks and Random Forest Regression. Technical Report, Center for Bioinformatics \& Molecular Biostatistics. University of California, San Francisco.

Sequeira, C.H., S.A. Wills, C.A. Seybold, and L.T. West. 2014. Predicting soil bulk density for incomplete databases. Geoderma. 213: 64-73.

Soil Survey Staff. 2014. Keys to Soil Taxonomy, 12th ed. USDA-Natural Resources Conservation Service, Washington, DC.

Soil Survey Staff. 2011. Soil Survey Laboratory Information Manual. Soil Survey Investigations Report No. 45, Version 2.0. R. Burt (ed.). U.S. Department of Agriculture, Natural Resources Conservation Service.

Statnikov A., L. Wang, and C. Aliferis. 2008. A comprehensive comparison of random forests and support vector machines for microarray-based cancer classification. BMC Bioinformatics. 9:139.

Strobl, C., J. Malley, and G. Tutz. 2009. An introduction to recursive partitioning: Rationale, application, and characteristics of classification and regression trees, bagging, and random forests. Psychological Methods. 14, 323-48

Sulaeman, Y., B. Minasny, A.B. McBratney, M. Sarwani, and A. Sutandi. 2013. Harmonizing legacy soil data for digital soil mapping in Indonesia. Geoderma, 192: 77-85.

Tivet, F., J. Carlos de Morases Sá. P. R. Borszowskei. P. Letourmy, C. Briedis, A. Oliveira Ferreira, J. Burkner dos Santos, and T. Massao Inagaki. 2012. Soil carbon inventory by wet oxidation and dry combustion methods: effects of land use, soil texture gradients, and sampling depth on the linear model of c-equivalent correction factor. Soil Science Society of America Journal. 76:1048-1059.

Tomasella, J., M.G. Hodnett, and L. Rossato. 2000. Pedotransfer function for the estimation of soil water retention in Brazilian soils. Soil Science Society of America Journal. 64: 327-338. 
University of California, Los Angelos (UCLA) Statistical Consulting Group. 2011. What are pseudo R-squareds.

<http://www.ats.ucla.edu/stat/mult_pkg/faq/general/Psuedo_RSquareds.htm〉.

U.S. Environmental Protection Agency (EPA) - Office of Emergency and Remedial Response. 2002. Guidance for comparing background and chemical concentrations in soil for CERCLA sites. EPA 540-R-01-003. OSWER 9285.7-41. $<$ http://www.epa.gov/oswer/riskassessment/pdf/background.pdf $>$.

Vincenzi, S., M. Zucchetta, P. Franzoi, M. Pellizzato, F. Pranovi, G.A. De Leo, and P. Torricelli. 2011. Application of a Random Forest algorithm to predict spatial distribution of the potential yield of Ruditapes philippinarum in the Venice lagoon, Italy. Ecological Modelling. 222: 1471-1478.

Waltman, W.J., E. J. Ciolkosz, E. J., and D. A. Miller. 2006. Meta-data and Data Dictionary for the Northeast Soil Climate Atlas, a poster presented at the $18^{\text {th }}$ World Congress of Soil Science, July 9-15, 2006 - Philadelphia, Pennsylvania, USA.

West, L.T., S.W. Waltman, S. Wills, T.G. Reinsch, E.C. Benham, C.S. Smith, and R. Ferguson. 2010. Soil carbon stocks in the US: current data and future inventories. USDA-NRCS. Proc. of Int. Workshop on Evaluation and Sustainable Management of Soil Carbon Sequestration in Asian Countries. Bogor, Indonesia. Sept. 28-29, 2010.

Wills, S., C. Seybold, J. Chiaretti, C. Sequeira, and L. West. 2013. Quantifying tacit knowledge about soil SOC stocks using soil taxa and official soil series descriptions. Soil Science Society of America Journal.

Winzeler, H.E., S. W. Waltman, W. J. Waltman, , Z. Libohova, and D. Beadette. 2013. A Methodology for Examining Changes in Soil Climate Geography through Time: U.S. Soil Moisture Regimes for the Period 1971-2000. Soil Science Society of America Journal. 77: 213- 225. 
Figures and Tables

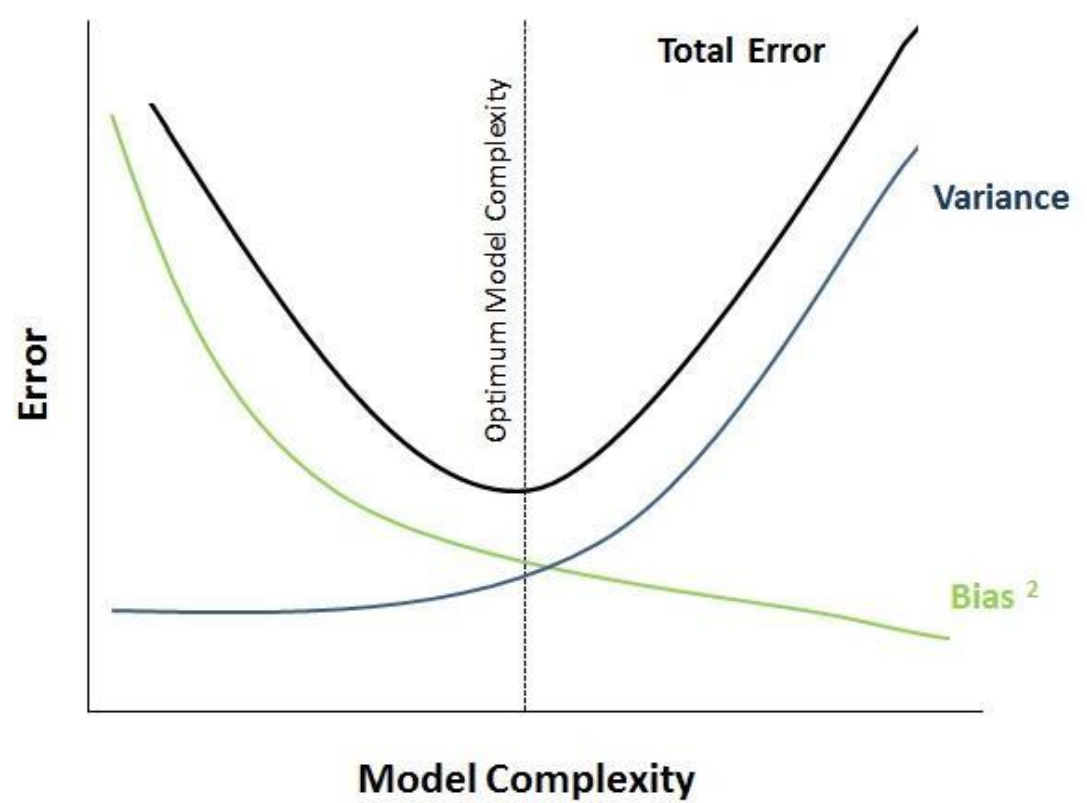

Figure 2.1 The relationship between model complexity and error adapted from Fortmann-Roe (2012). 

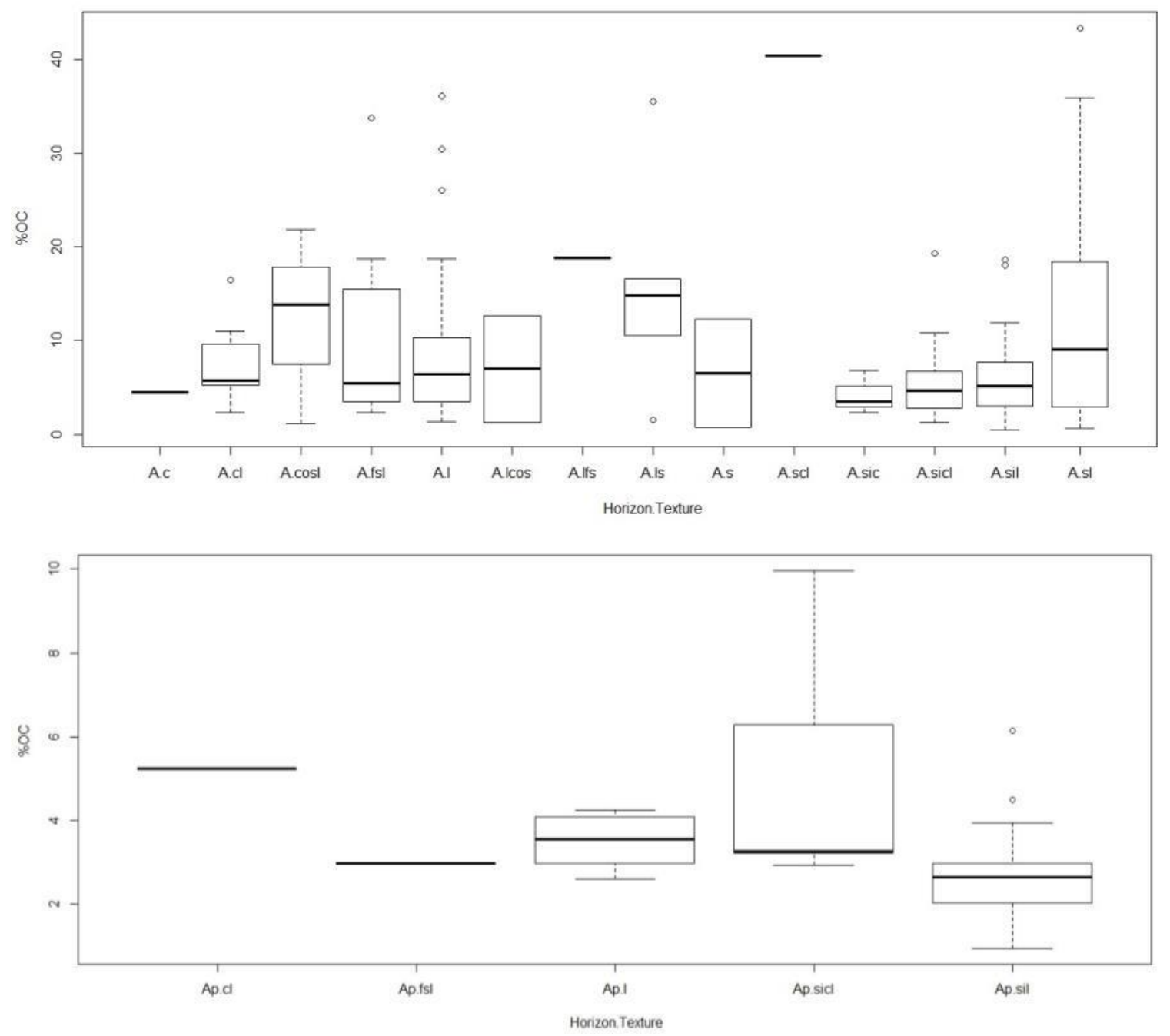

Figure 2.2 Two examples of the box and whisker plots used to determine outliers in horizon designation and texture class combinations. 


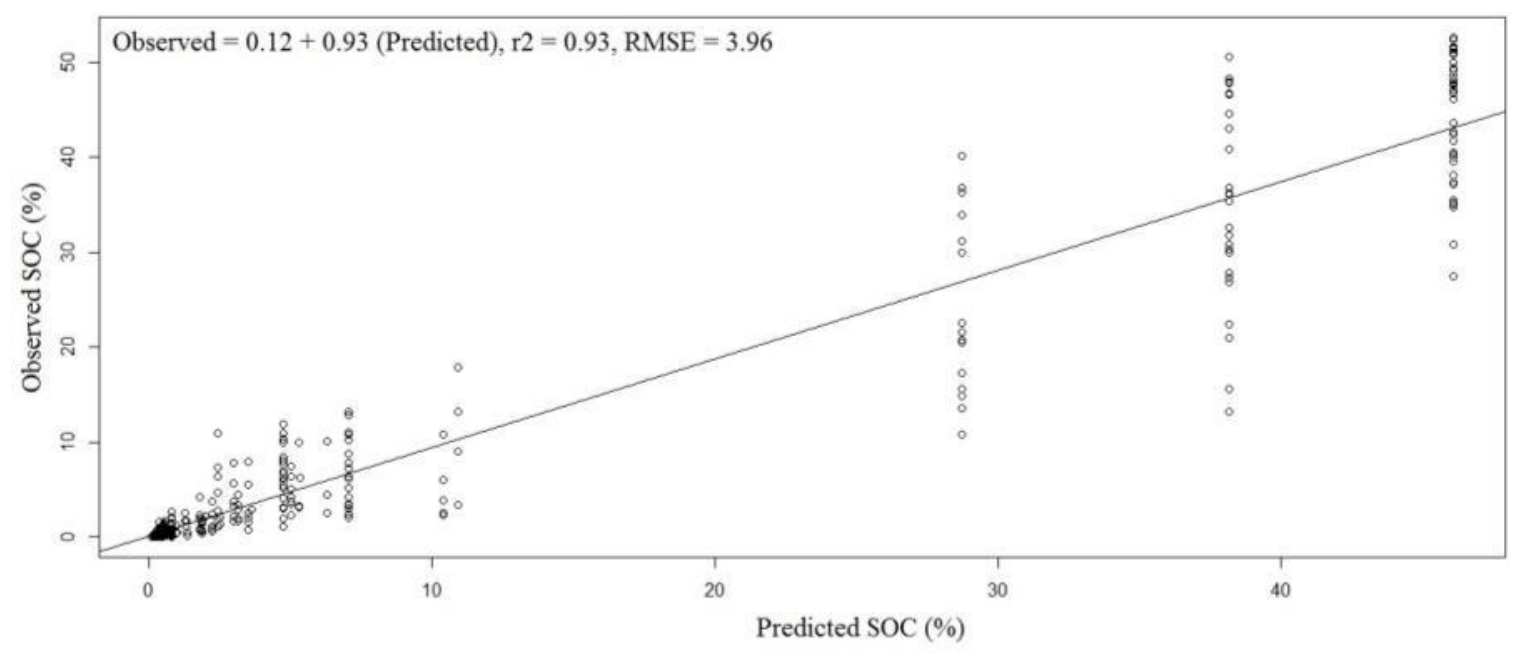

Figure 2.3 Scatter plot of predicted and observed SOC percentages using the mean by horizon and texture method with outliers included.

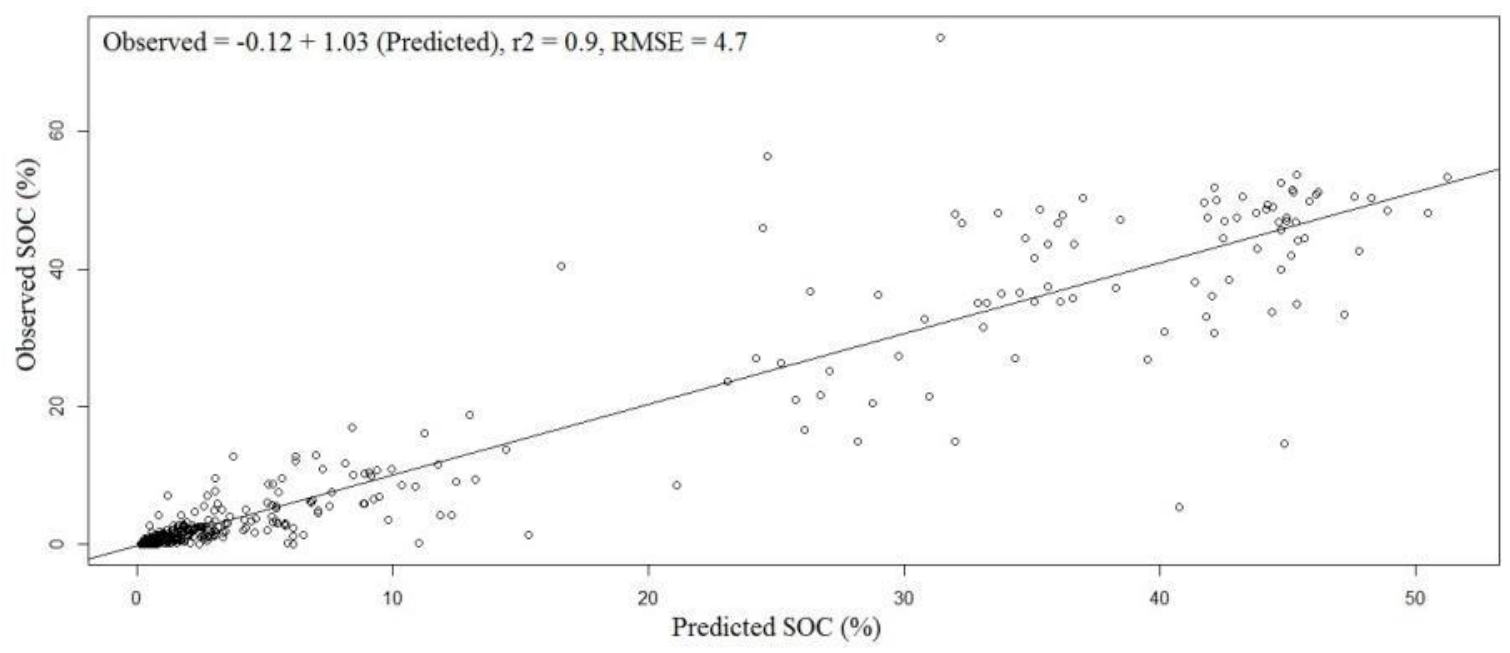

Figure 2.4 Scatter plot of predicted and observed SOC percentages using the RF method. 


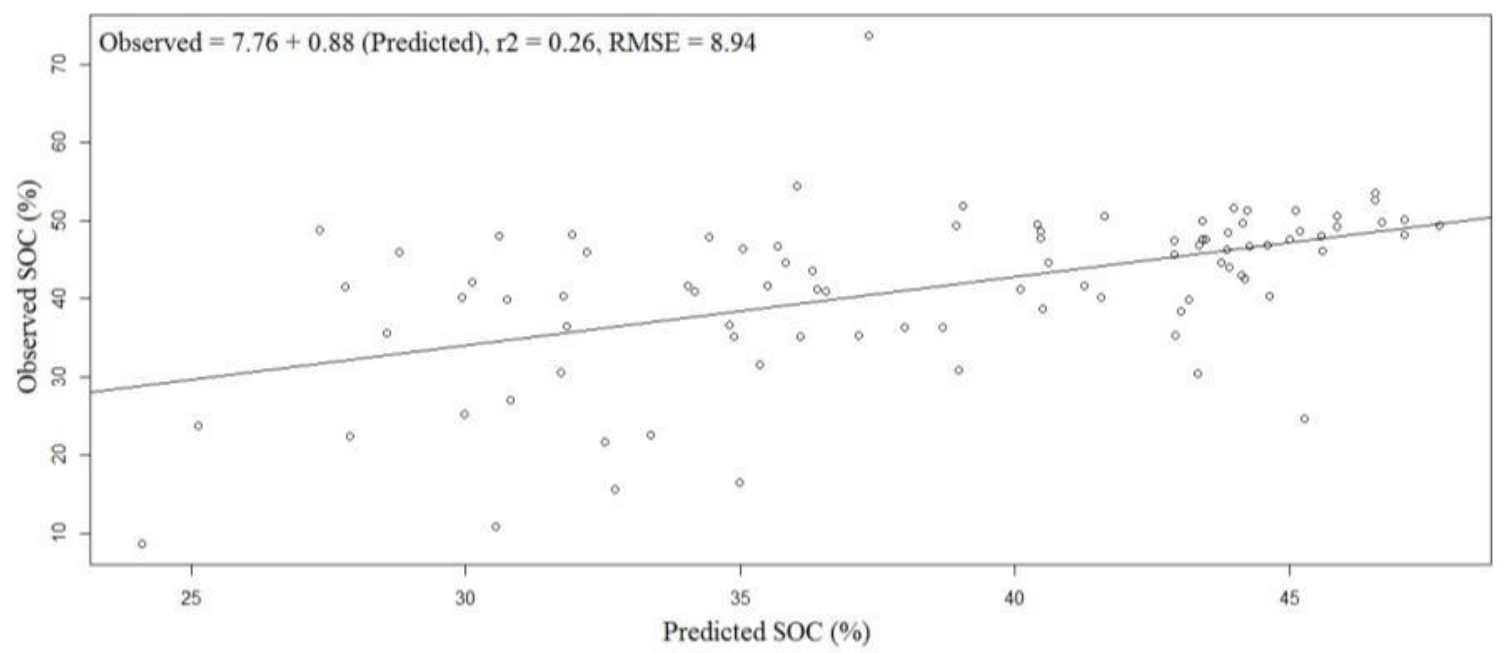

Figure 2.5 Scatter plot of predicted and observed organic horizon SOC percentages using the RF method.

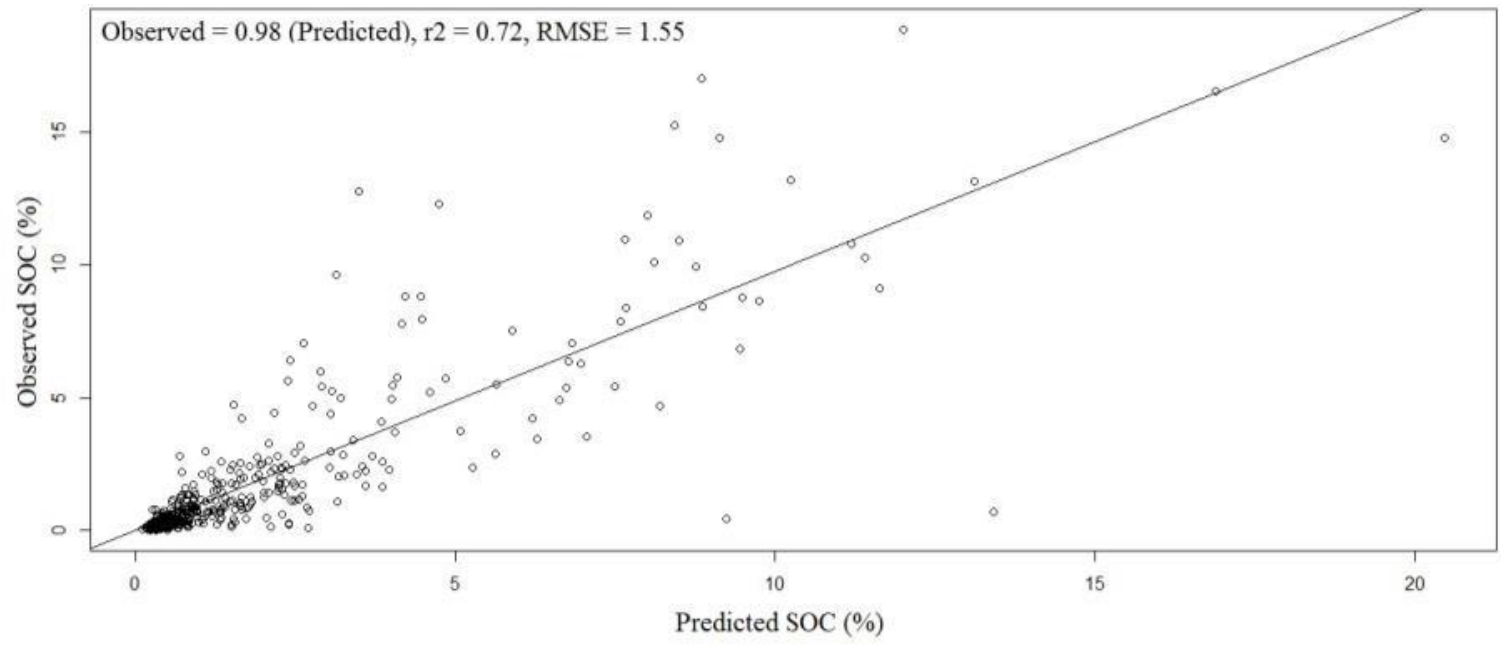

Figure 2.6 Scatter plot of predicted and observed mineral horizon SOC percentages using the RF method. 


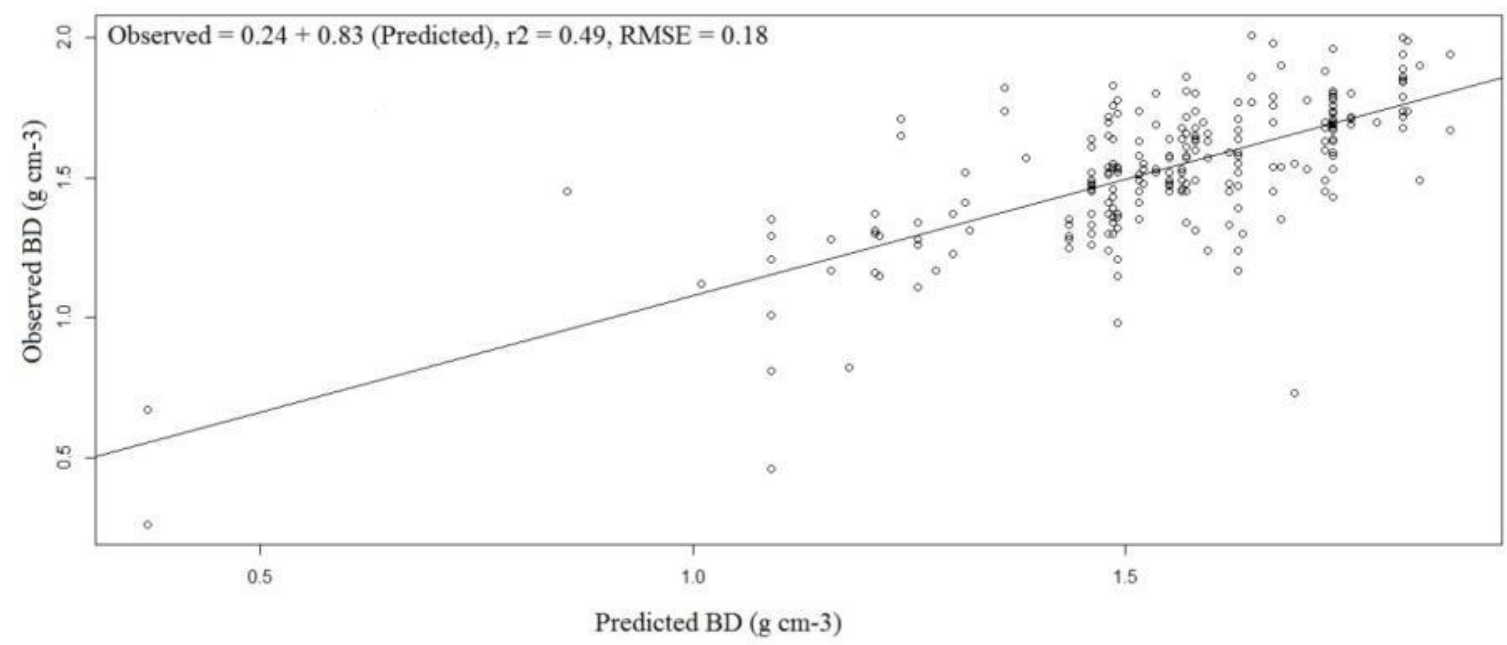

Figure 2.7 Scatter plot of predicted and observed BD values using the median by horizon and texture method with outliers included.

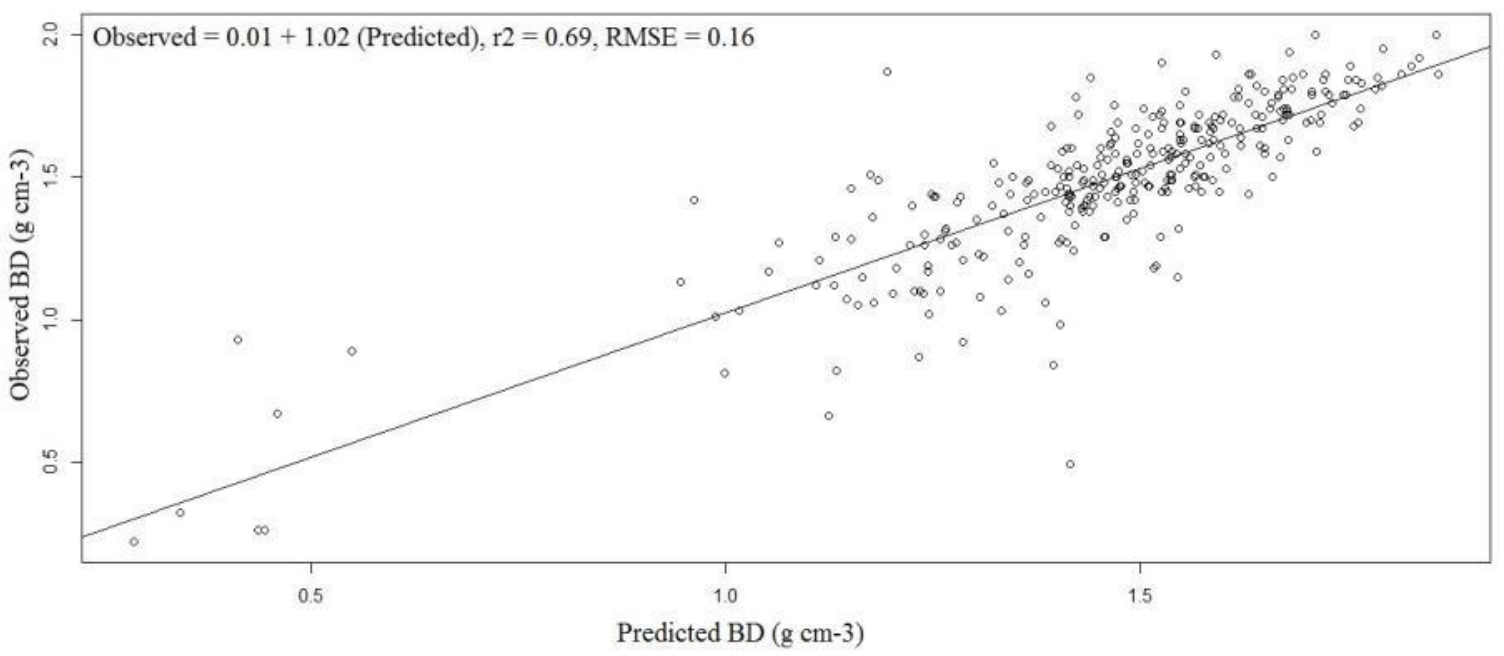

Figure 2.8 Scatter plot of predicted and observed BD values using the RF method. 


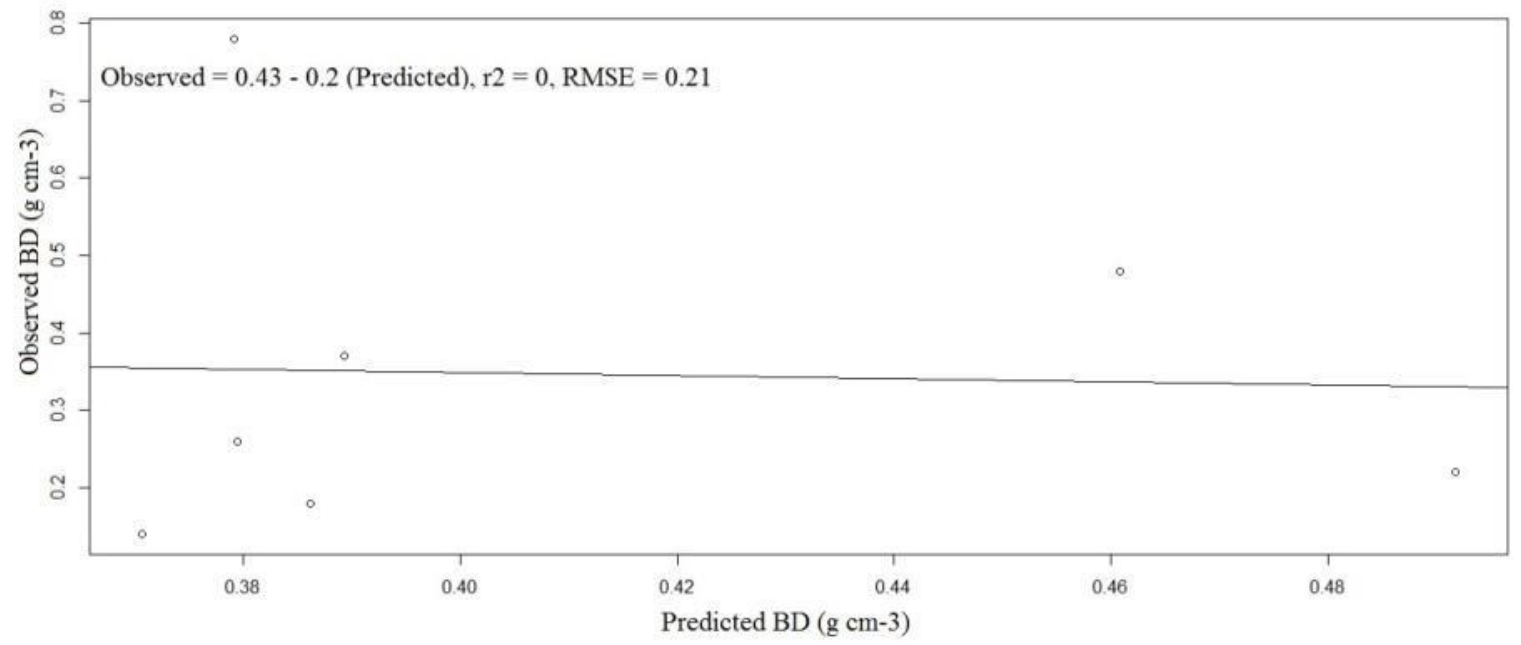

Figure 2.9 Scatter plot of predicted and observed organic horizon BD values using the RF method.

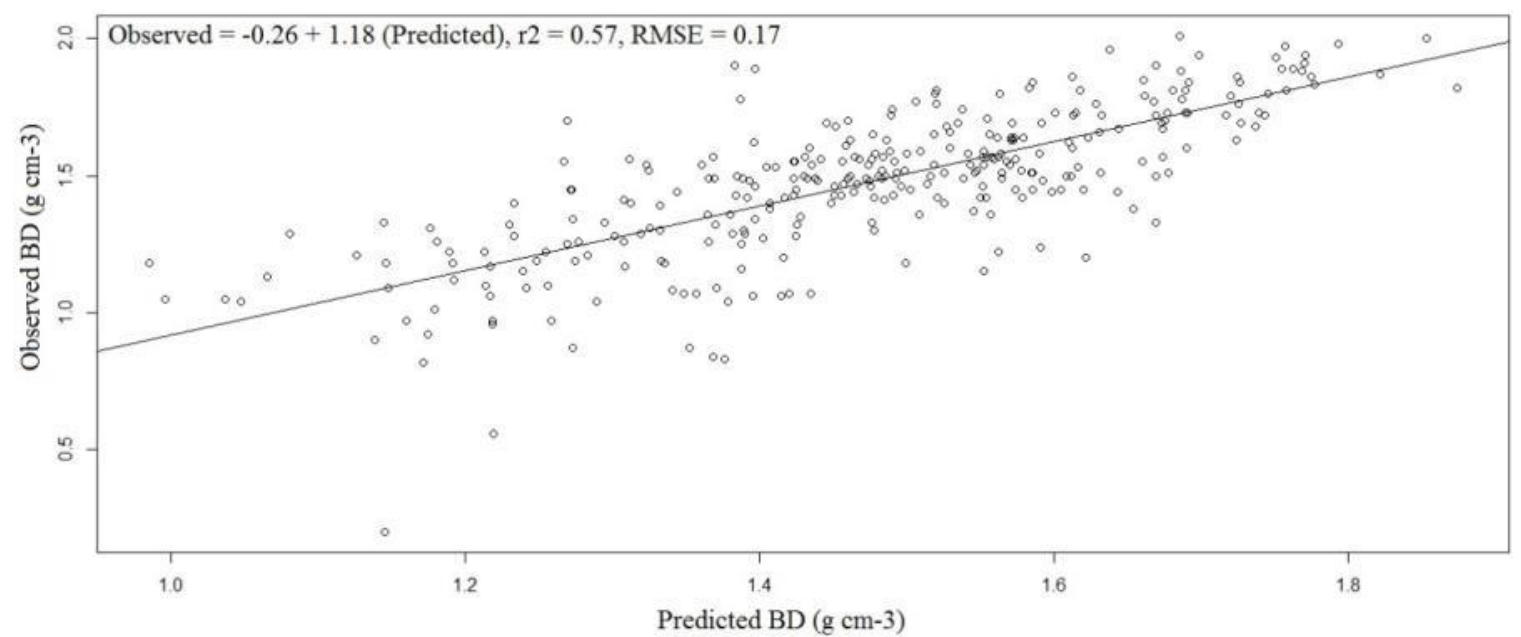

Figure 2.10 Scatter plot of predicted and observed mineral horizon BD values using the RF method. 

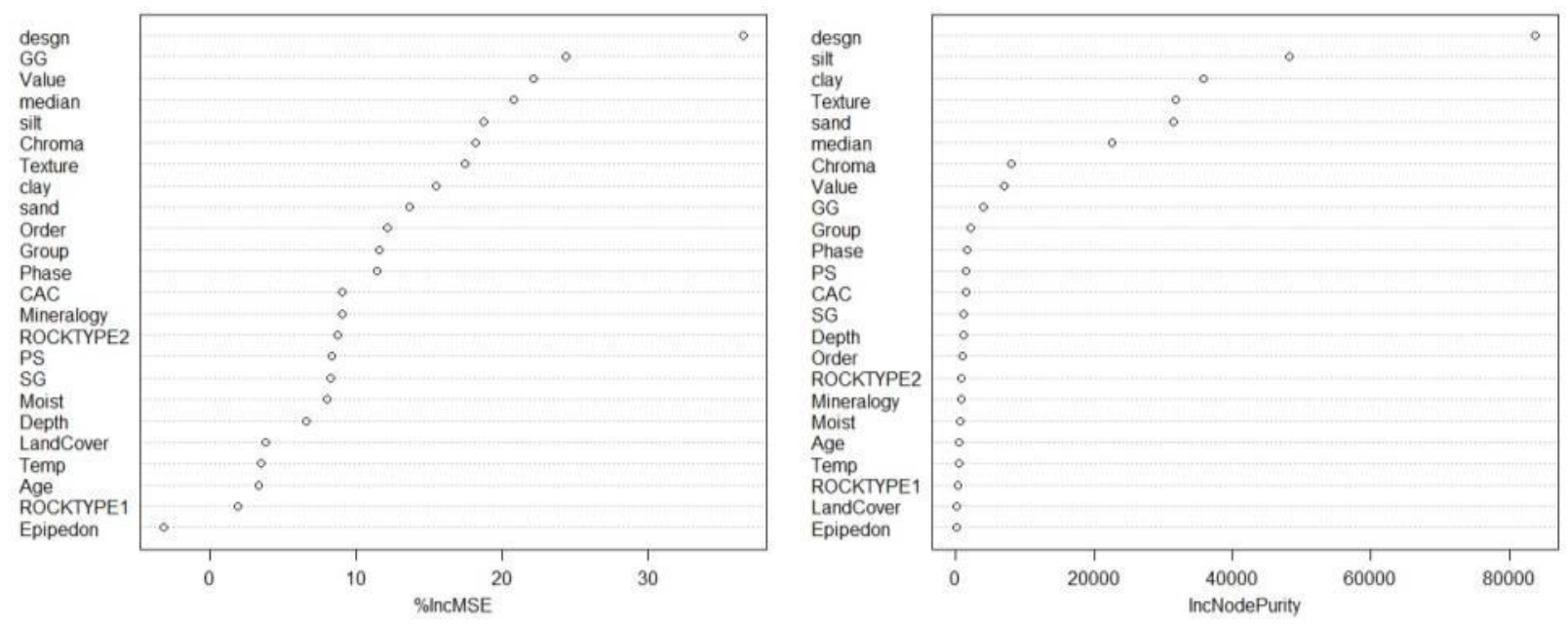

Figure 2.11 Variable importance plot for SOC percentages predicted by RF. The higher the percent increase of mean square error and node purity, the greater the importance of the given variable.
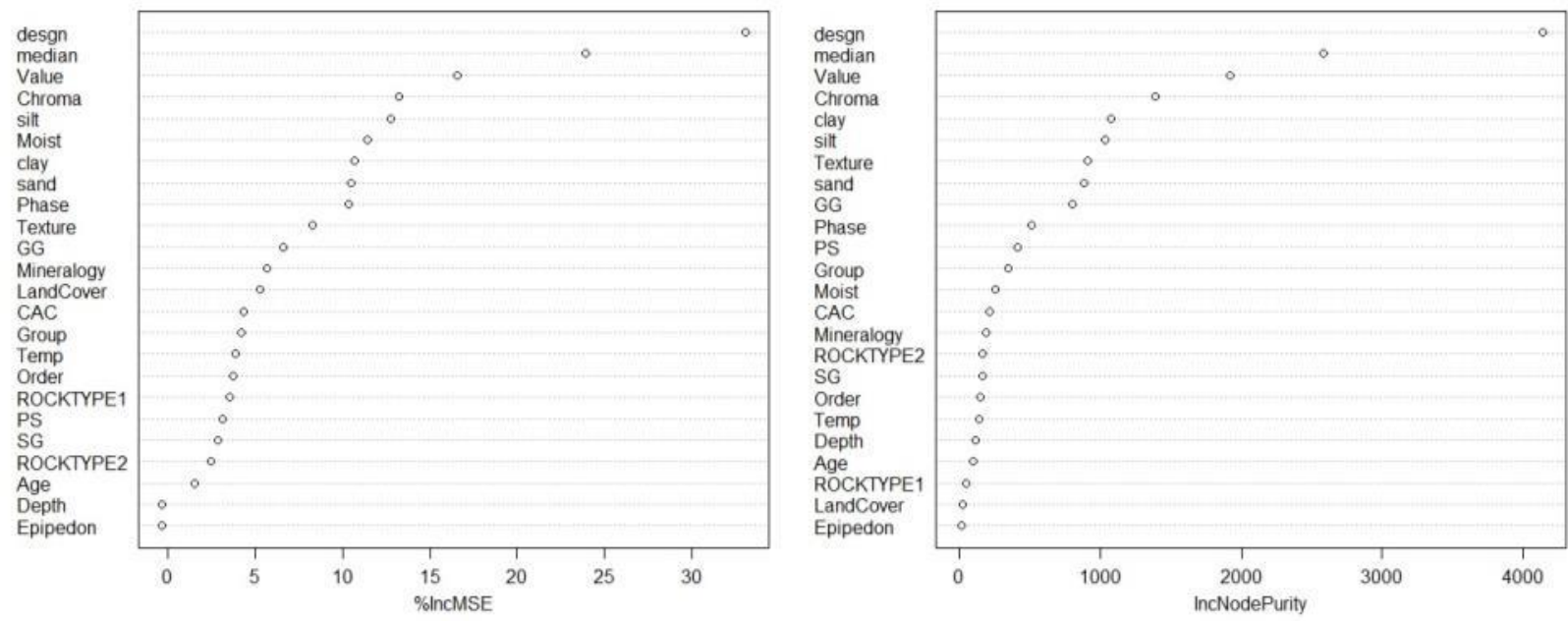

Figure 2.12 Variable importance plot for organic horizon SOC percentages predicted by RF. The higher the percent increase of mean square error and node purity, the greater the importance of the given variable. 

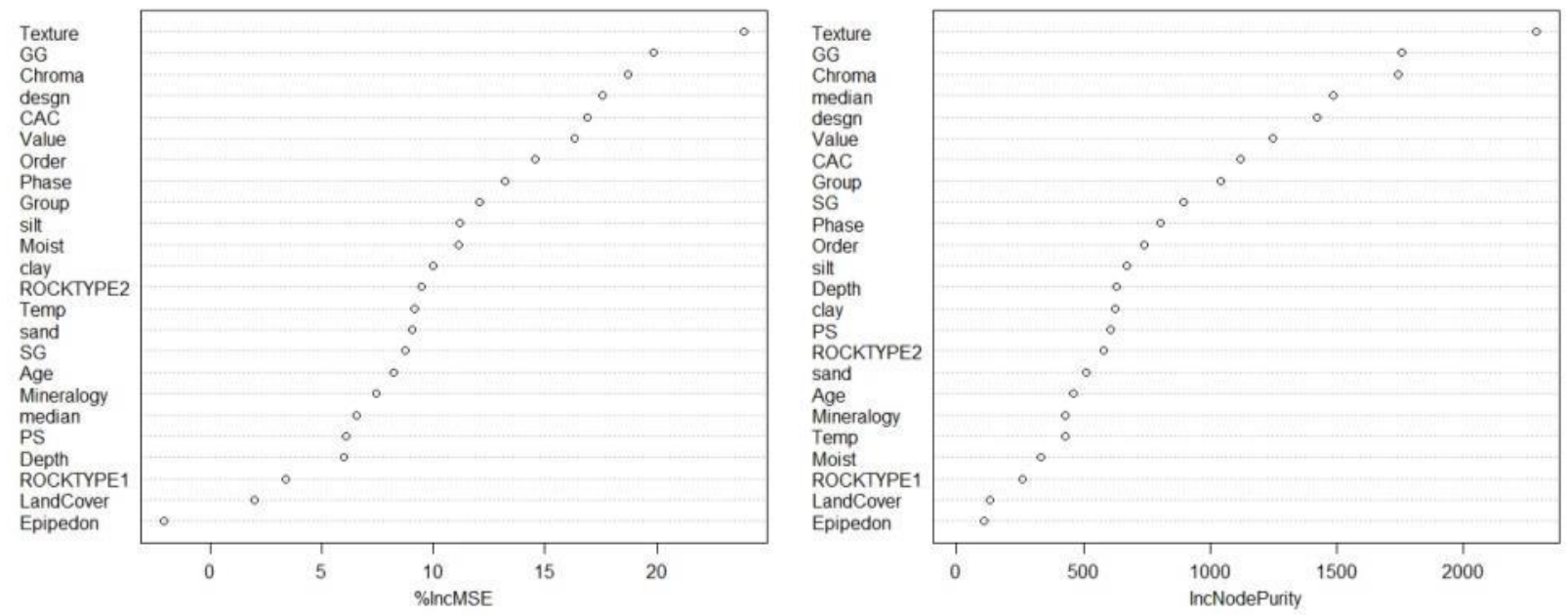

Figure 2.13 Variable importance plot for mineral horizon SOC percentages predicted by RF. The higher the percent increase of mean square error and node purity, the greater the importance of the given variable.
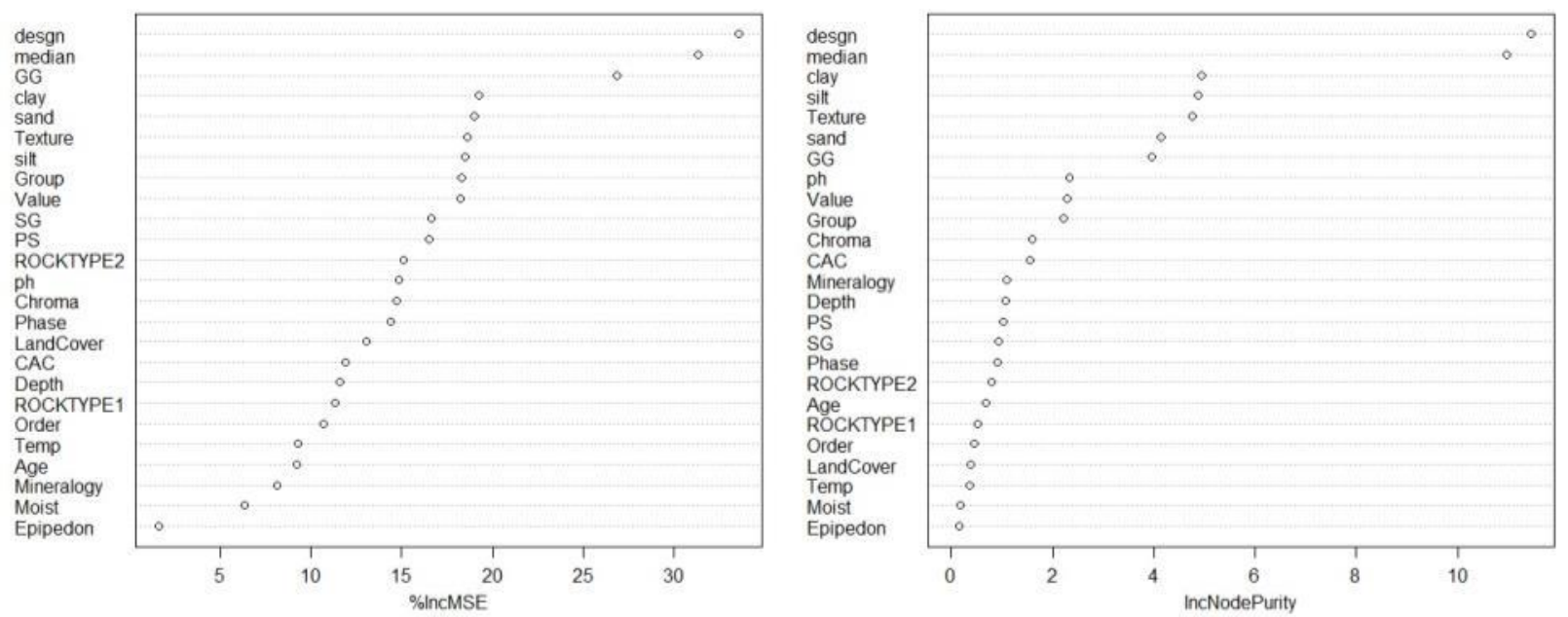

Figure 2.14 Variable importance plot for BD values predicted by RF. The higher the percent increase of mean square error and node purity, the greater the importance of the given variable. 

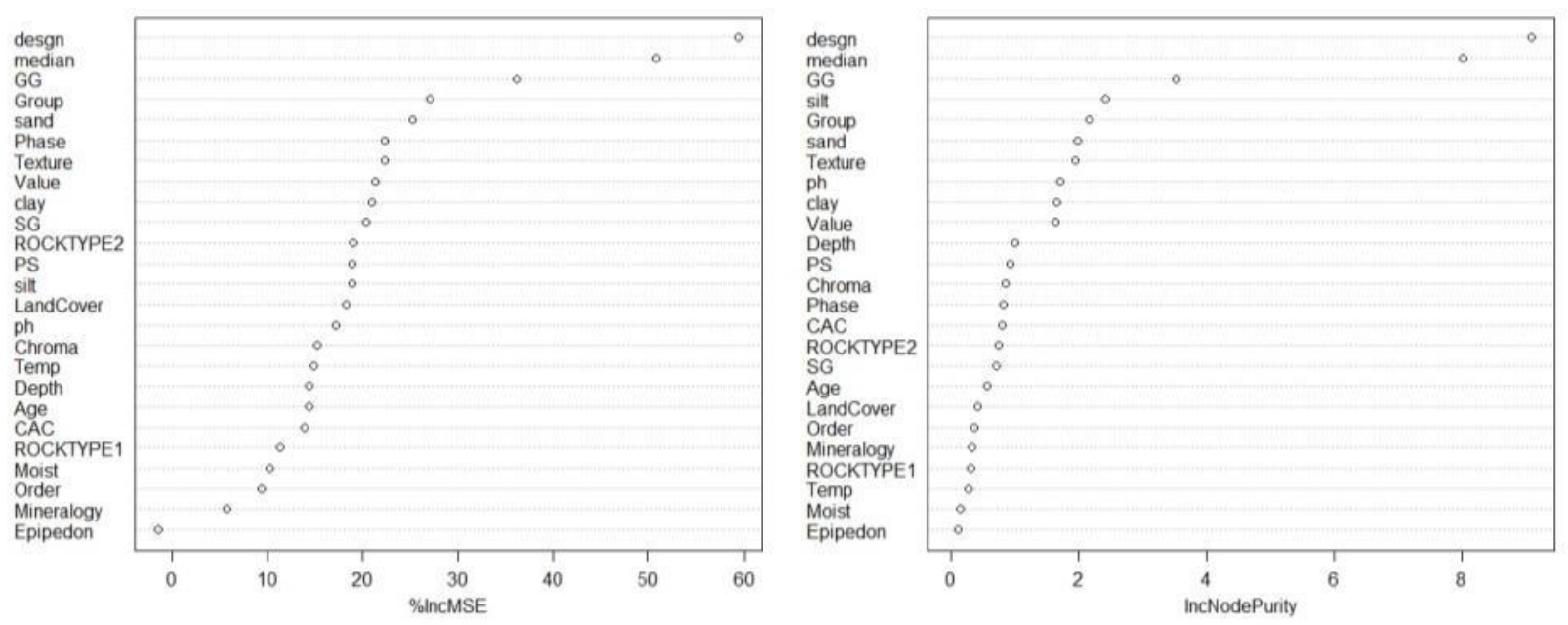

Figure 2.15 Variable importance plot for organic horizon BD values predicted by RF. The higher the percent increase of mean square error and node purity, the greater the importance of the given variable.
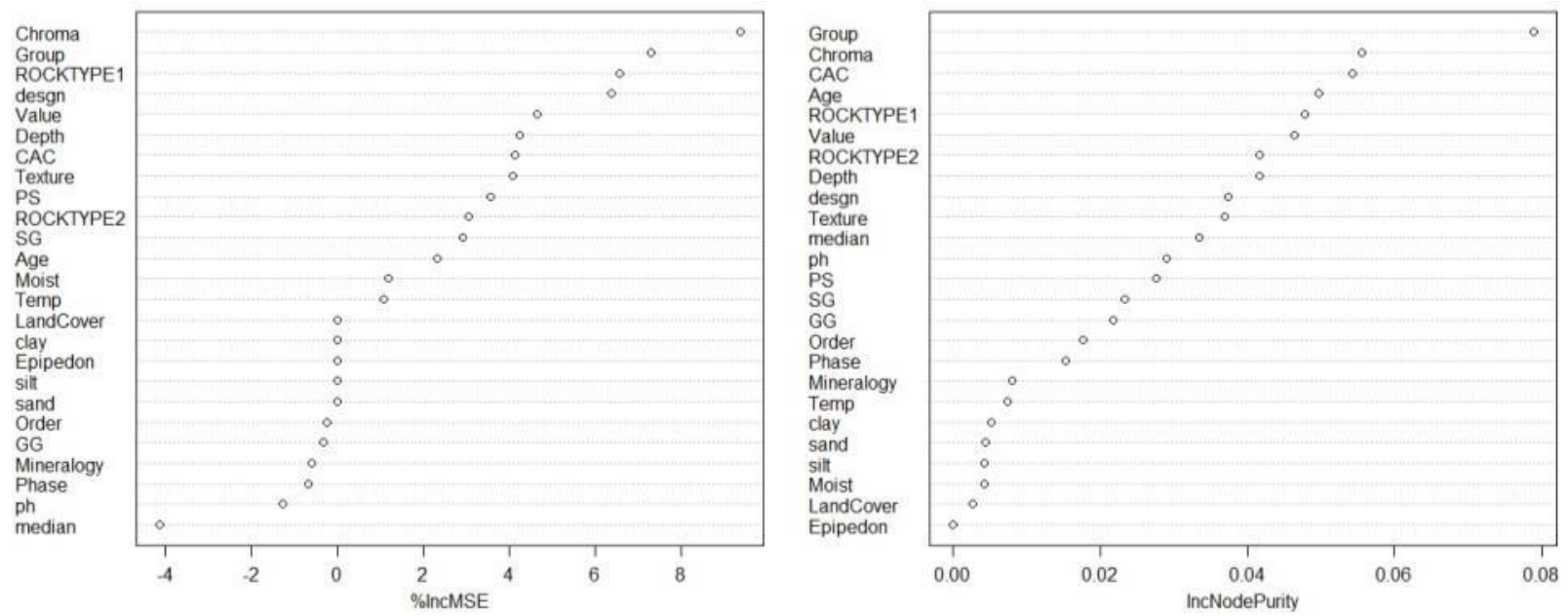

Figure 2.16 Variable importance plot for mineral horizon BD values predicted by RF. The higher the percent increase of mean square error and node purity, the greater the importance of the given variable. 
Table 2.1 A comparison of machine learning techniques adapted from Montillo (2009).

\begin{tabular}{|l|c|c|c|c|c|}
\hline Characteristic & Neural Networks & SVM & Trees & MARS & k-NN, Kernals \\
\hline Natural handling of "mixed" data & $\bullet$ & $\bullet$ & $\bullet$ & $\bullet$ & $\bullet$ \\
\hline Handling of missing data & $\bullet$ & $\bullet$ & $\bullet$ & $\bullet$ & $\bullet$ \\
\hline $\begin{array}{l}\text { Robustness to outliers in input } \\
\text { space }\end{array}$ & $\bullet$ & $\bullet$ & $\bullet$ & $\bullet$ & \\
\hline $\begin{array}{l}\text { Insensitive to monotone } \\
\text { transformations of inputs }\end{array}$ & $\bullet$ & $\bullet$ & $\bullet$ & $\bullet$ & $\bullet$ \\
\hline Computational scalability (large N) & $\bullet$ & $\bullet$ & $\bullet$ & $\bullet$ & $\bullet$ \\
\hline Ability to deal with irrelevent inputs & $\bullet$ & $\bullet$ & $\bullet$ & $\bullet$ & $\bullet$ \\
\hline $\begin{array}{l}\text { Ability to extract linear } \\
\text { combinations of features }\end{array}$ & $\bullet$ & $\bullet$ & $\bullet$ & $\bullet$ & \\
\hline Interpretability & $\bullet$ & $\bullet$ & & $\bullet$ & $\bullet$ \\
\hline Predictive power & $\bullet$ & $\bullet$ & $\bullet$ & & \\
\hline
\end{tabular}

Key: $=$ good, $\quad=$ fair, and $\mathbf{O}=$ poor .

Table 2.2 The D'Agostino chi-square, skewness, and kurtosis statistics for both SOC and BD with and without outliers by horizon and texture.

\begin{tabular}{|l|cc|cc|cc|}
\cline { 2 - 8 } \multicolumn{1}{c|}{} & Horizon & Texture & Horizon & Texture & Horizon & Texture \\
\hline Method & \multicolumn{2}{|c|}{$\chi^{\mathbf{2}}$} & \multicolumn{2}{c|}{ df } & \multicolumn{2}{c|}{ p-value } \\
\hline SOC with Outliers & 1,223 & 729 & 12 & 19 & $<0.001$ & $<0.001$ \\
SOC without Outliers & 1,287 & 759 & 12 & 19 & $<0.001$ & $<0.001$ \\
BD with Outliers & 318 & 115 & 11 & 15 & $<0.001$ & $<0.001$ \\
BD without Outliers & 394 & 134 & 11 & 15 & $<0.001$ & $<0.001$ \\
\hline
\end{tabular}


Table 2.3 Observation and outlier sample sizes by final horizon designation as suggested by Sequeira et al. (2014).

\begin{tabular}{|l|cc|cc|}
\cline { 2 - 5 } \multicolumn{1}{c|}{} & \multicolumn{2}{c|}{$\begin{array}{c}\text { Soil Organic } \\
\text { Carbon }\end{array}$} & \multicolumn{2}{c|}{$\begin{array}{c}\text { Bulk } \\
\text { Density }\end{array}$} \\
\hline Horizon & $\mathbf{N}^{\mathbf{a}}$ & $\mathbf{N}^{\mathbf{b}}$ & $\mathbf{N}^{\mathbf{a}}$ & $\mathbf{N}^{\mathbf{b}}$ \\
Designation & & 16 & 72 & 30 \\
\hline A & 208 & 7 & 21 & 6 \\
Ap & 31 & 30 & 203 & 43 \\
B & 247 & 9 & 50 & 18 \\
BA & 78 & 9 & 59 & 10 \\
Bhs & 94 & 45 & 291 & 58 \\
Bt & 352 & 20 & 172 & 17 \\
Bx & 177 & 8 & 77 & 10 \\
BC & 108 & 12 & 71 & 12 \\
C & 134 & 1 & 45 & 9 \\
E & 84 & 9 & 14 & 0 \\
Oi & 162 & 0 & 15 & 3 \\
Oe & 86 & 9 & 1,099 & 216 \\
Oa & 75 & 06 & & 0 \\
\hline Total & 1,836 & 166 & \\
\hline
\end{tabular}

${ }^{\mathrm{a}}$ Observation size, ${ }^{\mathrm{b}}$ Outlier size 
Table 2.4 Random Forest parameters and their resulting mean square errors and variances explained for SOC and BD.

\begin{tabular}{|c|c|c|c|c|}
\hline & ntree & mtry & $\begin{array}{c}\text { Mean } \\
\text { Square } \\
\text { Error }\end{array}$ & $\begin{array}{c}\% \\
\text { Variance } \\
\text { Explained }\end{array}$ \\
\hline Organic Carbon & 1000 & 6 & 21.7 & 90.6 \\
\hline $\begin{array}{l}\text { Organic Carbon: } \\
\text { Organic Horizons }\end{array}$ & 1250 & 2 & 95.9 & 29.6 \\
\hline $\begin{array}{l}\text { Organic Carbon: } \\
\text { Mineral Horizons }\end{array}$ & 1000 & 5 & 6.11 & 65.71 \\
\hline Bulk Density & 900 & 4 & 0.03 & 65.5 \\
\hline $\begin{array}{l}\text { Bulk Density: } \\
\text { Organic Horizons }\end{array}$ & 1500 & 2 & 0.06 & 7.85 \\
\hline $\begin{array}{l}\text { Bulk Density: } \\
\text { Mineral Horizons }\end{array}$ & 1500 & 6 & 0.03 & 54.2 \\
\hline
\end{tabular}

Table 2.5 Coefficient of determination values for SOC predictions of mineral (min), organic (org), and both mineral and organic (min+org) horizons using RF, mean, and median methods.

\begin{tabular}{|l|ccccc|}
\cline { 2 - 6 } & $\begin{array}{c}\text { Random } \\
\text { Forest }\end{array}$ & $\begin{array}{c}\text { Mean with } \\
\text { Outliers }\end{array}$ & $\begin{array}{c}\text { Mean } \\
\text { without } \\
\text { Outliers }\end{array}$ & $\begin{array}{c}\text { Median } \\
\text { with } \\
\text { Outliers }\end{array}$ & $\begin{array}{c}\text { Median } \\
\text { without } \\
\text { Outliers }\end{array}$ \\
\hline SOC (min+org) & 0.90 & 0.93 & 0.91 & 0.93 & 0.91 \\
SOC (min) & 0.72 & 0.62 & 0.42 & 0.54 & 0.42 \\
SOC (org) & 0.26 & 0.49 & 0.28 & 0.47 & 0.28 \\
\hline
\end{tabular}


Table 2.6 Root mean square errors for SOC predictions of mineral (min), organic (org), and both mineral and organic (min+org) horizons using RF, mean, and median methods.

\begin{tabular}{|l|ccccc|}
\cline { 2 - 6 } \multicolumn{1}{c|}{} & $\begin{array}{c}\text { Random } \\
\text { Forest }\end{array}$ & $\begin{array}{c}\text { Mean with } \\
\text { Outliers }\end{array}$ & $\begin{array}{c}\text { Mean } \\
\text { without } \\
\text { Outliers }\end{array}$ & $\begin{array}{c}\text { Median } \\
\text { with } \\
\text { Outliers }\end{array}$ & $\begin{array}{c}\text { Median } \\
\text { without } \\
\text { Outliers }\end{array}$ \\
\hline SOC (min+org) & 4.70 & 3.96 & 4.84 & 4.03 & 4.85 \\
SOC (min) & 1.55 & 1.69 & 2.43 & 1.86 & 2.43 \\
SOC (org) & 8.94 & 8.40 & 10.25 & 8.51 & 10.24 \\
\hline
\end{tabular}

Table 2.7 Coefficient of determination values for BD predictions of mineral (min), organic (org), and both mineral and organic (min+org) horizons using RF, mean, and median methods.

\begin{tabular}{|l|ccccc|}
\cline { 2 - 6 } \multicolumn{1}{c|}{} & $\begin{array}{c}\text { Random } \\
\text { Forest }\end{array}$ & $\begin{array}{c}\text { Mean with } \\
\text { Outliers }\end{array}$ & $\begin{array}{c}\text { Mean } \\
\text { without } \\
\text { Outliers }\end{array}$ & $\begin{array}{c}\text { Median } \\
\text { with } \\
\text { Outliers }\end{array}$ & $\begin{array}{c}\text { Median } \\
\text { without } \\
\text { Outliers }\end{array}$ \\
\hline BD (min+org) & 0.69 & 0.51 & 0.40 & 0.50 & 0.40 \\
BD (min) & 0.57 & 0.43 & 0.36 & 0.41 & 0.34 \\
\hline BD (org) & 0.00 & 0.54 & 0.79 & 0.55 & 0.79 \\
\hline
\end{tabular}


Table 2.8 Root mean square errors for BD predictions of mineral (min), organic (org), and both mineral and organic (min+org) horizons using RF, mean, and median methods.

\begin{tabular}{|l|ccccc|}
\cline { 2 - 6 } & $\begin{array}{c}\text { Random } \\
\text { Forest }\end{array}$ & $\begin{array}{c}\text { Mean } \\
\text { with } \\
\text { Outliers }\end{array}$ & $\begin{array}{c}\text { Mean } \\
\text { without } \\
\text { Outliers }\end{array}$ & $\begin{array}{c}\text { Median } \\
\text { with } \\
\text { Outliers }\end{array}$ & $\begin{array}{c}\text { Median } \\
\text { without } \\
\text { Outliers }\end{array}$ \\
\hline BD (min+org) & 0.16 & 0.18 & 0.20 & 0.18 & 0.20 \\
BD (min) & 0.17 & 0.18 & 0.20 & 0.18 & 0.20 \\
\hline BD (org) & 0.21 & 0.17 & 0.10 & 0.17 & 0.10 \\
\hline
\end{tabular}




\title{
Chapter 3: Modeling Soil Organic Carbon through Geographically Weighted Regression Kriging
}

\begin{abstract}
Because soil contains three to four times more carbon than the atmosphere, small changes in soil organic carbon (SOC) content can have profound impacts on the global carbon budget. In order to understand, predict, and manage these impacts, an initial assessment of SOC stock and its dynamic nature is needed within the realm of soil survey. MLRA 127 (Eastern Alleghany Plateau and Mountains) was chosen as the study area for this research due to its complex, highly dissected topography and diverse pedoecologic properties. Previous $1 \mathrm{~m}$ SOC stock estimates for MLRA 127 range from $2.20 \mathrm{~kg} \mathrm{~m}^{-2}$ to $32.00 \mathrm{~kg} \mathrm{~m}^{-2}$. This wide range of SOC stock estimates coupled with lack of uncertainty assessments and validation addresses a need to better understand and capture SOC variability across MLRA 127. In this study, SOC stock was modeled using environmental covariates and prepared Kellogg Soil Survey Laboratory (KSSL) pedons through geographically weighted regression (GWR) and geographically weighted regression kriging (GWRK). The resulting GWR and GWRK models were validated through ancillary data collected from the Rapid Carbon Assessment (RaCA) project and previous graduate research projects. Uncertainty was assessed using the fuzzy k-means with extragrades algorithm to create prediction intervals and a confusion idex (CI). It was found that the RaCA model had the lowest error $(\mathrm{RMSE}=0.22)$ followed by the GWRK prediction model $(\mathrm{RMSE}=$ 0.31) and the GWR model (RMSE= 0.41). The CI produced in the uncertainty assessment revealed that class membership was highest in areas with relatively low SOC (0 to $20 \mathrm{~kg} \mathrm{~m}^{-2}$ ) and lowest in areas with relatively high SOC (40 to $50 \mathrm{~kg} \mathrm{~m}^{-2}$ ). Total biosphere carbon, calculated using the Forest Inventory Analysis (FIA) model and substituting GWRK soil for soil carbon and forest litter, revealed that soils in MLRA 127 contain 69\% of the total carbon in the biosphere. This finding has significant implications on land management and land use in MLRA 127 given that $76 \%$ of the MLRA is forested. Future research is needed to better understand carbon sequestration and land use conversion effects on terrestrial biosphere carbon.

\section{Introduction}

Digital soil mapping (DSM) is a quantitative spatial modeling technique established in the 1990s that combines environmental covariates, such as the soil forming factors established by 
Jenny (1941), with legacy data or current field and lab observations to infer pedogenic properties or patterns across various temporal and/or spatial scales (Brungard, 2009; Grunwald, 2010; Minasny et al., 2013). By expanding the work of Jenny (1941), McBratney et al. (2003) developed the scorpan spatial prediction function:

$$
\mathrm{S}=f(\mathrm{~s}, \mathrm{c}, \mathrm{o}, \mathrm{r}, \mathrm{p}, \mathrm{a}, \mathrm{n})+\varepsilon
$$

where a soil property or class (S) is a function of soil observations (s), climate (c), organisms (o), relief (r), parent materials (p), age (a), and spatial position (n), and $\varepsilon$ are the spatially correlated errors (residuals). The empirical quantitative function $(f)$ can represent complex non-linear datamining techniques such as regression trees and random forests (RF), simple linear models, or geostatistical models such as kriging (McBratney et al., 2003; Minasny et al., 2013).

Environmental covariates used in DSM differ depending on the study area, available data, and the correlation between the desired soil property or class and its environmental influences. Soil observations, consisting of soil legacy data or recent field or lab measurements, are either fully incorporated into the model or are split into model training and validation sets (Kumar et al., 2012). The other scorpan covariates are used to train the model and create a continuous predictive surface. Climate data used in DSM exist in the form of measurements at meteorological stations and can be combined with a digital elevation model (DEM) data and derivatives to produce a continuous climate raster. Vegetation from remotely sensed imagery is often chosen to represent organisms given the impracticality of quantifying fauna (Brungard, 2009). Relief, represented by a digital elevation model (DEM) and its derivatives, is the most widely used scorpan covariate in DSM (Minasny et al., 2013). Parent material, often represented by lithology, determines the chemical composition and grain size of minerals that are exposed to chemical weathering at the beginning of pedogenesis (Brungard, 2009). The age of soil is an important covariate to consider when using DSM due to its influence on chemical, biological, and physical soil reactions. Because age determination techniques such as optical luminescence are labor and cost intensive, soil age has not previously been characterized in DSM models (Brungard, 2009). The spatial position of soil is inherently built into DSM. Environmental covariates provide the geospatial link that enables soil scientists to model aspects of pedogenesis. 
Soil properties and classes have been predicted at unsampled locations using geographic or spatial methodologies since the late 1960s. Geospatial techniques have greatly expanded since then due to the establishment of geographic information systems (GIS), remote sensing, and the availability of high resolution digital datasets (Kumar et al., 2012). Today soil properties can be predicted continuously across a geographical area using scorpan covariates and an empirical quantitative function $(f)$. MLR, ordinary kriging $(\mathrm{OK})$, regression trees, and regression kriging (RK) are the most common quantitative functions used for DSM of SOC (Kumar et al., 2012). RK is different than MLR, OK, and regression trees in that it incorporates kriged residuals with global regression to account for spatial autocorrelation, and thus can more accurately estimate SOC. Kumar et al. (2012) refers to MLR, OK, regression trees, and RK models as stationary because they do not vary with absolute location across space. Geographically weighted regression $(\mathrm{GWR})$ is a simple regression function that allows varying coefficient weights for the environmental covariates across space. Although GWR uses spatially varying covariate coefficients, it does not directly consider spatial autocorrelation in model development (Kumar et al., 2012). Geographically weighted regression kriging (GWRK) combines the frameworks of GWR and RK models to account for spatial non-stationarity and spatial autocorrelation of the residuals. Kumar et al. (2012) compared RK and GWRK and found that GWRK more precisely estimated SOC stock in Pennsylvania.

Minasny et al. (2013) reviewed 40 previous DSM of SOC studies and found that uncertainty was rarely reported and that if validation was performed, internal validation was used. Minasny et al. (2013) suggest using the fuzzy k-means with extragrades algorithm to quantify uncertainty for large geographical areas or when combing data mining tools with RK due to its high computational power and ability to quantify model parameter uncertainty. The fuzzy k-means with extragrades algorithm partitions covariates into several classes. Each class is represented by a prediction interval derived from the empirical distribution as a weighted average of membership values. This approach identifies and penalizes observations outside of the domain of the calibration data and allows a new observation to be assigned to an established class based on class centroids (Minasny et al., 2013). Validation of modeled SOC is performed through cross-validation, internal validation, or independent sampling. Both the cross-validation and internal validation techniques may produce biased estimates due to biased data inputs or spatially correlated prediction errors. Although unbiased independent sampling is the 
recommended validation approach, time and affordability often limit the applicability of independent validation. When uncertainty and validation assessments are both included in a study, the end user is able to better understand the nature and distribution of the input data, model error, and the overall accuracy and applicability of the model (Nemes, 2009). Uncertainty and validation allow for a better understanding of the dynamic nature of SOC in relation to its correlated covariates across space and are thus needed for all SOC prediction studies (Minasny et al., 2013).

The objective of this study was to predict SOC stock in MLRA 127 through GWR and GWRK models using KSSL pedons and available scorpan covariates (Table 3.1). Previous $1 \mathrm{~m}$ SOC stock estimates for MLRA 127 range from $2.20 \mathrm{~kg} \mathrm{~m}^{-2}$ (Bliss et al., 1995) to $32.00 \mathrm{~kg} \mathrm{~m}^{-2}$ (Kern, 1994) (Table 3.2). The Soil Survey Geographic (SSURGO) and the State Geographic (STATSGO2) databases often underestimate true SOC stock due to lack of organic horizon population and conservative representative values (Zhong and Xu, 2011; Nauman et al., 2012). This wide range of SOC stock estimates coupled with lack of uncertainty assessments and validation addresses signifies a need to better understand and capture SOC variability across MLRA 127. In this study, validation was assessed using an independent dataset developed from Rapid Carbon Assessment (RaCA) pedons and Sponaugle (2005). Once validated, the models were compared to the predicted RaCA model (Soil Survey Staff, 2013) and uncertainty was assessed using the fuzzy k-means with extragrades algorithm (Minasny et al., 2013).

\section{Materials and Methods}

Study Area

MLRA 127 was chosen as the study area for this research due to its complex, highly dissected topography and diverse pedoecologic properties. MLRA127 stretches from southwestern New York to Virginia, encompassing 50,370 $\mathrm{km}^{2}\left(19,440 \mathrm{mi}^{2}\right)$ through Maryland, New York, Pennsylvania, Virginia, and West Virginia. Elevation ranges from $300 \mathrm{~m}$ to $800 \mathrm{~m}$ (980 ft to 2,625 ft) in the plateau portion of MLRA 127 to $1,100 \mathrm{~m}$ to $1,400 \mathrm{~m}(3,600 \mathrm{ft}$ to 4,600ft) in the mountainous portion located in southeastern West Virginia (Fig. 3.1). The geology of MLRA 127 consists of alternating beds of sandstone, limestone, coal, and shale of the Permian, Mississipian, Pennsylvanian, and Cambrian ages. River valleys in this region are composed of stratified, unconsolidated alluvial deposits of sand, silt, clay, and gravel, with some outwash and glaciofluvial deposits in the northwest corner of Pennsylvania (United States 
Department of Agriculture, 2006). The footslopes and mid to lower backslopes of hills consists of colluvium from residual bedrock. MLRA 127 has all four climatic seasons, with an average annual temperature of 6 to $12^{\circ} \mathrm{C}\left(43^{\circ} \mathrm{F}\right.$ to $\left.54^{\circ} \mathrm{F}\right)$. Most of the precipitation occurs as intense, convective thunderstorms occurring in the spring and summer. Average annual precipitation ranges from $840 \mathrm{~mm}$ to $1,725 \mathrm{~mm}$ (33 in to $68 \mathrm{in}$ ), increasing in a southern direction and with elevation. Average annual snowfall ranges from $890 \mathrm{~mm}$ (35 in) in southern MLRA 127 to 2,285 mm (90 in) in the northern part (United States Department of Agriculture, 2006). The frost-free period ranges from 115 days in high elevations or in the north to 205 days in the lower elevations of southern MLRA 127. Ultisols and Inceptisols are the dominant soil orders of MLRA 127, with Entisols, Alfisols, and Spodosols occurring to a lesser extent. The soils in this area are dominantly in the udic moisture regime and mesic temperature regime, with the high-elevation and northern soils occurring in the frigid temperature regime (United States Department of Agriculture, 2006). These soils have mixed or siliceous mineralogy and are generally moderately deep to very deep with excessively well to somewhat poor drainage classes. MLRA 127 supports high-quality hardwoods, such as oak, black cherry, yellow-poplar, and maple, at the lower elevations and intermixed deciduous and coniferous species at higher elevation, including red spruce, hemlock, birch, maple, black cherry, and beech (United States Department of Agriculture, 2006). Due to the geographical makeup of MLRA 127, most of the area is forested (76\%). The remaining areas have been cleared to support crops (7\%), pasture (7\%), urban development (6\%), other land uses (3\%), and water (1\%) (United States Department of Agriculture, 2006).

\section{Environmental Covariates}

The prepared KSSL data from Chapter 2 were used to calculate SOC stock in the upper meter of soil for the 254 KSSL pedons in MLRA 127. These pedons along with scorpan environmental covariates were used to train the GWR and GWRK models. The scorpan covariates used in this study were numerical and chosen based on availability of national coverage and correlation to SOC. Although some software permit binary or dummy coded categorical data in GWR models, the combined use of categorical and numerical data is not recommended for GWR due to a high risk of local multicolinearity.

Climate was represented by the 1981-2010 30-year normals derived from the Parameterelevation Regressions on Independent Slopes Model (PRISM). The PRISM algorithm uses a 30- 
arcsec National Elevation Dataset (NED) DEM and available meterological station data to calculate a climate-elevation regression that is interpolated to to produce continuous preceipation and temperature rasters (PRISM, 2004). Vegetation was represented by 16-day Enhanced Vegetation Index (EVI) imagery obtained through the Moderate Resolution Imaging Spectroradiometer (MODIS) satellite and Landsat GeoCover standardized and orthorectified green, near-infrared (NIR) and mid-infrared (MIR) bands and band ratios (GLCF, 2005; Boettinger et al., 2008). The EVI, generated from the Normalized Difference Vegetation Index (NDVI) imagery, is more receptive to canopy structural variations and less sensitive to chlorophyll than the NDVI (Huete et al., 2002). In this study, mean, median, minimum, and maximum EVI values were calculated for 2000-2009 and for each climatic season (Tedrow and Weber, 2011). Relief, the most widely used scorpan covariate in the DSM of SOC (Minasny et al., 2013), was represented by the hydrologically corrected Elevation Derivatives for National Applications (EDNA) derived from the 30m NED. The following DEM attirbutes and derivatives were calculated using SAGA and ArcMap: slope gradient, normalized slope height, convergence index, southwestness, northeastness, eastness, northness, SAGA topographic wetness index, LS factor, total curvature, plan curvature, profile curvature, valley depth, stream power index, terrain ruggedness index, terrain surface convexity, terrain surface texture, flow path length, relative position, multiresolution valley bottom flatness, multiresolution ridge top flatness, and mid-slope position. Parent material was represented by seven gamma radiometric covariates: potassium (K), thorium (Th), uranium (U), total exposure, K/Th, K/U, and Th/U.

A total of 64 scorpan covariates were assessed for multicolinearity and the ability to predict SOC through Pearson's r, Kendall's $\tau$, Spearman's $\rho$, and RF. Covariates that showed the highest correlation to SOC that were not calculated from another covariate with a higher correlation to SOC were selected to train the GWR model. The following 14 covariates were selected to calculate SOC: gamma radiometric total exposure, available water storage (0-100 $\mathrm{cm}$ ), elevation, precipitation, maximum annual temperature, Landsat GeoCover MIR band, Landsat GeoCover green/NIR band ratio, convergence index, terrain roughness index, northeastness, valley depth, minimum fall EVI from 2000 to 2009, mean winter EVI from 2000 to 2009, and median spring EVI from 2000 to 2009 (Table 3.1). 


\section{Calculation of Soil Organic Carbon Stock}

The SOC stock for each site was calculated by summing the SOC concentrations in each horizon from the surface to $1 \mathrm{~m}$ depth as follows:

$$
C_{\text {stock }}=\sum_{i=1}^{n} \frac{C_{i} x \rho_{b} x D_{i} x\left(\frac{100-R F V_{i}}{100}\right)}{10} \quad \text { [Eq. 3-2] }
$$

where $\mathrm{C}_{\text {stock }}$ is the SOC stock $\left(\mathrm{kg} \mathrm{m}^{-2}\right)$ up to $1 \mathrm{~m}$ depth, $\mathrm{i}$ is the horizon, $\mathrm{C}_{\mathrm{i}}$ is the SOC concentration $\left(\mathrm{g} \mathrm{g}^{-1}\right)$ in the ith horizon, $\rho_{b}$ is the bulk density $\left(\mathrm{g} \mathrm{cm}^{-2}\right), \mathrm{D}_{\mathrm{i}}$ is the thickness of the ith horizon $(\mathrm{cm})$, and $\mathrm{RFV}_{\mathrm{i}}$ is the rock fragment volume content of the ith horizon (dimenionless). Random forest (RF) was used to prepare KSSL data for SOC stock calculation in Chapter 2 of this thesis.

\section{Geographically Weighted Regression Kriging}

Geographically weighted regression (GWR) is a simple regression function that allows varying coefficient weights for the environmental covariates across space. Although GWR uses spatially varying covariate coefficients, it does not directly consider spatial autocorrelation in model development (Kumar et al., 2012). The equation for GWR used in GWR 4.0 software is:

$$
\hat{C}_{g w r\left(s_{0}\right)}=\sum_{k=0}^{p} \hat{\beta}_{k}\left(s_{0}\right) x X_{k}\left(s_{0}\right)
$$

where $\hat{C}_{g w r\left(s_{0}\right)}$ is the predicted SOC stock at location $\mathrm{s}_{0}, \mathrm{p}$ is the total number of environmental covariates, $\hat{\beta}_{k}$ are the unknown regression coefficients that are spatially variant, and $\mathrm{X}_{\mathrm{k}}\left(\mathrm{s}_{0}\right)$ are the $k$ th environmental covariates with the value $X_{k}$ at location $s_{0}$ (Kumar et al., 2012). The GWRK approach takes the residuals produced by the GWR model and kriges them to the study area using isotropic variogram parameters. The kriged residuals are added to the GWR model to produce a GWRK model:

$$
\hat{C}_{g w r k\left(s_{0}\right)}=\hat{C}_{g w r\left(s_{0}\right)}+\hat{\varepsilon}_{o k}\left(s_{0}\right)
$$


where $\hat{C} g w r k\left(s_{0}\right)$ is the predicted SOC stock at location $\left(s_{0}\right), \hat{C} g w r\left(s_{0}\right)$ is the GWR model calculated in Eq. $(3-3)$, and $\hat{\varepsilon}_{o k}\left(s_{0}\right)$ are the residual values interpolated by ordinary kriging (OK)(Kumar et al., 2012).

In this study, the 254 prepared KSSL sites in MLRA 127 were used to train the GWR model. Due to limited computing power, $250 \mathrm{~m}, 800 \mathrm{~m}$, and 2,000 m spatial resolutions were explored to determine an appropriate spatial resolution to model SOC at a Major Land Resource Area (MLRA) scale. Environmental covariate values were extracted to the point grids using ArcMap software and the GWR model trained by the 254 KSSL sites was applied to the points at varying spatial resolutions using GWR 4.0 software with the following settings: adaptive Gaussian kernel, all covariates treated as local (non-stationary), and bandwith size determined by biased-corrected Akaike Information Criterion (AICc). Next, SOC stock was calculated for the varying spatial resolution point grids by multiplying the environmental covariate coefficients by the environmental covariate values and then adding the y-intercept for each point location. The calculated SOC stock for each point was then interpolated using OK in ArcMap across the study area. The normality and spatial autocorrelation of the GWR KSSL residuals were assessed in ArcMap using the Moran's I statistic, semivariogram analysis, and spatial observations. Ten out of the $254 \mathrm{KSSL}$ sites were removed due to being outliers on the quantile-quantile plot or being highly clustered or dispersed. The remaining 244 GWR KSSL residuals were kriged through OK in ArcMap using the parameter optimization option was used for OK to determine best fit of the semiovariogram through minimisation of the mean square error. The kriged residuals were added the the GWR interpolation to produce the GWRK model. The GWRK models were then validated using 175 independent observations from RaCA and Sponaugle (2005) to determine the appropriate spatial resolution.

$\underline{\text { Validation and Uncertainty }}$

Before validation and uncertainty were assessed for the GWR and GWRK models at the appropriate spatial resolution, a visual comparison between the GWR, GWRK, and RaCA models was performed. The RaCA prediction model was derived through a statisitical modeling effort from NRCS and university partners. In 2010, 32,084 soil profiles in the upper $1 \mathrm{~m}$ of soil were described and sampled across the United States based on land use and soil type. RF was used to model and interpolate soil carbon as a function of visible near-infrared scans (Soil Survey Staff, 2013). 
The GWR and GWRK models were validated using 175 independent observations from the RaCA and Sponaugle (2005) (Appendices F and G). The RaCA prediction model was validated with the 254 prepared KSSL pedons within MLRA 127 (Appendices A and B). Once validated, mean estimation error (MEE), mean absolute estimation error (MAEE), and root mean square error (RMSE) were calculated for the GWR, GWRK, and RaCA models as described in Eqs. (3-5) - (3-7) (Kumar et al., 2012).

$$
\begin{aligned}
& \text { MEE }=\frac{\sum_{i=1}^{n}\left[\hat{C}\left(s_{i}\right)-C\left(s_{i}\right)\right]}{n} \\
& \text { MAEE }=\frac{\sum_{i=1}^{n}\left|\hat{C}\left(s_{i}\right)-C\left(s_{i}\right)\right|}{n} \\
& \text { RMSE }=\sqrt{\frac{\sum_{i=1}^{n}\left[\hat{C}\left(s_{i}\right)-C\left(s_{i}\right)\right]^{2}}{n}}
\end{aligned}
$$

where $\hat{C}\left(s_{i}\right)$ is the predicted value at $s_{i}$ location, $C\left(s_{i}\right)$ is the observed value at location si, and $\mathrm{n}$ is the total number of sample observations. Standard data transformations were explored for the GWR and GWRK models, including lognormal, square root, squaring, Box-Cox, etc., but normality was not achieved, making the normality assumptions for $\mathrm{r}^{2}$ invalid. This is true in almost all environmental modeling (Keller et al., 2012; Razafimbelo et al., 2013). A recent study by Mishra et al. (2010) did not report $\mathrm{r}^{2}$ values for their SOC stock predictions. RMSE, MEE, and MAEE do not assume normality and were therefore used to statistically compare the GWR, GWRK, and RaCA models.

Once validated, overall uncertainty of the GWRK model was determined by the fuzzy kmeans with extragrades algorithm using FUZME software (Minasny and McBratney, 2002; Malone et al., 2011; Minasny et al., 2013). The fuzzy k-means with extragrades algorithm minimizes the following function:

$$
\left.J_{e(C, M)} \alpha \sum_{i=1}^{n} \sum_{j=1}^{c} m_{i j}^{\varphi} d_{i j}^{2}+(1-\alpha) \sum_{i=1}^{n} m_{i *}^{\varphi} \sum_{j=1}^{c} d_{i j}^{-2} \quad \text { [Eq. } 3-8\right]
$$


where $\mathrm{C}$ is the $c \times p$ matrix of class centroids (where $c$ is the cluster and $p$ is the number of variables), $\mathrm{M}$ is the $n \times c$ matrix of partial memberships (where $n$ is the number of observations), $\mathrm{m}_{\mathrm{ij}} \in[0,1]$ is the partial membership of the $i$ th observation to the $j$ th cluster, $\varphi \geq 1$ is the fuzziness exponent, $\mathrm{d}^{2}{ }_{\mathrm{ij}}$ is the square distance between the $i$ th observation and $j$ th cluster center, and $m_{\mathrm{i}} *$ represents membership to the extragrade class. The alpha $(\alpha)$ parameter in this function is used to determine the degree of importance attributed to the extragrade class.

The fuzzy k-means with extragrades algorithm partitions covariates into several classes, where each class is represented by a prediction interval derived from the empirical distribution as a weighted average of membership values. First, the fuzzy k-means with extragrades algorithm arranged the observations $(\mathrm{N})$ and the environmental covariates $(\mathrm{M})$ in a matrix (175 x 20). Iteratively, the algorithm was run using cluster sizes of two through 10, Mahalanobis as the distance metric, and fuzzy exponent value ( $\omega$ ) of 1.3 (Verheyen et al., 2001; Malone et al., 2011). Observations that did not lie between the main clusters were determined by the algorithm to be extragrades (outliers) and were assigned to an extragrade class. The optimal number of classes, where the fuzzy performance index (FPI) and the modified partition entropy (MPE) were minimized, was found to be 3 (Fig. 3.2). FPI measures the degree of separation between classes and the MPE defines the degree of fuzziness created by a specified number of classes for a defined $\omega$ value (Malone et al., 2011). The highest membership value to a cluster was used to determine which cluster each observation was assigned to. A confusion index (CI) was also generated from the FUZME software and was interpolated in ArcMap. This index measures the degree of class overlap in attribute space, depicting how well an observation was classified. The closer to zero the $\mathrm{CI}$ is, the more likely the observation belongs to the dominant class. The closer to one the $\mathrm{CI}$ is, the difference between the dominant and subdominant classes are neglible and there is confusion with the classification of the observation (Gorsevski et al., 2003). The upper 95\% and lower 5\% cluster prediction intervals (PIC) were calculated by summing the PIC and cluster centroids for every observation:

$$
\begin{aligned}
& \operatorname{PIC}^{\mathrm{L}}{ }_{\mathrm{i}}=\sum \mathrm{C}_{\mathrm{i}=1} \mathrm{~m}_{\mathrm{ij}} \mathrm{PIC}_{\mathrm{j}}^{\mathrm{L}} \\
& \mathrm{PIC}_{\mathrm{i}}=\sum \mathrm{C}_{\mathrm{i}=1} \mathrm{~m}_{\mathrm{j} j} \mathrm{PIC}_{\mathrm{j}}^{\mathrm{U}}
\end{aligned}
$$$$
\text { [Eq. } 3-9 \text { ] }
$$ 
where $\mathrm{PIC}^{\mathrm{L}}{ }_{\mathrm{i}}$ and $\mathrm{PIC}^{\mathrm{U}}{ }_{\mathrm{i}}$ represent the weighted lower and upper prediction intervals (PI) for the ith observation, $\mathrm{PIC}_{\mathrm{j}}^{\mathrm{L}}$ and $\mathrm{PIC}_{\mathrm{j}}^{\mathrm{U}}$ are the lower and upper PI for each cluster $j$, and $\mathrm{m}_{\mathrm{ij}}$ is the membership grade of the ith observation to the cluster $j$. The extragrade cluster error distributions were accounted for using Eqs. (3-11) - (3-12) (Malone et al., 2011):

$$
\begin{aligned}
& \mathrm{PIC}_{\text {ej }}^{\mathrm{L}}=2 \times \mathrm{q}_{2.5} \\
& \mathrm{PIC}_{\text {ej }}^{\mathrm{U}}=2 \times \mathrm{q}_{2.5}
\end{aligned}
$$

[Eq. $3-12]$

where PIC ${ }_{\text {ej and }}^{\mathrm{L}} \mathrm{PIC}^{\mathrm{U}}{ }_{\text {ej }}$ represent the lower and upper PI of the extragrade class and $\mathrm{q}$ is the quantile value of the extragrade cluster error distribution. This method penalizes extragrade regions where there is very low prediction confidence. Once the weighted PI were calculated, the lower and upper prediction limits $\left(\mathrm{PL}^{\mathrm{L}_{i}}\right.$ and $\mathrm{PL}_{\mathrm{i}}$ ) were calculated for each observation by summing the GWRK model value to $\mathrm{PL}^{\mathrm{L}}{ }_{\mathrm{i}}$ and $\mathrm{PL}_{\mathrm{i}} \mathrm{U}_{\mathrm{i}}$ (Malone et al., 2011). The lower and upper prediction limits were then interpolated in ArcMap.

\section{Results and Discussion}

\section{$\underline{\text { Descriptive Statistics }}$}

The statistical distribution of the SOC stock in the KSSL pedons used to train the GWR model was highly positively skewed, had more peaked values than a normal distribution, and was more spatially clustered than spatially random processes (Table 3.1). Standard data transformations were explored for the KSSL pedons, including lognormal, square root, squaring, Box-Cox, etc., but normality was not achieved. Untransformed KSSL SOC data were used to train the GWR model. The residuals of the GWR model mirrored the statistical distribution of the KSSL SOC data with positive skewness (1.14) and kurtosis (4.93) and a positive Moran's I statistic (0.09). The kriged residuals showed that the GWR model tended to overestimate SOC in the northeastern and southwestern part of MLRA 127, indicating an anisotropic trend in the GWR model (Fig. 3.3).

\section{GWR and GWRK Models}

Due to limited computing power, $250 \mathrm{~m}, 800 \mathrm{~m}$, and 2,000 $\mathrm{m}$ spatial resolutions of the covariate data were explored to determine an appropriate spatial resolution to model SOC at a MLRA scale (Fig. 3.4). The root mean square error (RMSE) was lowest at $250 \mathrm{~m}(0.28)$, 
followed by $2,000 \mathrm{~m}(0.31)$, and $800 \mathrm{~m}(0.48)$ while the mean absolute error (MAEE) was equivalent for the $250 \mathrm{~m}$ and 2,000 $\mathrm{m}$ spatial resolutions (0.02) and higher for $800 \mathrm{~m}(0.04)$ (Table 3.3). Statistical validation showed that the GWRK model performed similarly at $250 \mathrm{~m}$, $800 \mathrm{~m}$, and 2,000 m spatial resolutions. Pixel noise was apparent at the $250 \mathrm{~m}$ and $800 \mathrm{~m}$ spatial scales (Fig. 3.4). Given the similarity in statistical performance and decreased pixel noise, the 2,000 m spatial resolution was chosen for modeling SOC in MLRA 127 (Figs. 3.3 and 3.4). At a 2,000 m spatial resolution, the GWR and GWRK models reported SOC values ranging from 0 to $41 \mathrm{~kg} \mathrm{~m}^{-2}$, with means of $15 \mathrm{~kg} \mathrm{~m}^{-2}$ in the GWR model and $16 \mathrm{~kg} \mathrm{~m}^{-2}$ in the GWRK model. Both of these models showed highest SOC in the Monongahela National Forest and the lowest in Pennsylvania and New York (Figs. 3.5 and 3.6). The RaCA model predicted SOC values ranging from $0 \mathrm{~kg} \mathrm{~m}^{-2}$ to $258 \mathrm{~kg} \mathrm{~m}^{-2}$, with a mean of $9 \mathrm{~kg} \mathrm{~m}^{-2}$ (Fig. 3.7). When compared to the RaCA model, the GWR and GWRK models produced much smaller ranges and higher mean values. These statistical differences were due to the methodological errors and limited sampling in the higher carbon areas in the Monongahela National Forest. The RaCA model did show high SOC values in the Monongahela National Forest, but also showed equally as high values in New York. All three of the models depicted significantly more SOC than estimates derived from STATSGO2 (Fig. 3.8; Table 3.3) and SSURGO (Fig. 3.9; Table 3.3).

The mean SOC values of the GWR and GWRK models were similar to those predicted by Kern et al., (1994) using the taxonomy approach (Table 3.2). The taxonomy approach used KSSL and Soil Interpretation Record data to calculate SOC by taxonomic units created using National Resource Inventory data. Kern et al. (1994) found that the taxonomic approach tended to give more reliable results for Histosols, shallow soils, and soils with high rock fragment content when compared to the ecosystem approach. The GWR and GWRK models may have predicted similarly to the taxonomic approach since they all utilized measured data. The taxonomic approach was modeled at a 1:7,500,000 spatial resolution while the GWR and GWRK approaches were modeled at a finer resolution of 2,000 $\mathrm{m} \mathrm{x} \mathrm{2,000} \mathrm{m,} \mathrm{showing} \mathrm{more} \mathrm{spatial}$ variability in SOC stock. Mean SOC stock in the upper meter of soil in MLRA 127 has been predicted to be greater than $10 \mathrm{~kg} \mathrm{~m}^{-2}$ in most studies, including this one (Eswaren et al., 1993; Kern, 1994; Jenkins, 2001; Mishra et al., 2010; Soil Survey Staff, 2013) (Table 3.2). 


\section{Validation}

The GWR and GWRK models were validated using 175 independent observations from RaCA and Sponaugle (2005) (Appendices F and G). Additionally, the RaCA model was validated in this study with the 254 prepared KSSL pedons within MLRA 127 (Appendices A and B). The RaCA model reported the lowest RMSE and MAEE at $0.22 \mathrm{~kg} \mathrm{~m}^{-2}$ and $0.02 \mathrm{~kg} \mathrm{~m}^{-2}$, respectively (Table 3.4). The RaCA model had a lower SOC stock mean $\left(9 \mathrm{~kg} \mathrm{~m}^{-2}\right)$ than the GWRK $\left(16 \mathrm{~kg} \mathrm{~m}^{-2}\right)$ and GWR $\left(19 \mathrm{~kg} \mathrm{~m}^{-2}\right)$ models and showed less variation across MLRA 127. The GWRK model performed the second best with a RMSE of $0.31 \mathrm{~kg} \mathrm{~m}^{-2}$ and MAEE of 0.02 $\mathrm{kg} \mathrm{m}^{-2}$ (Table 3.4).

The GWRK approach used to predict SOC in Pennsylvania by Kumar et al. (2012) yielded a RMSE of $2.61 \mathrm{~kg} \mathrm{~m}^{-2}$ and MAEE of $2.34 \mathrm{~kg} \mathrm{~m}^{-2}$. Mishra et al. (2010) used GWR, regression kriging (RK), and multiple linear regression (MLR) to predict SOC stock in the upper $0.5 \mathrm{~m}$ for Midwestern MLRA, including MLRA 127. Their results showed that GWR performed the best with a RMSE of $6.40 \mathrm{~kg} \mathrm{~m}^{-2}$ and MAEE of $3.38 \mathrm{~kg} \mathrm{~m}^{-2}$. The error rates reported in this study are much lower than previous studies, indicating that: (i) SOC prediction by MLRA might be the most suitable way for NRCS to predict SOC stock, (ii) GWRK should be the recommended approach for the DSM of SOC, and (iii) Future research is needed to statistically validate spatial, nonparametric models.

\section{$\underline{\text { Uncertainty }}$}

Uncertainty of the GWRK model was assessed using the fuzzy k-means with extragrade algorithm in the FUZME software (Minasny and McBratney, 2002). The CI revealed that class membership was highest in areas with relatively low SOC (10 to $\left.20 \mathrm{~kg} \mathrm{~m}^{-2}\right)$ and lowest in areas with moderate to moderately high SOC (30 to $50 \mathrm{~kg} \mathrm{~m}^{-2}$ ) (Fig. 3.10). Strong variability in the training data, areas with limited training data, and strong variability in the environmental covariate data resulted in high a CI in most of the study area outside of the training sites. The spatial variability of SOC stock is due to extrinsic and intrinsic factors. The methodology presented in this study was able to explain some of the extrinsic variability through use of environmental covariates and spatial relationships. Intrinsic variability from factors like pedoturbation, microtopography, and biological influences has been shown to be more important than extrinsic factors in determining overall pedodiversity (Phillips, 2001). Intrinsic variability 
was not addressed in this study due to the coarse spatial resolution and time constraints. Future research is needed to capture the intrinsic variability of SOC in MLRA 127.

95\% prediction intervals were calculated from adding the sum of the cluster centroids multiplied by the cluster prediction intervals to the modeled GWRK values. The lower GWRK prediction interval ranged from 0 to $40 \mathrm{~kg} \mathrm{~m}^{-2}$, with a mean of $13 \mathrm{~kg} \mathrm{~m}^{-2}$ (Fig. 3.11) while the high GWRK prediction interval ranged from 9 to $69 \mathrm{~kg} \mathrm{~m}^{-2}$, with a mean of $23 \mathrm{~kg} \mathrm{~m}^{-2}$ (Fig. 3.12). Because the GWR and GWRK models were trained by KSSL pedons with forested, pastured, and cropped land uses, it is hypothesized that the lower prediction interval reflects SOC stock under cropped land use and the higher prediction interval reflects the SOC stock capacity of soils in MLRA 127 under forested land cover. A long-term land use conversion study would need to be conducted to prove this hypothesis in MLRA 127, but based on previous land use studies of Guo and Gifford (2002) and Zhou et al. (2008), this range in SOC stock due to land use is not unrealistic.

\section{$\underline{\text { Total Carbon Stock }}$}

The USDA Forest Service (FS) has developed the Forest Inventory and Analysis (FIA) program to estimate total biosphere carbon. In a forested ecosystem, there are seven sources of carbon. Aboveground carbon is composed of live aboveground vegetation, downed dead vegetation, standing dead vegetation, and understory vegetation. Belowground carbon is composed of soil carbon, forest litter (including fresh leaves, fine woody debris, and humus), and live belowground vegetation. For soil carbon estimation in the FIA program, the FS developed models using geographical area, forest type, and in some cases, stand age (USDA-USFS, 2014; Woodall and Monleon, 2008).

In this thesis, we were able to better capture the variability of SOC stock in MLRA 127 as compared to current NRCS soil survey products. In order to enhance the FIA estimation of total biosphere carbon and to understand the quantitative role that SOC has in the biosphere within MLRA 127, SOC stock values modeled by GWRK were substituted for soil carbon and forest litter values estimated by the FIA model. Total carbon (in Pg) was then calculated as follows:

$$
\mathrm{TC}_{\mathrm{s}}=\sum \mathrm{cc}_{\mathrm{s}}^{2} \times \mathrm{C}_{\mathrm{s}} \times \mathrm{CF}_{\mathrm{s}}
$$


where $\mathrm{TC}_{\mathrm{s}}$ is the total carbon for the given source, $\mathrm{cc}_{\mathrm{s}}{ }^{2}$ is the raster cell area, $\mathrm{C}_{\mathrm{s}}$ is the predicted carbon value, and $\mathrm{CF}_{\mathrm{s}}$ is the conversion factor to ensure that $\mathrm{TC}_{\mathrm{s}}$ is in petagrams $(\mathrm{Pg})$. Total SOC stock was also calculated for the gridded SSURGO (gSSURGO), GWR, GWRK, RaCA, GWRK-low prediction interval, and GWRK-high prediction interval models (Table 3.5). Total SOC stock for the upper $1 \mathrm{~m}$ in MLRA 127 ranged from $0.23 \mathrm{Pg}$ in $\mathrm{gSSURGO}$ to $1.28 \mathrm{Pg}$ in the high prediction interval for the GWRK model. According to the FIA model, the total SOC stock is $0.29 \mathrm{Pg}$ (Table 3.6) when litter is included and the total carbon in the biosphere is $0.67 \mathrm{Pg}$ (Table 3.7), showing that SOC makes up 43\% of the total biosphere carbon in MLRA 127 (Fig. 3.13). When SOC values from the low, representative, and high GWRK model were substituted for the SOC and litter values in the FIA model, total carbon in the biosphere in MLRA 127 ranged from $1.01 \mathrm{Pg}$ to $1.50 \mathrm{Pg}$ to $1.65 \mathrm{Pg}$, respectively. SOC was shown to represent $60 \%, 69 \%$, and $71 \%$ of the total biosphere carbon in MLRA 127, respectively (Figs. 3.14 through 3.16; Tables 3.5 and 3.7).

Using the representative GWRK estimate for SOC, soil accounted for $69 \%$ of the total carbon in MLRA 127. SOC reported in the FIA model only represents the upper $20 \mathrm{~cm}$ of soil while SOC in the GWRK model encompasses the upper $1 \mathrm{~m}$ of soil. Given the methodological differences between the FIA SOC estimate and the GWRK estimate and the low error statistcs reported for the GWRK model, it is expected that the GWRK estimate for SOC is more realistic for estimating total biosphere carbon. In MLRA 127, more carbon is stored in soils than in plant materials, supporting research from Jobbágy and Jackson (2000).

\section{Conclusions}

Soil organic carbon (SOC), a dynamic soil property and the largest pool of terrestrial organic carbon in the biosphere (Jobbágy and Jackson, 2000; Minasny et al., 2013; Stockmann et al., 2013), plays a critical role in supplying nutrients to plants, improving soil structure and aggregate stability, contributing to cation exchange capacity, and developing sustainable land management practices (Schulte, 1988; Droogers and Bouma, 1997; Jobbágy and Jackson, 2000; Stolt et al., 2010; Batlle-Auguilar et al., 2011). In order to understand, predict, and manage these impacts, an initial assessment of SOC stock and its dynamic nature is needed within the realm of soil survey (Stolt et al., 2010). In this study, it was shown that nonparametric spatial modeling techniques such as GWR and GWRK are able to effectively predict SOC stock within a MLRA. The error rates reported in this study are much lower than previous studies, indicating that: (i) 
SOC prediction by MLRA might be the most suitable way for NRCS to predict SOC stock, (ii) GWRK should be the recommended approach for the DSM of SOC, and (iii) future research is needed to statistically validate spatial, nonparametric models. Spatial models can always be improved with more statistically-designed soil samples to train and validate the models and finer resolution covariate data that have limited artifacts and errors. The methodology presented in this thesis, beginning with preparing KSSL data and ending with an interpolated GWRK model with 95\% prediction intervals depicting the SOC stock of the upper $1 \mathrm{~m}$ of soil in MLRA 127, is recommended to the NRCS as a guideline for future DSM research.

The biosphere carbon assement using the FS FIA model presented in this chapter revaled that there is more carbon stored in soil than in the entire biosphere in MLRA 127. This finding has huge implications on land management and land use in MLRA 127 given that 76\% of the MLRA is forested. Future research is needed to better capture the intrinsic variability of SOC and understand carbon sequestration in relation to land use conversion effects in the Eastern Allegheny Plateau and Mountains. 


\section{Literature Cited}

Batlle-Aguilar, J., A. Brovelli, A. Porporato, and D.A. Barry. 2011. Modeling soil carbon and nitrogen cycles during land use change. A review. Agronomy for Sustainable Development. 31: 251-274.

Bliss, N.B., S.W. Waltman, and G.W. Peterson. 1995. Preparing a soil carbon inventory for the United States using geographic information systems. In: Lal, R, J. Kimble, E. Levine, and B.A. Stewart (eds). Soils and Global Change. CRC Press Inc, Boca Raton, FL. 275-295.

Boettinger, J.L., R.D. Ramsey, J.M. Bodily, N.J. Cole, S. Kienast-Brown, S.J. Nield, A.M. Saunders, and A.K. Stum. 2008. "Landsat spectral data for digital soil mapping". Digital Soil Mapping with Limited Data, ED: Hartemink, A.E., McBratney, A.B., Mendonça Santos, M.L. Springer, Dordrecht. 15-30. Print.

Brungard, Colby W. 2009. "Alternative sampling and analysis methods for digital soil mapping in southwestern Utah." All Graduate Theses and Dissertations. Paper 472. $<$ http://digitalcommons.usu.edu/etd/472>.

Bui, E., B. Henderson, and K. Viergever. 2009. Using knowledge discovery with data mining from the Australian Soil Resource Information System database to inform soil carbon mapping in Australia. Global Biogeochemical Cycles. 23:GB4033, 1-15.

Droogers, P. and J. Bouma. 1997. Soil survey input in exploratory modeling of sustainable soil management practices. Soil Science Society of America Journal. 61: 1704-1710.

The Global Landcover Facility (GLCF). 2005. Landsat GeoCover Degree Subset. University of Maryland Institute for Advanced Computer Studies, College Park, MD. < http://glcf.umd.edu/data/degree/>.

Gorsevski, P. V., P.E. Gessler, and P. Jankowski. 2003. Integrating a fuzzy k-means classification and a Bayesian approach for spatial prediction of landslide hazard. Journal of Geographical Systems. 5, 223-251.

Grunwald, S. 2010. Current State of Digital Soil Mapping and What is Next? In: J.L. Boettinger et al. (eds.), Digital Soil Mapping, Progress in Soil Science 2, Springer. 3-12.

Guo, L. B. and R.M. Gifford. 2002. Soil carbon stocks and land use change: a meta-analysis. Global Change Biology. 8: 345-360. 
Huete, A., K. Didan, T. Miura, E.P. Rodriguez, X. Gao, and L.G. Ferreira. 2002. Overview of the radiometric and biophysical performance of the MODIS vegetation indices. Remote Sensing of Environment. 83: 195-213.

Jenkins, A. 2001. Organic Carbon and Fertility of Forest Soils on the Allegheny Plateau of West Virginia. M.S. thesis, West Virginia University, Morgantown, WV. <http://etd.wvu.edu/templates/showETD.cfm?recnum=2486>.

Jenny, H. 1941. Factors of soil formation. McGraw-Hill, New York, New York, USA.

Jobbágy, E. G. and R.B. Jackson. 2000. The vertical distribution of soil SOC and its relation to climate and vegetation. Ecological Applications. 10:423-436.

Keller, J.K., K.K. Takagi, M.E. Brown, K.N. Stump, C.G. Takahashi. 2012. Soil SOC storage in restored salt marshes in Huntington Beach, California. Bulletin of Southern California Academy of Sciences. 111 (2). 〈http://scholar.oxy.edu/scas/vol111/iss2/5>.

Kern, J.S. 1994. Spatial patterns of soil organic carbon distribution in the contiguous United States. Soil Science Society of America Journal. 58: 439-455.

Kumar, S., R. Lal, and D. Liu. 2012. A geographically weighted regression kriging approach for mapping soil organic carbon stock. Geoderma. 189-190: 627-634.

Malone, B.P., A.B. McBratney, and B. Minasny. 2011. Empirical estimates of uncertainty for mapping continuous depth functions of soil attributes. Geoderma. 160: 614-626.

McBratney, A.B., M.L. Mendonca Santos, and B. Minasny. 2003. On digital soil mapping. Geoderma. 117: 3-52.

Minasny, B., McBratney, A.B., 2002. FuzME version 3.0, Australian Centre for Precision Agriculture, The University of Sydney, Australia. $<$ http://sydney.edu.au/agriculture/pal/software/fuzme.shtml>.

Minasny, B., A.B. McBratney, N.J. McKenzie, and M.J. Grundy. 2008. Predicting soil properties using pedotransfer functions and environmental correlation. N.J. McKenzie, M.J. Grundy, R. Webster, A.J. Ringrose-Voase (Eds.). Guidelines for Surveying Soil and Land Resources, Australian Soil and Land Survey Handbook Series, CSIRO Publishing, Melbourne (2008). 349-367.

Minasny, B., A.B. McBratney, B.P. Malone, and I. Wheeler. 2013. Digital mapping of soil carbon. Advances in Agronomy. 118: 1-47. 
Mishra, U., R. Lal, D. Liu, and M. Van Meirvenne. 2010. Predicting the spatial variation of the soil organic carbon pool at a regional scale. Soil \& Water Management \& Conservation. Soil Science Society of American Journal. 74 (3): 906-914.

Nakaya, T. 2014. GWR 4.0 Software. Centre for GeoInformatics. University of St. Andrews. < http://geoinformatics.wp.st-andrews.ac.uk/gwr/gwr-downloads>.

Nauman, T.W., J.A. Thompson, N.P. Odgers, and Z. Libohova. 2012. Fuzzy disaggregation of conventional soil maps using database knowledge extraction to produce soil property maps.B. Minasny, B. Malone, A. McBratney (Eds.), Digital Soil Assessments and Beyond: 5th Global Workshop on Digital Soil Mapping, Sydney, Australia (2012).

Phillips, J.D. 2001. The relative importance of intrinsic and extrinsic factors in pedodiversity. Annals of the Association of American Geographers. 91:4, 609-621.

PRISM Climate Group. 2004. Oregon State University. < http://prism.oregonstate.edu>. Razafimbelo, T., T. Chevallier, A. Albrecht, L. Chapuis-Lardy, F. Nirina Rakotondrasolo, R. Michellon, L. Rabeharisoa, and M. Bernoux. 2013. Texture and organic carbon contents do not impact amount of carbon protected in Malagasy soils. Scientia Agricola. 70:3, 204-208.

Schulte, E.E. 1988. Recommended soil organic matter tests. In: Recommended Chemical Soil Test Procedures for the North Central Region. North Central Reg. Publ. 221 (Revised). North Dakota Agric. Exp. Stn. Bull. 499. Fargo, ND. 29-32.

Soil Survey Staff. 2010. Keys to Soil Taxonomy, 11th ed. USDA-Natural Resources Conservation Service, Washington, DC.

Soil Survey Staff. 2013. Rapid Assessment of U.S. Soil Carbon (RaCA) project. United States Department of Agriculture, Natural Resources Conservation Service. <http://www.nrcs.usda.gov/wps/portal/nrcs/detail/soils/survey/?cid=nrcs142p2_054164>. Sponaugle, C.L. 2005. Properties and acid risk assessment of soils in two parts of the Cherry River watershed, West Virginia. M.S. thesis, West Virginia University, Morgantown, WV. <http://hdl.handle.net/10450/4425>.

Stockmann, U., M.A. Adams, J.W. Crawford, D.J. Field, N. Henakaarchchi, M. Jenkins, B. Minasny, A.B. McBratney, V. de R. de Courcelles, K. Singh, I. Wheeler, L. Abbott, D.A. Angers, J. Baldock, M. Bird, P.C. Brookes, C. Chenu, J.D. Jastrow, R. Lal, J. Lehmann, A.G. O’Donnell, W.J. Parton, D. Whitehead, and M. Zimmermann. 2013. The knowns, known 
unknowns, and unknowns of sequestration of soil SOC. Agriculture, Ecosystems, and Environment, 164: 80-99.

Stolt, M.H., P.J. Drohan, and M.J. Richardson. 2010. Insights and Approaches for Mapping Soil SOC as a Dynamic Soil Property. Soil Science Society of America Journal. 74:5, 1685-1689.

Tedrow, L. and K.T. Weber. 2011. NDVI changes over a calender year in the rangelands of southeast Idaho. Final Report: Assessing post-fire recovery of sagebrush-steppe rangelands in southeastern Idaho. Ch. 9. 105-116.< http://giscenter.isu.edu/research/Techpg/nasa_postfire/pdf/Ch9.pdf>.

United States Department of Agriculture - United States Forest Service. 2014. Forest Inventory and Analysis DataMart. FIADB version $5.1<\mathrm{http}$ ://apps.fs.fed.us/fiadbdownloads/datamart.html>. Accessed: 10/11/2014.

Verheyen, K., D. Adriaens, M. Hermy, and S. Deckers. 2001. High-resolution continuous soil classification using morphological soil profile descriptions. Geoderma. 101, 31-48.

Woodall, C.W. and V.J. Monleon. 2008. Sampling protocols, estimation, and analysis procedures for down woody materials indicator of the FIA Program. Gen. Tech. Rep. NRS-22. Newtown Square, PA: U.S. Department of Agriculture, Forest Service, Northern Research Station. 68 p.

Zhong, B., and Y.J. Xu. 2011. Scale effects of geographical soil datasets on soil carbon estimation in Louisiana, USA: A comparison of STATSGO and SSURGO. Pedosphere. 21(4): 491-501.

Zhou, X., H.S. Lin, and E.A. White. 2008. Surface soil hydraulic properties in four soil series under different land uses and their temporal changes. Catena. 73:180-188. 
Figures and Tables

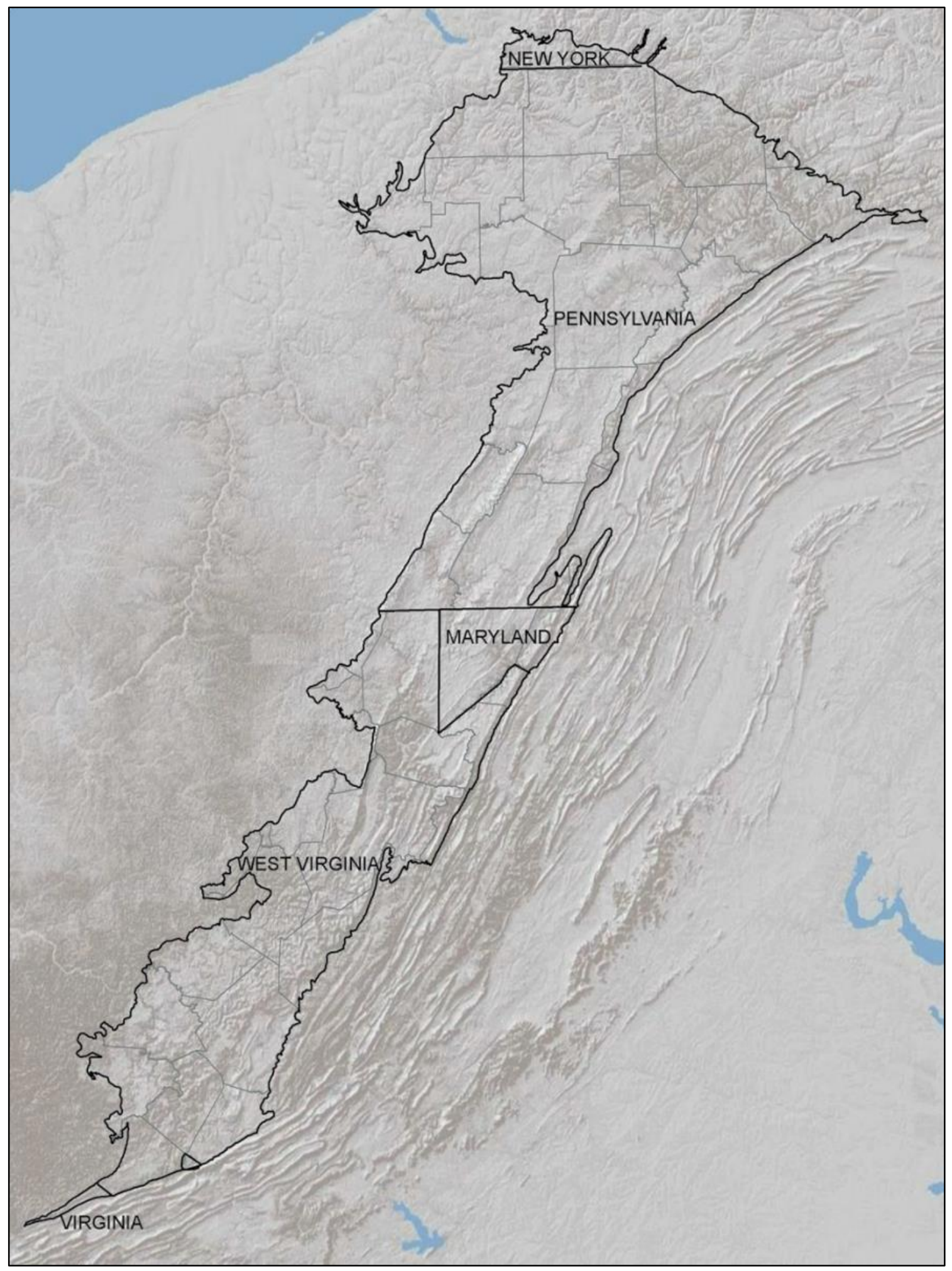

Figure 3.1 The Eastern Allegheny Plateau and Mountains (MLRA 127) encompassing parts of Maryland, New York, Pennsylvania, Virginia, and West Virginia. 


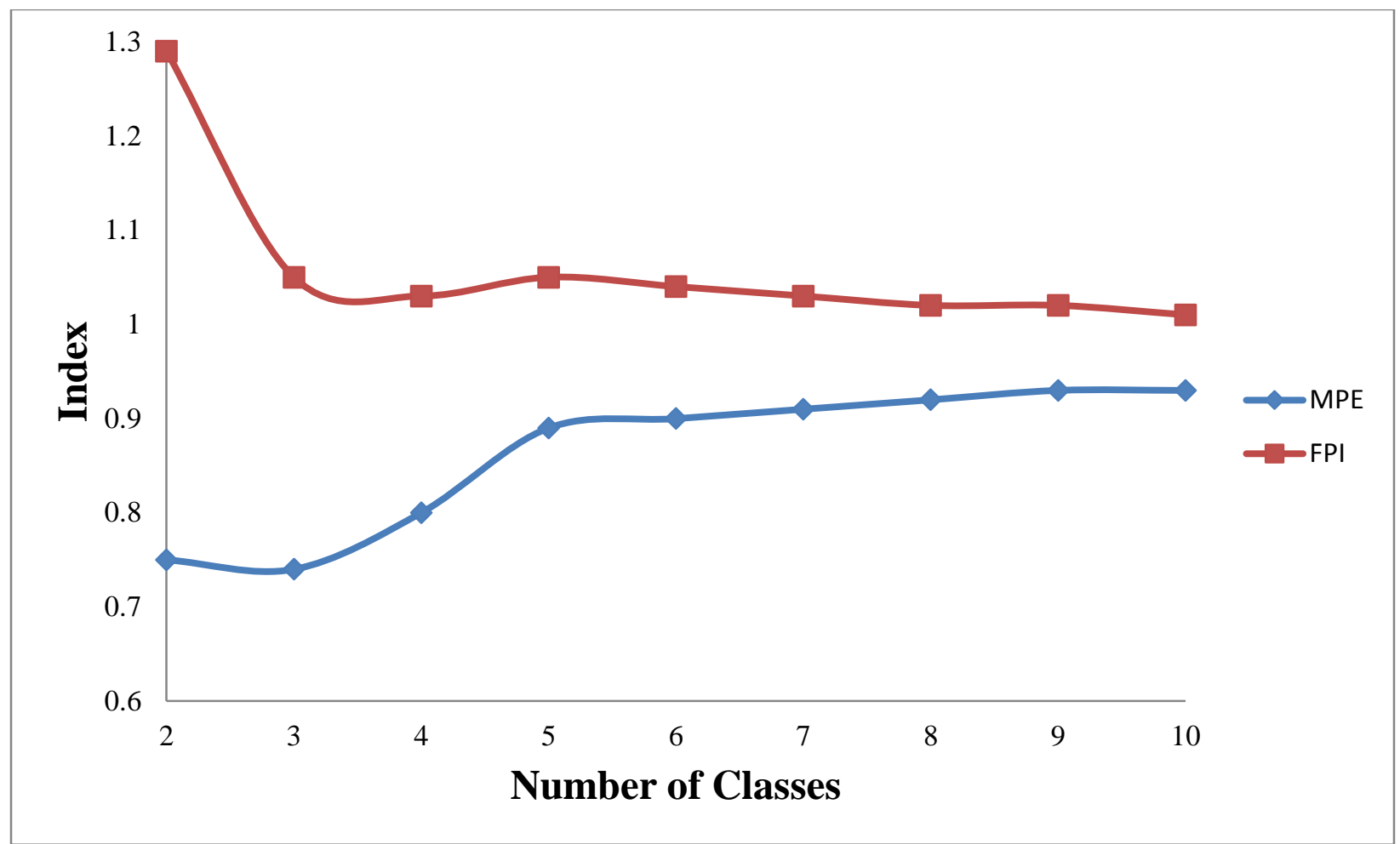

Figure 3.2 Cluster performance graph as a function of number of classes, fuzzy performance index (FPI), and the modified partition entropy (MPE) calculated using FUZME software. 


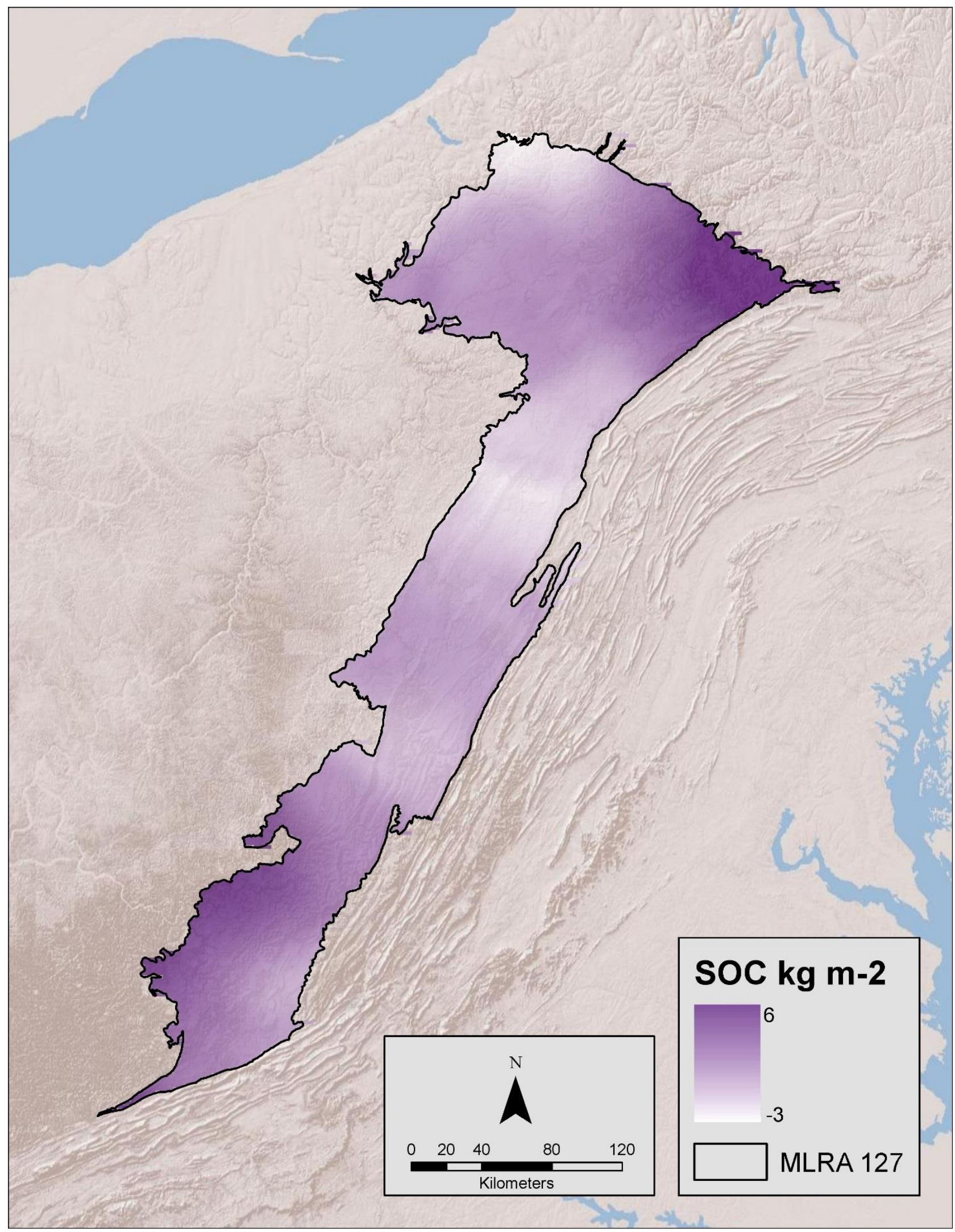

Figure 3.3 Residuals from the GWR model interpolated using OK. 

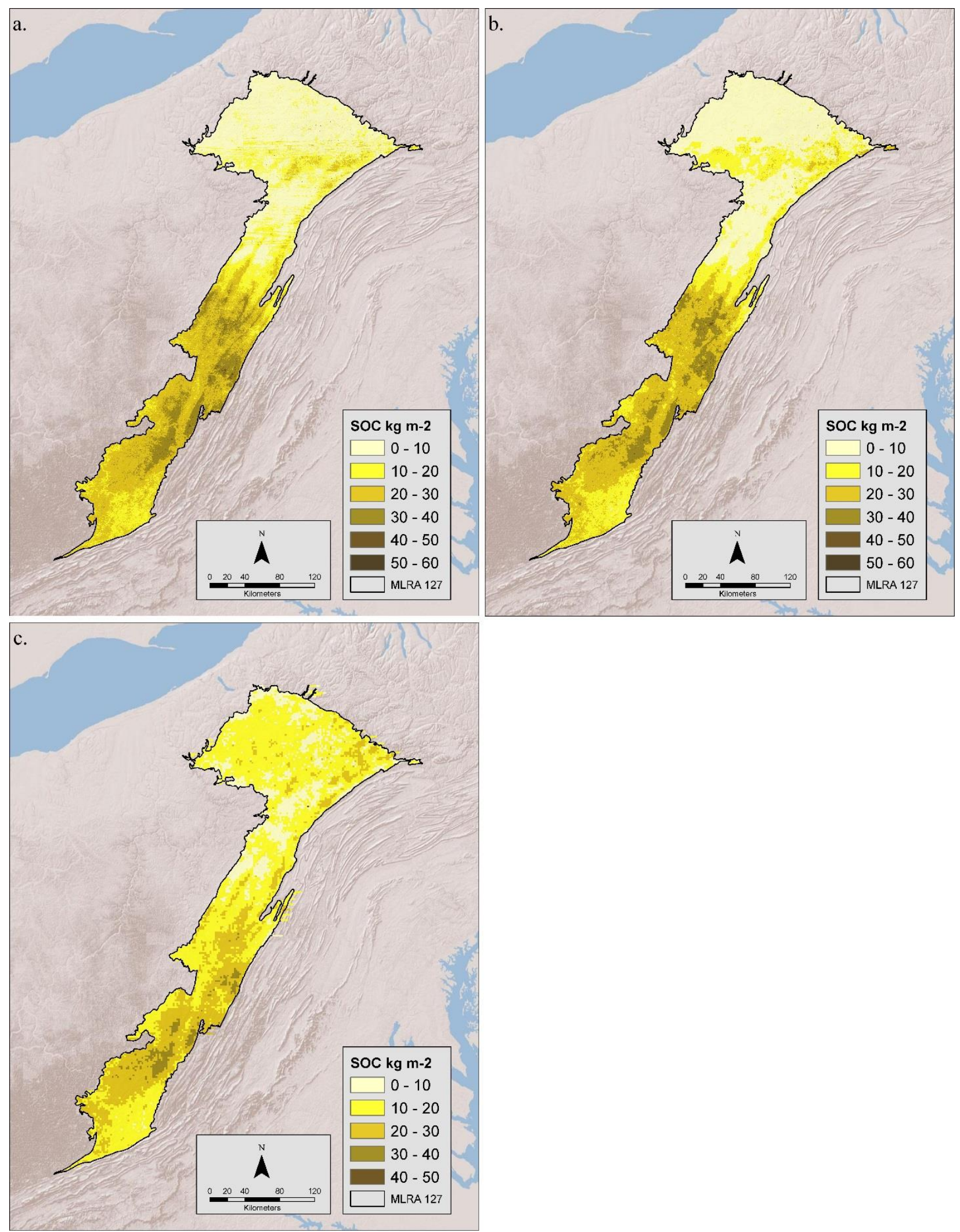

Figure 3.4 SOC stock in the upper meter of soil in MLRA 127 predicted by GWRK with the following resolution sizes: (a) $250 \mathrm{~m}$, (b) $800 \mathrm{~m}$, and (c) $2,000 \mathrm{~m}$. 


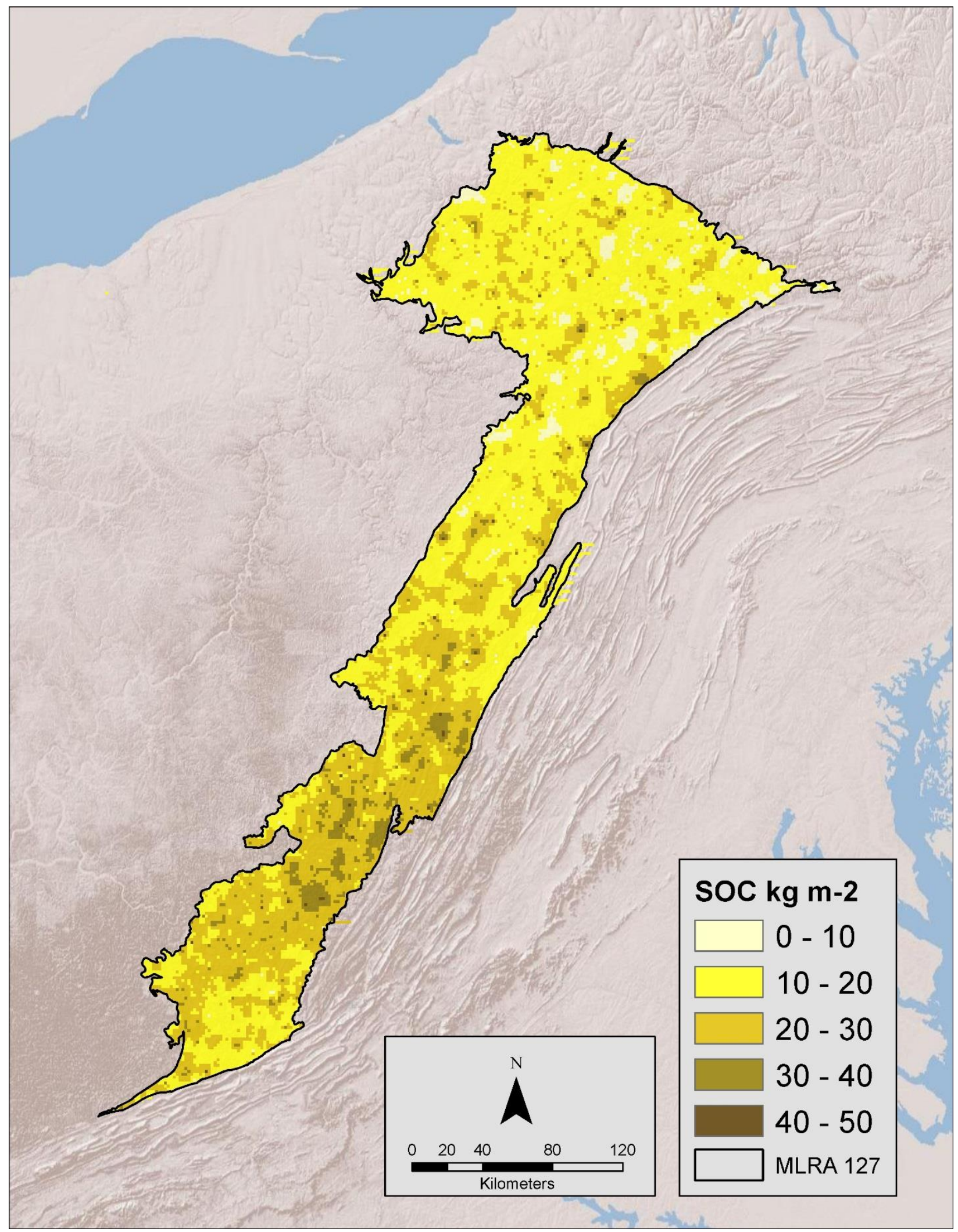

Figure 3.5 SOC stock in the upper meter of soil in MLRA 127 predicted through GWR. 


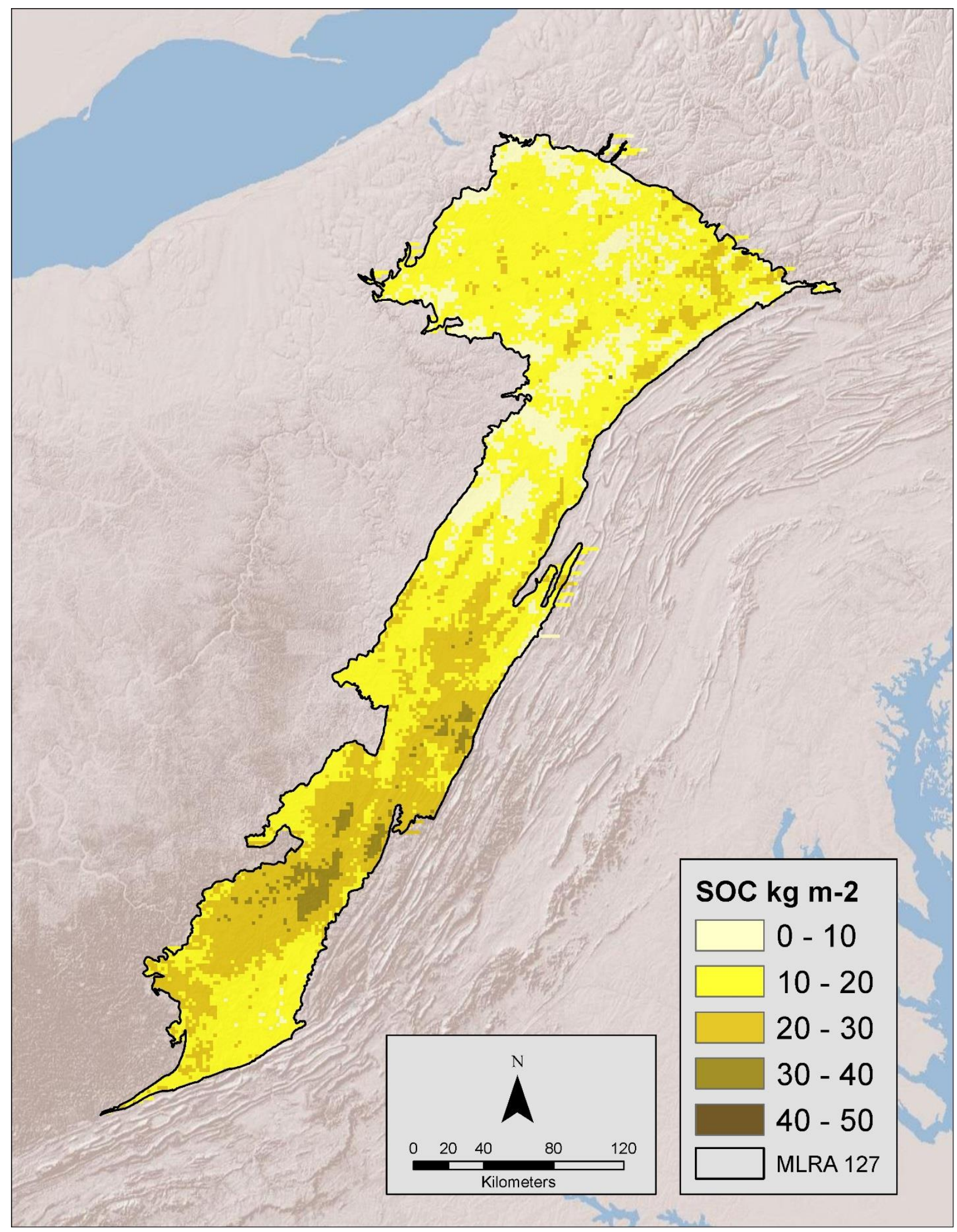

Figure 3.6 SOC stock in the upper meter of soil in MLRA 127 predicted through GWRK with 2,000 m spatial resolution. 


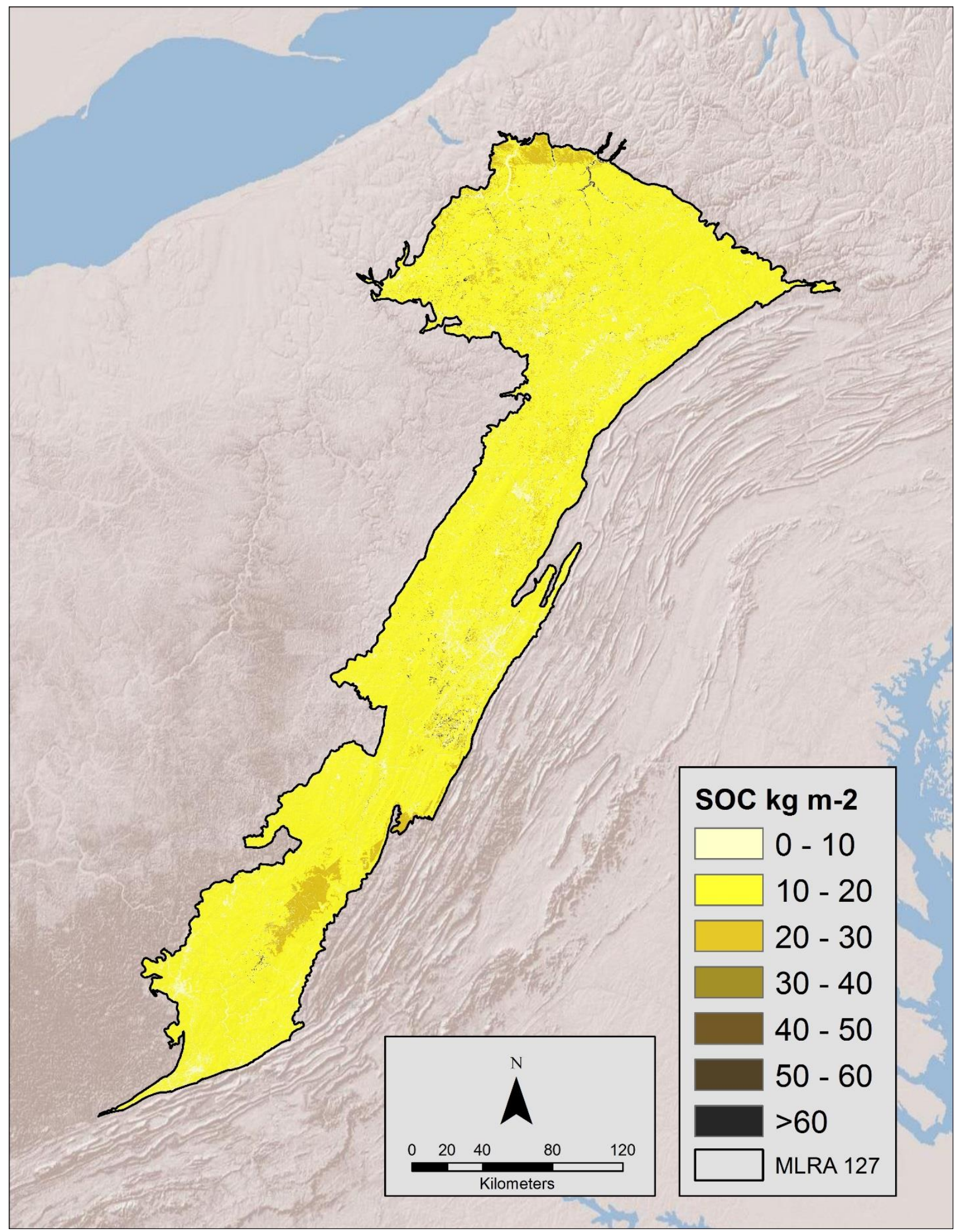

Figure 3.7 SOC stock in the upper meter of soil in MLRA 127 predicted by RaCA (Soil Survey Staff, 2013). 


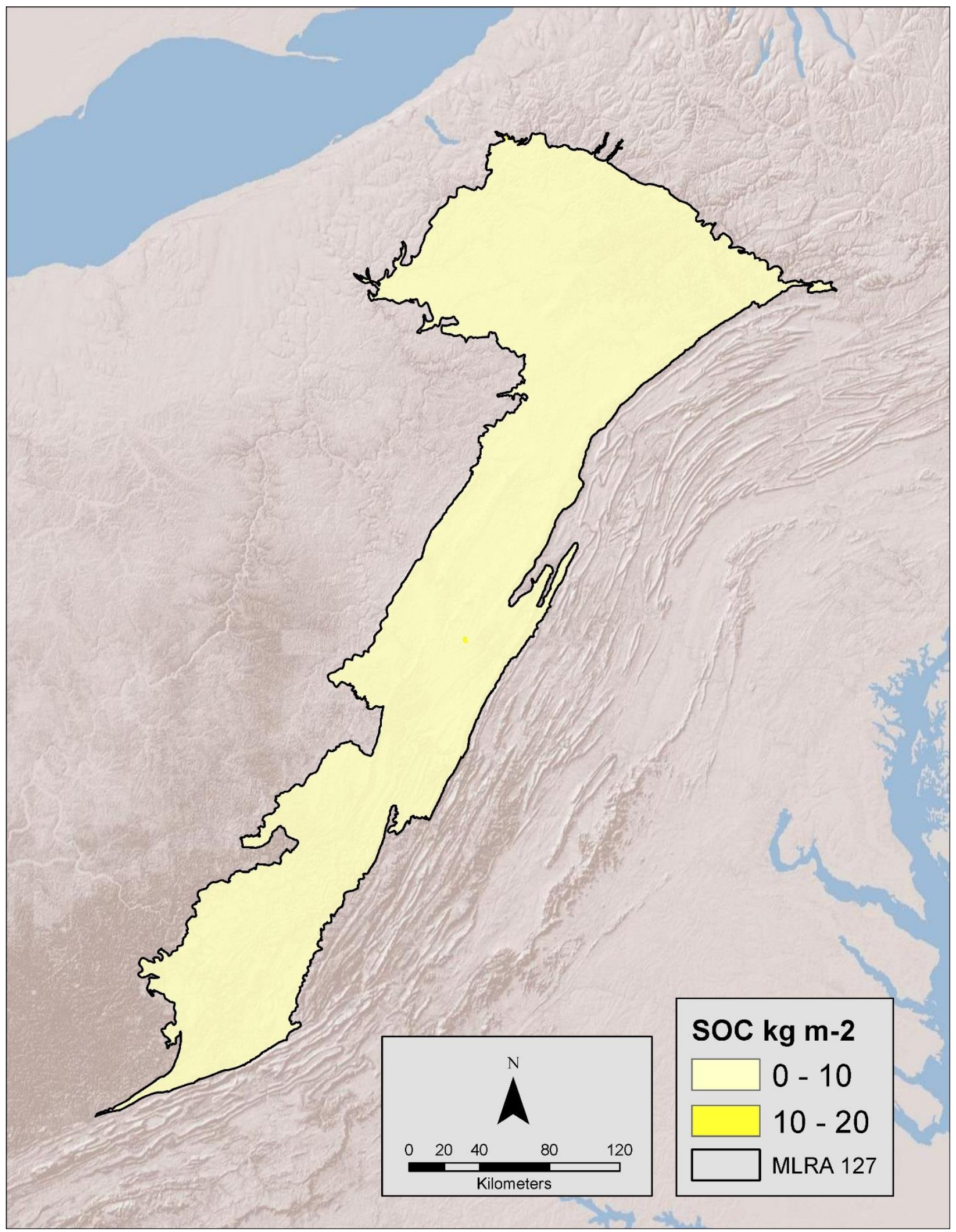

Figure 3.8 SOC stock in the upper meter of soil in MLRA 127 currently in STATSGO2. 


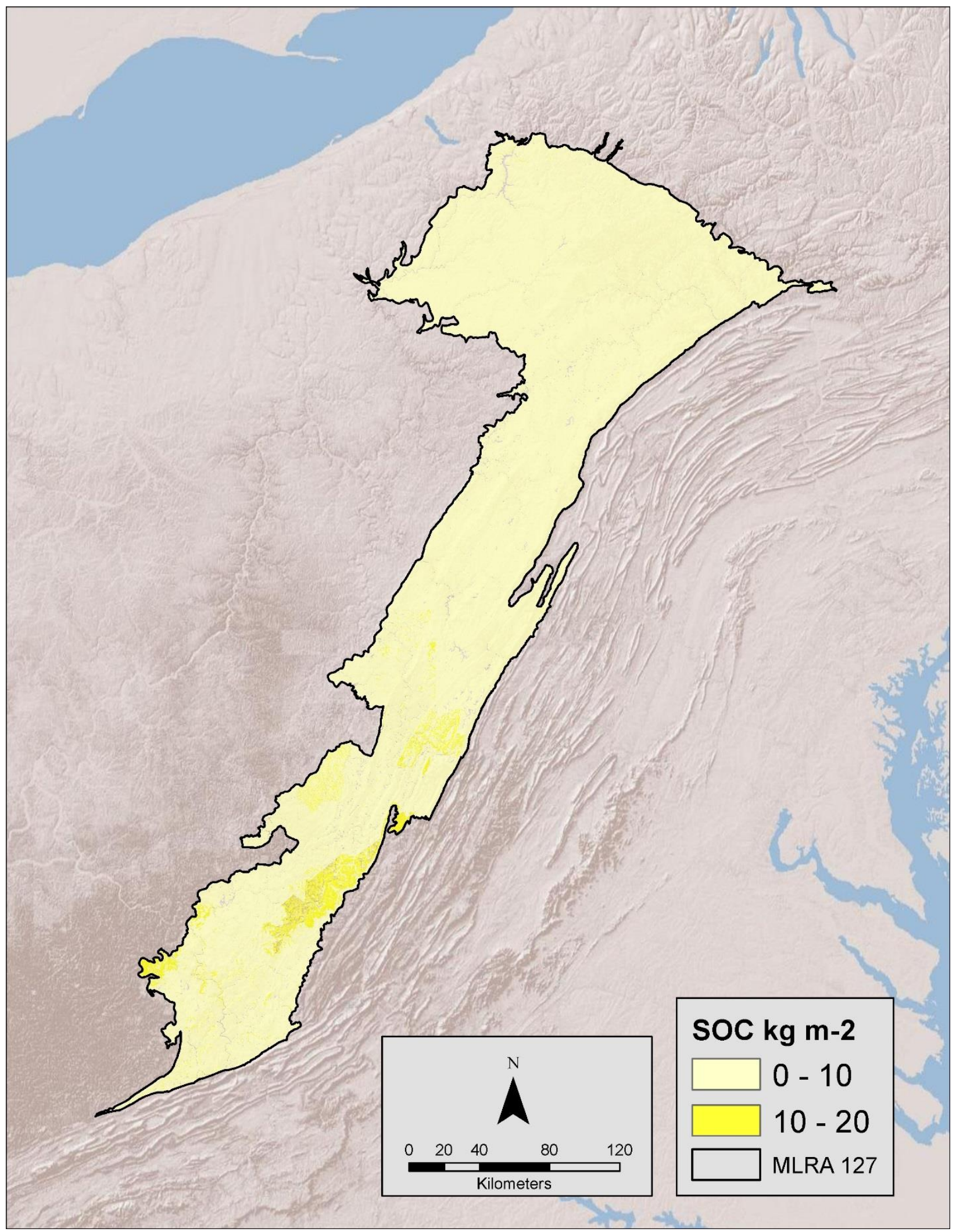

Figure 3.9 SOC stock in the upper meter of soil in MLRA 127 currently in SSURGO. 


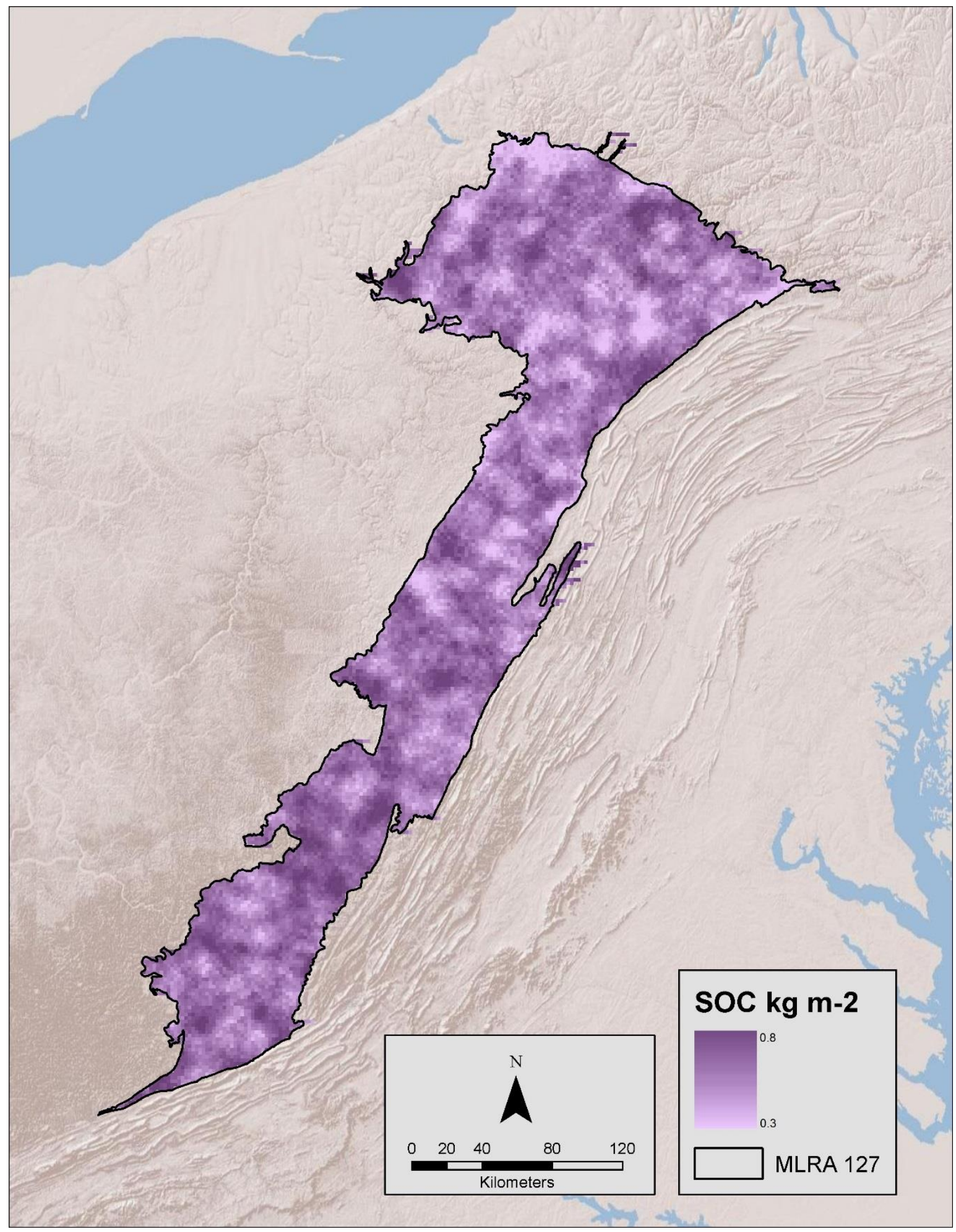

Figure 3.10 Confusion index of SOC stock in the upper meter of soil in MLRA 127 calculated using fuzzy $k$-means with extragrade analysis. As the confusion index increases, the difference between the dominant and subdominant classes become negligible and there is confusion with the classification of the observation. 


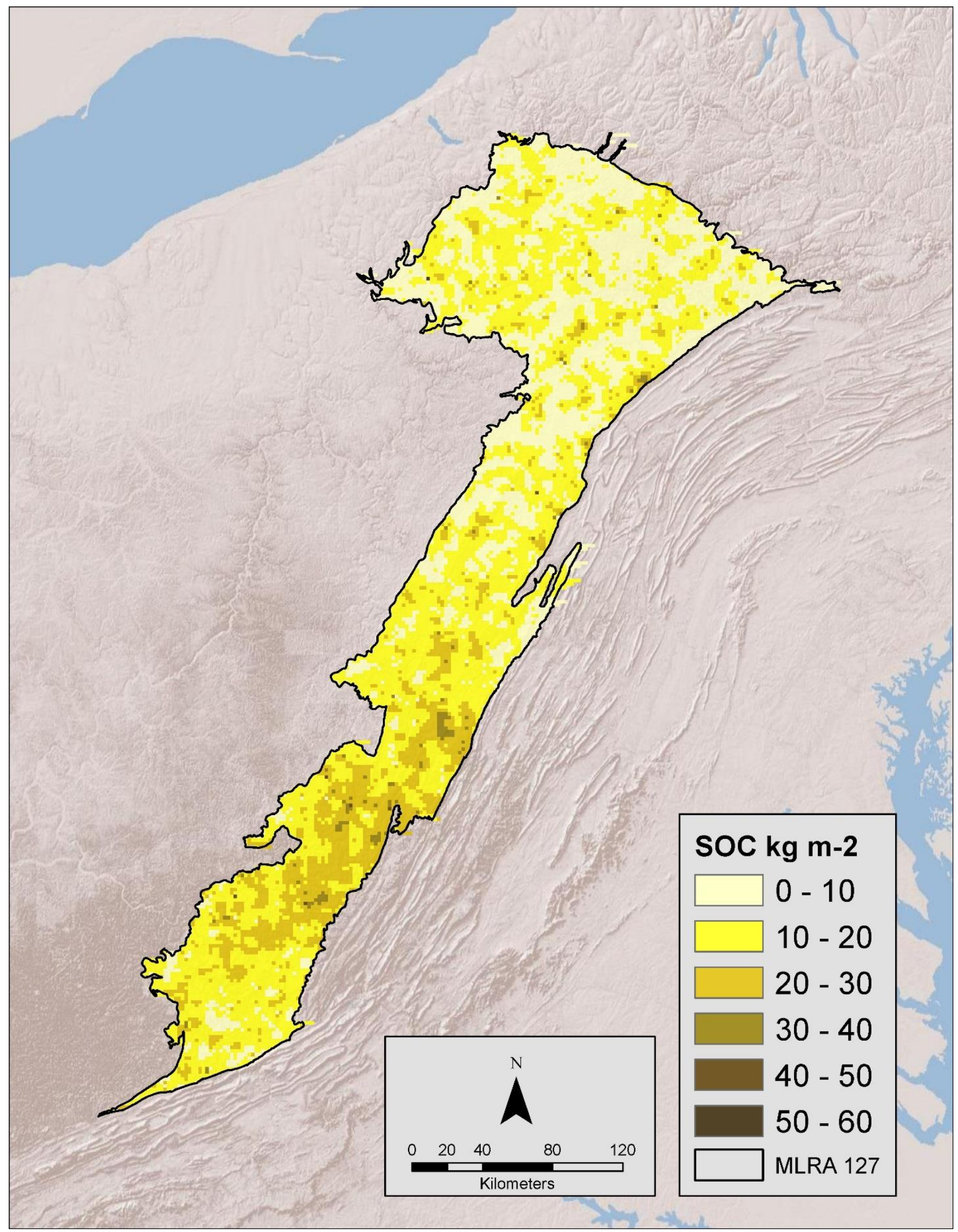

Figure 3.11 Lower 95\% prediction limit for the upper meter of SOC stock across MLRA 127 calculated using fuzzy k-means with extragrade analysis. 


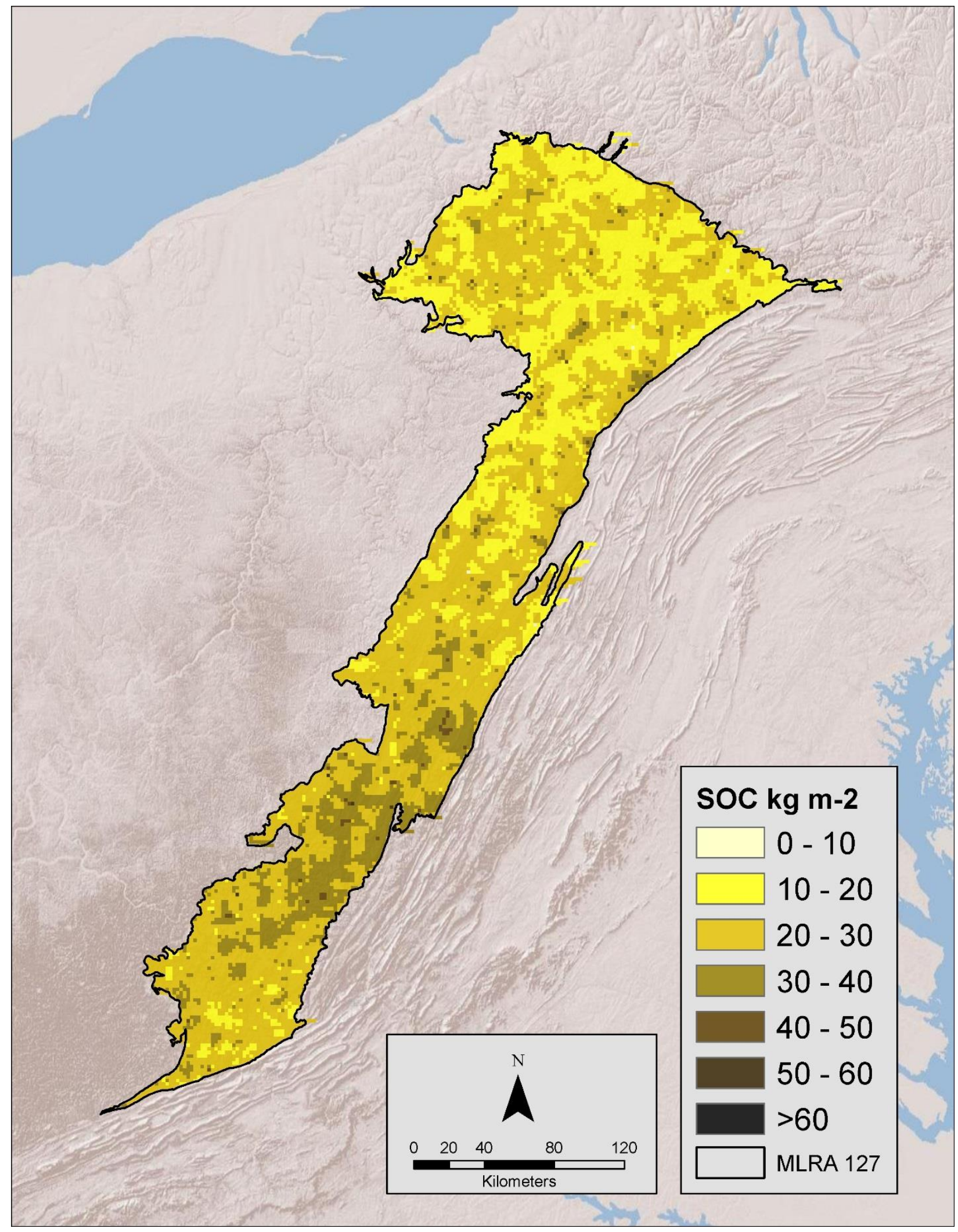

Figure 3.12 Upper 95\% prediction limit for the upper meter of SOC stock across MLRA 127 calculated using fuzzy k-means with extragrade analysis. 


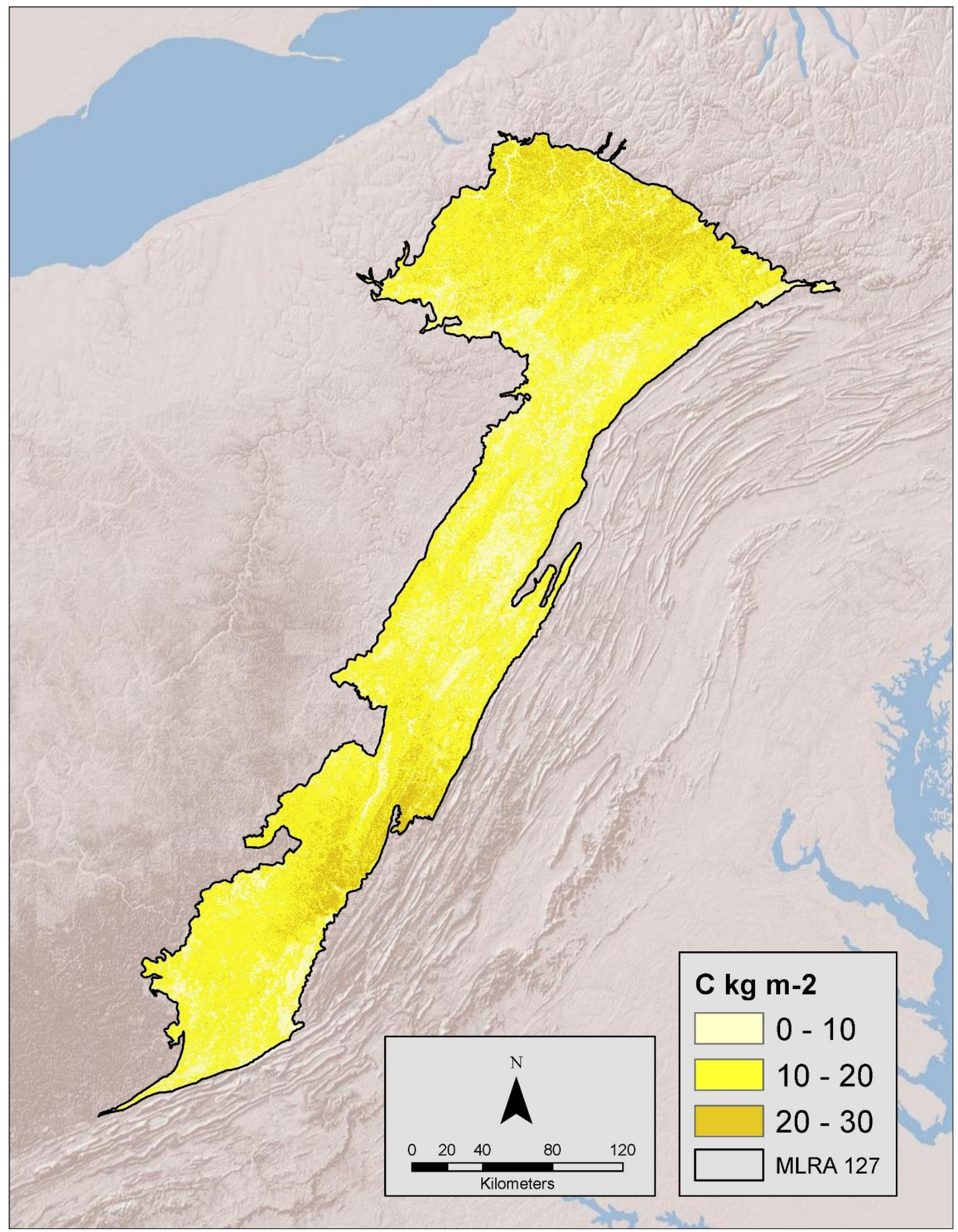

Figure 3.13 Total carbon stock, including above and below ground sources, in MLRA 127 as reported by the Forest Inventory and Analysis tool with $250 \mathrm{~m}$ resolution. 


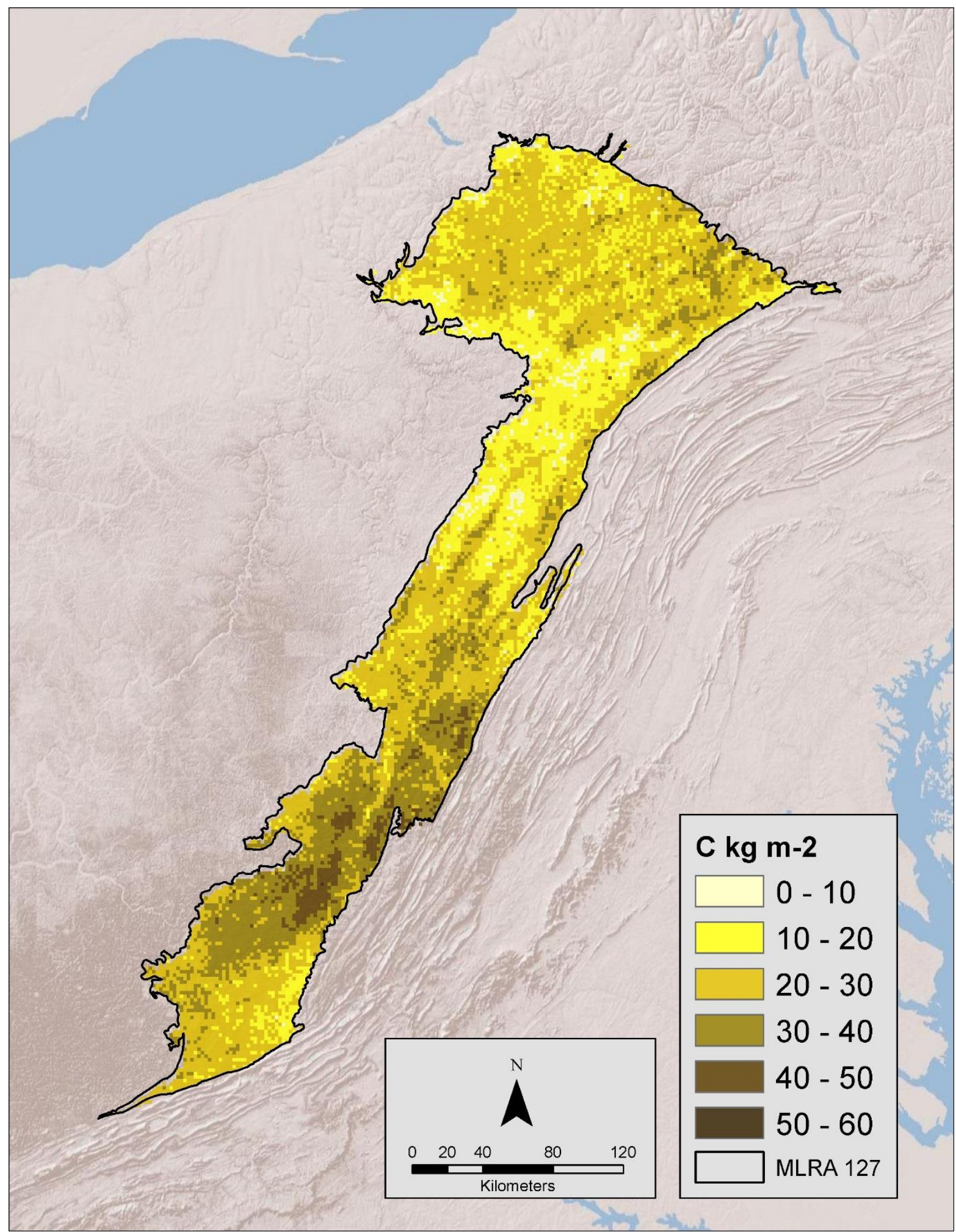

Figure 3.14 Total carbon stock, including above and below ground sources, in MLRA 127 as reported by the Forest Inventory and Analysis tool, substituting the geographically weighted regression kriging representative values for soil organic carbon with $2,000 \mathrm{~m}$ spatial resolution. 


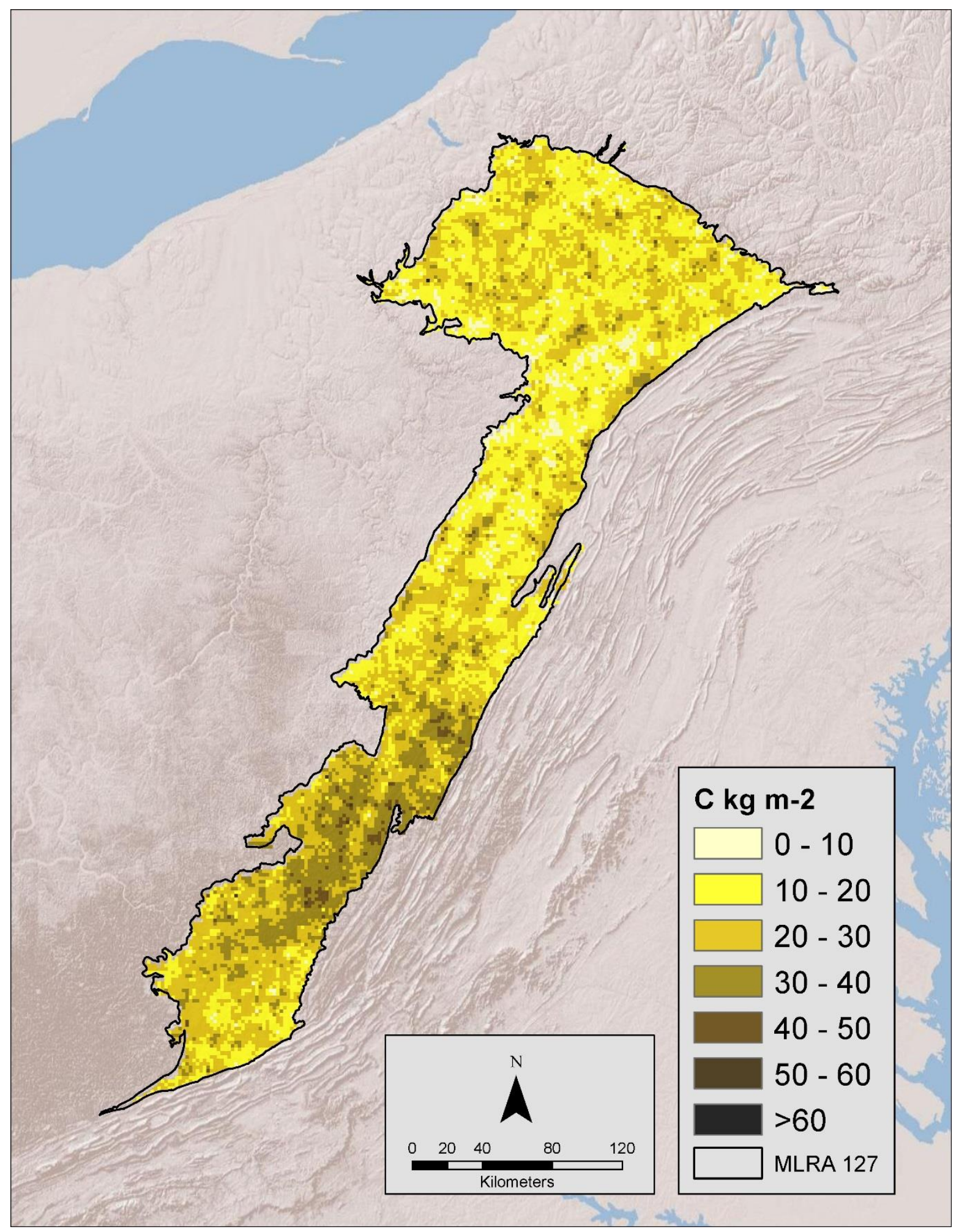

Figure 3.15 Total carbon stock, including above and below ground sources, in MLRA 127 as reported by the Forest Inventory and Analysis tool, substituting the lower 95\% prediction limit geographically weighted regression kriging for soil organic carbon with 2,000 m spatial resolution. 


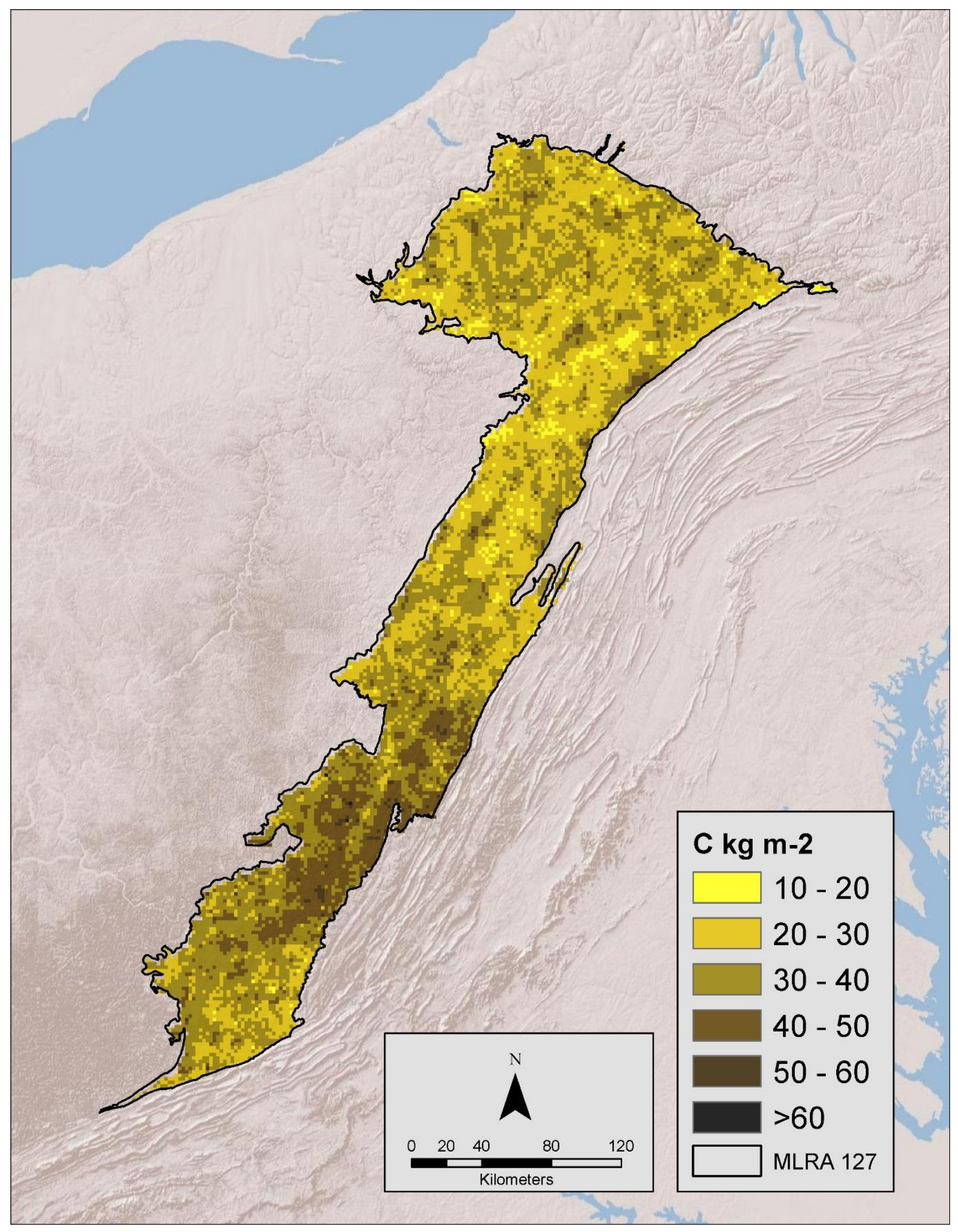

Figure 3.16 Total carbon stock, including above and below ground sources, in MLRA 127 as reported by the Forest Inventory and Analysis tool, substituting the upper 95\% prediction limit geographically weighted regression kriging for soil organic carbon with 2,000 m spatial resolution. 
Table 3.1. Normality and spatial autocorrelation analysis of the covariates used to predict SOC.

\begin{tabular}{|l|c|c|c|c|c|c|c|c|}
\hline & chi2 & skewness & kurtosis & $\begin{array}{c}\text { p-value: } \\
\text { omnibus }\end{array}$ & $\begin{array}{c}\text { p-value: } \\
\text { skewness }\end{array}$ & $\begin{array}{c}\text { p-value: } \\
\text { kurtosis }\end{array}$ & $\begin{array}{c}\text { moran's } \\
\text { i }\end{array}$ & $\begin{array}{c}\text { p-value: } \\
\text { moran's } \\
\text { i }\end{array}$ \\
\hline Precipitation & 1.22 & -1.07 & -0.3 & 0.54 & 0.29 & 0.78 & 0.98 & 0 \\
\hline $\begin{array}{l}\text { Convergence } \\
\text { index }\end{array}$ & 24.81 & 3.01 & 3.97 & $<0.0001$ & $2.00 \times 10^{-3}$ & $<0.0001$ & 0 & 0.81 \\
\hline $\begin{array}{l}\text { Terrain } \\
\text { ruggedness } \\
\text { index }\end{array}$ & 38.67 & 6 & 1.64 & $<0.0001$ & $<0.0001$ & 0.1 & 0.2 & 0 \\
\hline Valley depth & 190.12 & 11.35 & 7.82 & $<0.0001$ & $<0.0001$ & $<0.0001$ & 0.03 & 0.15 \\
\hline $\begin{array}{l}\text { Fall EVI } \\
\text { minimum }\end{array}$ & 29.46 & -5.18 & 1.61 & $<0.0001$ & $<0.0001$ & 0.11 & 0.16 & 0 \\
\hline Elevation & 45.74 & 6.42 & 2.6 & $<0.0001$ & $<0.0001$ & $9.20 \times 10^{-3}$ & 0.72 & 0 \\
\hline $\begin{array}{l}\text { Spring EVI } \\
\text { median }\end{array}$ & 17.64 & 3.58 & -2.2 & $<0.0001$ & $<0.0001$ & 0.03 & 0.53 & 0 \\
\hline $\begin{array}{l}\text { Winter EVI } \\
\text { mean }\end{array}$ & 35.46 & 4.48 & 3.93 & $<0.0001$ & $<0.0001$ & $<0.0001$ & 0.18 & 0 \\
\hline Northeastness & 588.33 & -20.85 & 12.4 & $<0.0001$ & $<0.0001$ & $<0.0001$ & -0.01 & 0.15 \\
\hline $\begin{array}{l}\text { Green/Near- } \\
\text { Infrared } \\
\text { Landsat } \\
\text { GeoCover }\end{array}$ & 393.72 & 16.55 & 10.94 & $<0.0001$ & $<0.0001$ & $<0.0001$ & 0.02 & 0.22 \\
\hline $\begin{array}{l}\text { Mid-infrared } \\
\text { Landsat } \\
\text { GeoCover }\end{array}$ & 32.37 & 5.23 & 2.23 & $<0.0001$ & $<0.0001$ & 0.02 & 0.11 & 0 \\
\hline $\begin{array}{l}\text { 1 m Available } \\
\text { water storage }\end{array}$ & 7.13 & -1.9 & 1.87 & 0.03 & 0.06 & 0.06 & 0.39 & 0 \\
\hline $\begin{array}{l}\text { Total Gama } \\
\text { Radiation (U, } \\
\text { K, and Th) }\end{array}$ & 12.59 & 0.65 & -3.49 & $1.84 \times 10^{-3}$ & 0.52 & $4.84 \times 10^{-4}$ & 0.29 & 0 \\
\hline $\begin{array}{l}\text { Average } \\
\text { Maximum } \\
\text { Temperature }\end{array}$ & 82.56 & 2.18 & -8.82 & $<0.0001$ & 0.03 & $<0.0001$ & 0.87 & 0 \\
\hline $\begin{array}{l}\text { 1 m KSSL } \\
\text { SOC Stock }\end{array}$ & 53.57 & 6.67 & 3.01 & $<0.0001$ & $<0.0001$ & $2.60 \times 10-3$ & 0.10 & 0 \\
\hline
\end{tabular}


Table 3.2 Average SOC Estimates for the upper $1 \mathrm{~m}$ of soil in the Eastern Allegheny Plateau and Mountains adapted from Jenkins (2001).

\begin{tabular}{|l|c|}
\hline Source & SOC $\mathbf{~} \mathbf{k g ~ m}^{-\mathbf{2}}$ ) \\
\hline Kern (1994) & \\
$\quad$ Ecosystem Approach & $28.1-32.0$ \\
$\quad$ Soil Taxonomy & $13.6-15.0$ \\
Eswaran et al. (1993) & $10.6-12.1$ \\
$\quad$ World Soils Map & \\
Bliss et al. (1995) & 2.2 \\
$\quad$ Soil Interpretation Database & \\
Jenkins (2001) & $8.9-11.7$ \\
$\quad$ Mesic Series & $12.9-18.8$ \\
$\quad$ Frigid Hardwood Sites & $11.3-13$ \\
$\quad$ Frigid Spruce Sites & 10.3 \\
Mishra et al. (2010) & 2.6 \\
STATSGO2 MLRA 127 & 4.4 \\
gSSURGO MLRA 127 & 9.0 \\
Rapid Carbon Assessment & 18.6 \\
GWR & 16.1 \\
GWRK & \\
\hline
\end{tabular}

Table 3.3 Statistical summary of the GWRK model with the following resolution sizes: $250 \mathrm{~m}$, $800 \mathrm{~m}$, and $2,000 \mathrm{~m}$.

\begin{tabular}{|l|c|c|c|}
\hline \multirow{2}{*}{} & \multicolumn{3}{|c|}{ Spatial Resolution } \\
\cline { 2 - 4 } & 250 & 800 & 2,000 \\
\hline RMSE & 0.28 & 0.48 & 0.31 \\
\hline MEE & -0.04 & 0.05 & 0.04 \\
\hline MAEE & 0.02 & 0.04 & 0.02 \\
\hline
\end{tabular}


Table 3.4 Statistical summary of the GWR, GWRK, and RaCA SOC stock models in MLRA 127.

\begin{tabular}{|l|ccc|}
\hline Method & RMSE & MEE & MAEE \\
\hline GWRK & 0.31 & 0.04 & 0.02 \\
GWR & 0.41 & 0.05 & 0.09 \\
RaCA & 0.22 & -0.02 & 0.02 \\
\hline
\end{tabular}

Table 3.5 Estimations of the total SOC stock in the upper $1 \mathrm{~m}$ of soil in MLRA 127. LowGWRK represents the lower 95\% prediction interval and highGWRK represents the higher 95\% prediction interval.

\begin{tabular}{|lc|}
\hline Estimation & SOC Stock \\
Source & -----Pg----- \\
\hline gSSURGO & 0.23 \\
RaCA & 0.71 \\
GWR & 1.24 \\
lowGWRK & 0.64 \\
GWRK & 1.13 \\
highGWRK & 1.28 \\
\hline
\end{tabular}


Table 3.6 Estimations of the sources of above and below ground carbon stock in MLRA 127 from the Forest Inventory and Analysis tool.

\begin{tabular}{|lc|}
\hline Carbon Source & $\begin{array}{c}\text { Carbon } \\
\text { A----Pg----- }\end{array}$ \\
\hline Forest Standing Dead Carbon & 0.29 \\
Forest Understory Carbon & $3.00 \times 10^{-3}$ \\
Below Ground Carbon in Live Trees & 0.05 \\
Forest Down Dead Carbon & $0.03 \times 10^{-3}$ \\
Forest Litter Carbon & 0.06 \\
Soil Organic Carbon & 0.23 \\
\hline
\end{tabular}

Table 3.7 Estimations of the total carbon stock in MLRA 127 from the Forest Inventory and Analysis tool and the the Forestry Inventory and Analysis tool with SOC and Forest Litter Carbon replaced with GWRK SOC stock. LowGWRK represents the lower 95\% prediction interval of the GWRK SOC, rvGWRK represents the modeled SOC, and highGWRK represents the upper $95 \%$ prediction interval of the GWRK SOC.

\begin{tabular}{|c|c|}
\hline Estimation Source & $\begin{array}{c}\text { Total Terrestrial } \\
\text { Biosphere Carbon } \\
\text { - }\end{array}$ \\
\hline FIA & 0.66 \\
\hline FIA with lowGWRK replacement & 1.01 \\
\hline FIA with rvGWRK replacement & 1.50 \\
\hline FIA with highGWRK replacement & 1.65 \\
\hline
\end{tabular}




\section{Chapter 4: Conclusions and Recommendations for the Natural Resources Conservation Service}

\section{Review of Objectives}

The purpose of this study was to develop standard methodology and recommendations for the Natural Resources Conservation Service (NRCS) to calculate soil organic carbon (SOC) stock across a Major Land Resource Area (MLRA) using legacy lab data, geospatial covariates, and legacy soil survey products. Due to its unique and diverse vegetative, climatic, geologic, and pedogenic properties, MLRA 127 (Eastern Alleghany Plateau and Mountains) was chosen as the study area. This research was aimed at developing a framework for the NRCS to model SOC as a continuous function using legacy Kellogg Soil Survey Laboratory (KSSL) data and environmental covariates. The objectives of this research were to:

d) Populate missing KSSL data using Random Forest (RF), median by horizonation and texture class, and mean by horizonation and texture class to provide a better input for the digital soil mapping (DSM) of SOC.

e) Model SOC through geographically weighted regression kriging (GWRK) as a function of harmonized legacy KSSL data and environmental covariates and assess the validity and uncertainty of the GWRK model.

f) Assess ecosystem carbon using the Forest Inventory Analysis (FIA) model and GWRK SOC model to determine the role that SOC has in relation to terrestrial biosphere carbon.

The statistical summary of the methodology used in Chapter 2 to predict missing KSSL data revelead that both RF and mean (by horizon and texture class) were valid approaches to populating missing KSSL data in MLRA 127, with RF being the preferred standard method for NRCS (Tables $2.4-2.7$ ). Comparisons between the geographically weighted regression (GWR) and GWRK models created in this study to the rapid carbon assessment (RaCA) prediction model developed by NRCS (Soil Survey Staff, 2013) in Chapter 3 showed that nonparametric spatial modeling techniques such as GWRK and RF are able to effectively predict SOC stock within a MLRA. The error rates calculated from the GWR, GWRK, and RaCA models were much lower than previous studies, indicating that SOC prediction by MLRA might be the most 
suitable way for NRCS to predict SOC stock and GWRK should be the recommended approach for the DSM of SOC. The methodology presented in this thesis beginning with preparing KSSL data and ending with an interpolated GWRK model with 95\% prediction intervals depicting the SOC stock of the upper $1 \mathrm{~m}$ of soil in MLRA 127, is recommended to the NRCS as a guideline for future DSM research.

\section{Recommendations for the NRCS}

NRCS Soil Survey Products

NRCS soil scientists are currently devoting most of their time to harmonizing legacy soil survey data in the National Soil Information Database (NASIS) through the Soil Data Join Recorrelation (SDJR) project. SDJR is designed to consolidate similar map units in soil survey areas across a MLRA, evaluate and document each map unit, eliminate as many tabular join conflicts as possible, and populate NASIS with future field and spatial editing projects (USDANRCS, 2013). DSM techniques can be used in current SDJR harmonization efforts to help create future spatial and field projects, determine which map units should be harmonized, and help with map unit component composition. When the tabular harmonization phase is complete, soil scientists can spatially disaggregate gridded SSURGO (gSSURGO) data into individual soil components and/or properties using DSM techniques. This will enable soil scientists to create pixel-based, multi-resolution raster products to coincide with their limitation/suitability STATSGO2 and SSURGO products. Vector products allow area calculations, provide users with crisp boundaries, and allow for easy attribute and line editing. Raster products, like the SOC map created with this research, can be used in DSM, provide more detailed and reliable soil data, are quick to process, and better represent soil variability across a landscape (Thompson et al., 2010). With diverse soil data products, NRCS will be able to better serve their customers and global community (Stolt et al., 2010; Grunwald et al., 2011).

\section{Legacy Lab Data}

There is an apparent need to update the KSSL database given that half of the KSSL pedons within MLRA 127 were correlated to the incorrect soil series, many pedons had incorrect depths and horizon designations due to organic horizons, half of the KSSL horizons in MLRA 127 lacked bulk density data, $13 \%$ lacked SOC data, and there were two different laboratory methods used for measuring carbon. Through the SDJR process, NRCS is currently working on updating KSSL pedons to current soil taxonomic classification and adjusting horizon depths and 
designations. Future workload should include developing or using an existing carbon-equivalent correction factor like the one used in Chapter 2 to ensure that carbon values have the same interpretability in the KSSL database. There is a future need to populate missing data, especially bulk density and carbon data. Whether it is best determined by the National Soil Survey Center to leave missing legacy data as is with the understanding that more field studies are needed or predict missing data from legacy KSSL data and environmental covariates like what was done in Chapter 2, this database deficiency needs to be addressed before DSM techniques can be utilized. Chapter 2 in this study has provided methodology for populating missing KSSL data and correcting carbon data for methodological errors.

Future Research

Although SOC was the dynamic soil property chosen to be modeled in this study, the methodology is applicable to modeling all soil properties. It is important to keep in mind that modeling can never be a complete substitute for detailed, ongoing field data collection (Elith et al., 2006), but it can be used to aid in management decisions, update soil survey data, and direct future field data acquisition. Future data collection sampling should be geostatistically designed and field bulk density methods (such as those used in the RaCA project and frame bulk density) should be explored because clod bulk densities may be inaccurate in some soils (Jenkins, 2001). Because most soil data are not normally distributed even with common transformations, nonparametric techniques such as RF, GWR, and GWRK should be used to predict soil properties and classes (Jobbágy and Jackson, 2000; Minasny et al., 2008; Keller et al., 2012; Pan et al., 2013; Razafimbelo et al., 2013). Future research is needed to better assess the statistical validation of nonparametric models and account for model over-fitting.

Given this time of changing climate and increased demand for soil productivity (crop yields), it is imperative that NRCS continue efforts to research and model land use change impacts on soil carbon sequestration and carbon greenhouse gas fluxes in and out of ecosystems. Currently the NRCS has provided the following programs/models to address carbon accounting and land use conversion: RaCA, COMET-FARM, Greenhouse Gas (GHG) and Carbon Sequestration Ranking Tool, Cover Crop Termination Guidelines, and Conservation Innovation Grants. Other agencies like the U.S. Forest Service, U.S. Geological Survey, and U.S. Environmental Protection Agency have also developed and are currently developing models and programs in support of GHG emmisions and carbon sequestration efforts required by Executive 
Order 13514, signed by President Obama in 2009 (U.S.EPA, 2012). Collaboration between NRCS and these agencies has been established through the U.S. Carbon Cycle Science Program aimed at determining the magnitudes and distributions of carbon sinks and sources in North America. Further collaboration is imperative in order to quantify biosphere carbon and GHG fluxes within an ecosystem, sustain the nation's environmental resources, and reduce human impacts on climate change. 


\section{Literature Cited}

Elith, J., C.H. Graham, R.P. Anderson, M. Dudík, S. Ferrier, A. Guisan, R.J. Hijmans, F. Huettmann, J.R. Leathwick, A. Lehmann, J. Li, L.G. Lohmann, B.A. Loiselle, G. Manion, C. Moritz, M. Nakamura, Y. Nakazawa, J.M. Overton, A.T. Peterson, S.J. Phillips, K. Richardson, R. Scachetti-Pereira, R.E. Schapire, J. Soberón, S. Williams, M.S. Wisz, and N.E. Zimmerman. 2006. Novel methods improve prediction of species' distributions from occurrence data. Ecography 29, 129-151.

Grunwald, S., J.A. Thompson, and J.L. Boettinger. 2011. Digital soil mapping and modeling at continental scales: finding solutions for global issues. Soil Science Society of America Journal. 75:4, 1201-1213.

Jenkins, A. 2001. Organic Carbon and Fertility of Forest Soils on the Allegheny Plateau of West Virginia. M.S. thesis, West Virginia University, Morgantown, WV. <http://etd.wvu.edu/templates/showETD.cfm?recnum=2486>.

Jobbágy, E. G. and R.B. Jackson. 2000. The vertical distribution of soil SOC and its relation to climate and vegetation. Ecological Applications. 10:423-436.

Keller, J.K., K.K. Takagi, M.E. Brown, K.N. Stump, C.G. Takahashi. 2012. Soil SOC storage in restored salt marshes in Huntington Beach, California. Bulletin of Southern California Academy of Sciences. 111 (2). 〈http://scholar.oxy.edu/scas/vol111/iss2/5〉.

Minasny, B., A.B. McBratney, N.J. McKenzie, and M.J. Grundy. 2008. Predicting soil properties using pedotransfer functions and environmental correlation. N.J. McKenzie, M.J. Grundy, R. Webster, A.J. Ringrose-Voase (Eds.). Guidelines for Surveying Soil and Land Resources, Australian Soil and Land Survey Handbook Series, CSIRO Publishing, Melbourne (2008). 349-367.

Nauman, T.W., J.A. Thompson, N.P. Odgers, and Z. Libohova. 2012. Fuzzy disaggregation of conventional soil maps using database knowledge extraction to produce soil property maps.B. Minasny, B. Malone, A. McBratney (Eds.). Digital Soil Assessments and Beyond: 5th Global Workshop on Digital Soil Mapping, Sydney, Australia (2012).

Pan, C., H. Zhao, X. Zhao, H. Han, Y. Wang., and J. Li. 2013. Biophysical properties as determinants for soil SOC and total nitrogen in grassland salinization. PLoS ONE. 8(1): e54827.doi:10.1371/journal.pone.0054827. 
Razafimbelo, T., T. Chevallier, A. Albrecht, L. Chapuis-Lardy, F. Nirina Rakotondrasolo, R. Michellon, L. Rabeharisoa, and M. Bernoux. 2013. Texture and organic carbon contents do not impact amount of carbon protected in Malagasy soils. Scientia Agricola. 70:3, 204-208.

Stolt, M.H., P.J. Drohan, and M.J. Richardson. 2010. Insights and Approaches for Mapping Soil SOC as a Dynamic Soil Property. Soil Science Society of America Journal. 74:5, 1685-1689.

Thompson, J.A., T. Prescott, A.C. Moore, J.W. Bell, D. Kautz, J. Hempel, S.W. Waltman, and C. H. Perry. 2010. Regional approach to soil property mapping using legacy data and spatial disaggregation techniques. Presented at the $19^{\text {th }}$ World Conference of Soil Science Symposium. < http://www.iuss.org/19th\%20WCSS/Symposium/pdf/2024.pdf>.

United States Department of Agriculture - Natural Resources Conservation Service. 2013. Soil Data Join Recorrelation Initiative. Title 430 - National Instruction. $2^{\text {nd }}$ edition. $<$ http://directives.sc.egov.usda.gov/OpenNonWebContent.aspx?content=34514.wba>.

United States Environmental Protection Agency. 2012. Executive Order 13514. < http://www.epa.gov/greeningepa/practices/eo13514.htm>.

Zhong, B., and Y.J. Xu. 2011. Scale effects of geographical soil datasets on soil carbon estimation in Louisiana, USA: A comparison of STATSGO and SSURGO. Pedosphere. 21(4): 491-501. 


\section{Appendix A: Kellogg Soil Survey Laboratory Site Data for Pedons in MLRA}

\section{7}

\begin{tabular}{|c|c|c|c|c|c|c|}
\hline PedonID & Longitude & Latitude & $\begin{array}{c}\text { Series } \\
\text { Sampled As }\end{array}$ & $\begin{array}{c}\text { Series } \\
\text { Correlated } \\
\text { As }\end{array}$ & $\begin{array}{c}\text { Series } \\
\text { Correlated } \\
\text { To }\end{array}$ & $\begin{array}{l}\text { Taxonomic } \\
\text { Classification }\end{array}$ \\
\hline 60WV093001 & -79.460111 & 39.140222 & Brinkerton & & $\begin{array}{l}\text { Brinkerton } \\
\text { Taxadjunct }\end{array}$ & $\begin{array}{l}\text { Fine-silty, } \\
\text { mixed, active, } \\
\text { mesic Typic } \\
\text { Fragiaquepts }\end{array}$ \\
\hline 60WV093002 & -79.482972 & 39.119639 & Brinkerton & & $\begin{array}{l}\text { Brinkerton } \\
\text { Taxadjunct }\end{array}$ & $\begin{array}{c}\text { Fine-silty, } \\
\text { mixed, active, } \\
\text { mesic Typic } \\
\text { Fragiaqults }\end{array}$ \\
\hline 61WV083006 & -79.668083 & 38.940389 & Ernest & & $\begin{array}{c}\text { Ernest } \\
\text { Taxadjunct }\end{array}$ & $\begin{array}{l}\text { Fine-loamy, } \\
\text { mixed, active, } \\
\text { mesic Aquic } \\
\text { Fragiudepts }\end{array}$ \\
\hline 61WV093003 & -79.484556 & 39.171972 & Ernest & & Ernest & $\begin{array}{l}\text { Fine-loamy, } \\
\text { mixed, active, } \\
\text { mesic Aquic } \\
\text { Fragiudults }\end{array}$ \\
\hline 62WV083005 & -79.848611 & 38.822778 & Monongahela & & Monongahela & $\begin{array}{l}\text { Fine-loamy, } \\
\text { mixed, } \\
\text { semiactive, } \\
\text { mesic Typic } \\
\text { Fragiudults }\end{array}$ \\
\hline 64PA051007 & -79.449722 & 39.9375 & Wharton & Cruze & $\begin{array}{c}\text { Cruz } \\
\text { Taxadjunct }\end{array}$ & $\begin{array}{l}\text { Fine, mixed, } \\
\text { semiactive, } \\
\text { mesic Mollic } \\
\text { Oxyaquic } \\
\text { Hapludalfs }\end{array}$ \\
\hline 64PA051008 & -79.42 & 39.884167 & Dekalb & Hazleton & $\begin{array}{c}\text { Hazleton } \\
\text { Taxadjunct }\end{array}$ & $\begin{array}{l}\text { Coarse-loamy, } \\
\text { siliceous, } \\
\text { active, mesic } \\
\text { Typic } \\
\text { Dystrudepts }\end{array}$ \\
\hline
\end{tabular}




\begin{tabular}{|c|c|c|c|c|c|c|}
\hline PedonID & Longitude & Latitude & $\begin{array}{c}\text { Series } \\
\text { Sampled As }\end{array}$ & $\begin{array}{c}\text { Series } \\
\text { Correlated } \\
\text { As }\end{array}$ & $\begin{array}{c}\text { Series } \\
\text { Correlated } \\
\text { To }\end{array}$ & $\begin{array}{c}\text { Taxonomic } \\
\text { Classification }\end{array}$ \\
\hline 64PA051009 & -79.379444 & 39.826389 & $\begin{array}{l}\text { Sequatchie/ } \\
\text { Chavies }\end{array}$ & Chavies & $\begin{array}{l}\text { Chavies } \\
\text { Taxadjunct }\end{array}$ & $\begin{array}{c}\text { Coarse-loamy, } \\
\text { mixed, active, } \\
\text { mesic Fragic } \\
\text { Dystrudepts }\end{array}$ \\
\hline 64PA051010 & -79.511667 & 39.781389 & Dekalb & Hazleton & Hazleton & $\begin{array}{c}\text { Loamy- } \\
\text { skeletal, } \\
\text { siliceous, } \\
\text { active, mesic } \\
\text { Typic } \\
\text { Dystrudepts }\end{array}$ \\
\hline 64PA051011 & -79.516667 & 39.730556 & Purdy & Ginat & $\begin{array}{c}\text { Ginat } \\
\text { Taxadjunct }\end{array}$ & $\begin{array}{l}\text { Fine-loamy, } \\
\text { mixed, active, } \\
\text { mesic Typic } \\
\text { Endoaquults }\end{array}$ \\
\hline 67PA123001 & -79.257778 & 41.720833 & Dekalb & Hazelton & Gauley & $\begin{array}{l}\text { Loamy- } \\
\text { skeletal, } \\
\text { siliceous, } \\
\text { superactive, } \\
\text { frigid Typic } \\
\text { Haplorthods }\end{array}$ \\
\hline 67PA123002 & -79.238611 & 41.706389 & Dekalb & Hazelton & Gauley & $\begin{array}{c}\text { Loamy- } \\
\text { skeletal, } \\
\text { siliceous, } \\
\text { superactive, } \\
\text { frigid Typic } \\
\text { Haplorthods }\end{array}$ \\
\hline 67PA123003 & -79.147222 & 41.670278 & Dekalb & Dekalb & Gauley & $\begin{array}{c}\text { Loamy- } \\
\text { skeletal, } \\
\text { siliceous, } \\
\text { superactive, } \\
\text { frigid Typic } \\
\text { Haplorthods }\end{array}$ \\
\hline 67PA123004 & -79.134167 & 41.6375 & Cookport & Cookport & Cookport & $\begin{array}{l}\text { Fine-loamy, } \\
\text { mixed, active, } \\
\text { mesic Aquic } \\
\text { Fragiudults }\end{array}$ \\
\hline
\end{tabular}




\begin{tabular}{|c|c|c|c|c|c|c|}
\hline PedonID & Longitude & Latitude & $\begin{array}{c}\text { Series } \\
\text { Sampled As }\end{array}$ & $\begin{array}{c}\text { Series } \\
\text { Correlated } \\
\text { As }\end{array}$ & $\begin{array}{c}\text { Series } \\
\text { Correlated } \\
\text { To }\end{array}$ & $\begin{array}{c}\text { Taxonomic } \\
\text { Classification }\end{array}$ \\
\hline 67PA123005 & -78.984444 & 41.798056 & Dekalb & Dekalb & $\begin{array}{c}\text { Dekalb } \\
\text { Taxadjunct }\end{array}$ & $\begin{array}{c}\text { Loamy- } \\
\text { skeletal, } \\
\text { siliceous, } \\
\text { active, mesic } \\
\text { Spodic } \\
\text { Dystrudepts }\end{array}$ \\
\hline 67PA123006 & -78.990278 & 41.809444 & Cookport & Cookport & Cookport & $\begin{array}{l}\text { Fine-loamy, } \\
\text { mixed, active, } \\
\text { mesic Aquic } \\
\text { Fragiudults }\end{array}$ \\
\hline 67PA123013 & -79.272222 & 41.825 & Lobdell & Philo & Philo & $\begin{array}{c}\text { Coarse-loamy, } \\
\text { mixed, active, } \\
\text { mesic } \\
\text { Fluvaquentic } \\
\text { Dystrudepts }\end{array}$ \\
\hline 71PA021001 & -78.389444 & 40.681111 & Blandburg & Blandburg & Blandburg & $\begin{array}{c}\text { Loamy- } \\
\text { skeletal, } \\
\text { mixed, } \\
\text { semiactive, } \\
\text { frigid Typic } \\
\text { Haplorthods }\end{array}$ \\
\hline 71PA021002 & -78.385556 & 40.698056 & Blandburg & Blandburg & Blandburg & $\begin{array}{l}\text { Loamy- } \\
\text { skeletal, } \\
\text { mixed, } \\
\text { semiactive, } \\
\text { frigid Typic } \\
\text { Haplorthods }\end{array}$ \\
\hline 71PA021003 & -78.37 & 40.698611 & Blandburg & Blandburg & $\begin{array}{l}\text { Blandburg } \\
\text { Taxadjunct }\end{array}$ & $\begin{array}{c}\text { Loamy- } \\
\text { skeletal, } \\
\text { mixed, } \\
\text { semiactive, } \\
\text { frigid Ultic } \\
\text { Haplorthods }\end{array}$ \\
\hline 71PA111001 & -79.061944 & 40.048611 & Rayne & Hartleton & Rayne & $\begin{array}{c}\text { Fine-loamy, } \\
\text { mixed, active, } \\
\text { mesic Typic } \\
\text { Hapludults }\end{array}$ \\
\hline
\end{tabular}




\begin{tabular}{|c|c|c|c|c|c|c|}
\hline PedonID & Longitude & Latitude & $\begin{array}{c}\text { Series } \\
\text { Sampled As }\end{array}$ & $\begin{array}{c}\text { Series } \\
\text { Correlated } \\
\text { As }\end{array}$ & $\begin{array}{c}\text { Series } \\
\text { Correlated } \\
\text { To }\end{array}$ & $\begin{array}{c}\text { Taxonomic } \\
\text { Classification }\end{array}$ \\
\hline 71PA111002 & -79.11 & 40.024167 & Rayne & Rayne & $\begin{array}{c}\text { Rayne } \\
\text { Taxadjunct }\end{array}$ & $\begin{array}{c}\text { Fine, mixed, } \\
\text { active, mesic } \\
\text { Typic } \\
\text { Hapludults }\end{array}$ \\
\hline 71PA111003 & -79.180556 & 39.995 & Rayne & Hartleton & Rayne & $\begin{array}{c}\text { Fine-loamy, } \\
\text { mixed, active, } \\
\text { mesic Typic } \\
\text { Hapludults }\end{array}$ \\
\hline 71PA111004 & -79.176667 & 39.786389 & Leetonia & Blandburg & $\begin{array}{l}\text { Blandburg } \\
\text { Taxadjunct }\end{array}$ & $\begin{array}{c}\text { Loamy- } \\
\text { skeletal, } \\
\text { mixed, } \\
\text { semiactive, } \\
\text { frigid Typic } \\
\text { Fragiorthods }\end{array}$ \\
\hline 72PA129018 & -79.269444 & 40.174722 & Cavode & Cavode & $\begin{array}{c}\text { Cavode } \\
\text { Taxadjunct }\end{array}$ & $\begin{array}{c}\text { Clayey, } \\
\text { mixed, active, } \\
\text { mesic Aeric } \\
\text { Endoaquults }\end{array}$ \\
\hline 72PA129019 & -79.279444 & 40.1675 & Wharton & Blairton & $\begin{array}{l}\text { Blairton } \\
\text { Taxadjunct }\end{array}$ & $\begin{array}{c}\text { Fine-loamy, } \\
\text { mixed, active, } \\
\text { mesic Aquic } \\
\text { Hapludalfs }\end{array}$ \\
\hline 72PA129020 & -79.275833 & 40.166667 & Wharton & Wharton & $\begin{array}{l}\text { Wharton } \\
\text { Taxadjunct }\end{array}$ & $\begin{array}{c}\text { Fine, mixed, } \\
\text { active, mesic } \\
\text { Aquic } \\
\text { Hapludults }\end{array}$ \\
\hline 72PA129021 & -79.273889 & 40.166667 & Gilpin & Gilpin & $\begin{array}{c}\text { Gilpin } \\
\text { Taxadjunct }\end{array}$ & $\begin{array}{l}\text { Fine-loamy, } \\
\text { mixed, active, } \\
\text { mesic Mollic } \\
\text { Hapludalfs }\end{array}$ \\
\hline 73РA033012 & -78.549167 & 41.186389 & Rayne & Brownsville & Brownsville & $\begin{array}{c}\text { Loamy- } \\
\text { skeletal, } \\
\text { mixed, active, } \\
\text { mesic Typic } \\
\text { Dystrudepts }\end{array}$ \\
\hline
\end{tabular}




\begin{tabular}{|c|c|c|c|c|c|c|}
\hline PedonID & Longitude & Latitude & $\begin{array}{c}\text { Series } \\
\text { Sampled As }\end{array}$ & $\begin{array}{c}\text { Series } \\
\text { Correlated } \\
\text { As }\end{array}$ & $\begin{array}{c}\text { Series } \\
\text { Correlated } \\
\text { To }\end{array}$ & $\begin{array}{c}\text { Taxonomic } \\
\text { Classification }\end{array}$ \\
\hline 73РA033013 & -78.531389 & 41.181389 & Rayne & Brownsville & Brownsville & $\begin{array}{c}\text { Loamy- } \\
\text { skeletal, } \\
\text { mixed, active, } \\
\text { mesic Typic } \\
\text { Dystrudepts }\end{array}$ \\
\hline 73РА033014 & -78.545 & 41.186667 & Ernest & Ernest & Ernest & $\begin{array}{l}\text { Fine-loamy, } \\
\text { mixed, } \\
\text { superactive, } \\
\text { mesic Aquic } \\
\text { Fragiudults }\end{array}$ \\
\hline 73РА033015 & -78.538889 & 41.178333 & Ernest & Buchanan & Buchanan & $\begin{array}{l}\text { Fine-loamy, } \\
\text { mixed, } \\
\text { semiactive, } \\
\text { mesic Aquic } \\
\text { Fragiudults }\end{array}$ \\
\hline 73РA033016 & -78.411944 & 41.2075 & Wharton & Cruze & Cruze & $\begin{array}{l}\text { Fine, mixed, } \\
\text { semiactive, } \\
\text { mesic Aquic } \\
\text { Hapludults }\end{array}$ \\
\hline 73РA033017 & -78.405278 & 41.195833 & Wharton & Wharton & Wharton & $\begin{array}{c}\text { Fine-loamy, } \\
\text { mixed, active, } \\
\text { mesic Aquic } \\
\text { Hapludults }\end{array}$ \\
\hline 73РА033018 & -78.519444 & 41.101667 & Nolo & Nolo & $\begin{array}{c}\text { Nolo } \\
\text { Taxadjunct }\end{array}$ & $\begin{array}{c}\text { Coarse-loamy, } \\
\text { mixed, } \\
\text { superactive, } \\
\text { mesic Typic } \\
\text { Fragiaquults }\end{array}$ \\
\hline 73РА033019 & -78.546389 & 41.078056 & Nolo & Nolo & Nolo & $\begin{array}{l}\text { Fine-loamy, } \\
\text { mixed, } \\
\text { superactive, } \\
\text { mesic Aquic } \\
\text { Fragiudults }\end{array}$ \\
\hline
\end{tabular}




\begin{tabular}{|c|c|c|c|c|c|c|}
\hline PedonID & Longitude & Latitude & $\begin{array}{c}\text { Series } \\
\text { Sampled As }\end{array}$ & $\begin{array}{c}\text { Series } \\
\text { Correlated } \\
\text { As }\end{array}$ & $\begin{array}{c}\text { Series } \\
\text { Correlated } \\
\text { To }\end{array}$ & $\begin{array}{c}\text { Taxonomic } \\
\text { Classification }\end{array}$ \\
\hline 75WV061001 & -79.816667 & 39.658333 & Dekalb & Dekalb & Gilpin & $\begin{array}{c}\text { Fine-loamy, } \\
\text { mixed, active, } \\
\text { mesic Typic } \\
\text { Hapludults }\end{array}$ \\
\hline 78PA105007 & -78.001389 & 41.751667 & Hazleton & Hazleton & Gauley & $\begin{array}{c}\text { Loamy- } \\
\text { skeletal, } \\
\text { siliceous, } \\
\text { superactive, } \\
\text { frigid Typic } \\
\text { Haplorthods }\end{array}$ \\
\hline 78PA105008 & -78.033333 & 41.789167 & Hazleton & Hazleton & $\begin{array}{c}\text { Gauley } \\
\text { Taxadjunct }\end{array}$ & $\begin{array}{c}\text { Loamy- } \\
\text { skeletal, } \\
\text { mixed, } \\
\text { superactive, } \\
\text { frigid Typic } \\
\text { Haplorthods }\end{array}$ \\
\hline 78PA111005 & -78.783056 & 40.038333 & Hazelton & Hazelton & $\begin{array}{l}\text { Hazelton } \\
\text { Taxadjunct }\end{array}$ & $\begin{array}{l}\text { Loamy- } \\
\text { skeletal, } \\
\text { siliceous, } \\
\text { active, mesic } \\
\text { Spodic } \\
\text { Dystrudepts }\end{array}$ \\
\hline 78PA111006 & -78.764167 & 40.036389 & Hazelton & Leetonia & $\begin{array}{l}\text { Blandburg } \\
\text { Taxadjunct }\end{array}$ & $\begin{array}{l}\text { Loamy- } \\
\text { skeletal, } \\
\text { mixed, } \\
\text { semiactive, } \\
\text { frigid Ultic } \\
\text { Fragiorthods }\end{array}$ \\
\hline 78WV083001 & -79.575 & 38.875 & Cheat & Cheat & Gilpin & $\begin{array}{c}\text { Fine-loamy, } \\
\text { mixed, active, } \\
\text { mesic Typic } \\
\text { Hapludults }\end{array}$ \\
\hline 78WV083002 & -79.666667 & 38.916667 & Cheat & Cheat & Gilpin & $\begin{array}{c}\text { Fine-loamy, } \\
\text { mixed, active, } \\
\text { mesic Typic } \\
\text { Hapludults }\end{array}$ \\
\hline
\end{tabular}




\begin{tabular}{|c|c|c|c|c|c|c|}
\hline PedonID & Longitude & Latitude & $\begin{array}{c}\text { Series } \\
\text { Sampled As }\end{array}$ & $\begin{array}{c}\text { Series } \\
\text { Correlated } \\
\text { As }\end{array}$ & $\begin{array}{c}\text { Series } \\
\text { Correlated } \\
\text { To }\end{array}$ & $\begin{array}{c}\text { Taxonomic } \\
\text { Classification }\end{array}$ \\
\hline 78WV083003 & -80.175 & 38.533333 & Cheat & Cheat & Berks & $\begin{array}{c}\text { Loamy- } \\
\text { skeletal, } \\
\text { mixed, active, } \\
\text { mesic Typic } \\
\text { Dystrudepts }\end{array}$ \\
\hline 78WV089007 & -80.825 & 37.572222 & Gilpin & Calvin & $\begin{array}{l}\text { Clifftop } \\
\text { taxadjunct }\end{array}$ & $\begin{array}{c}\text { Fine, mixed, } \\
\text { semiactive, } \\
\text { mesic Typic } \\
\text { Hapludults }\end{array}$ \\
\hline 78WV089008 & -80.908333 & 37.680556 & Gilpin & Calvin & Clifftop & $\begin{array}{l}\text { Fine-loamy, } \\
\text { mixed, } \\
\text { semiactive, } \\
\text { mesic Typic } \\
\text { Hapludults }\end{array}$ \\
\hline 78WV089009 & -80.7625 & 37.645833 & Kanawha & Kanawha & $\begin{array}{l}\text { Kanawha } \\
\text { Taxadjunct }\end{array}$ & $\begin{array}{l}\text { Fine-loamy, } \\
\text { mixed, } \\
\text { semiactive, } \\
\text { mesic Ultic } \\
\text { Hapludalfs }\end{array}$ \\
\hline 78WV089010 & -80.786111 & 37.6125 & Kanawha & & $\begin{array}{l}\text { Kanawha } \\
\text { Taxadjunct }\end{array}$ & $\begin{array}{l}\text { Fine-loamy, } \\
\text { mixed, } \\
\text { semiactive, } \\
\text { mesic Ultic } \\
\text { Hapludalfs }\end{array}$ \\
\hline 79PA083006 & -78.953056 & 41.647222 & Cookport & Cookport & $\begin{array}{l}\text { Cookport } \\
\text { Taxadjunct }\end{array}$ & $\begin{array}{c}\text { Coarse-loamy, } \\
\text { mixed, } \\
\text { superactive, } \\
\text { mesic Aquic } \\
\text { Fragiudepts }\end{array}$ \\
\hline 79PA083007 & -78.949444 & 41.6475 & Hazleton & Hazleton & Gauley & $\begin{array}{c}\text { Loamy- } \\
\text { skeletal, } \\
\text { siliceous, } \\
\text { superactive, } \\
\text { frigid Typic } \\
\text { Haplorthods }\end{array}$ \\
\hline
\end{tabular}




\begin{tabular}{|c|c|c|c|c|c|c|}
\hline PedonID & Longitude & Latitude & $\begin{array}{c}\text { Series } \\
\text { Sampled As }\end{array}$ & $\begin{array}{c}\text { Series } \\
\text { Correlated } \\
\text { As }\end{array}$ & $\begin{array}{c}\text { Series } \\
\text { Correlated } \\
\text { To }\end{array}$ & $\begin{array}{c}\text { Taxonomic } \\
\text { Classification }\end{array}$ \\
\hline 79PA083008 & -78.941667 & 41.626667 & Clymer & Clymer & $\begin{array}{c}\text { Lily } \\
\text { Taxadjunct }\end{array}$ & $\begin{array}{l}\text { Fine-loamy, } \\
\text { siliceous, } \\
\text { superactive, } \\
\text { mesic Inceptic } \\
\text { Hapludults }\end{array}$ \\
\hline 79PA083009 & -78.949444 & 41.641389 & Ernest & Ernest & Ernest & $\begin{array}{l}\text { Fine-loamy, } \\
\text { mixed, } \\
\text { superactive, } \\
\text { mesic Aquic } \\
\text { Fragiudults }\end{array}$ \\
\hline 79PA083010 & -78.946667 & 41.643056 & Ernest & Ernest & Ernest & $\begin{array}{l}\text { Fine-loamy, } \\
\text { mixed, } \\
\text { superactive, } \\
\text { mesic Aquic } \\
\text { Fragiudults }\end{array}$ \\
\hline 79PA083011 & -78.943056 & 41.628056 & Brinkerton & Brinkerton & Nolo & $\begin{array}{l}\text { Fine-loamy, } \\
\text { mixed, } \\
\text { superactive, } \\
\text { mesic Typic } \\
\text { Fragiaquults }\end{array}$ \\
\hline 79PA083012 & -78.936111 & 41.650278 & Nolo & Nolo & Nolo & $\begin{array}{l}\text { Fine-loamy, } \\
\text { mixed, } \\
\text { superactive, } \\
\text { mesic Typic } \\
\text { Fragiaquults }\end{array}$ \\
\hline 79WV067001 & -80.881944 & 38.179167 & Dekalb & Dekalb & $\begin{array}{c}\text { Dekalb } \\
\text { Taxadjunct }\end{array}$ & $\begin{array}{c}\text { Loamy- } \\
\text { skeletal, } \\
\text { siliceous, } \\
\text { active, mesic } \\
\text { Typic } \\
\text { Hapludults }\end{array}$ \\
\hline 79WV067002 & -80.593333 & 38.241667 & Ernest & & $\begin{array}{c}\text { Ernest } \\
\text { Taxadjunct }\end{array}$ & $\begin{array}{l}\text { Fine-loamy, } \\
\text { mixed, active, } \\
\text { mesic Typic } \\
\text { Fragiudults }\end{array}$ \\
\hline
\end{tabular}




\begin{tabular}{|c|c|c|c|c|c|c|}
\hline PedonID & Longitude & Latitude & $\begin{array}{c}\text { Series } \\
\text { Sampled As }\end{array}$ & $\begin{array}{c}\text { Series } \\
\text { Correlated } \\
\text { As }\end{array}$ & $\begin{array}{c}\text { Series } \\
\text { Correlated } \\
\text { To }\end{array}$ & $\begin{array}{c}\text { Taxonomic } \\
\text { Classification }\end{array}$ \\
\hline 79WV067006 & -80.531389 & 38.3 & Laidig & & $\begin{array}{c}\text { Laidig } \\
\text { Taxadjunct }\end{array}$ & $\begin{array}{l}\text { Fine-loamy, } \\
\text { mixed, } \\
\text { semiactive, } \\
\text { mesic Typic } \\
\text { Fragiudults }\end{array}$ \\
\hline 79WV067007 & -80.527778 & 38.3 & Ernest & & $\begin{array}{c}\text { Ernest } \\
\text { Taxadjunct }\end{array}$ & $\begin{array}{l}\text { Fine-loamy, } \\
\text { mixed, } \\
\text { semiactive, } \\
\text { mesic Aquic } \\
\text { Fragiudults }\end{array}$ \\
\hline 79WV067008 & -80.633333 & 38.303333 & Buchanan & Buchanan & $\begin{array}{l}\text { Buchanan } \\
\text { Taxadjunct }\end{array}$ & $\begin{array}{l}\text { Fine-loamy, } \\
\text { mixed, } \\
\text { semiactive, } \\
\text { mesic Typic } \\
\text { Fragiudults }\end{array}$ \\
\hline 79WV067010 & -80.868056 & 38.172222 & Buchanan & & $\begin{array}{l}\text { Buchanan } \\
\text { Taxadjunct }\end{array}$ & $\begin{array}{c}\text { Coarse-loamy, } \\
\text { mixed, } \\
\text { semiactive, } \\
\text { mesic Typic } \\
\text { Fragiudepts }\end{array}$ \\
\hline 79WV067011 & -80.734444 & 38.281944 & Gilpin & & $\begin{array}{l}\text { Clifftop } \\
\text { Taxadjunct }\end{array}$ & $\begin{array}{c}\text { Clayey, } \\
\text { mixed, } \\
\text { semiactive, } \\
\text { mesic Typic } \\
\text { Hapludults }\end{array}$ \\
\hline 80WV067005 & -80.883889 & 38.160556 & Clymer & Clymer & $\begin{array}{l}\text { Clymer } \\
\text { Taxadjunct }\end{array}$ & $\begin{array}{l}\text { Coarse-loamy, } \\
\text { mixed, } \\
\text { semiactive, } \\
\text { mesic Typic } \\
\text { Dystrudepts }\end{array}$ \\
\hline 80WV067006 & -80.865278 & 38.163889 & Clymer & Clymer & $\begin{array}{l}\text { Clymer } \\
\text { Taxadjunct }\end{array}$ & $\begin{array}{l}\text { Fine-loamy, } \\
\text { siliceous, } \\
\text { semiactive, } \\
\text { mesic Typic } \\
\text { Hapludults }\end{array}$ \\
\hline
\end{tabular}




\begin{tabular}{|c|c|c|c|c|c|c|}
\hline PedonID & Longitude & Latitude & $\begin{array}{c}\text { Series } \\
\text { Sampled As }\end{array}$ & $\begin{array}{c}\text { Series } \\
\text { Correlated } \\
\text { As }\end{array}$ & $\begin{array}{c}\text { Series } \\
\text { Correlated } \\
\text { To }\end{array}$ & $\begin{array}{c}\text { Taxonomic } \\
\text { Classification }\end{array}$ \\
\hline 81WV067001 & -80.502222 & 38.255556 & Laidig & & $\begin{array}{c}\text { Laidig } \\
\text { Taxadjunct }\end{array}$ & $\begin{array}{c}\text { Coarse-loamy, } \\
\text { mixed, active, } \\
\text { mesic Typic } \\
\text { Fragiudepts }\end{array}$ \\
\hline 81WV067002 & -80.573333 & 38.256111 & Laidig & & $\begin{array}{c}\text { Laidig } \\
\text { Taxadjunct }\end{array}$ & $\begin{array}{c}\text { Fine-loamy, } \\
\text { mixed, active, } \\
\text { mesic Typic } \\
\text { Fragiudults }\end{array}$ \\
\hline 81WV101001 & -80.489722 & 38.341111 & Cookport & & $\begin{array}{l}\text { Cookport } \\
\text { Taxadjunct }\end{array}$ & $\begin{array}{c}\text { Fine-loamy, } \\
\text { mixed, active, } \\
\text { mesic Aquic } \\
\text { Fragiudepts }\end{array}$ \\
\hline 82РA047009 & -78.891667 & 41.591667 & Ernest & Ernest & $\begin{array}{l}\text { Cookport } \\
\text { Taxadjunct }\end{array}$ & $\begin{array}{c}\text { Fine-loamy, } \\
\text { mixed, active, } \\
\text { mesic Typic } \\
\text { Fragiudepts }\end{array}$ \\
\hline 82PA083004 & -78.8725 & 41.720278 & Cookport & Cookport & $\begin{array}{l}\text { Cookport } \\
\text { Taxadjunct }\end{array}$ & $\begin{array}{c}\text { Coarse-loamy, } \\
\text { mixed, active, } \\
\text { mesic Aquic } \\
\text { Fragiudults }\end{array}$ \\
\hline 82PA083005 & -78.871389 & 41.696667 & Ernest & Ernest & $\begin{array}{l}\text { Buchanan } \\
\text { Taxadjunct }\end{array}$ & $\begin{array}{l}\text { Fine-loamy, } \\
\text { mixed, active, } \\
\text { mesic Aquic } \\
\text { Fragiudults }\end{array}$ \\
\hline 82PA105001 & -77.88 & 41.756667 & Ernest & Ernest & $\begin{array}{l}\text { Buchanan } \\
\text { Taxadjunct }\end{array}$ & $\begin{array}{l}\text { Fine-loamy, } \\
\text { mixed, } \\
\text { semiactive, } \\
\text { mesic Typic } \\
\text { Fragiudults }\end{array}$ \\
\hline 82PA105002 & -77.833333 & 41.808611 & Buchanan & Buchanan & $\begin{array}{l}\text { Buchanan } \\
\text { Taxadjunct }\end{array}$ & $\begin{array}{l}\text { Coarse-loamy, } \\
\text { mixed, } \\
\text { semiactive, } \\
\text { mesic Aquic } \\
\text { Fragiudults }\end{array}$ \\
\hline
\end{tabular}




\begin{tabular}{|c|c|c|c|c|c|c|}
\hline PedonID & Longitude & Latitude & $\begin{array}{c}\text { Series } \\
\text { Sampled As }\end{array}$ & $\begin{array}{c}\text { Series } \\
\text { Correlated } \\
\text { As }\end{array}$ & $\begin{array}{c}\text { Series } \\
\text { Correlated } \\
\text { To }\end{array}$ & $\begin{array}{c}\text { Taxonomic } \\
\text { Classification }\end{array}$ \\
\hline 82PA117017 & -77.481389 & 41.543333 & Cookport & Cookport & $\begin{array}{l}\text { Cookport } \\
\text { Taxadjunct }\end{array}$ & $\begin{array}{c}\text { Coarse-loamy, } \\
\text { mixed, active, } \\
\text { mesic Typic } \\
\text { Fragiudults }\end{array}$ \\
\hline 82PA117018 & -77.482778 & 41.526667 & Nolo & Nolo & $\begin{array}{c}\text { Nolo } \\
\text { Taxadjunct }\end{array}$ & $\begin{array}{c}\text { Coarse-loamy, } \\
\text { mixed, } \\
\text { superactive, } \\
\text { mesic Typic } \\
\text { Fragiaquults }\end{array}$ \\
\hline 82PA117019 & -77.4825 & 41.541667 & Cookport & Cookport & $\begin{array}{l}\text { Cookport } \\
\text { Taxadjunct }\end{array}$ & $\begin{array}{l}\text { Fine-loamy, } \\
\text { mixed, active, } \\
\text { mesic Aquic } \\
\text { Fragiudepts }\end{array}$ \\
\hline 82PA117020 & -77.482778 & 41.527778 & Nolo & Nolo & Nolo & $\begin{array}{l}\text { Fine-loamy, } \\
\text { mixed, } \\
\text { superactive, } \\
\text { mesic Typic } \\
\text { Fragiaquults }\end{array}$ \\
\hline 83PA105003 & -77.907778 & 41.808333 & Sweden & Sweden & Leck Kill & $\begin{array}{l}\text { Fine-loamy, } \\
\text { mixed, } \\
\text { semiactive, } \\
\text { mesic Typic } \\
\text { Hapludults }\end{array}$ \\
\hline 83PA105004 & -77.619722 & 41.525 & Sweden & Sweden & $\begin{array}{c}\text { Leck Kill } \\
\text { Taxadjunct }\end{array}$ & $\begin{array}{l}\text { Fine, mixed, } \\
\text { semiactive, } \\
\text { mesic Typic } \\
\text { Hapludults }\end{array}$ \\
\hline 83PA105005 & -77.62 & 41.524444 & Sweden & Sweden & Leck Kill & $\begin{array}{l}\text { Fine-loamy, } \\
\text { mixed, } \\
\text { semiactive, } \\
\text { mesic Typic } \\
\text { Hapludults }\end{array}$ \\
\hline
\end{tabular}




\begin{tabular}{|c|c|c|c|c|c|c|}
\hline PedonID & Longitude & Latitude & $\begin{array}{c}\text { Series } \\
\text { Sampled As }\end{array}$ & $\begin{array}{c}\text { Series } \\
\text { Correlated } \\
\text { As }\end{array}$ & $\begin{array}{c}\text { Series } \\
\text { Correlated } \\
\text { To }\end{array}$ & $\begin{array}{c}\text { Taxonomic } \\
\text { Classification }\end{array}$ \\
\hline 83PA117021 & -77.481389 & 41.529722 & Dekalb & Dekalb & $\begin{array}{c}\text { Dekalb } \\
\text { Taxadjunct }\end{array}$ & $\begin{array}{c}\text { Coarse-loamy, } \\
\text { siliceous, } \\
\text { active, mesic } \\
\text { Typic } \\
\text { Dystrudepts } \\
\end{array}$ \\
\hline 83PA117022 & -77.481389 & 41.528056 & Cookport & Cookport & $\begin{array}{l}\text { Cookport } \\
\text { Taxadjunct }\end{array}$ & $\begin{array}{c}\text { Coarse-loamy, } \\
\text { mixed, active, } \\
\text { mesic Typic } \\
\text { Fragiudults }\end{array}$ \\
\hline 83PA117023 & -77.481389 & 41.528611 & Cookport & Cookport & $\begin{array}{c}\text { Cookport } \\
\text { Taxadjunct }\end{array}$ & $\begin{array}{c}\text { Coarse-loamy, } \\
\text { mixed, active, } \\
\text { mesic Typic } \\
\text { Fragiudults }\end{array}$ \\
\hline 83PA117027 & -77.42 & 41.558333 & Sweden & Sweden & Ungers & $\begin{array}{l}\text { Fine-loamy, } \\
\text { mixed, } \\
\text { semiactive, } \\
\text { mesic Typic } \\
\text { Hapludults }\end{array}$ \\
\hline 83PA117028 & -77.42 & 41.559167 & Sweden & Sweden & Ungers & $\begin{array}{l}\text { Fine-loamy, } \\
\text { mixed, } \\
\text { semiactive, } \\
\text { mesic Typic } \\
\text { Hapludults }\end{array}$ \\
\hline 87PA027082 & -78.211944 & 40.851667 & Cookport & Cookport & $\begin{array}{l}\text { Cookport } \\
\text { Taxadjunct }\end{array}$ & $\begin{array}{c}\text { Coarse-loamy, } \\
\text { mixed, active, } \\
\text { mesic Typic } \\
\text { Fragiudepts }\end{array}$ \\
\hline 87PA027083 & -78.209722 & 40.851667 & Clymer & Clymer & $\begin{array}{l}\text { Cookport } \\
\text { Taxadjunct }\end{array}$ & $\begin{array}{l}\text { Fine-loamy, } \\
\text { mixed, active, } \\
\text { mesic Ultic } \\
\text { Haplorthods }\end{array}$ \\
\hline
\end{tabular}




\begin{tabular}{|c|c|c|c|c|c|c|}
\hline PedonID & Longitude & Latitude & $\begin{array}{c}\text { Series } \\
\text { Sampled As }\end{array}$ & $\begin{array}{c}\text { Series } \\
\text { Correlated } \\
\text { As }\end{array}$ & $\begin{array}{c}\text { Series } \\
\text { Correlated } \\
\text { To }\end{array}$ & $\begin{array}{c}\text { Taxonomic } \\
\text { Classification }\end{array}$ \\
\hline 88РA021011 & -78.766111 & 40.517778 & SND & Gilpin & $\begin{array}{c}\text { Berks } \\
\text { Taxadjunct }\end{array}$ & $\begin{array}{c}\text { Loamy- } \\
\text { skeletal, } \\
\text { mixed, } \\
\text { superactive, } \\
\text { mesic Typic } \\
\text { Dystrudepts }\end{array}$ \\
\hline 88РA021012 & -78.786667 & 40.505833 & SND & Dekalb & $\begin{array}{c}\text { Gilpin } \\
\text { Taxadjunct }\end{array}$ & $\begin{array}{c}\text { Loamy- } \\
\text { skeletal, } \\
\text { mixed, } \\
\text { superactive, } \\
\text { mesic Typic } \\
\text { Hapludults }\end{array}$ \\
\hline 88РA021013 & -78.751667 & 40.517778 & SND & SND & $\begin{array}{l}\text { Cavode } \\
\text { Taxadjunct }\end{array}$ & $\begin{array}{l}\text { Fine-loamy, } \\
\text { mixed, active, } \\
\text { mesic Aeric } \\
\text { Endoaquults }\end{array}$ \\
\hline 88РA021014 & -78.778611 & 40.495278 & SND & Cavode & $\begin{array}{c}\text { Cavode } \\
\text { Taxadjunct }\end{array}$ & $\begin{array}{l}\text { Fine-loamy, } \\
\text { mixed, active, } \\
\text { mesic Aeric } \\
\text { Endoaquults }\end{array}$ \\
\hline 88РA021015 & -78.773333 & 40.511944 & SND & Wharton & $\begin{array}{l}\text { Wharton } \\
\text { Taxadjunct }\end{array}$ & $\begin{array}{l}\text { Fine, mixed, } \\
\text { active, mesic } \\
\text { Aquic } \\
\text { Hapludults }\end{array}$ \\
\hline 88РA021016 & -78.752778 & 40.546111 & SND & Brinkerton & $\begin{array}{l}\text { Andover } \\
\text { Taxadjunct }\end{array}$ & $\begin{array}{l}\text { Fine-loamy, } \\
\text { mixed, } \\
\text { semiactive, } \\
\text { mesic Aeric } \\
\text { Fragiaquults }\end{array}$ \\
\hline 88РA033031 & -78.55 & 41.138333 & Gilpin & Gilpin & $\begin{array}{c}\text { Gilpin } \\
\text { Taxadjunct }\end{array}$ & $\begin{array}{c}\text { Coarse-loamy, } \\
\text { mixed, active, } \\
\text { mesic Typic } \\
\text { Hapludults }\end{array}$ \\
\hline
\end{tabular}




\begin{tabular}{|c|c|c|c|c|c|c|}
\hline PedonID & Longitude & Latitude & $\begin{array}{c}\text { Series } \\
\text { Sampled As }\end{array}$ & $\begin{array}{c}\text { Series } \\
\text { Correlated } \\
\text { As }\end{array}$ & $\begin{array}{c}\text { Series } \\
\text { Correlated } \\
\text { To }\end{array}$ & $\begin{array}{c}\text { Taxonomic } \\
\text { Classification }\end{array}$ \\
\hline 88РA033032 & -78.580278 & 41.1375 & SND & Buchanan & $\begin{array}{l}\text { Buchanan } \\
\text { Taxadjunct }\end{array}$ & $\begin{array}{l}\text { Fine-loamy, } \\
\text { mixed, } \\
\text { semiactive, } \\
\text { mesic Typic } \\
\text { Fragiudepts }\end{array}$ \\
\hline 88РA033033 & -78.575278 & 41.1325 & SND & Clymer & Rayne & $\begin{array}{c}\text { Fine-loamy, } \\
\text { mixed, active, } \\
\text { mesic Typic } \\
\text { Hapludults }\end{array}$ \\
\hline 88РA033034 & -78.586944 & 41.135278 & SND & Brinkerton & $\begin{array}{c}\text { Ernest } \\
\text { Taxadjunct }\end{array}$ & $\begin{array}{l}\text { Fine, mixed, } \\
\text { active, mesic } \\
\text { Aquic } \\
\text { Fragiudults }\end{array}$ \\
\hline 88РA033035 & -78.420278 & 41.133611 & SND & Hazleton & $\begin{array}{l}\text { Hazelton } \\
\text { Taxadjunct }\end{array}$ & $\begin{array}{c}\text { Coarse-loamy, } \\
\text { siliceous, } \\
\text { active, mesic } \\
\text { Typic } \\
\text { Dystrudepts }\end{array}$ \\
\hline 88РA033036 & -78.4375 & 41.122778 & SND & Cookport & $\begin{array}{c}\text { Cookport } \\
\text { Taxadjunct }\end{array}$ & $\begin{array}{c}\text { Coarse-loamy, } \\
\text { mixed, active, } \\
\text { mesic Aquic } \\
\text { Fragiudults }\end{array}$ \\
\hline 88РA033037 & -78.445278 & 41.134167 & SND & Nolo & $\begin{array}{l}\text { Cookport } \\
\text { Taxadjunct }\end{array}$ & $\begin{array}{c}\text { Fine-loamy, } \\
\text { mixed, active, } \\
\text { mesic Typic } \\
\text { Fragiudults }\end{array}$ \\
\hline 88PA033038 & -78.434167 & 41.141944 & SND & Dekalb & $\begin{array}{c}\text { Dekalb } \\
\text { Taxadjunct }\end{array}$ & $\begin{array}{c}\text { Loamy- } \\
\text { skeletal, } \\
\text { siliceous, } \\
\text { superactive, } \\
\text { mesic Typic } \\
\text { Dystrudepts }\end{array}$ \\
\hline
\end{tabular}




\begin{tabular}{|c|c|c|c|c|c|c|}
\hline PedonID & Longitude & Latitude & $\begin{array}{c}\text { Series } \\
\text { Sampled As }\end{array}$ & $\begin{array}{c}\text { Series } \\
\text { Correlated } \\
\text { As }\end{array}$ & $\begin{array}{c}\text { Series } \\
\text { Correlated } \\
\text { To }\end{array}$ & $\begin{array}{c}\text { Taxonomic } \\
\text { Classification }\end{array}$ \\
\hline 88РA033039 & -78.566944 & 41.03 & SND & Hazleton & Hazleton & $\begin{array}{c}\text { Loamy- } \\
\text { skeletal, } \\
\text { siliceous, } \\
\text { active, mesic } \\
\text { Typic } \\
\text { Dystrudepts }\end{array}$ \\
\hline 88РA033040 & -78.584444 & 41.059444 & SND & Buchanan & $\begin{array}{l}\text { Buchanan } \\
\text { Taxadjunct }\end{array}$ & $\begin{array}{l}\text { Fine, mixed, } \\
\text { active, mesic } \\
\text { Aquic } \\
\text { Fragiudults }\end{array}$ \\
\hline 88РA033041 & -78.566111 & 41.021111 & SND & Dekalb & $\begin{array}{c}\text { Clymer } \\
\text { Taxadjunct }\end{array}$ & $\begin{array}{l}\text { Loamy- } \\
\text { skeletal, } \\
\text { siliceous, } \\
\text { superactive, } \\
\text { mesic Typic } \\
\text { Hapludults }\end{array}$ \\
\hline 88PA051021 & -79.434167 & 39.934444 & SND & Clymer & Clymer & $\begin{array}{c}\text { Coarse-loamy, } \\
\text { siliceous, } \\
\text { active, mesic } \\
\text { Typic } \\
\text { Hapludults } \\
\end{array}$ \\
\hline 88PA051022 & -79.436944 & 39.937778 & SND & Nolo & $\begin{array}{c}\text { Nolo } \\
\text { Taxadjunct }\end{array}$ & $\begin{array}{c}\text { Fine-loamy, } \\
\text { mixed, active, } \\
\text { mesic Aeric } \\
\text { Fragiaquults }\end{array}$ \\
\hline 88PA105011 & -77.7575 & 41.660833 & SND & Leck Kill & $\begin{array}{c}\text { Lehew } \\
\text { Taxadjunct }\end{array}$ & $\begin{array}{l}\text { Loamy- } \\
\text { skeletal, } \\
\text { siliceous, } \\
\text { superactive, } \\
\text { mesic Typic } \\
\text { Dystrudepts }\end{array}$ \\
\hline 88PA105012 & -77.774444 & 41.673611 & SND & Craigsville & $\begin{array}{l}\text { Craigsville } \\
\text { Taxadjunct }\end{array}$ & $\begin{array}{c}\text { Loamy- } \\
\text { skeletal, } \\
\text { mixed, } \\
\text { superactive, } \\
\text { mesic Typic } \\
\text { Hapludalfs }\end{array}$ \\
\hline
\end{tabular}




\begin{tabular}{|c|c|c|c|c|c|c|}
\hline PedonID & Longitude & Latitude & $\begin{array}{c}\text { Series } \\
\text { Sampled As }\end{array}$ & $\begin{array}{c}\text { Series } \\
\text { Correlated } \\
\text { As }\end{array}$ & $\begin{array}{c}\text { Series } \\
\text { Correlated } \\
\text { To }\end{array}$ & $\begin{array}{c}\text { Taxonomic } \\
\text { Classification }\end{array}$ \\
\hline 88PA105013 & -77.771944 & 41.666944 & SND & Hazelton & $\begin{array}{l}\text { Hazleton } \\
\text { Taxadjunct }\end{array}$ & $\begin{array}{l}\text { Loamy- } \\
\text { skeletal, } \\
\text { siliceous, } \\
\text { superactive, } \\
\text { mesic Dystric } \\
\text { Eutrudepts }\end{array}$ \\
\hline 93NY009001 & -78.558889 & 42.045278 & Brinkerton & & $\begin{array}{l}\text { Brinkerton } \\
\text { Taxadjunct }\end{array}$ & $\begin{array}{l}\text { Fine-loamy, } \\
\text { mixed, active, } \\
\text { mesic Fragic } \\
\text { Endoaquepts }\end{array}$ \\
\hline 93NY009002 & -78.558611 & 42.045833 & Comly & & $\begin{array}{c}\text { Comly } \\
\text { Taxadjunct }\end{array}$ & $\begin{array}{l}\text { Fine-loamy, } \\
\text { mixed, active, } \\
\text { mesic Aquic } \\
\text { Fragiudults }\end{array}$ \\
\hline $93 \mathrm{NY} 009003$ & -78.770833 & 42.056389 & Carrollton & & $\begin{array}{l}\text { Carrollton } \\
\text { Taxadjunct }\end{array}$ & $\begin{array}{c}\text { Loamy- } \\
\text { skeletal, } \\
\text { mixed, active, } \\
\text { frigid Aquic } \\
\text { Dystrudepts }\end{array}$ \\
\hline 93NY009004 & -78.721111 & 42.0025 & Leetonia & & $\begin{array}{c}\text { Gauley } \\
\text { Taxadjunct }\end{array}$ & $\begin{array}{l}\text { Coarse-loamy, } \\
\text { siliceous, } \\
\text { superactive, } \\
\text { frigid Typic } \\
\text { Haplorthods }\end{array}$ \\
\hline 93NY009005 & -78.729167 & 42.045833 & Brinkerton & & $\begin{array}{l}\text { Brinkerton } \\
\text { Taxadjunct }\end{array}$ & $\begin{array}{c}\text { Clayey, } \\
\text { mixed, active, } \\
\text { mesic Aeric } \\
\text { Fragiaqualfs }\end{array}$ \\
\hline 93NY009006 & -78.446111 & 42.025833 & Hazleton & $\begin{array}{l}\text { Knapp } \\
\text { Creek }\end{array}$ & $\begin{array}{c}\text { Gauley } \\
\text { Taxadjunct }\end{array}$ & $\begin{array}{c}\text { Loamy- } \\
\text { skeletal, } \\
\text { siliceous, } \\
\text { active, frigid } \\
\text { Typic } \\
\text { Haplorthods }\end{array}$ \\
\hline
\end{tabular}




\begin{tabular}{|c|c|c|c|c|c|c|}
\hline PedonID & Longitude & Latitude & $\begin{array}{c}\text { Series } \\
\text { Sampled As }\end{array}$ & $\begin{array}{c}\text { Series } \\
\text { Correlated } \\
\text { As }\end{array}$ & $\begin{array}{c}\text { Series } \\
\text { Correlated } \\
\text { To }\end{array}$ & $\begin{array}{c}\text { Taxonomic } \\
\text { Classification }\end{array}$ \\
\hline 93NY009007 & -78.445 & 42.023056 & Hazleton & Flatiron & $\begin{array}{c}\text { Flatiron } \\
\text { Taxadjunct }\end{array}$ & $\begin{array}{c}\text { Coarse-loamy, } \\
\text { siliceous, } \\
\text { active, mesic } \\
\text { Typic } \\
\text { Dystrudepts }\end{array}$ \\
\hline 93NY009008 & -78.470278 & 42.016944 & Onoville & & $\begin{array}{l}\text { Onoville } \\
\text { Taxadjunct }\end{array}$ & $\begin{array}{c}\text { Coarse-loamy, } \\
\text { mixed, active, } \\
\text { mesic } \\
\text { Oxyaquic } \\
\text { Dystrudepts }\end{array}$ \\
\hline $93 \mathrm{NY} 009009$ & -78.4675 & 42.016667 & Onoville & & $\begin{array}{l}\text { Onoville } \\
\text { Taxadjunct }\end{array}$ & $\begin{array}{c}\text { Fine-loamy, } \\
\text { mixed, active, } \\
\text { mesic Typic } \\
\text { Fragiudepts }\end{array}$ \\
\hline 95WV075001 & -80.253889 & 38.301944 & Gauley & & $\begin{array}{c}\text { Gauley } \\
\text { Taxadjunct }\end{array}$ & $\begin{array}{c}\text { Loamy- } \\
\text { skeletal, } \\
\text { mixed, } \\
\text { superactive, } \\
\text { frigid Typic } \\
\text { Haplorthods }\end{array}$ \\
\hline 95WV075002 & -79.9325 & 38.448611 & Gauley & & Gauley & $\begin{array}{c}\text { Loamy- } \\
\text { skeletal, } \\
\text { siliceous, } \\
\text { superactive, } \\
\text { frigid Typic } \\
\text { Haplorthods }\end{array}$ \\
\hline 95WV083001 & -79.696333 & 38.97975 & Snowdog & & $\begin{array}{l}\text { Snowdog } \\
\text { Taxadjunct }\end{array}$ & $\begin{array}{l}\text { Fine-loamy, } \\
\text { mixed, } \\
\text { superactive, } \\
\text { frigid Typic } \\
\text { Fragiudepts }\end{array}$ \\
\hline 95WV083002 & -79.704056 & 38.938917 & snd & & $\begin{array}{c}\text { Gauley } \\
\text { Taxadjunct }\end{array}$ & $\begin{array}{c}\text { Loamy- } \\
\text { skeletal, } \\
\text { mixed, } \\
\text { superactive, } \\
\text { frigid Typic } \\
\text { Haplorthods }\end{array}$ \\
\hline
\end{tabular}




\begin{tabular}{|c|c|c|c|c|c|c|}
\hline PedonID & Longitude & Latitude & $\begin{array}{c}\text { Series } \\
\text { Sampled As }\end{array}$ & $\begin{array}{c}\text { Series } \\
\text { Correlated } \\
\text { As }\end{array}$ & $\begin{array}{c}\text { Series } \\
\text { Correlated } \\
\text { To }\end{array}$ & $\begin{array}{c}\text { Taxonomic } \\
\text { Classification }\end{array}$ \\
\hline 95WV083003 & -79.359 & 38.963778 & Gauley & & $\begin{array}{c}\text { Gauley } \\
\text { Taxadjunct }\end{array}$ & $\begin{array}{c}\text { Loamy- } \\
\text { skeletal, } \\
\text { mixed, } \\
\text { superactive, } \\
\text { frigid Typic } \\
\text { Haplorthods }\end{array}$ \\
\hline 95WV083004 & -79.369167 & 38.951111 & Snowdog & & $\begin{array}{l}\text { Snowdog } \\
\text { Taxadjunct }\end{array}$ & $\begin{array}{l}\text { Fine-loamy, } \\
\text { mixed, active, } \\
\text { frigid Typic } \\
\text { Fragiudepts }\end{array}$ \\
\hline 95WV083005 & -79.695833 & 38.983889 & Mandy & & $\begin{array}{c}\text { Mandy } \\
\text { Taxadjunct }\end{array}$ & $\begin{array}{l}\text { Loamy- } \\
\text { skeletal, } \\
\text { mixed, active, } \\
\text { frigid Spodic } \\
\text { Dystrudepts }\end{array}$ \\
\hline 95WV083006 & -79.693611 & 38.983889 & snd & & $\begin{array}{c}\text { Gauley } \\
\text { Taxadjunct }\end{array}$ & $\begin{array}{c}\text { Loamy- } \\
\text { skeletal, } \\
\text { mixed, } \\
\text { superactive, } \\
\text { frigid Typic } \\
\text { Haplorthods }\end{array}$ \\
\hline 95WV083007 & -79.703056 & 38.946389 & Mandy & & $\begin{array}{c}\text { Mandy } \\
\text { Taxadjunct }\end{array}$ & $\begin{array}{c}\text { Loamy- } \\
\text { skeletal, } \\
\text { mixed, } \\
\text { superactive, } \\
\text { frigid Spodic } \\
\text { Dystrudepts }\end{array}$ \\
\hline 95WV083008 & -79.696389 & 38.983056 & snd & & $\begin{array}{c}\text { Simoda } \\
\text { Taxadjunct }\end{array}$ & $\begin{array}{c}\text { Loamy- } \\
\text { skeletal, } \\
\text { mixed, active, } \\
\text { frigid Aquic } \\
\text { Fragiudepts }\end{array}$ \\
\hline 95WV093001 & -79.599139 & 39.107833 & snd & & $\begin{array}{l}\text { Snowdog } \\
\text { Taxadjunct }\end{array}$ & $\begin{array}{l}\text { Loamy- } \\
\text { skeletal, } \\
\text { siliceous, } \\
\text { active, frigid } \\
\text { Aquic } \\
\text { Fragiudults }\end{array}$ \\
\hline
\end{tabular}




\begin{tabular}{|c|c|c|c|c|c|c|}
\hline PedonID & Longitude & Latitude & $\begin{array}{c}\text { Series } \\
\text { Sampled As }\end{array}$ & $\begin{array}{c}\text { Series } \\
\text { Correlated } \\
\text { As }\end{array}$ & $\begin{array}{c}\text { Series } \\
\text { Correlated } \\
\text { To }\end{array}$ & $\begin{array}{c}\text { Taxonomic } \\
\text { Classification }\end{array}$ \\
\hline 95WV093002 & -79.455861 & 39.087861 & snd & & $\begin{array}{c}\text { Gauley } \\
\text { Taxadjunct }\end{array}$ & $\begin{array}{l}\text { Coarse-loamy, } \\
\text { siliceous, } \\
\text { superactive, } \\
\text { frigid Typic } \\
\text { Haplorthods }\end{array}$ \\
\hline 95WV093003 & -79.461111 & 39.083444 & snd & & $\begin{array}{c}\text { Gauley } \\
\text { Taxadjunct }\end{array}$ & $\begin{array}{l}\text { Coarse-loamy, } \\
\text { siliceous, } \\
\text { superactive, } \\
\text { frigid Typic } \\
\text { Haplorthods }\end{array}$ \\
\hline 95WV093004 & -79.428333 & 38.994722 & Mandy & & $\begin{array}{c}\text { Gauley } \\
\text { Taxadjunct }\end{array}$ & $\begin{array}{c}\text { Loamy- } \\
\text { skeletal, } \\
\text { mixed, } \\
\text { superactive, } \\
\text { frigid Typic } \\
\text { Haplorthods }\end{array}$ \\
\hline 95WV093005 & -79.429444 & 38.991944 & Mandy & & $\begin{array}{c}\text { Mandy } \\
\text { Taxadjunct }\end{array}$ & $\begin{array}{c}\text { Loamy- } \\
\text { skeletal, } \\
\text { mixed, active, } \\
\text { frigid Spodic } \\
\text { Dystrudepts }\end{array}$ \\
\hline 95WV093006 & -79.427222 & 38.996389 & Snowdog & & $\begin{array}{l}\text { Blandburg } \\
\text { Taxadjunct }\end{array}$ & $\begin{array}{l}\text { Fine-loamy, } \\
\text { mixed, } \\
\text { superactive, } \\
\text { frigid Typic } \\
\text { Fragiorthods }\end{array}$ \\
\hline 95WV093007 & -79.429722 & 38.993889 & Gauley & & $\begin{array}{c}\text { Gauley } \\
\text { Taxadjunct }\end{array}$ & $\begin{array}{c}\text { Loamy- } \\
\text { skeletal, } \\
\text { mixed, } \\
\text { superactive, } \\
\text { frigid Typic } \\
\text { Haplorthods }\end{array}$ \\
\hline 95WV093008 & -79.398611 & 38.992222 & Snowdog & & $\begin{array}{l}\text { Snowdog } \\
\text { Taxadjunct }\end{array}$ & $\begin{array}{l}\text { Fine-loamy, } \\
\text { mixed, } \\
\text { superactive, } \\
\text { frigid Typic } \\
\text { Fragiudepts }\end{array}$ \\
\hline
\end{tabular}




\begin{tabular}{|c|c|c|c|c|c|c|}
\hline PedonID & Longitude & Latitude & $\begin{array}{c}\text { Series } \\
\text { Sampled As }\end{array}$ & $\begin{array}{c}\text { Series } \\
\text { Correlated } \\
\text { As }\end{array}$ & $\begin{array}{c}\text { Series } \\
\text { Correlated } \\
\text { To }\end{array}$ & $\begin{array}{c}\text { Taxonomic } \\
\text { Classification }\end{array}$ \\
\hline 97WV093001 & -79.5975 & 39.171111 & Berks & & $\begin{array}{c}\text { Berks } \\
\text { Taxadjunct }\end{array}$ & $\begin{array}{c}\text { Loamy- } \\
\text { skeletal, } \\
\text { mixed, active, } \\
\text { mesic Typic } \\
\text { Hapludults }\end{array}$ \\
\hline 97WV093002 & -79.775278 & 39.041667 & Gilpin & & Berks & $\begin{array}{c}\text { Loamy- } \\
\text { skeletal, } \\
\text { mixed, active, } \\
\text { mesic Typic } \\
\text { Dystrudepts }\end{array}$ \\
\hline 97WV093003 & -79.775 & 39.0425 & Shelocta-like & & $\begin{array}{l}\text { Shelocta } \\
\text { Taxadjunct }\end{array}$ & $\begin{array}{l}\text { Fine-loamy, } \\
\text { mixed, } \\
\text { superactive, } \\
\text { mesic Typic } \\
\text { Dystrudepts }\end{array}$ \\
\hline 97WV093004 & -79.597778 & 39.186944 & Highsplint & & Highsplint & $\begin{array}{c}\text { Loamy- } \\
\text { skeletal, } \\
\text { mixed, active, } \\
\text { mesic Typic } \\
\text { Dystrudepts }\end{array}$ \\
\hline 97WV093005 & -79.597222 & 39.185833 & Highsplint & & Highsplint & $\begin{array}{c}\text { Loamy- } \\
\text { skeletal, } \\
\text { mixed, active, } \\
\text { mesic Typic } \\
\text { Dystrudepts }\end{array}$ \\
\hline 97WV093006 & -79.625278 & 39.201111 & Berks & & Berks & $\begin{array}{c}\text { Loamy- } \\
\text { skeletal, } \\
\text { mixed, active, } \\
\text { mesic Typic } \\
\text { Dystrudepts }\end{array}$ \\
\hline 97WV093007 & -79.718611 & 39.093333 & Macove & & Macove & $\begin{array}{c}\text { Loamy- } \\
\text { skeletal, } \\
\text { mixed, active, } \\
\text { mesic Typic } \\
\text { Hapludults }\end{array}$ \\
\hline 97WV093008 & -79.602778 & 39.185 & Berks & & Berks & $\begin{array}{c}\text { Loamy- } \\
\text { skeletal, } \\
\text { mixed, active, } \\
\text { mesic Typic } \\
\text { Dystrudepts }\end{array}$ \\
\hline
\end{tabular}




\begin{tabular}{|c|c|c|c|c|c|c|}
\hline PedonID & Longitude & Latitude & $\begin{array}{c}\text { Series } \\
\text { Sampled As }\end{array}$ & $\begin{array}{c}\text { Series } \\
\text { Correlated } \\
\text { As }\end{array}$ & $\begin{array}{c}\text { Series } \\
\text { Correlated } \\
\text { To }\end{array}$ & $\begin{array}{c}\text { Taxonomic } \\
\text { Classification }\end{array}$ \\
\hline 98NY009001 & -78.708889 & 42.001111 & Cookport & & $\begin{array}{l}\text { Cookport } \\
\text { Taxadjunct }\end{array}$ & $\begin{array}{l}\text { Fine-loamy, } \\
\text { mixed, } \\
\text { semiactive, } \\
\text { mesic Aquic } \\
\text { Fragiudults }\end{array}$ \\
\hline 98NY009002 & -78.724722 & 42.000833 & Cookport & & $\begin{array}{l}\text { Cookport } \\
\text { Taxadjunct }\end{array}$ & $\begin{array}{c}\text { Coarse-loamy, } \\
\text { mixed, } \\
\text { superactive, } \\
\text { mesic Aquic } \\
\text { Fragiudults }\end{array}$ \\
\hline 98PA129121 & -79.020833 & 40.335556 & Clymer & & Clymer & $\begin{array}{l}\text { Coarse-loamy, } \\
\text { siliceous, } \\
\text { active, mesic } \\
\text { Typic } \\
\text { Hapludults }\end{array}$ \\
\hline 98PA129123 & -79.023611 & 40.340278 & Clymer & & Hazleton & $\begin{array}{l}\text { Loamy- } \\
\text { skeletal, } \\
\text { siliceous, } \\
\text { active, mesic } \\
\text { Typic } \\
\text { Dystrudepts }\end{array}$ \\
\hline $\begin{array}{l}\text { S06WV071- } \\
001\end{array}$ & -79.535419 & 38.684833 & Gauley & & Gauley & $\begin{array}{l}\text { Loamy- } \\
\text { skeletal, } \\
\text { siliceous, } \\
\text { superactive, } \\
\text { frigid Typic } \\
\text { Haplorthods }\end{array}$ \\
\hline $\begin{array}{l}\text { S06WV081- } \\
002\end{array}$ & -80.208278 & 38.30375 & Meckesville & & $\begin{array}{l}\text { Leck Kill } \\
\text { Taxadjunct }\end{array}$ & $\begin{array}{l}\text { Fine-loamy, } \\
\text { mixed, } \\
\text { semiactive, } \\
\text { mesic Aquic } \\
\text { Hapludults }\end{array}$ \\
\hline $\begin{array}{l}\text { S06WV093- } \\
008\end{array}$ & -79.698056 & 38.991111 & SND & & $\begin{array}{c}\text { Gauley } \\
\text { Taxadjunct }\end{array}$ & $\begin{array}{c}\text { Loamy- } \\
\text { skeletal, } \\
\text { mixed, } \\
\text { semiactive, } \\
\text { mesic Typic } \\
\text { Haplorthods }\end{array}$ \\
\hline
\end{tabular}




\begin{tabular}{|c|c|c|c|c|c|c|}
\hline PedonID & Longitude & Latitude & $\begin{array}{c}\text { Series } \\
\text { Sampled As }\end{array}$ & $\begin{array}{c}\text { Series } \\
\text { Correlated } \\
\text { As }\end{array}$ & $\begin{array}{c}\text { Series } \\
\text { Correlated } \\
\text { To }\end{array}$ & $\begin{array}{c}\text { Taxonomic } \\
\text { Classification }\end{array}$ \\
\hline $\begin{array}{l}\text { S01PA-031- } \\
010\end{array}$ & -79.233778 & 41.329194 & Laidig & Laidig & $\begin{array}{c}\text { Laidig } \\
\text { Taxadjunct }\end{array}$ & $\begin{array}{c}\text { Coarse-loamy, } \\
\text { mixed, } \\
\text { semiactive, } \\
\text { mesic Typic } \\
\text { Fragiudepts }\end{array}$ \\
\hline $\begin{array}{l}\text { S01PA-031- } \\
050\end{array}$ & -79.241444 & 41.369861 & Buchanan & Buchanan & $\begin{array}{c}\text { Ernest } \\
\text { Taxadjunct }\end{array}$ & $\begin{array}{l}\text { Fine-loamy, } \\
\text { mixed, active, } \\
\text { mesic Aquic } \\
\text { Fragiudults }\end{array}$ \\
\hline $\begin{array}{l}\text { S01PA-031- } \\
053\end{array}$ & -79.344028 & 41.40625 & Tilsit & SND & $\begin{array}{c}\text { Ernest } \\
\text { Taxadjunct }\end{array}$ & $\begin{array}{l}\text { Fine, mixed, } \\
\text { semiactive, } \\
\text { mesic Aquic } \\
\text { Fragiudults }\end{array}$ \\
\hline $\begin{array}{c}\text { S01WV-019- } \\
001\end{array}$ & -80.975833 & 37.881944 & Highsplint & Layland & $\begin{array}{c}\text { Layland } \\
\text { Taxadjunct }\end{array}$ & $\begin{array}{c}\text { Loamy- } \\
\text { skeletal, } \\
\text { mixed, } \\
\text { semiactive, } \\
\text { mesic Typic } \\
\text { Dystrudepts }\end{array}$ \\
\hline $\begin{array}{l}\text { S01WV-019- } \\
\quad 002\end{array}$ & -80.922817 & 38.114933 & Gilpin & & Clifftop & $\begin{array}{l}\text { Fine-loamy, } \\
\text { mixed, } \\
\text { semiactive, } \\
\text { mesic Typic } \\
\text { Hapludults }\end{array}$ \\
\hline $\begin{array}{l}\text { S01WV-019- } \\
003\end{array}$ & -80.924667 & 38.113694 & Lily & & Nallen & $\begin{array}{l}\text { Coarse-loamy, } \\
\text { siliceous, } \\
\text { semiactive, } \\
\text { mesic Inceptic } \\
\text { Hapludults }\end{array}$ \\
\hline $\begin{array}{l}\text { S01WV-019- } \\
004\end{array}$ & -80.940811 & 38.048383 & Matewan & & $\begin{array}{c}\text { Dekalb } \\
\text { Taxadjunct }\end{array}$ & $\begin{array}{c}\text { Loamy- } \\
\text { skeletal, } \\
\text { siliceous, } \\
\text { semiactive, } \\
\text { mesic Typic } \\
\text { Dystrudepts }\end{array}$ \\
\hline
\end{tabular}




\begin{tabular}{|c|c|c|c|c|c|c|}
\hline PedonID & Longitude & Latitude & $\begin{array}{c}\text { Series } \\
\text { Sampled As }\end{array}$ & $\begin{array}{c}\text { Series } \\
\text { Correlated } \\
\text { As }\end{array}$ & $\begin{array}{c}\text { Series } \\
\text { Correlated } \\
\text { To }\end{array}$ & $\begin{array}{c}\text { Taxonomic } \\
\text { Classification }\end{array}$ \\
\hline $\begin{array}{c}\text { S01WV-019- } \\
005\end{array}$ & -80.941183 & 38.049883 & Lily & & Lily & $\begin{array}{l}\text { Fine-loamy, } \\
\text { siliceous, } \\
\text { semiactive, } \\
\text { mesic Typic } \\
\text { Hapludults }\end{array}$ \\
\hline $\begin{array}{c}\text { S01WV-019- } \\
006\end{array}$ & -81.075 & 38.091667 & Matewan & & $\begin{array}{c}\text { Dekalb } \\
\text { Taxadjunct }\end{array}$ & $\begin{array}{c}\text { Loamy- } \\
\text { skeletal, } \\
\text { siliceous, } \\
\text { semiactive, } \\
\text { mesic Typic } \\
\text { Dystrudepts }\end{array}$ \\
\hline $\begin{array}{c}\text { S01WV-019- } \\
007\end{array}$ & -80.951 & 38.0383 & Gilpin & & Clifftop & $\begin{array}{l}\text { Fine-loamy, } \\
\text { mixed, } \\
\text { semiactive, } \\
\text { mesic Typic } \\
\text { Hapludults }\end{array}$ \\
\hline $\begin{array}{c}\text { S01WV-019- } \\
008\end{array}$ & -80.949183 & 38.036717 & Highsplint & Layland & $\begin{array}{l}\text { Layland } \\
\text { Taxadjunct }\end{array}$ & $\begin{array}{c}\text { Loamy- } \\
\text { skeletal, } \\
\text { siliceous, } \\
\text { semiactive, } \\
\text { mesic Typic } \\
\text { Hapludults }\end{array}$ \\
\hline $\begin{array}{c}\text { S01WV-019- } \\
009\end{array}$ & -80.920483 & 38.1155 & Buchannon & & Buchanan & $\begin{array}{l}\text { Fine-loamy, } \\
\text { mixed, } \\
\text { semiactive, } \\
\text { mesic Aquic } \\
\text { Hapludults }\end{array}$ \\
\hline $\begin{array}{c}\text { S01WV-019- } \\
010\end{array}$ & -81.078117 & 38.091767 & Lily & Nallen & $\begin{array}{c}\text { Nallen } \\
\text { Taxadjunct }\end{array}$ & $\begin{array}{l}\text { Coarse-loamy, } \\
\text { siliceous, } \\
\text { semiactive, } \\
\text { mesic Typic } \\
\text { Dystrudepts }\end{array}$ \\
\hline $\begin{array}{c}\text { S01WV-019- } \\
011\end{array}$ & -81.154367 & 37.917533 & Lily & & $\begin{array}{c}\text { Nallen } \\
\text { Taxadjunct }\end{array}$ & $\begin{array}{c}\text { Coarse-loamy, } \\
\text { siliceous, } \\
\text { active, mesic } \\
\text { Typic } \\
\text { Dystrudepts }\end{array}$ \\
\hline
\end{tabular}




\begin{tabular}{|c|c|c|c|c|c|c|}
\hline PedonID & Longitude & Latitude & $\begin{array}{c}\text { Series } \\
\text { Sampled As }\end{array}$ & $\begin{array}{c}\text { Series } \\
\text { Correlated } \\
\text { As }\end{array}$ & $\begin{array}{c}\text { Series } \\
\text { Correlated } \\
\text { To }\end{array}$ & $\begin{array}{c}\text { Taxonomic } \\
\text { Classification }\end{array}$ \\
\hline S01WV025002 & -80.373889 & 37.92 & & & $\begin{array}{l}\text { Frankstown } \\
\text { Taxadjunct }\end{array}$ & $\begin{array}{l}\text { Fine-loamy, } \\
\text { mixed, } \\
\text { semiactive, } \\
\text { mesic Typic } \\
\text { Paleudults }\end{array}$ \\
\hline S01WV025003 & -80.503028 & 37.839778 & Frederick & & $\begin{array}{l}\text { Caneyville } \\
\text { Taxadjunct }\end{array}$ & $\begin{array}{l}\text { Fine, mixed, } \\
\text { semiactive, } \\
\text { mesic Typic } \\
\text { Paleudalfs }\end{array}$ \\
\hline S01WV025004 & -80.503 & 37.839611 & Caneyville & & Caneyville & $\begin{array}{c}\text { Fine, mixed, } \\
\text { active, mesic } \\
\text { Typic } \\
\text { Hapludalfs } \\
\end{array}$ \\
\hline S01WV063005 & -80.534278 & 37.608167 & Frederick & & Frederick & $\begin{array}{l}\text { Fine, mixed, } \\
\text { semiactive, } \\
\text { mesic Typic } \\
\text { Paleudults }\end{array}$ \\
\hline S01WV063006 & -80.508556 & 37.637472 & Pickaway & & $\begin{array}{l}\text { Guernsey } \\
\text { Taxadjunct }\end{array}$ & $\begin{array}{l}\text { Fine, mixed, } \\
\text { semiactive, } \\
\text { mesic Aquic } \\
\text { Hapludalfs }\end{array}$ \\
\hline S01WV063007 & -80.475972 & 37.692806 & Caneyville & & Caneyville & $\begin{array}{l}\text { Fine, mixed, } \\
\text { active, mesic } \\
\text { Typic } \\
\text { Hapludalfs }\end{array}$ \\
\hline S01WV063008 & -80.476222 & 37.692639 & Frederick & & $\begin{array}{l}\text { Caneyville } \\
\text { Taxadjunct }\end{array}$ & $\begin{array}{l}\text { Fine-silty, } \\
\text { mixed, } \\
\text { semiactive, } \\
\text { mesic Typic } \\
\text { Hapludalfs }\end{array}$ \\
\hline $\begin{array}{l}\text { S01WV-081- } \\
\quad 001\end{array}$ & -80.977028 & 37.755389 & Gilpin & & $\begin{array}{l}\text { Clifftop } \\
\text { taxadjunct }\end{array}$ & $\begin{array}{l}\text { Fine-loamy, } \\
\text { siliceous, } \\
\text { semiactive, } \\
\text { mesic Typic } \\
\text { Hapludults }\end{array}$ \\
\hline
\end{tabular}




\begin{tabular}{|c|c|c|c|c|c|c|}
\hline PedonID & Longitude & Latitude & $\begin{array}{c}\text { Series } \\
\text { Sampled As }\end{array}$ & $\begin{array}{c}\text { Series } \\
\text { Correlated } \\
\text { As }\end{array}$ & $\begin{array}{c}\text { Series } \\
\text { Correlated } \\
\text { To }\end{array}$ & $\begin{array}{c}\text { Taxonomic } \\
\text { Classification }\end{array}$ \\
\hline $\begin{array}{l}\text { S01WV-081- } \\
\quad 002\end{array}$ & -81.011867 & 37.728333 & Matewan & & $\begin{array}{c}\text { Dekalb } \\
\text { Taxadjunct }\end{array}$ & $\begin{array}{c}\text { Loamy- } \\
\text { skeletal, } \\
\text { siliceous, } \\
\text { semiactive, } \\
\text { mesic Typic } \\
\text { Dystrudepts }\end{array}$ \\
\hline $\begin{array}{l}\text { S01WV-081- } \\
003\end{array}$ & -81.010667 & 37.7314 & Highsplint & & $\begin{array}{l}\text { Highsplint } \\
\text { Taxadjunct }\end{array}$ & $\begin{array}{l}\text { Loamy- } \\
\text { skeletal, } \\
\text { mixed, } \\
\text { semiactive, } \\
\text { mesic Typic } \\
\text { Dystrudepts }\end{array}$ \\
\hline $\begin{array}{l}\text { S01WV-081- } \\
\quad 004\end{array}$ & -81.174733 & 37.8158 & Lily & & $\begin{array}{c}\text { Nallen } \\
\text { Taxadjunct }\end{array}$ & $\begin{array}{c}\text { Coarse-loamy, } \\
\text { siliceous, } \\
\text { semiactive, } \\
\text { mesic Typic } \\
\text { Dystrudepts }\end{array}$ \\
\hline $\begin{array}{l}\text { S01WV-081- } \\
\quad 005\end{array}$ & -81.173283 & 37.8175 & Cookport & & $\begin{array}{l}\text { Cookport } \\
\text { Taxadjunct }\end{array}$ & $\begin{array}{l}\text { Coarse-loamy, } \\
\text { siliceous, } \\
\text { semiactive, } \\
\text { mesic Aquic } \\
\text { Fragiudepts }\end{array}$ \\
\hline $\begin{array}{l}\text { S01WV-081- } \\
006\end{array}$ & -81.359767 & 37.80335 & Highsplint & & Highsplint & $\begin{array}{c}\text { Loamy- } \\
\text { skeletal, } \\
\text { mixed, active, } \\
\text { mesic Typic } \\
\text { Dystrudepts }\end{array}$ \\
\hline $\begin{array}{l}\text { S01WV-081- } \\
007\end{array}$ & -81.359767 & 37.80335 & Matewan & & Matewan & $\begin{array}{c}\text { Loamy- } \\
\text { skeletal, } \\
\text { mixed, active, } \\
\text { mesic Typic } \\
\text { Dystrudepts }\end{array}$ \\
\hline $\begin{array}{l}\text { S02PA-031- } \\
\quad 008\end{array}$ & -79.4745 & 41.273361 & Atkins & SND & $\begin{array}{c}\text { Atkins } \\
\text { Taxadjunct }\end{array}$ & $\begin{array}{l}\text { Fine-loamy, } \\
\text { mixed, } \\
\text { semiactive, } \\
\text { acid, mesic } \\
\text { Fluvaquentic } \\
\text { Endoaquults }\end{array}$ \\
\hline
\end{tabular}




\begin{tabular}{|c|c|c|c|c|c|c|}
\hline PedonID & Longitude & Latitude & $\begin{array}{c}\text { Series } \\
\text { Sampled As }\end{array}$ & $\begin{array}{c}\text { Series } \\
\text { Correlated } \\
\text { As }\end{array}$ & $\begin{array}{c}\text { Series } \\
\text { Correlated } \\
\text { To }\end{array}$ & $\begin{array}{c}\text { Taxonomic } \\
\text { Classification }\end{array}$ \\
\hline $\begin{array}{l}\text { S02PA-065- } \\
004\end{array}$ & -79.064333 & 41.317917 & Cookport & Cookport & $\begin{array}{l}\text { Cookport } \\
\text { Taxadjunct }\end{array}$ & $\begin{array}{l}\text { Fine-loamy, } \\
\text { mixed, } \\
\text { semiactive, } \\
\text { mesic Aquic } \\
\text { Fragiudults }\end{array}$ \\
\hline $\begin{array}{c}\text { S02WV-019- } \\
001\end{array}$ & -81.19725 & 37.901333 & Berks & & $\begin{array}{c}\text { Berks } \\
\text { Taxadjunct }\end{array}$ & $\begin{array}{c}\text { Loamy- } \\
\text { skeletal, } \\
\text { mixed, } \\
\text { semiactive, } \\
\text { mesic Typic } \\
\text { Dystrudepts }\end{array}$ \\
\hline $\begin{array}{c}\text { S02WV-019- } \\
006\end{array}$ & -81.198639 & 37.89525 & Matewan & & $\begin{array}{c}\text { Matewan } \\
\text { Taxadjunct }\end{array}$ & $\begin{array}{l}\text { Loamy- } \\
\text { skeletal, } \\
\text { mixed, } \\
\text { semiactive, } \\
\text { mesic Typic } \\
\text { Dystrudepts }\end{array}$ \\
\hline $\begin{array}{c}\text { S02WV-019- } \\
007\end{array}$ & -81.221889 & 37.89025 & Muskingum & & $\begin{array}{l}\text { Hazelton } \\
\text { Taxadjunct }\end{array}$ & $\begin{array}{c}\text { Loamy- } \\
\text { skeletal, } \\
\text { mixed, } \\
\text { semiactive, } \\
\text { mesic Typic } \\
\text { Hapludults }\end{array}$ \\
\hline $\begin{array}{c}\text { S02WV-019- } \\
008\end{array}$ & -81.221806 & 37.889194 & Guyandotte & Sharondale & $\begin{array}{l}\text { Sharondale } \\
\text { Taxadjunct }\end{array}$ & $\begin{array}{c}\text { Loamy- } \\
\text { skeletal, } \\
\text { mixed, active, } \\
\text { mesic Typic } \\
\text { Humudepts }\end{array}$ \\
\hline $\begin{array}{c}\text { S02WV-019- } \\
012\end{array}$ & -81.066389 & 38.175833 & Berks & & Berks & $\begin{array}{c}\text { Loamy- } \\
\text { skeletal, } \\
\text { mixed, active, } \\
\text { mesic Typic } \\
\text { Dystrudepts }\end{array}$ \\
\hline $\begin{array}{c}\text { S02WV-019- } \\
013\end{array}$ & -81.066267 & 38.175867 & Highsplint & & Highsplint & $\begin{array}{c}\text { Loamy- } \\
\text { skeletal, } \\
\text { mixed, active, } \\
\text { mesic Typic } \\
\text { Dystrudepts }\end{array}$ \\
\hline
\end{tabular}




\begin{tabular}{|c|c|c|c|c|c|c|}
\hline PedonID & Longitude & Latitude & $\begin{array}{c}\text { Series } \\
\text { Sampled As }\end{array}$ & $\begin{array}{c}\text { Series } \\
\text { Correlated } \\
\text { As }\end{array}$ & $\begin{array}{c}\text { Series } \\
\text { Correlated } \\
\text { To }\end{array}$ & $\begin{array}{c}\text { Taxonomic } \\
\text { Classification }\end{array}$ \\
\hline $\begin{array}{l}\text { S02WV-081- } \\
\quad 002\end{array}$ & -81.295611 & 37.873083 & Matewan & & $\begin{array}{l}\text { Matewan } \\
\text { Taxadjunct }\end{array}$ & $\begin{array}{c}\text { Loamy- } \\
\text { skeletal, } \\
\text { mixed, } \\
\text { superactive, } \\
\text { mesic Dystric } \\
\text { Eutrudepts }\end{array}$ \\
\hline $\begin{array}{l}\text { S02WV-081- } \\
004\end{array}$ & -81.295056 & 37.875083 & Highsplint & & Highsplint & $\begin{array}{c}\text { Loamy- } \\
\text { skeletal, } \\
\text { mixed, active, } \\
\text { mesic Typic } \\
\text { Dystrudepts }\end{array}$ \\
\hline $\begin{array}{l}\text { S02WV-081- } \\
\quad 005\end{array}$ & -81.294056 & 37.875444 & Matewan & & Matewan & $\begin{array}{c}\text { Loamy- } \\
\text { skeletal, } \\
\text { mixed, active, } \\
\text { mesic Typic } \\
\text { Dystrudepts }\end{array}$ \\
\hline $\begin{array}{c}\text { S03WV-025- } \\
001\end{array}$ & -80.684639 & 37.977139 & Cateache & & $\begin{array}{c}\text { Shouns } \\
\text { Taxadjunct }\end{array}$ & $\begin{array}{l}\text { Fine, mixed, } \\
\text { semiactive, } \\
\text { mesic Typic } \\
\text { Rhodudults }\end{array}$ \\
\hline $\begin{array}{c}\text { S03WV-025- } \\
002\end{array}$ & -80.628889 & 37.99975 & Shouns & & Shouns & $\begin{array}{l}\text { Fine-loamy, } \\
\text { mixed, } \\
\text { semiactive, } \\
\text { mesic Typic } \\
\text { Hapludults }\end{array}$ \\
\hline $\begin{array}{c}\text { S03WV-071- } \\
001\end{array}$ & -79.54925 & 38.679111 & Shouns & & $\begin{array}{c}\text { Shouns } \\
\text { Taxadjunct }\end{array}$ & $\begin{array}{c}\text { Fine-loamy, } \\
\text { mixed, active, } \\
\text { mesic Typic } \\
\text { Hapludults }\end{array}$ \\
\hline $\begin{array}{c}\text { S03WV-075- } \\
001\end{array}$ & -79.855 & 38.549167 & Cateache & & Clifftop & $\begin{array}{l}\text { Fine-loamy, } \\
\text { mixed, } \\
\text { semiactive, } \\
\text { mesic Typic } \\
\text { Hapludults }\end{array}$ \\
\hline
\end{tabular}




\begin{tabular}{|c|c|c|c|c|c|c|}
\hline PedonID & Longitude & Latitude & $\begin{array}{c}\text { Series } \\
\text { Sampled As }\end{array}$ & $\begin{array}{c}\text { Series } \\
\text { Correlated } \\
\text { As }\end{array}$ & $\begin{array}{c}\text { Series } \\
\text { Correlated } \\
\text { To }\end{array}$ & $\begin{array}{c}\text { Taxonomic } \\
\text { Classification }\end{array}$ \\
\hline $\begin{array}{c}\text { S03WV-077- } \\
001\end{array}$ & -79.766808 & 39.250169 & Calvin & & $\begin{array}{c}\text { Ungers } \\
\text { Taxadjunct }\end{array}$ & $\begin{array}{c}\text { Loamy- } \\
\text { skeletal, } \\
\text { mixed, } \\
\text { semiactive, } \\
\text { mesic Typic } \\
\text { Hapludults }\end{array}$ \\
\hline $\begin{array}{l}\text { S03WV-081- } \\
001\end{array}$ & -81.049889 & 37.831583 & Shouns & & Pipestem & $\begin{array}{c}\text { Fine, mixed, } \\
\text { active, mesic } \\
\text { Dystric } \\
\text { Eutrudepts }\end{array}$ \\
\hline $\begin{array}{c}\text { S03WV-081- } \\
002\end{array}$ & -81.059667 & 37.834889 & Cateache & Cateache & $\begin{array}{l}\text { Pipestem } \\
\text { Taxadjunct }\end{array}$ & $\begin{array}{c}\text { Loamy- } \\
\text { skeletal, } \\
\text { mixed, active, } \\
\text { mesic Dystric } \\
\text { Eutrudepts }\end{array}$ \\
\hline $\begin{array}{l}\text { S03WV-083- } \\
\quad 001\end{array}$ & -79.733492 & 38.966717 & Hampshire & & Ungers & $\begin{array}{l}\text { Fine- } \\
\text { loamy,mixed, } \\
\text { semiactive, } \\
\text { mesic Typic } \\
\text { Hapludults }\end{array}$ \\
\hline $\begin{array}{c}\text { S03WV-083- } \\
002\end{array}$ & -79.745083 & 38.947667 & Cateache & & Ungers & $\begin{array}{l}\text { Fine-loamy, } \\
\text { mixed, } \\
\text { semiactive, } \\
\text { mesic Typic } \\
\text { Hapludults }\end{array}$ \\
\hline $\begin{array}{c}\text { S03WV-083- } \\
003\end{array}$ & -79.746683 & 38.951433 & Cateache & & $\begin{array}{c}\text { Ungers } \\
\text { Taxadjunct }\end{array}$ & $\begin{array}{c}\text { Fine-loamy, } \\
\text { mixed, active, } \\
\text { mesic Typic } \\
\text { Hapludults }\end{array}$ \\
\hline $\begin{array}{l}\text { S03WV-083- } \\
\quad 004\end{array}$ & -79.600017 & 38.950117 & Calvin & & $\begin{array}{c}\text { Calvin } \\
\text { Taxadjunct }\end{array}$ & $\begin{array}{c}\text { Clayey- } \\
\text { skeletal, } \\
\text { mixed, active, } \\
\text { mesic Typic } \\
\text { Hapludults }\end{array}$ \\
\hline
\end{tabular}




\begin{tabular}{|c|c|c|c|c|c|c|}
\hline PedonID & Longitude & Latitude & $\begin{array}{c}\text { Series } \\
\text { Sampled As }\end{array}$ & $\begin{array}{c}\text { Series } \\
\text { Correlated } \\
\text { As }\end{array}$ & $\begin{array}{c}\text { Series } \\
\text { Correlated } \\
\text { To }\end{array}$ & $\begin{array}{c}\text { Taxonomic } \\
\text { Classification }\end{array}$ \\
\hline $\begin{array}{c}\text { S03WV-083- } \\
005\end{array}$ & -79.554028 & 38.997139 & Hampshire & & $\begin{array}{l}\text { Hazleton } \\
\text { Taxadjunct }\end{array}$ & $\begin{array}{c}\text { Loamy- } \\
\text { skeletal, } \\
\text { mixed, active, } \\
\text { mesic Typic } \\
\text { Dystrudepts }\end{array}$ \\
\hline $\begin{array}{c}\text { S03WV-083- } \\
006\end{array}$ & -79.550031 & 38.983581 & Calvin & & $\begin{array}{c}\text { Calvin } \\
\text { Taxadjunct }\end{array}$ & $\begin{array}{c}\text { Loamy- } \\
\text { skeletal, } \\
\text { mixed, active, } \\
\text { mesic Typic } \\
\text { Hapludults }\end{array}$ \\
\hline $\begin{array}{c}\text { S03WV-083- } \\
007\end{array}$ & -79.603056 & 38.945 & Escatawba & & $\begin{array}{l}\text { Meckesville } \\
\text { Taxadjunct }\end{array}$ & $\begin{array}{l}\text { Fine-loamy, } \\
\text { mixed, } \\
\text { semiactive, } \\
\text { mesic Fragic } \\
\text { Hapludults }\end{array}$ \\
\hline $\begin{array}{c}\text { S03WV-083- } \\
008\end{array}$ & -79.915278 & 38.657222 & Cateache & & Leck Kill & $\begin{array}{l}\text { Fine-loamy, } \\
\text { mixed, } \\
\text { semiactive, } \\
\text { mesic Typic } \\
\text { Hapludults }\end{array}$ \\
\hline $\begin{array}{c}\text { S03WV-089- } \\
001\end{array}$ & -80.90125 & 37.752611 & Shouns & & $\begin{array}{l}\text { Pipestem } \\
\text { Taxadjunct }\end{array}$ & $\begin{array}{l}\text { Fine-loamy, } \\
\text { mixed, } \\
\text { semiactive, } \\
\text { mesic Typic } \\
\text { Dystrudepts }\end{array}$ \\
\hline $\begin{array}{c}\text { S03WV-089- } \\
002\end{array}$ & -80.899389 & 37.833444 & Cateache & $\begin{array}{l}\text { Cateache } \\
\text { Taxadjunct }\end{array}$ & $\begin{array}{c}\text { Shouns } \\
\text { Taxadjunct }\end{array}$ & $\begin{array}{c}\text { Fine-loamy, } \\
\text { mixed, active, } \\
\text { mesic Typic } \\
\text { Hapludults }\end{array}$ \\
\hline $\begin{array}{c}\text { S03WV-089- } \\
003\end{array}$ & -80.899389 & 37.833444 & Cateache & $\begin{array}{l}\text { Cateache } \\
\text { Taxadjunct }\end{array}$ & $\begin{array}{l}\text { Pipestem } \\
\text { Taxadjunct }\end{array}$ & $\begin{array}{l}\text { Fine-loamy, } \\
\text { mixed, } \\
\text { semiactive, } \\
\text { mesic Dystric } \\
\text { Eutrudepts }\end{array}$ \\
\hline
\end{tabular}




\begin{tabular}{|c|c|c|c|c|c|c|}
\hline PedonID & Longitude & Latitude & $\begin{array}{c}\text { Series } \\
\text { Sampled As }\end{array}$ & $\begin{array}{c}\text { Series } \\
\text { Correlated } \\
\text { As }\end{array}$ & $\begin{array}{c}\text { Series } \\
\text { Correlated } \\
\text { To }\end{array}$ & $\begin{array}{c}\text { Taxonomic } \\
\text { Classification }\end{array}$ \\
\hline $\begin{array}{c}\text { S03WV-089- } \\
004\end{array}$ & -80.913722 & 37.8185 & Shouns & & $\begin{array}{c}\text { Shouns } \\
\text { Taxadjunct }\end{array}$ & $\begin{array}{l}\text { Fine, mixed, } \\
\text { semiactive, } \\
\text { mesic Typic } \\
\text { Rhodudults }\end{array}$ \\
\hline $\begin{array}{c}\text { S03WV-089- } \\
005\end{array}$ & -80.874944 & 37.531889 & Shouns & & $\begin{array}{l}\text { Pipestem } \\
\text { Taxadjunct }\end{array}$ & $\begin{array}{l}\text { Fine-loamy, } \\
\text { mixed, active, } \\
\text { mesic Dystric } \\
\text { Eutrudepts }\end{array}$ \\
\hline $\begin{array}{c}\text { S03WV-089- } \\
006\end{array}$ & -80.762222 & 37.78 & Cateache & Cateache & $\begin{array}{c}\text { Cateache } \\
\text { Taxadjunct }\end{array}$ & $\begin{array}{l}\text { Fine, mixed, } \\
\text { semiactive, } \\
\text { mesic Ultic } \\
\text { Hapludalfs }\end{array}$ \\
\hline $\begin{array}{c}\text { S03WV-089- } \\
007\end{array}$ & -80.761972 & 37.779694 & Shouns & $\begin{array}{l}\text { Pipestem } \\
\text { Taxadjunct }\end{array}$ & $\begin{array}{l}\text { Cateache } \\
\text { Taxadjunct }\end{array}$ & $\begin{array}{l}\text { Fine, mixed, } \\
\text { semiactive, } \\
\text { mesic Typic } \\
\text { Hapludalfs }\end{array}$ \\
\hline $\begin{array}{c}\text { S03WV-093- } \\
001\end{array}$ & -79.666914 & 39.050194 & Calvin & & $\begin{array}{c}\text { Calvin } \\
\text { Taxadjunct }\end{array}$ & $\begin{array}{c}\text { Loamy- } \\
\text { skeletal, } \\
\text { mixed, active, } \\
\text { mesic Typic } \\
\text { Hapludults }\end{array}$ \\
\hline $\begin{array}{c}\text { S03WV-093- } \\
002\end{array}$ & -79.666847 & 39.050219 & Calvin & & Calvin & $\begin{array}{c}\text { Loamy- } \\
\text { skeletal, } \\
\text { mixed, active, } \\
\text { mesic Typic } \\
\text { Dystrudepts }\end{array}$ \\
\hline $\begin{array}{c}\text { S03WV-101- } \\
001\end{array}$ & -80.296972 & 38.481333 & Shouns & & $\begin{array}{c}\text { Pipestem } \\
\text { Taxadjunct }\end{array}$ & $\begin{array}{l}\text { Fine-loamy, } \\
\text { mixed, } \\
\text { semiactive, } \\
\text { mesic Dystric } \\
\text { Eutrudepts }\end{array}$ \\
\hline $\begin{array}{c}\text { S03WV-101- } \\
002\end{array}$ & -80.297194 & 38.479583 & Cateache & & $\begin{array}{l}\text { Pipestem } \\
\text { Taxadjunct }\end{array}$ & $\begin{array}{c}\text { Fine-loamy, } \\
\text { mixed, active, } \\
\text { mesic Typic } \\
\text { Dystrudepts }\end{array}$ \\
\hline
\end{tabular}




\begin{tabular}{|c|c|c|c|c|c|c|}
\hline PedonID & Longitude & Latitude & $\begin{array}{c}\text { Series } \\
\text { Sampled As }\end{array}$ & $\begin{array}{c}\text { Series } \\
\text { Correlated } \\
\text { As }\end{array}$ & $\begin{array}{c}\text { Series } \\
\text { Correlated } \\
\text { To }\end{array}$ & $\begin{array}{c}\text { Taxonomic } \\
\text { Classification }\end{array}$ \\
\hline $\begin{array}{c}\text { S04WV-001- } \\
002\end{array}$ & -79.561667 & 39.076111 & Brinkerton & & Clifftop & $\begin{array}{l}\text { Fine-loamy, } \\
\text { mixed, } \\
\text { semiactive, } \\
\text { mesic Typic } \\
\text { Hapludults }\end{array}$ \\
\hline $\begin{array}{l}\text { S04WV-093- } \\
\quad 001\end{array}$ & -79.543056 & 39.324167 & Gilpin & & Gilpin & $\begin{array}{c}\text { Fine-loamy, } \\
\text { mixed, active, } \\
\text { mesic Typic } \\
\text { Hapludults }\end{array}$ \\
\hline $\begin{array}{l}\text { S04WV-093- } \\
\quad 002\end{array}$ & -79.443611 & 39.15 & Ernest & & $\begin{array}{l}\text { Buchanan } \\
\text { Taxadjunct }\end{array}$ & $\begin{array}{c}\text { Fine-loamy, } \\
\text { mixed, active, } \\
\text { mesic Aquic } \\
\text { Fragiudults }\end{array}$ \\
\hline $\begin{array}{l}\text { S04WV-093- } \\
003\end{array}$ & -79.443889 & 39.140278 & Brinkerton & & $\begin{array}{c}\text { Cavode } \\
\text { Taxadjunct }\end{array}$ & $\begin{array}{l}\text { Fine-loamy, } \\
\text { mixed, active, } \\
\text { mesic Aeric } \\
\text { Endoaquults }\end{array}$ \\
\hline $\begin{array}{l}\text { S04WV-093- } \\
004\end{array}$ & -79.443611 & 39.134167 & Brinkerton & & $\begin{array}{l}\text { Buchanan } \\
\text { Taxadjunct }\end{array}$ & $\begin{array}{l}\text { Fine-loamy, } \\
\text { mixed, active, } \\
\text { mesic Aquic } \\
\text { Fragiorthods }\end{array}$ \\
\hline $\begin{array}{l}\text { S04WV-093- } \\
005\end{array}$ & -79.566667 & 39.08 & Trussel & & $\begin{array}{l}\text { Snowdog } \\
\text { Taxadjunct }\end{array}$ & $\begin{array}{l}\text { Fine-loamy, } \\
\text { mixed, active, } \\
\text { mesic Aquic } \\
\text { Fragiudepts }\end{array}$ \\
\hline $\begin{array}{c}\text { S04WV-093- } \\
006\end{array}$ & -79.561722 & 39.077139 & Gilpin & & $\begin{array}{c}\text { Gilpin } \\
\text { Taxadjunct }\end{array}$ & $\begin{array}{c}\text { Fine, mixed, } \\
\text { active, mesic } \\
\text { Typic } \\
\text { Hapludults }\end{array}$ \\
\hline $\begin{array}{c}\text { S04WV-093- } \\
007\end{array}$ & -79.563611 & 39.078333 & & & $\begin{array}{c}\text { Gauley } \\
\text { Taxadjunct }\end{array}$ & $\begin{array}{l}\text { Fine-loamy, } \\
\text { mixed, } \\
\text { superactive, } \\
\text { mesic Typic } \\
\text { Haplorthods }\end{array}$ \\
\hline
\end{tabular}




\begin{tabular}{|c|c|c|c|c|c|c|}
\hline PedonID & Longitude & Latitude & $\begin{array}{c}\text { Series } \\
\text { Sampled As }\end{array}$ & $\begin{array}{c}\text { Series } \\
\text { Correlated } \\
\text { As }\end{array}$ & $\begin{array}{c}\text { Series } \\
\text { Correlated } \\
\text { To }\end{array}$ & $\begin{array}{c}\text { Taxonomic } \\
\text { Classification }\end{array}$ \\
\hline $\begin{array}{c}\text { S04WV-093- } \\
008\end{array}$ & -79.565278 & 39.079444 & Ernest & & $\begin{array}{c}\text { Ernest } \\
\text { Taxadjunct }\end{array}$ & $\begin{array}{l}\text { Fine, mixed, } \\
\text { active, mesic } \\
\text { Ultic } \\
\text { Fragiorthods }\end{array}$ \\
\hline $\begin{array}{c}\text { S06WV019- } \\
001\end{array}$ & -80.970278 & 38.015 & Laidig & Laidig & $\begin{array}{c}\text { Laidig } \\
\text { Taxadjunct }\end{array}$ & $\begin{array}{l}\text { Fine-loamy, } \\
\text { mixed, } \\
\text { semiactive, } \\
\text { mesic Fragic } \\
\text { Hapludults }\end{array}$ \\
\hline $\begin{array}{c}\text { S06WV019- } \\
002\end{array}$ & -81.119444 & 37.93 & Cookport & & $\begin{array}{c}\text { Cookport } \\
\text { Taxadjunct }\end{array}$ & $\begin{array}{l}\text { Fine-loamy, } \\
\text { mixed, } \\
\text { semiactive, } \\
\text { mesic Typic } \\
\text { Fragiudults }\end{array}$ \\
\hline $\begin{array}{c}\text { S06WV019- } \\
004\end{array}$ & -81.032778 & 38.000556 & Laidig & & $\begin{array}{c}\text { Laidig } \\
\text { Taxadjunct }\end{array}$ & $\begin{array}{l}\text { Fine-loamy, } \\
\text { mixed, } \\
\text { semiactive, } \\
\text { mesic Fragic } \\
\text { Hapludults }\end{array}$ \\
\hline $\begin{array}{c}\text { S06WV019- } \\
005\end{array}$ & -81.195278 & 37.941944 & Gilpin & & Clifftop & $\begin{array}{l}\text { Fine-loamy, } \\
\text { mixed, } \\
\text { semiactive, } \\
\text { mesic Typic } \\
\text { Hapludults }\end{array}$ \\
\hline $\begin{array}{c}\text { S06WV025- } \\
001\end{array}$ & -80.59 & 37.746667 & Cookport & & $\begin{array}{c}\text { Cookport } \\
\text { Taxadjunct }\end{array}$ & $\begin{array}{c}\text { Coarse-loamy, } \\
\text { mixed, } \\
\text { semiactive, } \\
\text { mesic Typic } \\
\text { Fragiudults }\end{array}$ \\
\hline $\begin{array}{c}\text { S06WV067- } \\
001\end{array}$ & -80.808972 & 38.342944 & Gilpin & & Clifftop & $\begin{array}{c}\text { Fine-loamy, } \\
\text { mixed, } \\
\text { semiactive, } \\
\text { mesic Typic } \\
\text { Hapludults }\end{array}$ \\
\hline
\end{tabular}




\begin{tabular}{|c|c|c|c|c|c|c|}
\hline PedonID & Longitude & Latitude & $\begin{array}{c}\text { Series } \\
\text { Sampled As }\end{array}$ & $\begin{array}{c}\text { Series } \\
\text { Correlated } \\
\text { As }\end{array}$ & $\begin{array}{c}\text { Series } \\
\text { Correlated } \\
\text { To }\end{array}$ & $\begin{array}{c}\text { Taxonomic } \\
\text { Classification }\end{array}$ \\
\hline $\begin{array}{l}\text { S06WV067- } \\
002\end{array}$ & -80.660583 & 38.204 & Fenwick & & Fenwick & $\begin{array}{l}\text { Fine-loamy, } \\
\text { mixed, } \\
\text { semiactive, } \\
\text { mesic Aquic } \\
\text { Hapludults }\end{array}$ \\
\hline $\begin{array}{c}\text { S06WV067- } \\
003\end{array}$ & -80.669361 & 38.206972 & Laidig & & $\begin{array}{c}\text { Laidig } \\
\text { Taxadjunct }\end{array}$ & $\begin{array}{l}\text { Coarse-loamy, } \\
\text { mixed, } \\
\text { semiactive, } \\
\text { mesic Fragic } \\
\text { Hapludults }\end{array}$ \\
\hline $\begin{array}{c}\text { S06WV067- } \\
004\end{array}$ & -80.558889 & 38.259417 & Fenwick & & Fenwick & $\begin{array}{l}\text { Fine-loamy, } \\
\text { mixed, } \\
\text { semiactive, } \\
\text { mesic Aquic } \\
\text { Hapludults }\end{array}$ \\
\hline $\begin{array}{l}\text { S06WV067- } \\
005\end{array}$ & -80.5774444 & 38.255583 & Laidig & & $\begin{array}{c}\text { Laidig } \\
\text { Taxadjunct }\end{array}$ & $\begin{array}{l}\text { Fine-loamy, } \\
\text { mixed, } \\
\text { semiactive, } \\
\text { mesic Typic } \\
\text { Fragiudults }\end{array}$ \\
\hline $\begin{array}{c}\text { S06WV067- } \\
006\end{array}$ & -80.868333 & 38.261389 & Gilpin & Clifftop & $\begin{array}{l}\text { Clifftop } \\
\text { taxadjunct }\end{array}$ & $\begin{array}{l}\text { Fine, mixed, } \\
\text { semiactive, } \\
\text { mesic Typic } \\
\text { Hapludults }\end{array}$ \\
\hline $\begin{array}{c}\text { S06WV081- } \\
001\end{array}$ & -81.062917 & 37.695833 & Cookport & & $\begin{array}{l}\text { Cookport } \\
\text { Taxadjunct }\end{array}$ & $\begin{array}{l}\text { Coarse-loamy, } \\
\text { mixed, } \\
\text { semiactive, } \\
\text { mesic Typic } \\
\text { Fragiudults }\end{array}$ \\
\hline $\begin{array}{c}\text { S06WV101- } \\
001\end{array}$ & -80.609167 & 38.404444 & Gilpin & & $\begin{array}{l}\text { Clifftop } \\
\text { Taxadjunct }\end{array}$ & $\begin{array}{c}\text { Fine-loamy, } \\
\text { mixed, } \\
\text { semiactive, } \\
\text { mesic } \\
\text { Oxyaquic } \\
\text { Hapludults }\end{array}$ \\
\hline
\end{tabular}




\begin{tabular}{|c|c|c|c|c|c|c|}
\hline PedonID & Longitude & Latitude & $\begin{array}{c}\text { Series } \\
\text { Sampled As }\end{array}$ & $\begin{array}{c}\text { Series } \\
\text { Correlated } \\
\text { As }\end{array}$ & $\begin{array}{c}\text { Series } \\
\text { Correlated } \\
\text { To }\end{array}$ & $\begin{array}{c}\text { Taxonomic } \\
\text { Classification }\end{array}$ \\
\hline $\begin{array}{l}\text { S06WV101- } \\
002\end{array}$ & -79.78975 & 39.651806 & Fenwick & & $\begin{array}{l}\text { Cookport } \\
\text { Taxadjunct }\end{array}$ & $\begin{array}{l}\text { Fine-loamy, } \\
\text { mixed, } \\
\text { semiactive, } \\
\text { mesic Typic } \\
\text { Fragiudults }\end{array}$ \\
\hline S09WV167500 & -80.491111 & 38.355 & Fenwick & & $\begin{array}{c}\text { Fenwick } \\
\text { Taxadjunct }\end{array}$ & $\begin{array}{c}\text { Loamy- } \\
\text { skeletal, } \\
\text { mixed, } \\
\text { semiactive, } \\
\text { mesic Aquic } \\
\text { Hapludults }\end{array}$ \\
\hline S09WV167510 & -79.789778 & 39.650444 & Buchanan & & $\begin{array}{l}\text { Buchanan } \\
\text { Taxadjunct }\end{array}$ & $\begin{array}{l}\text { Fine-loamy, } \\
\text { mixed, } \\
\text { semiactive, } \\
\text { mesic Typic } \\
\text { Fragiudults }\end{array}$ \\
\hline S09WV167515 & -79.790111 & 39.649944 & Buchanan & & Buchanan & $\begin{array}{l}\text { Fine-loamy, } \\
\text { mixed, } \\
\text { semiactive, } \\
\text { mesic Aquic } \\
\text { Fragiudults }\end{array}$ \\
\hline S09WV167530 & -79.7915 & 39.64775 & Buchanan & & $\begin{array}{l}\text { Buchanan } \\
\text { Taxadjunct }\end{array}$ & $\begin{array}{l}\text { Fine-loamy, } \\
\text { mixed, active, } \\
\text { mesic Aquic } \\
\text { Fragiudults }\end{array}$ \\
\hline S09WV167540 & -79.791361 & 39.646778 & Gilpin & & $\begin{array}{c}\text { Clifftop } \\
\text { Taxadjunct }\end{array}$ & $\begin{array}{l}\text { Fine-loamy, } \\
\text { mixed, } \\
\text { semiactive, } \\
\text { mesic Typic } \\
\text { Dystrudepts }\end{array}$ \\
\hline S12WV071001 & -79.573269 & 38.707322 & Mandy & & $\begin{array}{c}\text { Wildell } \\
\text { Taxadjunct }\end{array}$ & $\begin{array}{c}\text { Loamy- } \\
\text { skeletal, } \\
\text { mixed, active, } \\
\text { frigid Typic } \\
\text { Haplorthods }\end{array}$ \\
\hline
\end{tabular}




\begin{tabular}{|c|c|c|c|c|c|c|}
\hline PedonID & Longitude & Latitude & $\begin{array}{c}\text { Series } \\
\text { Sampled As }\end{array}$ & $\begin{array}{c}\text { Series } \\
\text { Correlated } \\
\text { As }\end{array}$ & $\begin{array}{c}\text { Series } \\
\text { Correlated } \\
\text { To }\end{array}$ & $\begin{array}{c}\text { Taxonomic } \\
\text { Classification }\end{array}$ \\
\hline S12WV075001 & $\begin{array}{c}- \\
79.70592713\end{array}$ & 38.47024552 & Mandy & & Wildell & $\begin{array}{c}\text { Loamy- } \\
\text { skeletal, } \\
\text { mixed, } \\
\text { superactive, } \\
\text { frigid Typic } \\
\text { Haplorthods }\end{array}$ \\
\hline S12WV075002 & $\begin{array}{c}- \\
79.70154108\end{array}$ & 38.47320687 & Wildell & & $\begin{array}{c}\text { Wildell } \\
\text { Taxadjunct }\end{array}$ & $\begin{array}{l}\text { Fine-loamy, } \\
\text { mixed, } \\
\text { superactive, } \\
\text { frigid Typic } \\
\text { Haplorthods }\end{array}$ \\
\hline S12WV075003 & $\begin{array}{c}- \\
79.74244996\end{array}$ & 38.60650192 & Wildell & & $\begin{array}{c}\text { Wildell } \\
\text { Taxadjunct }\end{array}$ & $\begin{array}{l}\text { Fine-loamy, } \\
\text { mixed, } \\
\text { superactive, } \\
\text { frigid Typic } \\
\text { Haplorthods }\end{array}$ \\
\hline S12WV075004 & -79.740297 & 38.71701256 & Mandy & & $\begin{array}{c}\text { Mandy } \\
\text { Taxadjunct }\end{array}$ & $\begin{array}{c}\text { Loamy- } \\
\text { skeletal, } \\
\text { mixed, active, } \\
\text { frigid Spodic } \\
\text { Dystrudepts }\end{array}$ \\
\hline S12WV075005 & -79.7521504 & 38.71467058 & Wildell & & Wildell & $\begin{array}{c}\text { Loamy- } \\
\text { skeletal, } \\
\text { mixed, } \\
\text { superative, } \\
\text { frigid Typic } \\
\text { Haplorthods }\end{array}$ \\
\hline S12WV083001 & -79.6554495 & 38.8565603 & Mandy & & $\begin{array}{c}\text { Mandy } \\
\text { Taxadjunct }\end{array}$ & $\begin{array}{c}\text { Loamy- } \\
\text { skeletal, } \\
\text { mixed, active, } \\
\text { frigid Spodic } \\
\text { Dystrudepts }\end{array}$ \\
\hline
\end{tabular}


Appendix B: Kellogg Soil Survey Laboratory Pedon Data for Sites in MLRA 127

\begin{tabular}{|c|c|c|c|c|c|c|c|c|c|}
\hline PedonID & $\begin{array}{c}\text { Top } \\
\text { Depth } \\
\text { (cm) }\end{array}$ & $\begin{array}{c}\text { Bottom } \\
\text { Depth } \\
\text { (cm) }\end{array}$ & Horizon & $\begin{array}{c}\text { Total } \\
\text { Carbon\% } \\
\text { (Dry } \\
\text { Combustion, } \\
\text { Including } \\
\text { Converted } \\
\text { Walkley- } \\
\text { Black) }\end{array}$ & $\begin{array}{c}\text { 33kPa } \\
\text { Bulk } \\
\text { Density } \\
\left(\mathrm{g} \mathrm{cm}^{-3}\right)\end{array}$ & $\begin{array}{c}\text { Fragment } \\
\% \text { by } \\
\text { Volume }\end{array}$ & $\begin{array}{c}\text { Predicted } \\
\text { OC } \%\end{array}$ & $\begin{array}{c}\text { Predicted } \\
\text { 33kPa BD } \\
\left(\mathrm{g} \mathrm{cm}^{-3}\right)\end{array}$ & $\begin{array}{c}\text { SOC } \\
\text { Stock } \\
(\mathbf{k g} \\
\left.\mathbf{m}^{-2}\right)\end{array}$ \\
\hline 60WV093001 & 0 & 5 & $\mathrm{~A}$ & 19.31 & & 0 & 19.31 & 1.08 & 10.40 \\
\hline 60WV093001 & 5 & 13 & $\mathrm{E}$ & 4.39 & & 0 & 4.39 & 1.26 & 4.43 \\
\hline 60WV093001 & 13 & 43 & $\mathrm{Bg} 1$ & 0.53 & & 0 & 0.53 & 1.21 & 1.91 \\
\hline 60WV093001 & 43 & 66 & $\mathrm{Bg} 2$ & 0.33 & & 0 & 0.33 & 1.40 & 1.05 \\
\hline 60WV093001 & 66 & 97 & Bx1 & 0.24 & & 0 & 0.24 & 1.67 & 1.25 \\
\hline 60WV093001 & 97 & 135 & $\mathrm{Bx} 2$ & 0.20 & & 3 & 0.20 & 1.67 & 1.22 \\
\hline 60WV093001 & 135 & 224 & $\mathrm{C}$ & 0.18 & & 3 & 0.18 & 1.63 & 2.60 \\
\hline 60WV093002 & 0 & 5 & $\mathrm{~A}$ & 11.06 & & 0 & 11.06 & 0.98 & 5.40 \\
\hline 60WV093002 & 5 & 8 & $\mathrm{E}$ & 7.36 & & 0 & 7.36 & 1.29 & 2.84 \\
\hline 60WV093002 & 8 & 28 & Btg1 & 0.88 & & 0 & 0.88 & 1.36 & 2.39 \\
\hline 60WV093002 & 28 & 36 & Btg2 & 0.23 & & 0 & 0.23 & 1.38 & 0.25 \\
\hline 60WV093002 & 36 & 61 & Btx1 & 0.18 & & 0 & 0.18 & 1.51 & 0.70 \\
\hline 60WV093002 & 61 & 84 & Btx2 & 0.14 & & 0 & 0.14 & 1.56 & 0.51 \\
\hline 60WV093002 & 84 & 99 & $\mathrm{C}$ & 0.10 & & 60 & 0.10 & 1.51 & 0.09 \\
\hline 61WV083006 & 0 & 5 & Oi & & & 0 & 38.45 & 0.45 & 8.60 \\
\hline 61WV083006 & 5 & 8 & $\mathrm{Oe}$ & & & 0 & 28.40 & 0.57 & 4.87 \\
\hline 61WV083006 & 8 & 13 & $\mathrm{~A}$ & 9.12 & & 0 & 9.12 & 1.10 & 5.00 \\
\hline 61WV083006 & 13 & 23 & $E$ & 6.30 & 1.13 & 0 & 6.30 & 1.13 & 7.12 \\
\hline 61WV083006 & 23 & 49 & Bw1 & 3.00 & 1.09 & 0 & 3.00 & 1.09 & 8.49 \\
\hline 61WV083006 & 49 & 67 & Bw2 & 1.29 & 1.53 & 0 & 1.29 & 1.53 & 3.56 \\
\hline 61WV083006 & 67 & 102 & $\mathrm{Bx} 1$ & 0.67 & 1.70 & 0 & 0.67 & 1.70 & 3.97 \\
\hline
\end{tabular}




\begin{tabular}{|c|c|c|c|c|c|c|c|c|c|}
\hline PedonID & $\begin{array}{c}\text { Top } \\
\text { Depth } \\
\text { (cm) }\end{array}$ & $\begin{array}{c}\text { Bottom } \\
\text { Depth } \\
\text { (cm) }\end{array}$ & Horizon & $\begin{array}{c}\text { Total } \\
\text { Carbon\% } \\
\text { (Dry } \\
\text { Combustion, } \\
\text { Including } \\
\text { Converted } \\
\text { Walkley- } \\
\text { Black) }\end{array}$ & $\begin{array}{c}\text { 33kPa } \\
\text { Bulk } \\
\text { Density } \\
\left(\mathrm{g} \mathrm{cm}^{-3}\right)\end{array}$ & $\begin{array}{c}\text { Fragment } \\
\% \text { by } \\
\text { Volume }\end{array}$ & $\begin{array}{c}\text { Predicted } \\
\text { OC } \%\end{array}$ & $\begin{array}{c}\text { Predicted } \\
33 \mathrm{kPa} \mathrm{BD} \\
\left(\mathrm{g} \mathrm{cm}^{-3}\right)\end{array}$ & $\begin{array}{c}\text { SOC } \\
\text { Stock } \\
(\mathbf{k g} \\
\left.\mathbf{m}^{-2}\right)\end{array}$ \\
\hline 61WV083006 & 102 & 153 & $\mathrm{Bx} 2$ & 0.62 & 1.67 & 55 & 0.62 & 1.67 & 2.39 \\
\hline 61WV083006 & 153 & 191 & $\mathrm{Cx}$ & 0.80 & & 37 & 0.80 & 1.60 & 3.05 \\
\hline 61WV093003 & 0 & 3 & Oi & & & 0 & 44.18 & 0.37 & 4.84 \\
\hline 61WV093003 & 3 & 8 & $\mathrm{Oe}$ & & & 0 & 34.73 & 0.49 & 8.53 \\
\hline 61WV093003 & 8 & 13 & $\mathrm{~A}$ & 16.47 & 0.94 & 0 & 16.47 & 0.94 & 7.74 \\
\hline 61WV093003 & 13 & 18 & $\mathrm{E}$ & 8.09 & 1.23 & 15 & 8.09 & 1.23 & 4.23 \\
\hline 61WV093003 & 18 & 41 & Bw1 & 2.47 & 1.43 & 0 & 2.47 & 1.43 & 8.13 \\
\hline 61WV093003 & 41 & 66 & Bw2 & 2.24 & 1.72 & 12 & 2.24 & 1.72 & 8.49 \\
\hline 61WV093003 & 66 & 84 & $\mathrm{Bx}$ & 2.94 & 1.76 & 0 & 2.94 & 1.76 & 9.31 \\
\hline 61WV093003 & 84 & 122 & Btx & 2.02 & & 0 & 2.02 & 1.72 & 13.17 \\
\hline 62WV083005 & 0 & 15 & Ap & 2.98 & & 0 & 2.98 & 1.18 & 5.27 \\
\hline 62WV083005 & 15 & 30 & Bt1 & 0.21 & & 0 & 0.21 & 1.36 & 0.43 \\
\hline 62WV083005 & 30 & 56 & $\mathrm{Bt} 2$ & 0.38 & & 0 & 0.38 & 1.42 & 1.41 \\
\hline 62WV083005 & 56 & 79 & Btx1 & 0.06 & & 0 & 0.06 & 1.51 & 0.20 \\
\hline 62WV083005 & 79 & 107 & Btx2 & 0.09 & & 0 & 0.09 & 1.54 & 0.37 \\
\hline 62WV083005 & 107 & 132 & Btx3 & 0.13 & & 25 & 0.13 & 1.55 & 0.37 \\
\hline 62WV083005 & 132 & 165 & $2 \mathrm{C}$ & 0.13 & & 35 & 0.13 & 1.50 & 0.41 \\
\hline 64PA051007 & 0 & 18 & $\mathrm{Ap}$ & 2.30 & 1.37 & 2 & 2.30 & 1.37 & 5.56 \\
\hline 64PA051007 & 18 & 33 & Bt1 & 0.68 & 1.44 & 2 & 0.68 & 1.44 & 1.44 \\
\hline 64PA051007 & 33 & 48 & Bt2 & 0.53 & 1.42 & 2 & 0.53 & 1.42 & 1.10 \\
\hline 64PA051007 & 48 & 64 & Bt3 & 0.37 & 1.55 & 2 & 0.37 & 1.55 & 0.90 \\
\hline 64PA051007 & 64 & 76 & $\mathrm{Bt} 4$ & 0.18 & 1.46 & 5 & 0.18 & 1.46 & 0.31 \\
\hline 64PA051007 & 76 & 91 & $\mathrm{Bt5}$ & 0.11 & 1.66 & 2 & 0.11 & 1.66 & 0.28 \\
\hline
\end{tabular}




\begin{tabular}{|c|c|c|c|c|c|c|c|c|c|}
\hline PedonID & $\begin{array}{c}\text { Top } \\
\text { Depth } \\
\text { (cm) }\end{array}$ & $\begin{array}{c}\text { Bottom } \\
\text { Depth } \\
(\mathrm{cm})\end{array}$ & Horizon & $\begin{array}{c}\text { Total } \\
\text { Carbon\% } \\
\text { (Dry } \\
\text { Combustion, } \\
\text { Including } \\
\text { Converted } \\
\text { Walkley- } \\
\text { Black) } \\
\end{array}$ & $\begin{array}{c}\text { 33kPa } \\
\text { Bulk } \\
\text { Density } \\
\left(\mathrm{g} \mathrm{cm}^{-3}\right)\end{array}$ & $\begin{array}{c}\text { Fragment } \\
\% \text { by } \\
\text { Volume }\end{array}$ & $\begin{array}{l}\text { Predicted } \\
\text { OC } \%\end{array}$ & $\begin{array}{c}\text { Predicted } \\
\text { 33kPa BD } \\
\left(\mathrm{g} \mathrm{cm}^{-3}\right)\end{array}$ & $\begin{array}{c}\text { SOC } \\
\text { Stock } \\
(\mathbf{k g} \\
\left.\mathbf{m}^{-2}\right)\end{array}$ \\
\hline 64PA051007 & 91 & 107 & $\mathrm{BCg} 1$ & 0.11 & 1.63 & 1 & 0.11 & 1.63 & 0.29 \\
\hline 64PA051007 & 107 & 127 & $\mathrm{BCg} 2$ & 0.07 & 1.39 & 30 & 0.07 & 1.39 & 0.14 \\
\hline 64PA051008 & 0 & 18 & Ap & 2.97 & 1.17 & 20 & 2.97 & 1.17 & 5.00 \\
\hline 64PA051008 & 18 & 28 & $\mathrm{BE}$ & 1.05 & 1.23 & 20 & 1.05 & 1.23 & 1.03 \\
\hline 64PA051008 & 28 & 46 & Bw1 & 0.38 & 1.29 & 20 & 0.38 & 1.29 & 0.71 \\
\hline 64PA051008 & 46 & 64 & Bw2 & 0.09 & 1.40 & 20 & 0.09 & 1.40 & 0.17 \\
\hline 64PA051008 & 64 & 79 & $\mathrm{BC}$ & 0.09 & 1.47 & 22 & 0.09 & 1.47 & 0.15 \\
\hline 64PA051008 & 79 & 99 & $\mathrm{C} 1$ & 0.10 & 1.44 & 50 & 0.10 & 1.44 & 0.14 \\
\hline 64PA051008 & 99 & 127 & $\mathrm{C} 2$ & 0.14 & 1.52 & 20 & 0.14 & 1.52 & 0.48 \\
\hline 64PA051008 & 127 & 150 & C3 & 0.11 & 1.33 & 60 & 0.11 & 1.33 & 0.14 \\
\hline 64PA051009 & 0 & 20 & Ap & 2.98 & 1.28 & 0 & 2.98 & 1.28 & 7.63 \\
\hline 64PA051009 & 20 & 38 & $\mathrm{BA}$ & 1.11 & 1.32 & 0 & 1.11 & 1.32 & 2.63 \\
\hline 64PA051009 & 38 & 53 & Bw1 & 0.60 & 1.34 & 0 & 0.60 & 1.34 & 1.20 \\
\hline 64PA051009 & 53 & 81 & Bw2 & 0.45 & 1.30 & 0 & 0.45 & 1.30 & 1.65 \\
\hline 64PA051009 & 81 & 102 & Bw3 & 0.57 & 1.42 & 0 & 0.57 & 1.42 & 1.69 \\
\hline 64PA051009 & 102 & 124 & Bw4 & 0.38 & 1.40 & 0 & 0.38 & 1.40 & 1.18 \\
\hline 64PA051009 & 124 & 163 & $\mathrm{Bx} 1$ & 0.55 & 1.50 & 0 & 0.55 & 1.50 & 3.24 \\
\hline 64PA051009 & 163 & 203 & $\mathrm{~B} \times 2$ & 0.43 & 1.56 & 0 & 0.43 & 1.56 & 2.66 \\
\hline 64PA051010 & 0 & 23 & Ap & 3.55 & 1.16 & 20 & 3.55 & 1.16 & 7.58 \\
\hline 64PA051010 & 23 & 38 & BA & 0.68 & 1.41 & 20 & 0.68 & 1.41 & 1.15 \\
\hline 64PA051010 & 38 & 66 & $\mathrm{Bw}$ & 0.24 & 1.46 & 50 & 0.24 & 1.46 & 0.49 \\
\hline 64PA051010 & 66 & 86 & $\mathrm{BC}$ & 0.13 & & 50 & 0.13 & 1.57 & 0.20 \\
\hline 64PA051011 & 0 & 20 & Ap & 6.13 & 0.92 & 0 & 6.13 & 0.92 & 11.29 \\
\hline
\end{tabular}




\begin{tabular}{|c|c|c|c|c|c|c|c|c|c|}
\hline PedonID & $\begin{array}{c}\text { Top } \\
\text { Depth } \\
\text { (cm) }\end{array}$ & $\begin{array}{c}\text { Bottom } \\
\text { Depth } \\
(\mathrm{cm})\end{array}$ & Horizon & $\begin{array}{c}\text { Total } \\
\text { Carbon\% } \\
\text { (Dry } \\
\text { Combustion, } \\
\text { Including } \\
\text { Converted } \\
\text { Walkley- } \\
\text { Black) } \\
\end{array}$ & $\begin{array}{c}\text { 33kPa } \\
\text { Bulk } \\
\text { Density } \\
\left(\mathrm{g} \mathrm{cm}^{-3}\right)\end{array}$ & $\begin{array}{c}\text { Fragment } \\
\% \text { by } \\
\text { Volume }\end{array}$ & $\begin{array}{c}\text { Predicted } \\
\text { OC } \%\end{array}$ & $\begin{array}{c}\text { Predicted } \\
\text { 33kPa BD } \\
\left(\mathrm{g} \mathrm{cm}^{-3}\right)\end{array}$ & $\begin{array}{c}\text { SOC } \\
\text { Stock } \\
(\mathbf{k g} \\
\left.\mathbf{m}^{-2}\right)\end{array}$ \\
\hline 64PA051011 & 20 & 46 & $\mathrm{Eg}$ & 3.48 & 0.82 & 0 & 3.48 & 0.82 & 7.42 \\
\hline 64PA051011 & 46 & 69 & Btg1 & 1.83 & 0.95 & 0 & 1.83 & 0.95 & 4.00 \\
\hline 64PA051011 & 69 & 99 & Btg2 & 1.49 & 1.03 & 0 & 1.49 & 1.03 & 4.61 \\
\hline 64PA051011 & 99 & 114 & Btg3 & 0.74 & 1.51 & 1 & 0.74 & 1.51 & 1.66 \\
\hline 64PA051011 & 114 & 135 & Btg4 & 0.68 & 1.69 & 15 & 0.68 & 1.69 & 2.06 \\
\hline 64PA051011 & 135 & 157 & $2 \mathrm{BCg}$ & 0.80 & 1.65 & 15 & 0.80 & 1.65 & 2.45 \\
\hline 64PA051011 & 157 & 183 & $2 \mathrm{Cg}$ & 0.65 & 1.59 & 10 & 0.65 & 1.59 & 2.43 \\
\hline 67PA123001 & 0 & 3 & Oi & & & 15 & 43.21 & 0.44 & 4.90 \\
\hline 67PA123001 & 3 & 8 & $\mathrm{Oa}$ & 55.83 & & 15 & 55.83 & 0.59 & 14.01 \\
\hline 67PA123001 & 8 & 13 & $\mathrm{E}$ & 2.04 & 1.35 & 15 & 2.04 & 1.35 & 1.17 \\
\hline 67PA123001 & 13 & 18 & Bhs & 3.25 & & 15 & 3.25 & 1.27 & 1.76 \\
\hline 67PA123001 & 18 & 23 & Bs & 4.44 & & 15 & 4.44 & 1.19 & 2.24 \\
\hline 67PA123001 & 23 & 46 & Bw1 & 1.01 & 1.17 & 25 & 1.01 & 1.17 & 2.03 \\
\hline 67PA123001 & 46 & 64 & Bw2 & 0.30 & 1.49 & 45 & 0.30 & 1.49 & 0.44 \\
\hline 67PA123001 & 64 & 89 & Bw3 & 0.27 & 1.82 & 60 & 0.27 & 1.82 & 0.49 \\
\hline 67PA123001 & 89 & 117 & $\mathrm{C} 1$ & 0.13 & 1.86 & 80 & 0.13 & 1.86 & 0.13 \\
\hline 67PA123001 & 117 & 150 & $\mathrm{C} 2$ & 0.10 & & 95 & 0.10 & 1.75 & 0.03 \\
\hline 67PA123002 & 0 & 2 & Oi & & & 0 & 42.22 & 0.45 & 3.76 \\
\hline 67PA123002 & 2 & 5 & $\mathrm{Oa}$ & 35.78 & & 0 & 35.78 & 0.60 & 6.44 \\
\hline 67PA123002 & 5 & 8 & $\mathrm{E}$ & 3.18 & & 20 & 3.18 & 1.48 & 1.13 \\
\hline 67PA123002 & 8 & 10 & Bhs & 2.24 & & 20 & 2.24 & 1.28 & 0.46 \\
\hline 67PA123002 & 10 & 20 & Bs & 2.38 & 0.92 & 25 & 2.38 & 0.92 & 1.64 \\
\hline 67PA123002 & 20 & 30 & Bw1 & 0.66 & 1.07 & 30 & 0.66 & 1.07 & 0.49 \\
\hline
\end{tabular}




\begin{tabular}{|c|c|c|c|c|c|c|c|c|c|}
\hline PedonID & $\begin{array}{c}\text { Top } \\
\text { Depth } \\
\text { (cm) }\end{array}$ & $\begin{array}{c}\text { Bottom } \\
\text { Depth } \\
(\mathrm{cm})\end{array}$ & Horizon & $\begin{array}{c}\text { Total } \\
\text { Carbon\% } \\
\text { (Dry } \\
\text { Combustion, } \\
\text { Including } \\
\text { Converted } \\
\text { Walkley- } \\
\text { Black) } \\
\end{array}$ & $\begin{array}{c}\text { 33kPa } \\
\text { Bulk } \\
\text { Density } \\
\left(\mathrm{g} \mathrm{cm}^{-3}\right)\end{array}$ & $\begin{array}{c}\text { Fragment } \\
\% \text { by } \\
\text { Volume }\end{array}$ & $\begin{array}{c}\text { Predicted } \\
\text { OC } \%\end{array}$ & $\begin{array}{c}\text { Predicted } \\
\text { 33kPa BD } \\
\left(\mathrm{g} \mathrm{cm}^{-3}\right)\end{array}$ & $\begin{array}{c}\text { SOC } \\
\text { Stock } \\
(\mathbf{k g} \\
\left.\mathbf{m}^{-2}\right)\end{array}$ \\
\hline 67PA123002 & 30 & 48 & Bw2 & 0.56 & 1.50 & 30 & 0.56 & 1.50 & 1.06 \\
\hline 67PA123002 & 48 & 76 & Bw3 & 0.21 & 1.65 & 50 & 0.21 & 1.65 & 0.48 \\
\hline 67PA123002 & 76 & 112 & $\mathrm{BC} 1$ & 0.04 & & 80 & 0.04 & 1.72 & 0.05 \\
\hline 67PA123002 & 112 & 135 & $\mathrm{BC} 2$ & 0.07 & & 75 & 0.07 & 1.67 & 0.06 \\
\hline 67PA123002 & 135 & 162 & $\mathrm{C} 1$ & 0.08 & 1.73 & 30 & 0.08 & 1.73 & 0.25 \\
\hline 67PA123002 & 162 & 180 & $\mathrm{C} 2$ & 0.03 & 1.70 & 40 & 0.03 & 1.70 & 0.06 \\
\hline 67PA123002 & 180 & 208 & C3 & 0.12 & & 50 & 0.12 & 1.75 & 0.30 \\
\hline 67PA123003 & 0 & 2 & Oi & & & 0 & 43.31 & 0.43 & 3.72 \\
\hline 67PA123003 & 2 & 5 & $\mathrm{Oa}$ & 17.27 & & 0 & 17.27 & 1.01 & 5.21 \\
\hline 67PA123003 & 5 & 23 & $\mathrm{E}$ & 0.43 & 1.62 & 20 & 0.43 & 1.62 & 1.00 \\
\hline 67PA123003 & 23 & 28 & Bhs & 2.06 & & 25 & 2.06 & 1.29 & 1.00 \\
\hline 67PA123003 & 28 & 48 & Bs & 1.20 & 1.30 & 30 & 1.20 & 1.30 & 2.18 \\
\hline 67PA123003 & 48 & 79 & $\mathrm{Bw}$ & 0.47 & 1.49 & 50 & 0.47 & 1.49 & 1.09 \\
\hline 67PA123003 & 79 & 96 & $\mathrm{C} 1$ & 0.26 & & 70 & 0.26 & 1.65 & 0.22 \\
\hline 67PA123003 & 96 & 119 & $\mathrm{C} 2$ & 0.10 & & 85 & 0.10 & 1.66 & 0.06 \\
\hline 67PA123004 & 0 & 2 & $\mathrm{Oi}$ & & & 0 & 42.07 & 0.44 & 3.72 \\
\hline 67PA123004 & 2 & 5 & $\mathrm{Oa}$ & 32.94 & & 0 & 32.94 & 0.62 & 6.11 \\
\hline 67PA123004 & 5 & 8 & $\mathrm{~A}$ & 9.68 & & 10 & 9.68 & 0.89 & 2.32 \\
\hline 67PA123004 & 8 & 13 & $E$ & 1.14 & & 10 & 1.14 & 1.40 & 0.72 \\
\hline 67PA123004 & 13 & 15 & Bhs & 3.35 & & 10 & 3.35 & 1.23 & 0.74 \\
\hline 67PA123004 & 15 & 28 & $\mathrm{Bw}$ & 3.31 & & 15 & 3.31 & 1.33 & 4.85 \\
\hline 67PA123004 & 28 & 51 & $\mathrm{Bt}$ & 1.35 & 1.23 & 20 & 1.35 & 1.23 & 3.05 \\
\hline 67PA123004 & 51 & 76 & Btgx1 & 0.27 & 1.53 & 20 & 0.27 & 1.53 & 0.83 \\
\hline
\end{tabular}




\begin{tabular}{|c|c|c|c|c|c|c|c|c|c|}
\hline PedonID & $\begin{array}{c}\text { Top } \\
\text { Depth } \\
\text { (cm) }\end{array}$ & $\begin{array}{c}\text { Bottom } \\
\text { Depth } \\
\text { (cm) }\end{array}$ & Horizon & $\begin{array}{c}\text { Total } \\
\text { Carbon\% } \\
\text { (Dry } \\
\text { Combustion, } \\
\text { Including } \\
\text { Converted } \\
\text { Walkley- } \\
\text { Black) } \\
\end{array}$ & $\begin{array}{c}\text { 33kPa } \\
\text { Bulk } \\
\text { Density } \\
\left(\mathrm{g} \mathrm{cm}^{-3}\right)\end{array}$ & $\begin{array}{c}\text { Fragment } \\
\% \text { by } \\
\text { Volume }\end{array}$ & $\begin{array}{c}\text { Predicted } \\
\text { OC } \%\end{array}$ & $\begin{array}{c}\text { Predicted } \\
\text { 33kPa BD } \\
\left(\mathrm{g} \mathrm{cm}^{-3}\right)\end{array}$ & $\begin{array}{r}\text { SOC } \\
\text { Stock } \\
(\mathbf{k g} \\
\left.\mathbf{m}^{-2}\right)\end{array}$ \\
\hline 67PA123004 & 76 & 86 & $B \operatorname{tg} x 2$ & 0.20 & 1.69 & 25 & 0.20 & 1.69 & 0.25 \\
\hline 67PA123004 & 86 & 104 & Btgx3 & 0.33 & 1.78 & 30 & 0.33 & 1.78 & 0.73 \\
\hline 67PA123004 & 104 & 114 & $B \operatorname{tg} x 4$ & 0.92 & 1.67 & 30 & 0.92 & 1.67 & 1.08 \\
\hline 67PA123004 & 114 & 135 & $2 \mathrm{Bgx} 5$ & 9.66 & 1.51 & 70 & 9.66 & 1.51 & 9.19 \\
\hline 67PA123004 & 135 & 150 & $2 \mathrm{Bgx} 6$ & 2.24 & 1.59 & 60 & 2.24 & 1.59 & 2.14 \\
\hline 67PA123004 & 150 & 183 & $2 \mathrm{Cx}$ & 0.43 & & 80 & 0.43 & 1.66 & 0.47 \\
\hline 67PA123005 & 0 & 2 & Oi & & & 0 & 37.40 & 0.38 & 2.88 \\
\hline 67PA123005 & 2 & 5 & $\mathrm{Oa}$ & 29.93 & & 0 & 29.93 & 0.51 & 4.62 \\
\hline 67PA123005 & 5 & 15 & $\mathrm{E}$ & 2.04 & & 35 & 2.04 & 1.34 & 1.77 \\
\hline 67PA123005 & 15 & 18 & $\mathrm{Bh}$ & 2.49 & & 35 & 2.49 & 1.15 & 0.56 \\
\hline 67PA123005 & 18 & 20 & Bs & 2.06 & & 35 & 2.06 & 1.14 & 0.31 \\
\hline 67PA123005 & 20 & 48 & Bw1 & 1.51 & & 35 & 1.51 & 1.27 & 3.47 \\
\hline 67PA123005 & 48 & 74 & Bw2 & 0.89 & & 60 & 0.89 & 1.40 & 1.30 \\
\hline 67PA123005 & 74 & 94 & $\mathrm{C}$ & 0.61 & & 90 & 0.61 & 1.47 & 0.18 \\
\hline 67PA123006 & 0 & 3 & $\mathrm{~A}$ & 7.38 & & 0 & 7.38 & 0.84 & 1.87 \\
\hline 67PA123006 & 3 & 5 & $E$ & & & 0 & 6.78 & 1.28 & 1.74 \\
\hline 67PA123006 & 5 & 13 & EB & 3.22 & 1.01 & 0 & 3.22 & 1.01 & 2.60 \\
\hline 67PA123006 & 13 & 23 & BA & & 1.10 & 0 & 1.96 & 1.10 & 2.16 \\
\hline 67PA123006 & 23 & 33 & Bt1 & 0.81 & 1.33 & 0 & 0.81 & 1.33 & 1.08 \\
\hline 67PA123006 & 33 & 46 & Bt2 & 0.38 & 1.43 & 0 & 0.38 & 1.43 & 0.71 \\
\hline 67PA123006 & 46 & 58 & Bt3 & 0.24 & 1.54 & 0 & 0.24 & 1.54 & 0.45 \\
\hline 67PA123006 & 58 & 81 & Btx1 & 0.26 & 1.63 & 0 & 0.26 & 1.63 & 0.96 \\
\hline 67PA123006 & 81 & 102 & Btx2 & 0.60 & 1.80 & 5 & 0.60 & 1.80 & 2.14 \\
\hline
\end{tabular}




\begin{tabular}{|c|c|c|c|c|c|c|c|c|c|}
\hline PedonID & $\begin{array}{c}\text { Top } \\
\text { Depth } \\
\text { (cm) }\end{array}$ & $\begin{array}{c}\text { Bottom } \\
\text { Depth } \\
(\mathrm{cm})\end{array}$ & Horizon & $\begin{array}{c}\text { Total } \\
\text { Carbon\% } \\
\text { (Dry } \\
\text { Combustion, } \\
\text { Including } \\
\text { Converted } \\
\text { Walkley- } \\
\text { Black) } \\
\end{array}$ & $\begin{array}{c}\text { 33kPa } \\
\text { Bulk } \\
\text { Density } \\
\left(\mathrm{g} \mathrm{cm}^{-3}\right)\end{array}$ & $\begin{array}{c}\text { Fragment } \\
\% \text { by } \\
\text { Volume }\end{array}$ & $\begin{array}{c}\text { Predicted } \\
\text { OC } \%\end{array}$ & $\begin{array}{c}\text { Predicted } \\
\text { 33kPa BD } \\
\left(\mathrm{g} \mathrm{cm}^{-3}\right)\end{array}$ & $\begin{array}{c}\text { SOC } \\
\text { Stock } \\
(\mathbf{k g} \\
\left.\mathbf{m}^{-2}\right)\end{array}$ \\
\hline 67PA123006 & 102 & 137 & Btx3 & 0.33 & 1.81 & 20 & 0.33 & 1.81 & 1.66 \\
\hline 67PA123006 & 137 & 170 & Btx4 & 0.62 & 1.74 & 75 & 0.62 & 1.74 & 0.90 \\
\hline 67PA123013 & 0 & 10 & Ap1 & 1.89 & 1.23 & 0 & 1.89 & 1.23 & 2.32 \\
\hline 67PA123013 & 10 & 20 & Ap2 & 1.62 & 1.32 & 0 & 1.62 & 1.32 & 2.14 \\
\hline 67PA123013 & 20 & 53 & Bw1 & 0.23 & 1.39 & 0 & 0.23 & 1.39 & 1.04 \\
\hline 67PA123013 & 53 & 69 & Bw2 & 0.33 & 1.48 & 0 & 0.33 & 1.48 & 0.77 \\
\hline 67PA123013 & 69 & 94 & Bwg1 & 0.16 & 1.42 & 0 & 0.16 & 1.42 & 0.55 \\
\hline 67PA123013 & 94 & 127 & Bwg2 & 0.14 & 1.43 & 0 & 0.14 & 1.43 & 0.67 \\
\hline 67PA123013 & 127 & 152 & Bwg3 & 0.11 & 1.46 & 0 & 0.11 & 1.46 & 0.41 \\
\hline 67PA123013 & 152 & 165 & $2 \mathrm{C}$ & 0.07 & & 0 & 0.07 & 1.44 & 0.13 \\
\hline 71PA021001 & 0 & 5 & Oi & 46.82 & & 0 & 46.82 & 0.41 & 9.52 \\
\hline 71PA021001 & 5 & 10 & $\mathrm{Oa}$ & 16.50 & & 0 & 16.50 & 1.13 & 9.29 \\
\hline 71PA021001 & 10 & 15 & $\mathrm{~A}$ & 10.56 & & 60 & 10.56 & 1.16 & 2.44 \\
\hline 71PA021001 & 15 & 33 & $\mathrm{E}$ & 0.53 & & 60 & 0.53 & 1.60 & 0.61 \\
\hline 71PA021001 & 33 & 41 & $\mathrm{Bh}$ & 3.20 & 1.30 & 30 & 3.20 & 1.30 & 2.33 \\
\hline 71PA021001 & 41 & 46 & Bs1 & 2.33 & 1.18 & 30 & 2.33 & 1.18 & 0.96 \\
\hline 71PA021001 & 46 & 53 & Bs2 & 0.84 & 1.25 & 10 & 0.84 & 1.25 & 0.66 \\
\hline 71PA021001 & 53 & 76 & Bw1 & 0.57 & 1.64 & 55 & 0.57 & 1.64 & 0.97 \\
\hline 71PA021001 & 76 & 96 & Bw2 & 0.33 & 1.66 & 60 & 0.33 & 1.66 & 0.44 \\
\hline 71PA021001 & 96 & 112 & $\mathrm{BC}$ & 0.09 & 1.78 & 65 & 0.09 & 1.78 & 0.09 \\
\hline 71PA021001 & 112 & 168 & $\mathrm{C} 1$ & 0.13 & 1.79 & 65 & 0.13 & 1.79 & 0.46 \\
\hline 71PA021001 & 168 & 221 & $\mathrm{C} 2$ & 0.11 & & 85 & 0.11 & 1.74 & 0.15 \\
\hline 71PA021002 & 0 & 2 & $\mathrm{Oi}$ & 44.56 & & 0 & 44.56 & 0.35 & 3.12 \\
\hline
\end{tabular}




\begin{tabular}{|c|c|c|c|c|c|c|c|c|c|}
\hline PedonID & $\begin{array}{c}\text { Top } \\
\text { Depth } \\
\text { (cm) }\end{array}$ & $\begin{array}{c}\text { Bottom } \\
\text { Depth } \\
(\mathrm{cm})\end{array}$ & Horizon & $\begin{array}{c}\text { Total } \\
\text { Carbon\% } \\
\text { (Dry } \\
\text { Combustion, } \\
\text { Including } \\
\text { Converted } \\
\text { Walkley- } \\
\text { Black) } \\
\end{array}$ & $\begin{array}{c}\text { 33kPa } \\
\text { Bulk } \\
\text { Density } \\
\left(\mathrm{g} \mathrm{cm}^{-3}\right)\end{array}$ & $\begin{array}{c}\text { Fragment } \\
\% \text { by } \\
\text { Volume }\end{array}$ & $\begin{array}{l}\text { Predicted } \\
\text { OC } \%\end{array}$ & $\begin{array}{c}\text { Predicted } \\
\text { 33kPa BD } \\
\left(\mathrm{g} \mathrm{cm}^{-3}\right)\end{array}$ & $\begin{array}{c}\text { SOC } \\
\text { Stock } \\
(\mathbf{k g} \\
\left.\mathbf{m}^{-2}\right)\end{array}$ \\
\hline 71PA021002 & 2 & 5 & $\mathrm{Oa}$ & 40.34 & & 0 & 40.34 & 1.05 & 12.74 \\
\hline 71PA021002 & 5 & 8 & $\mathrm{~A}$ & 18.87 & & 75 & 18.87 & 1.07 & 1.52 \\
\hline 71PA021002 & 8 & 33 & $\mathrm{E}$ & 0.47 & & 75 & 0.47 & 1.58 & 0.47 \\
\hline 71PA021002 & 33 & 46 & $\mathrm{Bh}$ & 0.78 & & 75 & 0.78 & 1.41 & 0.36 \\
\hline 71PA021002 & 46 & 53 & Bhs & 4.08 & & 65 & 4.08 & 1.33 & 1.33 \\
\hline 71PA021002 & 53 & 61 & Bs & 4.21 & & 75 & 4.21 & 1.32 & 1.11 \\
\hline 71PA021002 & 61 & 69 & Bw1 & 1.42 & & 70 & 1.42 & 1.58 & 0.54 \\
\hline 71PA021002 & 69 & 91 & Bw2 & 0.30 & 1.55 & 70 & 0.30 & 1.55 & 0.30 \\
\hline 71PA021002 & 91 & 109 & Bw3 & 0.29 & 1.62 & 70 & 0.29 & 1.62 & 0.25 \\
\hline 71PA021002 & 109 & 142 & Bw4 & 0.17 & 1.73 & 70 & 0.17 & 1.73 & 0.28 \\
\hline 71PA021002 & 142 & 157 & Bw5 & 0.09 & 1.51 & 70 & 0.09 & 1.51 & 0.06 \\
\hline 71PA021002 & 157 & 198 & $\mathrm{C}$ & 0.08 & 1.79 & 80 & 0.08 & 1.79 & 0.11 \\
\hline 71PA021003 & 0 & 2 & $\mathrm{Oi}$ & & & 0 & 39.21 & 0.34 & 2.70 \\
\hline 71PA021003 & 2 & 5 & $\mathrm{Oa}$ & 31.11 & & 0 & 31.11 & 1.00 & 9.34 \\
\hline 71PA021003 & 5 & 13 & $\mathrm{~A}$ & 0.72 & & 10 & 0.72 & 1.02 & 0.52 \\
\hline 71PA021003 & 13 & 38 & $\mathrm{E}$ & 1.19 & & 70 & 1.19 & 1.56 & 1.39 \\
\hline 71PA021003 & 38 & 46 & $\mathrm{Bh}$ & 8.83 & & 70 & 8.83 & 1.40 & 2.96 \\
\hline 71PA021003 & 46 & 51 & Bs1 & 7.06 & 1.51 & 80 & 7.06 & 1.51 & 1.07 \\
\hline 71PA021003 & 51 & 58 & Bs2 & 3.70 & 1.28 & 70 & 3.70 & 1.28 & 0.99 \\
\hline 71PA021003 & 58 & 81 & Bw1 & 0.74 & 1.71 & 65 & 0.74 & 1.71 & 1.01 \\
\hline 71PA021003 & 81 & 119 & Bw2 & 0.15 & & 75 & 0.15 & 1.65 & 0.24 \\
\hline 71PA021003 & 119 & 145 & $\mathrm{Bt} 1$ & 0.26 & 1.77 & 30 & 0.26 & 1.77 & 0.85 \\
\hline 71PA021003 & 145 & 170 & $\mathrm{Bt} 2$ & 0.11 & 1.72 & 50 & 0.11 & 1.72 & 0.24 \\
\hline
\end{tabular}




\begin{tabular}{|c|c|c|c|c|c|c|c|c|c|}
\hline PedonID & $\begin{array}{c}\text { Top } \\
\text { Depth } \\
\text { (cm) }\end{array}$ & $\begin{array}{c}\text { Bottom } \\
\text { Depth } \\
(\mathrm{cm})\end{array}$ & Horizon & $\begin{array}{c}\text { Total } \\
\text { Carbon\% } \\
\text { (Dry } \\
\text { Combustion, } \\
\text { Including } \\
\text { Converted } \\
\text { Walkley- } \\
\text { Black) } \\
\end{array}$ & $\begin{array}{c}\text { 33kPa } \\
\text { Bulk } \\
\text { Density } \\
\left(\mathrm{g} \mathrm{cm}^{-3}\right)\end{array}$ & $\begin{array}{c}\text { Fragment } \\
\% \text { by } \\
\text { Volume }\end{array}$ & $\begin{array}{l}\text { Predicted } \\
\text { OC } \%\end{array}$ & $\begin{array}{c}\text { Predicted } \\
\text { 33kPa BD } \\
\left(\mathrm{g} \mathrm{cm}^{-3}\right)\end{array}$ & $\begin{array}{c}\text { SOC } \\
\text { Stock } \\
(\mathbf{k g} \\
\left.\mathbf{m}^{-2}\right)\end{array}$ \\
\hline 71PA021003 & 170 & 195 & $\mathrm{Bt3}$ & 0.11 & 1.80 & 50 & 0.11 & 1.80 & 0.25 \\
\hline 71PA111001 & 0 & 23 & Ap & 2.60 & 1.29 & 10 & 2.60 & 1.29 & 6.94 \\
\hline 71PA111001 & 23 & 48 & Bt1 & 0.55 & 1.28 & 15 & 0.55 & 1.28 & 1.51 \\
\hline 71PA111001 & 48 & 71 & $\mathrm{Bt} 2$ & 0.21 & 1.54 & 17 & 0.21 & 1.54 & 0.63 \\
\hline 71PA111001 & 71 & 94 & $\mathrm{Bt} 3$ & 0.14 & 1.42 & 60 & 0.14 & 1.42 & 0.19 \\
\hline 71PA111001 & 94 & 117 & $\mathrm{Bt} 4$ & 0.10 & 1.51 & 75 & 0.10 & 1.51 & 0.09 \\
\hline 71PA111001 & 117 & 152 & $\mathrm{BC}$ & 0.09 & & 75 & 0.09 & 1.54 & 0.11 \\
\hline 71PA111001 & 152 & 178 & $\mathrm{C} 1$ & 0.06 & & 75 & 0.06 & 1.50 & 0.06 \\
\hline 71PA111001 & 178 & 208 & $\mathrm{C} 2$ & 0.06 & & 75 & 0.06 & 1.46 & 0.06 \\
\hline 71PA111002 & 0 & 23 & $\mathrm{Ap}$ & 2.60 & 1.41 & 10 & 2.60 & 1.41 & 7.58 \\
\hline 71PA111002 & 23 & 43 & Bt1 & 0.53 & 1.48 & 30 & 0.53 & 1.48 & 1.09 \\
\hline 71PA111002 & 43 & 66 & $\mathrm{Bt} 2$ & 0.26 & 1.63 & 25 & 0.26 & 1.63 & 0.72 \\
\hline 71PA111002 & 66 & 97 & $\mathrm{Bt} 3$ & 0.07 & 1.63 & 30 & 0.07 & 1.63 & 0.25 \\
\hline 71PA111002 & 97 & 130 & $\mathrm{Bt} 4$ & 0.07 & 1.68 & 20 & 0.07 & 1.68 & 0.31 \\
\hline 71PA111002 & 130 & 168 & $\mathrm{BC}$ & 0.11 & 1.53 & 80 & 0.11 & 1.53 & 0.13 \\
\hline 71PA111002 & 168 & 208 & $\mathrm{C} 1$ & 0.04 & & 80 & 0.04 & 1.49 & 0.05 \\
\hline 71PA111002 & 208 & 305 & $\mathrm{C} 2$ & 0.13 & & 40 & 0.13 & 1.52 & 1.13 \\
\hline 71PA111003 & 0 & 20 & Ap & 2.64 & 1.30 & 10 & 2.64 & 1.30 & 6.18 \\
\hline 71PA111003 & 20 & 51 & Bt1 & 0.50 & 1.43 & 25 & 0.50 & 1.43 & 1.65 \\
\hline 71PA111003 & 51 & 86 & $\mathrm{Bt} 2$ & 0.24 & 1.36 & 40 & 0.24 & 1.36 & 0.69 \\
\hline 71PA111003 & 86 & 109 & $\mathrm{Bt} 3$ & 0.18 & 1.42 & 30 & 0.18 & 1.42 & 0.42 \\
\hline 71PA111003 & 109 & 140 & $\mathrm{Bt} 4$ & 0.13 & 1.52 & 5 & 0.13 & 1.52 & 0.57 \\
\hline 71PA111003 & 140 & 160 & $\mathrm{BC}$ & 0.14 & 1.45 & 5 & 0.14 & 1.45 & 0.39 \\
\hline
\end{tabular}




\begin{tabular}{|c|c|c|c|c|c|c|c|c|c|}
\hline PedonID & $\begin{array}{c}\text { Top } \\
\text { Depth } \\
\text { (cm) }\end{array}$ & $\begin{array}{c}\text { Bottom } \\
\text { Depth } \\
(\mathrm{cm})\end{array}$ & Horizon & $\begin{array}{c}\text { Total } \\
\text { Carbon\% } \\
\text { (Dry } \\
\text { Combustion, } \\
\text { Including } \\
\text { Converted } \\
\text { Walkley- } \\
\text { Black) } \\
\end{array}$ & $\begin{array}{c}\text { 33kPa } \\
\text { Bulk } \\
\text { Density } \\
\left(\mathrm{g} \mathrm{cm}^{-3}\right)\end{array}$ & $\begin{array}{c}\text { Fragment } \\
\% \text { by } \\
\text { Volume }\end{array}$ & $\begin{array}{l}\text { Predicted } \\
\text { OC } \%\end{array}$ & $\begin{array}{c}\text { Predicted } \\
\text { 33kPa BD } \\
\left(\mathrm{g} \mathrm{cm}^{-3}\right)\end{array}$ & $\begin{array}{c}\text { SOC } \\
\text { Stock } \\
(\mathbf{k g} \\
\left.\mathbf{m}^{-2}\right)\end{array}$ \\
\hline 71PA111003 & 160 & 196 & $\mathrm{C} 1$ & 0.21 & & 95 & 0.21 & 1.47 & 0.06 \\
\hline 71PA111003 & 196 & 236 & $\mathrm{C} 2$ & 0.14 & & 80 & 0.14 & 1.47 & 0.17 \\
\hline 71PA111004 & 0 & 1 & $\mathrm{Oi}$ & 48.54 & & 0 & 48.54 & 0.49 & 2.37 \\
\hline 71PA111004 & 1 & 6 & $\mathrm{Oa}$ & 56.35 & & 0 & 56.35 & 0.84 & 23.56 \\
\hline 71PA111004 & 6 & 11 & $\mathrm{~A}$ & 17.92 & & 0 & 17.92 & 1.21 & 10.83 \\
\hline 71PA111004 & 11 & 26 & $E$ & 1.09 & 1.54 & 55 & 1.09 & 1.54 & 1.14 \\
\hline 71PA111004 & 26 & 31 & $\mathrm{Bh}$ & 5.34 & 1.33 & 35 & 5.34 & 1.33 & 2.31 \\
\hline 71PA111004 & 31 & 52 & Bhs & 1.82 & 1.31 & 35 & 1.82 & 1.31 & 3.25 \\
\hline 71PA111004 & 52 & 59 & $\mathrm{Bw}$ & 0.81 & 1.60 & 35 & 0.81 & 1.60 & 0.59 \\
\hline 71PA111004 & 59 & 85 & $\mathrm{Bx} 1$ & 0.80 & 1.69 & 35 & 0.80 & 1.69 & 2.27 \\
\hline 71PA111004 & 85 & 110 & $\mathrm{Bx} 2$ & 0.77 & 1.75 & 40 & 0.77 & 1.75 & 2.01 \\
\hline 71PA111004 & 110 & 138 & $\mathrm{~B} \times 3$ & 0.99 & 1.50 & 85 & 0.99 & 1.50 & 0.63 \\
\hline 71PA111004 & 138 & 166 & $\mathrm{Bx} 4$ & 0.89 & & 85 & 0.89 & 1.68 & 0.63 \\
\hline 72PA129018 & 0 & 23 & Ap & 2.94 & 1.30 & 0 & 2.94 & 1.30 & 8.79 \\
\hline 72PA129018 & 23 & 30 & Bt1 & 1.31 & 1.47 & 5 & 1.31 & 1.47 & 1.28 \\
\hline 72PA129018 & 30 & 43 & $\mathrm{Bt} 2$ & 0.72 & 1.48 & 5 & 0.72 & 1.48 & 1.32 \\
\hline 72PA129018 & 43 & 66 & Bt3 & 0.26 & 1.68 & 5 & 0.26 & 1.68 & 0.94 \\
\hline 72PA129018 & 66 & 74 & $\mathrm{C}$ & 0.23 & & 5 & 0.23 & 1.42 & 0.25 \\
\hline 72PA129019 & 0 & 20 & Ap & 0.94 & 1.44 & 5 & 0.94 & 1.44 & 2.56 \\
\hline 72PA129019 & 20 & 38 & $\mathrm{Bt}$ & 0.38 & 1.49 & 5 & 0.38 & 1.49 & 0.98 \\
\hline 72PA129019 & 38 & 53 & $\mathrm{BCt}$ & 0.31 & & 50 & 0.31 & 1.45 & 0.34 \\
\hline 72PA129019 & 53 & 71 & $\mathrm{C}$ & 0.20 & & 90 & 0.20 & 1.43 & 0.05 \\
\hline 72PA129020 & 0 & 18 & Ap & 3.20 & 1.38 & 5 & 3.20 & 1.38 & 7.54 \\
\hline
\end{tabular}




\begin{tabular}{|c|c|c|c|c|c|c|c|c|c|}
\hline PedonID & $\begin{array}{c}\text { Top } \\
\text { Depth } \\
\text { (cm) }\end{array}$ & $\begin{array}{c}\text { Bottom } \\
\text { Depth } \\
(\mathrm{cm})\end{array}$ & Horizon & $\begin{array}{c}\text { Total } \\
\text { Carbon\% } \\
\text { (Dry } \\
\text { Combustion, } \\
\text { Including } \\
\text { Converted } \\
\text { Walkley- } \\
\text { Black) }\end{array}$ & $\begin{array}{c}\text { 33kPa } \\
\text { Bulk } \\
\text { Density } \\
\left(\mathrm{g} \mathrm{cm}^{-3}\right)\end{array}$ & $\begin{array}{c}\text { Fragment } \\
\% \text { by } \\
\text { Volume }\end{array}$ & $\begin{array}{c}\text { Predicted } \\
\text { OC } \%\end{array}$ & $\begin{array}{c}\text { Predicted } \\
\text { 33kPa BD } \\
\left(\mathrm{g} \mathrm{cm}^{-3}\right)\end{array}$ & $\begin{array}{c}\text { SOC } \\
\text { Stock } \\
(\mathbf{k g} \\
\left.\mathbf{m}^{-2}\right)\end{array}$ \\
\hline 72PA129020 & 18 & 36 & Bt1 & 0.75 & 1.46 & 5 & 0.75 & 1.46 & 1.88 \\
\hline 72PA129020 & 36 & 51 & $\mathrm{Bt} 2$ & 0.43 & 1.57 & 5 & 0.43 & 1.57 & 0.95 \\
\hline 72PA129020 & 51 & 69 & $\mathrm{Bt} 3$ & 0.26 & 1.57 & 5 & 0.26 & 1.57 & 0.69 \\
\hline 72PA129020 & 69 & 84 & $\mathrm{Bt} 4$ & 0.09 & 1.67 & 5 & 0.09 & 1.67 & 0.20 \\
\hline 72PA129020 & 84 & 117 & $\mathrm{BC}$ & 0.14 & 1.80 & 5 & 0.14 & 1.80 & 0.80 \\
\hline 72PA129021 & 0 & 25 & Ap & 2.94 & 1.25 & 15 & 2.94 & 1.25 & 7.81 \\
\hline 72PA129021 & 25 & 46 & $\mathrm{Bt}$ & 0.36 & 1.52 & 10 & 0.36 & 1.52 & 1.02 \\
\hline 72PA129021 & 46 & 58 & $\mathrm{BCt}$ & 0.74 & & 80 & 0.74 & 1.45 & 0.26 \\
\hline 72PA129021 & 86 & 157 & $\mathrm{C}$ & 0.10 & & 50 & 0.10 & 1.44 & 0.51 \\
\hline 73PA033013 & 0 & 8 & $\mathrm{Oa}$ & 8.61 & & 0 & 17.17 & 0.47 & 4.07 \\
\hline 73PA033013 & 8 & 23 & $\mathrm{BA}$ & 2.57 & 1.10 & 10 & 3.76 & 0.97 & 1.37 \\
\hline 73PA033013 & 23 & 46 & Bw1 & 0.58 & 1.29 & 15 & 1.97 & 1.12 & 2.65 \\
\hline 73PA033013 & 46 & 72 & Bw2 & 0.37 & 1.41 & 20 & 1.10 & 1.27 & 1.18 \\
\hline 73PA033013 & 72 & 99 & Bw3 & 0.13 & 1.37 & 50 & 0.56 & 1.49 & 1.87 \\
\hline 73PA033013 & 99 & 148 & $\mathrm{BC}$ & 0.18 & & 70 & 0.25 & 1.54 & 0.44 \\
\hline 73PA033013 & 148 & 173 & $\mathrm{C}$ & 0.21 & & 85 & 0.30 & 1.52 & 0.57 \\
\hline 73PA033012 & 0 & 5 & $\mathrm{Oa}$ & 17.17 & & 0 & 0.24 & 1.45 & 0.28 \\
\hline 73PA033012 & 5 & 10 & $\mathrm{~A}$ & 3.76 & & 25 & 0.28 & 1.65 & 0.84 \\
\hline 73PA033012 & 10 & 25 & $\mathrm{BA}$ & 1.97 & 1.12 & 20 & 0.32 & 1.52 & 0.44 \\
\hline 73PA033012 & 25 & 38 & Bw1 & 1.10 & 1.27 & 35 & 8.61 & 0.50 & 3.42 \\
\hline 73PA033012 & 38 & 66 & Bw2 & 0.56 & 1.49 & 20 & 2.57 & 1.10 & 3.82 \\
\hline 73PA033012 & 66 & 81 & Bw3 & 0.25 & 1.54 & 25 & 0.58 & 1.29 & 1.47 \\
\hline 73PA033012 & 81 & 109 & Bw4 & 0.30 & 1.52 & 55 & 0.37 & 1.41 & 1.08 \\
\hline
\end{tabular}




\begin{tabular}{|c|c|c|c|c|c|c|c|c|c|}
\hline PedonID & $\begin{array}{c}\text { Top } \\
\text { Depth } \\
\text { (cm) }\end{array}$ & $\begin{array}{c}\text { Bottom } \\
\text { Depth } \\
(\mathrm{cm})\end{array}$ & Horizon & $\begin{array}{c}\text { Total } \\
\text { Carbon\% } \\
\text { (Dry } \\
\text { Combustion, } \\
\text { Including } \\
\text { Converted } \\
\text { Walkley- } \\
\text { Black) } \\
\end{array}$ & $\begin{array}{c}\text { 33kPa } \\
\text { Bulk } \\
\text { Density } \\
\left(\mathrm{g} \mathrm{cm}^{-3}\right)\end{array}$ & $\begin{array}{c}\text { Fragment } \\
\% \text { by } \\
\text { Volume }\end{array}$ & $\begin{array}{l}\text { Predicted } \\
\text { OC } \%\end{array}$ & $\begin{array}{c}\text { Predicted } \\
\text { 33kPa BD } \\
\left(\mathrm{g} \mathrm{cm}^{-3}\right)\end{array}$ & $\begin{array}{c}\text { SOC } \\
\text { Stock } \\
(\mathbf{k g} \\
\left.\mathbf{m}^{-2}\right)\end{array}$ \\
\hline 73PA033012 & 109 & 132 & Bw5 & 0.24 & 1.45 & 65 & 0.13 & 1.37 & 0.24 \\
\hline 73PA033012 & 132 & 185 & Bw6 & 0.28 & 1.65 & 65 & 0.18 & 1.49 & 0.40 \\
\hline 73PA033012 & 185 & 211 & $\mathrm{C}$ & 0.32 & & 65 & 0.21 & 1.48 & 0.12 \\
\hline 73PA033014 & 0 & 3 & $\mathrm{Oi}$ & 14.71 & & 0 & 14.71 & 0.41 & 1.83 \\
\hline 73PA033014 & 3 & 8 & $\mathrm{Oa}$ & 10.80 & & 0 & 10.80 & 0.55 & 2.95 \\
\hline 73PA033014 & 8 & 13 & $\mathrm{~A}$ & 6.23 & & 0 & 6.23 & 1.11 & 3.44 \\
\hline 73PA033014 & 13 & 24 & BA & 0.83 & 1.29 & 10 & 0.83 & 1.29 & 1.05 \\
\hline 73PA033014 & 24 & 38 & Bt1 & 0.56 & 1.49 & 20 & 0.56 & 1.49 & 0.94 \\
\hline 73PA033014 & 38 & 49 & $\mathrm{Bt} 2$ & 0.32 & 1.43 & 20 & 0.32 & 1.43 & 0.40 \\
\hline 73PA033014 & 49 & 82 & Btx1 & 0.31 & 1.38 & 10 & 0.31 & 1.38 & 1.26 \\
\hline 73PA033014 & 82 & 120 & Btx2 & 0.15 & 1.54 & 35 & 0.15 & 1.54 & 0.59 \\
\hline 73PA033014 & 120 & 158 & $2 \mathrm{Bx} 3$ & 2.19 & 1.65 & 10 & 2.19 & 1.65 & 12.35 \\
\hline 73PA033014 & 158 & 191 & $2 \mathrm{Bx} 4$ & 0.64 & 1.44 & 10 & 0.64 & 1.44 & 2.73 \\
\hline 73PA033015 & 0 & 5 & $\mathrm{~A}$ & 8.45 & & 5 & 8.45 & 0.96 & 3.86 \\
\hline 73PA033015 & 5 & 15 & BA & 3.29 & 1.02 & 10 & 3.29 & 1.02 & 3.02 \\
\hline 73PA033015 & 15 & 25 & Bt1 & 1.33 & 1.45 & 15 & 1.33 & 1.45 & 1.65 \\
\hline 73PA033015 & 25 & 38 & $\mathrm{Bt} 2$ & 1.35 & 1.49 & 10 & 1.35 & 1.49 & 2.35 \\
\hline 73PA033015 & 38 & 58 & Btx1 & 0.45 & 1.58 & 15 & 0.45 & 1.58 & 1.22 \\
\hline 73PA033015 & 58 & 84 & Btx2 & 0.36 & 1.62 & 20 & 0.36 & 1.62 & 1.20 \\
\hline 73PA033015 & 84 & 119 & Btx3 & 0.72 & 1.86 & 25 & 0.72 & 1.86 & 3.54 \\
\hline 73PA033015 & 119 & 147 & Btx4 & 0.64 & 1.71 & 30 & 0.64 & 1.71 & 2.14 \\
\hline 73PA033015 & 147 & 165 & Btx5 & 0.64 & 1.64 & 40 & 0.64 & 1.64 & 1.13 \\
\hline 73PA033016 & 0 & 5 & $\mathrm{Oa}$ & 46.01 & & 0 & 46.01 & 0.62 & 14.17 \\
\hline
\end{tabular}




\begin{tabular}{|c|c|c|c|c|c|c|c|c|c|}
\hline PedonID & $\begin{array}{c}\text { Top } \\
\text { Depth } \\
\text { (cm) }\end{array}$ & $\begin{array}{c}\text { Bottom } \\
\text { Depth } \\
(\mathrm{cm})\end{array}$ & Horizon & $\begin{array}{c}\text { Total } \\
\text { Carbon\% } \\
\text { (Dry } \\
\text { Combustion, } \\
\text { Including } \\
\text { Converted } \\
\text { Walkley- } \\
\text { Black) } \\
\end{array}$ & $\begin{array}{c}\text { 33kPa } \\
\text { Bulk } \\
\text { Density } \\
\left(\mathrm{g} \mathrm{cm}^{-3}\right)\end{array}$ & $\begin{array}{c}\text { Fragment } \\
\% \text { by } \\
\text { Volume }\end{array}$ & $\begin{array}{l}\text { Predicted } \\
\text { OC } \%\end{array}$ & $\begin{array}{c}\text { Predicted } \\
\text { 33kPa BD } \\
\left(\mathrm{g} \mathrm{cm}^{-3}\right)\end{array}$ & $\begin{array}{c}\text { SOC } \\
\text { Stock } \\
(\mathbf{k g} \\
\left.\mathbf{m}^{-2}\right)\end{array}$ \\
\hline 73PA033016 & 5 & 15 & $\mathrm{~A}$ & 8.62 & 1.07 & 0 & 8.62 & 1.07 & 9.22 \\
\hline 73PA033016 & 15 & 33 & Bt1 & 1.33 & 1.27 & 0 & 1.33 & 1.27 & 3.05 \\
\hline 73PA033016 & 33 & 61 & $\mathrm{Bt} 2$ & 0.55 & 1.43 & 0 & 0.55 & 1.43 & 2.22 \\
\hline 73PA033016 & 61 & 91 & Btg1 & 0.36 & 1.61 & 0 & 0.36 & 1.61 & 1.71 \\
\hline 73PA033016 & 91 & 132 & Btg2 & 0.28 & 1.67 & 0 & 0.28 & 1.67 & 1.94 \\
\hline 73PA033016 & 132 & 160 & $\mathrm{BC}$ & 0.23 & 1.58 & 30 & 0.23 & 1.58 & 0.70 \\
\hline 73PA033016 & 160 & 195 & $\mathrm{C}$ & 0.37 & & 60 & 0.37 & 1.58 & 0.82 \\
\hline 73PA033017 & 0 & 3 & $\mathrm{Oa}$ & 7.76 & & 0 & 7.76 & 0.60 & 1.39 \\
\hline 73PA033017 & 3 & 11 & $\mathrm{~A}$ & 1.36 & & 0 & 1.36 & 1.00 & 1.09 \\
\hline 73PA033017 & 11 & 28 & Bt1 & 0.69 & 1.29 & 5 & 0.69 & 1.29 & 1.44 \\
\hline 73PA033017 & 28 & 49 & $\mathrm{Bt} 2$ & 0.37 & 1.49 & 5 & 0.37 & 1.49 & 1.11 \\
\hline 73PA033017 & 49 & 74 & Btg1 & 0.22 & 1.72 & 5 & 0.22 & 1.72 & 0.90 \\
\hline 73PA033017 & 74 & 94 & Btg2 & 0.23 & 1.73 & 5 & 0.23 & 1.73 & 0.76 \\
\hline 73PA033017 & 94 & 112 & Btg3 & 0.22 & & 5 & 0.22 & 1.65 & 0.62 \\
\hline 73PA033017 & 112 & 138 & Btg4 & 0.19 & 1.58 & 10 & 0.19 & 1.58 & 0.69 \\
\hline 73PA033018 & 0 & 5 & $\mathrm{Oa}$ & 27.34 & & 0 & 27.34 & 0.55 & 7.58 \\
\hline 73PA033018 & 5 & 18 & A & 2.67 & 1.53 & 0 & 2.67 & 1.53 & 5.31 \\
\hline 73PA033018 & 18 & 30 & Btg1 & 0.71 & 1.48 & 0 & 0.71 & 1.48 & 1.26 \\
\hline 73PA033018 & 30 & 48 & Btg2 & 0.51 & 1.46 & 0 & 0.51 & 1.46 & 1.34 \\
\hline 73PA033018 & 48 & 81 & Bgx 1 & 0.26 & 1.49 & 15 & 0.26 & 1.49 & 1.07 \\
\hline 73PA033018 & 81 & 129 & Bgx 2 & 0.31 & 1.57 & 0 & 0.31 & 1.57 & 2.35 \\
\hline 73PA033018 & 129 & 175 & Bgx3 & 0.21 & 1.60 & 0 & 0.21 & 1.60 & 1.57 \\
\hline 73PA033019 & 0 & 8 & $\mathrm{Oa}$ & 33.09 & & 0 & 33.09 & 0.62 & 16.47 \\
\hline
\end{tabular}




\begin{tabular}{|c|c|c|c|c|c|c|c|c|c|}
\hline PedonID & $\begin{array}{c}\text { Top } \\
\text { Depth } \\
\text { (cm) }\end{array}$ & $\begin{array}{c}\text { Bottom } \\
\text { Depth } \\
(\mathrm{cm})\end{array}$ & Horizon & $\begin{array}{c}\text { Total } \\
\text { Carbon\% } \\
\text { (Dry } \\
\text { Combustion, } \\
\text { Including } \\
\text { Converted } \\
\text { Walkley- } \\
\text { Black) } \\
\end{array}$ & $\begin{array}{c}\text { 33kPa } \\
\text { Bulk } \\
\text { Density } \\
\left(\mathrm{g} \mathrm{cm}^{-3}\right)\end{array}$ & $\begin{array}{c}\text { Fragment } \\
\% \text { by } \\
\text { Volume }\end{array}$ & $\begin{array}{c}\text { Predicted } \\
\text { OC } \%\end{array}$ & $\begin{array}{c}\text { Predicted } \\
\text { 33kPa BD } \\
\left(\mathrm{g} \mathrm{cm}^{-3}\right)\end{array}$ & $\begin{array}{c}\text { SOC } \\
\text { Stock } \\
(\mathbf{k g} \\
\left.\mathbf{m}^{-2}\right)\end{array}$ \\
\hline 73PA033019 & 8 & 18 & $\mathrm{~A}$ & 4.71 & 1.29 & 0 & 4.71 & 1.29 & 6.08 \\
\hline 73PA033019 & 18 & 36 & $E$ & 1.78 & 1.39 & 0 & 1.78 & 1.39 & 4.44 \\
\hline 73PA033019 & 36 & 44 & Btg & 0.98 & 1.46 & 5 & 0.98 & 1.46 & 1.09 \\
\hline 73PA033019 & 44 & 87 & $\operatorname{Bgx} 1$ & 0.78 & 1.74 & 10 & 0.78 & 1.74 & 5.26 \\
\hline 73PA033019 & 87 & 132 & $\operatorname{Bgx} 2$ & 1.01 & 1.81 & 10 & 1.01 & 1.81 & 7.39 \\
\hline 73PA033019 & 132 & 163 & Bgx3 & 1.02 & 1.76 & 30 & 1.02 & 1.76 & 3.90 \\
\hline 73PA033019 & 163 & 201 & $\operatorname{Bgx} 4$ & 0.37 & 1.86 & 30 & 0.37 & 1.86 & 1.83 \\
\hline 75WV061001 & 0 & 5 & Oe & 21.74 & & 0 & 21.74 & 0.91 & 9.93 \\
\hline 75WV061001 & 5 & 8 & $\mathrm{~A}$ & 9.36 & 1.01 & 20 & 21.74 & 0.92 & 10.01 \\
\hline 75WV061001 & 8 & 13 & $\mathrm{E}$ & 4.53 & & 20 & 9.36 & 1.01 & 2.27 \\
\hline 75WV061001 & 13 & 23 & Bt1 & 1.85 & & 20 & 9.36 & 1.01 & 2.27 \\
\hline 75WV061001 & 23 & 46 & $\mathrm{Bt} 2$ & 1.29 & 1.28 & 35 & 4.53 & 1.16 & 2.10 \\
\hline 75WV061001 & 46 & 69 & $\mathrm{BC} / \mathrm{C}$ & 0.68 & & 70 & 4.49 & 1.16 & 2.08 \\
\hline 78PA105007 & 0 & 1 & $\mathrm{Oi}$ & & & 60 & 42.83 & 0.45 & 0.77 \\
\hline 78PA105007 & 1 & 4 & $\mathrm{Oa}$ & & & 60 & 36.33 & 0.58 & 2.51 \\
\hline 78PA105007 & 4 & 24 & $\mathrm{E}$ & 0.29 & & 60 & 0.29 & 1.37 & 0.31 \\
\hline 78PA105007 & 24 & 27 & Bhs1 & 2.75 & & 60 & 2.75 & 1.28 & 0.42 \\
\hline 78PA105007 & 27 & 34 & Bhs2 & 1.82 & & 60 & 1.82 & 1.28 & 0.65 \\
\hline 78PA105007 & 34 & 103 & $\mathrm{BC}$ & 0.96 & & 60 & 0.96 & 1.56 & 4.12 \\
\hline 78PA105007 & 103 & 128 & $\mathrm{C}$ & 0.25 & & 60 & 0.25 & 1.56 & 0.40 \\
\hline 78PA105008 & 0 & 4 & $\mathrm{Oi}$ & & & 0 & 44.62 & 0.32 & 5.66 \\
\hline 78PA105008 & 4 & 5 & $\mathrm{Oa}$ & & & 0 & 34.86 & 0.49 & 1.72 \\
\hline 78PA105008 & 5 & 8 & $\mathrm{~A}$ & 8.79 & & 10 & 8.79 & 1.04 & 2.46 \\
\hline
\end{tabular}




\begin{tabular}{|c|c|c|c|c|c|c|c|c|c|}
\hline PedonID & $\begin{array}{c}\text { Top } \\
\text { Depth } \\
\text { (cm) }\end{array}$ & $\begin{array}{c}\text { Bottom } \\
\text { Depth } \\
(\mathrm{cm})\end{array}$ & Horizon & $\begin{array}{c}\text { Total } \\
\text { Carbon\% } \\
\text { (Dry } \\
\text { Combustion, } \\
\text { Including } \\
\text { Converted } \\
\text { Walkley- } \\
\text { Black) } \\
\end{array}$ & $\begin{array}{c}\text { 33kPa } \\
\text { Bulk } \\
\text { Density } \\
\left(\mathrm{g} \mathrm{cm}^{-3}\right)\end{array}$ & $\begin{array}{c}\text { Fragment } \\
\% \text { by } \\
\text { Volume }\end{array}$ & $\begin{array}{c}\text { Predicted } \\
\text { OC } \%\end{array}$ & $\begin{array}{c}\text { Predicted } \\
\text { 33kPa BD } \\
\left(\mathrm{g} \mathrm{cm}^{-3}\right)\end{array}$ & $\begin{array}{c}\text { SOC } \\
\text { Stock } \\
(\mathbf{k g} \\
\left.\mathbf{m}^{-2}\right)\end{array}$ \\
\hline 78PA105008 & 8 & 20 & $E$ & 0.64 & & 20 & 0.64 & 1.30 & 0.80 \\
\hline 78PA105008 & 20 & 23 & Bhs & 4.98 & & 20 & 4.98 & 1.27 & 1.52 \\
\hline 78PA105008 & 23 & 30 & Bs & 4.31 & & 25 & 4.31 & 1.23 & 2.79 \\
\hline 78PA105008 & 30 & 35 & $\mathrm{Bw}$ & 1.84 & & 40 & 1.84 & 1.31 & 0.72 \\
\hline 78PA105008 & 35 & 53 & $\mathrm{BC}$ & 0.94 & & 60 & 0.94 & 1.37 & 0.92 \\
\hline 78PA105008 & 53 & 86 & $\mathrm{C}$ & 0.57 & & 90 & 0.57 & 1.39 & 0.26 \\
\hline 78PA111005 & 0 & 3 & $\mathrm{Oi}$ & & & 0 & 37.99 & 0.45 & 5.16 \\
\hline 78PA111005 & 3 & 6 & $\mathrm{Oa}$ & & & 0 & 25.78 & 0.53 & 4.10 \\
\hline 78PA111005 & 6 & 11 & $\mathrm{~A}$ & 17.88 & & 35 & 17.88 & 1.10 & 6.41 \\
\hline 78PA111005 & 11 & 26 & $\mathrm{E}$ & 1.28 & & 60 & 1.28 & 1.28 & 0.98 \\
\hline 78PA111005 & 26 & 29 & Bhs & 5.69 & & 45 & 5.69 & 1.27 & 1.19 \\
\hline 78PA111005 & 29 & 34 & Bs & 2.50 & & 50 & 2.50 & 1.18 & 0.74 \\
\hline 78PA111005 & 34 & 59 & $\mathrm{Bw}$ & 0.98 & & 60 & 0.98 & 1.41 & 1.38 \\
\hline 78PA111005 & 59 & 72 & $\mathrm{BC} 1$ & 0.44 & & 65 & 0.44 & 1.51 & 0.30 \\
\hline 78PA111005 & 72 & 97 & $\mathrm{BC} 2$ & 0.55 & & 75 & 0.55 & 1.50 & 0.51 \\
\hline 78PA111006 & 0 & 2 & Oi & & & 0 & 33.79 & 0.49 & 3.30 \\
\hline 78PA111006 & 2 & 8 & $\mathrm{Oa}$ & & & 0 & 24.56 & 0.54 & 7.96 \\
\hline 78PA111006 & 8 & 11 & $\mathrm{~A}$ & 9.06 & & 25 & 9.06 & 1.23 & 2.50 \\
\hline 78PA111006 & 11 & 26 & $E$ & 0.48 & & 50 & 0.48 & 1.50 & 0.54 \\
\hline 78PA111006 & 26 & 33 & Bhs & 7.77 & & 30 & 7.77 & 1.31 & 4.99 \\
\hline 78PA111006 & 33 & 46 & Bs & 1.93 & & 30 & 1.93 & 1.30 & 2.28 \\
\hline 78PA111006 & 46 & 59 & $\mathrm{Bt}$ & 0.50 & & 30 & 0.50 & 1.53 & 0.69 \\
\hline 78PA111006 & 59 & 79 & Btx1 & 0.21 & & 40 & 0.21 & 1.66 & 0.43 \\
\hline
\end{tabular}




\begin{tabular}{|c|c|c|c|c|c|c|c|c|c|}
\hline PedonID & $\begin{array}{c}\text { Top } \\
\text { Depth } \\
\text { (cm) }\end{array}$ & $\begin{array}{c}\text { Bottom } \\
\text { Depth } \\
\text { (cm) }\end{array}$ & Horizon & $\begin{array}{c}\text { Total } \\
\text { Carbon\% } \\
\text { (Dry } \\
\text { Combustion, } \\
\text { Including } \\
\text { Converted } \\
\text { Walkley- } \\
\text { Black) } \\
\end{array}$ & $\begin{array}{c}\text { 33kPa } \\
\text { Bulk } \\
\text { Density } \\
\left(\mathrm{g} \mathrm{cm}^{-3}\right)\end{array}$ & $\begin{array}{c}\text { Fragment } \\
\% \text { by } \\
\text { Volume }\end{array}$ & $\begin{array}{l}\text { Predicted } \\
\text { OC } \%\end{array}$ & $\begin{array}{c}\text { Predicted } \\
\text { 33kPa BD } \\
\left(\mathrm{g} \mathrm{cm}^{-3}\right)\end{array}$ & $\begin{array}{c}\text { SOC } \\
\text { Stock } \\
(\mathbf{k g} \\
\left.\mathbf{m}^{-2}\right)\end{array}$ \\
\hline 78PA111006 & 79 & 107 & Btx2 & 0.38 & & 30 & 0.38 & 1.61 & 1.21 \\
\hline 78PA111006 & 107 & 135 & Btx3 & 0.17 & & 30 & 0.17 & 1.70 & 0.57 \\
\hline 78PA111006 & 135 & 163 & Btx4 & 0.28 & & 30 & 0.28 & 1.69 & 0.94 \\
\hline 78WV083001 & 0 & 5 & Ap1 & 7.51 & & 5 & 7.51 & 1.22 & 4.34 \\
\hline 78WV083001 & 5 & 15 & Ap2 & 5.07 & & 5 & 5.07 & 1.30 & 6.27 \\
\hline 78WV083001 & 15 & 30 & $\mathrm{Bt1}$ & 1.52 & & 10 & 1.52 & 1.44 & 2.95 \\
\hline 78WV083001 & 30 & 43 & Bt2 & 0.55 & & 15 & 0.55 & 1.48 & 0.90 \\
\hline 78WV083001 & 43 & 58 & $\mathrm{Bt} 3$ & 0.28 & & 20 & 0.28 & 1.44 & 0.49 \\
\hline 78WV083001 & 58 & 71 & $\mathrm{C}$ & 0.13 & & 15 & 0.13 & 1.41 & 0.20 \\
\hline 78WV083002 & 0 & 15 & $\mathrm{~A}$ & & & 10 & 5.44 & 1.14 & 8.34 \\
\hline 78WV083002 & 15 & 36 & Bt1 & & & 15 & 1.21 & 1.46 & 3.14 \\
\hline 78WV083002 & 36 & 64 & $\mathrm{Bt} 2$ & & & 25 & 0.62 & 1.54 & 1.99 \\
\hline 78WV083002 & 64 & 84 & $\mathrm{C}$ & & & 80 & 0.63 & 1.53 & 0.39 \\
\hline 78WV083003 & 0 & 20 & $\mathrm{~A}$ & & & 15 & 6.86 & 1.09 & 12.73 \\
\hline 78WV083003 & 20 & 36 & Bw1 & & & 25 & 1.51 & 1.36 & 2.47 \\
\hline 78WV083003 & 36 & 56 & Bw2 & & & 30 & 1.01 & 1.42 & 2.02 \\
\hline 78WV083003 & 56 & 69 & $\mathrm{C}$ & & & 65 & 0.69 & 1.43 & 0.45 \\
\hline 78WV089007 & 0 & 23 & Ap & & & 0 & 2.91 & 1.28 & 8.60 \\
\hline 78WV089007 & 23 & 38 & Bt1 & & & 0 & 0.76 & 1.45 & 1.66 \\
\hline 78WV089007 & 38 & 56 & $\mathrm{Bt} 2$ & & & 25 & 0.51 & 1.47 & 1.01 \\
\hline 78WV089007 & 56 & 76 & $\mathrm{C}$ & & & 50 & 0.38 & 1.47 & 0.56 \\
\hline 78WV089008 & 0 & 20 & Ap & & & 0 & 2.51 & 1.28 & 6.44 \\
\hline 78WV089008 & 20 & 41 & Bt1 & & & 0 & 0.80 & 1.46 & 2.44 \\
\hline
\end{tabular}




\begin{tabular}{|c|c|c|c|c|c|c|c|c|c|}
\hline PedonID & $\begin{array}{c}\text { Top } \\
\text { Depth } \\
\text { (cm) }\end{array}$ & $\begin{array}{c}\text { Bottom } \\
\text { Depth } \\
\text { (cm) }\end{array}$ & Horizon & $\begin{array}{c}\text { Total } \\
\text { Carbon\% } \\
\text { (Dry } \\
\text { Combustion, } \\
\text { Including } \\
\text { Converted } \\
\text { Walkley- } \\
\text { Black) } \\
\end{array}$ & $\begin{array}{c}\text { 33kPa } \\
\text { Bulk } \\
\text { Density } \\
\left(\mathrm{g} \mathrm{cm}^{-3}\right)\end{array}$ & $\begin{array}{c}\text { Fragment } \\
\% \text { by } \\
\text { Volume }\end{array}$ & $\begin{array}{c}\text { Predicted } \\
\text { OC } \%\end{array}$ & $\begin{array}{c}\text { Predicted } \\
\text { 33kPa BD } \\
\left(\mathrm{g} \mathrm{cm}^{-3}\right)\end{array}$ & $\begin{array}{c}\text { SOC } \\
\text { Stock } \\
(\mathbf{k g} \\
\left.\mathbf{m}^{-2}\right)\end{array}$ \\
\hline 78WV089008 & 41 & 56 & $\mathrm{Bt} 2$ & & & 30 & 0.50 & 1.49 & 0.78 \\
\hline 78WV089008 & 56 & 79 & $\mathrm{C}$ & & & 55 & 0.47 & 1.39 & 0.68 \\
\hline 78WV089009 & 0 & 20 & Ap & & & 0 & 2.66 & 1.26 & 6.73 \\
\hline 78WV089009 & 20 & 33 & Bt1 & & & 0 & 0.86 & 1.46 & 1.63 \\
\hline 78WV089009 & 33 & 71 & $\mathrm{Bt} 2$ & & & 0 & 0.51 & 1.50 & 2.89 \\
\hline 78WV089009 & 71 & 137 & Bt3 & & & 0 & 0.34 & 1.53 & 3.40 \\
\hline 78WV089009 & 137 & 190 & $\mathrm{BC}$ & & & 0 & 0.29 & 1.52 & 2.34 \\
\hline 78WV089010 & 0 & 18 & Ap & & & 5 & 2.81 & 1.25 & 6.03 \\
\hline 78WV089010 & 18 & 30 & $\mathrm{BA}$ & & & 5 & 1.17 & 1.30 & 1.74 \\
\hline 78WV089010 & 30 & 56 & Bt1 & & & 5 & 0.49 & 1.48 & 1.79 \\
\hline 78WV089010 & 56 & 102 & $\mathrm{Bt} 2$ & & & 5 & 0.28 & 1.53 & 1.86 \\
\hline 78WV089010 & 102 & 132 & Bt3 & & & 5 & 0.33 & 1.52 & 1.43 \\
\hline 78WV089010 & 132 & 157 & $\mathrm{C}$ & & & 0 & 0.45 & 1.48 & 1.67 \\
\hline 79PA083006 & 0 & 2 & $\mathrm{Oi}$ & & & 0 & 37.11 & 0.43 & 3.18 \\
\hline 79PA083006 & 2 & 4 & $\mathrm{Oe}$ & & & 0 & 29.26 & 0.52 & 3.06 \\
\hline 79PA083006 & 4 & 6 & $\mathrm{Oa}$ & 23.94 & & 0 & 23.94 & 0.59 & 2.83 \\
\hline 79PA083006 & 6 & 12 & $\mathrm{E}$ & 1.23 & 1.54 & 5 & 1.23 & 1.54 & 1.08 \\
\hline 79PA083006 & 12 & 17 & Bhs & 2.97 & & 5 & 2.97 & 1.25 & 1.76 \\
\hline 79PA083006 & 17 & 33 & Bw1 & 1.94 & 1.16 & 10 & 1.94 & 1.16 & 3.23 \\
\hline 79PA083006 & 33 & 49 & Bw2 & 1.10 & 1.53 & 15 & 1.10 & 1.53 & 2.29 \\
\hline 79PA083006 & 49 & 64 & Bw3 & 0.39 & 1.53 & 15 & 0.39 & 1.53 & 0.75 \\
\hline 79PA083006 & 64 & 86 & Bx1 & 0.39 & 1.69 & 25 & 0.39 & 1.69 & 1.07 \\
\hline 79PA083006 & 86 & 108 & $\mathrm{~B} \times 2$ & 0.20 & 1.69 & 25 & 0.20 & 1.69 & 0.55 \\
\hline
\end{tabular}




\begin{tabular}{|c|c|c|c|c|c|c|c|c|c|}
\hline PedonID & $\begin{array}{c}\text { Top } \\
\text { Depth } \\
\text { (cm) }\end{array}$ & $\begin{array}{c}\text { Bottom } \\
\text { Depth } \\
(\mathrm{cm})\end{array}$ & Horizon & $\begin{array}{c}\text { Total } \\
\text { Carbon\% } \\
\text { (Dry } \\
\text { Combustion, } \\
\text { Including } \\
\text { Converted } \\
\text { Walkley- } \\
\text { Black) } \\
\end{array}$ & $\begin{array}{c}\text { 33kPa } \\
\text { Bulk } \\
\text { Density } \\
\left(\mathrm{g} \mathrm{cm}^{-3}\right)\end{array}$ & $\begin{array}{c}\text { Fragment } \\
\% \text { by } \\
\text { Volume }\end{array}$ & $\begin{array}{l}\text { Predicted } \\
\text { OC } \%\end{array}$ & $\begin{array}{c}\text { Predicted } \\
\text { 33kPa BD } \\
\left(\mathrm{g} \mathrm{cm}^{-3}\right)\end{array}$ & $\begin{array}{c}\text { SOC } \\
\text { Stock } \\
(\mathbf{k g} \\
\left.\mathrm{m}^{-2}\right)\end{array}$ \\
\hline 79PA083006 & 108 & 131 & $\mathrm{C}$ & 0.32 & 1.77 & 60 & 0.32 & 1.77 & 0.52 \\
\hline 79PA083007 & 0 & 2 & $\mathrm{Oi}$ & & & 0 & 46.01 & 0.37 & 3.43 \\
\hline 79PA083007 & 2 & 4 & $\mathrm{Oe}$ & & & 0 & 40.72 & 0.54 & 4.41 \\
\hline 79PA083007 & 4 & 6 & $\mathrm{Oa}$ & 37.52 & & 10 & 37.52 & 0.60 & 4.05 \\
\hline 79PA083007 & 6 & 23 & $E$ & 0.39 & & 30 & 0.39 & 1.54 & 0.71 \\
\hline 79PA083007 & 23 & 28 & Bhs1 & 3.37 & & 40 & 3.37 & 1.26 & 1.27 \\
\hline 79PA083007 & 28 & 44 & Bhs2 & 2.00 & & 35 & 2.00 & 1.34 & 2.79 \\
\hline 79PA083007 & 44 & 63 & Bs & 0.78 & & 40 & 0.78 & 1.49 & 1.32 \\
\hline 79PA083007 & 63 & 84 & $\mathrm{Bw}$ & 0.45 & & 45 & 0.45 & 1.65 & 0.86 \\
\hline 79PA083007 & 84 & 102 & $\mathrm{BC}$ & 0.20 & & 60 & 0.20 & 1.68 & 0.24 \\
\hline 79PA083007 & 102 & 151 & $\mathrm{C}$ & 0.32 & & 80 & 0.32 & 1.70 & 0.53 \\
\hline 79PA083008 & 0 & 4 & $\mathrm{Oi}$ & & & 0 & 42.54 & 0.36 & 6.16 \\
\hline 79PA083008 & 2 & 4 & $\mathrm{Oe}$ & & & 0 & 36.26 & 0.48 & 3.51 \\
\hline 79PA083008 & 4 & 6 & $\mathrm{Oa}$ & 33.32 & & 0 & 33.32 & 0.55 & 3.69 \\
\hline 79PA083008 & 6 & 12 & $\mathrm{E}$ & 1.36 & 1.45 & 0 & 1.36 & 1.45 & 1.19 \\
\hline 79PA083008 & 12 & 16 & Bhs & 4.40 & 0.90 & 0 & 4.40 & 0.90 & 1.58 \\
\hline 79PA083008 & 16 & 29 & $2 \mathrm{Bt} 1$ & 2.46 & 1.20 & 10 & 2.46 & 1.20 & 3.46 \\
\hline 79PA083008 & 29 & 45 & $2 \mathrm{Bt} 2$ & 1.94 & 1.17 & 15 & 1.94 & 1.17 & 3.08 \\
\hline 79PA083008 & 45 & 61 & $2 \mathrm{BC}$ & 0.65 & 1.40 & 15 & 0.65 & 1.40 & 1.24 \\
\hline 79PA083008 & 61 & 95 & $2 \mathrm{C}$ & 0.39 & & 75 & 0.39 & 1.40 & 0.46 \\
\hline 79PA083009 & 0 & 1 & $\mathrm{Oi}$ & & & 0 & 38.65 & 0.44 & 1.70 \\
\hline 79PA083009 & 1 & 3 & $\mathrm{Oe}$ & & & 0 & 38.40 & 0.51 & 3.90 \\
\hline 79PA083009 & 3 & 5 & $\mathrm{Oa}$ & 47.87 & & 5 & 47.87 & 0.62 & 5.66 \\
\hline
\end{tabular}




\begin{tabular}{|c|c|c|c|c|c|c|c|c|c|}
\hline PedonID & $\begin{array}{c}\text { Top } \\
\text { Depth } \\
\text { (cm) }\end{array}$ & $\begin{array}{c}\text { Bottom } \\
\text { Depth } \\
(\mathrm{cm})\end{array}$ & Horizon & $\begin{array}{c}\text { Total } \\
\text { Carbon\% } \\
\text { (Dry } \\
\text { Combustion, } \\
\text { Including } \\
\text { Converted } \\
\text { Walkley- } \\
\text { Black) } \\
\end{array}$ & $\begin{array}{c}\text { 33kPa } \\
\text { Bulk } \\
\text { Density } \\
\left(\mathrm{g} \mathrm{cm}^{-3}\right)\end{array}$ & $\begin{array}{c}\text { Fragment } \\
\% \text { by } \\
\text { Volume }\end{array}$ & $\begin{array}{c}\text { Predicted } \\
\text { OC } \%\end{array}$ & $\begin{array}{c}\text { Predicted } \\
\text { 33kPa BD } \\
\left(\mathrm{g} \mathrm{cm}^{-3}\right)\end{array}$ & $\begin{array}{c}\text { SOC } \\
\text { Stock } \\
(\mathbf{k g} \\
\left.\mathbf{m}^{-2}\right)\end{array}$ \\
\hline 79PA083009 & 5 & 15 & $E$ & 1.68 & 1.52 & 10 & 1.68 & 1.52 & 2.30 \\
\hline 79PA083009 & 15 & 18 & Bhs & 5.05 & & 10 & 5.05 & 1.21 & 1.65 \\
\hline 79PA083009 & 18 & 30 & Bt1 & 2.65 & 1.14 & 15 & 2.65 & 1.14 & 3.08 \\
\hline 79PA083009 & 30 & 51 & $\mathrm{Bt} 2$ & 1.17 & 1.25 & 11 & 1.17 & 1.25 & 2.72 \\
\hline 79PA083009 & 51 & 95 & $2 \mathrm{Bx} 1$ & 0.58 & 1.69 & 60 & 0.58 & 1.69 & 1.73 \\
\hline 79PA083009 & 95 & 143 & $2 \mathrm{~B} \times 2$ & 0.74 & 1.79 & 65 & 0.74 & 1.79 & 2.22 \\
\hline 79PA083010 & 0 & 2 & $\mathrm{Oi}$ & & & 0 & 38.92 & 0.44 & 3.43 \\
\hline 79PA083010 & 2 & 5 & $\mathrm{Oe}$ & & & 0 & 38.62 & 0.51 & 5.91 \\
\hline 79PA083010 & 5 & 7 & $\mathrm{Oa}$ & 47.87 & & 0 & 47.87 & 0.63 & 6.00 \\
\hline 79PA083010 & 7 & 13 & $\mathrm{E}$ & 1.75 & 1.44 & 5 & 1.75 & 1.44 & 1.44 \\
\hline 79PA083010 & 13 & 18 & Bhs & 3.42 & & 8 & 3.42 & 1.22 & 1.92 \\
\hline 79PA083010 & 18 & 29 & Bt1 & 2.40 & 1.04 & 10 & 2.40 & 1.04 & 2.47 \\
\hline 79PA083010 & 29 & 52 & $\mathrm{Bt} 2$ & 1.17 & 1.33 & 10 & 1.17 & 1.33 & 3.21 \\
\hline 79PA083010 & 52 & 102 & $\mathrm{Bx} 1$ & 0.26 & 1.71 & 20 & 0.26 & 1.71 & 1.81 \\
\hline 79PA083010 & 102 & 137 & $\mathrm{~B} \times 2$ & 0.65 & 1.74 & 10 & 0.65 & 1.74 & 3.56 \\
\hline 79PA083011 & 0 & 3 & $\mathrm{Oi}$ & & & 0 & 38.96 & 0.39 & 4.55 \\
\hline 79PA083011 & 3 & 4 & $\mathrm{Oe}$ & & & 0 & 36.16 & 0.43 & 1.57 \\
\hline 79PA083011 & 4 & 6 & $\mathrm{Oa}$ & 45.94 & & 0 & 45.94 & 0.54 & 4.97 \\
\hline 79PA083011 & 6 & 14 & $\mathrm{E}$ & 2.84 & 1.57 & 0 & 2.84 & 1.57 & 3.57 \\
\hline 79PA083011 & 14 & 30 & Btg1 & 1.83 & 1.63 & 5 & 1.83 & 1.63 & 4.54 \\
\hline 79PA083011 & 30 & 56 & Btg2 & 0.58 & 1.60 & 10 & 0.58 & 1.60 & 2.18 \\
\hline 79PA083011 & 56 & 80 & 2Bgx1 & 0.50 & 1.67 & 15 & 0.50 & 1.67 & 1.69 \\
\hline 79PA083011 & 80 & 119 & $2 \mathrm{Bgx} 2$ & 0.33 & 1.72 & 30 & 0.33 & 1.72 & 1.53 \\
\hline
\end{tabular}




\begin{tabular}{|c|c|c|c|c|c|c|c|c|c|}
\hline PedonID & $\begin{array}{c}\text { Top } \\
\text { Depth } \\
\text { (cm) }\end{array}$ & $\begin{array}{c}\text { Bottom } \\
\text { Depth } \\
(\mathrm{cm})\end{array}$ & Horizon & $\begin{array}{c}\text { Total } \\
\text { Carbon\% } \\
\text { (Dry } \\
\text { Combustion, } \\
\text { Including } \\
\text { Converted } \\
\text { Walkley- } \\
\text { Black) } \\
\end{array}$ & $\begin{array}{c}\text { 33kPa } \\
\text { Bulk } \\
\text { Density } \\
\left(\mathrm{g} \mathrm{cm}^{-3}\right)\end{array}$ & $\begin{array}{c}\text { Fragment } \\
\% \text { by } \\
\text { Volume }\end{array}$ & $\begin{array}{c}\text { Predicted } \\
\text { OC } \%\end{array}$ & $\begin{array}{c}\text { Predicted } \\
\text { 33kPa BD } \\
\left(\mathrm{g} \mathrm{cm}^{-3}\right)\end{array}$ & $\begin{array}{c}\text { SOC } \\
\text { Stock } \\
(\mathbf{k g} \\
\left.\mathbf{m}^{-2}\right)\end{array}$ \\
\hline 79PA083011 & 119 & 141 & $2 \mathrm{Bgx} 3$ & 0.33 & 1.79 & 15 & 0.33 & 1.79 & 1.09 \\
\hline 79PA083012 & 0 & 4 & Oi & & & 0 & 43.47 & 0.44 & 7.72 \\
\hline 79PA083012 & 4 & 17 & $\mathrm{Oe}$ & & & 0 & 37.49 & 0.55 & 26.66 \\
\hline 79PA083012 & 17 & 19 & $\mathrm{Oa}$ & 40.12 & & 0 & 40.12 & 0.67 & 5.34 \\
\hline 79PA083012 & 19 & 26 & $\mathrm{E}$ & 1.62 & 1.76 & 5 & 1.62 & 1.76 & 1.89 \\
\hline 79PA083012 & 26 & 38 & $\mathrm{Bt}$ & 2.52 & 1.06 & 5 & 2.52 & 1.06 & 3.04 \\
\hline 79PA083012 & 38 & 51 & Btg & 0.84 & 1.30 & 5 & 0.84 & 1.30 & 1.34 \\
\hline 79PA083012 & 51 & 69 & Btx1 & 0.39 & 1.73 & 12 & 0.39 & 1.73 & 1.06 \\
\hline 79PA083012 & 69 & 87 & Btx2 & 0.32 & 1.73 & 12 & 0.32 & 1.73 & 0.87 \\
\hline 79PA083012 & 87 & 125 & Btx3 & 0.19 & 1.80 & 15 & 0.19 & 1.80 & 1.09 \\
\hline 79PA083012 & 125 & 144 & Btx4 & 0.32 & 1.79 & 30 & 0.32 & 1.79 & 0.76 \\
\hline 79WV067001 & 0 & 5 & Oe & 41.54 & & 0 & 41.54 & 0.96 & 19.98 \\
\hline 79WV067001 & 5 & 9 & $\mathrm{~A}$ & 14.80 & & 25 & 14.80 & 1.08 & 4.78 \\
\hline 79WV067001 & 9 & 13 & $\mathrm{E}$ & 5.37 & & 20 & 5.37 & 1.29 & 2.21 \\
\hline 79WV067001 & 13 & 20 & Bt1 & 2.49 & & 25 & 2.49 & 1.39 & 1.81 \\
\hline 79WV067001 & 20 & 43 & $\mathrm{Bt} 2$ & 1.21 & 1.07 & 40 & 1.21 & 1.07 & 1.78 \\
\hline 79WV067001 & 43 & 56 & Bt3 & 0.60 & 1.39 & 60 & 0.60 & 1.39 & 0.43 \\
\hline 79WV067001 & 56 & 76 & $\mathrm{C}$ & 0.67 & & 75 & 0.67 & 1.43 & 0.48 \\
\hline 79WV067002 & 0 & 5 & $\mathrm{Oi}$ & & & 0 & 46.86 & 0.45 & 10.61 \\
\hline 79WV067002 & 5 & 8 & $\mathrm{Oe}$ & & & 0 & 41.65 & 0.59 & 7.36 \\
\hline 79WV067002 & 8 & 13 & $\mathrm{~A}$ & 8.02 & & 15 & 8.02 & 1.06 & 3.60 \\
\hline 79WV067002 & 13 & 28 & Bt1 & 1.28 & 1.29 & 15 & 1.28 & 1.29 & 2.10 \\
\hline 79WV067002 & 28 & 53 & $\mathrm{Bt} 2$ & 0.91 & 1.39 & 20 & 0.91 & 1.39 & 2.53 \\
\hline
\end{tabular}




\begin{tabular}{|c|c|c|c|c|c|c|c|c|c|}
\hline PedonID & $\begin{array}{c}\text { Top } \\
\text { Depth } \\
\text { (cm) }\end{array}$ & $\begin{array}{c}\text { Bottom } \\
\text { Depth } \\
(\mathrm{cm})\end{array}$ & Horizon & $\begin{array}{c}\text { Total } \\
\text { Carbon\% } \\
\text { (Dry } \\
\text { Combustion, } \\
\text { Including } \\
\text { Converted } \\
\text { Walkley- } \\
\text { Black) }\end{array}$ & $\begin{array}{c}\text { 33kPa } \\
\text { Bulk } \\
\text { Density } \\
\left(\mathrm{g} \mathrm{cm}^{-3}\right)\end{array}$ & $\begin{array}{c}\text { Fragment } \\
\% \text { by } \\
\text { Volume }\end{array}$ & $\begin{array}{c}\text { Predicted } \\
\text { OC } \%\end{array}$ & $\begin{array}{c}\text { Predicted } \\
33 \mathrm{kPa} \mathrm{BD} \\
\left(\mathrm{g} \mathrm{cm}^{-3}\right)\end{array}$ & $\begin{array}{c}\text { SOC } \\
\text { Stock } \\
(\mathbf{k g} \\
\left.\mathbf{m}^{-2}\right)\end{array}$ \\
\hline 79WV067002 & 53 & 79 & Btx1 & 0.41 & 1.45 & 30 & 0.41 & 1.45 & 1.09 \\
\hline 79WV067002 & 79 & 136 & Btx2 & 0.20 & 1.60 & 35 & 0.20 & 1.60 & 1.18 \\
\hline 79WV067002 & 136 & 171 & Btx3 & 0.16 & 1.58 & 30 & 0.16 & 1.58 & 0.60 \\
\hline 79WV067006 & 0 & 5 & Oi & & & 0 & 47.74 & 0.47 & 11.34 \\
\hline 79WV067006 & 5 & 8 & $\mathrm{Oe}$ & & & 0 & 44.37 & 0.61 & 8.15 \\
\hline 79WV067006 & 8 & 13 & $\mathrm{~A}$ & 35.50 & & 25 & 35.50 & 1.15 & 15.35 \\
\hline 79WV067006 & 13 & 18 & $\mathrm{E}$ & 8.83 & & 25 & 8.83 & 1.35 & 4.48 \\
\hline 79WV067006 & 18 & 33 & Bt1 & 2.31 & & 20 & 2.31 & 1.45 & 4.03 \\
\hline 79WV067006 & 33 & 69 & $\mathrm{Bt} 2$ & 0.53 & 1.48 & 20 & 0.53 & 1.48 & 2.24 \\
\hline 79WV067006 & 69 & 81 & $\mathrm{Bt} 3$ & 0.23 & 1.66 & 20 & 0.23 & 1.66 & 0.36 \\
\hline 79WV067006 & 81 & 109 & $\mathrm{Bx} 1$ & 0.14 & 1.68 & 30 & 0.14 & 1.68 & 0.47 \\
\hline 79WV067006 & 109 & 142 & $\mathrm{~B} \times 2$ & 0.13 & 1.76 & 30 & 0.13 & 1.76 & 0.52 \\
\hline 79WV067006 & 142 & 158 & $\mathrm{Bx} 3$ & 0.16 & 1.78 & 30 & 0.16 & 1.78 & 0.31 \\
\hline 79WV067007 & 0 & 7 & Oi & & & 0 & 45.37 & 0.51 & 16.06 \\
\hline 79WV067007 & 7 & 10 & $\mathrm{Oe}$ & & & 0 & 44.11 & 0.63 & 8.36 \\
\hline 79WV067007 & 10 & 13 & $\mathrm{~A}$ & 40.46 & & 50 & 40.46 & 1.00 & 6.09 \\
\hline 79WV067007 & 13 & 20 & $\mathrm{E}$ & 7.94 & & 50 & 7.94 & 1.31 & 3.65 \\
\hline 79WV067007 & 20 & 40 & Bt1 & 1.69 & 1.38 & 25 & 1.69 & 1.38 & 3.50 \\
\hline 79WV067007 & 40 & 71 & Bt2 & 0.54 & 1.52 & 15 & 0.54 & 1.52 & 2.16 \\
\hline 79WV067007 & 71 & 91 & Bt3 & 0.48 & 1.47 & 15 & 0.48 & 1.47 & 1.21 \\
\hline 79WV067007 & 91 & 137 & Btx1 & 0.81 & 1.38 & 40 & 0.81 & 1.38 & 3.08 \\
\hline 79WV067007 & 137 & 163 & Btx2 & 0.60 & 1.69 & 3 & 0.60 & 1.69 & 2.54 \\
\hline 79WV067008 & 0 & 7 & $\mathrm{Oi}$ & & & 0 & 47.42 & 0.48 & 16.03 \\
\hline
\end{tabular}




\begin{tabular}{|c|c|c|c|c|c|c|c|c|c|}
\hline PedonID & $\begin{array}{c}\text { Top } \\
\text { Depth } \\
\text { (cm) }\end{array}$ & $\begin{array}{c}\text { Bottom } \\
\text { Depth } \\
(\mathrm{cm})\end{array}$ & Horizon & $\begin{array}{c}\text { Total } \\
\text { Carbon\% } \\
\text { (Dry } \\
\text { Combustion, } \\
\text { Including } \\
\text { Converted } \\
\text { Walkley- } \\
\text { Black) }\end{array}$ & $\begin{array}{c}\text { 33kPa } \\
\text { Bulk } \\
\text { Density } \\
\left(\mathrm{g} \mathrm{cm}^{-3}\right)\end{array}$ & $\begin{array}{c}\text { Fragment } \\
\% \text { by } \\
\text { Volume }\end{array}$ & $\begin{array}{c}\text { Predicted } \\
\text { OC } \%\end{array}$ & $\begin{array}{c}\text { Predicted } \\
33 \mathrm{kPa} \mathrm{BD} \\
\left(\mathrm{g} \mathrm{cm}^{-3}\right)\end{array}$ & $\begin{array}{c}\text { SOC } \\
\text { Stock } \\
(\mathbf{k g} \\
\left.\mathbf{m}^{-2}\right)\end{array}$ \\
\hline 79WV067008 & 7 & 10 & $\mathrm{Oe}$ & & & 0 & 43.67 & 0.62 & 8.11 \\
\hline 79WV067008 & 10 & 17 & $\mathrm{~A}$ & 35.94 & & 20 & 35.94 & 1.27 & 25.57 \\
\hline 79WV067008 & 17 & 28 & $\mathrm{E}$ & 5.62 & & 20 & 5.62 & 1.37 & 6.77 \\
\hline 79WV067008 & 28 & 40 & Bt1 & 1.68 & & 20 & 1.68 & 1.46 & 2.34 \\
\hline 79WV067008 & 40 & 61 & $\mathrm{Bt} 2$ & 0.61 & 1.34 & 25 & 0.61 & 1.34 & 1.29 \\
\hline 79WV067008 & 61 & 81 & $\mathrm{Bx} 1$ & 0.18 & 1.58 & 30 & 0.18 & 1.58 & 0.41 \\
\hline 79WV067008 & 81 & 163 & $\mathrm{Bx} 2$ & 0.17 & 1.70 & 40 & 0.17 & 1.70 & 1.43 \\
\hline 79WV067010 & 0 & 5 & $\mathrm{Oi}$ & & & 0 & 44.94 & 0.46 & 10.29 \\
\hline 79WV067010 & 5 & 8 & $\mathrm{Oe}$ & & & 0 & 34.24 & 0.57 & 5.90 \\
\hline 79WV067010 & 8 & 11 & $\mathrm{~A}$ & 43.38 & & 5 & 43.38 & 1.23 & 15.23 \\
\hline 79WV067010 & 11 & 16 & $\mathrm{E}$ & 6.75 & & 5 & 6.75 & 1.31 & 4.21 \\
\hline 79WV067010 & 16 & 33 & Bw1 & 1.49 & & 5 & 1.49 & 1.39 & 3.34 \\
\hline 79WV067010 & 33 & 56 & Bw2 & 0.75 & 1.51 & 10 & 0.75 & 1.51 & 2.35 \\
\hline 79WV067010 & 56 & 74 & Bw3 & 0.23 & 1.62 & 15 & 0.23 & 1.62 & 0.56 \\
\hline 79WV067010 & 74 & 112 & Bx1 & 0.10 & 1.57 & 2 & 0.10 & 1.57 & 0.58 \\
\hline 79WV067010 & 112 & 161 & $\mathrm{~B} \times 2$ & 0.13 & 1.84 & 20 & 0.13 & 1.84 & 0.92 \\
\hline 79WV067011 & 0 & 5 & Oi & & & 0 & 40.59 & 0.40 & 8.05 \\
\hline 79WV067011 & 5 & 8 & $\mathrm{Oe}$ & & & 0 & 39.74 & 0.52 & 6.25 \\
\hline 79WV067011 & 8 & 11 & $\mathrm{~A}$ & 33.77 & & 5 & 33.77 & 1.07 & 10.29 \\
\hline 79WV067011 & 11 & 16 & $\mathrm{E}$ & 6.15 & & 5 & 6.15 & 1.16 & 3.39 \\
\hline 79WV067011 & 16 & 33 & $\mathrm{Bw}$ & 1.16 & 1.28 & 20 & 1.16 & 1.28 & 2.03 \\
\hline 79WV067011 & 33 & 54 & Bt1 & 0.37 & 1.36 & 15 & 0.37 & 1.36 & 0.90 \\
\hline 79WV067011 & 54 & 64 & $\mathrm{Bt} 2$ & 0.40 & 1.27 & 45 & 0.40 & 1.27 & 0.28 \\
\hline
\end{tabular}




\begin{tabular}{|c|c|c|c|c|c|c|c|c|c|}
\hline PedonID & $\begin{array}{c}\text { Top } \\
\text { Depth } \\
\text { (cm) }\end{array}$ & $\begin{array}{c}\text { Bottom } \\
\text { Depth } \\
(\mathrm{cm})\end{array}$ & Horizon & $\begin{array}{c}\text { Total } \\
\text { Carbon\% } \\
\text { (Dry } \\
\text { Combustion, } \\
\text { Including } \\
\text { Converted } \\
\text { Walkley- } \\
\text { Black) }\end{array}$ & $\begin{array}{c}\text { 33kPa } \\
\text { Bulk } \\
\text { Density } \\
\left(\mathrm{g} \mathrm{cm}^{-3}\right)\end{array}$ & $\begin{array}{c}\text { Fragment } \\
\% \text { by } \\
\text { Volume }\end{array}$ & $\begin{array}{c}\text { Predicted } \\
\text { OC } \%\end{array}$ & $\begin{array}{c}\text { Predicted } \\
33 \mathrm{kPa} \mathrm{BD} \\
\left(\mathrm{g} \mathrm{cm}^{-3}\right)\end{array}$ & $\begin{array}{c}\text { SOC } \\
\text { Stock } \\
(\mathbf{k g} \\
\left.\mathbf{m}^{-2}\right)\end{array}$ \\
\hline 79WV067011 & 64 & 74 & $\mathrm{C}$ & 0.34 & 1.46 & 65 & 0.34 & 1.46 & 0.17 \\
\hline 80WV067005 & 0 & 15 & $\mathrm{Ap}$ & 2.75 & 1.36 & 0 & 2.75 & 1.36 & 5.62 \\
\hline 80WV067005 & 15 & 28 & Bw1 & 0.77 & 1.57 & 0 & 0.77 & 1.57 & 1.57 \\
\hline 80WV067005 & 28 & 53 & Bw2 & 0.37 & 1.55 & 5 & 0.37 & 1.55 & 1.36 \\
\hline 80WV067005 & 53 & 81 & Bw3 & 0.14 & 1.75 & 25 & 0.14 & 1.75 & 0.52 \\
\hline 80WV067005 & 81 & 104 & $\mathrm{C}$ & 0.16 & 1.75 & 40 & 0.16 & 1.75 & 0.38 \\
\hline 80WV067006 & 0 & 23 & $\mathrm{Ap}$ & 4.09 & 1.40 & 0 & 4.09 & 1.40 & 13.17 \\
\hline 80WV067006 & 23 & 38 & Bt1 & 0.88 & 1.56 & 0 & 0.88 & 1.56 & 2.06 \\
\hline 80WV067006 & 38 & 63 & $\mathrm{Bt} 2$ & 0.24 & 1.65 & 5 & 0.24 & 1.65 & 0.95 \\
\hline 80WV067006 & 63 & 79 & $\mathrm{Bt} 3$ & 0.16 & 1.67 & 30 & 0.16 & 1.67 & 0.29 \\
\hline 80WV067006 & 79 & 104 & $\mathrm{C}$ & 0.09 & 1.29 & 65 & 0.09 & 1.29 & 0.10 \\
\hline 81WV067001 & 0 & 7 & $\mathrm{Oi}$ & & & 0 & 43.54 & 0.44 & 13.56 \\
\hline 81WV067001 & 7 & 9 & $\mathrm{Oe}$ & & & 0 & 33.38 & 0.56 & 3.71 \\
\hline 81WV067001 & 9 & 14 & $\mathrm{~A}$ & 14.64 & & 30 & 14.64 & 1.17 & 5.98 \\
\hline 81WV067001 & 14 & 22 & $\mathrm{E}$ & 5.51 & & 25 & 5.51 & 1.34 & 4.44 \\
\hline 81WV067001 & 22 & 34 & Bw1 & 2.49 & 1.26 & 20 & 2.49 & 1.26 & 3.01 \\
\hline 81WV067001 & 34 & 49 & Bw2 & 1.05 & 1.36 & 25 & 1.05 & 1.36 & 1.61 \\
\hline 81WV067001 & 49 & 84 & Bw3 & 0.64 & 1.49 & 30 & 0.64 & 1.49 & 2.33 \\
\hline 81WV067001 & 84 & 112 & $\mathrm{Bx} 1$ & 0.34 & 1.73 & 40 & 0.34 & 1.73 & 0.99 \\
\hline 81WV067001 & 112 & 159 & $\mathrm{~B} \times 2$ & 0.34 & 1.69 & 35 & 0.34 & 1.69 & 1.76 \\
\hline 81WV067002 & 0 & 5 & Oi & & & 0 & 46.86 & 0.45 & 10.61 \\
\hline 81WV067002 & 5 & 8 & $\mathrm{Oe}$ & & & 0 & 41.65 & 0.59 & 7.36 \\
\hline 81WV067002 & 8 & 11 & $\mathrm{~A}$ & 21.91 & & 20 & 21.91 & 1.04 & 5.46 \\
\hline
\end{tabular}




\begin{tabular}{|c|c|c|c|c|c|c|c|c|c|}
\hline PedonID & $\begin{array}{c}\text { Top } \\
\text { Depth } \\
\text { (cm) }\end{array}$ & $\begin{array}{c}\text { Bottom } \\
\text { Depth } \\
\text { (cm) }\end{array}$ & Horizon & $\begin{array}{c}\text { Total } \\
\text { Carbon\% } \\
\text { (Dry } \\
\text { Combustion, } \\
\text { Including } \\
\text { Converted } \\
\text { Walkley- } \\
\text { Black) }\end{array}$ & $\begin{array}{c}\text { 33kPa } \\
\text { Bulk } \\
\text { Density } \\
\left(\mathrm{g} \mathrm{cm}^{-3}\right)\end{array}$ & $\begin{array}{c}\text { Fragment } \\
\% \text { by } \\
\text { Volume }\end{array}$ & $\begin{array}{c}\text { Predicted } \\
\text { OC } \%\end{array}$ & $\begin{array}{c}\text { Predicted } \\
33 \mathrm{kPa} \mathrm{BD} \\
\left(\mathrm{g} \mathrm{cm}^{-3}\right)\end{array}$ & $\begin{array}{c}\text { SOC } \\
\text { Stock } \\
(\mathbf{k g} \\
\left.\mathbf{m}^{-2}\right)\end{array}$ \\
\hline 81WV067002 & 11 & 16 & $\mathrm{E}$ & 6.72 & & 20 & 6.72 & 1.23 & 3.31 \\
\hline 81WV067002 & 16 & 31 & Bt1 & 2.16 & 1.08 & 15 & 2.16 & 1.08 & 2.97 \\
\hline 81WV067002 & 31 & 83 & $\mathrm{Bt} 2$ & 0.74 & & 15 & 0.74 & 1.49 & 4.85 \\
\hline 81WV067002 & 83 & 106 & $\mathrm{~B} \times 1$ & 0.60 & & 20 & 0.60 & 1.61 & 1.76 \\
\hline 81WV067002 & 106 & 160 & $\mathrm{~B} \times 2$ & 0.55 & & 25 & 0.55 & 1.63 & 3.65 \\
\hline 81WV101001 & 0 & 5 & Oi & & & 0 & 37.50 & 0.44 & 8.32 \\
\hline 81WV101001 & 5 & 8 & Oe & & & 0 & 29.60 & 0.57 & 5.08 \\
\hline 81WV101001 & 8 & 11 & $\mathrm{~A}$ & 30.50 & & 10 & 30.50 & 1.11 & 9.18 \\
\hline 81WV101001 & 11 & 16 & $\mathrm{E}$ & 10.99 & & 15 & 10.99 & 1.21 & 5.67 \\
\hline 81WV101001 & 16 & 28 & Bw1 & 3.91 & 1.15 & 15 & 3.91 & 1.15 & 4.58 \\
\hline 81WV101001 & 28 & 46 & Bw2 & 0.88 & 1.43 & 20 & 0.88 & 1.43 & 1.81 \\
\hline 81WV101001 & 46 & 61 & Bw3 & 0.71 & 1.50 & 20 & 0.71 & 1.50 & 1.28 \\
\hline 81WV101001 & 61 & 111 & $\mathrm{Bx}$ & 0.48 & 1.52 & 20 & 0.48 & 1.52 & 2.94 \\
\hline 82PA047009 & 0 & 5 & $\mathrm{Oi}$ & & & 0 & 45.01 & 0.43 & 9.63 \\
\hline 82PA047009 & 5 & 13 & $\mathrm{~A}$ & 4.91 & & 0 & 4.91 & 1.13 & 4.45 \\
\hline 82PA047009 & 13 & 30 & Bw1 & 2.67 & & 0 & 2.67 & 1.36 & 6.17 \\
\hline 82PA047009 & 30 & 53 & Bw2 & 0.38 & 1.60 & 0 & 0.38 & 1.60 & 1.41 \\
\hline 82PA047009 & 53 & 86 & $\mathrm{Bx} 1$ & 0.23 & 1.57 & 0 & 0.23 & 1.57 & 1.18 \\
\hline 82PA047009 & 86 & 114 & $\mathrm{Bx} 2$ & 0.16 & 1.70 & 0 & 0.16 & 1.70 & 0.74 \\
\hline 82PA047009 & 114 & 140 & $\mathrm{~B} \times 3$ & 0.07 & 1.68 & 0 & 0.07 & 1.68 & 0.31 \\
\hline 82PA047009 & 140 & 157 & $2 \mathrm{~B}^{\prime} \mathrm{t} 1$ & 0.06 & 1.71 & 0 & 0.06 & 1.71 & 0.17 \\
\hline 82PA047009 & 157 & 170 & $2 \mathrm{~B}^{\prime} \mathrm{t} 2$ & 0.13 & & 0 & 0.13 & 1.61 & 0.27 \\
\hline 82PA047009 & 170 & 208 & $2 \mathrm{~B}^{\prime} \mathrm{t} 3$ & 0.10 & & 0 & 0.10 & 1.63 & 0.62 \\
\hline
\end{tabular}




\begin{tabular}{|c|c|c|c|c|c|c|c|c|c|}
\hline PedonID & $\begin{array}{c}\text { Top } \\
\text { Depth } \\
\text { (cm) }\end{array}$ & $\begin{array}{c}\text { Bottom } \\
\text { Depth } \\
(\mathrm{cm})\end{array}$ & Horizon & $\begin{array}{c}\text { Total } \\
\text { Carbon\% } \\
\text { (Dry } \\
\text { Combustion, } \\
\text { Including } \\
\text { Converted } \\
\text { Walkley- } \\
\text { Black) } \\
\end{array}$ & $\begin{array}{c}\text { 33kPa } \\
\text { Bulk } \\
\text { Density } \\
\left(\mathrm{g} \mathrm{cm}^{-3}\right)\end{array}$ & $\begin{array}{c}\text { Fragment } \\
\% \text { by } \\
\text { Volume }\end{array}$ & $\begin{array}{l}\text { Predicted } \\
\text { OC } \%\end{array}$ & $\begin{array}{c}\text { Predicted } \\
\text { 33kPa BD } \\
\left(\mathrm{g} \mathrm{cm}^{-3}\right)\end{array}$ & $\begin{array}{c}\text { SOC } \\
\text { Stock } \\
(\mathbf{k g} \\
\left.\mathbf{m}^{-2}\right)\end{array}$ \\
\hline 82PA083004 & 0 & 3 & Oi & & & 0 & 40.99 & 0.45 & 5.58 \\
\hline 82PA083004 & 3 & 11 & $\mathrm{~A}$ & 5.52 & & 0 & 5.52 & 1.07 & 4.72 \\
\hline 82PA083004 & 11 & 28 & $\mathrm{BA}$ & 2.13 & & 0 & 2.13 & 1.24 & 4.51 \\
\hline 82PA083004 & 28 & 41 & $\mathrm{Bw}$ & 0.92 & 1.45 & 0 & 0.92 & 1.45 & 1.74 \\
\hline 82PA083004 & 41 & 51 & $\mathrm{Bt}$ & 0.61 & 1.61 & 0 & 0.61 & 1.61 & 0.98 \\
\hline 82PA083004 & 51 & 72 & Btx1 & 0.64 & 1.74 & 0 & 0.64 & 1.74 & 2.33 \\
\hline 82PA083004 & 72 & 89 & Btx2 & 0.85 & 1.76 & 0 & 0.85 & 1.76 & 2.55 \\
\hline 82PA083004 & 89 & 110 & $\mathrm{BCx}$ & 1.07 & 1.77 & 0 & 1.07 & 1.77 & 3.96 \\
\hline 82PA083004 & 110 & 150 & $\mathrm{C} 1$ & 0.98 & 1.72 & 0 & 0.98 & 1.72 & 6.74 \\
\hline 82PA083004 & 150 & 176 & $\mathrm{C} 2$ & 0.89 & 1.70 & 0 & 0.89 & 1.70 & 3.95 \\
\hline 82PA083005 & 0 & 1 & Oi & & & 0 & 37.74 & 0.38 & 1.45 \\
\hline 82PA083005 & 1 & 5 & $\mathrm{Oe}$ & & & 0 & 34.16 & 0.46 & 6.31 \\
\hline 82PA083005 & 5 & 10 & $\mathrm{~A}$ & 18.67 & & 0 & 18.67 & 0.95 & 8.90 \\
\hline 82PA083005 & 10 & 18 & $\mathrm{E}$ & 2.53 & 1.07 & 0 & 2.53 & 1.07 & 2.16 \\
\hline 82PA083005 & 18 & 33 & $\mathrm{BE}$ & 1.28 & 1.49 & 0 & 1.28 & 1.49 & 2.86 \\
\hline 82PA083005 & 33 & 48 & Bt1 & 1.08 & 1.54 & 0 & 1.08 & 1.54 & 2.49 \\
\hline 82PA083005 & 48 & 66 & $\mathrm{Bt} 2$ & 0.38 & 1.62 & 0 & 0.38 & 1.62 & 1.12 \\
\hline 82PA083005 & 66 & 91 & Btx1 & 0.57 & 1.69 & 0 & 0.57 & 1.69 & 2.40 \\
\hline 82PA083005 & 91 & 104 & Btx2 & 0.23 & 1.74 & 0 & 0.23 & 1.74 & 0.51 \\
\hline 82PA083005 & 104 & 124 & $2 \mathrm{Btx} 3$ & 0.16 & 1.77 & 0 & 0.16 & 1.77 & 0.55 \\
\hline 82PA083005 & 124 & 137 & $2 \mathrm{BC}$ & 0.14 & 1.80 & 0 & 0.14 & 1.80 & 0.33 \\
\hline 82PA083005 & 137 & 168 & $2 \mathrm{C} 1$ & 0.14 & 1.74 & 0 & 0.14 & 1.74 & 0.77 \\
\hline 82PA083005 & 168 & 195 & $2 \mathrm{C} 2$ & 0.16 & 1.82 & 0 & 0.16 & 1.82 & 0.77 \\
\hline
\end{tabular}




\begin{tabular}{|c|c|c|c|c|c|c|c|c|c|}
\hline PedonID & $\begin{array}{c}\text { Top } \\
\text { Depth } \\
\text { (cm) }\end{array}$ & $\begin{array}{c}\text { Bottom } \\
\text { Depth } \\
(\mathrm{cm})\end{array}$ & Horizon & $\begin{array}{c}\text { Total } \\
\text { Carbon\% } \\
\text { (Dry } \\
\text { Combustion, } \\
\text { Including } \\
\text { Converted } \\
\text { Walkley- } \\
\text { Black) } \\
\end{array}$ & $\begin{array}{c}\text { 33kPa } \\
\text { Bulk } \\
\text { Density } \\
\left(\mathrm{g} \mathrm{cm}^{-3}\right)\end{array}$ & $\begin{array}{c}\text { Fragment } \\
\% \text { by } \\
\text { Volume }\end{array}$ & $\begin{array}{c}\text { Predicted } \\
\text { OC } \%\end{array}$ & $\begin{array}{c}\text { Predicted } \\
\text { 33kPa BD } \\
\left(\mathrm{g} \mathrm{cm}^{-3}\right)\end{array}$ & $\begin{array}{c}\text { SOC } \\
\text { Stock } \\
(\mathbf{k g} \\
\left.\mathbf{m}^{-2}\right)\end{array}$ \\
\hline 82PA105001 & 0 & 3 & $\mathrm{Oi}$ & & & 0 & 42.50 & 0.51 & 6.48 \\
\hline 82PA105001 & 3 & 8 & $\mathrm{Oe}$ & & & 0 & 39.26 & 0.58 & 11.35 \\
\hline 82PA105001 & 8 & 11 & A & 7.89 & & 0 & 7.89 & 1.13 & 2.68 \\
\hline 82PA105001 & 11 & 13 & $\mathrm{E}$ & 1.06 & & 0 & 1.06 & 1.34 & 0.28 \\
\hline 82PA105001 & 13 & 31 & $\mathrm{BE}$ & 0.81 & & 0 & 0.81 & 1.34 & 1.96 \\
\hline 82PA105001 & 31 & 49 & $\mathrm{Bw}$ & 1.00 & 1.56 & 0 & 1.00 & 1.56 & 2.81 \\
\hline 82PA105001 & 49 & 72 & Btx1 & 0.08 & 1.86 & 0 & 0.08 & 1.86 & 0.33 \\
\hline 82PA105001 & 72 & 92 & Btx2 & 0.28 & 1.89 & 0 & 0.28 & 1.89 & 1.04 \\
\hline 82PA105001 & 92 & 117 & Btx3 & 0.07 & 1.91 & 0 & 0.07 & 1.91 & 0.32 \\
\hline 82PA105001 & 117 & 143 & Btx4 & 0.42 & 1.88 & 0 & 0.42 & 1.88 & 2.04 \\
\hline 82PA105002 & 0 & 3 & Oi & & & 0 & 38.75 & 0.47 & 5.47 \\
\hline 82PA105002 & 3 & 8 & $\mathrm{Oe}$ & & & 0 & 35.74 & 0.51 & 9.13 \\
\hline 82PA105002 & 8 & 13 & $\mathrm{~A}$ & 15.51 & & 0 & 15.51 & 1.17 & 9.05 \\
\hline 82PA105002 & 13 & 31 & $\mathrm{AE}$ & 3.31 & & 0 & 3.31 & 1.41 & 8.37 \\
\hline 82PA105002 & 31 & 51 & $\mathrm{Bw}$ & 0.44 & 1.77 & 0 & 0.44 & 1.77 & 1.56 \\
\hline 82PA105002 & 51 & 66 & $\mathrm{Bt1}$ & 0.41 & 1.73 & 0 & 0.41 & 1.73 & 1.07 \\
\hline 82PA105002 & 66 & 82 & Btx1 & 0.21 & 1.80 & 0 & 0.21 & 1.80 & 0.61 \\
\hline 82PA105002 & 82 & 102 & Btx2 & 0.11 & 1.76 & 0 & 0.11 & 1.76 & 0.40 \\
\hline 82PA105002 & 102 & 132 & Btx3 & 0.10 & 1.81 & 0 & 0.10 & 1.81 & 0.54 \\
\hline 82PA105002 & 132 & 150 & $2 \mathrm{Bt} 2$ & 0.06 & 1.82 & 0 & 0.06 & 1.82 & 0.19 \\
\hline 82PA105002 & 150 & 176 & $2 \mathrm{Bt} 3$ & 0.06 & 1.76 & 0 & 0.06 & 1.76 & 0.26 \\
\hline 82PA105002 & 176 & 193 & $2 \mathrm{BC}$ & 0.04 & & 0 & 0.04 & 1.74 & 0.13 \\
\hline 82PA117017 & 0 & 2 & Oi & 23.10 & & 25 & 23.10 & 1.04 & 3.62 \\
\hline
\end{tabular}




\begin{tabular}{|c|c|c|c|c|c|c|c|c|c|}
\hline PedonID & $\begin{array}{c}\text { Top } \\
\text { Depth } \\
\text { (cm) }\end{array}$ & $\begin{array}{c}\text { Bottom } \\
\text { Depth } \\
(\mathrm{cm})\end{array}$ & Horizon & $\begin{array}{c}\text { Total } \\
\text { Carbon\% } \\
\text { (Dry } \\
\text { Combustion, } \\
\text { Including } \\
\text { Converted } \\
\text { Walkley- } \\
\text { Black) } \\
\end{array}$ & $\begin{array}{c}\text { 33kPa } \\
\text { Bulk } \\
\text { Density } \\
\left(\mathrm{g} \mathrm{cm}^{-3}\right)\end{array}$ & $\begin{array}{c}\text { Fragment } \\
\% \text { by } \\
\text { Volume }\end{array}$ & $\begin{array}{c}\text { Predicted } \\
\text { OC } \%\end{array}$ & $\begin{array}{c}\text { Predicted } \\
\text { 33kPa BD } \\
\left(\mathrm{g} \mathrm{cm}^{-3}\right)\end{array}$ & $\begin{array}{c}\text { SOC } \\
\text { Stock } \\
(\mathbf{k g} \\
\left.\mathbf{m}^{-2}\right)\end{array}$ \\
\hline 82PA117017 & 2 & 5 & $\mathrm{Oe}$ & 35.31 & & 25 & 35.31 & 0.52 & 4.15 \\
\hline 82PA117017 & 5 & 8 & $\mathrm{~A}$ & 1.54 & & 25 & 1.54 & 1.22 & 0.42 \\
\hline 82PA117017 & 8 & 15 & $E$ & 0.11 & 1.85 & 25 & 0.11 & 1.85 & 0.11 \\
\hline 82PA117017 & 15 & 30 & $\mathrm{BE}$ & & 1.63 & 15 & 0.95 & 1.63 & 1.97 \\
\hline 82PA117017 & 30 & 51 & Bt1 & & 1.71 & 20 & 0.50 & 1.71 & 1.42 \\
\hline 82PA117017 & 51 & 66 & $\mathrm{Bt} 2$ & & 1.64 & 15 & 0.30 & 1.64 & 0.62 \\
\hline 82PA117017 & 66 & 71 & $\mathrm{E}^{\prime}$ & & & 15 & 0.80 & 1.71 & 0.58 \\
\hline 82PA117017 & 71 & 91 & Btx1 & & 1.83 & 10 & 0.23 & 1.83 & 0.77 \\
\hline 82PA117017 & 91 & 114 & Btx2 & & 1.84 & 15 & 0.24 & 1.84 & 0.86 \\
\hline 82PA117017 & 114 & 137 & Btx3 & & 1.81 & 15 & 0.33 & 1.81 & 1.18 \\
\hline 82PA117017 & 137 & 155 & 2Btb1 & & & 50 & 0.22 & 1.73 & 0.34 \\
\hline 82PA117017 & 155 & 170 & $2 \mathrm{Btb} 2$ & & & 50 & 0.24 & 1.70 & 0.31 \\
\hline 82PA117017 & 170 & 208 & 2Btb3 & & & 50 & 0.24 & 1.70 & 0.77 \\
\hline 82PA117017 & 208 & 259 & 2Btb4 & & & 50 & 0.21 & 1.72 & 0.90 \\
\hline 82PA117018 & 0 & 5 & Oi & 44.11 & & 0 & 44.11 & 1.00 & 21.97 \\
\hline 82PA117018 & 5 & 10 & $\mathrm{Oa}$ & 36.85 & & 0 & 36.85 & 0.54 & 9.92 \\
\hline 82PA117018 & 10 & 13 & $\mathrm{~A}$ & 7.37 & & 0 & 7.37 & 1.26 & 2.77 \\
\hline 82PA117018 & 13 & 23 & $\mathrm{Eg}$ & 1.10 & 1.56 & 0 & 1.10 & 1.56 & 1.72 \\
\hline 82PA117018 & 23 & 33 & $\mathrm{BEg}$ & 0.33 & 1.67 & 0 & 0.33 & 1.67 & 0.55 \\
\hline 82PA117018 & 33 & 48 & Btg1 & & 1.72 & 0 & 0.58 & 1.72 & 1.49 \\
\hline 82PA117018 & 48 & 76 & Btg2 & & 1.72 & 0 & 0.50 & 1.72 & 2.43 \\
\hline 82PA117018 & 76 & 99 & Bx1 & & 1.93 & 0 & 0.26 & 1.93 & 1.14 \\
\hline 82PA117018 & 99 & 124 & Btx1 & & 1.82 & 0 & 0.43 & 1.82 & 1.94 \\
\hline
\end{tabular}




\begin{tabular}{|c|c|c|c|c|c|c|c|c|c|}
\hline PedonID & $\begin{array}{c}\text { Top } \\
\text { Depth } \\
\text { (cm) }\end{array}$ & $\begin{array}{c}\text { Bottom } \\
\text { Depth } \\
\text { (cm) }\end{array}$ & Horizon & $\begin{array}{c}\text { Total } \\
\text { Carbon\% } \\
\text { (Dry } \\
\text { Combustion, } \\
\text { Including } \\
\text { Converted } \\
\text { Walkley- } \\
\text { Black) } \\
\end{array}$ & $\begin{array}{c}\text { 33kPa } \\
\text { Bulk } \\
\text { Density } \\
\left(\mathrm{g} \mathrm{cm}^{-3}\right)\end{array}$ & $\begin{array}{c}\text { Fragment } \\
\% \text { by } \\
\text { Volume }\end{array}$ & $\begin{array}{c}\text { Predicted } \\
\text { OC } \%\end{array}$ & $\begin{array}{c}\text { Predicted } \\
\text { 33kPa BD } \\
\left(\mathrm{g} \mathrm{cm}^{-3}\right)\end{array}$ & $\begin{array}{c}\text { SOC } \\
\text { Stock } \\
(\mathbf{k g} \\
\left.\mathbf{m}^{-2}\right)\end{array}$ \\
\hline 82PA117018 & 124 & 145 & $2 \mathrm{Btx} 2$ & & 1.79 & 5 & 0.45 & 1.79 & 1.61 \\
\hline 82PA117018 & 145 & 160 & $2 \mathrm{Bt} 1$ & & 1.81 & 5 & 0.49 & 1.81 & 1.28 \\
\hline 82PA117018 & 160 & 193 & $2 \mathrm{Bt} 2$ & & 1.80 & 10 & 0.29 & 1.80 & 1.57 \\
\hline 82PA117018 & 193 & 193 & $2 \mathrm{Bt} 3$ & & & 15 & 0.31 & 1.71 & 0.31 \\
\hline 82PA117019 & 0 & 5 & Oi & 41.69 & & 0 & 41.69 & 0.97 & 20.23 \\
\hline 82PA117019 & 5 & 8 & $\mathrm{Oe}$ & 25.19 & & 0 & 25.19 & 0.55 & 4.12 \\
\hline 82PA117019 & 8 & 13 & $\mathrm{~A}$ & 6.49 & & 10 & 6.49 & 1.15 & 3.37 \\
\hline 82PA117019 & 13 & 31 & $\mathrm{BA}$ & 1.98 & 1.24 & 10 & 1.98 & 1.24 & 3.98 \\
\hline 82PA117019 & 31 & 46 & Bw1 & & 1.27 & 10 & 1.05 & 1.27 & 1.80 \\
\hline 82PA117019 & 46 & 64 & Bw2 & & 1.49 & 10 & 0.63 & 1.49 & 1.51 \\
\hline 82PA117019 & 64 & 82 & $\mathrm{Bx} 1$ & & 1.69 & 10 & 0.31 & 1.69 & 0.84 \\
\hline 82PA117019 & 82 & 97 & $\mathrm{Bx} 2$ & & 1.69 & 10 & 0.23 & 1.69 & 0.53 \\
\hline 82PA117019 & 97 & 115 & $\mathrm{Bx} 3$ & & 1.74 & 10 & 0.23 & 1.74 & 0.63 \\
\hline 82PA117019 & 115 & 135 & $\mathrm{Bx} 4$ & & 1.72 & 15 & 0.22 & 1.72 & 0.64 \\
\hline 82PA117019 & 135 & 148 & $\mathrm{~B} \times 5$ & & 1.74 & 15 & 0.35 & 1.74 & 0.67 \\
\hline 82PA117019 & 148 & 171 & $\mathrm{BC} 1$ & & & 15 & 0.20 & 1.76 & 0.69 \\
\hline 82PA117019 & 171 & 186 & $\mathrm{BC} 2$ & & & 15 & 0.20 & 1.76 & 0.45 \\
\hline 82PA117019 & 186 & 211 & BC3 & & & 15 & 0.21 & 1.78 & 0.79 \\
\hline 82PA117019 & 211 & 226 & $\mathrm{C} 1$ & & & 15 & 0.32 & 1.72 & 0.69 \\
\hline 82PA117019 & 226 & 267 & $\mathrm{C} 2$ & & & 15 & 0.31 & 1.72 & 1.87 \\
\hline 82PA117019 & 267 & 313 & $2 \mathrm{Cg} 1$ & & & 25 & 0.57 & 1.62 & 3.22 \\
\hline 82PA117019 & 313 & 374 & $2 \mathrm{Cg} 2$ & & & 10 & 0.65 & 1.61 & 5.74 \\
\hline 82PA117020 & 0 & 12 & Oi & 44.55 & & 25 & 44.55 & 1.08 & 43.32 \\
\hline
\end{tabular}




\begin{tabular}{|c|c|c|c|c|c|c|c|c|c|}
\hline PedonID & $\begin{array}{c}\text { Top } \\
\text { Depth } \\
\text { (cm) }\end{array}$ & $\begin{array}{c}\text { Bottom } \\
\text { Depth } \\
(\mathrm{cm})\end{array}$ & Horizon & $\begin{array}{c}\text { Total } \\
\text { Carbon\% } \\
\text { (Dry } \\
\text { Combustion, } \\
\text { Including } \\
\text { Converted } \\
\text { Walkley- } \\
\text { Black) } \\
\end{array}$ & $\begin{array}{c}\text { 33kPa } \\
\text { Bulk } \\
\text { Density } \\
\left(\mathrm{g} \mathrm{cm}^{-3}\right)\end{array}$ & $\begin{array}{c}\text { Fragment } \\
\% \text { by } \\
\text { Volume }\end{array}$ & $\begin{array}{c}\text { Predicted } \\
\text { OC } \%\end{array}$ & $\begin{array}{c}\text { Predicted } \\
\text { 33kPa BD } \\
\left(\mathrm{g} \mathrm{cm}^{-3}\right)\end{array}$ & $\begin{array}{c}\text { SOC } \\
\text { Stock } \\
(\mathbf{k g} \\
\left.\mathbf{m}^{-2}\right)\end{array}$ \\
\hline 82PA117020 & 12 & 15 & $\mathrm{Oa}$ & 22.77 & & 20 & 22.77 & 0.61 & 3.33 \\
\hline 82PA117020 & 15 & 25 & $\mathrm{Eg}$ & 0.99 & 1.29 & 30 & 0.99 & 1.29 & 0.89 \\
\hline 82PA117020 & 25 & 35 & Btg1 & & 1.57 & 0 & 1.02 & 1.57 & 1.60 \\
\hline 82PA117020 & 35 & 48 & Btg2 & & 1.62 & 0 & 0.63 & 1.62 & 1.33 \\
\hline 82PA117020 & 48 & 58 & $\mathrm{~B} \times 1$ & & 1.72 & 15 & 0.65 & 1.72 & 0.95 \\
\hline 82PA117020 & 58 & 76 & $\mathrm{Bx} 2$ & & 1.68 & 15 & 0.41 & 1.68 & 1.04 \\
\hline 82PA117020 & 76 & 91 & $\mathrm{~B} \times 3$ & & 1.79 & 15 & 0.31 & 1.79 & 0.71 \\
\hline 82PA117020 & 91 & 114 & $\mathrm{Bx} 4$ & & 1.68 & 15 & 0.25 & 1.68 & 0.82 \\
\hline 82PA117020 & 114 & 134 & $\mathrm{~B} \times 5$ & & 1.68 & 30 & 0.25 & 1.68 & 0.59 \\
\hline 82PA117020 & 134 & 152 & $2 \mathrm{Cg} 1$ & & & 65 & 0.27 & 1.73 & 0.30 \\
\hline 82PA117020 & 152 & 167 & $2 \mathrm{Cg} 2$ & & & 75 & 0.26 & 1.74 & 0.17 \\
\hline 82PA117020 & 167 & 203 & $2 \mathrm{Cg} 3$ & & & 70 & 0.26 & 1.74 & 0.49 \\
\hline 82PA117020 & 203 & 233 & $2 \mathrm{Cg} 4$ & & & 70 & 0.42 & 1.73 & 0.66 \\
\hline 83PA105003 & 0 & 5 & $\mathrm{Oa}$ & 54.44 & & 10 & 54.44 & 0.53 & 13.03 \\
\hline 83PA105003 & 5 & 13 & $\mathrm{~A}$ & 12.17 & 1.17 & 15 & 12.17 & 1.17 & 9.68 \\
\hline 83PA105003 & 13 & 28 & Bw1 & 3.41 & 1.19 & 15 & 3.41 & 1.19 & 5.17 \\
\hline 83PA105003 & 28 & 53 & Bw2 & 1.35 & 1.78 & 10 & 1.35 & 1.78 & 5.40 \\
\hline 83PA105003 & 53 & 79 & Bw3 & 0.38 & 1.71 & 35 & 0.38 & 1.71 & 1.11 \\
\hline 83PA105003 & 79 & 96 & $\mathrm{Bt1}$ & 0.20 & 1.58 & 35 & 0.20 & 1.58 & 0.35 \\
\hline 83PA105003 & 96 & 122 & $\mathrm{Bt} 2$ & 0.27 & 1.57 & 35 & 0.27 & 1.57 & 0.72 \\
\hline 83PA105003 & 122 & 147 & $\mathrm{Bt} 3$ & 0.20 & 1.59 & 40 & 0.20 & 1.59 & 0.47 \\
\hline 83PA105003 & 147 & 168 & 2Btb1 & 0.21 & 1.52 & 10 & 0.21 & 1.52 & 0.61 \\
\hline 83PA105003 & 168 & 185 & 2Btb2 & 0.18 & 1.52 & 10 & 0.18 & 1.52 & 0.43 \\
\hline
\end{tabular}




\begin{tabular}{|c|c|c|c|c|c|c|c|c|c|}
\hline PedonID & $\begin{array}{c}\text { Top } \\
\text { Depth } \\
\text { (cm) }\end{array}$ & $\begin{array}{c}\text { Bottom } \\
\text { Depth } \\
(\mathrm{cm})\end{array}$ & Horizon & $\begin{array}{c}\text { Total } \\
\text { Carbon\% } \\
\text { (Dry } \\
\text { Combustion, } \\
\text { Including } \\
\text { Converted } \\
\text { Walkley- } \\
\text { Black) }\end{array}$ & $\begin{array}{c}\text { 33kPa } \\
\text { Bulk } \\
\text { Density } \\
\left(\mathrm{g} \mathrm{cm}^{-3}\right)\end{array}$ & $\begin{array}{c}\text { Fragment } \\
\% \text { by } \\
\text { Volume }\end{array}$ & $\begin{array}{c}\text { Predicted } \\
\text { OC } \%\end{array}$ & $\begin{array}{c}\text { Predicted } \\
\text { 33kPa BD } \\
\left(\mathrm{g} \mathrm{cm}^{-3}\right)\end{array}$ & $\begin{array}{c}\text { SOC } \\
\text { Stock } \\
(\mathbf{k g} \\
\left.\mathbf{m}^{-2}\right)\end{array}$ \\
\hline 83PA105003 & 185 & 203 & 2Btb3 & 0.18 & 1.55 & 5 & 0.18 & 1.55 & 0.49 \\
\hline 83PA105003 & 203 & 236 & $2 \mathrm{Btb} 4$ & 0.14 & 1.53 & 10 & 0.14 & 1.53 & 0.65 \\
\hline 83PA105003 & 236 & 267 & 2BC1 & 0.07 & 1.54 & 25 & 0.07 & 1.54 & 0.25 \\
\hline 83PA105003 & 267 & 300 & $2 \mathrm{BC} 2$ & 0.09 & 1.51 & 45 & 0.09 & 1.51 & 0.23 \\
\hline 83PA105003 & 300 & 345 & $2 \mathrm{BC} 3$ & 0.07 & & 45 & 0.07 & 1.57 & 0.28 \\
\hline 83PA105004 & 0 & 5 & $\mathrm{Oi}$ & 49.39 & & 10 & 49.39 & 0.41 & 9.10 \\
\hline 83PA105004 & 5 & 10 & $\mathrm{Oe}$ & 46.65 & & 10 & 46.65 & 0.46 & 9.60 \\
\hline 83PA105004 & 10 & 13 & $\mathrm{Oa}$ & 30.51 & & 10 & 30.51 & 0.58 & 4.82 \\
\hline 83PA105004 & 13 & 16 & $\mathrm{E}$ & 2.51 & 1.56 & 10 & 2.51 & 1.56 & 1.06 \\
\hline 83PA105004 & 16 & 26 & Bt1 & 0.91 & 1.57 & 10 & 0.91 & 1.57 & 1.29 \\
\hline 83PA105004 & 26 & 38 & $\mathrm{Bt} 2$ & 0.79 & 1.60 & 10 & 0.79 & 1.60 & 1.37 \\
\hline 83PA105004 & 38 & 59 & $\mathrm{Bt3}$ & 0.42 & 1.58 & 10 & 0.42 & 1.58 & 1.25 \\
\hline 83PA105004 & 59 & 71 & 2Btb1 & 0.32 & 1.56 & 5 & 0.32 & 1.56 & 0.57 \\
\hline 83PA105004 & 71 & 89 & 2Btb2 & 0.26 & & 5 & 0.26 & 1.55 & 0.70 \\
\hline 83PA105004 & 89 & 110 & 2Btb3 & 0.20 & & 15 & 0.20 & 1.56 & 0.55 \\
\hline 83PA105004 & 110 & 140 & 2Btb4 & 0.24 & & 15 & 0.24 & 1.57 & 0.97 \\
\hline 83PA105004 & 140 & 165 & 2Btb5 & 0.23 & & 15 & 0.23 & 1.58 & 0.77 \\
\hline 83PA105005 & 0 & 5 & Oi & & & 10 & 47.82 & 0.41 & 8.88 \\
\hline 83PA105005 & 5 & 10 & $\mathrm{Oe}$ & & & 10 & 38.92 & 0.46 & 8.13 \\
\hline 83PA105005 & 10 & 15 & $\mathrm{Oa}$ & & & 10 & 29.35 & 0.59 & 7.79 \\
\hline 83PA105005 & 15 & 18 & $\mathrm{E}$ & & & 20 & 1.49 & 1.40 & 0.50 \\
\hline 83PA105005 & 18 & 33 & Bt1 & & & 20 & 1.29 & 1.45 & 2.23 \\
\hline 83PA105005 & 33 & 51 & $\mathrm{Bt} 2$ & & & 20 & 0.64 & 1.47 & 1.37 \\
\hline
\end{tabular}




\begin{tabular}{|c|c|c|c|c|c|c|c|c|c|}
\hline PedonID & $\begin{array}{c}\text { Top } \\
\text { Depth } \\
\text { (cm) }\end{array}$ & $\begin{array}{c}\text { Bottom } \\
\text { Depth } \\
\text { (cm) }\end{array}$ & Horizon & $\begin{array}{c}\text { Total } \\
\text { Carbon\% } \\
\text { (Dry } \\
\text { Combustion, } \\
\text { Including } \\
\text { Converted } \\
\text { Walkley- } \\
\text { Black) } \\
\end{array}$ & $\begin{array}{c}\text { 33kPa } \\
\text { Bulk } \\
\text { Density } \\
\left(\mathrm{g} \mathrm{cm}^{-3}\right)\end{array}$ & $\begin{array}{c}\text { Fragment } \\
\% \text { by } \\
\text { Volume }\end{array}$ & $\begin{array}{c}\text { Predicted } \\
\text { OC } \%\end{array}$ & $\begin{array}{c}\text { Predicted } \\
\text { 33kPa BD } \\
\left(\mathrm{g} \mathrm{cm}^{-3}\right)\end{array}$ & $\begin{array}{r}\text { SOC } \\
\text { Stock } \\
(\mathbf{k g} \\
\left.\mathbf{m}^{-2}\right)\end{array}$ \\
\hline 83PA105005 & 51 & 73 & $\mathrm{Bt} 3$ & & & 20 & 0.37 & 1.53 & 1.00 \\
\hline 83PA105005 & 73 & 104 & $\mathrm{Bt} 4$ & & & 25 & 0.36 & 1.56 & 1.30 \\
\hline 83PA105005 & 104 & 132 & 2Btb1 & & & 30 & 0.24 & 1.55 & 0.72 \\
\hline 83PA105005 & 132 & 162 & 2Btb2 & & & 30 & 0.28 & 1.55 & 0.91 \\
\hline 83PA105005 & 162 & 185 & 2Btb3 & & & 30 & 0.23 & 1.56 & 0.58 \\
\hline 83PA105005 & 185 & 200 & 2Btb4 & & & 30 & 0.23 & 1.54 & 0.37 \\
\hline 83PA105005 & 200 & 226 & 2Btb5 & & & 70 & 0.22 & 1.56 & 0.26 \\
\hline 83PA105005 & 226 & 251 & $3 \mathrm{C} 1$ & & & 70 & 0.23 & 1.52 & 0.27 \\
\hline 83PA105005 & 251 & 274 & $3 \mathrm{C} 2$ & & & 70 & 0.16 & 1.55 & 0.17 \\
\hline 83PA105005 & 274 & 302 & $3 \mathrm{C} 3$ & & & 80 & 0.18 & 1.56 & 0.15 \\
\hline 83PA117021 & 0 & 7 & Oi & 49.94 & & 25 & 49.94 & 0.35 & 9.21 \\
\hline 83PA117021 & 7 & 10 & $\mathrm{Oa}$ & 16.61 & & 15 & 16.61 & 0.43 & 1.80 \\
\hline 83PA117021 & 10 & 20 & $E$ & 0.66 & 1.56 & 25 & 0.66 & 1.56 & 0.77 \\
\hline 83PA117021 & 20 & 23 & Bhs & 1.98 & & 20 & 1.98 & 1.28 & 0.61 \\
\hline 83PA117021 & 23 & 40 & Bw1 & 0.77 & 1.45 & 20 & 0.77 & 1.45 & 1.52 \\
\hline 83PA117021 & 40 & 56 & Bw2 & & 1.49 & 20 & 0.58 & 1.49 & 1.10 \\
\hline 83PA117021 & 56 & 66 & Bw3 & & 1.58 & 20 & 0.40 & 1.58 & 0.51 \\
\hline 83PA117021 & 66 & 76 & $2 \mathrm{C} 1$ & & & 75 & 0.44 & 1.44 & 0.16 \\
\hline 83PA117021 & 76 & 91 & $2 \mathrm{C} 2$ & & & 95 & 0.36 & 1.46 & 0.04 \\
\hline 83PA117022 & 0 & 5 & Oi & 52.47 & & 15 & 0.27 & 1.69 & 1.13 \\
\hline 83PA117022 & 5 & 8 & $\mathrm{Oa}$ & 22.44 & & 15 & 0.25 & 1.70 & 0.61 \\
\hline 83PA117022 & 8 & 18 & $\mathrm{BA}$ & 1.76 & & 10 & 0.24 & 1.71 & 0.55 \\
\hline 83PA117022 & 18 & 38 & Bw1 & & 1.47 & 15 & 0.23 & 1.73 & 0.65 \\
\hline
\end{tabular}




\begin{tabular}{|c|c|c|c|c|c|c|c|c|c|}
\hline PedonID & $\begin{array}{c}\text { Top } \\
\text { Depth } \\
\text { (cm) }\end{array}$ & $\begin{array}{c}\text { Bottom } \\
\text { Depth } \\
(\mathrm{cm})\end{array}$ & Horizon & $\begin{array}{c}\text { Total } \\
\text { Carbon\% } \\
\text { (Dry } \\
\text { Combustion, } \\
\text { Including } \\
\text { Converted } \\
\text { Walkley- } \\
\text { Black) } \\
\end{array}$ & $\begin{array}{c}\text { 33kPa } \\
\text { Bulk } \\
\text { Density } \\
\left(\mathrm{g} \mathrm{cm}^{-3}\right)\end{array}$ & $\begin{array}{c}\text { Fragment } \\
\% \text { by } \\
\text { Volume }\end{array}$ & $\begin{array}{c}\text { Predicted } \\
\text { OC } \%\end{array}$ & $\begin{array}{c}\text { Predicted } \\
\text { 33kPa BD } \\
\left(\mathrm{g} \mathrm{cm}^{-3}\right)\end{array}$ & $\begin{array}{c}\text { SOC } \\
\text { Stock } \\
(\mathbf{k g} \\
\left.\mathbf{m}^{-2}\right)\end{array}$ \\
\hline 83PA117022 & 38 & 54 & Bw2 & & 1.52 & 15 & 48.62 & 1.02 & 9.90 \\
\hline 83PA117022 & 54 & 69 & Bw3 & & 1.64 & 15 & 25.96 & 0.50 & 3.92 \\
\hline 83PA117022 & 69 & 94 & Bx1 & & 1.89 & 20 & 0.99 & 1.46 & 1.04 \\
\hline 83PA117022 & 94 & 112 & $\mathrm{Bx} 2$ & & 1.86 & 20 & 1.98 & 1.30 & 1.53 \\
\hline 83PA117022 & 112 & 130 & $\mathrm{~B} \times 3$ & & 1.85 & 20 & 1.38 & 1.45 & 2.55 \\
\hline 83PA117022 & 130 & 150 & Btx & & 1.87 & 20 & 0.57 & 1.36 & 1.38 \\
\hline 83PA117022 & 150 & 165 & 2Btb1 & & 1.73 & 10 & 0.36 & 1.61 & 1.31 \\
\hline 83PA117022 & 165 & 181 & 2Btb2 & & 1.76 & 10 & 0.29 & 1.83 & 1.05 \\
\hline 83PA117022 & 181 & 209 & 2Btb3 & & 1.69 & 10 & 0.27 & 1.85 & 0.93 \\
\hline 83PA117022 & 209 & 226 & 2Btb4 & & 1.70 & 15 & 0.25 & 1.88 & 0.49 \\
\hline 83PA117022 & 226 & 242 & 2Btb5 & & & 15 & 0.18 & 1.66 & 0.19 \\
\hline 83PA117022 & 242 & 262 & 2Btb6 & & & 20 & 0.18 & 1.71 & 0.16 \\
\hline 83PA117023 & 0 & 2 & Oi & 48.62 & & 0 & 52.47 & 0.39 & 8.66 \\
\hline 83PA117023 & 2 & 5 & $\mathrm{Oa}$ & 25.96 & & 0 & 22.44 & 0.52 & 2.99 \\
\hline 83PA117023 & 5 & 13 & $\mathrm{E}$ & 0.99 & & 10 & 1.76 & 1.25 & 1.98 \\
\hline 83PA117023 & 13 & 20 & Bs & 1.98 & & 15 & 1.14 & 1.47 & 2.85 \\
\hline 83PA117023 & 20 & 35 & Bt1 & & & 15 & 0.46 & 1.52 & 0.95 \\
\hline 83PA117023 & 35 & 56 & $\mathrm{Bt} 2$ & & 1.36 & 15 & 0.34 & 1.64 & 0.72 \\
\hline 83PA117023 & 56 & 84 & $\mathrm{Bx} 1$ & & 1.61 & 20 & 0.24 & 1.89 & 0.89 \\
\hline 83PA117023 & 84 & 109 & $\mathrm{~B} \times 2$ & & 1.83 & 20 & 0.21 & 1.86 & 0.57 \\
\hline 83PA117023 & 109 & 132 & $\mathrm{~B} \times 3$ & & 1.85 & 20 & 0.16 & 1.85 & 0.43 \\
\hline 83PA117023 & 132 & 145 & $\mathrm{BC}$ & & 1.88 & 20 & 0.18 & 1.87 & 0.53 \\
\hline 83PA117023 & 145 & 157 & $2 \mathrm{C} 1$ & & & 45 & 0.29 & 1.73 & 0.69 \\
\hline
\end{tabular}




\begin{tabular}{|c|c|c|c|c|c|c|c|c|c|}
\hline PedonID & $\begin{array}{c}\text { Top } \\
\text { Depth } \\
\text { (cm) }\end{array}$ & $\begin{array}{c}\text { Bottom } \\
\text { Depth } \\
\text { (cm) }\end{array}$ & Horizon & $\begin{array}{c}\text { Total } \\
\text { Carbon\% } \\
\text { (Dry } \\
\text { Combustion, } \\
\text { Including } \\
\text { Converted } \\
\text { Walkley- } \\
\text { Black) } \\
\end{array}$ & $\begin{array}{c}\text { 33kPa } \\
\text { Bulk } \\
\text { Density } \\
\left(\mathrm{g} \mathrm{cm}^{-3}\right)\end{array}$ & $\begin{array}{c}\text { Fragment } \\
\% \text { by } \\
\text { Volume }\end{array}$ & $\begin{array}{c}\text { Predicted } \\
\text { OC } \%\end{array}$ & $\begin{array}{c}\text { Predicted } \\
\text { 33kPa BD } \\
\left(\mathrm{g} \mathrm{cm}^{-3}\right)\end{array}$ & $\begin{array}{c}\text { SOC } \\
\text { Stock } \\
(\mathbf{k g} \\
\left.\mathbf{m}^{-2}\right)\end{array}$ \\
\hline 83PA117023 & 157 & 183 & $2 \mathrm{C} 2$ & & & 80 & 0.31 & 1.76 & 0.80 \\
\hline 83PA117027 & 0 & 5 & Oi & 52.58 & & 0 & 52.58 & 0.47 & 12.44 \\
\hline 83PA117027 & 5 & 8 & $\mathrm{Oa}$ & 22.55 & & 25 & 22.55 & 0.62 & 3.13 \\
\hline 83PA117027 & 8 & 16 & $E$ & 1.32 & & 15 & 1.32 & 1.45 & 1.31 \\
\hline 83PA117027 & 16 & 18 & Bhs & 2.86 & & 10 & 2.86 & 1.26 & 0.65 \\
\hline 83PA117027 & 18 & 31 & $\mathrm{Bw}$ & 0.77 & & 20 & 0.77 & 1.45 & 1.16 \\
\hline 83PA117027 & 31 & 44 & Bt1 & & & 20 & 0.73 & 1.49 & 1.12 \\
\hline 83PA117027 & 44 & 56 & $\mathrm{Bt} 2$ & & & 20 & 0.44 & 1.53 & 0.65 \\
\hline 83PA117027 & 56 & 66 & 2Btb1 & & & 15 & 0.35 & 1.56 & 0.47 \\
\hline 83PA117027 & 66 & 79 & 2Btb2 & & & 15 & 0.31 & 1.55 & 0.54 \\
\hline 83PA117027 & 79 & 97 & 2Btb3 & & & 30 & 0.25 & 1.58 & 0.50 \\
\hline 83PA117027 & 97 & 110 & 2Btb4 & & & 30 & 0.31 & 1.59 & 0.45 \\
\hline 83PA117027 & 110 & 130 & 2Btb5 & & & 35 & 0.36 & 1.61 & 0.74 \\
\hline 83PA117027 & 130 & 148 & 2Btb6 & & & 35 & 0.35 & 1.59 & 0.65 \\
\hline 83PA117027 & 148 & 176 & 2Btb7 & & & 40 & 0.34 & 1.59 & 0.92 \\
\hline 83PA117027 & 176 & 191 & 2Btb8 & & & 40 & 0.34 & 1.60 & 0.49 \\
\hline 83PA117027 & 191 & 216 & 2Btb9 & & & 45 & 0.35 & 1.59 & 0.78 \\
\hline 83PA117027 & 216 & 226 & $2 \mathrm{BC}$ & & & 35 & 0.30 & 1.64 & 0.32 \\
\hline 83PA117027 & 226 & 242 & $2 \mathrm{C} 1$ & & & 90 & 0.31 & 1.58 & 0.08 \\
\hline 83PA117027 & 242 & 257 & $2 \mathrm{C} 2$ & & & 90 & 0.37 & 1.60 & 0.09 \\
\hline 83PA117028 & 0 & 5 & Oi & 73.70 & & 10 & 73.70 & 1.11 & 36.80 \\
\hline 83PA117028 & 5 & 8 & $\mathrm{Oa}$ & 39.90 & & 20 & 39.90 & 1.00 & 9.58 \\
\hline 83PA117028 & 8 & 16 & $\mathrm{E}$ & 0.99 & & 20 & 0.99 & 1.48 & 0.94 \\
\hline
\end{tabular}




\begin{tabular}{|c|c|c|c|c|c|c|c|c|c|}
\hline PedonID & $\begin{array}{c}\text { Top } \\
\text { Depth } \\
\text { (cm) }\end{array}$ & $\begin{array}{c}\text { Bottom } \\
\text { Depth } \\
(\mathrm{cm})\end{array}$ & Horizon & $\begin{array}{c}\text { Total } \\
\text { Carbon\% } \\
\text { (Dry } \\
\text { Combustion, } \\
\text { Including } \\
\text { Converted } \\
\text { Walkley- } \\
\text { Black) } \\
\end{array}$ & $\begin{array}{c}\text { 33kPa } \\
\text { Bulk } \\
\text { Density } \\
\left(\mathrm{g} \mathrm{cm}^{-3}\right)\end{array}$ & $\begin{array}{c}\text { Fragment } \\
\% \text { by } \\
\text { Volume }\end{array}$ & $\begin{array}{c}\text { Predicted } \\
\text { OC } \%\end{array}$ & $\begin{array}{c}\text { Predicted } \\
\text { 33kPa BD } \\
\left(\mathrm{g} \mathrm{cm}^{-3}\right)\end{array}$ & $\begin{array}{c}\text { SOC } \\
\text { Stock } \\
(\mathbf{k g} \\
\left.\mathbf{m}^{-2}\right)\end{array}$ \\
\hline 83PA117028 & 16 & 26 & $\mathrm{Bw}$ & 1.14 & & 10 & 1.14 & 1.51 & 1.55 \\
\hline 83PA117028 & 26 & 33 & Bt1 & & & 5 & 0.87 & 1.50 & 0.87 \\
\hline 83PA117028 & 33 & 46 & $\mathrm{Bt} 2$ & & & 5 & 0.50 & 1.55 & 0.96 \\
\hline 83PA117028 & 46 & 56 & Bt3 & & & 15 & 0.51 & 1.54 & 0.67 \\
\hline 83PA117028 & 56 & 69 & 2Btb1 & & & 10 & 0.36 & 1.56 & 0.65 \\
\hline 83PA117028 & 69 & 84 & 2Btb2 & & & 10 & 0.32 & 1.56 & 0.68 \\
\hline 83PA117028 & 84 & 110 & 2Btb3 & & & 10 & 0.40 & 1.53 & 1.42 \\
\hline 83PA117028 & 110 & 132 & 2Btb4 & & & 10 & 0.28 & 1.56 & 0.87 \\
\hline 83PA117028 & 132 & 160 & 2Btb5 & & & 15 & 0.28 & 1.57 & 1.06 \\
\hline 83PA117028 & 160 & 173 & $2 \mathrm{BC} 1$ & & & 20 & 0.18 & 1.67 & 0.31 \\
\hline 83PA117028 & 173 & 183 & $2 \mathrm{BC} 2$ & & & 70 & 0.30 & 1.65 & 0.15 \\
\hline 83PA117028 & 183 & 232 & $\mathrm{C}$ & & & 0 & 0.21 & 1.61 & 1.68 \\
\hline 87PA027082 & 0 & 8 & $\mathrm{~A}$ & 13.21 & & 15 & 13.21 & 1.06 & 9.48 \\
\hline 87PA027082 & 8 & 23 & $E$ & 0.80 & 1.58 & 15 & 0.80 & 1.58 & 1.60 \\
\hline 87PA027082 & 23 & 41 & Bw1 & 0.30 & 1.64 & 15 & 0.30 & 1.64 & 0.75 \\
\hline 87PA027082 & 41 & 61 & Bw2 & 0.20 & 1.65 & 15 & 0.20 & 1.65 & 0.56 \\
\hline 87PA027082 & 61 & 79 & $\mathrm{Bx} 1$ & 0.80 & 1.67 & 20 & 0.80 & 1.67 & 1.91 \\
\hline 87PA027082 & 79 & 104 & $\mathrm{Bx} 2$ & & 1.86 & 25 & 0.30 & 1.86 & 1.06 \\
\hline 87PA027082 & 104 & 132 & $\mathrm{~B} \times 3$ & 0.20 & 1.86 & 30 & 0.20 & 1.86 & 0.72 \\
\hline 87PA027082 & 132 & 158 & $\mathrm{Bx} 4$ & 0.11 & 1.88 & 30 & 0.11 & 1.88 & 0.39 \\
\hline 87PA027082 & 158 & 203 & $\mathrm{Bx} 5$ & 0.23 & 1.94 & 20 & 0.23 & 1.94 & 1.59 \\
\hline 87PA027082 & 203 & 243 & Bx6 & 0.38 & 1.89 & 15 & 0.38 & 1.89 & 2.46 \\
\hline 87PA027082 & 243 & 305 & $2 \mathrm{C}$ & 0.13 & 1.81 & 35 & 0.13 & 1.81 & 0.93 \\
\hline
\end{tabular}




\begin{tabular}{|c|c|c|c|c|c|c|c|c|c|}
\hline PedonID & $\begin{array}{c}\text { Top } \\
\text { Depth } \\
\text { (cm) }\end{array}$ & $\begin{array}{c}\text { Bottom } \\
\text { Depth } \\
(\mathrm{cm})\end{array}$ & Horizon & $\begin{array}{c}\text { Total } \\
\text { Carbon\% } \\
\text { (Dry } \\
\text { Combustion, } \\
\text { Including } \\
\text { Converted } \\
\text { Walkley- } \\
\text { Black) } \\
\end{array}$ & $\begin{array}{c}\text { 33kPa } \\
\text { Bulk } \\
\text { Density } \\
\left(\mathrm{g} \mathrm{cm}^{-3}\right)\end{array}$ & $\begin{array}{c}\text { Fragment } \\
\% \text { by } \\
\text { Volume }\end{array}$ & $\begin{array}{l}\text { Predicted } \\
\text { OC } \%\end{array}$ & $\begin{array}{c}\text { Predicted } \\
\text { 33kPa BD } \\
\left(\mathrm{g} \mathrm{cm}^{-3}\right)\end{array}$ & $\begin{array}{c}\text { SOC } \\
\text { Stock } \\
(\mathbf{k g} \\
\left.\mathrm{m}^{-2}\right)\end{array}$ \\
\hline 87PA027083 & 0 & 2 & $\mathrm{Oi}$ & & & 10 & 42.37 & 0.39 & 2.96 \\
\hline 87PA027083 & 2 & 4 & $\mathrm{Oa}$ & & & 10 & 31.02 & 0.57 & 3.21 \\
\hline 87PA027083 & 4 & 12 & $\mathrm{E}$ & 0.47 & & 10 & 0.47 & 1.51 & 0.51 \\
\hline 87PA027083 & 12 & 17 & Bhs & 1.68 & & 10 & 1.68 & 1.35 & 1.02 \\
\hline 87PA027083 & 17 & 27 & Bs & 0.92 & 1.36 & 10 & 0.92 & 1.36 & 1.13 \\
\hline 87PA027083 & 27 & 47 & Bt1 & 0.13 & 1.75 & 10 & 0.13 & 1.75 & 0.40 \\
\hline 87PA027083 & 47 & 75 & $\mathrm{Bt} 2$ & 0.01 & 1.78 & 20 & 0.01 & 1.78 & 0.06 \\
\hline 87PA027083 & 75 & 98 & $\mathrm{Bt3}$ & 0.01 & 1.69 & 45 & 0.01 & 1.69 & 0.03 \\
\hline 87PA027083 & 98 & 126 & $\mathrm{Bt} 4$ & & 1.80 & 25 & 0.15 & 1.80 & 0.58 \\
\hline 87PA027083 & 126 & 141 & $\mathrm{BC}$ & & 1.75 & 30 & 0.12 & 1.75 & 0.23 \\
\hline 87PA027083 & 141 & 172 & $\mathrm{C} 1$ & & & 65 & 2.86 & 1.65 & 5.12 \\
\hline 87PA027083 & 172 & 207 & $\mathrm{C} 2$ & 0.04 & & 80 & 0.04 & 1.73 & 0.05 \\
\hline 88PA021011 & 0 & 6 & $\mathrm{Oe}$ & 27.35 & 0.26 & 5 & 27.35 & 0.26 & 4.05 \\
\hline 88PA021011 & 6 & 20 & Ap & 3.94 & 1.02 & 15 & 3.94 & 1.02 & 4.78 \\
\hline 88PA021011 & 20 & 48 & $\mathrm{Bw}$ & 1.47 & 1.42 & 25 & 1.47 & 1.42 & 4.40 \\
\hline 88PA021011 & 48 & 68 & CB1 & 0.36 & 1.43 & 40 & 0.36 & 1.43 & 0.62 \\
\hline 88PA021011 & 68 & 94 & CB2 & 0.35 & 1.48 & 40 & 0.35 & 1.48 & 0.81 \\
\hline 88PA021012 & 0 & 8 & Oe & 27.11 & 0.37 & 25 & 27.11 & 0.37 & 6.02 \\
\hline 88PA021012 & 8 & 14 & $\mathrm{AE}$ & 2.50 & 1.55 & 20 & 2.50 & 1.55 & 1.86 \\
\hline 88PA021012 & 22 & 33 & Bt1 & 2.78 & 1.24 & 45 & 2.78 & 1.24 & 2.09 \\
\hline 88PA021012 & 41 & 60 & $\mathrm{Bt} 2$ & 2.98 & 1.27 & 50 & 2.98 & 1.27 & 3.60 \\
\hline 88PA021012 & 68 & 77 & $\mathrm{C}$ & 2.80 & 0.49 & 70 & 2.80 & 0.49 & 0.37 \\
\hline 88PA021013 & 0 & 3 & Oe & 48.71 & 0.48 & 5 & 48.71 & 0.48 & 6.66 \\
\hline
\end{tabular}




\begin{tabular}{|c|c|c|c|c|c|c|c|c|c|}
\hline PedonID & $\begin{array}{c}\text { Top } \\
\text { Depth } \\
\text { (cm) }\end{array}$ & $\begin{array}{c}\text { Bottom } \\
\text { Depth } \\
(\mathrm{cm})\end{array}$ & Horizon & $\begin{array}{c}\text { Total } \\
\text { Carbon\% } \\
\text { (Dry } \\
\text { Combustion, } \\
\text { Including } \\
\text { Converted } \\
\text { Walkley- } \\
\text { Black) } \\
\end{array}$ & $\begin{array}{c}\text { 33kPa } \\
\text { Bulk } \\
\text { Density } \\
\left(\mathrm{g} \mathrm{cm}^{-3}\right)\end{array}$ & $\begin{array}{c}\text { Fragment } \\
\% \text { by } \\
\text { Volume }\end{array}$ & $\begin{array}{c}\text { Predicted } \\
\text { OC } \%\end{array}$ & $\begin{array}{c}\text { Predicted } \\
\text { 33kPa BD } \\
\left(\mathrm{g} \mathrm{cm}^{-3}\right)\end{array}$ & $\begin{array}{c}\text { SOC } \\
\text { Stock } \\
(\mathbf{k g} \\
\left.\mathbf{m}^{-2}\right)\end{array}$ \\
\hline 88PA021013 & 3 & 19 & $\mathrm{AE}$ & 3.32 & 1.44 & 8 & 3.32 & 1.44 & 7.04 \\
\hline 88PA021013 & 19 & 34 & $\mathrm{Bw}$ & 0.43 & 1.83 & 15 & 0.43 & 1.83 & 0.99 \\
\hline 88PA021013 & 34 & 60 & Bt1 & 0.33 & 1.58 & 15 & 0.33 & 1.58 & 1.14 \\
\hline 88PA021013 & 60 & 86 & $\mathrm{Bt} 2$ & 0.26 & 1.73 & 20 & 0.26 & 1.73 & 0.92 \\
\hline 88PA021013 & 86 & 131 & $\mathrm{Bt} 3$ & 0.17 & 1.81 & 20 & 0.17 & 1.81 & 1.11 \\
\hline 88PA021013 & 131 & 193 & $\mathrm{Bt} 4$ & 0.30 & 1.61 & 50 & 0.30 & 1.61 & 1.49 \\
\hline 88PA021014 & 0 & 3 & $\mathrm{Oe}$ & & & 2 & 39.13 & 0.44 & 5.12 \\
\hline 88PA021014 & 3 & 20 & $\mathrm{AE}$ & 2.31 & 1.56 & 4 & 2.31 & 1.56 & 5.89 \\
\hline 88PA021014 & 20 & 28 & $\mathrm{Bw}$ & 1.28 & 1.41 & 4 & 1.28 & 1.41 & 1.38 \\
\hline 88PA021014 & 28 & 42 & Bt1 & 1.29 & 1.35 & 6 & 1.29 & 1.35 & 2.30 \\
\hline 88PA021014 & 42 & 61 & $\mathrm{Bt} 2$ & 3.17 & 1.15 & 6 & 3.17 & 1.15 & 6.50 \\
\hline 88PA021014 & 61 & 98 & $\mathrm{Bt} 3$ & 0.78 & 1.50 & 10 & 0.78 & 1.50 & 3.90 \\
\hline 88PA021014 & 98 & 131 & $\mathrm{Bt} 4$ & 0.50 & 1.66 & 10 & 0.50 & 1.66 & 2.45 \\
\hline 88PA021014 & 131 & 203 & $\mathrm{Bt} 5$ & 0.31 & 1.62 & 13 & 0.31 & 1.62 & 3.17 \\
\hline 88PA021015 & 0 & 3 & $\mathrm{Oe}$ & & & 0 & 30.95 & 0.46 & 4.27 \\
\hline 88PA021015 & 3 & 20 & $\mathrm{AB}$ & 2.32 & 1.25 & 5 & 2.32 & 1.25 & 4.69 \\
\hline 88PA021015 & 20 & 42 & Bt1 & 0.75 & 1.43 & 5 & 0.75 & 1.43 & 2.24 \\
\hline 88PA021015 & 42 & 72 & $\mathrm{Bt} 2$ & 0.42 & 1.47 & 5 & 0.42 & 1.47 & 1.75 \\
\hline 88PA021015 & 72 & 99 & $\mathrm{Bt} 3$ & 0.19 & 1.68 & 15 & 0.19 & 1.68 & 0.72 \\
\hline 88PA021015 & 99 & 123 & $\mathrm{Bt} 4$ & 0.14 & 1.73 & 15 & 0.14 & 1.73 & 0.50 \\
\hline 88PA021015 & 123 & 157 & $\mathrm{Bt} 5$ & 0.17 & 1.70 & 15 & 0.17 & 1.70 & 0.81 \\
\hline 88PA021015 & 157 & 203 & $\mathrm{C}$ & 0.11 & 1.70 & 15 & 0.11 & 1.70 & 0.73 \\
\hline 88PA021016 & 0 & 7 & Ap1 & 9.97 & 1.67 & 2 & 0.31 & 1.42 & 1.13 \\
\hline
\end{tabular}




\begin{tabular}{|c|c|c|c|c|c|c|c|c|c|}
\hline PedonID & $\begin{array}{c}\text { Top } \\
\text { Depth } \\
\text { (cm) }\end{array}$ & $\begin{array}{c}\text { Bottom } \\
\text { Depth } \\
\text { (cm) }\end{array}$ & Horizon & $\begin{array}{c}\text { Total } \\
\text { Carbon\% } \\
\text { (Dry } \\
\text { Combustion, } \\
\text { Including } \\
\text { Converted } \\
\text { Walkley- } \\
\text { Black) }\end{array}$ & $\begin{array}{c}\text { 33kPa } \\
\text { Bulk } \\
\text { Density } \\
\left(\mathrm{g} \mathrm{cm}^{-3}\right)\end{array}$ & $\begin{array}{c}\text { Fragment } \\
\% \text { by } \\
\text { Volume }\end{array}$ & $\begin{array}{c}\text { Predicted } \\
\text { OC } \%\end{array}$ & $\begin{array}{c}\text { Predicted } \\
\text { 33kPa BD } \\
\left(\mathrm{g} \mathrm{cm}^{-3}\right)\end{array}$ & $\begin{array}{c}\text { SOC } \\
\text { Stock } \\
(\mathbf{k g} \\
\left.\mathbf{m}^{-2}\right)\end{array}$ \\
\hline 88PA021016 & 7 & 18 & Ap2 & 3.25 & 1.60 & 3 & 0.31 & 1.69 & 1.44 \\
\hline 88PA021016 & 18 & 32 & Bt1 & 1.04 & 1.72 & 5 & 0.27 & 1.18 & 1.38 \\
\hline 88PA021016 & 32 & 49 & $\mathrm{Bt} 2$ & 0.38 & 1.70 & 20 & 0.28 & 1.42 & 1.02 \\
\hline 88PA021016 & 49 & 79 & Btx1 & 0.31 & 1.42 & 15 & 20.59 & 0.26 & 2.68 \\
\hline 88PA021016 & 79 & 111 & Btx2 & 0.31 & 1.69 & 15 & 5.96 & 0.56 & 2.19 \\
\hline 88PA021016 & 111 & 164 & Btx3 & 0.27 & 1.18 & 18 & 1.68 & 1.34 & 5.19 \\
\hline 88PA021016 & 164 & 200 & $\mathrm{C}$ & 0.28 & 1.42 & 30 & 0.50 & 1.65 & 0.83 \\
\hline 88PA033031 & 0 & 5 & $\mathrm{Oe}$ & 20.59 & 0.26 & 0 & 9.97 & 1.67 & 11.42 \\
\hline 88PA033031 & 5 & 13 & $\mathrm{E}$ & 5.96 & 0.56 & 18 & 3.25 & 1.60 & 5.55 \\
\hline 88PA033031 & 13 & 43 & $\mathrm{Bt}$ & 1.68 & 1.34 & 23 & 1.04 & 1.72 & 2.37 \\
\hline 88PA033031 & 43 & 72 & $\mathrm{BC}$ & 0.50 & 1.65 & 65 & 0.38 & 1.70 & 0.89 \\
\hline 88PA033032 & 0 & 3 & $\mathrm{Oa}$ & & & 0 & 24.64 & 0.54 & 3.98 \\
\hline 88PA033032 & 3 & 19 & $\mathrm{E}$ & 2.68 & 1.29 & 5 & 2.68 & 1.29 & 5.26 \\
\hline 88PA033032 & 19 & 47 & Bw1 & 1.19 & 1.52 & 10 & 1.19 & 1.52 & 4.57 \\
\hline 88PA033032 & 47 & 60 & Bw2 & 1.09 & 1.72 & 10 & 1.09 & 1.72 & 2.20 \\
\hline 88PA033032 & 60 & 89 & $\mathrm{Bx}$ & 0.80 & 1.84 & 20 & 0.80 & 1.84 & 3.39 \\
\hline 88PA033032 & 89 & 126 & $\mathrm{C}$ & 0.33 & 1.33 & 65 & 0.33 & 1.33 & 0.56 \\
\hline 88PA033033 & 0 & 3 & Oi & & & 0 & 33.99 & 0.42 & 4.32 \\
\hline 88PA033033 & 3 & 13 & $\mathrm{~A}$ & 5.20 & 0.66 & 10 & 5.20 & 0.66 & 3.09 \\
\hline 88PA033033 & 13 & 27 & Bt1 & 2.70 & 1.53 & 15 & 2.70 & 1.53 & 4.91 \\
\hline 88PA033033 & 27 & 55 & $\mathrm{Bt} 2$ & 0.95 & 1.44 & 20 & 0.95 & 1.44 & 3.07 \\
\hline 88PA033033 & 55 & 82 & $\mathrm{Bt} 3$ & 0.61 & 1.48 & 30 & 0.61 & 1.48 & 1.71 \\
\hline 88PA033033 & 82 & 109 & $\mathrm{BC}$ & 0.68 & 1.50 & 50 & 0.68 & 1.50 & 1.38 \\
\hline
\end{tabular}




\begin{tabular}{|c|c|c|c|c|c|c|c|c|c|}
\hline PedonID & $\begin{array}{c}\text { Top } \\
\text { Depth } \\
\text { (cm) }\end{array}$ & $\begin{array}{c}\text { Bottom } \\
\text { Depth } \\
(\mathrm{cm})\end{array}$ & Horizon & $\begin{array}{c}\text { Total } \\
\text { Carbon\% } \\
\text { (Dry } \\
\text { Combustion, } \\
\text { Including } \\
\text { Converted } \\
\text { Walkley- } \\
\text { Black) } \\
\end{array}$ & $\begin{array}{c}\text { 33kPa } \\
\text { Bulk } \\
\text { Density } \\
\left(\mathrm{g} \mathrm{cm}^{-3}\right)\end{array}$ & $\begin{array}{c}\text { Fragment } \\
\% \text { by } \\
\text { Volume }\end{array}$ & $\begin{array}{l}\text { Predicted } \\
\text { OC } \%\end{array}$ & $\begin{array}{c}\text { Predicted } \\
\text { 33kPa BD } \\
\left(\mathrm{g} \mathrm{cm}^{-3}\right)\end{array}$ & $\begin{array}{c}\text { SOC } \\
\text { Stock } \\
(\mathbf{k g} \\
\left.\mathbf{m}^{-2}\right)\end{array}$ \\
\hline 88PA033033 & 109 & 154 & $\mathrm{C}$ & 0.67 & 1.20 & 95 & 0.67 & 1.20 & 0.18 \\
\hline 88PA033034 & 0 & 8 & $\mathrm{Oa}$ & 45.40 & 0.67 & 0 & 45.40 & 0.67 & 24.33 \\
\hline 88PA033034 & 8 & 17 & EA & 6.40 & 1.48 & 0 & 6.40 & 1.48 & 8.53 \\
\hline 88PA033034 & 17 & 39 & Bt1 & 2.78 & 1.32 & 0 & 2.78 & 1.32 & 8.08 \\
\hline 88PA033034 & 39 & 68 & $\mathrm{Bt} 2$ & 1.32 & 1.44 & 0 & 1.32 & 1.44 & 5.51 \\
\hline 88PA033034 & 68 & 93 & Btx & 1.02 & 1.67 & 0 & 1.02 & 1.67 & 4.27 \\
\hline 88PA033034 & 93 & 124 & Btgx & 0.95 & 1.68 & 25 & 0.95 & 1.68 & 3.72 \\
\hline 88PA033034 & 124 & 165 & $2 \mathrm{C}$ & 0.78 & 1.00 & 90 & 0.78 & 1.00 & 0.32 \\
\hline 88PA033035 & 0 & 3 & $\mathrm{Oe}$ & & & 0 & 31.48 & 0.47 & 4.40 \\
\hline 88PA033035 & 3 & 6 & $\mathrm{~A}$ & & & 5 & 12.66 & 1.00 & 3.60 \\
\hline 88PA033035 & 6 & 9 & $\mathrm{E}$ & & & 8 & 3.87 & 1.34 & 1.43 \\
\hline 88PA033035 & 9 & 37 & Bw1 & 1.92 & 1.30 & 10 & 1.92 & 1.30 & 6.28 \\
\hline 88PA033035 & 37 & 67 & Bw2 & 0.31 & 1.70 & 14 & 0.31 & 1.70 & 1.37 \\
\hline 88PA033035 & 67 & 92 & Bw3 & 0.14 & 1.71 & 14 & 0.14 & 1.71 & 0.52 \\
\hline 88PA033035 & 92 & 117 & $\mathrm{BC}$ & 0.16 & 1.67 & 35 & 0.16 & 1.67 & 0.42 \\
\hline 88PA033035 & 117 & 145 & $\mathrm{C}$ & 0.14 & 1.24 & 75 & 0.14 & 1.24 & 0.12 \\
\hline 88PA033036 & 0 & 3 & $\mathrm{Oe}$ & & & 0 & 36.06 & 0.52 & 5.59 \\
\hline 88PA033036 & 3 & 12 & $\mathrm{E}$ & 1.79 & 1.51 & 15 & 1.79 & 1.51 & 2.07 \\
\hline 88PA033036 & 12 & 27 & Bt1 & 1.72 & 1.19 & 15 & 1.72 & 1.19 & 2.61 \\
\hline 88PA033036 & 27 & 49 & $\mathrm{Bt} 2$ & 0.87 & 1.40 & 15 & 0.87 & 1.40 & 2.27 \\
\hline 88PA033036 & 49 & 71 & $\mathrm{Bt} 3$ & 0.21 & 1.76 & 15 & 0.21 & 1.76 & 0.70 \\
\hline 88PA033036 & 71 & 93 & Bgx 1 & 0.11 & 1.82 & 20 & 0.11 & 1.82 & 0.36 \\
\hline 88PA033036 & 93 & 116 & Bgx 2 & 0.10 & 1.92 & 20 & 0.10 & 1.92 & 0.35 \\
\hline
\end{tabular}




\begin{tabular}{|c|c|c|c|c|c|c|c|c|c|}
\hline PedonID & $\begin{array}{c}\text { Top } \\
\text { Depth } \\
(\mathbf{c m})\end{array}$ & $\begin{array}{c}\text { Bottom } \\
\text { Depth } \\
\text { (cm) }\end{array}$ & Horizon & $\begin{array}{c}\text { Total } \\
\text { Carbon\% } \\
\text { (Dry } \\
\text { Combustion, } \\
\text { Including } \\
\text { Converted } \\
\text { Walkley- } \\
\text { Black) } \\
\end{array}$ & $\begin{array}{c}\text { 33kPa } \\
\text { Bulk } \\
\text { Density } \\
\left(\mathrm{g} \mathrm{cm}^{-3}\right)\end{array}$ & $\begin{array}{c}\text { Fragment } \\
\% \text { by } \\
\text { Volume }\end{array}$ & $\begin{array}{c}\text { Predicted } \\
\text { OC } \%\end{array}$ & $\begin{array}{c}\text { Predicted } \\
\text { 33kPa BD } \\
\left(\mathrm{g} \mathrm{cm}^{-3}\right)\end{array}$ & $\begin{array}{c}\text { SOC } \\
\text { Stock } \\
(\mathbf{k g} \\
\left.\mathrm{m}^{-2}\right)\end{array}$ \\
\hline 88PA033036 & 116 & 150 & $\mathrm{BC}$ & 0.11 & 1.99 & 15 & 0.11 & 1.99 & 0.65 \\
\hline 88PA033036 & 150 & 185 & $\mathrm{C}$ & 0.13 & 1.82 & 15 & 0.13 & 1.82 & 0.69 \\
\hline 88PA033036 & 185 & 203 & $2 \mathrm{Bt} 3$ & 0.14 & 1.93 & 15 & 0.14 & 1.93 & 0.42 \\
\hline 88PA033037 & 0 & 3 & $\mathrm{Oe}$ & & & 0 & 37.84 & 0.55 & 6.21 \\
\hline 88PA033037 & 3 & 6 & A & & & 8 & 6.28 & 1.08 & 1.87 \\
\hline 88PA033037 & 6 & 32 & Bt1 & 1.62 & 1.43 & 0 & 1.62 & 1.43 & 6.02 \\
\hline 88PA033037 & 32 & 49 & $\mathrm{Bt} 2$ & 0.13 & 1.80 & 0 & 0.13 & 1.80 & 0.39 \\
\hline 88PA033037 & 49 & 79 & Bgx 1 & 0.13 & 1.85 & 5 & 0.13 & 1.85 & 0.67 \\
\hline 88PA033037 & 79 & 98 & Bgx 2 & 7.10 & 1.84 & 8 & 7.10 & 1.84 & 22.84 \\
\hline 88PA033037 & 98 & 119 & $\mathrm{~B} \times 3$ & 0.13 & 1.84 & 5 & 0.13 & 1.84 & 0.47 \\
\hline 88PA033037 & 119 & 173 & $\mathrm{BC}$ & 0.09 & 1.97 & 0 & 0.09 & 1.97 & 0.91 \\
\hline 88PA033037 & 173 & 203 & $2 \mathrm{Bt} 3$ & 0.16 & 1.85 & 19 & 0.16 & 1.85 & 0.70 \\
\hline 88PA033038 & 0 & 3 & Oe & & & 0 & 31.45 & 0.39 & 3.69 \\
\hline 88PA033038 & 3 & 8 & $\mathrm{~A}$ & 7.04 & 0.46 & 20 & 7.04 & 0.46 & 1.30 \\
\hline 88PA033038 & 8 & 27 & Bw1 & 2.19 & 1.51 & 40 & 2.19 & 1.51 & 3.76 \\
\hline 88PA033038 & 27 & 57 & Bw2 & 0.91 & 1.03 & 50 & 0.91 & 1.03 & 1.40 \\
\hline 88PA033038 & 57 & 73 & Bw3 & 0.38 & 0.96 & 65 & 0.38 & 0.96 & 0.21 \\
\hline 88PA033038 & 73 & 97 & $\mathrm{Bw} 4$ & 0.31 & & 65 & 0.31 & 1.37 & 0.36 \\
\hline 88PA033039 & 0 & 3 & Oe & & & 14 & 32.98 & 0.49 & 4.21 \\
\hline 88PA033039 & 3 & 5 & $\mathrm{Oa}$ & & & 0 & 24.52 & 0.54 & 2.65 \\
\hline 88PA033039 & 5 & 9 & $\mathrm{E}$ & & & 40 & 4.86 & 1.40 & 1.63 \\
\hline 88PA033039 & 9 & 20 & Bw1 & 1.75 & 1.12 & 25 & 1.75 & 1.12 & 1.61 \\
\hline 88PA033039 & 20 & 49 & Bw2 & 0.58 & 1.48 & 30 & 0.58 & 1.48 & 1.75 \\
\hline
\end{tabular}




\begin{tabular}{|c|c|c|c|c|c|c|c|c|c|}
\hline PedonID & $\begin{array}{c}\text { Top } \\
\text { Depth } \\
\text { (cm) }\end{array}$ & $\begin{array}{c}\text { Bottom } \\
\text { Depth } \\
\text { (cm) }\end{array}$ & Horizon & $\begin{array}{c}\text { Total } \\
\text { Carbon\% } \\
\text { (Dry } \\
\text { Combustion, } \\
\text { Including } \\
\text { Converted } \\
\text { Walkley- } \\
\text { Black) } \\
\end{array}$ & $\begin{array}{c}\text { 33kPa } \\
\text { Bulk } \\
\text { Density } \\
\left(\mathrm{g} \mathrm{cm}^{-3}\right)\end{array}$ & $\begin{array}{c}\text { Fragment } \\
\% \text { by } \\
\text { Volume }\end{array}$ & $\begin{array}{c}\text { Predicted } \\
\text { OC } \%\end{array}$ & $\begin{array}{c}\text { Predicted } \\
\text { 33kPa BD } \\
\left(\mathrm{g} \mathrm{cm}^{-3}\right)\end{array}$ & $\begin{array}{c}\text { SOC } \\
\text { Stock } \\
(\mathbf{k g} \\
\left.\mathbf{m}^{-2}\right)\end{array}$ \\
\hline 88PA033039 & 49 & 75 & Bw3 & 0.37 & 1.62 & 55 & 0.37 & 1.62 & 0.70 \\
\hline 88PA033039 & 75 & 105 & $\mathrm{C} 1$ & 0.20 & 1.66 & 60 & 0.20 & 1.66 & 0.40 \\
\hline 88PA033039 & 105 & 165 & $\mathrm{C} 2$ & 0.11 & 1.78 & 75 & 0.11 & 1.78 & 0.30 \\
\hline 88PA033040 & 0 & 4 & $\mathrm{Oe}$ & 47.98 & 0.49 & 5 & 47.98 & 0.49 & 8.93 \\
\hline 88PA033040 & 4 & 9 & A & 18.01 & 0.20 & 3 & 18.01 & 0.20 & 1.75 \\
\hline 88PA033040 & 9 & 34 & Bt1 & 2.87 & 1.34 & 3 & 2.87 & 1.34 & 9.33 \\
\hline 88PA033040 & 34 & 45 & $\mathrm{Bt} 2$ & 1.94 & 1.44 & 5 & 1.94 & 1.44 & 2.91 \\
\hline 88PA033040 & 45 & 58 & Btg & 0.51 & 1.62 & 7 & 0.51 & 1.62 & 0.99 \\
\hline 88PA033040 & 58 & 87 & $\mathrm{Bgx}$ & 0.17 & 1.96 & 10 & 0.17 & 1.96 & 0.84 \\
\hline 88PA033040 & 87 & 133 & $\mathrm{Bx} 1$ & 0.14 & 1.95 & 8 & 0.14 & 1.95 & 1.18 \\
\hline 88PA033040 & 133 & 153 & $\mathrm{Bx} 2$ & 0.14 & 2.00 & 10 & 0.14 & 2.00 & 0.51 \\
\hline 88PA033041 & 0 & 5 & $\mathrm{Oi}$ & & & 20 & 35.17 & 0.41 & 5.74 \\
\hline 88PA033041 & 5 & 12 & $\mathrm{E}$ & 2.64 & 0.87 & 50 & 2.64 & 0.87 & 0.80 \\
\hline 88PA033041 & 12 & 34 & Bt1 & 1.60 & 1.20 & 40 & 1.60 & 1.20 & 2.54 \\
\hline 88PA033041 & 34 & 55 & $\mathrm{Bt} 2$ & 0.58 & 1.57 & 40 & 0.58 & 1.57 & 1.15 \\
\hline 88PA033041 & 55 & 76 & $\mathrm{Bt} 3$ & 0.41 & 1.69 & 55 & 0.41 & 1.69 & 0.66 \\
\hline 88PA033041 & 76 & 95 & $\mathrm{BC}$ & 0.44 & 1.74 & 70 & 0.44 & 1.74 & 0.44 \\
\hline 88PA051021 & 0 & 16 & $\mathrm{~A}$ & 7.77 & 1.19 & 30 & 7.77 & 1.19 & 10.35 \\
\hline 88PA051021 & 16 & 43 & Bt1 & 1.45 & 1.69 & 10 & 1.45 & 1.69 & 5.95 \\
\hline 88PA051021 & 43 & 67 & $\mathrm{Bt} 2$ & 0.28 & 1.85 & 10 & 0.28 & 1.85 & 1.13 \\
\hline 88PA051021 & 67 & 85 & Bt3 & 0.11 & 1.76 & 15 & 0.11 & 1.76 & 0.31 \\
\hline 88PA051021 & 85 & 132 & $\mathrm{C}$ & 0.17 & 1.72 & 55 & 0.17 & 1.72 & 0.62 \\
\hline 88PA051022 & 0 & 10 & $\mathrm{AE}$ & 2.67 & 1.50 & 15 & 2.67 & 1.50 & 3.40 \\
\hline
\end{tabular}




\begin{tabular}{|c|c|c|c|c|c|c|c|c|c|}
\hline PedonID & $\begin{array}{c}\text { Top } \\
\text { Depth } \\
\text { (cm) }\end{array}$ & $\begin{array}{c}\text { Bottom } \\
\text { Depth } \\
\text { (cm) }\end{array}$ & Horizon & $\begin{array}{c}\text { Total } \\
\text { Carbon\% } \\
\text { (Dry } \\
\text { Combustion, } \\
\text { Including } \\
\text { Converted } \\
\text { Walkley- } \\
\text { Black) } \\
\end{array}$ & $\begin{array}{c}\text { 33kPa } \\
\text { Bulk } \\
\text { Density } \\
\left(\mathrm{g} \mathrm{cm}^{-3}\right)\end{array}$ & $\begin{array}{c}\text { Fragment } \\
\% \text { by } \\
\text { Volume }\end{array}$ & $\begin{array}{c}\text { Predicted } \\
\text { OC } \%\end{array}$ & $\begin{array}{c}\text { Predicted } \\
\text { 33kPa BD } \\
\left(\mathrm{g} \mathrm{cm}^{-3}\right)\end{array}$ & $\begin{array}{c}\text { SOC } \\
\text { Stock } \\
(\mathbf{k g} \\
\left.\mathbf{m}^{-2}\right)\end{array}$ \\
\hline 88PA051022 & 10 & 33 & $\mathrm{Bt}$ & 0.74 & 1.72 & 8 & 0.74 & 1.72 & 2.69 \\
\hline 88PA051022 & 33 & 58 & Btg & 0.44 & 1.81 & 10 & 0.44 & 1.81 & 1.79 \\
\hline 88PA051022 & 58 & 87 & Btx1 & 0.30 & 1.89 & 10 & 0.30 & 1.89 & 1.47 \\
\hline 88PA051022 & 87 & 132 & Btx2 & 0.34 & 1.88 & 15 & 0.34 & 1.88 & 2.45 \\
\hline 88PA051022 & 132 & 200 & Btg & 0.34 & 1.86 & 11 & 0.34 & 1.86 & 3.84 \\
\hline 88PA105011 & 0 & 2 & $\mathrm{Oe}$ & & & 15 & 31.47 & 0.42 & 2.25 \\
\hline 88PA105011 & 2 & 8 & $\mathrm{~A}$ & 3.39 & 1.14 & 20 & 3.39 & 1.14 & 1.86 \\
\hline 88PA105011 & 8 & 24 & $\mathrm{BA}$ & 1.76 & 1.28 & 20 & 1.76 & 1.28 & 2.88 \\
\hline 88PA105011 & 24 & 41 & Bw1 & 1.02 & 1.26 & 35 & 1.02 & 1.26 & 1.42 \\
\hline 88PA105011 & 41 & 66 & Bw2 & 0.94 & 1.28 & 55 & 0.94 & 1.28 & 1.35 \\
\hline 88PA105011 & 66 & 85 & $\mathrm{C} 1$ & 0.43 & 1.20 & 80 & 0.43 & 1.20 & 0.19 \\
\hline 88PA105011 & 85 & 124 & $\mathrm{C} 2$ & 0.26 & 1.78 & 80 & 0.26 & 1.78 & 0.35 \\
\hline 88PA105012 & 0 & 23 & Ap & 4.25 & 0.96 & 20 & 4.25 & 0.96 & 7.50 \\
\hline 88PA105012 & 23 & 48 & $\mathrm{BE}$ & 1.28 & 1.70 & 55 & 1.28 & 1.70 & 2.44 \\
\hline 88PA105012 & 48 & 76 & Bt1 & 1.16 & 1.38 & 55 & 1.16 & 1.38 & 2.02 \\
\hline 88PA105012 & 76 & 105 & $\mathrm{Bt} 2$ & 0.84 & 1.43 & 60 & 0.84 & 1.43 & 1.39 \\
\hline 88PA105012 & 105 & 128 & Bt3 & 0.54 & 1.38 & 65 & 0.54 & 1.38 & 0.60 \\
\hline 88PA105012 & 128 & 164 & $\mathrm{BC}$ & 0.41 & 1.32 & 70 & 0.41 & 1.32 & 0.59 \\
\hline 88PA105013 & 0 & 3 & $\mathrm{Oa}$ & & & 10 & 26.66 & 0.47 & 3.41 \\
\hline 88PA105013 & 3 & 10 & $E$ & 2.98 & 1.36 & 13 & 2.98 & 1.36 & 2.47 \\
\hline 88PA105013 & 10 & 33 & Bs & 2.81 & 1.22 & 25 & 2.81 & 1.22 & 5.92 \\
\hline 88PA105013 & 33 & 57 & Bw1 & 1.33 & 1.40 & 40 & 1.33 & 1.40 & 2.69 \\
\hline 88PA105013 & 57 & 85 & Bw2 & 0.54 & 1.55 & 70 & 0.54 & 1.55 & 0.70 \\
\hline
\end{tabular}




\begin{tabular}{|c|c|c|c|c|c|c|c|c|c|}
\hline PedonID & $\begin{array}{c}\text { Top } \\
\text { Depth } \\
\text { (cm) }\end{array}$ & $\begin{array}{c}\text { Bottom } \\
\text { Depth } \\
(\mathrm{cm})\end{array}$ & Horizon & $\begin{array}{c}\text { Total } \\
\text { Carbon\% } \\
\text { (Dry } \\
\text { Combustion, } \\
\text { Including } \\
\text { Converted } \\
\text { Walkley- } \\
\text { Black) }\end{array}$ & $\begin{array}{c}\text { 33kPa } \\
\text { Bulk } \\
\text { Density } \\
\left(\mathrm{g} \mathrm{cm}^{-3}\right)\end{array}$ & $\begin{array}{c}\text { Fragment } \\
\% \text { by } \\
\text { Volume }\end{array}$ & $\begin{array}{c}\text { Predicted } \\
\text { OC } \%\end{array}$ & $\begin{array}{c}\text { Predicted } \\
33 \mathrm{kPa} \mathrm{BD} \\
\left(\mathrm{g} \mathrm{cm}^{-3}\right)\end{array}$ & $\begin{array}{c}\text { SOC } \\
\text { Stock } \\
(\mathbf{k g} \\
\left.\mathbf{m}^{-2}\right)\end{array}$ \\
\hline 88PA105013 & 85 & 148 & $\mathrm{BC}$ & 0.23 & 1.70 & 85 & 0.23 & 1.70 & 0.36 \\
\hline 93NY009001 & 0 & 23 & $\mathrm{Ap}$ & 3.27 & & 5 & 3.27 & 1.22 & 8.72 \\
\hline 93NY009001 & 23 & 56 & $\mathrm{BE}$ & 0.25 & & 10 & 0.25 & 1.36 & 1.01 \\
\hline 93NY009001 & 56 & 76 & Bw1 & 0.16 & 1.75 & 15 & 0.16 & 1.75 & 0.48 \\
\hline 93NY009001 & 76 & 102 & Bw2 & 0.18 & 1.65 & 25 & 0.18 & 1.65 & 0.58 \\
\hline 93NY009001 & 102 & 140 & $\mathrm{Bx}$ & 0.10 & & 30 & 0.10 & 1.59 & 0.42 \\
\hline 93NY009001 & 140 & 178 & $\mathrm{C}$ & 0.13 & & 30 & 0.13 & 1.60 & 0.55 \\
\hline 93NY009002 & 0 & 20 & $\mathrm{Ap}$ & 2.44 & & 10 & 2.44 & 1.25 & 5.50 \\
\hline 93NY009002 & 20 & 41 & Bw1 & 0.83 & & 10 & 0.83 & 1.40 & 2.20 \\
\hline 93NY009002 & 41 & 61 & Bw2 & 0.27 & 1.54 & 15 & 0.27 & 1.54 & 0.71 \\
\hline 93NY009002 & 61 & 97 & $\mathrm{Bt}$ & 0.17 & 1.69 & 20 & 0.17 & 1.69 & 0.83 \\
\hline $93 \mathrm{NY} 009002$ & 97 & 157 & Btx & 0.10 & & 25 & 0.10 & 1.64 & 0.74 \\
\hline $93 \mathrm{NY} 009002$ & 157 & & $\mathrm{C}$ & 0.08 & & 50 & 0.08 & 1.61 & 0.28 \\
\hline 93NY009003 & 0 & 3 & $\mathrm{Oa}$ & 27.05 & & 0 & 27.05 & 0.43 & 3.47 \\
\hline $93 \mathrm{NY} 009003$ & 3 & 13 & $\mathrm{~A}$ & 5.68 & & 20 & 5.68 & 0.94 & 4.28 \\
\hline $93 \mathrm{NY} 009003$ & 13 & 41 & $\mathrm{Bw}$ & 1.37 & & 30 & 1.37 & 1.32 & 3.54 \\
\hline $93 \mathrm{NY} 009003$ & 41 & 66 & $\mathrm{Bt}$ & 0.38 & & 40 & 0.38 & 1.40 & 0.80 \\
\hline 93NY009004 & 0 & 8 & $\mathrm{Oe}$ & 46.89 & & 0 & 46.89 & 0.40 & 14.91 \\
\hline 93NY009004 & 8 & 20 & $\mathrm{E}$ & 0.25 & & 4 & 0.25 & 1.46 & 0.42 \\
\hline $93 \mathrm{NY} 009004$ & 20 & 25 & Bhs & & & 1 & 1.63 & 1.37 & 1.10 \\
\hline 93NY009004 & 25 & 48 & $\mathrm{Bh}$ & 0.88 & & 5 & 0.88 & 1.35 & 2.60 \\
\hline 93NY009004 & 48 & 91 & $\mathrm{BC} 1$ & 0.26 & & 10 & 0.26 & 1.59 & 1.60 \\
\hline 93NY009004 & 91 & 119 & $\mathrm{BC} 2$ & 0.14 & & 20 & 0.14 & 1.61 & 0.50 \\
\hline
\end{tabular}




\begin{tabular}{|c|c|c|c|c|c|c|c|c|c|}
\hline PedonID & $\begin{array}{c}\text { Top } \\
\text { Depth } \\
\text { (cm) }\end{array}$ & $\begin{array}{c}\text { Bottom } \\
\text { Depth } \\
(\mathrm{cm})\end{array}$ & Horizon & $\begin{array}{c}\text { Total } \\
\text { Carbon\% } \\
\text { (Dry } \\
\text { Combustion, } \\
\text { Including } \\
\text { Converted } \\
\text { Walkley- } \\
\text { Black) }\end{array}$ & $\begin{array}{c}\text { 33kPa } \\
\text { Bulk } \\
\text { Density } \\
\left(\mathrm{g} \mathrm{cm}^{-3}\right)\end{array}$ & $\begin{array}{c}\text { Fragment } \\
\% \text { by } \\
\text { Volume }\end{array}$ & $\begin{array}{c}\text { Predicted } \\
\text { OC } \%\end{array}$ & $\begin{array}{c}\text { Predicted } \\
33 \mathrm{kPa} \mathrm{BD} \\
\left(\mathrm{g} \mathrm{cm}^{-3}\right)\end{array}$ & $\begin{array}{c}\text { SOC } \\
\text { Stock } \\
(\mathbf{k g} \\
\left.\mathbf{m}^{-2}\right)\end{array}$ \\
\hline 93NY009004 & 119 & 147 & $\mathrm{C}$ & 0.06 & & 10 & 0.06 & 1.60 & 0.24 \\
\hline $93 \mathrm{NY} 009005$ & 0 & 15 & $\mathrm{Ap}$ & 2.81 & & 0 & 2.81 & 1.23 & 5.19 \\
\hline 93NY009005 & 15 & 36 & Btg1 & 1.97 & & 1 & 1.97 & 1.40 & 5.72 \\
\hline 93NY009005 & 36 & 61 & Btg2 & 0.63 & & 5 & 0.63 & 1.45 & 2.17 \\
\hline 93NY009005 & 61 & 79 & Btg3 & 0.16 & & 20 & 0.16 & 1.48 & 0.34 \\
\hline 93NY009005 & 79 & 124 & Btxg & 0.14 & & 30 & 0.14 & 1.56 & 0.69 \\
\hline $93 \mathrm{NY} 009005$ & 124 & 152 & $\mathrm{Cg}$ & 0.48 & & 25 & 0.48 & 1.50 & 1.52 \\
\hline 93NY009006 & 0 & 8 & $\mathrm{Oe}$ & 40.89 & & 0 & 40.89 & 0.42 & 13.71 \\
\hline 93NY009006 & 8 & 28 & $\mathrm{E}$ & 0.22 & & 25 & 0.22 & 1.28 & 0.42 \\
\hline 93NY009006 & 28 & 41 & Bs1 & 0.41 & & 25 & 0.41 & 1.28 & 0.51 \\
\hline 93NY009006 & 41 & 56 & Bs2 & 0.90 & & 40 & 0.90 & 1.35 & 1.10 \\
\hline $93 \mathrm{NY} 009006$ & 56 & 122 & $\mathrm{BC}$ & 0.24 & & 70 & 0.24 & 1.62 & 0.77 \\
\hline $93 \mathrm{NY} 009007$ & 0 & 3 & Oe & 27.83 & & 0 & 27.83 & 0.43 & 3.55 \\
\hline 93NY009007 & 3 & 5 & $\mathrm{E}$ & & & 10 & 4.47 & 1.33 & 1.07 \\
\hline 93NY009007 & 5 & 64 & Bw1 & 0.41 & & 15 & 0.41 & 1.39 & 2.87 \\
\hline 93NY009007 & 64 & 91 & Bw2 & 0.14 & & 32 & 0.14 & 1.53 & 0.39 \\
\hline 93NY009007 & 91 & 119 & $\mathrm{C} 1$ & & & 50 & 0.15 & 1.58 & 0.34 \\
\hline 93NY009007 & 119 & 152 & $\mathrm{C} 2$ & & & 10 & 0.15 & 1.55 & 0.68 \\
\hline $93 \mathrm{NY} 009007$ & 152 & 203 & C3 & & & 20 & 0.32 & 1.57 & 2.06 \\
\hline $93 \mathrm{NY} 009008$ & 0 & 20 & Ap & 5.24 & & 5 & 5.24 & 1.14 & 11.34 \\
\hline 93NY009008 & 20 & 48 & Bw1 & 0.32 & & 10 & 0.32 & 1.37 & 1.10 \\
\hline 93NY009008 & 48 & 74 & Bw2 & 0.23 & & 15 & 0.23 & 1.49 & 0.76 \\
\hline 93NY009008 & 74 & 91 & $\mathrm{BC}$ & 0.12 & & 10 & 0.12 & 1.54 & 0.28 \\
\hline
\end{tabular}




\begin{tabular}{|c|c|c|c|c|c|c|c|c|c|}
\hline PedonID & $\begin{array}{c}\text { Top } \\
\text { Depth } \\
\text { (cm) }\end{array}$ & $\begin{array}{c}\text { Bottom } \\
\text { Depth } \\
(\mathrm{cm})\end{array}$ & Horizon & $\begin{array}{c}\text { Total } \\
\text { Carbon\% } \\
\text { (Dry } \\
\text { Combustion, } \\
\text { Including } \\
\text { Converted } \\
\text { Walkley- } \\
\text { Black) } \\
\end{array}$ & $\begin{array}{c}\text { 33kPa } \\
\text { Bulk } \\
\text { Density } \\
\left(\mathrm{g} \mathrm{cm}^{-3}\right)\end{array}$ & $\begin{array}{c}\text { Fragment } \\
\% \text { by } \\
\text { Volume }\end{array}$ & $\begin{array}{c}\text { Predicted } \\
\text { OC } \%\end{array}$ & $\begin{array}{c}\text { Predicted } \\
\text { 33kPa BD } \\
\left(\mathrm{g} \mathrm{cm}^{-3}\right)\end{array}$ & $\begin{array}{c}\text { SOC } \\
\text { Stock } \\
(\mathbf{k g} \\
\left.\mathbf{m}^{-2}\right)\end{array}$ \\
\hline 93NY009008 & 91 & 117 & $\mathrm{C}$ & 0.14 & & 10 & 0.14 & 1.51 & 0.50 \\
\hline 93NY009009 & 0 & 3 & $\mathrm{Oe}$ & 35.64 & & 0 & 35.64 & 0.48 & 5.09 \\
\hline 93NY009009 & 3 & 10 & $\mathrm{~A}$ & 4.12 & & 1 & 4.12 & 1.03 & 2.94 \\
\hline 93NY009009 & 10 & 46 & Bw1 & 0.70 & & 2 & 0.70 & 1.38 & 3.41 \\
\hline 93NY009009 & 46 & 56 & Bw2 & 0.14 & & 5 & 0.14 & 1.52 & 0.20 \\
\hline 93NY009009 & 56 & 69 & E / Btx & 0.08 & 1.65 & 5 & 0.08 & 1.65 & 0.16 \\
\hline 93NY009009 & 69 & 119 & $2 \mathrm{Btx} 1$ & 0.06 & 1.65 & 15 & 0.06 & 1.65 & 0.42 \\
\hline 93NY009009 & 119 & 165 & $2 \mathrm{Btx} 2$ & 0.12 & 1.73 & 15 & 0.12 & 1.73 & 0.81 \\
\hline 95WV075001 & 0 & 1 & Oi1 & 53.18 & & 0 & 53.18 & 0.35 & 1.85 \\
\hline 95WV075001 & 1 & 4 & Oi2 & 50.14 & & 0 & 50.14 & 0.37 & 5.52 \\
\hline 95WV075001 & 4 & 8 & $\mathrm{Oa}$ & 36.30 & & 25 & 36.30 & 0.62 & 6.70 \\
\hline 95WV075001 & 8 & 12 & $\mathrm{~A}$ & 13.83 & & 40 & 13.83 & 1.18 & 3.91 \\
\hline 95WV075001 & 12 & 27 & $E$ & 0.53 & 1.74 & 50 & 0.53 & 1.74 & 0.69 \\
\hline 95WV075001 & 27 & 39 & $\mathrm{Bh} / \mathrm{Bhs}$ & 3.40 & 1.30 & 35 & 3.40 & 1.30 & 3.45 \\
\hline 95WV075001 & 39 & 61 & $\mathrm{Bw}$ & 0.97 & 1.51 & 45 & 0.97 & 1.51 & 1.77 \\
\hline 95WV075001 & 61 & 94 & $\mathrm{BC}$ & 0.33 & 1.50 & 50 & 0.33 & 1.50 & 0.82 \\
\hline 95WV075001 & 94 & 124 & $\mathrm{C}$ & 0.17 & 1.65 & 50 & 0.17 & 1.65 & 0.42 \\
\hline 95WV075002 & 0 & 1 & Oi1 & 51.42 & & 0 & 51.42 & 0.33 & 1.71 \\
\hline 95WV075002 & 1 & 4 & Oi2 & 51.68 & & 0 & 51.68 & 0.35 & 5.45 \\
\hline 95WV075002 & 4 & 9 & Oe & 50.59 & & 0 & 50.59 & 0.54 & 13.60 \\
\hline 95WV075002 & 9 & 14 & $\mathrm{Oa}$ & 43.59 & & 25 & 43.59 & 0.61 & 9.94 \\
\hline 95WV075002 & 14 & 26 & $\mathrm{E}$ & 1.61 & 1.71 & 35 & 1.61 & 1.71 & 2.15 \\
\hline 95WV075002 & 26 & 34 & Bhs & 2.36 & 1.62 & 25 & 2.36 & 1.62 & 2.29 \\
\hline
\end{tabular}




\begin{tabular}{|c|c|c|c|c|c|c|c|c|c|}
\hline PedonID & $\begin{array}{c}\text { Top } \\
\text { Depth } \\
\text { (cm) }\end{array}$ & $\begin{array}{c}\text { Bottom } \\
\text { Depth } \\
\text { (cm) }\end{array}$ & Horizon & $\begin{array}{c}\text { Total } \\
\text { Carbon\% } \\
\text { (Dry } \\
\text { Combustion, } \\
\text { Including } \\
\text { Converted } \\
\text { Walkley- } \\
\text { Black) }\end{array}$ & $\begin{array}{c}\text { 33kPa } \\
\text { Bulk } \\
\text { Density } \\
\left(\mathrm{g} \mathrm{cm}^{-3}\right)\end{array}$ & $\begin{array}{c}\text { Fragment } \\
\% \text { by } \\
\text { Volume }\end{array}$ & $\begin{array}{c}\text { Predicted } \\
\text { OC } \%\end{array}$ & $\begin{array}{c}\text { Predicted } \\
33 \mathrm{kPa} \mathrm{BD} \\
\left(\mathrm{g} \mathrm{cm}^{-3}\right)\end{array}$ & $\begin{array}{c}\text { SOC } \\
\text { Stock } \\
(\mathbf{k g} \\
\left.\mathrm{m}^{-2}\right)\end{array}$ \\
\hline 95WV075002 & 34 & 42 & Bs & 1.02 & 1.29 & 30 & 1.02 & 1.29 & 0.74 \\
\hline 95WV075002 & 42 & 63 & $\mathrm{Bw}$ & 0.53 & 1.69 & 50 & 0.53 & 1.69 & 0.94 \\
\hline 95WV075002 & 63 & 94 & $\mathrm{C}$ & 0.83 & & 70 & 0.83 & 1.60 & 1.23 \\
\hline 95WV083001 & 0 & 5 & Oi1 & 51.26 & & 0 & 51.26 & 0.43 & 10.95 \\
\hline 95WV083001 & 5 & 8 & Oi2 & 42.90 & & 0 & 42.90 & 0.44 & 5.66 \\
\hline 95WV083001 & 8 & 9 & $\mathrm{Oa}$ & 25.26 & & 0 & 25.26 & 0.60 & 1.52 \\
\hline 95WV083001 & 9 & 23 & $\mathrm{~A}$ & 18.70 & & 30 & 18.70 & 1.06 & 19.41 \\
\hline 95WV083001 & 23 & 33 & $\mathrm{AB}$ & 6.34 & & 30 & 6.34 & 1.25 & 5.55 \\
\hline 95WV083001 & 33 & 61 & $\mathrm{Bw}$ & 2.98 & & 30 & 2.98 & 1.42 & 8.27 \\
\hline 95WV083001 & 61 & 107 & $\mathrm{Bx} 1$ & 0.45 & 1.83 & 10 & 0.45 & 1.83 & 3.41 \\
\hline 95WV083001 & 107 & 165 & $\mathrm{~B} \times 2$ & 0.31 & 1.80 & 25 & 0.31 & 1.80 & 2.43 \\
\hline 95WV083001 & 165 & 267 & $2 \mathrm{C} 1$ & 0.91 & 1.69 & 30 & 0.91 & 1.69 & 10.98 \\
\hline 95WV083001 & 267 & 307 & $2 \mathrm{C} 2$ & 2.91 & 1.74 & 10 & 2.91 & 1.74 & 18.23 \\
\hline 95WV083001 & 307 & 376 & $2 \mathrm{C} 3$ & 0.26 & 1.75 & 10 & 0.26 & 1.75 & 2.83 \\
\hline 95WV083001 & 376 & 404 & $2 \mathrm{C} 4$ & 0.24 & 1.33 & 45 & 0.24 & 1.33 & 0.49 \\
\hline 95WV083002 & 0 & 4 & $\mathrm{Oi}$ & 49.06 & & 0 & 49.06 & 0.35 & 6.89 \\
\hline 95WV083002 & 4 & 8 & $\mathrm{Oe}$ & 47.52 & & 0 & 47.52 & 0.54 & 10.27 \\
\hline 95WV083002 & 8 & 13 & $\mathrm{Oa} / \mathrm{A}$ & 33.96 & & 5 & 33.96 & 0.59 & 9.59 \\
\hline 95WV083002 & 13 & 21 & $\mathrm{AE}$ & 1.26 & 1.54 & 40 & 1.26 & 1.54 & 0.93 \\
\hline 95WV083002 & 21 & 32 & $\mathrm{E}$ & 0.36 & 1.90 & 40 & 0.36 & 1.90 & 0.45 \\
\hline 95WV083002 & 32 & 40 & $\mathrm{Bh}$ & 2.80 & 1.43 & 20 & 2.80 & 1.43 & 2.56 \\
\hline 95WV083002 & 40 & 52 & $\mathrm{Bh} / \mathrm{Bs}$ & 1.14 & 1.42 & 30 & 1.14 & 1.42 & 1.36 \\
\hline 95WV083002 & 52 & 57 & Bs & 0.34 & 1.60 & 60 & 0.34 & 1.60 & 0.11 \\
\hline
\end{tabular}




\begin{tabular}{|c|c|c|c|c|c|c|c|c|c|}
\hline PedonID & $\begin{array}{c}\text { Top } \\
\text { Depth } \\
\text { (cm) }\end{array}$ & $\begin{array}{c}\text { Bottom } \\
\text { Depth } \\
\text { (cm) }\end{array}$ & Horizon & $\begin{array}{c}\text { Total } \\
\text { Carbon\% } \\
\text { (Dry } \\
\text { Combustion, } \\
\text { Including } \\
\text { Converted } \\
\text { Walkley- } \\
\text { Black) } \\
\end{array}$ & $\begin{array}{c}\text { 33kPa } \\
\text { Bulk } \\
\text { Density } \\
\left(\mathrm{g} \mathrm{cm}^{-3}\right)\end{array}$ & $\begin{array}{c}\text { Fragment } \\
\% \text { by } \\
\text { Volume }\end{array}$ & $\begin{array}{c}\text { Predicted } \\
\text { OC } \%\end{array}$ & $\begin{array}{c}\text { Predicted } \\
\text { 33kPa BD } \\
\left(\mathrm{g} \mathrm{cm}^{-3}\right)\end{array}$ & $\begin{array}{c}\text { SOC } \\
\text { Stock } \\
(\mathbf{k g} \\
\left.\mathbf{m}^{-2}\right)\end{array}$ \\
\hline 95WV083002 & 57 & 71 & $\mathrm{C}$ & 0.15 & 1.71 & 75 & 0.15 & 1.71 & 0.09 \\
\hline 95WV083003 & 0 & 1 & Oi1 & 54.23 & & 0 & 0.41 & 1.74 & 0.32 \\
\hline 95WV083003 & 1 & 6 & Oi2 & 51.85 & & 0 & 51.40 & 0.35 & 2.51 \\
\hline 95WV083003 & 6 & 9 & $\mathrm{Oe}$ & 49.61 & & 0 & 39.72 & 0.37 & 5.95 \\
\hline 95WV083003 & 9 & 14 & A & 16.54 & & 70 & 11.56 & 1.16 & 4.36 \\
\hline 95WV083003 & 14 & 18 & $\mathrm{AE}$ & 2.42 & & 70 & 5.46 & 1.26 & 5.51 \\
\hline 95WV083003 & 18 & 29 & $\mathrm{E}$ & 0.17 & 1.66 & 60 & 2.77 & 0.98 & 5.29 \\
\hline 95WV083003 & 29 & 35 & $\mathrm{Bh}$ & 0.47 & 1.35 & 50 & 1.45 & 1.21 & 3.16 \\
\hline 95WV083003 & 35 & 41 & Bhs & 2.32 & 1.33 & 50 & 0.94 & 1.75 & 1.78 \\
\hline 95WV083003 & 41 & 54 & Bhs / BC & 0.97 & 1.63 & 60 & 0.73 & 1.84 & 7.02 \\
\hline 95WV083003 & 54 & 69 & $\mathrm{C}$ & 0.41 & 1.74 & 70 & 0.88 & 1.71 & 2.77 \\
\hline 95WV083004 & 0 & 2 & Oi1 & 51.40 & & 30 & 54.23 & 0.26 & 1.43 \\
\hline 95WV083004 & 2 & 6 & Oi2 & 39.72 & & 0 & 51.85 & 0.29 & 7.51 \\
\hline 95WV083004 & 6 & 11 & $\mathrm{~A}$ & 11.56 & & 35 & 49.61 & 0.43 & 6.39 \\
\hline 95WV083004 & 11 & 19 & $\mathrm{AB}$ & 5.46 & & 0 & 16.54 & 1.13 & 2.80 \\
\hline 95WV083004 & 19 & 45 & Bw1 & 2.77 & 0.98 & 25 & 2.42 & 1.47 & 0.43 \\
\hline 95WV083004 & 45 & 69 & Bw2 & 1.45 & 1.21 & 25 & 0.17 & 1.66 & 0.12 \\
\hline 95WV083004 & 69 & 87 & $\mathrm{Bx} 1$ & 0.94 & 1.75 & 40 & 0.47 & 1.35 & 0.19 \\
\hline 95WV083004 & 87 & 182 & $\mathrm{Bx} 2$ & 0.73 & 1.84 & 45 & 2.32 & 1.33 & 0.93 \\
\hline 95WV083004 & 182 & 205 & $\mathrm{BC}$ & 0.88 & & 20 & 0.97 & 1.63 & 0.82 \\
\hline 95WV083005 & 0 & 1 & Oi1 & 50.30 & & 0 & 50.30 & 0.32 & 1.61 \\
\hline 95WV083005 & 1 & 3 & Oi2 & 49.03 & & 0 & 49.03 & 0.34 & 3.29 \\
\hline 95WV083005 & 3 & 5 & $\mathrm{Oe}$ & 48.24 & & 0 & 48.24 & 0.47 & 4.57 \\
\hline
\end{tabular}




\begin{tabular}{|c|c|c|c|c|c|c|c|c|c|}
\hline PedonID & $\begin{array}{c}\text { Top } \\
\text { Depth } \\
(\mathbf{c m})\end{array}$ & $\begin{array}{c}\text { Bottom } \\
\text { Depth } \\
\text { (cm) }\end{array}$ & Horizon & $\begin{array}{c}\text { Total } \\
\text { Carbon\% } \\
\text { (Dry } \\
\text { Combustion, } \\
\text { Including } \\
\text { Converted } \\
\text { Walkley- } \\
\text { Black) } \\
\end{array}$ & $\begin{array}{c}\text { 33kPa } \\
\text { Bulk } \\
\text { Density } \\
\left(\mathrm{g} \mathrm{cm}^{-3}\right)\end{array}$ & $\begin{array}{c}\text { Fragment } \\
\% \text { by } \\
\text { Volume }\end{array}$ & $\begin{array}{c}\text { Predicted } \\
\text { OC } \%\end{array}$ & $\begin{array}{c}\text { Predicted } \\
\text { 33kPa BD } \\
\left(\mathrm{g} \mathrm{cm}^{-3}\right)\end{array}$ & $\begin{array}{c}\text { SOC } \\
\text { Stock } \\
(\mathbf{k g} \\
\left.\mathbf{m}^{-2}\right)\end{array}$ \\
\hline 95WV083005 & 5 & 14 & $\mathrm{~A}$ & 10.27 & 1.03 & 35 & 10.27 & 1.03 & 6.19 \\
\hline 95WV083005 & 14 & 26 & $\mathrm{BA}$ & 2.85 & 1.14 & 30 & 2.85 & 1.14 & 2.73 \\
\hline 95WV083005 & 26 & 47 & Bw1 & 1.52 & 1.22 & 40 & 1.52 & 1.22 & 2.34 \\
\hline 95WV083005 & 47 & 80 & Bw2 & 1.92 & 1.27 & 55 & 1.92 & 1.27 & 3.62 \\
\hline 95WV083005 & 80 & 98 & $\mathrm{C}$ & 0.87 & 1.36 & 80 & 0.87 & 1.36 & 0.43 \\
\hline 95WV083006 & 0 & 1 & Oi1 & 53.44 & & 0 & 53.44 & 0.33 & 1.77 \\
\hline 95WV083006 & 1 & 4 & Oi2 & 52.62 & & 0 & 52.62 & 0.35 & 5.53 \\
\hline 95WV083006 & 4 & 11 & $\mathrm{Oe}$ & 45.39 & & 0 & 45.39 & 0.53 & 16.94 \\
\hline 95WV083006 & 11 & 18 & $\mathrm{Oa}$ & 15.59 & & 0 & 15.59 & 0.60 & 6.57 \\
\hline 95WV083006 & 18 & 24 & $\mathrm{~A}$ & 12.72 & & 20 & 12.72 & 1.28 & 7.83 \\
\hline 95WV083006 & 24 & 31 & $\mathrm{E}$ & 0.24 & 1.49 & 30 & 0.24 & 1.49 & 0.18 \\
\hline 95WV083006 & 31 & 45 & EB & 0.35 & 1.90 & 30 & 0.35 & 1.90 & 0.65 \\
\hline 95WV083006 & 45 & 60 & $\mathrm{Bh}$ & 0.14 & 1.51 & 60 & 0.14 & 1.51 & 0.13 \\
\hline 95WV083006 & 60 & 81 & $\mathrm{C}$ & 0.14 & 1.75 & 50 & 0.14 & 1.75 & 0.26 \\
\hline 95WV083007 & 0 & 1 & Oil & 5.41 & & 0 & 5.41 & 0.32 & 0.17 \\
\hline 95WV083007 & 1 & 4 & Oi2 & 17.68 & & 30 & 17.68 & 0.34 & 1.26 \\
\hline 95WV083007 & 4 & 7 & Oe & 15.61 & & 30 & 15.61 & 0.49 & 1.62 \\
\hline 95WV083007 & 7 & 19 & $\mathrm{~A}$ & 10.82 & 0.73 & 40 & 10.82 & 0.73 & 5.69 \\
\hline 95WV083007 & 19 & 64 & $\mathrm{Bw}$ & 2.57 & 0.87 & 50 & 2.57 & 0.87 & 5.03 \\
\hline 95WV083007 & 64 & 92 & $\mathrm{BC}$ & 0.92 & 1.07 & 70 & 0.92 & 1.07 & 0.83 \\
\hline 95WV083008 & 0 & 2 & Oi1 & 15.78 & & 0 & 15.78 & 0.40 & 1.27 \\
\hline 95WV083008 & 2 & 5 & Oi2 & 13.29 & & 0 & 13.29 & 0.43 & 1.70 \\
\hline 95WV083008 & 5 & 8 & $\mathrm{Oe}$ & 15.01 & & 0 & 15.01 & 0.55 & 2.49 \\
\hline
\end{tabular}




\begin{tabular}{|c|c|c|c|c|c|c|c|c|c|}
\hline PedonID & $\begin{array}{c}\text { Top } \\
\text { Depth } \\
\text { (cm) }\end{array}$ & $\begin{array}{c}\text { Bottom } \\
\text { Depth } \\
(\mathrm{cm})\end{array}$ & Horizon & $\begin{array}{c}\text { Total } \\
\text { Carbon\% } \\
\text { (Dry } \\
\text { Combustion, } \\
\text { Including } \\
\text { Converted } \\
\text { Walkley- } \\
\text { Black) }\end{array}$ & $\begin{array}{c}\text { 33kPa } \\
\text { Bulk } \\
\text { Density } \\
\left(\mathrm{g} \mathrm{cm}^{-3}\right)\end{array}$ & $\begin{array}{c}\text { Fragment } \\
\% \text { by } \\
\text { Volume }\end{array}$ & $\begin{array}{c}\text { Predicted } \\
\text { OC } \%\end{array}$ & $\begin{array}{c}\text { Predicted } \\
33 \mathrm{kPa} \mathrm{BD} \\
\left(\mathrm{g} \mathrm{cm}^{-3}\right)\end{array}$ & $\begin{array}{c}\text { SOC } \\
\text { Stock } \\
(\mathbf{k g} \\
\left.\mathbf{m}^{-2}\right)\end{array}$ \\
\hline 95WV083008 & 8 & 15 & $\mathrm{Oa}$ & 14.91 & & 0 & 14.91 & 0.62 & 6.46 \\
\hline 95WV083008 & 15 & 22 & $\mathrm{~A}$ & 13.17 & 1.71 & 55 & 13.17 & 1.71 & 7.09 \\
\hline 95WV083008 & 22 & 44 & $\mathrm{~A} / \mathrm{E}$ & 0.69 & 1.68 & 55 & 0.69 & 1.68 & 1.15 \\
\hline 95WV083008 & 44 & 57 & $\mathrm{Bw}$ & 0.34 & 1.73 & 45 & 0.34 & 1.73 & 0.42 \\
\hline 95WV083008 & 57 & 110 & $\mathrm{Bx}$ & 0.21 & 1.89 & 40 & 0.21 & 1.89 & 1.26 \\
\hline 95WV083008 & 110 & 136 & $\mathrm{BCx}$ & 0.12 & 1.94 & 50 & 0.12 & 1.94 & 0.30 \\
\hline 95WV093001 & 0 & 2 & Oi1 & 50.37 & & 0 & 50.37 & 0.39 & 3.97 \\
\hline 95WV093001 & 2 & 5 & Oi2 & 48.89 & & 0 & 48.89 & 0.41 & 6.06 \\
\hline 95WV093001 & 5 & 8 & $\mathrm{Oe}$ & 44.63 & & 0 & 44.63 & 0.51 & 6.79 \\
\hline 95WV093001 & 8 & 14 & $\mathrm{Oa}$ & 38.23 & & 0 & 38.23 & 0.57 & 13.11 \\
\hline 95WV093001 & 14 & 17 & $\mathrm{~A}$ & 18.92 & & 30 & 18.92 & 1.29 & 5.13 \\
\hline 95WV093001 & 17 & 35 & $\mathrm{E}$ & 0.34 & 1.94 & 30 & 0.34 & 1.94 & 0.83 \\
\hline 95WV093001 & 35 & 58 & Btx1 & 0.27 & 1.98 & 35 & 0.27 & 1.98 & 0.80 \\
\hline 95WV093001 & 58 & 87 & Btx2 & 0.24 & 1.79 & 45 & 0.24 & 1.79 & 0.69 \\
\hline 95WV093001 & 87 & 121 & $\mathrm{Cg}$ & 0.68 & 1.93 & 45 & 0.68 & 1.93 & 2.45 \\
\hline 95WV093002 & 0 & 2 & Oi1 & 45.76 & & 0 & 45.76 & 0.33 & 3.04 \\
\hline 95WV093002 & 2 & 5 & Oi2 & 48.59 & & 0 & 48.59 & 0.36 & 5.20 \\
\hline 95WV093002 & 5 & 7 & $\mathrm{Oe}$ & 46.68 & & 0 & 46.68 & 0.53 & 4.97 \\
\hline 95WV093002 & 7 & 12 & $\mathrm{~A}$ & 26.07 & & 5 & 26.07 & 1.01 & 12.46 \\
\hline 95WV093002 & 12 & 20 & $\mathrm{E}$ & 0.90 & 1.90 & 5 & 0.90 & 1.90 & 1.30 \\
\hline 95WV093002 & 20 & 29 & $\mathrm{Bh}$ & 1.21 & 1.62 & 5 & 1.21 & 1.62 & 1.68 \\
\hline 95WV093002 & 29 & 36 & Bhs & & & 5 & 3.44 & 1.39 & 3.17 \\
\hline 95WV093002 & 36 & 43 & Bsm & 1.20 & 1.77 & 10 & 1.20 & 1.77 & 1.34 \\
\hline
\end{tabular}




\begin{tabular}{|c|c|c|c|c|c|c|c|c|c|}
\hline PedonID & $\begin{array}{c}\text { Top } \\
\text { Depth } \\
\text { (cm) }\end{array}$ & $\begin{array}{c}\text { Bottom } \\
\text { Depth } \\
(\mathrm{cm})\end{array}$ & Horizon & $\begin{array}{c}\text { Total } \\
\text { Carbon\% } \\
\text { (Dry } \\
\text { Combustion, } \\
\text { Including } \\
\text { Converted } \\
\text { Walkley- } \\
\text { Black) }\end{array}$ & $\begin{array}{c}\text { 33kPa } \\
\text { Bulk } \\
\text { Density } \\
\left(\mathrm{g} \mathrm{cm}^{-3}\right)\end{array}$ & $\begin{array}{c}\text { Fragment } \\
\% \text { by } \\
\text { Volume }\end{array}$ & $\begin{array}{c}\text { Predicted } \\
\text { OC } \%\end{array}$ & $\begin{array}{c}\text { Predicted } \\
33 \mathrm{kPa} \mathrm{BD} \\
\left(\mathrm{g} \mathrm{cm}^{-3}\right)\end{array}$ & $\begin{array}{c}\text { SOC } \\
\text { Stock } \\
(\mathbf{k g} \\
\left.\mathbf{m}^{-2}\right)\end{array}$ \\
\hline 95WV093002 & 43 & 60 & Bs & 0.73 & 1.75 & 25 & 0.73 & 1.75 & 1.63 \\
\hline 95WV093002 & 60 & 92 & $\mathrm{C}$ & 0.46 & 2.01 & 15 & 0.46 & 2.01 & 2.51 \\
\hline 95WV093003 & 0 & 2 & Oi1 & 51.64 & & 0 & 51.64 & 0.39 & 4.06 \\
\hline 95WV093003 & 2 & 6 & Oi2 & 49.34 & & 0 & 49.34 & 0.36 & 7.09 \\
\hline 95WV093003 & 6 & 9 & Oe & 46.79 & & 0 & 46.79 & 0.53 & 7.37 \\
\hline 95WV093003 & 9 & 11 & $\mathrm{Oa}$ & 35.31 & & 0 & 35.31 & 0.59 & 4.13 \\
\hline 95WV093003 & 11 & 13 & $\mathrm{~A}$ & & & 0 & 19.10 & 1.22 & 4.65 \\
\hline 95WV093003 & 13 & 26 & $\mathrm{E}$ & & 1.81 & 0 & 0.97 & 1.81 & 2.29 \\
\hline 95WV093003 & 26 & 31 & $\mathrm{Bh}$ & & 1.74 & 0 & 2.32 & 1.74 & 2.02 \\
\hline 95WV093003 & 31 & 45 & $\mathrm{Bw}$ & & 1.67 & 10 & 0.85 & 1.67 & 1.78 \\
\hline 95WV093003 & 45 & 54 & $\mathrm{BC}$ & & & 10 & 0.69 & 1.68 & 0.94 \\
\hline 95WV093003 & 54 & 85 & $\mathrm{C}$ & & 1.82 & 10 & 0.65 & 1.82 & 3.28 \\
\hline 95WV093004 & 0 & 2 & Oi1 & 46.19 & & 0 & 46.19 & 0.35 & 3.22 \\
\hline 95WV093004 & 2 & 5 & Oi2 & 46.67 & & 0 & 46.67 & 0.37 & 5.23 \\
\hline 95WV093004 & 5 & 7 & $\mathrm{Oe}$ & 43.02 & & 30 & 43.02 & 0.58 & 3.48 \\
\hline 95WV093004 & 7 & 17 & $\mathrm{~A}$ & 17.00 & 0.98 & 30 & 17.00 & 0.98 & 11.66 \\
\hline 95WV093004 & 17 & 53 & Bs & 2.12 & 0.97 & 35 & 2.12 & 0.97 & 4.81 \\
\hline 95WV093004 & 53 & 90 & $\mathrm{BC}$ & 1.10 & 1.42 & 60 & 1.10 & 1.42 & 2.31 \\
\hline 95WV093004 & 90 & 110 & $2 \mathrm{C}$ & 0.89 & 1.22 & 75 & 0.89 & 1.22 & 0.54 \\
\hline 95WV093005 & 0 & 2 & Oil & 47.00 & & 0 & 47.00 & 0.32 & 3.02 \\
\hline 95WV093005 & 2 & 5 & Oi2 & 48.13 & & 0 & 48.13 & 0.34 & 4.94 \\
\hline 95WV093005 & 5 & 7 & $\mathrm{Oe}$ & 36.40 & & 0 & 36.40 & 0.49 & 3.54 \\
\hline 95WV093005 & 7 & 13 & A & 10.39 & 1.18 & 35 & 10.39 & 1.18 & 4.78 \\
\hline
\end{tabular}




\begin{tabular}{|c|c|c|c|c|c|c|c|c|c|}
\hline PedonID & $\begin{array}{c}\text { Top } \\
\text { Depth } \\
(\mathbf{c m})\end{array}$ & $\begin{array}{c}\text { Bottom } \\
\text { Depth } \\
\text { (cm) }\end{array}$ & Horizon & $\begin{array}{c}\text { Total } \\
\text { Carbon\% } \\
\text { (Dry } \\
\text { Combustion, } \\
\text { Including } \\
\text { Converted } \\
\text { Walkley- } \\
\text { Black) }\end{array}$ & $\begin{array}{c}\text { 33kPa } \\
\text { Bulk } \\
\text { Density } \\
\left(\mathrm{g} \mathrm{cm}^{-3}\right)\end{array}$ & $\begin{array}{c}\text { Fragment } \\
\% \text { by } \\
\text { Volume }\end{array}$ & $\begin{array}{c}\text { Predicted } \\
\text { OC } \%\end{array}$ & $\begin{array}{c}\text { Predicted } \\
\text { 33kPa BD } \\
\left(\mathrm{g} \mathrm{cm}^{-3}\right)\end{array}$ & $\begin{array}{c}\text { SOC } \\
\text { Stock } \\
(\mathbf{k g} \\
\left.\mathbf{m}^{-2}\right)\end{array}$ \\
\hline 95WV093005 & 13 & 26 & Bhs & 3.52 & 1.05 & 30 & 3.52 & 1.05 & 3.36 \\
\hline 95WV093005 & 26 & 48 & $\mathrm{Bw}$ & 1.59 & 1.21 & 45 & 1.59 & 1.21 & 2.33 \\
\hline 95WV093005 & 48 & 69 & $\mathrm{BC}$ & 0.73 & 1.68 & 45 & 0.73 & 1.68 & 1.42 \\
\hline 95WV093005 & 69 & 102 & $\mathrm{C}$ & 1.44 & & 80 & 1.44 & 1.44 & 1.37 \\
\hline 95WV093006 & 0 & 2 & Oi1 & 46.72 & & 20 & 46.72 & 0.40 & 2.99 \\
\hline 95WV093006 & 2 & 4 & Oi2 & 47.12 & & 0 & 47.12 & 0.42 & 3.96 \\
\hline 95WV093006 & 4 & 6 & $\mathrm{Oe}$ & 13.20 & & 0 & 13.20 & 0.58 & 1.54 \\
\hline 95WV093006 & 6 & 18 & $\mathrm{~A}$ & 12.91 & & 30 & 12.91 & 1.05 & 11.40 \\
\hline 95WV093006 & 18 & 26 & Bhs & 3.53 & & 20 & 3.53 & 1.21 & 2.73 \\
\hline 95WV093006 & 26 & 38 & Bs1 & 2.04 & 1.17 & 15 & 2.04 & 1.17 & 2.43 \\
\hline 95WV093006 & 38 & 50 & Bs2 & 2.18 & 1.21 & 15 & 2.18 & 1.21 & 2.69 \\
\hline 95WV093006 & 50 & 94 & $\mathrm{Bx}$ & 0.98 & 1.61 & 35 & 0.98 & 1.61 & 4.51 \\
\hline 95WV093006 & 94 & 134 & $\mathrm{BC}$ & 0.44 & 1.74 & 40 & 0.44 & 1.74 & 1.84 \\
\hline 95WV093006 & 134 & 202 & $2 \mathrm{BC}$ & 0.35 & 1.55 & 45 & 0.35 & 1.55 & 2.03 \\
\hline 95WV093007 & 0 & 1 & Oi1 & 48.15 & & 0 & 48.15 & 0.35 & 1.67 \\
\hline 95WV093007 & 1 & 5 & Oi2 & 50.99 & & 0 & 50.99 & 0.37 & 7.49 \\
\hline 95WV093007 & 5 & 7 & Oe & 49.06 & & 0 & 49.06 & 0.58 & 5.67 \\
\hline 95WV093007 & 7 & 13 & $\mathrm{Oa} / \mathrm{A}$ & 42.50 & & 75 & 42.50 & 0.62 & 3.97 \\
\hline 95WV093007 & 13 & 16 & $\mathrm{AE}$ & 12.31 & & 75 & 12.31 & 1.24 & 1.14 \\
\hline 95WV093007 & 16 & 51 & $\mathrm{E}$ & 0.73 & 1.50 & 75 & 0.73 & 1.50 & 0.96 \\
\hline 95WV093007 & 51 & 68 & $\mathrm{Bh} / \mathrm{Bhs}$ & 6.52 & 1.04 & 45 & 6.52 & 1.04 & 6.34 \\
\hline 95WV093007 & 68 & 94 & $\mathrm{Bw}$ & 1.37 & 1.16 & 75 & 1.37 & 1.16 & 1.03 \\
\hline 95WV093007 & 94 & 114 & $\mathrm{C}$ & 1.00 & 1.32 & 55 & 1.00 & 1.32 & 1.19 \\
\hline
\end{tabular}




\begin{tabular}{|c|c|c|c|c|c|c|c|c|c|}
\hline PedonID & $\begin{array}{c}\text { Top } \\
\text { Depth } \\
\text { (cm) }\end{array}$ & $\begin{array}{c}\text { Bottom } \\
\text { Depth } \\
(\mathrm{cm})\end{array}$ & Horizon & $\begin{array}{c}\text { Total } \\
\text { Carbon\% } \\
\text { (Dry } \\
\text { Combustion, } \\
\text { Including } \\
\text { Converted } \\
\text { Walkley- } \\
\text { Black) }\end{array}$ & $\begin{array}{c}\text { 33kPa } \\
\text { Bulk } \\
\text { Density } \\
\left(\mathrm{g} \mathrm{cm}^{-3}\right)\end{array}$ & $\begin{array}{c}\text { Fragment } \\
\% \text { by } \\
\text { Volume }\end{array}$ & $\begin{array}{c}\text { Predicted } \\
\text { OC } \%\end{array}$ & $\begin{array}{c}\text { Predicted } \\
33 \mathrm{kPa} \mathrm{BD} \\
\left(\mathrm{g} \mathrm{cm}^{-3}\right)\end{array}$ & $\begin{array}{c}\text { SOC } \\
\text { Stock } \\
(\mathbf{k g} \\
\left.\mathbf{m}^{-2}\right)\end{array}$ \\
\hline 95WV093008 & 0 & 2 & Oi1 & 51.51 & & 0 & 51.51 & 0.41 & 4.22 \\
\hline 95WV093008 & 2 & 5 & Oi2 & 49.88 & & 0 & 49.88 & 0.44 & 6.52 \\
\hline 95WV093008 & 5 & 8 & $\mathrm{Oe}$ & 38.96 & & 0 & 38.96 & 0.57 & 6.64 \\
\hline 95WV093008 & 8 & 16 & $\mathrm{~A}$ & 16.02 & & 25 & 16.02 & 1.09 & 10.52 \\
\hline 95WV093008 & 16 & 34 & $\mathrm{~A} / \mathrm{E}$ & 3.05 & 1.34 & 25 & 3.05 & 1.34 & 5.52 \\
\hline 95WV093008 & 34 & 57 & $\mathrm{Bw}$ & 1.10 & 1.08 & 20 & 1.10 & 1.08 & 2.19 \\
\hline 95WV093008 & 57 & 102 & $\mathrm{Bx}$ & 0.59 & 1.56 & 30 & 0.59 & 1.56 & 2.90 \\
\hline 95WV093008 & 102 & 133 & $2 \mathrm{BC}$ & 0.54 & & 65 & 0.54 & 1.69 & 0.99 \\
\hline 95WV093008 & 133 & 167 & $2 \mathrm{C}$ & 0.65 & & 75 & 0.65 & 1.58 & 0.88 \\
\hline 97WV093001 & 0 & 2 & $\mathrm{Oi}$ & 48.40 & & 0 & 48.40 & 0.26 & 2.48 \\
\hline 97WV093001 & 2 & 7 & $\mathrm{Oi} / \mathrm{A}$ & 38.44 & & 60 & 38.44 & 0.28 & 2.15 \\
\hline 97WV093001 & 7 & 16 & $\mathrm{Oa} / \mathrm{A}$ & 12.93 & & 60 & 12.93 & 1.02 & 4.74 \\
\hline 97WV093001 & 16 & 27 & BA & 2.65 & 1.11 & 50 & 2.65 & 1.11 & 1.62 \\
\hline 97WV093001 & 27 & 63 & $\mathrm{Bw}$ & 0.38 & 1.40 & 40 & 0.38 & 1.40 & 1.15 \\
\hline 97WV093001 & 63 & 100 & $\mathrm{BC}$ & 0.14 & 1.47 & 50 & 0.14 & 1.47 & 0.38 \\
\hline 97WV093002 & 0 & 3 & $\mathrm{Oi}$ & 50.79 & & 0 & 50.79 & 0.24 & 3.67 \\
\hline 97WV093002 & 3 & 6 & $\mathrm{Oi} / \mathrm{Oe}$ & 40.14 & & 10 & 40.14 & 0.26 & 2.78 \\
\hline 97WV093002 & 6 & 10 & $\mathrm{~A}$ & 0.46 & & 10 & 0.46 & 0.98 & 0.16 \\
\hline 97WV093002 & 10 & 20 & $\mathrm{BA}$ & 1.84 & 1.18 & 15 & 1.84 & 1.18 & 1.85 \\
\hline 97WV093002 & 20 & 41 & Bt1 & 0.88 & 1.26 & 20 & 0.88 & 1.26 & 1.86 \\
\hline 97WV093002 & 41 & 65 & $\mathrm{Bt} 2$ & 0.18 & 1.38 & 20 & 0.18 & 1.38 & 0.48 \\
\hline 97WV093002 & 65 & 82 & Bt3 & 0.19 & 1.26 & 40 & 0.19 & 1.26 & 0.24 \\
\hline 97WV093002 & 82 & 100 & $2 \mathrm{C}$ & 0.19 & 0.83 & 60 & 0.19 & 0.83 & 0.11 \\
\hline
\end{tabular}




\begin{tabular}{|c|c|c|c|c|c|c|c|c|c|}
\hline PedonID & $\begin{array}{c}\text { Top } \\
\text { Depth } \\
\text { (cm) }\end{array}$ & $\begin{array}{c}\text { Bottom } \\
\text { Depth } \\
(\mathrm{cm})\end{array}$ & Horizon & $\begin{array}{c}\text { Total } \\
\text { Carbon\% } \\
\text { (Dry } \\
\text { Combustion, } \\
\text { Including } \\
\text { Converted } \\
\text { Walkley- } \\
\text { Black) }\end{array}$ & $\begin{array}{c}\text { 33kPa } \\
\text { Bulk } \\
\text { Density } \\
\left(\mathrm{g} \mathrm{cm}^{-3}\right)\end{array}$ & $\begin{array}{c}\text { Fragment } \\
\% \text { by } \\
\text { Volume }\end{array}$ & $\begin{array}{c}\text { Predicted } \\
\text { OC } \%\end{array}$ & $\begin{array}{c}\text { Predicted } \\
33 \mathrm{kPa} \mathrm{BD} \\
\left(\mathrm{g} \mathrm{cm}^{-3}\right)\end{array}$ & $\begin{array}{c}\text { SOC } \\
\text { Stock } \\
(\mathbf{k g} \\
\left.\mathbf{m}^{-2}\right)\end{array}$ \\
\hline 97WV093003 & 0 & 4 & $\mathrm{Oi}$ & 50.48 & & 0 & 50.48 & 0.29 & 5.92 \\
\hline 97WV093003 & 4 & 7 & Oi/E & 39.90 & & 10 & 39.90 & 0.31 & 3.33 \\
\hline 97WV093003 & 7 & 13 & $\mathrm{~A}$ & 9.54 & & 20 & 9.54 & 1.05 & 4.83 \\
\hline 97WV093003 & 13 & 25 & $\mathrm{BE}$ & 1.21 & 1.30 & 20 & 1.21 & 1.30 & 1.51 \\
\hline 97WV093003 & 25 & 52 & $\mathrm{Bw} 1$ & 0.32 & 1.44 & 20 & 0.32 & 1.44 & 1.00 \\
\hline 97WV093003 & 52 & 74 & Bw2 & 0.10 & 1.44 & 25 & 0.10 & 1.44 & 0.24 \\
\hline 97WV093003 & 74 & 114 & Bw3 & 0.10 & 1.46 & 30 & 0.10 & 1.46 & 0.41 \\
\hline 97WV093003 & 114 & 142 & Bw4 & 0.05 & 1.53 & 30 & 0.05 & 1.53 & 0.15 \\
\hline 97WV093003 & 142 & 164 & $2 \mathrm{BCx}$ & 0.04 & 1.39 & 40 & 0.04 & 1.39 & 0.07 \\
\hline 97WV093004 & 0 & 4 & Oi & 46.98 & & 0 & 46.98 & 0.28 & 5.21 \\
\hline 97WV093004 & 4 & 8 & $\mathrm{Oa}$ & 23.72 & & 30 & 23.72 & 0.46 & 3.07 \\
\hline 97WV093004 & 8 & 17 & $\mathrm{~A}$ & 10.28 & & 30 & 10.28 & 0.99 & 6.39 \\
\hline 97WV093004 & 17 & 28 & $\mathrm{AB}$ & 5.43 & & 40 & 5.43 & 1.12 & 4.03 \\
\hline 97WV093004 & 28 & 40 & $\mathrm{BA}$ & 1.44 & 0.97 & 40 & 1.44 & 0.97 & 1.01 \\
\hline 97WV093004 & 40 & 66 & Bw1 & 0.48 & & 70 & 0.48 & 1.30 & 0.49 \\
\hline 97WV093004 & 66 & 108 & Bw2 & 0.28 & 1.40 & 50 & 0.28 & 1.40 & 0.82 \\
\hline 97WV093004 & 108 & 133 & Bw3 & 0.15 & 1.58 & 60 & 0.15 & 1.58 & 0.24 \\
\hline 97WV093004 & 133 & 169 & $\mathrm{BCx}$ & 0.11 & 1.54 & 60 & 0.11 & 1.54 & 0.24 \\
\hline 97WV093005 & 0 & 2 & Oi & 45.93 & & 0 & 45.93 & 0.27 & 2.47 \\
\hline 97WV093005 & 2 & 4 & $\mathrm{Oa}$ & 13.85 & & 35 & 13.85 & 0.45 & 0.82 \\
\hline 97WV093005 & 4 & 12 & $\mathrm{~A}$ & 3.57 & & 35 & 3.57 & 1.03 & 1.91 \\
\hline 97WV093005 & 12 & 32 & $\mathrm{BA}$ & 0.99 & & 30 & 0.99 & 1.19 & 1.65 \\
\hline 97WV093005 & 32 & 72 & Bw1 & 0.20 & & 50 & 0.20 & 1.42 & 0.57 \\
\hline
\end{tabular}




\begin{tabular}{|c|c|c|c|c|c|c|c|c|c|}
\hline PedonID & $\begin{array}{c}\text { Top } \\
\text { Depth } \\
\text { (cm) }\end{array}$ & $\begin{array}{c}\text { Bottom } \\
\text { Depth } \\
(\mathrm{cm})\end{array}$ & Horizon & $\begin{array}{c}\text { Total } \\
\text { Carbon\% } \\
\text { (Dry } \\
\text { Combustion, } \\
\text { Including } \\
\text { Converted } \\
\text { Walkley- } \\
\text { Black) }\end{array}$ & $\begin{array}{c}\text { 33kPa } \\
\text { Bulk } \\
\text { Density } \\
\left(\mathrm{g} \mathrm{cm}^{-3}\right)\end{array}$ & $\begin{array}{c}\text { Fragment } \\
\% \text { by } \\
\text { Volume }\end{array}$ & $\begin{array}{c}\text { Predicted } \\
\text { OC } \%\end{array}$ & $\begin{array}{c}\text { Predicted } \\
33 \mathrm{kPa} \mathrm{BD} \\
\left(\mathrm{g} \mathrm{cm}^{-3}\right)\end{array}$ & $\begin{array}{c}\text { SOC } \\
\text { Stock } \\
(\mathbf{k g} \\
\left.\mathbf{m}^{-2}\right)\end{array}$ \\
\hline 97WV093005 & 72 & 91 & Bw2 & 0.08 & & 60 & 0.08 & 1.47 & 0.09 \\
\hline 97WV093005 & 91 & 124 & $\mathrm{BC}$ & 0.08 & & 65 & 0.08 & 1.44 & 0.13 \\
\hline 97WV093005 & 124 & 162 & $\mathrm{C}$ & 0.07 & & 60 & 0.07 & 1.43 & 0.15 \\
\hline 97WV093006 & 0 & 2 & Oi1 & 46.18 & & 40 & 46.18 & 0.23 & 1.29 \\
\hline 97WV093006 & 2 & 4 & Oi2 & 31.08 & & 40 & 31.08 & 0.24 & 0.90 \\
\hline 97WV093006 & 4 & 6 & $\mathrm{Oe}$ & 26.58 & & 50 & 26.58 & 0.36 & 0.95 \\
\hline 97WV093006 & 6 & 13 & $\mathrm{Oa} / \mathrm{A}$ & 10.79 & & 40 & 10.79 & 0.94 & 4.27 \\
\hline 97WV093006 & 13 & 23 & $\mathrm{BA}$ & 3.97 & & 35 & 3.97 & 1.05 & 2.71 \\
\hline 97WV093006 & 23 & 38 & Bw1 & 1.71 & & 45 & 1.71 & 1.07 & 1.51 \\
\hline 97WV093006 & 38 & 57 & Bw2 & 1.02 & & 80 & 1.02 & 1.03 & 0.40 \\
\hline 97WV093007 & 0 & 2 & Oi1 & 34.96 & & 0 & 34.96 & 0.29 & 2.03 \\
\hline 97WV093007 & 2 & 5 & Oi2 & 44.46 & & 20 & 44.46 & 0.31 & 3.26 \\
\hline 97WV093007 & 5 & 10 & Oe & 41.62 & & 20 & 41.62 & 0.41 & 6.85 \\
\hline 97WV093007 & 10 & 15 & $\mathrm{Oa}$ & 30.70 & & 40 & 30.70 & 0.50 & 4.65 \\
\hline 97WV093007 & 15 & 27 & $\mathrm{~A}$ & 7.67 & & 40 & 7.67 & 1.07 & 5.89 \\
\hline 97WV093007 & 27 & 35 & $\mathrm{BE}$ & 1.20 & 1.10 & 30 & 1.20 & 1.10 & 0.74 \\
\hline 97WV093007 & 35 & 48 & Bt1 & 0.70 & 1.14 & 35 & 0.70 & 1.14 & 0.67 \\
\hline 97WV093007 & 48 & 80 & Bt2 & 0.44 & 1.35 & 45 & 0.44 & 1.35 & 1.05 \\
\hline 97WV093007 & 80 & 112 & Bt3 & 0.14 & 1.28 & 50 & 0.14 & 1.28 & 0.29 \\
\hline 97WV093007 & 112 & 129 & $2 \mathrm{BCx}$ & 0.12 & 1.48 & 60 & 0.12 & 1.48 & 0.12 \\
\hline 97WV093007 & 129 & 162 & $2 \mathrm{C}$ & 0.07 & 1.57 & 60 & 0.07 & 1.57 & 0.15 \\
\hline 97WV093008 & 0 & 3 & $\mathrm{Oi}$ & 51.54 & & 0 & 51.54 & 0.24 & 3.72 \\
\hline 97WV093008 & 3 & 6 & $\mathrm{Oi} / \mathrm{E}$ & 31.56 & & 30 & 31.56 & 0.30 & 2.01 \\
\hline
\end{tabular}




\begin{tabular}{|c|c|c|c|c|c|c|c|c|c|}
\hline PedonID & $\begin{array}{c}\text { Top } \\
\text { Depth } \\
\text { (cm) }\end{array}$ & $\begin{array}{c}\text { Bottom } \\
\text { Depth } \\
(\mathrm{cm})\end{array}$ & Horizon & $\begin{array}{c}\text { Total } \\
\text { Carbon\% } \\
\text { (Dry } \\
\text { Combustion, } \\
\text { Including } \\
\text { Converted } \\
\text { Walkley- } \\
\text { Black) }\end{array}$ & $\begin{array}{c}\text { 33kPa } \\
\text { Bulk } \\
\text { Density } \\
\left(\mathrm{g} \mathrm{cm}^{-3}\right)\end{array}$ & $\begin{array}{c}\text { Fragment } \\
\% \text { by } \\
\text { Volume }\end{array}$ & $\begin{array}{c}\text { Predicted } \\
\text { OC } \%\end{array}$ & $\begin{array}{c}\text { Predicted } \\
33 \mathrm{kPa} \mathrm{BD} \\
\left(\mathrm{g} \mathrm{cm}^{-3}\right)\end{array}$ & $\begin{array}{c}\text { SOC } \\
\text { Stock } \\
(\mathbf{k g} \\
\left.\mathbf{m}^{-2}\right)\end{array}$ \\
\hline 97WV093008 & 6 & 15 & $\mathrm{~A}$ & 8.60 & & 40 & 8.60 & 1.02 & 4.74 \\
\hline 97WV093008 & 15 & 24 & $\mathrm{BA}$ & 1.98 & & 30 & 1.98 & 1.09 & 1.36 \\
\hline 97WV093008 & 24 & 52 & Bw1 & 0.76 & & 40 & 0.76 & 1.07 & 1.36 \\
\hline 97WV093008 & 52 & 93 & Bw2 & 0.37 & & 70 & 0.37 & 1.28 & 0.58 \\
\hline 98NY009001 & 0 & 5 & Oe & & & 0 & 35.34 & 0.51 & 8.94 \\
\hline 98NY009001 & 5 & 8 & $\mathrm{~A}$ & 16.11 & & 10 & 16.11 & 1.09 & 4.73 \\
\hline 98NY009001 & 8 & 13 & $\mathrm{E}$ & 1.61 & & 10 & 1.61 & 1.35 & 0.98 \\
\hline 98NY009001 & 13 & 46 & Bt1 & 0.60 & & 10 & 0.60 & 1.43 & 2.55 \\
\hline 98NY009001 & 46 & 69 & $\mathrm{Bt} 2$ & 0.20 & & 15 & 0.20 & 1.59 & 0.62 \\
\hline 98NY009001 & 69 & 97 & Btx1 & 0.05 & 1.98 & 20 & 0.05 & 1.98 & 0.22 \\
\hline 98NY009001 & 97 & 147 & Btx2 & 0.02 & 1.95 & 25 & 0.02 & 1.95 & 0.15 \\
\hline 98NY009001 & 147 & 175 & $\mathrm{C}$ & 0.04 & & 45 & 0.04 & 1.75 & 0.11 \\
\hline 98NY009002 & 0 & 5 & Oe & & & 0 & 30.73 & 0.50 & 7.66 \\
\hline 98NY009002 & 5 & 8 & $\mathrm{~A}$ & 18.70 & & 10 & 18.70 & 1.09 & 5.52 \\
\hline 98NY009002 & 8 & 15 & $\mathrm{E}$ & 0.76 & & 10 & 0.76 & 1.39 & 0.66 \\
\hline 98NY009002 & 15 & 48 & Bt1 & 0.17 & & 15 & 0.17 & 1.45 & 0.69 \\
\hline 98NY009002 & 48 & 66 & $\mathrm{Bt} 2$ & 1.39 & & 15 & 1.39 & 1.60 & 3.40 \\
\hline 98NY009002 & 66 & 107 & Btx1 & 0.06 & & 30 & 0.06 & 1.77 & 0.30 \\
\hline 98NY009002 & 107 & 163 & Btx2 & 0.05 & 1.96 & 35 & 0.05 & 1.96 & 0.36 \\
\hline 98NY009002 & 163 & 191 & $\mathrm{C}$ & 0.21 & & 60 & 0.21 & 1.73 & 0.41 \\
\hline 98PA129121 & 0 & 3 & $\mathrm{Oi}$ & & & 0 & 40.49 & 0.37 & 4.47 \\
\hline 98PA129121 & 3 & 5 & $\mathrm{Oe}$ & & & 0 & 36.77 & 0.51 & 3.73 \\
\hline 98PA129121 & 5 & 6 & $\mathrm{Oa}$ & & & 0 & 28.71 & 0.55 & 1.58 \\
\hline
\end{tabular}




\begin{tabular}{|c|c|c|c|c|c|c|c|c|c|}
\hline PedonID & $\begin{array}{c}\text { Top } \\
\text { Depth } \\
\text { (cm) }\end{array}$ & $\begin{array}{c}\text { Bottom } \\
\text { Depth } \\
\text { (cm) }\end{array}$ & Horizon & $\begin{array}{c}\text { Total } \\
\text { Carbon\% } \\
\text { (Dry } \\
\text { Combustion, } \\
\text { Including } \\
\text { Converted } \\
\text { Walkley- } \\
\text { Black) }\end{array}$ & $\begin{array}{c}\text { 33kPa } \\
\text { Bulk } \\
\text { Density } \\
\left(\mathrm{g} \mathrm{cm}^{-3}\right)\end{array}$ & $\begin{array}{c}\text { Fragment } \\
\% \text { by } \\
\text { Volume }\end{array}$ & $\begin{array}{c}\text { Predicted } \\
\text { OC } \%\end{array}$ & $\begin{array}{c}\text { Predicted } \\
33 \mathrm{kPa} \mathrm{BD} \\
\left(\mathrm{g} \mathrm{cm}^{-3}\right)\end{array}$ & $\begin{array}{c}\text { SOC } \\
\text { Stock } \\
(\mathbf{k g} \\
\left.\mathrm{m}^{-2}\right)\end{array}$ \\
\hline 98PA129121 & 6 & 9 & $\mathrm{~A}$ & & & 0 & 12.08 & 1.19 & 4.32 \\
\hline 98PA129121 & 9 & 11 & $\mathrm{E}$ & 2.36 & & 25 & 2.36 & 1.45 & 0.51 \\
\hline 98PA129121 & 11 & 17 & Bs & & & 25 & 2.91 & 1.29 & 1.69 \\
\hline 98PA129121 & 17 & 43 & $\mathrm{Bt}$ & 0.33 & & 20 & 0.33 & 1.43 & 0.98 \\
\hline 98PA129121 & 43 & 79 & $\mathrm{BC}$ & 0.18 & & 25 & 0.18 & 1.63 & 0.79 \\
\hline 98PA129121 & 79 & 114 & $\mathrm{C}$ & & & 30 & 0.21 & 1.62 & 0.84 \\
\hline 98PA129123 & 0 & 3 & $\mathrm{Oi}$ & & & 0 & 41.47 & 0.36 & 4.43 \\
\hline 98PA129123 & 3 & 5 & $\mathrm{Oe}$ & & & 5 & 33.41 & 0.50 & 3.19 \\
\hline 98PA129123 & 5 & 13 & $\mathrm{~A}$ & 5.37 & & 15 & 5.37 & 1.08 & 3.93 \\
\hline 98PA129123 & 13 & 38 & $\mathrm{Bw}$ & 0.74 & & 35 & 0.74 & 1.32 & 1.59 \\
\hline 98PA129123 & 38 & 76 & $\mathrm{BC}$ & 0.26 & & 55 & 0.26 & 1.47 & 0.65 \\
\hline 98PA129123 & 76 & 114 & $\mathrm{C}$ & & & 35 & 0.33 & 1.48 & 1.20 \\
\hline S06WV071001 & 0 & 2 & $\mathrm{Oi}$ & 51.25 & & 0 & 51.25 & 0.27 & 2.74 \\
\hline S06WV071001 & 2 & 4 & Oe & 49.47 & & 0 & 49.47 & 0.45 & 4.49 \\
\hline S06WV071001 & 4 & 13 & $\mathrm{Oa} / \mathrm{A}$ & 21.59 & & 90 & 21.59 & 0.88 & 1.71 \\
\hline S06WV071001 & 13 & 26 & $\mathrm{E}$ & 6.44 & & 75 & 6.44 & 1.30 & 2.72 \\
\hline S06WV071001 & 26 & 42 & Bhs & 9.64 & & 70 & 9.64 & 1.27 & 5.88 \\
\hline S06WV071001 & 42 & 57 & $\mathrm{Bs}$ & 5.75 & & 0 & 5.75 & 1.31 & 11.27 \\
\hline S06WV071001 & 57 & 75 & $\mathrm{C}$ & 4.17 & & 75 & 4.17 & 1.52 & 2.84 \\
\hline S06WV081002 & 0 & 3 & Oe & 47.87 & & 0 & 47.87 & 0.52 & 7.48 \\
\hline S06WV081002 & 3 & 8 & $\mathrm{Oa} / \mathrm{A}$ & 34.85 & & 5 & 34.85 & 0.58 & 9.59 \\
\hline S06WV081002 & 8 & 25 & $\mathrm{AB}$ & 2.34 & 1.45 & 5 & 2.34 & 1.45 & 5.48 \\
\hline S06WV081002 & 25 & 51 & Bt1 & 0.82 & 1.49 & 5 & 0.82 & 1.49 & 3.02 \\
\hline
\end{tabular}




\begin{tabular}{|c|c|c|c|c|c|c|c|c|c|}
\hline PedonID & $\begin{array}{c}\text { Top } \\
\text { Depth } \\
\text { (cm) }\end{array}$ & $\begin{array}{c}\text { Bottom } \\
\text { Depth } \\
(\mathrm{cm})\end{array}$ & Horizon & $\begin{array}{c}\text { Total } \\
\text { Carbon\% } \\
\text { (Dry } \\
\text { Combustion, } \\
\text { Including } \\
\text { Converted } \\
\text { Walkley- } \\
\text { Black) }\end{array}$ & $\begin{array}{c}\text { 33kPa } \\
\text { Bulk } \\
\text { Density } \\
\left(\mathrm{g} \mathrm{cm}^{-3}\right)\end{array}$ & $\begin{array}{c}\text { Fragment } \\
\% \text { by } \\
\text { Volume }\end{array}$ & $\begin{array}{c}\text { Predicted } \\
\text { OC } \%\end{array}$ & $\begin{array}{c}\text { Predicted } \\
33 \mathrm{kPa} \mathrm{BD} \\
\left(\mathrm{g} \mathrm{cm}^{-3}\right)\end{array}$ & $\begin{array}{c}\text { SOC } \\
\text { Stock } \\
(\mathbf{k g} \\
\left.\mathbf{m}^{-2}\right)\end{array}$ \\
\hline S06WV081002 & 51 & 74 & $2 \mathrm{Bt} 2$ & 0.27 & 1.64 & 10 & 0.27 & 1.64 & 0.92 \\
\hline S06WV081002 & 74 & 97 & $2 \mathrm{Bt} 3$ & 0.15 & 1.67 & 25 & 0.15 & 1.67 & 0.43 \\
\hline S06WV081002 & 97 & 130 & $2 \mathrm{Bt} 4$ & 0.20 & 1.66 & 35 & 0.20 & 1.66 & 0.71 \\
\hline S06WV093008 & 0 & 1 & Oi & 44.19 & & 0 & 44.19 & 0.30 & 1.32 \\
\hline S06WV093008 & 1 & 3 & Oe & 36.25 & & 0 & 36.25 & 0.50 & 3.62 \\
\hline S06WV093008 & 3 & 15 & $\mathrm{Oa} / \mathrm{A}$ & 6.90 & & 10 & 6.90 & 1.10 & 8.16 \\
\hline S06WV093008 & 15 & 33 & $\mathrm{AE}$ & 5.53 & 0.83 & 15 & 5.53 & 0.83 & 7.02 \\
\hline S06WV093008 & 33 & 51 & Bs1 & 2.56 & 1.37 & 55 & 2.56 & 1.37 & 2.84 \\
\hline S06WV093008 & 51 & 69 & Bs2 & 1.18 & 1.50 & 55 & 1.18 & 1.50 & 1.43 \\
\hline S06WV093008 & 69 & 137 & Bs3 & 0.70 & 1.30 & 75 & 0.70 & 1.30 & 1.55 \\
\hline S06WV093008 & 137 & & $\mathrm{BC}$ & 0.45 & & 75 & 0.45 & 1.62 & 1.15 \\
\hline S01PA031010 & 0 & 3 & $\mathrm{Oe}$ & & & 0 & 30.35 & 0.46 & 4.20 \\
\hline S01PA031010 & 3 & 6 & $\mathrm{~A}$ & 1.47 & & 15 & 1.47 & 1.03 & 0.39 \\
\hline S01PA031010 & 6 & 10 & $\mathrm{E}$ & 0.55 & & 10 & 0.55 & 1.42 & 0.28 \\
\hline S01PA031010 & 10 & 28 & $\mathrm{BE}$ & 0.21 & & 10 & 0.21 & 1.37 & 0.47 \\
\hline S01PA031010 & 28 & 58 & Bw1 & 0.13 & & 20 & 0.13 & 1.51 & 0.47 \\
\hline S01PA031010 & 58 & 97 & Bw2 & 0.15 & & 40 & 0.15 & 1.66 & 0.58 \\
\hline S01PA031010 & 97 & 157 & $\mathrm{Bx}$ & 0.12 & & 60 & 0.12 & 1.78 & 0.51 \\
\hline S01PA031-050 & 0 & 3 & $\mathrm{Oe}$ & & & 0 & 34.14 & 0.49 & 5.02 \\
\hline S01PA031-050 & 3 & 8 & $\mathrm{~A}$ & 5.60 & & 5 & 5.60 & 1.02 & 2.72 \\
\hline S01PA031-050 & 8 & 25 & $\mathrm{BE}$ & 1.24 & & 5 & 1.24 & 1.28 & 2.57 \\
\hline S01PA031-050 & 25 & 46 & Bt1 & 0.53 & & 5 & 0.53 & 1.44 & 1.52 \\
\hline S01PA031-050 & 46 & 66 & $\mathrm{Bt} 2$ & 0.27 & & 10 & 0.27 & 1.57 & 0.76 \\
\hline
\end{tabular}




\begin{tabular}{|c|c|c|c|c|c|c|c|c|c|}
\hline PedonID & $\begin{array}{c}\text { Top } \\
\text { Depth } \\
\text { (cm) }\end{array}$ & $\begin{array}{c}\text { Bottom } \\
\text { Depth } \\
(\mathrm{cm})\end{array}$ & Horizon & $\begin{array}{c}\text { Total } \\
\text { Carbon\% } \\
\text { (Dry } \\
\text { Combustion, } \\
\text { Including } \\
\text { Converted } \\
\text { Walkley- } \\
\text { Black) }\end{array}$ & $\begin{array}{c}\text { 33kPa } \\
\text { Bulk } \\
\text { Density } \\
\left(\mathrm{g} \mathrm{cm}^{-3}\right)\end{array}$ & $\begin{array}{c}\text { Fragment } \\
\% \text { by } \\
\text { Volume }\end{array}$ & $\begin{array}{c}\text { Predicted } \\
\text { OC } \%\end{array}$ & $\begin{array}{c}\text { Predicted } \\
33 \mathrm{kPa} \mathrm{BD} \\
\left(\mathrm{g} \mathrm{cm}^{-3}\right)\end{array}$ & $\begin{array}{c}\text { SOC } \\
\text { Stock } \\
(\mathbf{k g} \\
\left.\mathbf{m}^{-2}\right)\end{array}$ \\
\hline S01PA031-050 & 66 & 127 & Btx1 & 0.12 & & 20 & 0.12 & 1.66 & 0.97 \\
\hline S01PA031-050 & 127 & 177 & Btx2 & 0.16 & & 35 & 0.16 & 1.76 & 0.91 \\
\hline S01PA031-050 & 177 & 200 & $\mathrm{BC}$ & 0.05 & & 50 & 0.05 & 1.74 & 0.10 \\
\hline S01PA031-053 & 0 & 3 & $\mathrm{Oa}$ & & & 0 & 33.84 & 0.64 & 6.52 \\
\hline S01PA031-053 & 3 & 13 & $\mathrm{~A}$ & 10.79 & & 0 & 10.79 & 1.02 & 11.04 \\
\hline S01PA031-053 & 13 & 25 & BA & 2.40 & & 0 & 2.40 & 1.21 & 3.49 \\
\hline S01PA031-053 & 25 & 50 & $\mathrm{Bt}$ & 0.63 & & 0 & 0.63 & 1.38 & 2.18 \\
\hline S01PA031-053 & 50 & 75 & Btg & 0.47 & & 0 & 0.47 & 1.58 & 1.86 \\
\hline S01PA031-053 & 75 & 117 & Btx & 0.45 & & 10 & 0.45 & 1.68 & 2.85 \\
\hline S01PA031-053 & 117 & 150 & $\mathrm{C}$ & 0.41 & & 35 & 0.41 & 1.61 & 1.41 \\
\hline S01WV019001 & 0 & 3 & Oi2 & 44.69 & & 0 & 44.69 & 0.42 & 5.66 \\
\hline S01WV019001 & 3 & 6 & $\mathrm{Oe}$ & 26.31 & & 0 & 26.31 & 1.04 & 8.19 \\
\hline S01WV019001 & 6 & 18 & $\mathrm{~A}$ & 4.05 & 1.04 & 40 & 4.05 & 1.04 & 3.03 \\
\hline S01WV019001 & 18 & 26 & $\mathrm{~A} / \mathrm{B}$ & 2.49 & 1.19 & 30 & 2.49 & 1.19 & 1.66 \\
\hline S01WV019001 & 26 & 39 & Bw1 & 0.90 & 1.48 & 30 & 0.90 & 1.48 & 1.21 \\
\hline S01WV019001 & 39 & 74 & Bw2 & 0.37 & 1.52 & 42 & 0.37 & 1.52 & 1.14 \\
\hline S01WV019001 & 74 & 120 & Bw3 & 0.18 & 1.66 & 45 & 0.18 & 1.66 & 0.76 \\
\hline S01WV019001 & 120 & 148 & $\mathrm{BC}$ & 0.29 & 1.47 & 45 & 0.29 & 1.47 & 0.66 \\
\hline S01WV019001 & 148 & 168 & $\mathrm{C}$ & 0.32 & 1.68 & 45 & 0.32 & 1.68 & 0.59 \\
\hline S01WV019002 & 0 & 3 & Oi1 & 49.86 & & 0 & 49.86 & 0.41 & 6.07 \\
\hline S01WV019002 & 3 & 5 & Oi2 & 49.16 & & 0 & 49.16 & 0.42 & 4.08 \\
\hline S01WV019002 & 5 & 8 & $\mathrm{Oe}$ & 44.99 & & 0 & 44.99 & 0.55 & 7.42 \\
\hline S01WV019002 & 8 & 14 & A & 6.75 & 1.03 & 10 & 6.75 & 1.03 & 3.75 \\
\hline
\end{tabular}




\begin{tabular}{|c|c|c|c|c|c|c|c|c|c|}
\hline PedonID & $\begin{array}{c}\text { Top } \\
\text { Depth } \\
(\mathbf{c m})\end{array}$ & $\begin{array}{c}\text { Bottom } \\
\text { Depth } \\
(\mathrm{cm})\end{array}$ & Horizon & $\begin{array}{c}\text { Total } \\
\text { Carbon \% } \\
\text { (Dry } \\
\text { Combustion, } \\
\text { Including } \\
\text { Converted } \\
\text { Walkley- } \\
\text { Black) } \\
\end{array}$ & $\begin{array}{c}\text { 33kPa } \\
\text { Bulk } \\
\text { Density } \\
\left(\mathrm{g} \mathrm{cm}^{-3}\right)\end{array}$ & $\begin{array}{c}\text { Fragment } \\
\% \text { by } \\
\text { Volume }\end{array}$ & $\begin{array}{c}\text { Predicted } \\
\text { OC } \%\end{array}$ & $\begin{array}{c}\text { Predicted } \\
\text { 33kPa BD } \\
\left(\mathrm{g} \mathrm{cm}^{-3}\right)\end{array}$ & $\begin{array}{c}\text { SOC } \\
\text { Stock } \\
(\mathbf{k g} \\
\left.\mathbf{m}^{-2}\right)\end{array}$ \\
\hline S01WV019002 & 14 & 25 & $\mathrm{~B} / \mathrm{A}$ & 2.12 & 1.15 & 15 & 2.12 & 1.15 & 2.28 \\
\hline S01WV019002 & 25 & 38 & $\mathrm{Bt1}$ & 0.98 & 1.42 & 15 & 0.98 & 1.42 & 1.54 \\
\hline S01WV019002 & 38 & 65 & $\mathrm{Bt} 2$ & 0.27 & 1.50 & 15 & 0.27 & 1.50 & 0.93 \\
\hline S01WV019002 & 65 & 91 & $\mathrm{BC}$ & 0.16 & 1.49 & 45 & 0.16 & 1.49 & 0.34 \\
\hline S01WV019003 & 0 & 3 & Oi1 & 42.45 & & 0 & 42.45 & 0.40 & 5.04 \\
\hline S01WV019003 & 3 & 5 & Oi2 & 46.22 & & 0 & 46.22 & 0.40 & 3.73 \\
\hline S01WV019003 & 5 & 7 & Oe & 41.60 & & 0 & 41.60 & 0.52 & 4.36 \\
\hline S01WV019003 & 7 & 16 & $\mathrm{~A}$ & 4.67 & 0.96 & 5 & 4.67 & 0.96 & 3.83 \\
\hline S01WV019003 & 16 & 27 & $\mathrm{BA}$ & 4.59 & 1.26 & 5 & 4.59 & 1.26 & 6.04 \\
\hline S01WV019003 & 27 & 51 & $\mathrm{Bt}$ & 1.14 & 1.37 & 5 & 1.14 & 1.37 & 3.56 \\
\hline S01WV019003 & 51 & 68 & $\mathrm{BC}$ & 0.20 & 1.66 & 10 & 0.20 & 1.66 & 0.51 \\
\hline S01WV019003 & 68 & 90 & $\mathrm{C}$ & 0.08 & 1.52 & 20 & 0.08 & 1.52 & 0.21 \\
\hline S01WV019004 & 0 & 3 & $\mathrm{Oe}$ & 50.30 & & 0 & 50.30 & 0.52 & 7.81 \\
\hline S01WV019004 & 3 & 10 & $\mathrm{Oa}$ & & & 40 & 29.98 & 0.57 & 7.24 \\
\hline S01WV019004 & 3 & 10 & $\mathrm{~A}$ & 36.11 & & 40 & 36.11 & 0.99 & 15.02 \\
\hline S01WV019004 & 10 & 25 & $\mathrm{BA}$ & 3.76 & & 40 & 3.76 & 1.17 & 3.96 \\
\hline S01WV019004 & 25 & 40 & Bw1 & 1.72 & 1.11 & 50 & 1.72 & 1.11 & 1.43 \\
\hline S01WV019004 & 40 & 70 & Bw2 & 1.72 & 1.25 & 50 & 1.72 & 1.25 & 3.23 \\
\hline S01WV019004 & 70 & 95 & $\mathrm{C}$ & 1.15 & & 80 & 1.15 & 1.47 & 0.84 \\
\hline S01WV019005 & 0 & 2 & Oil & 49.27 & & 0 & 49.27 & 0.39 & 3.86 \\
\hline S01WV019005 & 2 & 3 & Oi2 & 48.48 & & 0 & 48.48 & 0.41 & 1.98 \\
\hline S01WV019005 & 3 & 5 & Oe & 33.74 & & 0 & 33.74 & 0.55 & 3.70 \\
\hline S01WV019005 & 5 & 10 & $\mathrm{Oa}$ & 24.04 & & 5 & 24.04 & 0.93 & 10.65 \\
\hline
\end{tabular}




\begin{tabular}{|c|c|c|c|c|c|c|c|c|c|}
\hline PedonID & $\begin{array}{c}\text { Top } \\
\text { Depth } \\
\text { (cm) }\end{array}$ & $\begin{array}{c}\text { Bottom } \\
\text { Depth } \\
(\mathrm{cm})\end{array}$ & Horizon & $\begin{array}{c}\text { Total } \\
\text { Carbon\% } \\
\text { (Dry } \\
\text { Combustion, } \\
\text { Including } \\
\text { Converted } \\
\text { Walkley- } \\
\text { Black) }\end{array}$ & $\begin{array}{c}\text { 33kPa } \\
\text { Bulk } \\
\text { Density } \\
\left(\mathrm{g} \mathrm{cm}^{-3}\right)\end{array}$ & $\begin{array}{c}\text { Fragment } \\
\% \text { by } \\
\text { Volume }\end{array}$ & $\begin{array}{c}\text { Predicted } \\
\text { OC } \%\end{array}$ & $\begin{array}{c}\text { Predicted } \\
33 \mathrm{kPa} \mathrm{BD} \\
\left(\mathrm{g} \mathrm{cm}^{-3}\right)\end{array}$ & $\begin{array}{c}\text { SOC } \\
\text { Stock } \\
(\mathbf{k g} \\
\left.\mathbf{m}^{-2}\right)\end{array}$ \\
\hline S01WV019005 & 5 & 10 & $\mathrm{~A}$ & 6.44 & & 5 & 6.44 & 0.98 & 2.99 \\
\hline S01WV019005 & 10 & 25 & $\mathrm{BA}$ & 1.98 & 1.20 & 5 & 1.98 & 1.20 & 3.39 \\
\hline S01WV019005 & 25 & 47 & Bt1 & 0.53 & 1.30 & 5 & 0.53 & 1.30 & 1.44 \\
\hline S01WV019005 & 47 & 75 & Bt2 & 0.16 & 1.49 & 10 & 0.16 & 1.49 & 0.60 \\
\hline S01WV019005 & 75 & 88 & $\mathrm{BC}$ & 0.10 & 1.52 & 15 & 0.10 & 1.52 & 0.17 \\
\hline S01WV019006 & 0 & 3 & Oi1 & 47.60 & & 0 & 47.60 & 0.36 & 5.19 \\
\hline S01WV019006 & 3 & 5 & Oi2 & 47.95 & & 0 & 47.95 & 0.37 & 3.58 \\
\hline S01WV019006 & 5 & 7 & $\mathrm{Oe}$ & 41.11 & & 0 & 41.11 & 0.50 & 4.10 \\
\hline S01WV019006 & 7 & 14 & $\mathrm{Oa}$ & 36.32 & & 55 & 36.32 & 0.58 & 6.69 \\
\hline S01WV019006 & 14 & 23 & $\mathrm{~B} / \mathrm{E}$ & 1.98 & & 60 & 1.98 & 1.28 & 0.91 \\
\hline S01WV019006 & 23 & 40 & Bw1 & 1.46 & 1.24 & 50 & 1.46 & 1.24 & 1.54 \\
\hline S01WV019006 & 40 & 57 & Bw2 & 0.76 & & 50 & 0.76 & 1.44 & 0.93 \\
\hline S01WV019006 & 57 & 70 & $\mathrm{BC}$ & 0.77 & 1.42 & 60 & 0.77 & 1.42 & 0.57 \\
\hline S01WV019007 & 0 & 2 & Oil & 39.58 & & 0 & 39.58 & 0.39 & 3.10 \\
\hline S01WV019007 & 2 & 4 & Oi2 & 27.48 & & 0 & 27.48 & 0.87 & 4.79 \\
\hline S01WV019007 & 4 & 9 & $\mathrm{~A}$ & 5.33 & 0.81 & 15 & 5.33 & 0.81 & 1.83 \\
\hline S01WV019007 & 9 & 21 & BA & 1.61 & 1.15 & 10 & 1.61 & 1.15 & 2.00 \\
\hline S01WV019007 & 21 & 42 & Bt1 & 0.67 & 1.45 & 15 & 0.67 & 1.45 & 1.73 \\
\hline S01WV019007 & 42 & 65 & Bt2 & 0.41 & 1.43 & 15 & 0.41 & 1.43 & 1.15 \\
\hline S01WV019007 & 65 & 76 & $\mathrm{BC}$ & 0.45 & 1.40 & 20 & 0.45 & 1.40 & 0.55 \\
\hline S01WV019007 & 76 & 93 & $\mathrm{C}$ & 0.32 & 1.50 & 50 & 0.32 & 1.50 & 0.41 \\
\hline S01WV019008 & 0 & 1 & Oi1 & 25.97 & & 0 & 25.97 & 0.95 & 2.47 \\
\hline S01WV019008 & 117 & 171 & $2 \mathrm{C}$ & 0.14 & 1.47 & 30 & 35.24 & 0.44 & 3.07 \\
\hline
\end{tabular}




\begin{tabular}{|c|c|c|c|c|c|c|c|c|c|}
\hline PedonID & $\begin{array}{c}\text { Top } \\
\text { Depth } \\
\text { (cm) }\end{array}$ & $\begin{array}{c}\text { Bottom } \\
\text { Depth } \\
(\mathrm{cm})\end{array}$ & Horizon & $\begin{array}{c}\text { Total } \\
\text { Carbon\% } \\
\text { (Dry } \\
\text { Combustion, } \\
\text { Including } \\
\text { Converted } \\
\text { Walkley- } \\
\text { Black) }\end{array}$ & $\begin{array}{c}\text { 33kPa } \\
\text { Bulk } \\
\text { Density } \\
\left(\mathrm{g} \mathrm{cm}^{-3}\right)\end{array}$ & $\begin{array}{c}\text { Fragment } \\
\% \text { by } \\
\text { Volume }\end{array}$ & $\begin{array}{c}\text { Predicted } \\
\text { OC } \%\end{array}$ & $\begin{array}{c}\text { Predicted } \\
33 \mathrm{kPa} \mathrm{BD} \\
\left(\mathrm{g} \mathrm{cm}^{-3}\right)\end{array}$ & $\begin{array}{c}\text { SOC } \\
\text { Stock } \\
(\mathbf{k g} \\
\left.\mathbf{m}^{-2}\right)\end{array}$ \\
\hline S01WV019008 & 1 & 3 & Oi2 & 35.24 & & 0 & 5.39 & 1.01 & 1.74 \\
\hline S01WV019008 & 3 & 7 & $\mathrm{~A}$ & 5.39 & & 20 & 2.01 & 1.18 & 0.95 \\
\hline S01WV019008 & 7 & 12 & $\mathrm{~A} / \mathrm{B}$ & 2.01 & & 20 & 1.49 & 1.33 & 1.52 \\
\hline S01WV019008 & 12 & 21 & $\mathrm{~B} / \mathrm{A}$ & 1.49 & 1.33 & 15 & 0.69 & 1.44 & 2.38 \\
\hline S01WV019008 & 21 & 53 & $\mathrm{Bt1}$ & 0.69 & 1.44 & 25 & 0.27 & 1.47 & 0.26 \\
\hline S01WV019008 & 53 & 66 & $\mathrm{Bt} 2$ & 0.27 & 1.47 & 50 & 0.13 & 1.43 & 0.25 \\
\hline S01WV019008 & 66 & 93 & $\mathrm{Bx}$ & 0.13 & 1.43 & 50 & 0.22 & 1.49 & 0.47 \\
\hline S01WV019008 & 93 & 117 & $2 \mathrm{BC}$ & 0.22 & 1.49 & 40 & 0.14 & 1.47 & 0.78 \\
\hline S01WV019009 & 2 & 0 & Oi1 & 35.22 & & 0 & 35.22 & 0.95 & 6.66 \\
\hline S01WV019009 & 0 & 2 & Oi2 & 46.11 & & 0 & 49.42 & 0.61 & 5.99 \\
\hline S01WV019009 & 2 & 6 & $\mathrm{Oe}$ & 49.42 & & 0 & 16.24 & 0.89 & 6.94 \\
\hline S01WV019009 & 6 & 14 & $\mathrm{Oa} / \mathrm{A}$ & 16.24 & 0.89 & 40 & 3.99 & 1.14 & 2.39 \\
\hline S01WV019009 & 14 & 21 & $\mathrm{~B} / \mathrm{A}$ & 3.99 & 1.14 & 25 & 2.89 & 1.54 & 5.67 \\
\hline S01WV019009 & 21 & 38 & $\mathrm{Bw}$ & 2.89 & 1.54 & 25 & 0.51 & 1.53 & 1.37 \\
\hline S01WV019009 & 38 & 60 & Bt1 & 0.51 & & 20 & 0.25 & 1.45 & 0.84 \\
\hline S01WV019009 & 60 & 89 & $2 \mathrm{Bt} 2$ & 0.25 & 1.45 & 20 & 0.26 & 1.65 & 0.59 \\
\hline S01WV019009 & 89 & 112 & $2 \mathrm{Btx} 1$ & 0.26 & 1.65 & 40 & 0.20 & 1.70 & 0.39 \\
\hline S01WV019009 & 112 & 135 & $2 \mathrm{Btx} 2$ & 0.20 & 1.70 & 50 & 46.11 & 0.46 & 4.21 \\
\hline S01WV019010 & 0 & 2 & Oi1 & 39.97 & & 0 & 39.97 & 0.35 & 2.80 \\
\hline S01WV019010 & 2 & 4 & Oi2 & 38.06 & & 0 & 38.06 & 0.36 & 2.76 \\
\hline S01WV019010 & 4 & 7 & $\mathrm{Oe} / \mathrm{Oa}$ & 31.81 & & 10 & 31.81 & 0.47 & 4.01 \\
\hline S01WV019010 & 7 & 13 & $\mathrm{~A}$ & 5.75 & & 15 & 5.75 & 1.07 & 3.13 \\
\hline S01WV019010 & 13 & 22 & $\mathrm{~B} / \mathrm{A}$ & 2.48 & 1.18 & 15 & 2.48 & 1.18 & 2.24 \\
\hline
\end{tabular}




\begin{tabular}{|c|c|c|c|c|c|c|c|c|c|}
\hline PedonID & $\begin{array}{c}\text { Top } \\
\text { Depth } \\
\text { (cm) }\end{array}$ & $\begin{array}{c}\text { Bottom } \\
\text { Depth } \\
(\mathrm{cm})\end{array}$ & Horizon & $\begin{array}{c}\text { Total } \\
\text { Carbon\% } \\
\text { (Dry } \\
\text { Combustion, } \\
\text { Including } \\
\text { Converted } \\
\text { Walkley- } \\
\text { Black) }\end{array}$ & $\begin{array}{c}\text { 33kPa } \\
\text { Bulk } \\
\text { Density } \\
\left(\mathrm{g} \mathrm{cm}^{-3}\right)\end{array}$ & $\begin{array}{c}\text { Fragment } \\
\% \text { by } \\
\text { Volume }\end{array}$ & $\begin{array}{c}\text { Predicted } \\
\text { OC } \%\end{array}$ & $\begin{array}{c}\text { Predicted } \\
33 \mathrm{kPa} \mathrm{BD} \\
\left(\mathrm{g} \mathrm{cm}^{-3}\right)\end{array}$ & $\begin{array}{c}\text { SOC } \\
\text { Stock } \\
(\mathbf{k g} \\
\left.\mathrm{m}^{-2}\right)\end{array}$ \\
\hline S01WV019010 & 22 & 40 & Bw1 & 0.54 & 1.36 & 30 & 0.54 & 1.36 & 0.93 \\
\hline S01WV019010 & 40 & 54 & Bw2 & 0.30 & 1.39 & 90 & 0.30 & 1.39 & 0.06 \\
\hline S01WV019010 & 54 & 68 & $\mathrm{BC}$ & 0.13 & 1.63 & 70 & 0.13 & 1.63 & 0.09 \\
\hline S01WV019011 & 0 & 1 & Oi1 & 49.06 & & 0 & 49.06 & 0.32 & 1.59 \\
\hline S01WV019011 & 1 & 2 & Oi2 & 43.98 & & 0 & 43.98 & 0.34 & 1.49 \\
\hline S01WV019011 & 2 & 3 & $\mathrm{Oe}$ & 30.34 & & 0 & 30.34 & 0.98 & 2.96 \\
\hline S01WV019011 & 3 & 10 & $\mathrm{~A}$ & 3.85 & 0.90 & 10 & 3.85 & 0.90 & 2.18 \\
\hline S01WV019011 & 10 & 18 & $\mathrm{BE}$ & 0.88 & 1.29 & 5 & 0.88 & 1.29 & 0.86 \\
\hline S01WV019011 & 18 & 30 & Bw1 & 0.59 & 1.26 & 10 & 0.59 & 1.26 & 0.80 \\
\hline S01WV019011 & 30 & 53 & Bw2 & 0.38 & 1.29 & 15 & 0.38 & 1.29 & 0.96 \\
\hline S01WV019011 & 53 & 68 & Bw3 & 0.25 & 1.53 & 25 & 0.25 & 1.53 & 0.43 \\
\hline S01WV019011 & 68 & 78 & $\mathrm{C}$ & 0.15 & 1.53 & 60 & 0.15 & 1.53 & 0.09 \\
\hline S01WV025002 & 0 & 5 & $\mathrm{~A}$ & 4.07 & & 0 & 4.07 & 1.03 & 2.10 \\
\hline S01WV025002 & 5 & 15 & $\mathrm{E}$ & 0.59 & & 0 & 0.59 & 1.26 & 0.74 \\
\hline S01WV025002 & 15 & 30 & $\mathrm{BE}$ & 0.40 & & 0 & 0.40 & 1.26 & 0.76 \\
\hline S01WV025002 & 30 & 64 & Bt1 & 0.18 & & 5 & 0.18 & 1.35 & 0.78 \\
\hline S01WV025002 & 64 & 109 & Bt2 & 0.14 & & 10 & 0.14 & 1.42 & 0.80 \\
\hline S01WV025002 & 109 & 137 & Bt3 & 0.19 & & 25 & 0.19 & 1.43 & 0.57 \\
\hline S01WV025002 & 137 & 201 & $\mathrm{BC}$ & 0.19 & & 0 & 0.19 & 1.45 & 1.76 \\
\hline S01WV025002 & 201 & 216 & $\mathrm{C}$ & 0.14 & & 0 & 0.14 & 1.41 & 0.30 \\
\hline S01WV025003 & 0 & 23 & $\mathrm{~A}$ & 1.99 & & 0 & 1.99 & 1.11 & 5.08 \\
\hline S01WV025003 & 23 & 56 & $\mathrm{BA}$ & 0.44 & & 0 & 0.44 & 1.26 & 1.83 \\
\hline S01WV025003 & 56 & 87 & Bt1 & 0.30 & & 0 & 0.30 & 1.41 & 1.32 \\
\hline
\end{tabular}




\begin{tabular}{|c|c|c|c|c|c|c|c|c|c|}
\hline PedonID & $\begin{array}{c}\text { Top } \\
\text { Depth } \\
\text { (cm) }\end{array}$ & $\begin{array}{c}\text { Bottom } \\
\text { Depth } \\
\text { (cm) }\end{array}$ & Horizon & $\begin{array}{c}\text { Total } \\
\text { Carbon\% } \\
\text { (Dry } \\
\text { Combustion, } \\
\text { Including } \\
\text { Converted } \\
\text { Walkley- } \\
\text { Black) }\end{array}$ & $\begin{array}{c}\text { 33kPa } \\
\text { Bulk } \\
\text { Density } \\
\left(\mathrm{g} \mathrm{cm}^{-3}\right)\end{array}$ & $\begin{array}{c}\text { Fragment } \\
\% \text { by } \\
\text { Volume }\end{array}$ & $\begin{array}{c}\text { Predicted } \\
\text { OC } \%\end{array}$ & $\begin{array}{c}\text { Predicted } \\
\text { 33kPa BD } \\
\left(\mathrm{g} \mathrm{cm}^{-3}\right)\end{array}$ & $\begin{array}{c}\text { SOC } \\
\text { Stock } \\
(\mathbf{k g} \\
\left.\mathbf{m}^{-2}\right)\end{array}$ \\
\hline S01WV025003 & 87 & 145 & $\mathrm{Bt} 2$ & 0.55 & & 10 & 0.55 & 1.41 & 4.05 \\
\hline S01WV025003 & 145 & 183 & $\mathrm{Bt} 3$ & 0.43 & & 10 & 0.43 & 1.25 & 1.84 \\
\hline S01WV025003 & 183 & 203 & $\mathrm{Bt} 4$ & 0.26 & & 10 & 0.26 & 1.41 & 0.66 \\
\hline S01WV025004 & 0 & 15 & $\mathrm{~A}$ & 3.05 & & 0 & 3.05 & 1.03 & 4.71 \\
\hline S01WV025004 & 15 & 30 & BA & 0.73 & & 0 & 0.73 & 1.22 & 1.33 \\
\hline S01WV025004 & 30 & 48 & Bt1 & 0.39 & & 0 & 0.39 & 1.36 & 0.96 \\
\hline S01WV025004 & 48 & 89 & $\mathrm{Bt} 2$ & 0.59 & & 0 & 0.59 & 1.41 & 3.40 \\
\hline S01WV063005 & 0 & 20 & Ap & 3.52 & & 5 & 3.52 & 1.23 & 8.20 \\
\hline S01WV063005 & 20 & 36 & $\mathrm{BA}$ & 0.57 & & 5 & 0.57 & 1.31 & 1.14 \\
\hline S01WV063005 & 36 & 71 & Bt1 & 0.32 & & 5 & 0.32 & 1.41 & 1.50 \\
\hline S01WV063005 & 71 & 107 & $\mathrm{Bt} 2$ & 0.37 & & 10 & 0.37 & 1.43 & 1.72 \\
\hline S01WV063005 & 107 & 132 & $\mathrm{Bt3}$ & 0.38 & & 15 & 0.38 & 1.43 & 1.15 \\
\hline S01WV063005 & 132 & 155 & $\mathrm{Bt} 4$ & 0.33 & & 2 & 0.33 & 1.38 & 1.03 \\
\hline S01WV063005 & 155 & 188 & $\mathrm{C}$ & 0.28 & & 5 & 0.28 & 1.43 & 1.26 \\
\hline S01WV063006 & 0 & 20 & Ap & 1.13 & & 5 & 1.13 & 1.21 & 2.60 \\
\hline S01WV063006 & 20 & 30 & $\mathrm{BA}$ & 0.41 & & 5 & 0.41 & 1.28 & 0.50 \\
\hline S01WV063006 & 30 & 51 & Bt1 & 0.22 & & 10 & 0.22 & 1.41 & 0.58 \\
\hline S01WV063006 & 51 & 97 & $\mathrm{Bt} 2$ & 0.16 & & 10 & 0.16 & 1.45 & 0.96 \\
\hline S01WV063006 & 97 & 132 & $\mathrm{Bt} 3$ & 0.18 & & 10 & 0.18 & 1.44 & 0.82 \\
\hline S01WV063006 & 132 & 155 & $\mathrm{C} 1$ & 0.18 & & 5 & 0.18 & 1.42 & 0.56 \\
\hline S01WV063006 & 155 & 191 & $\mathrm{C} 2$ & 0.25 & & 25 & 0.25 & 1.42 & 0.96 \\
\hline S01WV063007 & 0 & 13 & $\mathrm{~A}$ & 2.09 & & 5 & 2.09 & 1.04 & 2.68 \\
\hline S01WV063007 & 13 & 25 & BA & 0.81 & & 2 & 0.81 & 1.27 & 1.21 \\
\hline
\end{tabular}




\begin{tabular}{|c|c|c|c|c|c|c|c|c|c|}
\hline PedonID & $\begin{array}{c}\text { Top } \\
\text { Depth } \\
\text { (cm) }\end{array}$ & $\begin{array}{c}\text { Bottom } \\
\text { Depth } \\
\text { (cm) }\end{array}$ & Horizon & $\begin{array}{c}\text { Total } \\
\text { Carbon\% } \\
\text { (Dry } \\
\text { Combustion, } \\
\text { Including } \\
\text { Converted } \\
\text { Walkley- } \\
\text { Black) }\end{array}$ & $\begin{array}{c}\text { 33kPa } \\
\text { Bulk } \\
\text { Density } \\
\left(\mathrm{g} \mathrm{cm}^{-3}\right)\end{array}$ & $\begin{array}{c}\text { Fragment } \\
\% \text { by } \\
\text { Volume }\end{array}$ & $\begin{array}{c}\text { Predicted } \\
\text { OC } \%\end{array}$ & $\begin{array}{c}\text { Predicted } \\
33 \mathrm{kPa} \mathrm{BD} \\
\left(\mathrm{g} \mathrm{cm}^{-3}\right)\end{array}$ & $\begin{array}{c}\text { SOC } \\
\text { Stock } \\
(\mathbf{k g} \\
\left.\mathbf{m}^{-2}\right)\end{array}$ \\
\hline S01WV063007 & 25 & 51 & Bt1 & 0.53 & & 0 & 0.53 & 1.38 & 1.90 \\
\hline S01WV063007 & 51 & 94 & $\mathrm{Bt} 2$ & 0.54 & & 0 & 0.54 & 1.43 & 3.32 \\
\hline S01WV063007 & 94 & 119 & Bt3 & 0.62 & & 0 & 0.62 & 1.41 & 2.19 \\
\hline S01WV063008 & 0 & 10 & $\mathrm{~A}$ & 1.68 & & 5 & 1.68 & 1.08 & 1.72 \\
\hline S01WV063008 & 10 & 23 & $\mathrm{AB}$ & 0.82 & & 1 & 0.82 & 1.24 & 1.31 \\
\hline S01WV063008 & 23 & 36 & $\mathrm{BA}$ & 0.49 & & 1 & 0.49 & 1.30 & 0.82 \\
\hline S01WV063008 & 36 & 56 & Bt1 & 0.30 & & 0 & 0.30 & 1.41 & 0.85 \\
\hline S01WV063008 & 56 & 79 & Bt2 & 0.26 & & 0 & 0.26 & 1.42 & 0.85 \\
\hline S01WV063008 & 79 & 112 & Bt3 & 0.43 & & 0 & 0.43 & 1.42 & 2.01 \\
\hline S01WV063008 & 112 & 140 & $\mathrm{Bt} 4$ & 0.70 & & 0 & 0.70 & 1.25 & 2.46 \\
\hline S01WV081001 & 0 & 3 & Oi1 & 50.54 & & 0 & 50.54 & 0.39 & 5.86 \\
\hline S01WV081001 & 3 & 5 & Oi2 & 46.48 & & 0 & 46.48 & 0.40 & 3.68 \\
\hline S01WV081001 & 5 & 6 & Oe & 22.39 & & 15 & 22.39 & 0.94 & 1.79 \\
\hline S01WV081001 & 6 & 16 & $\mathrm{~A}$ & 3.46 & 1.05 & 10 & 3.46 & 1.05 & 3.27 \\
\hline S01WV081001 & 16 & 22 & $\mathrm{~A} / \mathrm{B}$ & 2.48 & 1.18 & 5 & 2.48 & 1.18 & 1.67 \\
\hline S01WV081001 & 22 & 32 & $\mathrm{~B} / \mathrm{A}$ & 1.05 & 1.43 & 5 & 1.05 & 1.43 & 1.43 \\
\hline S01WV081001 & 32 & 59 & Bt1 & 0.26 & 1.49 & 5 & 0.26 & 1.49 & 0.99 \\
\hline S01WV081001 & 59 & 81 & Bt2 & 0.15 & 1.54 & 10 & 0.15 & 1.54 & 0.46 \\
\hline S01WV081001 & 81 & 105 & $\mathrm{BC}$ & 0.19 & 1.52 & 15 & 0.19 & 1.52 & 0.59 \\
\hline S01WV081002 & 0 & 1 & $\mathrm{Oi}$ & 40.02 & & 15 & 40.02 & 0.30 & 1.01 \\
\hline S01WV081002 & 1 & 3 & $\mathrm{Oe}$ & 15.39 & & 15 & 15.39 & 0.95 & 2.47 \\
\hline S01WV081002 & 3 & 8 & $\mathrm{~A}$ & 10.83 & & 15 & 10.83 & 1.05 & 4.82 \\
\hline S01WV081002 & 8 & 20 & $\mathrm{~B} / \mathrm{A}$ & 2.63 & 0.91 & 15 & 2.63 & 0.91 & 2.44 \\
\hline
\end{tabular}




\begin{tabular}{|c|c|c|c|c|c|c|c|c|c|}
\hline PedonID & $\begin{array}{c}\text { Top } \\
\text { Depth } \\
\text { (cm) }\end{array}$ & $\begin{array}{c}\text { Bottom } \\
\text { Depth } \\
(\mathrm{cm})\end{array}$ & Horizon & $\begin{array}{c}\text { Total } \\
\text { Carbon \% } \\
\text { (Dry } \\
\text { Combustion, } \\
\text { Including } \\
\text { Converted } \\
\text { Walkley- } \\
\text { Black) } \\
\end{array}$ & $\begin{array}{c}\text { 33kPa } \\
\text { Bulk } \\
\text { Density } \\
\left(\mathrm{g} \mathrm{cm}^{-3}\right)\end{array}$ & $\begin{array}{c}\text { Fragment } \\
\% \text { by } \\
\text { Volume }\end{array}$ & $\begin{array}{c}\text { Predicted } \\
\text { OC } \%\end{array}$ & $\begin{array}{c}\text { Predicted } \\
\text { 33kPa BD } \\
\left(\mathrm{g} \mathrm{cm}^{-3}\right)\end{array}$ & $\begin{array}{c}\text { SOC } \\
\text { Stock } \\
(\mathbf{k g} \\
\left.\mathbf{m}^{-2}\right)\end{array}$ \\
\hline S01WV081002 & 20 & 30 & Bw1 & 2.00 & 1.14 & 15 & 2.00 & 1.14 & 1.94 \\
\hline S01WV081002 & 30 & 54 & Bw2 & 0.66 & 1.32 & 25 & 0.66 & 1.32 & 1.57 \\
\hline S01WV081002 & 54 & 65 & Bw3 & 0.54 & 1.53 & 50 & 0.54 & 1.53 & 0.45 \\
\hline S01WV081002 & 65 & 80 & $\mathrm{BC}$ & 0.28 & 1.48 & 60 & 0.28 & 1.48 & 0.25 \\
\hline S01WV081003 & 0 & 2 & $\mathrm{Oi}$ & 43.66 & & 0 & 43.66 & 0.33 & 2.88 \\
\hline S01WV081003 & 2 & 4 & $\mathrm{Oe}$ & 32.56 & & 0 & 32.56 & 0.46 & 2.99 \\
\hline S01WV081003 & 4 & 13 & A1 & 12.75 & & 35 & 12.75 & 1.09 & 8.13 \\
\hline S01WV081003 & 13 & 23 & $\mathrm{~A} 2$ & 4.22 & 1.07 & 35 & 4.22 & 1.07 & 2.94 \\
\hline S01WV081003 & 23 & 33 & $\mathrm{~B} / \mathrm{A}$ & 1.24 & 1.26 & 25 & 1.24 & 1.26 & 1.17 \\
\hline S01WV081003 & 33 & 55 & Bw1 & 0.43 & 1.57 & 25 & 0.43 & 1.57 & 1.11 \\
\hline S01WV081003 & 55 & 95 & Bw2 & 0.33 & 1.56 & 40 & 0.33 & 1.56 & 1.24 \\
\hline S01WV081003 & 95 & 155 & $\mathrm{BC}$ & 0.23 & 1.31 & 70 & 0.23 & 1.31 & 0.54 \\
\hline S01WV081004 & 0 & 2 & Oi1 & 45.64 & & 0 & 45.64 & 0.35 & 3.20 \\
\hline S01WV081004 & 2 & 5 & Oi2 & 35.52 & & 0 & 35.52 & 0.37 & 3.94 \\
\hline S01WV081004 & 5 & 10 & $\mathrm{~A}$ & 6.01 & & 10 & 6.01 & 1.01 & 2.73 \\
\hline S01WV081004 & 10 & 17 & $\mathrm{~A} / \mathrm{B}$ & 2.30 & & 10 & 2.30 & 1.15 & 1.66 \\
\hline S01WV081004 & 17 & 27 & BA & 0.90 & 1.31 & 5 & 0.90 & 1.31 & 1.12 \\
\hline S01WV081004 & 27 & 40 & Bw1 & 0.44 & 1.38 & 10 & 0.44 & 1.38 & 0.71 \\
\hline S01WV081004 & 40 & 62 & Bw2 & 0.19 & 1.50 & 10 & 0.19 & 1.50 & 0.56 \\
\hline S01WV081004 & 62 & 84 & Bw3 & 0.15 & 1.66 & 20 & 0.15 & 1.66 & 0.44 \\
\hline S01WV081004 & 84 & 104 & $\mathrm{BC}$ & 0.12 & 1.57 & 30 & 0.12 & 1.57 & 0.26 \\
\hline S01WV081005 & 0 & 3 & Oi1 & 50.28 & & 0 & 50.28 & 0.44 & 6.67 \\
\hline S01WV081005 & 3 & 5 & Oi2 & 40.03 & & 0 & 40.03 & 0.45 & 3.63 \\
\hline
\end{tabular}




\begin{tabular}{|c|c|c|c|c|c|c|c|c|c|}
\hline PedonID & $\begin{array}{c}\text { Top } \\
\text { Depth } \\
(\mathbf{c m})\end{array}$ & $\begin{array}{c}\text { Bottom } \\
\text { Depth } \\
(\mathrm{cm})\end{array}$ & Horizon & $\begin{array}{c}\text { Total } \\
\text { Carbon \% } \\
\text { (Dry } \\
\text { Combustion, } \\
\text { Including } \\
\text { Converted } \\
\text { Walkley- } \\
\text { Black) } \\
\end{array}$ & $\begin{array}{c}\text { 33kPa } \\
\text { Bulk } \\
\text { Density } \\
\left(\mathrm{g} \mathrm{cm}^{-3}\right)\end{array}$ & $\begin{array}{c}\text { Fragment } \\
\% \text { by } \\
\text { Volume }\end{array}$ & $\begin{array}{c}\text { Predicted } \\
\text { OC } \%\end{array}$ & $\begin{array}{c}\text { Predicted } \\
\text { 33kPa BD } \\
\left(\mathrm{g} \mathrm{cm}^{-3}\right)\end{array}$ & $\begin{array}{c}\text { SOC } \\
\text { Stock } \\
(\mathbf{k g} \\
\left.\mathbf{m}^{-2}\right)\end{array}$ \\
\hline S01WV081005 & 5 & 7 & $\mathrm{Oe}$ & 25.23 & & 0 & 25.23 & 1.00 & 5.04 \\
\hline S01WV081005 & 7 & 17 & $\mathrm{~A}$ & 5.96 & 0.97 & 10 & 5.96 & 0.97 & 5.20 \\
\hline S01WV081005 & 17 & 30 & $\mathrm{BA}$ & 1.92 & 1.09 & 10 & 1.92 & 1.09 & 2.45 \\
\hline S01WV081005 & 30 & 59 & Bw1 & 0.43 & 1.45 & 5 & 0.43 & 1.45 & 1.72 \\
\hline S01WV081005 & 59 & 74 & Bw2 & 0.19 & 1.50 & 5 & 0.19 & 1.50 & 0.41 \\
\hline S01WV081005 & 74 & 110 & $\mathrm{Bx}$ & 0.07 & 1.53 & 10 & 0.07 & 1.53 & 0.35 \\
\hline S01WV081006 & 0 & 3 & $\mathrm{~A}$ & 5.43 & & 30 & 5.43 & 0.97 & 1.10 \\
\hline S01WV081006 & 3 & 12 & $\mathrm{BA}$ & 1.75 & 1.09 & 20 & 1.75 & 1.09 & 1.37 \\
\hline S01WV081006 & 12 & 27 & Bw1 & 0.99 & 1.43 & 25 & 0.99 & 1.43 & 1.59 \\
\hline S01WV081006 & 27 & 52 & Bw2 & 0.43 & 1.37 & 35 & 0.43 & 1.37 & 0.96 \\
\hline S01WV081006 & 52 & 70 & Bw3 & 0.29 & 1.55 & 50 & 0.29 & 1.55 & 0.40 \\
\hline S01WV081006 & 70 & 106 & $\mathrm{BC}$ & 0.17 & 1.77 & 50 & 0.17 & 1.77 & 0.54 \\
\hline S01WV081006 & 106 & 130 & $\mathrm{C}$ & 0.24 & 1.41 & 80 & 0.24 & 1.41 & 0.16 \\
\hline S01WV081007 & 0 & 2 & Oi1 & 50.15 & & 0 & 50.15 & 0.33 & 3.27 \\
\hline S01WV081007 & 2 & 4 & Oi2 & 47.47 & & 0 & 47.47 & 0.34 & 3.23 \\
\hline S01WV081007 & 4 & 7 & $\mathrm{Oa}$ & 20.76 & & 20 & 20.76 & 0.53 & 2.63 \\
\hline S01WV081007 & 7 & 17 & BA & 1.77 & & 35 & 1.77 & 1.18 & 1.35 \\
\hline S01WV081007 & 17 & 36 & Bw1 & 0.86 & 1.31 & 60 & 0.86 & 1.31 & 0.86 \\
\hline S01WV081007 & 36 & 67 & Bw2 & 0.44 & & 60 & 0.44 & 1.45 & 0.79 \\
\hline S01WV081007 & 67 & 92 & $\mathrm{C}$ & 0.16 & 1.53 & 70 & 0.16 & 1.53 & 0.18 \\
\hline S02PA031008 & 0 & 8 & A1 & 2.60 & & 0 & 2.60 & 1.01 & 2.10 \\
\hline S02PA031008 & 8 & 20 & $\mathrm{~A} 2$ & 4.94 & & 0 & 4.94 & 1.10 & 6.55 \\
\hline S02PA031008 & 20 & 48 & $\mathrm{Bg} 1$ & 1.48 & & 0 & 1.48 & 1.19 & 4.94 \\
\hline
\end{tabular}




\begin{tabular}{|c|c|c|c|c|c|c|c|c|c|}
\hline PedonID & $\begin{array}{c}\text { Top } \\
\text { Depth } \\
\text { (cm) }\end{array}$ & $\begin{array}{c}\text { Bottom } \\
\text { Depth } \\
\text { (cm) }\end{array}$ & Horizon & $\begin{array}{c}\text { Total } \\
\text { Carbon\% } \\
\text { (Dry } \\
\text { Combustion, } \\
\text { Including } \\
\text { Converted } \\
\text { Walkley- } \\
\text { Black) } \\
\end{array}$ & $\begin{array}{c}\text { 33kPa } \\
\text { Bulk } \\
\text { Density } \\
\left(\mathrm{g} \mathrm{cm}^{-3}\right)\end{array}$ & $\begin{array}{c}\text { Fragment } \\
\% \text { by } \\
\text { Volume }\end{array}$ & $\begin{array}{c}\text { Predicted } \\
\text { OC } \%\end{array}$ & $\begin{array}{c}\text { Predicted } \\
\text { 33kPa BD } \\
\left(\mathrm{g} \mathrm{cm}^{-3}\right)\end{array}$ & $\begin{array}{c}\text { SOC } \\
\text { Stock } \\
(\mathbf{k g} \\
\left.\mathbf{m}^{-2}\right)\end{array}$ \\
\hline S02PA031008 & 48 & 71 & $\mathrm{Bg} 2$ & 0.74 & & 0 & 0.74 & 1.41 & 2.40 \\
\hline S02PA031008 & 71 & 94 & $\mathrm{BCg}$ & 0.40 & & 0 & 0.40 & 1.53 & 1.41 \\
\hline S02PA031008 & 94 & 124 & $\mathrm{Cg}$ & 0.61 & & 0 & 0.61 & 1.51 & 2.77 \\
\hline S02PA031008 & 124 & 165 & $2 \mathrm{C}$ & 0.70 & & 60 & 0.70 & 1.56 & 1.79 \\
\hline S02PA065004 & 0 & 3 & $\mathrm{Oe}$ & & & 0 & 40.60 & 0.58 & 7.01 \\
\hline S02PA065004 & 3 & 5 & $\mathrm{~A}$ & 9.65 & & 5 & 9.65 & 1.01 & 1.84 \\
\hline S02PA065004 & 5 & 20 & BA & 0.59 & & 5 & 0.59 & 1.18 & 0.99 \\
\hline S02PA065004 & 20 & 43 & $\mathrm{Bt1}$ & 0.27 & & 10 & 0.27 & 1.41 & 0.79 \\
\hline S02PA065004 & 43 & 61 & Bt2 & 0.21 & & 15 & 0.21 & 1.53 & 0.49 \\
\hline S02PA065004 & 61 & 142 & Btx & 0.25 & & 25 & 0.25 & 1.72 & 2.61 \\
\hline S02WV019001 & 0 & 3 & Oi1 & 41.99 & & 0 & 41.99 & 0.36 & 4.57 \\
\hline S02WV019001 & 3 & 6 & Oi2 & 37.20 & & 0 & 37.20 & 0.38 & 4.21 \\
\hline S02WV019001 & 6 & 9 & $\mathrm{Oe}$ & 36.53 & & 0 & 36.53 & 0.49 & 5.38 \\
\hline S02WV019001 & 9 & 21 & $\mathrm{~A}$ & 5.15 & & 25 & 5.15 & 1.05 & 4.87 \\
\hline S02WV019001 & 21 & 28 & $\mathrm{BA}$ & 1.76 & & 25 & 1.76 & 1.26 & 1.17 \\
\hline S02WV019001 & 28 & 54 & Bw1 & 0.75 & 1.50 & 30 & 0.75 & 1.50 & 2.05 \\
\hline S02WV019001 & 54 & 69 & Bw2 & 0.56 & 1.30 & 50 & 0.56 & 1.30 & 0.55 \\
\hline S02WV019001 & 69 & 85 & $\mathrm{BC}$ & 0.46 & 1.63 & 70 & 0.46 & 1.63 & 0.36 \\
\hline S02WV019006 & 3 & 0 & Oi1 & 47.88 & & 0 & 32.17 & 0.49 & 4.48 \\
\hline S02WV019006 & 0 & 2 & $\mathrm{Oi} 2$ & 46.78 & & 0 & 47.88 & 0.36 & 3.47 \\
\hline S02WV019006 & 2 & 5 & $\mathrm{Oe}$ & 32.17 & & 5 & 3.46 & 1.01 & 1.79 \\
\hline S02WV019006 & 5 & 11 & $\mathrm{~A}$ & 3.46 & & 15 & 1.26 & 1.01 & 0.76 \\
\hline S02WV019006 & 11 & 18 & $\mathrm{~B} / \mathrm{A}$ & 1.26 & 1.01 & 15 & 0.75 & 1.39 & 1.33 \\
\hline
\end{tabular}




\begin{tabular}{|c|c|c|c|c|c|c|c|c|c|}
\hline PedonID & $\begin{array}{c}\text { Top } \\
\text { Depth } \\
\text { (cm) }\end{array}$ & $\begin{array}{c}\text { Bottom } \\
\text { Depth } \\
\text { (cm) }\end{array}$ & Horizon & $\begin{array}{c}\text { Total } \\
\text { Carbon \% } \\
\text { (Dry } \\
\text { Combustion, } \\
\text { Including } \\
\text { Converted } \\
\text { Walkley- } \\
\text { Black) } \\
\end{array}$ & $\begin{array}{c}\text { 33kPa } \\
\text { Bulk } \\
\text { Density } \\
\left(\mathrm{g} \mathrm{cm}^{-3}\right)\end{array}$ & $\begin{array}{c}\text { Fragment } \\
\% \text { by } \\
\text { Volume }\end{array}$ & $\begin{array}{c}\text { Predicted } \\
\text { OC } \%\end{array}$ & $\begin{array}{c}\text { Predicted } \\
\text { 33kPa BD } \\
\left(\mathrm{g} \mathrm{cm}^{-3}\right)\end{array}$ & $\begin{array}{c}\text { SOC } \\
\text { Stock } \\
(\mathbf{k g} \\
\left.\mathbf{m}^{-2}\right)\end{array}$ \\
\hline S02WV019006 & 18 & 34 & Bw1 & 0.75 & 1.39 & 20 & 0.36 & 1.48 & 0.86 \\
\hline S02WV019006 & 34 & 61 & Bw2 & 0.36 & 1.48 & 40 & 0.24 & 1.56 & 0.46 \\
\hline S02WV019006 & 61 & 80 & 2Bw3 & 0.24 & 1.56 & 35 & 0.24 & 1.59 & 0.21 \\
\hline S02WV019006 & 80 & 94 & $2 \mathrm{C}$ & 0.24 & 1.59 & 60 & 0.24 & 1.59 & 0.21 \\
\hline S02WV019007 & 0 & 5 & A1 & 6.42 & & 25 & 6.42 & 1.01 & 2.43 \\
\hline S02WV019007 & 5 & 15 & A2 & 1.42 & 0.99 & 25 & 1.42 & 0.99 & 1.05 \\
\hline S02WV019007 & 15 & 30 & $\mathrm{~B} / \mathrm{A}$ & 0.82 & 1.26 & 20 & 0.82 & 1.26 & 1.24 \\
\hline S02WV019007 & 30 & 60 & Bt1 & 0.29 & 1.49 & 30 & 0.29 & 1.49 & 0.91 \\
\hline S02WV019007 & 60 & 81 & $\mathrm{Bt} 2$ & 0.27 & 1.18 & 40 & 0.27 & 1.18 & 0.40 \\
\hline S02WV019007 & 81 & 104 & $\mathrm{BC}$ & 0.20 & & 50 & 0.20 & 1.45 & 0.33 \\
\hline S02WV019008 & 0 & 8 & A1 & 3.45 & & 20 & 3.45 & 1.03 & 2.28 \\
\hline S02WV019008 & 8 & 35 & A2 & 1.64 & 1.05 & 20 & 1.64 & 1.05 & 3.72 \\
\hline S02WV019008 & 35 & 54 & $\mathrm{BA}$ & 0.65 & 1.34 & 40 & 0.65 & 1.34 & 0.99 \\
\hline S02WV019008 & 54 & 96 & Bw4 & 0.61 & 1.48 & 40 & 0.61 & 1.48 & 2.28 \\
\hline S02WV019008 & 96 & 134 & 2Bw2 & 0.26 & 1.27 & 40 & 0.26 & 1.27 & 0.75 \\
\hline S02WV019008 & 134 & 190 & $2 \mathrm{BC}$ & 0.34 & 1.06 & 30 & 0.34 & 1.06 & 1.41 \\
\hline S02WV019012 & 0 & 2 & Oi & 35.19 & & 0 & 35.19 & 0.33 & 2.29 \\
\hline S02WV019012 & 2 & 5 & A1 & 6.24 & & 25 & 6.24 & 0.97 & 1.36 \\
\hline S02WV019012 & 5 & 19 & A2 & 3.18 & 1.01 & 30 & 3.18 & 1.01 & 3.15 \\
\hline S02WV019012 & 19 & 28 & $\mathrm{BA}$ & 2.76 & 1.09 & 30 & 2.76 & 1.09 & 1.90 \\
\hline S02WV019012 & 28 & 41 & Bw1 & 2.19 & 1.40 & 40 & 2.19 & 1.40 & 2.39 \\
\hline S02WV019012 & 41 & 56 & Bw2 & 0.79 & 1.56 & 40 & 0.79 & 1.56 & 1.11 \\
\hline S02WV019012 & 56 & 76 & Bw3 & 0.46 & 1.60 & 45 & 0.46 & 1.60 & 0.81 \\
\hline
\end{tabular}




\begin{tabular}{|c|c|c|c|c|c|c|c|c|c|}
\hline PedonID & $\begin{array}{c}\text { Top } \\
\text { Depth } \\
(\mathbf{c m})\end{array}$ & $\begin{array}{c}\text { Bottom } \\
\text { Depth } \\
\text { (cm) }\end{array}$ & Horizon & $\begin{array}{c}\text { Total } \\
\text { Carbon\% } \\
\text { (Dry } \\
\text { Combustion, } \\
\text { Including } \\
\text { Converted } \\
\text { Walkley- } \\
\text { Black) }\end{array}$ & $\begin{array}{c}\text { 33kPa } \\
\text { Bulk } \\
\text { Density } \\
\left(\mathrm{g} \mathrm{cm}^{-3}\right)\end{array}$ & $\begin{array}{c}\text { Fragment } \\
\% \text { by } \\
\text { Volume }\end{array}$ & $\begin{array}{c}\text { Predicted } \\
\text { OC } \%\end{array}$ & $\begin{array}{c}\text { Predicted } \\
\text { 33kPa BD } \\
\left(\mathrm{g} \mathrm{cm}^{-3}\right)\end{array}$ & $\begin{array}{c}\text { SOC } \\
\text { Stock } \\
(\mathbf{k g} \\
\left.\mathbf{m}^{-2}\right)\end{array}$ \\
\hline S02WV019012 & 76 & 98 & $\mathrm{C}$ & 0.35 & 1.67 & 60 & 0.35 & 1.67 & 0.51 \\
\hline S02WV019013 & 0 & 18 & $\mathrm{~A}$ & 4.13 & & 30 & 4.13 & 1.06 & 5.50 \\
\hline S02WV019013 & 18 & 27 & $\mathrm{AB}$ & 1.13 & 1.44 & 30 & 1.13 & 1.44 & 1.03 \\
\hline S02WV019013 & 27 & 60 & Bw1 & 0.67 & 1.41 & 35 & 0.67 & 1.41 & 2.03 \\
\hline S02WV019013 & 60 & 95 & Bw2 & 0.30 & 1.46 & 40 & 0.30 & 1.46 & 0.92 \\
\hline S02WV019013 & 95 & 108 & Bw3 & 0.22 & 1.51 & 45 & 0.22 & 1.51 & 0.24 \\
\hline S02WV019013 & 108 & 135 & $\mathrm{BC}$ & 0.21 & & 50 & 0.21 & 1.48 & 0.42 \\
\hline S02WV019013 & 135 & 155 & $\mathrm{C}$ & 0.24 & & 60 & 0.24 & 1.48 & 0.28 \\
\hline S02WV081002 & 3 & 0 & Oi1 & 47.10 & & 0 & 44.82 & 0.37 & 3.36 \\
\hline S02WV081002 & 0 & 2 & Oi2 & 40.25 & & 0 & 36.84 & 0.48 & 3.52 \\
\hline S02WV081002 & 2 & 4 & $\mathrm{Oe}$ & 36.84 & & 0 & 47.10 & 0.36 & 3.38 \\
\hline S02WV081002 & 4 & 9 & A1 & 5.33 & & 0 & 5.33 & 1.12 & 2.98 \\
\hline S02WV081002 & 9 & 16 & $\mathrm{~A} 2$ & 3.44 & & 0 & 3.44 & 1.13 & 2.71 \\
\hline S02WV081002 & 16 & 32 & $\mathrm{AB}$ & 2.13 & 1.06 & 0 & 2.13 & 1.06 & 3.61 \\
\hline S02WV081002 & 32 & 64 & Bw1 & 0.76 & & 0 & 0.76 & 1.47 & 3.57 \\
\hline S02WV081002 & 64 & 89 & Bw2 & 0.61 & & 0 & 0.61 & 1.50 & 2.28 \\
\hline S02WV081004 & 0 & 3 & Oi1 & 48.95 & & 0 & 48.95 & 0.38 & 5.53 \\
\hline S02WV081004 & 3 & 5 & Oi2 & 46.98 & & 0 & 46.98 & 0.39 & 3.63 \\
\hline S02WV081004 & 5 & 7 & $\mathrm{Oe}$ & 35.12 & & 0 & 35.12 & 0.52 & 3.64 \\
\hline S02WV081004 & 7 & 13 & A1 & 5.53 & & 30 & 5.53 & 1.08 & 2.51 \\
\hline S02WV081004 & 13 & 25 & $\mathrm{~A} 2$ & 3.45 & 1.12 & 40 & 3.45 & 1.12 & 2.78 \\
\hline S02WV081004 & 25 & 34 & $\mathrm{BA}$ & 1.59 & 1.34 & 40 & 1.59 & 1.34 & 1.15 \\
\hline S02WV081004 & 34 & 76 & Bw1 & 0.65 & 1.51 & 45 & 0.65 & 1.51 & 2.27 \\
\hline
\end{tabular}




\begin{tabular}{|c|c|c|c|c|c|c|c|c|c|}
\hline PedonID & $\begin{array}{c}\text { Top } \\
\text { Depth } \\
\text { (cm) }\end{array}$ & $\begin{array}{c}\text { Bottom } \\
\text { Depth } \\
(\mathrm{cm})\end{array}$ & Horizon & $\begin{array}{c}\text { Total } \\
\text { Carbon\% } \\
\text { (Dry } \\
\text { Combustion, } \\
\text { Including } \\
\text { Converted } \\
\text { Walkley- } \\
\text { Black) }\end{array}$ & $\begin{array}{c}\text { 33kPa } \\
\text { Bulk } \\
\text { Density } \\
\left(\mathrm{g} \mathrm{cm}^{-3}\right)\end{array}$ & $\begin{array}{c}\text { Fragment } \\
\% \text { by } \\
\text { Volume }\end{array}$ & $\begin{array}{c}\text { Predicted } \\
\text { OC } \%\end{array}$ & $\begin{array}{c}\text { Predicted } \\
33 \mathrm{kPa} \mathrm{BD} \\
\left(\mathrm{g} \mathrm{cm}^{-3}\right)\end{array}$ & $\begin{array}{c}\text { SOC } \\
\text { Stock } \\
(\mathbf{k g} \\
\left.\mathbf{m}^{-2}\right)\end{array}$ \\
\hline S02WV081004 & 76 & 123 & Bw2 & 0.35 & 1.59 & 50 & 0.35 & 1.59 & 1.31 \\
\hline S02WV081004 & 123 & 143 & $\mathrm{BC}$ & 0.55 & 1.54 & 60 & 0.59 & 1.54 & 0.46 \\
\hline S02WV081004 & 143 & 168 & $\mathrm{C}$ & 0.59 & & 80 & 0.55 & 1.54 & 0.68 \\
\hline S02WV081005 & 0 & 4 & Oi1 & 50.01 & & 0 & 50.01 & 0.35 & 7.10 \\
\hline S02WV081005 & 4 & 6 & Oi2 & 44.82 & & 0 & 44.82 & 0.37 & 3.36 \\
\hline S02WV081005 & 6 & 12 & $\mathrm{Oe}$ & 48.12 & & 0 & 48.12 & 0.51 & 14.76 \\
\hline S02WV081005 & 12 & 15 & $\mathrm{Oa} / \mathrm{A}$ & 14.87 & & 0 & 14.87 & 1.13 & 5.03 \\
\hline S02WV081005 & 15 & 22 & $\mathrm{~A} / \mathrm{E}$ & 2.40 & 1.19 & 0 & 2.40 & 1.19 & 2.00 \\
\hline S02WV081005 & 22 & 44 & Bw1 & 0.91 & 0.84 & 0 & 0.91 & 0.84 & 1.68 \\
\hline S02WV081005 & 44 & 74 & Bw2 & 0.59 & & 0 & 0.59 & 1.49 & 2.64 \\
\hline S02WV081005 & 74 & 96 & $2 \mathrm{BC}$ & 0.37 & & 0 & 0.37 & 1.49 & 1.22 \\
\hline S02WV081005 & 96 & 112 & $2 \mathrm{C}$ & 0.37 & & 0 & 0.37 & 1.47 & 0.87 \\
\hline S03WV025001 & 0 & 1 & $\mathrm{Oi}$ & 37.36 & & 0 & 37.36 & 1.06 & 3.95 \\
\hline S03WV025001 & 1 & 2 & $\mathrm{Oe}$ & 35.38 & & 0 & 35.38 & 0.52 & 1.84 \\
\hline S03WV025001 & 2 & 5 & $\mathrm{~A}$ & 4.44 & & 5 & 4.44 & 1.07 & 1.36 \\
\hline S03WV025001 & 5 & 16 & $\mathrm{BA}$ & 1.49 & 1.41 & 5 & 1.49 & 1.41 & 2.20 \\
\hline S03WV025001 & 16 & 28 & Bt1 & 1.08 & 1.48 & 5 & 1.08 & 1.48 & 1.82 \\
\hline S03WV025001 & 28 & 53 & Bt2 & 0.65 & 1.42 & 5 & 0.65 & 1.42 & 2.19 \\
\hline S03WV025001 & 53 & 78 & Bt3 & 0.45 & 1.52 & 15 & 0.45 & 1.52 & 1.45 \\
\hline S03WV025001 & 78 & 99 & $\mathrm{BC}$ & 0.23 & 1.61 & 15 & 0.23 & 1.61 & 0.66 \\
\hline S03WV025001 & 99 & 115 & $\mathrm{C}$ & 0.19 & & 30 & 0.19 & 1.55 & 0.33 \\
\hline S03WV025002 & 0 & 2 & Oi1 & 46.68 & & 0 & 46.68 & 1.00 & 9.33 \\
\hline S03WV025002 & 2 & 3 & Oi2 & 30.32 & & 0 & 30.32 & 0.36 & 1.11 \\
\hline
\end{tabular}




\begin{tabular}{|c|c|c|c|c|c|c|c|c|c|}
\hline PedonID & $\begin{array}{c}\text { Top } \\
\text { Depth } \\
\text { (cm) }\end{array}$ & $\begin{array}{c}\text { Bottom } \\
\text { Depth } \\
(\mathrm{cm})\end{array}$ & Horizon & $\begin{array}{c}\text { Total } \\
\text { Carbon\% } \\
\text { (Dry } \\
\text { Combustion, } \\
\text { Including } \\
\text { Converted } \\
\text { Walkley- } \\
\text { Black) }\end{array}$ & $\begin{array}{c}\text { 33kPa } \\
\text { Bulk } \\
\text { Density } \\
\left(\mathrm{g} \mathrm{cm}^{-3}\right)\end{array}$ & $\begin{array}{c}\text { Fragment } \\
\% \text { by } \\
\text { Volume }\end{array}$ & $\begin{array}{c}\text { Predicted } \\
\text { OC } \%\end{array}$ & $\begin{array}{c}\text { Predicted } \\
33 \mathrm{kPa} \mathrm{BD} \\
\left(\mathrm{g} \mathrm{cm}^{-3}\right)\end{array}$ & $\begin{array}{c}\text { SOC } \\
\text { Stock } \\
(\mathbf{k g} \\
\left.\mathbf{m}^{-2}\right)\end{array}$ \\
\hline S03WV025002 & 3 & 9 & $\mathrm{~A}$ & 5.49 & & 5 & 5.49 & 1.12 & 3.49 \\
\hline S03WV025002 & 9 & 14 & $\mathrm{AB}$ & 2.86 & & 5 & 2.86 & 1.32 & 1.79 \\
\hline S03WV025002 & 14 & 19 & BA & 1.68 & & 5 & 1.68 & 1.29 & 1.03 \\
\hline S03WV025002 & 19 & 42 & Bt1 & 0.72 & 1.53 & 15 & 0.72 & 1.53 & 2.15 \\
\hline S03WV025002 & 42 & 73 & $\mathrm{Bt} 2$ & 0.45 & 1.62 & 25 & 0.45 & 1.62 & 1.69 \\
\hline S03WV025002 & 73 & 93 & $\mathrm{Bt} 3$ & 0.19 & 1.68 & 30 & 0.19 & 1.68 & 0.45 \\
\hline S03WV025002 & 93 & 160 & $\mathrm{BC}$ & 0.24 & 1.67 & 60 & 0.24 & 1.67 & 1.07 \\
\hline S03WV071001 & 0 & 2 & $\mathrm{Oi}$ & 40.54 & & 0 & 40.54 & 0.33 & 2.65 \\
\hline S03WV071001 & 2 & 4 & $\mathrm{Oe}$ & 30.76 & & 0 & 10.39 & 1.04 & 2.60 \\
\hline S03WV071001 & 4 & 7 & $\mathrm{Oa} / \mathrm{A}$ & 10.39 & & 20 & 5.24 & 1.24 & 1.56 \\
\hline S03WV071001 & 7 & 10 & $\mathrm{AB}$ & 5.24 & & 20 & 2.77 & 1.40 & 2.80 \\
\hline S03WV071001 & 10 & 19 & $\mathrm{Bt} 1 / \mathrm{A}$ & 2.77 & & 20 & 1.79 & 1.40 & 5.21 \\
\hline S03WV071001 & 19 & 45 & $\mathrm{Bt} 2$ & 1.79 & 1.40 & 20 & 1.64 & 1.72 & 4.29 \\
\hline S03WV071001 & 45 & 64 & Bt3 & 1.64 & 1.72 & 20 & 0.36 & 1.62 & 1.19 \\
\hline S03WV071001 & 64 & 98 & $\mathrm{Bt} 4$ & 0.36 & 1.62 & 40 & 0.16 & 1.82 & 0.38 \\
\hline S03WV071001 & 98 & 120 & $\mathrm{Bt5}$ & 0.16 & 1.82 & 40 & 0.11 & 1.86 & 0.39 \\
\hline S03WV071001 & 120 & 155 & $\mathrm{BCt}$ & 0.11 & 1.86 & 45 & 30.76 & 0.48 & 2.97 \\
\hline S03WV075001 & 0 & 2 & $\mathrm{Oi}$ & 47.65 & & 0 & 47.65 & 0.32 & 3.07 \\
\hline S03WV075001 & 2 & 12 & $\mathrm{~A}$ & 10.10 & & 20 & 10.10 & 0.95 & 7.65 \\
\hline S03WV075001 & 12 & 26 & $\mathrm{AB}$ & 5.65 & & 20 & 5.65 & 1.22 & 7.70 \\
\hline S03WV075001 & 26 & 40 & Bt1 & 0.84 & 1.21 & 20 & 0.84 & 1.21 & 1.14 \\
\hline S03WV075001 & 40 & 77 & $\mathrm{Bt} 2$ & 0.79 & 1.32 & 25 & 0.79 & 1.32 & 2.89 \\
\hline S03WV075001 & 77 & 100 & $\mathrm{BC}$ & 0.40 & & 50 & 0.40 & 1.44 & 0.66 \\
\hline
\end{tabular}




\begin{tabular}{|c|c|c|c|c|c|c|c|c|c|}
\hline PedonID & $\begin{array}{c}\text { Top } \\
\text { Depth } \\
\text { (cm) }\end{array}$ & $\begin{array}{c}\text { Bottom } \\
\text { Depth } \\
\text { (cm) }\end{array}$ & Horizon & $\begin{array}{c}\text { Total } \\
\text { Carbon \% } \\
\text { (Dry } \\
\text { Combustion, } \\
\text { Including } \\
\text { Converted } \\
\text { Walkley- } \\
\text { Black) } \\
\end{array}$ & $\begin{array}{c}\text { 33kPa } \\
\text { Bulk } \\
\text { Density } \\
\left(\mathrm{g} \mathrm{cm}^{-3}\right)\end{array}$ & $\begin{array}{c}\text { Fragment } \\
\% \text { by } \\
\text { Volume }\end{array}$ & $\begin{array}{c}\text { Predicted } \\
\text { OC } \%\end{array}$ & $\begin{array}{c}\text { Predicted } \\
\text { 33kPa BD } \\
\left(\mathrm{g} \mathrm{cm}^{-3}\right)\end{array}$ & $\begin{array}{c}\text { SOC } \\
\text { Stock } \\
(\mathbf{k g} \\
\left.\mathbf{m}^{-2}\right)\end{array}$ \\
\hline S03WV077001 & 0 & 1 & Oi & 42.56 & & 0 & 42.56 & 0.27 & 1.17 \\
\hline S03WV077001 & 1 & 2 & Oe & 35.80 & & 0 & 35.80 & 0.40 & 1.42 \\
\hline S03WV077001 & 2 & 10 & $\mathrm{Oa} / \mathrm{A}$ & 7.06 & & 25 & 7.06 & 1.00 & 4.22 \\
\hline S03WV077001 & 10 & 20 & $\mathrm{BA}$ & 2.42 & & 40 & 2.42 & 1.16 & 1.68 \\
\hline S03WV077001 & 20 & 35 & Bt1 & 0.92 & & 55 & 0.92 & 1.30 & 0.81 \\
\hline S03WV077001 & 35 & 60 & $\mathrm{Bt} 2$ & 0.66 & & 60 & 0.66 & 1.33 & 0.87 \\
\hline S03WV077001 & 60 & 72 & $\mathrm{CB}$ & 0.58 & & 80 & 0.58 & 1.34 & 0.19 \\
\hline S03WV081001 & 0 & 11 & $\mathrm{~A}$ & 2.80 & & 15 & 2.80 & 1.27 & 3.32 \\
\hline S03WV081001 & 11 & 30 & $\mathrm{BA}$ & 0.59 & 1.43 & 20 & 0.59 & 1.43 & 1.28 \\
\hline S03WV081001 & 30 & 61 & Bw1 & 0.54 & 1.52 & 20 & 0.54 & 1.52 & 2.04 \\
\hline S03WV081001 & 61 & 98 & Bw2 & 0.51 & 1.58 & 25 & 0.51 & 1.58 & 2.24 \\
\hline S03WV081001 & 98 & 137 & Bw3 & 0.46 & 1.49 & 25 & 0.46 & 1.49 & 2.00 \\
\hline S03WV081001 & 137 & 160 & $\mathrm{BC}$ & 0.52 & 1.54 & 35 & 0.52 & 1.54 & 1.20 \\
\hline S03WV081002 & 0 & 3 & $\mathrm{Oa} / \mathrm{A}$ & 10.97 & & 30 & 10.97 & 1.09 & 2.51 \\
\hline S03WV081002 & 3 & 16 & $\mathrm{~A}$ & 6.39 & 1.07 & 30 & 6.39 & 1.07 & 6.22 \\
\hline S03WV081002 & 16 & 25 & $\mathrm{BA}$ & 2.23 & 1.22 & 40 & 2.23 & 1.22 & 1.47 \\
\hline S03WV081002 & 25 & 46 & Bw1 & 1.01 & 1.57 & 35 & 1.01 & 1.57 & 2.16 \\
\hline S03WV081002 & 46 & 82 & Bw2 & 0.84 & 1.45 & 65 & 0.84 & 1.45 & 1.53 \\
\hline S03WV083001 & 0 & 2 & $\mathrm{Oi}$ & 40.36 & & 0 & 40.36 & 0.30 & 2.40 \\
\hline S03WV083001 & 2 & 10 & $\mathrm{~A}$ & 7.26 & & 20 & 7.26 & 0.96 & 4.44 \\
\hline S03WV083001 & 10 & 15 & $\mathrm{AB}$ & 2.11 & & 20 & 2.11 & 1.20 & 1.02 \\
\hline S03WV083001 & 15 & 28 & $\mathrm{BA}$ & 0.83 & 1.20 & 20 & 0.83 & 1.20 & 1.04 \\
\hline S03WV083001 & 28 & 75 & Bt1 & 0.43 & 1.41 & 30 & 0.43 & 1.41 & 1.99 \\
\hline
\end{tabular}




\begin{tabular}{|c|c|c|c|c|c|c|c|c|c|}
\hline PedonID & $\begin{array}{c}\text { Top } \\
\text { Depth } \\
\text { (cm) }\end{array}$ & $\begin{array}{c}\text { Bottom } \\
\text { Depth } \\
(\mathrm{cm})\end{array}$ & Horizon & $\begin{array}{c}\text { Total } \\
\text { Carbon\% } \\
\text { (Dry } \\
\text { Combustion, } \\
\text { Including } \\
\text { Converted } \\
\text { Walkley- } \\
\text { Black) }\end{array}$ & $\begin{array}{c}\text { 33kPa } \\
\text { Bulk } \\
\text { Density } \\
\left(\mathrm{g} \mathrm{cm}^{-3}\right)\end{array}$ & $\begin{array}{c}\text { Fragment } \\
\% \text { by } \\
\text { Volume }\end{array}$ & $\begin{array}{c}\text { Predicted } \\
\text { OC } \%\end{array}$ & $\begin{array}{c}\text { Predicted } \\
33 \mathrm{kPa} \mathrm{BD} \\
\left(\mathrm{g} \mathrm{cm}^{-3}\right)\end{array}$ & $\begin{array}{c}\text { SOC } \\
\text { Stock } \\
(\mathbf{k g} \\
\left.\mathbf{m}^{-2}\right)\end{array}$ \\
\hline S03WV083001 & 75 & 110 & $\mathrm{Bt} 2$ & 0.25 & 1.51 & 45 & 0.25 & 1.51 & 0.73 \\
\hline S03WV083001 & 110 & 160 & $\mathrm{C}$ & 0.15 & 1.62 & 70 & 0.15 & 1.62 & 0.36 \\
\hline S03WV083002 & 0 & 3 & $\mathrm{Oa} / \mathrm{A}$ & 13.57 & & 40 & 13.57 & 0.91 & 2.21 \\
\hline S03WV083002 & 3 & 13 & $\mathrm{E}$ & 1.78 & & 40 & 1.78 & 1.20 & 1.28 \\
\hline S03WV083002 & 13 & 26 & $\mathrm{BE}$ & 1.02 & & 40 & 1.02 & 1.23 & 0.98 \\
\hline S03WV083002 & 26 & 49 & Bt1 & 0.63 & 1.28 & 30 & 0.63 & 1.28 & 1.30 \\
\hline S03WV083002 & 49 & 57 & Bt2 & 0.51 & 1.46 & 35 & 0.51 & 1.46 & 0.39 \\
\hline S03WV083002 & 57 & 77 & $\mathrm{BC}$ & 0.38 & 1.47 & 40 & 0.38 & 1.47 & 0.67 \\
\hline S03WV083002 & 77 & 95 & $\mathrm{C}$ & 0.28 & 1.45 & 65 & 0.28 & 1.45 & 0.26 \\
\hline S03WV083003 & 0 & 2 & Oi & & & 3 & 42.17 & 0.27 & 2.24 \\
\hline S03WV083003 & 2 & 3 & $\mathrm{Oe}$ & 37.32 & & 3 & 37.32 & 0.43 & 1.56 \\
\hline S03WV083003 & 3 & 18 & $\mathrm{~A}$ & 5.95 & & 25 & 5.95 & 1.01 & 6.76 \\
\hline S03WV083003 & 18 & 26 & BA & 1.15 & 1.34 & 25 & 1.15 & 1.34 & 0.92 \\
\hline S03WV083003 & 26 & 39 & Bt1 & 0.51 & 1.48 & 25 & 0.51 & 1.48 & 0.74 \\
\hline S03WV083003 & 39 & 69 & $\mathrm{Bt} 2$ & 0.54 & 1.50 & 35 & 0.54 & 1.50 & 1.58 \\
\hline S03WV083003 & 69 & 97 & $\mathrm{BC}$ & 0.61 & 1.65 & 50 & 0.61 & 1.65 & 1.41 \\
\hline S03WV083004 & 0 & 2 & Oi & 24.55 & & 0 & 24.55 & 0.23 & 1.15 \\
\hline S03WV083004 & 2 & 11 & $\mathrm{~A}$ & 6.38 & & 40 & 6.38 & 1.01 & 3.49 \\
\hline S03WV083004 & 11 & 20 & $\mathrm{BA}$ & 2.55 & & 40 & 2.55 & 1.21 & 1.67 \\
\hline S03WV083004 & 20 & 36 & Bt1 & 1.84 & & 25 & 1.84 & 1.30 & 2.86 \\
\hline S03WV083004 & 36 & 59 & $2 \mathrm{Bt} 2$ & 1.21 & 1.20 & 35 & 1.21 & 1.20 & 2.17 \\
\hline S03WV083004 & 59 & 79 & $2 \mathrm{Bt} 3$ & 0.76 & 1.38 & 45 & 0.76 & 1.38 & 1.15 \\
\hline S03WV083004 & 79 & 99 & $2 \mathrm{C}$ & 0.55 & & 80 & 0.55 & 1.41 & 0.31 \\
\hline
\end{tabular}




\begin{tabular}{|c|c|c|c|c|c|c|c|c|c|}
\hline PedonID & $\begin{array}{c}\text { Top } \\
\text { Depth } \\
\text { (cm) }\end{array}$ & $\begin{array}{c}\text { Bottom } \\
\text { Depth } \\
\text { (cm) }\end{array}$ & Horizon & $\begin{array}{c}\text { Total } \\
\text { Carbon \% } \\
\text { (Dry } \\
\text { Combustion, } \\
\text { Including } \\
\text { Converted } \\
\text { Walkley- } \\
\text { Black) } \\
\end{array}$ & $\begin{array}{c}\text { 33kPa } \\
\text { Bulk } \\
\text { Density } \\
\left(\mathrm{g} \mathrm{cm}^{-3}\right)\end{array}$ & $\begin{array}{c}\text { Fragment } \\
\% \text { by } \\
\text { Volume }\end{array}$ & $\begin{array}{c}\text { Predicted } \\
\text { OC } \%\end{array}$ & $\begin{array}{c}\text { Predicted } \\
\text { 33kPa BD } \\
\left(\mathrm{g} \mathrm{cm}^{-3}\right)\end{array}$ & $\begin{array}{c}\text { SOC } \\
\text { Stock } \\
(\mathbf{k g} \\
\left.\mathrm{m}^{-2}\right)\end{array}$ \\
\hline S03WV083005 & 0 & 1 & Oi & 34.77 & & 0 & 34.77 & 0.25 & 0.85 \\
\hline S03WV083005 & 1 & 6 & $\mathrm{~A}$ & 9.95 & & 15 & 9.95 & 0.98 & 4.13 \\
\hline S03WV083005 & 6 & 10 & $\mathrm{AE}$ & 3.96 & & 10 & 3.96 & 1.16 & 1.65 \\
\hline S03WV083005 & 10 & 35 & $\mathrm{BE}$ & 2.10 & 1.31 & 20 & 2.10 & 1.31 & 5.50 \\
\hline S03WV083005 & 36 & 60 & $\mathrm{Bw} 1$ & 0.43 & 1.54 & 30 & 0.43 & 1.54 & 1.11 \\
\hline S03WV083005 & 60 & 95 & Bw2 & 0.18 & 1.55 & 45 & 0.18 & 1.55 & 0.54 \\
\hline S03WV083005 & 95 & 130 & $2 \mathrm{BC}$ & 0.12 & 1.74 & 60 & 0.12 & 1.74 & 0.29 \\
\hline S03WV083005 & 130 & 170 & $2 \mathrm{C}$ & 0.13 & & 60 & 0.13 & 1.53 & 0.32 \\
\hline S03WV083006 & 0 & 1 & $\mathrm{Oi}$ & 49.64 & & 0 & 49.64 & 0.25 & 1.23 \\
\hline S03WV083006 & 1 & 2 & $\mathrm{Oe}$ & 42.38 & & 0 & 42.38 & 0.43 & 1.82 \\
\hline S03WV083006 & 2 & 5 & $\mathrm{~A}$ & 8.66 & & 20 & 8.66 & 0.94 & 1.95 \\
\hline S03WV083006 & 5 & 13 & $E$ & 3.57 & & 25 & 3.57 & 1.17 & 2.51 \\
\hline S03WV083006 & 13 & 35 & $\mathrm{BE}$ & 1.57 & & 25 & 1.57 & 1.26 & 3.27 \\
\hline S03WV083006 & 35 & 52 & Bt1 & 0.62 & 1.42 & 35 & 0.62 & 1.42 & 0.97 \\
\hline S03WV083006 & 52 & 68 & $\mathrm{Bt} 2$ & 0.47 & 1.48 & 40 & 0.47 & 1.48 & 0.67 \\
\hline S03WV083006 & 68 & 80 & $\mathrm{Bt} 3$ & 0.23 & 1.56 & 50 & 0.23 & 1.56 & 0.22 \\
\hline S03WV083006 & 80 & 104 & $\mathrm{BC}$ & 0.17 & 1.65 & 40 & 0.17 & 1.65 & 0.40 \\
\hline S03WV083007 & 0 & 8 & $\mathrm{~A}$ & 6.79 & & 15 & 6.79 & 1.01 & 4.67 \\
\hline S03WV083007 & 8 & 28 & BA & 1.44 & 1.10 & 15 & 1.44 & 1.10 & 2.69 \\
\hline S03WV083007 & 28 & 65 & $\mathrm{Bw}$ & 0.36 & 1.21 & 20 & 0.36 & 1.21 & 1.29 \\
\hline S03WV083007 & 65 & 80 & 2Bt1 & 0.24 & 1.52 & 30 & 0.24 & 1.52 & 0.38 \\
\hline S03WV083007 & 80 & 103 & $2 \mathrm{Bt} 2$ & 0.11 & 1.60 & 30 & 0.11 & 1.60 & 0.28 \\
\hline S03WV083007 & 103 & 125 & $2 \mathrm{Bt} 3$ & 0.11 & 1.57 & 50 & 0.11 & 1.57 & 0.19 \\
\hline
\end{tabular}




\begin{tabular}{|c|c|c|c|c|c|c|c|c|c|}
\hline PedonID & $\begin{array}{c}\text { Top } \\
\text { Depth } \\
\text { (cm) }\end{array}$ & $\begin{array}{c}\text { Bottom } \\
\text { Depth } \\
(\mathrm{cm})\end{array}$ & Horizon & $\begin{array}{c}\text { Total } \\
\text { Carbon\% } \\
\text { (Dry } \\
\text { Combustion, } \\
\text { Including } \\
\text { Converted } \\
\text { Walkley- } \\
\text { Black) }\end{array}$ & $\begin{array}{c}\text { 33kPa } \\
\text { Bulk } \\
\text { Density } \\
\left(\mathrm{g} \mathrm{cm}^{-3}\right)\end{array}$ & $\begin{array}{c}\text { Fragment } \\
\% \text { by } \\
\text { Volume }\end{array}$ & $\begin{array}{c}\text { Predicted } \\
\text { OC } \%\end{array}$ & $\begin{array}{c}\text { Predicted } \\
33 \mathrm{kPa} \mathrm{BD} \\
\left(\mathrm{g} \mathrm{cm}^{-3}\right)\end{array}$ & $\begin{array}{c}\text { SOC } \\
\text { Stock } \\
(\mathbf{k g} \\
\left.\mathbf{m}^{-2}\right)\end{array}$ \\
\hline S03WV083007 & 125 & 150 & $2 \mathrm{BCX}$ & 0.07 & 1.59 & 65 & 0.07 & 1.59 & 0.10 \\
\hline S03WV083008 & 0 & 11 & $\mathrm{~A}$ & 5.91 & & 30 & 5.91 & 1.07 & 4.88 \\
\hline S03WV083008 & 11 & 22 & BA & 2.19 & & 20 & 2.19 & 1.31 & 2.52 \\
\hline S03WV083008 & 22 & 52 & Bt1 & 0.52 & 1.59 & 30 & 0.52 & 1.59 & 1.74 \\
\hline S03WV083008 & 52 & 75 & $\mathrm{Bt} 2$ & 0.17 & 1.63 & 20 & 0.17 & 1.63 & 0.51 \\
\hline S03WV083008 & 75 & 98 & Bt3 & 0.12 & 1.63 & 20 & 0.12 & 1.63 & 0.36 \\
\hline S03WV083008 & 98 & 110 & $\mathrm{BCt}$ & 0.17 & 1.61 & 35 & 0.17 & 1.61 & 0.21 \\
\hline S03WV089001 & 0 & 1 & $\mathrm{Oi}$ & 38.13 & & 0 & 38.13 & 1.05 & 3.99 \\
\hline S03WV089001 & 1 & 12 & $\mathrm{~A}$ & 3.10 & 1.17 & 10 & 3.10 & 1.17 & 3.59 \\
\hline S03WV089001 & 12 & 27 & $\mathrm{BA}$ & 1.13 & 1.41 & 10 & 1.13 & 1.41 & 2.15 \\
\hline S03WV089001 & 27 & 53 & Bw1 & 0.56 & 1.48 & 10 & 0.56 & 1.48 & 1.94 \\
\hline S03WV089001 & 53 & 93 & Bw2 & 0.31 & 1.56 & 20 & 0.31 & 1.56 & 1.55 \\
\hline S03WV089001 & 93 & 146 & Bw3 & 0.14 & 1.70 & 35 & 0.14 & 1.70 & 0.82 \\
\hline S03WV089001 & 146 & 165 & $\mathrm{BC}$ & 0.14 & 1.64 & 45 & 0.14 & 1.64 & 0.24 \\
\hline S03WV089002 & 0 & 3 & Oi & 46.44 & & 0 & 46.44 & 1.02 & 14.18 \\
\hline S03WV089002 & 3 & 16 & $\mathrm{~A}$ & 2.07 & 1.21 & 10 & 2.07 & 1.21 & 2.93 \\
\hline S03WV089002 & 16 & 34 & BA & 0.98 & 1.44 & 10 & 0.98 & 1.44 & 2.29 \\
\hline S03WV089002 & 34 & 67 & Bt1 & 0.34 & 1.58 & 15 & 0.34 & 1.58 & 1.51 \\
\hline S03WV089002 & 67 & 101 & Bt2 & 0.32 & 1.51 & 30 & 0.32 & 1.51 & 1.15 \\
\hline S03WV089002 & 101 & 122 & $\mathrm{C}$ & 0.31 & & 50 & 0.31 & 1.56 & 0.51 \\
\hline S03WV089003 & 0 & 10 & $\mathrm{~A}$ & 3.73 & 1.36 & 5 & 3.73 & 1.36 & 4.82 \\
\hline S03WV089003 & 10 & 16 & $\mathrm{AB}$ & 2.36 & 1.40 & 5 & 2.36 & 1.40 & 1.88 \\
\hline S03WV089003 & 16 & 25 & BA & 1.76 & & 15 & 1.76 & 1.34 & 1.81 \\
\hline
\end{tabular}




\begin{tabular}{|c|c|c|c|c|c|c|c|c|c|}
\hline PedonID & $\begin{array}{c}\text { Top } \\
\text { Depth } \\
(\mathbf{c m})\end{array}$ & $\begin{array}{c}\text { Bottom } \\
\text { Depth } \\
(\mathrm{cm})\end{array}$ & Horizon & $\begin{array}{c}\text { Total } \\
\text { Carbon\% } \\
\text { (Dry } \\
\text { Combustion, } \\
\text { Including } \\
\text { Converted } \\
\text { Walkley- } \\
\text { Black) } \\
\end{array}$ & $\begin{array}{c}\text { 33kPa } \\
\text { Bulk } \\
\text { Density } \\
\left(\mathrm{g} \mathrm{cm}^{-3}\right)\end{array}$ & $\begin{array}{c}\text { Fragment } \\
\% \text { by } \\
\text { Volume }\end{array}$ & $\begin{array}{c}\text { Predicted } \\
\text { OC } \%\end{array}$ & $\begin{array}{c}\text { Predicted } \\
\text { 33kPa BD } \\
\left(\mathrm{g} \mathrm{cm}^{-3}\right)\end{array}$ & $\begin{array}{c}\text { SOC } \\
\text { Stock } \\
(\mathbf{k g} \\
\left.\mathbf{m}^{-2}\right)\end{array}$ \\
\hline S03WV089003 & 25 & 48 & Bt1 & 0.36 & 1.69 & 25 & 0.36 & 1.69 & 1.05 \\
\hline S03WV089003 & 48 & 66 & Bt2 & 0.19 & 1.68 & 20 & 0.19 & 1.68 & 0.46 \\
\hline S03WV089003 & 66 & 90 & $\mathrm{BC}$ & 0.28 & 1.63 & 35 & 0.28 & 1.63 & 0.71 \\
\hline S03WV089004 & 0 & 2 & $\mathrm{Oi}$ & 40.50 & & 0 & 40.50 & 1.10 & 8.93 \\
\hline S03WV089004 & 2 & 4 & $\mathrm{Oe}$ & 20.99 & & 0 & 5.15 & 1.19 & 1.66 \\
\hline S03WV089004 & 4 & 7 & $\mathrm{~A}$ & 5.15 & & 10 & 2.33 & 1.39 & 1.75 \\
\hline S03WV089004 & 7 & 13 & $\mathrm{AE}$ & 2.33 & & 10 & 1.25 & 1.55 & 1.74 \\
\hline S03WV089004 & 13 & 23 & $\mathrm{BE}$ & 1.25 & 1.55 & 10 & 0.69 & 1.40 & 1.83 \\
\hline S03WV089004 & 23 & 44 & Bt1 & 0.69 & 1.40 & 10 & 0.20 & 1.63 & 0.97 \\
\hline S03WV089004 & 44 & 77 & $\mathrm{Bt} 2$ & 0.20 & 1.63 & 10 & 0.12 & 1.64 & 0.55 \\
\hline S03WV089004 & 77 & 112 & $\mathrm{Bt} 3$ & 0.12 & 1.64 & 20 & 0.09 & 1.62 & 0.26 \\
\hline S03WV089004 & 112 & 137 & $2 \mathrm{Bt} 4$ & 0.09 & 1.62 & 30 & 0.07 & 1.58 & 0.15 \\
\hline S03WV089004 & 137 & 160 & $2 \mathrm{BCt}$ & 0.07 & 1.58 & 40 & 20.99 & 1.05 & 4.40 \\
\hline S03WV089005 & 0 & 10 & A1 & 5.06 & & 20 & 5.06 & 1.27 & 5.16 \\
\hline S03WV089005 & 10 & 24 & $\mathrm{~A} 2$ & 2.60 & & 20 & 2.60 & 1.31 & 3.81 \\
\hline S03WV089005 & 24 & 38 & $\mathrm{BA}$ & 1.17 & 1.27 & 20 & 1.17 & 1.27 & 1.66 \\
\hline S03WV089005 & 38 & 61 & Bw1 & 0.63 & 1.56 & 20 & 0.63 & 1.56 & 1.81 \\
\hline S03WV089005 & 61 & 106 & Bw2 & 0.57 & 1.47 & 35 & 0.57 & 1.47 & 2.45 \\
\hline S03WV089005 & 106 & 160 & $2 \mathrm{Bt}$ & 0.44 & 1.55 & 55 & 0.44 & 1.55 & 1.66 \\
\hline S03WV089006 & 0 & 9 & $\mathrm{~A}$ & 3.08 & 1.04 & 22 & 3.08 & 1.04 & 2.25 \\
\hline S03WV089006 & 9 & 21 & Bt1 & 0.79 & 1.46 & 38 & 0.79 & 1.46 & 0.86 \\
\hline S03WV089006 & 21 & 53 & Bt2 & 0.42 & 1.49 & 32 & 0.42 & 1.49 & 1.36 \\
\hline S03WV089006 & 53 & 75 & $\mathrm{Bt3}$ & 0.38 & 1.54 & 10 & 0.38 & 1.54 & 1.16 \\
\hline
\end{tabular}




\begin{tabular}{|c|c|c|c|c|c|c|c|c|c|}
\hline PedonID & $\begin{array}{c}\text { Top } \\
\text { Depth } \\
\text { (cm) }\end{array}$ & $\begin{array}{c}\text { Bottom } \\
\text { Depth } \\
(\mathrm{cm})\end{array}$ & Horizon & $\begin{array}{c}\text { Total } \\
\text { Carbon\% } \\
\text { (Dry } \\
\text { Combustion, } \\
\text { Including } \\
\text { Converted } \\
\text { Walkley- } \\
\text { Black) }\end{array}$ & $\begin{array}{c}\text { 33kPa } \\
\text { Bulk } \\
\text { Density } \\
\left(\mathrm{g} \mathrm{cm}^{-3}\right)\end{array}$ & $\begin{array}{c}\text { Fragment } \\
\% \text { by } \\
\text { Volume }\end{array}$ & $\begin{array}{c}\text { Predicted } \\
\text { OC } \%\end{array}$ & $\begin{array}{c}\text { Predicted } \\
33 \mathrm{kPa} \mathrm{BD} \\
\left(\mathrm{g} \mathrm{cm}^{-3}\right)\end{array}$ & $\begin{array}{c}\text { SOC } \\
\text { Stock } \\
(\mathbf{k g} \\
\left.\mathbf{m}^{-2}\right)\end{array}$ \\
\hline S03WV089006 & 75 & 92 & $\mathrm{Bt} 4$ & 0.35 & 1.58 & 21 & 0.35 & 1.58 & 0.74 \\
\hline S03WV089007 & 0 & 6 & $\mathrm{~A}$ & 7.80 & & 15 & 7.80 & 1.14 & 4.55 \\
\hline S03WV089007 & 6 & 18 & $\mathrm{BE}$ & 1.87 & & 15 & 1.87 & 1.36 & 2.59 \\
\hline S03WV089007 & 18 & 45 & Bt1 & 0.42 & 1.61 & 15 & 0.42 & 1.61 & 1.55 \\
\hline S03WV089007 & 45 & 70 & $\mathrm{Bt} 2$ & 0.35 & 1.66 & 15 & 0.35 & 1.66 & 1.23 \\
\hline S03WV089007 & 70 & 110 & $2 \mathrm{Bt} 3$ & 0.36 & 1.44 & 25 & 0.36 & 1.44 & 1.56 \\
\hline S03WV089007 & 110 & 150 & $2 \mathrm{Bt} 4$ & 0.22 & 1.63 & 45 & 0.22 & 1.63 & 0.79 \\
\hline S03WV093001 & 0 & 1 & $\mathrm{Oi}$ & 42.93 & & 0 & 42.93 & 0.29 & 1.26 \\
\hline S03WV093001 & 1 & 2 & $\mathrm{Oe}$ & 35.39 & & 0 & 35.39 & 0.43 & 1.54 \\
\hline S03WV093001 & 2 & 10 & $\mathrm{~A}$ & 5.26 & 0.92 & 20 & 5.26 & 0.92 & 3.10 \\
\hline S03WV093001 & 10 & 20 & BA & 1.73 & 1.52 & 20 & 1.73 & 1.52 & 2.10 \\
\hline S03WV093001 & 20 & 35 & Bt1 & 0.49 & 1.54 & 35 & 0.49 & 1.54 & 0.74 \\
\hline S03WV093001 & 35 & 60 & $\mathrm{Bt} 2$ & 0.20 & 1.55 & 40 & 0.20 & 1.55 & 0.47 \\
\hline S03WV093001 & 60 & 72 & $\mathrm{BC}$ & 0.22 & 1.59 & 60 & 0.22 & 1.59 & 0.17 \\
\hline S03WV093002 & 0 & 2 & Oi & 41.21 & & 0 & 41.21 & 0.37 & 3.03 \\
\hline S03WV093002 & 2 & 23 & $\mathrm{~A}$ & 5.65 & & 25 & 5.65 & 1.11 & 9.85 \\
\hline S03WV093002 & 23 & 35 & BA & 2.83 & & 30 & 2.83 & 1.23 & 2.93 \\
\hline S03WV093002 & 35 & 47 & Bw1 & 1.82 & & 45 & 1.82 & 1.35 & 1.62 \\
\hline S03WV093002 & 47 & 80 & Bw2 & 0.68 & & 45 & 0.68 & 1.41 & 1.75 \\
\hline S03WV093002 & 80 & 130 & Bw3 & 0.31 & 1.49 & 55 & 0.31 & 1.49 & 1.04 \\
\hline S03WV093002 & 130 & 160 & $\mathrm{BC}$ & 0.25 & & 70 & 0.25 & 1.52 & 0.34 \\
\hline S03WV101001 & 0 & 1 & Oi & 42.11 & & 0 & 42.11 & 1.05 & 4.42 \\
\hline S03WV101001 & 1 & 3 & $\mathrm{Oa}$ & 20.49 & & 25 & 20.49 & 1.12 & 3.45 \\
\hline
\end{tabular}




\begin{tabular}{|c|c|c|c|c|c|c|c|c|c|}
\hline PedonID & $\begin{array}{c}\text { Top } \\
\text { Depth } \\
\text { (cm) }\end{array}$ & $\begin{array}{c}\text { Bottom } \\
\text { Depth } \\
(\mathrm{cm})\end{array}$ & Horizon & $\begin{array}{c}\text { Total } \\
\text { Carbon\% } \\
\text { (Dry } \\
\text { Combustion, } \\
\text { Including } \\
\text { Converted } \\
\text { Walkley- } \\
\text { Black) } \\
\end{array}$ & $\begin{array}{c}\text { 33kPa } \\
\text { Bulk } \\
\text { Density } \\
\left(\mathrm{g} \mathrm{cm}^{-3}\right)\end{array}$ & $\begin{array}{c}\text { Fragment } \\
\% \text { by } \\
\text { Volume }\end{array}$ & $\begin{array}{c}\text { Predicted } \\
\text { OC } \%\end{array}$ & $\begin{array}{c}\text { Predicted } \\
\text { 33kPa BD } \\
\left(\mathrm{g} \mathrm{cm}^{-3}\right)\end{array}$ & $\begin{array}{c}\text { SOC } \\
\text { Stock } \\
(\mathbf{k g} \\
\left.\mathbf{m}^{-2}\right)\end{array}$ \\
\hline S03WV101001 & 3 & 10 & $\mathrm{~A}$ & 2.91 & & 25 & 2.91 & 1.23 & 1.88 \\
\hline S03WV101001 & 10 & 25 & $\mathrm{BA}$ & 0.89 & 1.52 & 30 & 0.89 & 1.52 & 1.42 \\
\hline S03WV101001 & 25 & 48 & Bw1 & 0.59 & 1.58 & 25 & 0.59 & 1.58 & 1.61 \\
\hline S03WV101001 & 48 & 109 & Bw2 & 0.48 & 1.64 & 30 & 0.48 & 1.64 & 3.36 \\
\hline S03WV101001 & 109 & 148 & Bw3 & 0.47 & 1.55 & 40 & 0.47 & 1.55 & 1.70 \\
\hline S03WV101001 & 148 & 170 & $2 \mathrm{BCt}$ & 0.19 & 1.62 & 60 & 0.19 & 1.62 & 0.27 \\
\hline S03WV101002 & 0 & 2 & $\mathrm{Oi}$ & 41.70 & & 0 & 41.70 & 0.97 & 8.10 \\
\hline S03WV101002 & 2 & 12 & $\mathrm{~A}$ & 5.92 & & 15 & 5.92 & 1.16 & 5.86 \\
\hline S03WV101002 & 12 & 37 & Bt1 & 0.81 & 1.53 & 15 & 0.81 & 1.53 & 2.63 \\
\hline S03WV101002 & 37 & 67 & $\mathrm{Bt} 2$ & 0.60 & 1.67 & 20 & 0.60 & 1.67 & 2.40 \\
\hline S04WV001002 & 0 & 2 & $\mathrm{Oi}$ & 51.56 & & 0 & 51.56 & 0.31 & 3.17 \\
\hline S04WV001002 & 2 & 5 & $\mathrm{~A}$ & 11.06 & & 0 & 11.06 & 0.97 & 3.21 \\
\hline S04WV001002 & 5 & 16 & BA & 1.28 & & 5 & 1.28 & 1.15 & 1.54 \\
\hline S04WV001002 & 16 & 32 & Bt1 & 1.16 & & 10 & 1.16 & 1.40 & 2.34 \\
\hline S04WV001002 & 32 & 55 & $\mathrm{Bt} 2$ & 0.55 & & 10 & 0.55 & 1.47 & 1.67 \\
\hline S04WV001002 & 55 & 75 & $\mathrm{Bt} 3$ & 0.52 & & 30 & 0.52 & 1.54 & 1.12 \\
\hline S04WV093001 & 0 & 1 & Oi & 40.47 & & 0 & 40.47 & 0.39 & 1.56 \\
\hline S04WV093001 & 1 & 2 & $\mathrm{Oe}$ & 48.85 & & 0 & 48.85 & 0.59 & 2.90 \\
\hline S04WV093001 & 2 & 5 & $\mathrm{~A}$ & 9.83 & & 20 & 9.83 & 1.03 & 2.42 \\
\hline S04WV093001 & 5 & 19 & Bt1 & 1.58 & 1.59 & 20 & 1.58 & 1.59 & 2.81 \\
\hline S04WV093001 & 19 & 38 & $\mathrm{Bt} 2$ & 2.20 & 1.45 & 20 & 2.20 & 1.45 & 4.85 \\
\hline S04WV093001 & 38 & 55 & $\mathrm{Bt} 3$ & 1.28 & 1.56 & 20 & 1.28 & 1.56 & 2.72 \\
\hline S04WV093001 & 55 & 71 & $\mathrm{BC}$ & 1.23 & 1.74 & 40 & 1.23 & 1.74 & 2.05 \\
\hline
\end{tabular}




\begin{tabular}{|c|c|c|c|c|c|c|c|c|c|}
\hline PedonID & $\begin{array}{c}\text { Top } \\
\text { Depth } \\
\text { (cm) }\end{array}$ & $\begin{array}{c}\text { Bottom } \\
\text { Depth } \\
(\mathrm{cm})\end{array}$ & Horizon & $\begin{array}{c}\text { Total } \\
\text { Carbon\% } \\
\text { (Dry } \\
\text { Combustion, } \\
\text { Including } \\
\text { Converted } \\
\text { Walkley- } \\
\text { Black) }\end{array}$ & $\begin{array}{c}\text { 33kPa } \\
\text { Bulk } \\
\text { Density } \\
\left(\mathrm{g} \mathrm{cm}^{-3}\right)\end{array}$ & $\begin{array}{c}\text { Fragment } \\
\% \text { by } \\
\text { Volume }\end{array}$ & $\begin{array}{c}\text { Predicted } \\
\text { OC } \%\end{array}$ & $\begin{array}{c}\text { Predicted } \\
33 \mathrm{kPa} \mathrm{BD} \\
\left(\mathrm{g} \mathrm{cm}^{-3}\right)\end{array}$ & $\begin{array}{c}\text { SOC } \\
\text { Stock } \\
(\mathbf{k g} \\
\left.\mathbf{m}^{-2}\right)\end{array}$ \\
\hline S04WV093001 & 71 & 96 & C1 & 1.28 & 1.57 & 53 & 1.28 & 1.57 & 2.36 \\
\hline S04WV093001 & 96 & 109 & $\mathrm{C} 2$ & 0.66 & & 80 & 0.66 & 1.51 & 0.26 \\
\hline S04WV093002 & 0 & 2 & Oi & 46.47 & & 0 & 46.47 & 0.38 & 3.50 \\
\hline S04WV093002 & 2 & 4 & $\mathrm{Oe}$ & 26.85 & & 0 & 26.85 & 0.49 & 2.65 \\
\hline S04WV093002 & 4 & 12 & $\mathrm{~A}$ & 6.75 & & 0 & 6.75 & 1.08 & 5.84 \\
\hline S04WV093002 & 12 & 22 & BA & 2.91 & & 0 & 2.91 & 1.23 & 3.59 \\
\hline S04WV093002 & 22 & 43 & $\mathrm{Bw}$ & 1.42 & 1.44 & 0 & 1.42 & 1.44 & 4.29 \\
\hline S04WV093002 & 43 & 75 & $2 \mathrm{Btx} 1$ & 0.84 & 1.73 & 15 & 0.84 & 1.73 & 3.95 \\
\hline S04WV093002 & 75 & 117 & $2 \mathrm{Btx} 2$ & 0.55 & 1.80 & 17 & 0.55 & 1.80 & 3.45 \\
\hline S04WV093002 & 117 & 140 & $3 \mathrm{BC}$ & 0.75 & 1.60 & 12 & 0.75 & 1.60 & 2.43 \\
\hline S04WV093002 & 140 & 160 & $3 \mathrm{C}$ & 0.98 & 1.58 & 25 & 0.98 & 1.58 & 2.32 \\
\hline S04WV093003 & 0 & 3 & $\mathrm{Oi}$ & & & 0 & 40.76 & 0.36 & 4.41 \\
\hline S04WV093003 & 3 & 23 & Ap & 4.49 & & 0 & 4.49 & 1.06 & 9.55 \\
\hline S04WV093003 & 23 & 33 & $\mathrm{Bg}$ & 0.75 & & 40 & 0.75 & 1.26 & 0.57 \\
\hline S04WV093003 & 33 & 72 & Btg & 0.41 & & 0 & 0.41 & 1.48 & 2.37 \\
\hline S04WV093003 & 72 & 110 & $\mathrm{Bt}$ & 0.39 & & 0 & 0.39 & 1.47 & 2.17 \\
\hline S04WV093003 & 110 & 151 & $\mathrm{C} 1$ & 1.03 & & 10 & 1.03 & 1.54 & 5.86 \\
\hline S04WV093003 & 151 & 164 & $2 \mathrm{C} 2$ & 0.62 & & 0 & 0.62 & 1.50 & 1.21 \\
\hline S04WV093003 & 164 & 183 & $2 \mathrm{C} 3$ & 0.30 & & 0 & 0.30 & 1.54 & 0.88 \\
\hline S04WV093004 & 0 & 6 & Oe1 & 32.72 & & 0 & 32.72 & 0.58 & 11.30 \\
\hline S04WV093004 & 6 & 9 & Oe2 & 14.44 & & 0 & 14.44 & 0.96 & 4.16 \\
\hline S04WV093004 & 9 & 14 & $\mathrm{~A}$ & 4.29 & & 3 & 4.29 & 1.05 & 2.18 \\
\hline S04WV093004 & 14 & 21 & $\mathrm{AE}$ & 1.17 & & 3 & 1.17 & 1.40 & 1.12 \\
\hline
\end{tabular}




\begin{tabular}{|c|c|c|c|c|c|c|c|c|c|}
\hline PedonID & $\begin{array}{c}\text { Top } \\
\text { Depth } \\
\text { (cm) }\end{array}$ & $\begin{array}{c}\text { Bottom } \\
\text { Depth } \\
(\mathrm{cm})\end{array}$ & Horizon & $\begin{array}{c}\text { Total } \\
\text { Carbon\% } \\
\text { (Dry } \\
\text { Combustion, } \\
\text { Including } \\
\text { Converted } \\
\text { Walkley- } \\
\text { Black) }\end{array}$ & $\begin{array}{c}\text { 33kPa } \\
\text { Bulk } \\
\text { Density } \\
\left(\mathrm{g} \mathrm{cm}^{-3}\right)\end{array}$ & $\begin{array}{c}\text { Fragment } \\
\% \text { by } \\
\text { Volume }\end{array}$ & $\begin{array}{c}\text { Predicted } \\
\text { OC } \%\end{array}$ & $\begin{array}{c}\text { Predicted } \\
33 \mathrm{kPa} \mathrm{BD} \\
\left(\mathrm{g} \mathrm{cm}^{-3}\right)\end{array}$ & $\begin{array}{c}\text { SOC } \\
\text { Stock } \\
(\mathbf{k g} \\
\left.\mathbf{m}^{-2}\right)\end{array}$ \\
\hline S04WV093004 & 21 & 44 & $\mathrm{Bt}$ & 0.89 & & 5 & 0.89 & 1.34 & 2.60 \\
\hline S04WV093004 & 44 & 82 & Btg & 0.84 & & 15 & 0.84 & 1.48 & 4.01 \\
\hline S04WV093004 & 82 & 125 & Btx & 0.62 & & 25 & 0.62 & 1.58 & 3.17 \\
\hline S04WV093005 & 0 & 2 & $\mathrm{Oi}$ & 49.93 & & 0 & 49.93 & 0.37 & 3.67 \\
\hline S04WV093005 & 2 & 4 & $\mathrm{Oe}$ & 47.74 & & 0 & 47.74 & 0.98 & 9.32 \\
\hline S04WV093005 & 4 & 9 & $\mathrm{Oa}$ & 20.52 & & 0 & 20.52 & 0.53 & 5.48 \\
\hline S04WV093005 & 9 & 21 & $\mathrm{E} / \mathrm{A}$ & 2.03 & 1.52 & 2 & 2.03 & 1.52 & 3.63 \\
\hline S04WV093005 & 21 & 42 & Bw1 & 0.45 & 1.69 & 2 & 0.45 & 1.69 & 1.57 \\
\hline S04WV093005 & 42 & 67 & Bw2 & 0.34 & 1.76 & 5 & 0.34 & 1.76 & 1.42 \\
\hline S04WV093005 & 67 & 121 & $\mathrm{Bx}$ & 0.27 & 2.00 & 5 & 0.27 & 2.00 & 2.77 \\
\hline S04WV093005 & 121 & 165 & $\mathrm{BCt}$ & 0.35 & 1.90 & 3 & 0.35 & 1.90 & 2.84 \\
\hline S04WV093006 & 0 & 2 & Oi & 48.80 & & 0 & 48.80 & 0.28 & 2.77 \\
\hline S04WV093006 & 2 & 3 & $\mathrm{Oe}$ & 40.87 & & 0 & 40.87 & 0.41 & 1.68 \\
\hline S04WV093006 & 3 & 10 & $\mathrm{~A}$ & 6.84 & 0.90 & 5 & 6.84 & 0.90 & 4.09 \\
\hline S04WV093006 & 10 & 16 & $\mathrm{~A} / \mathrm{B}$ & 2.30 & 1.22 & 5 & 2.30 & 1.22 & 1.60 \\
\hline S04WV093006 & 16 & 38 & $\mathrm{Bt1}$ & 1.99 & 1.24 & 5 & 1.99 & 1.24 & 5.16 \\
\hline S04WV093006 & 38 & 51 & Bt2 & 0.95 & 1.64 & 15 & 0.95 & 1.64 & 1.72 \\
\hline S04WV093006 & 51 & 70 & $\mathrm{BC}$ & 0.30 & 1.80 & 20 & 0.30 & 1.80 & 0.82 \\
\hline S04WV093007 & 0 & 4 & $\mathrm{Oi}$ & 35.40 & & 0 & 35.40 & 0.30 & 4.25 \\
\hline S04WV093007 & 4 & 11 & $\mathrm{~A}$ & 4.10 & & 10 & 4.10 & 1.00 & 2.58 \\
\hline S04WV093007 & 11 & 16 & $\mathrm{E}$ & 4.69 & & 16 & 4.69 & 1.32 & 2.59 \\
\hline S04WV093007 & 16 & 27 & $\mathrm{BE}$ & 1.71 & 1.44 & 20 & 1.71 & 1.44 & 2.17 \\
\hline S04WV093007 & 27 & 41 & Bs1 & 1.94 & & 28 & 1.94 & 1.23 & 2.41 \\
\hline
\end{tabular}




\begin{tabular}{|c|c|c|c|c|c|c|c|c|c|}
\hline PedonID & $\begin{array}{c}\text { Top } \\
\text { Depth } \\
\text { (cm) }\end{array}$ & $\begin{array}{c}\text { Bottom } \\
\text { Depth } \\
(\mathrm{cm})\end{array}$ & Horizon & $\begin{array}{c}\text { Total } \\
\text { Carbon \% } \\
\text { (Dry } \\
\text { Combustion, } \\
\text { Including } \\
\text { Converted } \\
\text { Walkley- } \\
\text { Black) } \\
\end{array}$ & $\begin{array}{c}\text { 33kPa } \\
\text { Bulk } \\
\text { Density } \\
\left(\mathrm{g} \mathrm{cm}^{-3}\right)\end{array}$ & $\begin{array}{c}\text { Fragment } \\
\% \text { by } \\
\text { Volume }\end{array}$ & $\begin{array}{c}\text { Predicted } \\
\text { OC } \%\end{array}$ & $\begin{array}{c}\text { Predicted } \\
\text { 33kPa BD } \\
\left(\mathrm{g} \mathrm{cm}^{-3}\right)\end{array}$ & $\begin{array}{c}\text { SOC } \\
\text { Stock } \\
(\mathbf{k g} \\
\left.\mathbf{m}^{-2}\right)\end{array}$ \\
\hline S04WV093007 & 41 & 67 & Bs2 & 1.71 & 1.16 & 33 & 1.71 & 1.16 & 3.46 \\
\hline S04WV093007 & 67 & 95 & Bw1 & 1.39 & 1.24 & 33 & 1.39 & 1.24 & 3.23 \\
\hline S04WV093007 & 95 & 122 & Bw2 & 0.38 & 1.51 & 60 & 0.38 & 1.51 & 0.62 \\
\hline S04WV093007 & 122 & 147 & $2 \mathrm{CB}$ & 0.33 & 1.76 & 55 & 0.33 & 1.76 & 0.65 \\
\hline S04WV093008 & 0 & 1 & Oi & 41.59 & & 0 & 41.59 & 0.33 & 1.38 \\
\hline S04WV093008 & 1 & 2 & $\mathrm{Oe}$ & 29.44 & & 0 & 9.56 & 1.08 & 2.79 \\
\hline S04WV093008 & 2 & 5 & $\mathrm{~A}$ & 9.56 & & 10 & 3.51 & 1.17 & 2.58 \\
\hline S04WV093008 & 5 & 12 & $\mathrm{~A} / \mathrm{B}$ & 3.51 & & 10 & 2.70 & 1.20 & 3.69 \\
\hline S04WV093008 & 12 & 24 & $\mathrm{BA}$ & 2.70 & & 5 & 1.72 & 1.41 & 4.61 \\
\hline S04WV093008 & 24 & 44 & Bt1 & 1.72 & 1.41 & 5 & 0.25 & 1.73 & 0.53 \\
\hline S04WV093008 & 44 & 57 & $\mathrm{Bt} 2$ & 0.25 & 1.73 & 5 & 0.18 & 1.76 & 0.86 \\
\hline S04WV093008 & 57 & 87 & Btx1 & 0.18 & 1.76 & 10 & 0.16 & 1.73 & 0.82 \\
\hline S04WV093008 & 87 & 118 & Btx2 & 0.16 & 1.73 & 5 & 0.21 & 1.49 & 0.03 \\
\hline S04WV093008 & 118 & 119 & $2 \mathrm{Bt}$ & 0.21 & 1.49 & 5 & 29.44 & 0.46 & 1.36 \\
\hline S06WV019001 & 0 & 2 & Oi & 41.19 & & 0 & 41.19 & 0.43 & 3.53 \\
\hline S06WV019001 & 2 & 8 & $\mathrm{~A}$ & 3.28 & & 15 & 3.28 & 0.99 & 1.65 \\
\hline S06WV019001 & 8 & 18 & $\mathrm{BA}$ & 1.24 & & 15 & 1.24 & 1.19 & 1.26 \\
\hline S06WV019001 & 18 & 53 & Bt1 & 0.29 & 1.60 & 10 & 0.29 & 1.60 & 1.46 \\
\hline S06WV019001 & 53 & 69 & $\mathrm{Bt} 2$ & 0.16 & 1.67 & 15 & 0.16 & 1.67 & 0.36 \\
\hline S06WV019001 & 69 & 104 & $2 \mathrm{Bt} 3$ & 0.20 & 1.65 & 15 & 0.20 & 1.65 & 0.98 \\
\hline S06WV019001 & 104 & 141 & $3 \mathrm{Bx}$ & 0.13 & 1.70 & 25 & 0.13 & 1.70 & 0.61 \\
\hline S06WV019001 & 141 & 165 & $3 \mathrm{BC}$ & 0.12 & 1.67 & 40 & 0.12 & 1.67 & 0.29 \\
\hline S06WV019001 & 165 & 200 & $4 \mathrm{C}$ & 0.12 & 1.66 & 55 & 0.12 & 1.66 & 0.31 \\
\hline
\end{tabular}




\begin{tabular}{|c|c|c|c|c|c|c|c|c|c|}
\hline PedonID & $\begin{array}{c}\text { Top } \\
\text { Depth } \\
\text { (cm) }\end{array}$ & $\begin{array}{c}\text { Bottom } \\
\text { Depth } \\
\text { (cm) }\end{array}$ & Horizon & $\begin{array}{c}\text { Total } \\
\text { Carbon \% } \\
\text { (Dry } \\
\text { Combustion, } \\
\text { Including } \\
\text { Converted } \\
\text { Walkley- } \\
\text { Black) } \\
\end{array}$ & $\begin{array}{c}\text { 33kPa } \\
\text { Bulk } \\
\text { Density } \\
\left(\mathrm{g} \mathrm{cm}^{-3}\right)\end{array}$ & $\begin{array}{c}\text { Fragment } \\
\% \text { by } \\
\text { Volume }\end{array}$ & $\begin{array}{c}\text { Predicted } \\
\text { OC } \%\end{array}$ & $\begin{array}{c}\text { Predicted } \\
\text { 33kPa BD } \\
\left(\mathrm{g} \mathrm{cm}^{-3}\right)\end{array}$ & $\begin{array}{c}\text { SOC } \\
\text { Stock } \\
(\mathbf{k g} \\
\left.\mathbf{m}^{-2}\right)\end{array}$ \\
\hline S06WV019002 & 0 & 3 & Oi & 42.63 & & 0 & 42.63 & 0.46 & 5.85 \\
\hline S06WV019002 & 3 & 12 & $\mathrm{~A}$ & 4.20 & 0.97 & 0 & 4.20 & 0.97 & 3.67 \\
\hline S06WV019002 & 12 & 25 & $\mathrm{AE}$ & 1.08 & 1.40 & 0 & 1.08 & 1.40 & 1.97 \\
\hline S06WV019002 & 25 & 60 & $\mathrm{BE}$ & 0.23 & 1.65 & 0 & 0.23 & 1.65 & 1.33 \\
\hline S06WV019002 & 60 & 78 & Btx1 & 0.08 & 1.64 & 0 & 0.08 & 1.64 & 0.24 \\
\hline S06WV019002 & 78 & 121 & Btx2 & 0.08 & 1.57 & 0 & 0.08 & 1.57 & 0.54 \\
\hline S06WV019002 & 121 & 193 & $2 \mathrm{Btg}$ & 0.11 & 1.57 & 0 & 0.11 & 1.57 & 1.24 \\
\hline S06WV019004 & 0 & 2 & Oi & 48.67 & & 0 & 48.67 & 0.41 & 3.98 \\
\hline S06WV019004 & 2 & 9 & $\mathrm{Oa} / \mathrm{A}$ & 5.72 & & 10 & 5.72 & 1.00 & 3.61 \\
\hline S06WV019004 & 9 & 19 & $\mathrm{~A} / \mathrm{B}$ & 2.55 & & 10 & 2.55 & 1.19 & 2.72 \\
\hline S06WV019004 & 19 & 35 & Bt1 & 0.44 & 1.45 & 10 & 0.44 & 1.45 & 0.92 \\
\hline S06WV019004 & 35 & 80 & $\mathrm{Bt} 2$ & 0.35 & 1.47 & 10 & 0.35 & 1.47 & 2.08 \\
\hline S06WV019004 & 80 & 112 & $\mathrm{Bt} 3$ & 0.40 & 1.37 & 30 & 0.40 & 1.37 & 1.23 \\
\hline S06WV019004 & 112 & 122 & $2 \mathrm{Bt} 4$ & 0.21 & 1.57 & 30 & 0.21 & 1.57 & 0.23 \\
\hline S06WV019004 & 122 & 180 & $2 \mathrm{Btx}$ & 0.15 & 1.68 & 40 & 0.15 & 1.68 & 0.88 \\
\hline S06WV019005 & 0 & 2 & $\mathrm{Oi}$ & 51.63 & & 0 & 51.63 & 0.37 & 3.84 \\
\hline S06WV019005 & 2 & 4 & $\mathrm{Oe}$ & 43.63 & & 0 & 43.63 & 0.52 & 4.49 \\
\hline S06WV019005 & 4 & 10 & $\mathrm{~A}$ & 4.94 & & 5 & 4.94 & 0.98 & 2.76 \\
\hline S06WV019005 & 10 & 17 & $\mathrm{~B} / \mathrm{A}$ & 2.19 & & 5 & 2.19 & 1.22 & 1.78 \\
\hline S06WV019005 & 17 & 35 & Bt1 & 0.70 & 1.45 & 10 & 0.70 & 1.45 & 1.64 \\
\hline S06WV019005 & 35 & 60 & $\mathrm{Bt} 2$ & 0.47 & 1.44 & 40 & 0.47 & 1.44 & 1.02 \\
\hline S06WV019005 & 60 & 69 & $\mathrm{C}$ & 0.49 & & 70 & 0.49 & 1.45 & 0.19 \\
\hline S06WV025001 & 0 & 2 & Oi & 50.48 & & 0 & 50.48 & 0.36 & 3.67 \\
\hline
\end{tabular}




\begin{tabular}{|c|c|c|c|c|c|c|c|c|c|}
\hline PedonID & $\begin{array}{c}\text { Top } \\
\text { Depth } \\
\text { (cm) }\end{array}$ & $\begin{array}{c}\text { Bottom } \\
\text { Depth } \\
(\mathrm{cm})\end{array}$ & Horizon & $\begin{array}{c}\text { Total } \\
\text { Carbon \% } \\
\text { (Dry } \\
\text { Combustion, } \\
\text { Including } \\
\text { Converted } \\
\text { Walkley- } \\
\text { Black) } \\
\end{array}$ & $\begin{array}{c}\text { 33kPa } \\
\text { Bulk } \\
\text { Density } \\
\left(\mathrm{g} \mathrm{cm}^{-3}\right)\end{array}$ & $\begin{array}{c}\text { Fragment } \\
\% \text { by } \\
\text { Volume }\end{array}$ & $\begin{array}{c}\text { Predicted } \\
\text { OC } \%\end{array}$ & $\begin{array}{c}\text { Predicted } \\
\text { 33kPa BD } \\
\left(\mathrm{g} \mathrm{cm}^{-3}\right)\end{array}$ & $\begin{array}{c}\text { SOC } \\
\text { Stock } \\
(\mathbf{k g} \\
\left.\mathbf{m}^{-2}\right)\end{array}$ \\
\hline S06WV025001 & 2 & 4 & $\mathrm{Oe}$ & 35.87 & & 0 & 35.87 & 0.49 & 3.54 \\
\hline S06WV025001 & 4 & 7 & $\mathrm{Oa} / \mathrm{A}$ & 21.53 & & 0 & 21.53 & 0.55 & 3.57 \\
\hline S06WV025001 & 7 & 19 & $\mathrm{AE}$ & 1.46 & 1.35 & 0 & 1.46 & 1.35 & 2.37 \\
\hline S06WV025001 & 19 & 53 & Bt1 & 0.39 & 1.60 & 0 & 0.39 & 1.60 & 2.12 \\
\hline S06WV025001 & 53 & 62 & $\mathrm{Bt} 2$ & 0.15 & 1.69 & 0 & 0.15 & 1.69 & 0.23 \\
\hline S06WV025001 & 62 & 105 & Btx & 0.07 & 1.74 & 0 & 0.07 & 1.74 & 0.52 \\
\hline S06WV025001 & 105 & 130 & $\mathrm{C}$ & 0.08 & 1.72 & 0 & 0.08 & 1.72 & 0.34 \\
\hline S06WV067001 & 0 & 1 & $\mathrm{Oi}$ & & & 0 & 0.35 & 1.45 & 0.23 \\
\hline S06WV067001 & 1 & 6 & $\mathrm{~A}$ & 3.81 & 1.03 & 5 & 46.49 & 0.39 & 1.82 \\
\hline S06WV067001 & 6 & 26 & $\mathrm{ABp}$ & 2.03 & 1.27 & 5 & 3.81 & 1.03 & 1.86 \\
\hline S06WV067001 & 26 & 38 & $\mathrm{BA}$ & 1.09 & 1.43 & 10 & 2.03 & 1.27 & 4.90 \\
\hline S06WV067001 & 38 & 60 & Bt1 & 0.51 & 1.35 & 15 & 1.09 & 1.43 & 1.68 \\
\hline S06WV067001 & 60 & 80 & $\mathrm{Bt} 2$ & 0.33 & 1.38 & 20 & 0.51 & 1.35 & 1.29 \\
\hline S06WV067001 & 80 & 89 & $\mathrm{BC}$ & 0.35 & 1.45 & 50 & 0.33 & 1.38 & 0.73 \\
\hline S06WV067002 & 0 & 3 & $\mathrm{Oi}$ & 51.58 & & 0 & 51.58 & 0.43 & 6.66 \\
\hline S06WV067002 & 3 & 5 & $\mathrm{Oe}$ & 38.73 & & 0 & 38.73 & 0.56 & 4.36 \\
\hline S06WV067002 & 5 & 7 & $\mathrm{Oa}$ & 41.74 & & 0 & 41.74 & 0.62 & 5.20 \\
\hline S06WV067002 & 7 & 10 & $\mathrm{~A}$ & 11.86 & & 0 & 11.86 & 0.98 & 3.48 \\
\hline S06WV067002 & 10 & 25 & $\mathrm{BA}$ & 3.41 & 1.01 & 5 & 3.41 & 1.01 & 4.91 \\
\hline S06WV067002 & 25 & 44 & Bt1 & 0.63 & 1.35 & 5 & 0.63 & 1.35 & 1.54 \\
\hline S06WV067002 & 44 & 66 & $\mathrm{Bt} 2$ & 0.26 & 1.46 & 5 & 0.26 & 1.46 & 0.79 \\
\hline S06WV067002 & 66 & 79 & Bt3 & 0.20 & 1.50 & 0 & 0.20 & 1.50 & 0.39 \\
\hline S06WV067002 & 79 & 100 & $\mathrm{Cr}$ & 0.20 & & 17 & 0.20 & 1.51 & 0.53 \\
\hline
\end{tabular}




\begin{tabular}{|c|c|c|c|c|c|c|c|c|c|}
\hline PedonID & $\begin{array}{c}\text { Top } \\
\text { Depth } \\
\text { (cm) }\end{array}$ & $\begin{array}{c}\text { Bottom } \\
\text { Depth } \\
(\mathrm{cm})\end{array}$ & Horizon & $\begin{array}{c}\text { Total } \\
\text { Carbon\% } \\
\text { (Dry } \\
\text { Combustion, } \\
\text { Including } \\
\text { Converted } \\
\text { Walkley- } \\
\text { Black) }\end{array}$ & $\begin{array}{c}\text { 33kPa } \\
\text { Bulk } \\
\text { Density } \\
\left(\mathrm{g} \mathrm{cm}^{-3}\right)\end{array}$ & $\begin{array}{c}\text { Fragment } \\
\% \text { by } \\
\text { Volume }\end{array}$ & $\begin{array}{c}\text { Predicted } \\
\text { OC } \%\end{array}$ & $\begin{array}{c}\text { Predicted } \\
\text { 33kPa BD } \\
\left(\mathrm{g} \mathrm{cm}^{-3}\right)\end{array}$ & $\begin{array}{r}\text { SOC } \\
\text { Stock } \\
(\mathbf{k g} \\
\left.\mathbf{m}^{-2}\right)\end{array}$ \\
\hline S06WV067003 & 0 & 2 & $\mathrm{Oi}$ & 51.78 & & 0 & 51.78 & 0.42 & 4.37 \\
\hline S06WV067003 & 2 & 13 & $\mathrm{~A}$ & 6.59 & & 17 & 6.59 & 1.02 & 6.13 \\
\hline S06WV067003 & 13 & 35 & $\mathrm{BA}$ & 2.53 & 0.96 & 45 & 2.53 & 0.96 & 2.94 \\
\hline S06WV067003 & 35 & 81 & Bt1 & 0.15 & 1.64 & 45 & 0.15 & 1.64 & 0.62 \\
\hline S06WV067003 & 81 & 175 & $\mathrm{Bt} 2$ & 0.13 & 1.45 & 70 & 0.13 & 1.45 & 0.53 \\
\hline S06WV067003 & 175 & 193 & Btx & 0.12 & 1.46 & 0 & 0.12 & 1.46 & 0.32 \\
\hline S06WV067003 & 193 & 194 & $\mathrm{C}$ & 0.10 & 1.45 & 0 & 0.10 & 1.45 & 0.10 \\
\hline S06WV067004 & 0 & 2 & Oi & 51.41 & & 0 & 51.41 & 0.43 & 4.43 \\
\hline S06WV067004 & 2 & 3 & $\mathrm{Oe}$ & 46.27 & & 0 & 46.27 & 0.59 & 2.73 \\
\hline S06WV067004 & 3 & 8 & $\mathrm{~A}$ & 11.00 & 0.77 & 20 & 11.00 & 0.77 & 3.39 \\
\hline S06WV067004 & 8 & 16 & $\mathrm{BA}$ & 2.69 & 1.18 & 40 & 2.69 & 1.18 & 1.52 \\
\hline S06WV067004 & 16 & 34 & Bt1 & 0.95 & 1.26 & 40 & 0.95 & 1.26 & 1.29 \\
\hline S06WV067004 & 34 & 60 & $\mathrm{Bt} 2$ & 0.52 & 1.50 & 0 & 0.52 & 1.50 & 2.03 \\
\hline S06WV067004 & 60 & 87 & Btg1 & 0.24 & 1.58 & 0 & 0.24 & 1.58 & 1.02 \\
\hline S06WV067004 & 87 & 108 & Btg2 & 0.07 & 1.71 & 15 & 0.07 & 1.71 & 0.21 \\
\hline S06WV067005 & 0 & 2 & $\mathrm{Oi}$ & 50.27 & & 0 & 50.27 & 0.46 & 4.61 \\
\hline S06WV067005 & 190 & 320 & $2 \mathrm{Btx} 4$ & 0.15 & & 40 & 41.27 & 0.61 & 2.50 \\
\hline S06WV067005 & 320 & 400 & $3 \mathrm{Btx} 5$ & 0.11 & & 40 & 6.20 & 1.04 & 1.46 \\
\hline S06WV067005 & 2 & 3 & Oe & 41.27 & & 0 & 1.17 & 1.21 & 0.40 \\
\hline S06WV067005 & 3 & 8 & $\mathrm{~A}$ & 6.20 & & 55 & 0.30 & 1.51 & 0.90 \\
\hline S06WV067005 & 8 & 12 & BA & 1.17 & & 30 & 0.19 & 1.52 & 1.54 \\
\hline S06WV067005 & 12 & 33 & Bt1 & 0.30 & 1.51 & 5 & 0.12 & 1.76 & 0.71 \\
\hline S06WV067005 & 33 & 89 & $\mathrm{Bt} 2$ & 0.19 & 1.52 & 5 & 0.15 & 1.54 & 0.17 \\
\hline
\end{tabular}




\begin{tabular}{|c|c|c|c|c|c|c|c|c|c|}
\hline PedonID & $\begin{array}{c}\text { Top } \\
\text { Depth } \\
\text { (cm) }\end{array}$ & $\begin{array}{c}\text { Bottom } \\
\text { Depth } \\
(\mathrm{cm})\end{array}$ & Horizon & $\begin{array}{c}\text { Total } \\
\text { Carbon\% } \\
\text { (Dry } \\
\text { Combustion, } \\
\text { Including } \\
\text { Converted } \\
\text { Walkley- } \\
\text { Black) }\end{array}$ & $\begin{array}{c}\text { 33kPa } \\
\text { Bulk } \\
\text { Density } \\
\left(\mathrm{g} \mathrm{cm}^{-3}\right)\end{array}$ & $\begin{array}{c}\text { Fragment } \\
\% \text { by } \\
\text { Volume }\end{array}$ & $\begin{array}{c}\text { Predicted } \\
\text { OC } \%\end{array}$ & $\begin{array}{c}\text { Predicted } \\
33 \mathrm{kPa} \mathrm{BD} \\
\left(\mathrm{g} \mathrm{cm}^{-3}\right)\end{array}$ & $\begin{array}{c}\text { SOC } \\
\text { Stock } \\
(\mathbf{k g} \\
\left.\mathbf{m}^{-2}\right)\end{array}$ \\
\hline S06WV067005 & 89 & 141 & Btx1 & 0.12 & 1.76 & 35 & 0.15 & 1.56 & 0.58 \\
\hline S06WV067005 & 141 & 152 & $2 \mathrm{Btx} 2$ & 0.15 & 1.54 & 35 & 0.15 & 1.58 & 1.85 \\
\hline S06WV067005 & 152 & 190 & $2 \mathrm{Bt} x 3$ & 0.15 & 1.56 & 35 & 0.11 & 1.58 & 0.83 \\
\hline S06WV067006 & 0 & 3 & Oi & 48.10 & & 0 & 48.10 & 0.40 & 5.83 \\
\hline S06WV067006 & 3 & 4 & $\mathrm{Oe}$ & 36.05 & & 0 & 36.05 & 0.54 & 1.93 \\
\hline S06WV067006 & 4 & 11 & $\mathrm{~A}$ & 7.52 & & 5 & 7.52 & 1.00 & 5.02 \\
\hline S06WV067006 & 11 & 28 & $\mathrm{BA}$ & 0.52 & 1.44 & 15 & 0.52 & 1.44 & 1.08 \\
\hline S06WV067006 & 28 & 50 & Bt1 & 0.34 & 1.43 & 20 & 0.34 & 1.43 & 0.86 \\
\hline S06WV067006 & 50 & 63 & $\mathrm{Bt} 2$ & 0.28 & 1.44 & 40 & 0.28 & 1.44 & 0.31 \\
\hline S06WV067006 & 63 & 84 & $\mathrm{BC}$ & 0.28 & 1.42 & 60 & 0.28 & 1.42 & 0.33 \\
\hline S06WV081001 & 0 & 2 & $\mathrm{Oi}$ & 49.63 & & 0 & 49.63 & 0.41 & 4.10 \\
\hline S06WV081001 & 125 & 148 & $\mathrm{~B} / \mathrm{C}$ & 0.08 & & 0 & 29.92 & 0.55 & 1.65 \\
\hline S06WV081001 & 2 & 3 & Oe & 29.92 & & 0 & 12.74 & 1.04 & 5.31 \\
\hline S06WV081001 & 3 & 7 & $\mathrm{Oa} / \mathrm{A}$ & 12.74 & & 0 & 2.00 & 1.21 & 1.45 \\
\hline S06WV081001 & 7 & 13 & $\mathrm{AE}$ & 2.00 & 1.21 & 0 & 0.55 & 1.32 & 1.09 \\
\hline S06WV081001 & 13 & 28 & $\mathrm{BE}$ & 0.55 & 1.32 & 0 & 0.23 & 1.48 & 0.89 \\
\hline S06WV081001 & 28 & 54 & Bt1 & 0.23 & 1.48 & 0 & 0.12 & 1.70 & 0.49 \\
\hline S06WV081001 & 54 & 78 & $\mathrm{Bt} 2$ & 0.12 & 1.70 & 0 & 0.08 & 1.71 & 0.22 \\
\hline S06WV081001 & 78 & 94 & Btx1 & 0.08 & 1.71 & 0 & 0.07 & 1.81 & 0.39 \\
\hline S06WV081001 & 94 & 125 & Btx2 & 0.07 & 1.81 & 0 & 0.08 & 1.67 & 0.31 \\
\hline S06WV101001 & 0 & 2 & Oi1 & 50.65 & & 0 & 50.65 & 0.35 & 3.59 \\
\hline S06WV101001 & 2 & 3 & Oi2 & 47.60 & & 0 & 47.60 & 0.37 & 1.74 \\
\hline S06WV101001 & 3 & 9 & $\mathrm{~A}$ & 4.55 & & 0 & 4.55 & 0.93 & 2.55 \\
\hline
\end{tabular}




\begin{tabular}{|c|c|c|c|c|c|c|c|c|c|}
\hline PedonID & $\begin{array}{c}\text { Top } \\
\text { Depth } \\
\text { (cm) }\end{array}$ & $\begin{array}{c}\text { Bottom } \\
\text { Depth } \\
(\mathrm{cm})\end{array}$ & Horizon & $\begin{array}{c}\text { Total } \\
\text { Carbon\% } \\
\text { (Dry } \\
\text { Combustion, } \\
\text { Including } \\
\text { Converted } \\
\text { Walkley- } \\
\text { Black) } \\
\end{array}$ & $\begin{array}{c}\text { 33kPa } \\
\text { Bulk } \\
\text { Density } \\
\left(\mathrm{g} \mathrm{cm}^{-3}\right)\end{array}$ & $\begin{array}{c}\text { Fragment } \\
\% \text { by } \\
\text { Volume }\end{array}$ & $\begin{array}{c}\text { Predicted } \\
\text { OC } \%\end{array}$ & $\begin{array}{c}\text { Predicted } \\
\text { 33kPa BD } \\
\left(\mathrm{g} \mathrm{cm}^{-3}\right)\end{array}$ & $\begin{array}{c}\text { SOC } \\
\text { Stock } \\
(\mathbf{k g} \\
\left.\mathbf{m}^{-2}\right)\end{array}$ \\
\hline S06WV101001 & 9 & 15 & $\mathrm{BA}$ & 2.16 & 1.11 & 0 & 2.16 & 1.11 & 1.44 \\
\hline S06WV101001 & 15 & 47 & Bt1 & 0.49 & 1.41 & 27 & 0.49 & 1.41 & 1.61 \\
\hline S06WV101001 & 47 & 64 & $\mathrm{Bt} 2$ & 0.24 & 1.30 & 32 & 0.24 & 1.30 & 0.36 \\
\hline S06WV101001 & 64 & 82 & Bt3 & 0.21 & 1.46 & 70 & 0.21 & 1.46 & 0.17 \\
\hline S06WV101001 & 82 & 91 & $\mathrm{BC}$ & 0.16 & 1.60 & 25 & 0.16 & 1.60 & 0.17 \\
\hline S06WV101001 & 91 & 135 & $\mathrm{C}$ & 0.20 & 1.25 & 70 & 0.20 & 1.25 & 0.33 \\
\hline S06WV101002 & 0 & 2 & $\mathrm{Oi}$ & 52.37 & & 0 & 52.37 & 0.42 & 4.40 \\
\hline S06WV101002 & 2 & 4 & $\mathrm{Oe}$ & 46.00 & & 0 & 46.00 & 0.56 & 5.18 \\
\hline S06WV101002 & 4 & 16 & $\mathrm{~A}$ & 4.27 & 1.05 & 20 & 4.27 & 1.05 & 4.30 \\
\hline S06WV101002 & 16 & 25 & BA & 1.74 & & 20 & 1.74 & 1.21 & 1.51 \\
\hline S06WV101002 & 25 & 40 & Bt1 & 0.74 & & 20 & 0.74 & 1.42 & 1.26 \\
\hline S06WV101002 & 40 & 56 & $\mathrm{Bt} 2$ & 0.36 & 1.56 & 45 & 0.36 & 1.56 & 0.49 \\
\hline S06WV101002 & 56 & 72 & $\mathrm{Bt} 3$ & 0.31 & & 35 & 0.31 & 1.49 & 0.48 \\
\hline S09WV167500 & 0 & 3 & Oi & 36.88 & & 0 & 36.88 & 0.49 & 5.47 \\
\hline S09WV167500 & 3 & 7 & A & 6.27 & & 5 & 6.27 & 0.97 & 2.32 \\
\hline S09WV167500 & 7 & 15 & $\mathrm{AE}$ & 1.29 & 1.28 & 10 & 1.29 & 1.28 & 1.19 \\
\hline S09WV167500 & 15 & 47 & Bt1 & 0.43 & 1.49 & 10 & 0.43 & 1.49 & 1.85 \\
\hline S09WV167500 & 47 & 66 & $\mathrm{Bt} 2$ & 0.49 & 1.59 & 10 & 0.49 & 1.59 & 1.33 \\
\hline S09WV167500 & 66 & 102 & Btx & 0.62 & 1.85 & 10 & 0.62 & 1.85 & 3.72 \\
\hline S09WV167510 & 0 & 3 & Oi & 53.66 & & 0 & 53.66 & 0.54 & 8.69 \\
\hline S09WV167510 & 3 & 6 & Oe & 47.77 & & 0 & 47.77 & 0.60 & 8.58 \\
\hline S09WV167510 & 6 & 10 & $\mathrm{Oa} / \mathrm{A}$ & 34.63 & & 5 & 34.63 & 1.03 & 13.59 \\
\hline S09WV167510 & 10 & 24 & $\mathrm{BE}$ & 1.43 & 1.30 & 12 & 1.43 & 1.30 & 2.29 \\
\hline
\end{tabular}




\begin{tabular}{|c|c|c|c|c|c|c|c|c|c|}
\hline PedonID & $\begin{array}{c}\text { Top } \\
\text { Depth } \\
\text { (cm) }\end{array}$ & $\begin{array}{c}\text { Bottom } \\
\text { Depth } \\
(\mathrm{cm})\end{array}$ & Horizon & $\begin{array}{c}\text { Total } \\
\text { Carbon \% } \\
\text { (Dry } \\
\text { Combustion, } \\
\text { Including } \\
\text { Converted } \\
\text { Walkley- } \\
\text { Black) } \\
\end{array}$ & $\begin{array}{c}\text { 33kPa } \\
\text { Bulk } \\
\text { Density } \\
\left(\mathrm{g} \mathrm{cm}^{-3}\right)\end{array}$ & $\begin{array}{c}\text { Fragment } \\
\% \text { by } \\
\text { Volume }\end{array}$ & $\begin{array}{c}\text { Predicted } \\
\text { OC } \%\end{array}$ & $\begin{array}{c}\text { Predicted } \\
\text { 33kPa BD } \\
\left(\mathrm{g} \mathrm{cm}^{-3}\right)\end{array}$ & $\begin{array}{c}\text { SOC } \\
\text { Stock } \\
(\mathbf{k g} \\
\left.\mathbf{m}^{-2}\right)\end{array}$ \\
\hline S09WV167510 & 24 & 37 & Bt1 & 0.46 & 1.51 & 12 & 0.46 & 1.51 & 0.79 \\
\hline S09WV167510 & 37 & 59 & $\mathrm{Bt} 2$ & 0.33 & 1.49 & 12 & 0.33 & 1.49 & 0.95 \\
\hline S09WV167510 & 59 & 80 & Btx1 & 0.16 & 1.78 & 12 & 0.16 & 1.78 & 0.53 \\
\hline S09WV167510 & 80 & 117 & Btx2 & 0.08 & 1.84 & 12 & 0.08 & 1.84 & 0.48 \\
\hline S09WV167515 & 0 & 3 & Oi & 53.00 & & 0 & 53.00 & 0.57 & 9.05 \\
\hline S09WV167515 & 3 & 6 & $\mathrm{Oe}$ & 51.94 & & 0 & 51.94 & 0.62 & 9.72 \\
\hline S09WV167515 & 6 & 10 & $\mathrm{~A}$ & 10.93 & & 0 & 10.93 & 1.04 & 4.53 \\
\hline S09WV167515 & 10 & 17 & $\mathrm{BE}$ & 2.93 & 1.05 & 0 & 2.93 & 1.05 & 2.15 \\
\hline S09WV167515 & 17 & 25 & Bt1 & 2.18 & 1.26 & 0 & 2.18 & 1.26 & 2.20 \\
\hline S09WV167515 & 25 & 52 & $\mathrm{Bt} 2$ & 0.42 & 1.55 & 2 & 0.42 & 1.55 & 1.72 \\
\hline S09WV167515 & 52 & 72 & Btx1 & 0.14 & 1.76 & 3 & 0.14 & 1.76 & 0.48 \\
\hline S09WV167515 & 72 & 116 & Btx2 & 0.12 & 1.63 & 15 & 0.12 & 1.63 & 0.73 \\
\hline S09WV167515 & 116 & 150 & Btx3 & 0.15 & 1.66 & 5 & 0.15 & 1.66 & 0.80 \\
\hline S09WV167530 & 0 & 3 & $\mathrm{Oi}$ & 30.84 & & 0 & 30.84 & 0.49 & 4.50 \\
\hline S09WV167530 & 3 & 8 & $\mathrm{~A}$ & 8.37 & & 2 & 8.37 & 1.13 & 4.65 \\
\hline S09WV167530 & 8 & 17 & $\mathrm{BA}$ & 1.93 & 1.28 & 2 & 1.93 & 1.28 & 2.18 \\
\hline S09WV167530 & 17 & 33 & Bt1 & 0.50 & 1.61 & 5 & 0.50 & 1.61 & 1.22 \\
\hline S09WV167530 & 33 & 58 & $\mathrm{Bt} 2$ & 0.33 & 1.46 & 8 & 0.33 & 1.46 & 1.11 \\
\hline S09WV167530 & 58 & 72 & Btx1 & 0.33 & 1.50 & 8 & 0.33 & 1.50 & 0.64 \\
\hline S09WV167530 & 72 & 96 & Btx2 & 0.36 & 1.42 & 10 & 0.36 & 1.42 & 1.10 \\
\hline S09WV167530 & 96 & 123 & Btx3 & 0.35 & 1.73 & 10 & 0.35 & 1.73 & 1.47 \\
\hline S09WV167530 & 123 & 150 & Btx4 & 0.22 & 1.62 & 10 & 0.22 & 1.62 & 0.87 \\
\hline S09WV167540 & 0 & 6 & $\mathrm{Oi}$ & 31.12 & & 0 & 31.12 & 0.41 & 7.69 \\
\hline
\end{tabular}




\begin{tabular}{|c|c|c|c|c|c|c|c|c|c|}
\hline PedonID & $\begin{array}{c}\text { Top } \\
\text { Depth } \\
\text { (cm) }\end{array}$ & $\begin{array}{c}\text { Bottom } \\
\text { Depth } \\
(\mathrm{cm})\end{array}$ & Horizon & $\begin{array}{c}\text { Total } \\
\text { Carbon\% } \\
\text { (Dry } \\
\text { Combustion, } \\
\text { Including } \\
\text { Converted } \\
\text { Walkley- } \\
\text { Black) }\end{array}$ & $\begin{array}{c}\text { 33kPa } \\
\text { Bulk } \\
\text { Density } \\
\left(\mathrm{g} \mathrm{cm}^{-3}\right)\end{array}$ & $\begin{array}{c}\text { Fragment } \\
\% \text { by } \\
\text { Volume }\end{array}$ & $\begin{array}{c}\text { Predicted } \\
\text { OC } \%\end{array}$ & $\begin{array}{c}\text { Predicted } \\
33 \mathrm{kPa} \mathrm{BD} \\
\left(\mathrm{g} \mathrm{cm}^{-3}\right)\end{array}$ & $\begin{array}{c}\text { SOC } \\
\text { Stock } \\
(\mathbf{k g} \\
\left.\mathbf{m}^{-2}\right)\end{array}$ \\
\hline S09WV167540 & 6 & 14 & $\mathrm{~A}$ & 8.17 & & 2 & 8.17 & 1.15 & 7.37 \\
\hline S09WV167540 & 14 & 22 & $\mathrm{BA}$ & 2.23 & 1.19 & 2 & 2.23 & 1.19 & 2.08 \\
\hline S09WV167540 & 22 & 50 & Bw1 & 0.49 & 1.47 & 5 & 0.49 & 1.47 & 1.92 \\
\hline S09WV167540 & 50 & 60 & Bw2 & 0.35 & 1.41 & 15 & 0.35 & 1.41 & 0.42 \\
\hline S09WV167540 & 60 & 68 & $\mathrm{BC}$ & 0.28 & 1.58 & 15 & 0.28 & 1.58 & 0.30 \\
\hline S12WV071001 & 0 & 3 & Oi & 40.17 & 0.31 & & 40.17 & 0.31 & 3.74 \\
\hline S12WV071001 & 3 & 7 & $\mathrm{~A}$ & 12.81 & 1.20 & 20 & 12.81 & 1.20 & 4.92 \\
\hline S12WV071001 & 7 & 13 & Bhs & 5.52 & 1.53 & 20 & 5.52 & 1.53 & 4.05 \\
\hline S12WV071001 & 13 & 34 & Bs1 & 1.43 & 1.15 & 40 & 1.43 & 1.15 & 2.07 \\
\hline S12WV071001 & 34 & 58 & Bs2 & 1.30 & 1.12 & 32 & 1.30 & 1.12 & 2.38 \\
\hline S12WV071001 & 58 & 75 & $\mathrm{BC}$ & 0.70 & 0.16 & 55 & 0.70 & 0.16 & 0.09 \\
\hline S12WV075001 & 0 & 1 & $\mathrm{Oi}$ & 33.46 & 0.22 & & 33.46 & 0.22 & 0.74 \\
\hline S12WV075001 & 1 & 2 & $\mathrm{Oe}$ & 30.67 & 0.93 & & 30.67 & 0.93 & 2.85 \\
\hline S12WV075001 & 2 & 7 & A1 & 15.25 & 1.06 & 5 & 15.25 & 1.06 & 7.68 \\
\hline S12WV075001 & 7 & 13 & $\mathrm{~A} 2$ & 8.93 & 1.19 & 10 & 8.93 & 1.19 & 5.74 \\
\hline S12WV075001 & 13 & 26 & $\mathrm{BE}$ & 1.96 & 1.07 & 12 & 1.96 & 1.07 & 2.40 \\
\hline S12WV075001 & 26 & 55 & Bs & 1.72 & & 20 & 1.72 & 1.15 & 4.58 \\
\hline S12WV075001 & 55 & 92 & $\mathrm{BC}$ & 0.32 & & 45 & 0.32 & 1.44 & 0.94 \\
\hline S12WV075001 & 92 & 113 & $\mathrm{C}$ & 0.25 & & 65 & 0.25 & 1.43 & 0.26 \\
\hline S12WV075002 & 0 & 2 & $\mathrm{Oi}$ & 54.33 & 0.18 & & 54.33 & 0.18 & 1.96 \\
\hline S12WV075002 & 2 & 5 & $\mathrm{Oe}$ & 54.52 & 0.43 & & 54.52 & 0.43 & 7.03 \\
\hline S12WV075002 & 5 & 10 & $\mathrm{Oa}$ & 47.33 & 0.53 & & 47.33 & 0.53 & 12.54 \\
\hline S12WV075002 & 10 & 18 & $\mathrm{E}$ & 1.67 & 1.02 & 50 & 1.67 & 1.02 & 0.68 \\
\hline
\end{tabular}




\begin{tabular}{|c|c|c|c|c|c|c|c|c|c|}
\hline PedonID & $\begin{array}{c}\text { Top } \\
\text { Depth } \\
\text { (cm) }\end{array}$ & $\begin{array}{c}\text { Bottom } \\
\text { Depth } \\
(\mathrm{cm})\end{array}$ & Horizon & $\begin{array}{c}\text { Total } \\
\text { Carbon\% } \\
\text { (Dry } \\
\text { Combustion, } \\
\text { Including } \\
\text { Converted } \\
\text { Walkley- } \\
\text { Black) } \\
\end{array}$ & $\begin{array}{c}\text { 33kPa } \\
\text { Bulk } \\
\text { Density } \\
\left(\mathrm{g} \mathrm{cm}^{-3}\right)\end{array}$ & $\begin{array}{c}\text { Fragment } \\
\% \text { by } \\
\text { Volume }\end{array}$ & $\begin{array}{c}\text { Predicted } \\
\text { OC } \%\end{array}$ & $\begin{array}{c}\text { Predicted } \\
\text { 33kPa BD } \\
\left(\mathrm{g} \mathrm{cm}^{-3}\right)\end{array}$ & $\begin{array}{c}\text { SOC } \\
\text { Stock } \\
(\mathbf{k g} \\
\left.\mathbf{m}^{-2}\right)\end{array}$ \\
\hline S12WV075002 & 18 & 26 & Bhs & 4.71 & 1.35 & 40 & 4.71 & 1.35 & 3.05 \\
\hline S12WV075002 & 26 & 46 & Bs & 2.15 & 1.17 & 25 & 2.15 & 1.17 & 3.77 \\
\hline S12WV075002 & 46 & 68 & $\mathrm{Bw}$ & 0.16 & 1.56 & 37 & 0.16 & 1.56 & 0.35 \\
\hline S12WV075002 & 68 & 91 & $2 \mathrm{BC}$ & 0.09 & 1.89 & 10 & 0.09 & 1.89 & 0.35 \\
\hline S12WV075002 & 91 & 117 & $2 \mathrm{CB}$ & 0.09 & 1.90 & 25 & 0.09 & 1.90 & 0.33 \\
\hline S12WV075003 & 0 & 1 & Oi & 53.97 & 0.14 & & 53.97 & 0.14 & 0.76 \\
\hline S12WV075003 & 1 & 4 & Oe & 47.48 & 0.51 & & 47.48 & 0.51 & 7.26 \\
\hline S12WV075003 & 4 & 9 & $\mathrm{~A} / \mathrm{Oa}$ & 45.32 & 0.74 & 12 & 45.32 & 0.74 & 14.76 \\
\hline S12WV075003 & 9 & 18 & $\mathrm{E}$ & 2.61 & 0.99 & 20 & 2.61 & 0.99 & 1.86 \\
\hline S12WV075003 & 18 & 27 & Bhs & 3.88 & 1.87 & 10 & 3.88 & 1.87 & 5.88 \\
\hline S12WV075003 & 27 & 37 & Bs & 3.79 & 1.06 & 10 & 3.79 & 1.06 & 3.62 \\
\hline S12WV075003 & 37 & 68 & $\mathrm{Bw}$ & 2.14 & 1.06 & 20 & 2.14 & 1.06 & 5.63 \\
\hline S12WV075003 & 68 & 88 & $\mathrm{BC}$ & 0.93 & 1.47 & 50 & 0.93 & 1.47 & 1.37 \\
\hline S12WV075004 & 0 & 1 & $\mathrm{Oi}$ & 44.04 & 0.14 & & 44.04 & 0.14 & 0.62 \\
\hline S12WV075004 & 1 & 5 & $\mathrm{Oe}$ & 35.16 & 0.32 & & 35.16 & 0.32 & 4.50 \\
\hline S12WV075004 & 5 & 8 & $\mathrm{Oa} / \mathrm{A}$ & 27.02 & 0.78 & 5 & 27.02 & 0.78 & 6.01 \\
\hline S12WV075004 & 8 & 15 & $\mathrm{AE}$ & 12.76 & 1.06 & 20 & 12.76 & 1.06 & 7.57 \\
\hline S12WV075004 & 15 & 46 & $\mathrm{Bs} / \mathrm{Bhs}$ & 2.58 & 1.27 & 35 & 2.58 & 1.27 & 6.60 \\
\hline S12WV075004 & 46 & 65 & $\mathrm{BC}$ & 0.42 & 1.42 & 50 & 0.42 & 1.42 & 0.57 \\
\hline S12WV075005 & 0 & 6 & $\mathrm{Oi}$ & 57.17 & 0.22 & & 57.17 & 0.22 & 7.55 \\
\hline S12WV075005 & 6 & 13 & Oe & 53.98 & 0.04 & & 53.98 & 0.04 & 1.51 \\
\hline S12WV075005 & 13 & 23 & $\mathrm{Oa} / \mathrm{A}$ & 36.65 & 0.59 & 3 & 36.65 & 0.59 & 20.97 \\
\hline S12WV075005 & 23 & 29 & $\mathrm{E}$ & 2.52 & 1.29 & 3 & 2.52 & 1.29 & 1.89 \\
\hline
\end{tabular}




\begin{tabular}{|c|c|c|c|c|c|c|c|c|c|}
\hline PedonID & $\begin{array}{c}\text { Top } \\
\text { Depth } \\
\text { (cm) }\end{array}$ & $\begin{array}{c}\text { Bottom } \\
\text { Depth } \\
\text { (cm) }\end{array}$ & Horizon & $\begin{array}{c}\text { Total } \\
\text { Carbon\% } \\
\text { (Dry } \\
\text { Combustion, } \\
\text { Including } \\
\text { Converted } \\
\text { Walkley- } \\
\text { Black) } \\
\end{array}$ & $\begin{array}{c}\text { 33kPa } \\
\text { Bulk } \\
\text { Density } \\
\left(\mathrm{g} \mathrm{cm}^{-3}\right)\end{array}$ & $\begin{array}{c}\text { Fragment } \\
\% \text { by } \\
\text { Volume }\end{array}$ & $\begin{array}{c}\text { Predicted } \\
\text { OC } \%\end{array}$ & $\begin{array}{c}\text { Predicted } \\
33 \mathrm{kPa} \mathrm{BD} \\
\left(\mathrm{g} \mathrm{cm}^{-3}\right)\end{array}$ & $\begin{array}{c}\text { SOC } \\
\text { Stock } \\
(\mathbf{k g} \\
\left.\mathbf{m}^{-2}\right)\end{array}$ \\
\hline S12WV075005 & 29 & 37 & Bhs & 5.76 & & 3 & 5.76 & 1.16 & 5.17 \\
\hline S12WV075005 & 37 & 50 & Bs & 4.72 & 0.82 & 5 & 4.72 & 0.82 & 4.78 \\
\hline S12WV075005 & 50 & 64 & $\mathrm{Bw}$ & 1.61 & 1.49 & 30 & 1.61 & 1.49 & 2.35 \\
\hline S12WV075005 & 64 & 77 & $\mathrm{BC}$ & 0.91 & 1.45 & 50 & 0.91 & 1.45 & 0.86 \\
\hline S12WV075005 & 77 & 98 & $\mathrm{C}$ & 0.60 & 1.40 & 75 & 0.60 & 1.40 & 0.44 \\
\hline S12WV083001 & 0 & 3 & Oi & 49.42 & 0.19 & & 49.42 & 0.19 & 2.82 \\
\hline S12WV083001 & 3 & 10 & $\mathrm{~A}$ & 14.79 & 1.13 & 10 & 14.79 & 1.13 & 10.53 \\
\hline S12WV083001 & 10 & 26 & Bs1 & 2.41 & 0.97 & 10 & 2.41 & 0.97 & 3.37 \\
\hline S12WV083001 & 26 & 54 & Bs2 & 1.01 & 1.02 & 15 & 1.01 & 1.02 & 2.45 \\
\hline S12WV083001 & 54 & 76 & $\mathrm{Bw}$ & 0.32 & 1.46 & 27 & 0.32 & 1.46 & 0.75 \\
\hline S12WV083001 & 76 & 120 & $\mathrm{BC}$ & 0.21 & & 30 & 0.21 & 1.43 & 0.92 \\
\hline
\end{tabular}




\section{Appendix C: R Code Used for Outlier Detection and Normality Testing}

\#\#\# Soil organic carbon outliers\#\#\#

outoc<-read.csv('C:/R/outoc.csv', header=TRUE)

$\operatorname{attach}($ outoc)

outliers=boxplot(SOC $\sim$ Horizon+Texture, plot=FALSE $)$ \$out

outlieroc<-outoc[outoc\$SOC \%in\% outliers,]

write.csv(outlieroc, "C:/R/outlieroc.csv")

\#\#\# To detect outliers in the bulk density dataset, use the above code and replace SOC with BD.

\#\#\#

\#\#\#Normality Testing Using D’Agostino\#\#\#

oc<-read.csv('C:/R/outoc.csv', header=TRUE)

$\operatorname{attach}(\mathrm{oc})$

library(fBasics)

dagoTest(oc)

dagoTest $(\log (\mathrm{oc}))$ \#\#\# 


\section{Appendix D: R Code Used for Random Forest Models}

\#\#\#Load randomForest package\#\#\#

library(randomForest)

\#\#\#Divide soil organic carbon data into training and testing sets\#\#\#

oc<-read.csv('C:/R/oc.csv', header=TRUE)

set.seed(1789)

alpha<-0.7 \#\#\#Percentage of training set\#\#\#

inTrain<-sample(1:nrow(oc), alpha*nrow(oc))

train<-oc[inTrain,]

test<-oc[-inTrain,]

\#\#\#Random forest model\#\#\#

rfoc $<$ randomForest $($ SOC $\sim$ median+desgn+sand+silt+clay+Texture+Value+Chroma+Epipedon+D epth+LandCover+Order+Age+ROCKTYPE1+ROCKTYPE2+Group+Temp+Moist+Phase+Min eralogy $+\mathrm{CAC}+\mathrm{SG}+\mathrm{GG}+\mathrm{PS}$, data=train, importance=TRUE, mtry=6, ntree=1000)

\#\#\#Use random forest model to predict soil organic carbon for the test data\#\#\#

predict<-predict(rfoc, test)

write.csv(predict, file $=$ "predictoc.csv")

write.csv(test, file="testoc.csv")

\#\#\#Variable importance plot\#\#\#

varImpPlot(rfoc, main='Average Variable Importance for Soil Organic Carbon')

\#\#\#Copy and paste predicted values into the test dataset and then bring the test dataset back into

\section{R\#\#\#}

predictedoc<-read.csv('C:/R/testoc.csv', header=TRUE)

$\operatorname{detach}(\mathrm{oc})$

$\operatorname{attach}($ predictedoc)

\#\#\#Plot observed versus predicted values from the test dataset and calculate the slope and

intercept of the line of best fit, coefficient of determination, and root mean square error.\#\#\#

plot(Observed Predicted)

fit $<-\operatorname{lm}($ Observed $\sim$ Predicted, data=predictedoc $)$

abline(fit)

rmse<-round $\left(\operatorname{sqrt}\left(\operatorname{mean}\left(\operatorname{resid}(\text { fit })^{\wedge} 2\right)\right), 2\right)$ 
r2<-round(summary(fit)\$r.squared, 2)

coefs $<-\operatorname{coef}($ fit $)$

b0<-round(coefs[1],2)

b1<-round (coefs[2],2)

eqn $<$-bquote $($ italic $($ Observed $)==$.(b0)

+.(b1)*italic(Predicted)*"," $\mathrm{r}^{\wedge} 2==.(\mathrm{r} 2)^{*}$ "," RMSE==.(rmse))

\#\#\# To create a random forest model for bulk density, use the above code and replace SOC with BD. \#\#\# 


\section{Appendix E: Microsoft Excel Code for Calculating Mean and Median by Horizon and Texture}

$=\operatorname{MEDIAN}(\operatorname{IF}(\mathrm{C} \$ 2: \mathrm{C} \$ 1572=\mathrm{C} 2, \operatorname{IF}(\mathrm{D} \$ 2: \mathrm{D} \$ 1572=\mathrm{D} 2, \mathrm{E} \$ 2: \mathrm{E} \$ 1572)))$

$=\mathrm{MEAN}(\mathrm{IF}(\mathrm{C} \$ 2: \mathrm{C} \$ 1572=\mathrm{C} 2, \mathrm{IF}(\mathrm{D} \$ 2: \mathrm{D} \$ 1572=\mathrm{D} 2, \mathrm{E} \$ 2: \mathrm{E} \$ 1572)))$

Where $\mathrm{C}$ represents the horizon column, $\mathrm{D}$ is the texture column, and $\mathrm{E}$ is soil organic carbon or bulk density. In order to extrapolate this function for every row in the dataset, type in the above formula in the first row and then hold down Ctrl+Shift+Enter. 


\section{Appendix F: Soil Organic Carbon Stock of Rapid Carbon Assessment Sites in}

\section{MLRA 127}

\begin{tabular}{|c|c|c|c|c|c|c|}
\hline RaCA SiteID & $\begin{array}{c}\text { SOC Stock } \\
\% 1 \mathrm{~m}\end{array}$ & Soil Series & Particle-Size & Subgroup & $\begin{array}{c}\text { Great } \\
\text { Group } \\
\end{array}$ & Order \\
\hline C1303F01-2 & 22.25 & Onoville & Fine-loamy & Aquic & Fragiudults & Ultisols \\
\hline C1303F01-3 & 15.60 & Onoville & Fine-loamy & Aquic & Fragiudults & Ultisols \\
\hline C1303F01-4 & 32.98 & Onoville & Fine-loamy & Aquic & Fragiudults & Ultisols \\
\hline C1303F01-5 & 15.31 & Onoville & Fine-loamy & Aquic & Fragiudults & Ultisols \\
\hline C1304P01-2 & 18.30 & Chavies & Coarse-loamy & Ultic & Hapludalfs & Alfisols \\
\hline C1304P01-3 & 15.44 & Chavies & Coarse-loamy & Ultic & Hapludalfs & Alfisols \\
\hline C1304P01-4 & 18.42 & Chavies & Coarse-loamy & Ultic & Hapludalfs & Alfisols \\
\hline C1304P01-5 & 23.97 & Chavies & Coarse-loamy & Ultic & Hapludalfs & Alfisols \\
\hline C1305F07-2 & 32.09 & Ernest & Fine-loamy & Aquic & Fragiudults & Ultisols \\
\hline C1305F07-3 & 30.18 & Ernest & Fine-loamy & Aquic & Fragiudults & Ultisols \\
\hline C1305F07-4 & 26.49 & Ernest & Fine-loamy & Aquic & Fragiudults & Ultisols \\
\hline C1305F07-5 & 44.60 & Ernest & Fine-loamy & Aquic & Fragiudults & Ultisols \\
\hline C1305F08-2 & 13.30 & Cookport & Fine-loamy & Aquic & Fragiudults & Ultisols \\
\hline C1305F08-3 & 11.42 & Cookport & Fine-loamy & Aquic & Fragiudults & Ultisols \\
\hline C1305F08-4 & 10.74 & Cookport & Fine-loamy & Aquic & Fragiudults & Ultisols \\
\hline C1305F08-5 & 11.58 & Cookport & Fine-loamy & Aquic & Fragiudults & Ultisols \\
\hline C1305F11-2 & 21.04 & Hazleton & Loamy-skeletal & Typic & Dystrudepts & Inceptisols \\
\hline C1305F11-3 & 34.58 & Cookport & Fine-loamy & Aquic & Fragiudults & Ultisols \\
\hline C1305F11-4 & 32.33 & Cookport & Fine-loamy & Aquic & Fragiudults & Ultisols \\
\hline C1305F11-5 & 32.24 & Cookport & Fine-loamy & Aquic & Fragiudults & Ultisols \\
\hline C1305F14-2 & 17.92 & Cookport & Fine-loamy & Aquic & Fragiudults & Ultisols \\
\hline C1305F14-3 & 13.98 & Cookport & Fine-loamy & Aquic & Fragiudults & Ultisols \\
\hline C1305F14-4 & 12.53 & Cookport & Fine-loamy & Aquic & Fragiudults & Ultisols \\
\hline C1305F16-2 & 20.59 & Buchanan & Fine-loamy & Aquic & Fragiudults & Ultisols \\
\hline C1305F16-3 & 53.39 & Buchanan & Fine-loamy & Aquic & Fragiudults & Ultisols \\
\hline C1305F16-4 & 36.07 & Buchanan & Fine-loamy & Aquic & Fragiudults & Ultisols \\
\hline C1305F16-5 & 40.22 & Buchanan & Fine-loamy & Aquic & Fragiudults & Ultisols \\
\hline C1305F20-2 & 33.72 & Buchanan & Fine-loamy & Aquic & Fragiudults & Ultisols \\
\hline C1305F20-3 & 31.55 & Buchanan & Fine-loamy & Aquic & Fragiudults & Ultisols \\
\hline C1305F20-4 & 27.10 & Buchanan & Fine-loamy & Aquic & Fragiudults & Ultisols \\
\hline C1305F20-5 & 25.80 & Layland & Loamy-skeletal & Typic & Dystrudepts & Inceptisols \\
\hline C1305F29-2 & 12.06 & Wharton & Fine-loamy & Aquic & Hapludults & Ultisols \\
\hline C1305F29-3 & 15.17 & Wharton & Fine-loamy & Aquic & Hapludults & Ultisols \\
\hline C1305F29-4 & 19.66 & Hazleton & Loamy-skeletal & Typic & Dystrudepts & Inceptisols \\
\hline C1305F29-5 & 23.10 & Wharton & Fine-loamy & Aquic & Hapludults & Ultisols \\
\hline C1307C06-2 & 8.91 & Fairpoint & Loamy-skeletal & Typic & Udorthents & Entisols \\
\hline
\end{tabular}




\begin{tabular}{|c|c|c|c|c|c|c|}
\hline RaCA SiteID & $\begin{array}{c}\text { SOC Stock } \\
\% 1 \mathrm{~m}\end{array}$ & Soil Series & Particle-Size & Subgroup & $\begin{array}{l}\text { Great } \\
\text { Group }\end{array}$ & Order \\
\hline C1307C06-3 & 12.26 & Fairpoint & Loamy-skeletal & Typic & Udorthents & Entisols \\
\hline C1307C06-4 & 10.66 & Fairpoint & Loamy-skeletal & Typic & Udorthents & Entisols \\
\hline C1307C06-5 & 9.67 & Fairpoint & Loamy-skeletal & Typic & Udorthents & Entisols \\
\hline C1307F10-2 & 11.17 & Gilpin & Fine-loamy & Typic & Hapludults & Ultisols \\
\hline C1307F10-3 & 16.69 & Gilpin & Fine-loamy & Typic & Hapludults & Ultisols \\
\hline C1307F10-4 & 13.47 & Gilpin & Fine-loamy & Typic & Hapludults & Ultisols \\
\hline C1307F10-5 & 24.53 & Gilpin & Fine-loamy & Typic & Hapludults & Ultisols \\
\hline C1307F21-2 & 7.90 & Gilpin & Fine-loamy & Typic & Hapludults & Ultisols \\
\hline C1307F21-3 & 4.55 & Dekalb & Loamy-skeletal & Typic & Dystrudepts & Inceptisols \\
\hline C1307F21-4 & 11.01 & Dekalb & Loamy-skeletal & Typic & Dystrudepts & Inceptisols \\
\hline C1307F21-5 & 10.12 & Gilpin & Fine-loamy & Typic & Hapludults & Ultisols \\
\hline C1307F28-2 & 14.03 & Gilpin & Fine-loamy & Typic & Hapludults & Ultisols \\
\hline C1307F28-3 & 12.44 & Gilpin & Fine-loamy & Typic & Hapludults & Ultisols \\
\hline C1307F28-4 & 12.54 & Gilpin & Fine-loamy & Typic & Hapludults & Ultisols \\
\hline C1307F28-5 & 21.07 & Gilpin & Fine-loamy & Typic & Hapludults & Ultisols \\
\hline C1307F31-2 & 12.17 & $\begin{array}{c}\text { Laidig } \\
\text { Taxadjunct }\end{array}$ & Fine-loamy & Typic & Fragiudults & Ultisols \\
\hline C1307F31-3 & 21.04 & Ernest & Fine-loamy & Aquic & Fragiudults & Ultisols \\
\hline C1307F31-4 & 7.25 & Ernest & Fine-loamy & Aquic & Fragiudults & Ultisols \\
\hline C1307F31-5 & 18.44 & Ernest & Fine-loamy & Aquic & Fragiudults & Ultisols \\
\hline C1307F34-2 & 7.21 & Gilpin & Fine-loamy & Typic & Hapludults & Ultisols \\
\hline C1307F34-3 & 10.83 & Gilpin & Fine-loamy & Typic & Hapludults & Ultisols \\
\hline C1307F34-4 & 5.67 & Gilpin & Fine-loamy & Typic & Hapludults & Ultisols \\
\hline C1307F34-5 & 6.85 & Gilpin & Fine-loamy & Typic & Hapludults & Ultisols \\
\hline C1307F37-2 & 11.90 & Shouns & Fine-loamy & Typic & Hapludults & Ultisols \\
\hline C1307F37-4 & 6.26 & Shouns & Fine-loamy & Typic & Hapludults & Ultisols \\
\hline C1307F37-5 & 6.06 & Shouns & Fine-loamy & Typic & Hapludults & Ultisols \\
\hline C1307F39-2 & 8.54 & Culleoka & Fine-loamy & Ultic & Hapludalfs & Alfisols \\
\hline C1307F39-3 & 9.56 & Culleoka & Fine-loamy & Ultic & Hapludalfs & Alfisols \\
\hline C1307F39-4 & 7.06 & Culleoka & Fine-loamy & Ultic & Hapludalfs & Alfisols \\
\hline C1307F39-5 & 10.03 & Culleoka & Fine-loamy & Ultic & Hapludalfs & Alfisols \\
\hline $\mathrm{C} 1307 \mathrm{~F} 46-2$ & 20.46 & $\begin{array}{c}\text { Leck Kill } \\
\text { Taxadjunct }\end{array}$ & Loamy-skeletal & Typic & Hapludults & Ultisols \\
\hline C1307F46-3 & 14.34 & Clymer & Coarse-loamy & Typic & Hapludults & Ultisols \\
\hline C1307F46-4 & 24.51 & Clymer & Coarse-loamy & Typic & Hapludults & Ultisols \\
\hline C1307F46-5 & 20.04 & Leck Kill & Fine-loamy & Typic & Hapludults & Ultisols \\
\hline C1307F53-2 & 8.65 & Cateache & Fine-loamy & Ultic & Hapludalfs & Alfisols \\
\hline C1307F53-3 & 9.71 & Cateache & Fine-loamy & Ultic & Hapludalfs & Alfisols \\
\hline C1307F53-4 & 14.77 & Cateache & Fine-loamy & Ultic & Hapludalfs & Alfisols \\
\hline C1307F53-5 & 18.28 & Cateache & Fine-loamy & Ultic & Hapludalfs & Alfisols \\
\hline
\end{tabular}




\begin{tabular}{|c|c|c|c|c|c|c|}
\hline RaCA SiteID & $\begin{array}{c}\text { SOC Stock } \\
\% 1 \mathrm{~m}\end{array}$ & Soil Series & Particle-Size & Subgroup & $\begin{array}{l}\text { Great } \\
\text { Group }\end{array}$ & Order \\
\hline C1307P03-2 & 5.71 & Cateache & Fine-loamy & Ultic & Hapludalfs & Alfisols \\
\hline C1307P03-3 & 4.36 & Litz & Loamy-skeletal & Ruptic-Ultic & Dystrudepts & Inceptisols \\
\hline C1307P03-4 & 7.77 & Litz & Loamy-skeletal & Ruptic-Ultic & Dystrudepts & Inceptisols \\
\hline C1307P03-5 & 5.32 & Cateache & Fine-loamy & Ultic & Hapludalfs & Alfisols \\
\hline C1307P13-2 & 12.51 & Gilpin & Fine-loamy & Typic & Hapludults & Ultisols \\
\hline C1307P13-3 & 7.14 & Gilpin & Fine-loamy & Typic & Hapludults & Ultisols \\
\hline C1307P13-4 & 8.86 & Gilpin & Fine-loamy & Typic & Hapludults & Ultisols \\
\hline C1307P13-5 & 8.66 & Gilpin & Fine-loamy & Typic & Hapludults & Ultisols \\
\hline C1309C03-2 & 18.94 & Atkins & Fine-loamy & Fluvaquentic & Endoaquepts & Inceptisols \\
\hline C1309C03-3 & 55.26 & Atkins & Fine-loamy & Fluvaquentic & Endoaquepts & Inceptisols \\
\hline C1309C03-4 & 30.45 & Atkins & Fine-loamy & Fluvaquentic & Endoaquepts & Inceptisols \\
\hline C1309C03-5 & 22.14 & Atkins & Fine-loamy & Fluvaquentic & Endoaquepts & Inceptisols \\
\hline C1309F03-2 & 22.05 & Basher & Coarse-loamy & Fluvaquentic & Dystrudepts & Inceptisols \\
\hline C1309F03-3 & 29.42 & Barbour & Coarse-loamy & Fluventic & Dystrudepts & Inceptisols \\
\hline C1309F03-4 & 15.02 & Basher & Coarse-loamy & Fluvaquentic & Dystrudepts & Inceptisols \\
\hline C1309F03-5 & 24.59 & Basher & Coarse-loamy & Fluvaquentic & Dystrudepts & Inceptisols \\
\hline C1309F05-2 & 18.72 & Philo & Coarse-loamy & Fluvaquentic & Dystrudepts & Inceptisols \\
\hline C1309F05-3 & 13.32 & Philo & Coarse-loamy & Fluvaquentic & Dystrudepts & Inceptisols \\
\hline C1309F05-4 & 17.05 & Philo & Coarse-loamy & Fluvaquentic & Dystrudepts & Inceptisols \\
\hline C1310F01-2 & 15.98 & Brinkerton & Fine-silty & Typic & Fragiaqualfs & Alfisols \\
\hline C1310F01-3 & 21.13 & Brinkerton & Fine-silty & Typic & Fragiaqualfs & Alfisols \\
\hline C1310F01-4 & 23.19 & Brinkerton & Fine-silty & Typic & Fragiaqualfs & Alfisols \\
\hline C1310F01-5 & 13.16 & Rayne & Fine-loamy & Typic & Hapludults & Ultisols \\
\hline C1310F03-2 & 21.65 & Portville & Fine-loamy & Aeric & Fragiaqualfs & Alfisols \\
\hline C1310F03-3 & 34.15 & Portville & Fine-loamy & Aeric & Fragiaqualfs & Alfisols \\
\hline C1310F03-4 & 24.61 & Portville & Fine-loamy & Aeric & Fragiaqualfs & Alfisols \\
\hline $\mathrm{C} 1310 \mathrm{~F} 03-5$ & 41.91 & Portville & Fine-loamy & Aeric & Fragiaqualfs & Alfisols \\
\hline C1310P02-2 & 21.36 & Cavode & Fine & Aeric & Endoaquults & Ultisols \\
\hline C1310P02-3 & 20.59 & Cavode & Fine & Aeric & Endoaquults & Ultisols \\
\hline С1310P02-4 & 15.18 & Cavode & Fine & Aeric & Endoaquults & Ultisols \\
\hline C1310P02-5 & 10.91 & Cavode & Fine & Aeric & Endoaquults & Ultisols \\
\hline C1311P04-2 & 11.66 & Caneyville & Fine & Typic & Hapludalfs & Alfisols \\
\hline C1311P04-3 & 10.00 & Caneyville & Fine & Typic & Hapludalfs & Alfisols \\
\hline C1311P04-4 & 10.57 & Frederick & Fine & Typic & Paleudults & Ultisols \\
\hline C1311P04-5 & 9.49 & Frankstown & Fine-loamy & Typic & Hapludults & Ultisols \\
\hline C1311P05-2 & 12.80 & Caneyville & Fine & Typic & Hapludalfs & Alfisols \\
\hline C1311P05-3 & 14.76 & Caneyville & Fine & Typic & Hapludalfs & Alfisols \\
\hline C1311P05-4 & 14.51 & Caneyville & Fine & Typic & Hapludalfs & Alfisols \\
\hline C1311P05-5 & 8.49 & Caneyville & Fine & Typic & Hapludalfs & Alfisols \\
\hline
\end{tabular}




\begin{tabular}{|c|c|c|c|c|c|c|}
\hline RaCA SiteID & $\begin{array}{c}\text { SOC Stock } \\
\% 1 \mathrm{~m}\end{array}$ & Soil Series & Particle-Size & Subgroup & $\begin{array}{l}\text { Great } \\
\text { Group }\end{array}$ & Order \\
\hline C1311P10-2 & 10.79 & Caneyville & Fine & Typic & Hapludalfs & Alfisols \\
\hline C1311P10-3 & 12.16 & Caneyville & Fine & Typic & Hapludalfs & Alfisols \\
\hline C1311P10-4 & 9.18 & Caneyville & Fine & Typic & Hapludalfs & Alfisols \\
\hline C1311P10-5 & 8.90 & Caneyville & Fine & Typic & Hapludalfs & Alfisols \\
\hline $\begin{array}{l}\text { C1313W05- } \\
2\end{array}$ & 36.76 & Brinkerton & Fine-silty & Typic & Fragiaqualfs & Alfisols \\
\hline C1313W05-3 & 24.26 & Philo & Coarse-loamy & Fluvaquentic & Dystrudepts & Inceptisols \\
\hline C1313W05-4 & 25.25 & Brinkerton & Fine-silty & Typic & Fragiaqualfs & Alfisols \\
\hline C1313W05-5 & 35.78 & Brinkerton & Fine-silty & Typic & Fragiaqualfs & Alfisols \\
\hline C1314F01-2 & 25.52 & Berks & Loamy-skeletal & Typic & Dystrudepts & Inceptisols \\
\hline C1314F01-3 & 12.60 & Muskingum & Fine-loamy & Typic & Dystrudepts & Inceptisols \\
\hline C1314F01-4 & 14.29 & Berks & Loamy-skeletal & Typic & Dystrudepts & Inceptisols \\
\hline C1314F01-5 & 5.84 & Berks & Loamy-skeletal & Typic & Dystrudepts & Inceptisols \\
\hline C1314F02-2 & 10.03 & Hazleton & Loamy-skeletal & Typic & Dystrudepts & Inceptisols \\
\hline C1314F02-3 & 7.41 & Hazleton & Loamy-skeletal & Typic & Dystrudepts & Inceptisols \\
\hline C1314F02-4 & 7.94 & Hazleton & Loamy-skeletal & Typic & Dystrudepts & Inceptisols \\
\hline C1314F02-5 & 17.69 & Hazleton & Loamy-skeletal & Typic & Dystrudepts & Inceptisols \\
\hline C1314F07-2 & 13.54 & Cookport & Fine-loamy & Aquic & Fragiudults & Ultisols \\
\hline C1314F07-3 & 13.40 & Cookport & Fine-loamy & Aquic & Fragiudults & Ultisols \\
\hline C1314F07-4 & 12.24 & Clymer & Coarse-loamy & Typic & Hapludults & Ultisols \\
\hline C1314F07-5 & 11.39 & Clymer & Coarse-loamy & Typic & Hapludults & Ultisols \\
\hline C1314F17-3 & 8.97 & Berks & Loamy-skeletal & Typic & Dystrudepts & Inceptisols \\
\hline C1314F17-4 & 20.52 & Ungers & Fine-loamy & Typic & Hapludults & Ultisols \\
\hline C1314F17-5 & 12.26 & Clymer & Coarse-loamy & Typic & Hapludults & Ultisols \\
\hline C1314F29-2 & 17.84 & Hazleton & Loamy-skeletal & Typic & Dystrudepts & Inceptisols \\
\hline C1314F29-3 & 15.36 & Hazleton & Loamy-skeletal & Typic & Dystrudepts & Inceptisols \\
\hline C1314F29-4 & 17.68 & Hazleton & Loamy-skeletal & Typic & Dystrudepts & Inceptisols \\
\hline C1314F29-5 & 7.27 & Hazleton & Loamy-skeletal & Typic & Dystrudepts & Inceptisols \\
\hline C1314F32-2 & 15.84 & Hazleton & Loamy-skeletal & Typic & Dystrudepts & Inceptisols \\
\hline C1314F32-3 & 20.87 & Hazleton & Loamy-skeletal & Typic & Dystrudepts & Inceptisols \\
\hline C1314F32-4 & 26.60 & Hazleton & Loamy-skeletal & Typic & Dystrudepts & Inceptisols \\
\hline C1314F32-5 & 21.79 & Hazleton & Loamy-skeletal & Typic & Dystrudepts & Inceptisols \\
\hline C1314F33-2 & 17.09 & Berks & Loamy-skeletal & Typic & Dystrudepts & Inceptisols \\
\hline C1314F33-3 & 21.16 & Berks & Loamy-skeletal & Typic & Dystrudepts & Inceptisols \\
\hline C1314F33-4 & 28.93 & Berks & Loamy-skeletal & Typic & Dystrudepts & Inceptisols \\
\hline C1314F33-5 & 10.85 & Berks & Loamy-skeletal & Typic & Dystrudepts & Inceptisols \\
\hline C1314P03-2 & 10.13 & Calvin & Loamy-skeletal & Typic & Dystrudepts & Inceptisols \\
\hline C1314P03-3 & 7.78 & Calvin & Loamy-skeletal & Typic & Dystrudepts & Inceptisols \\
\hline C1314P03-4 & 8.21 & Calvin & Loamy-skeletal & Typic & Dystrudepts & Inceptisols \\
\hline C1314P03-5 & 12.33 & Calvin & Loamy-skeletal & Typic & Dystrudepts & Inceptisols \\
\hline
\end{tabular}




\begin{tabular}{|c|c|c|c|c|c|c|}
\hline RaCA SiteID & $\begin{array}{c}\text { SOC Stock } \\
\text { \% 1m }\end{array}$ & Soil Series & Particle-Size & Subgroup & $\begin{array}{c}\text { Great } \\
\text { Group }\end{array}$ & Order \\
\hline F1303F03-2 & 23.08 & Mandy & Loamy-skeletal & Typic & Dystrudepts & Inceptisols \\
\hline F1303F03-3 & 9.19 & Mandy & Loamy-skeletal & Typic & Dystrudepts & Inceptisols \\
\hline F1303F03-4 & 11.95 & Mandy & Loamy-skeletal & Typic & Dystrudepts & Inceptisols \\
\hline F1303F03-5 & 19.56 & Mandy & Loamy-skeletal & Typic & Dystrudepts & Inceptisols \\
\hline F1314F03-2 & 8.52 & Dekalb & Loamy-skeletal & Typic & Dystrudepts & Inceptisols \\
\hline F1314F03-3 & 14.56 & Shouns & Fine-loamy & Typic & Hapludults & Ultisols \\
\hline F1314F03-4 & 22.80 & Shouns & Fine-loamy & Typic & Hapludults & Ultisols \\
\hline F1314F03-5 & 13.30 & Shouns & Fine-loamy & Typic & Hapludults & Ultisols \\
\hline
\end{tabular}




\section{Appendix G: Soil Organic Carbon Stock of Pedons Described and Sampled by Sponaugle (2005)}

\begin{tabular}{|c|c|c|c|c|c|}
\hline SiteID & $\begin{array}{c}\text { SOC Stock } \\
\% 1 \mathrm{~m}\end{array}$ & $\begin{array}{l}\text { Particle- } \\
\text { Size }\end{array}$ & Subgroup & $\begin{array}{l}\text { Great } \\
\text { Group }\end{array}$ & Order \\
\hline FS04WV025001 & 17.15 & Fine-loamy & Typic & Hapludults & Ultisols \\
\hline FS04WV025002 & 10.81 & Fine-loamy & Typic & Hapludults & Ultisols \\
\hline FS04WV025003 & 18.44 & Fine-loamy & Typic & Hapludults & Ultisols \\
\hline FS04WV025004 & 15.39 & Fine-loamy & Fragic & Hapludults & Ultisols \\
\hline FS04WV025005 & 28.81 & $\begin{array}{l}\text { Coarse- } \\
\text { loamy }\end{array}$ & Fragic & Hapludults & Ultisols \\
\hline FS04WV025010 & 17.64 & $\begin{array}{l}\text { Loamy- } \\
\text { skeletal }\end{array}$ & Typic & Fragiudults & Ultisols \\
\hline FS04WV101001 & 20.33 & $\begin{array}{c}\text { Coarse- } \\
\text { loamy }\end{array}$ & Typic & Hapludults & Ultisols \\
\hline FS04WV067007 & 12.63 & Fine-loamy & Typic & Hapludults & Ultisols \\
\hline FS04WV067001 & 7.71 & $\begin{array}{l}\text { Loamy- } \\
\text { skeletal }\end{array}$ & Psammentic & Hapludults & Ultisols \\
\hline FS04WV067002 & 10.66 & $\begin{array}{l}\text { Loamy- } \\
\text { skeletal }\end{array}$ & Typic & Dystrudepts & Inceptisols \\
\hline FS04WV067003 & 11.24 & $\begin{array}{c}\text { Coarse- } \\
\text { loamy }\end{array}$ & Typic & Hapludults & Ultisols \\
\hline FS04WV067004 & 2.68 & $\begin{array}{l}\text { Loamy- } \\
\text { skeletal }\end{array}$ & Aquic & Dystrudepts & Inceptisols \\
\hline FS04WV067005 & 8.94 & $\begin{array}{l}\text { Loamy- } \\
\text { skeletal }\end{array}$ & Typic & Fragiudults & Ultisols \\
\hline FS04WV067006 & 8.25 & $\begin{array}{l}\text { Loamy- } \\
\text { skeletal }\end{array}$ & Aquic & Dystrudepts & Inceptisols \\
\hline FS04WV067017 & 10.30 & $\begin{array}{l}\text { Coarse- } \\
\text { loamy }\end{array}$ & Typic & Dystrudepts & Inceptisols \\
\hline
\end{tabular}

